Zbigniew Tucholski

\title{
Polish State Railways \\ as a Mode of Transport for Troops of the Warsaw Pact
}

Technology in Service of a Doctrine

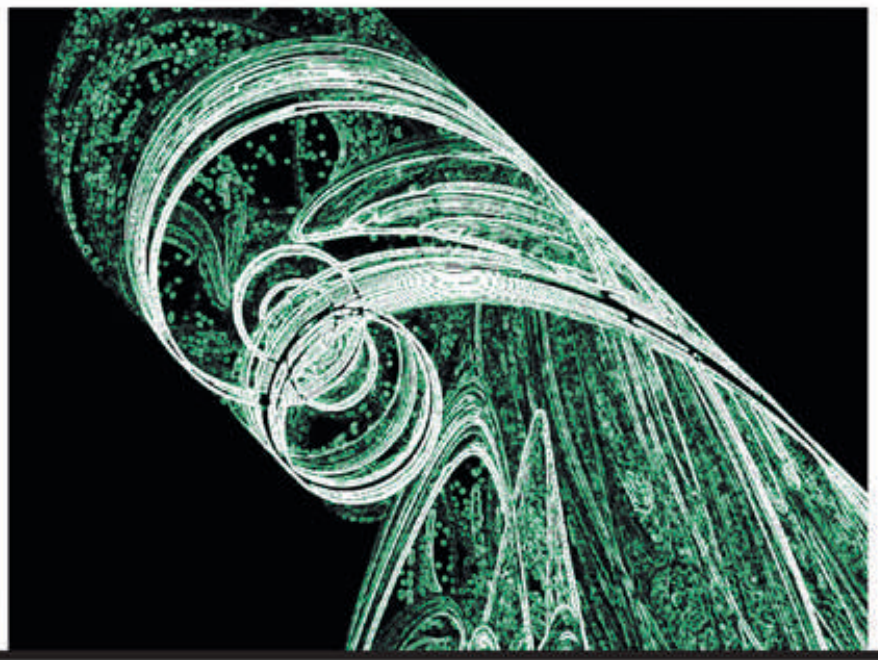


Zbigniew Tucholski

\section{Polish State Railways as a Mode of Transport for Troops of the Warsaw Pact}

The subject of the book is the history of the planned use of Polish railway infrastructure during the Cold War as part of the strategic plans of the Warsaw Pact. Analysing both technical and operational issues related to railway military transportation in a historical perspective, the book presents the history of the military transportation service of the Polish Army and provides a detailed characteristics of the organizational structure, equipment and tasks of the military transportation units and railway troops. The book also deals with rail transports of the Soviet Army on the Polish State Railways. It is not only the result of archival queries and interviews with retired officers of the military transportation service but also field research of railway infrastructure.

The Author

Zbigniew Tucholski, Ph.D., is a professor at the Institute of History of Science of the Polish Academy of Science, a technical historian, specialised in the history of railways, transportation, industry and military technology, and the preservation of transport infrastructure and architecture heritage. 
Polish State Railways as a Mode of Transport for Troops of the Warsaw Pact 


\section{GESCHICHTE - ERINNERUNG - POLITIK STUDIES IN HISTORY, MEMORY AND POLITICS}

Edited by Anna Wolff-Powęska \& Piotr Forecki

\section{Volume 35}

\section{PETER LANG}


Zbigniew Tucholski

\title{
Polish State Railways as a Mode of Transport for Troops of the Warsaw Pact
}

\author{
Technology in Service of a Doctrine
}

Translated by Marek Ciesielski

\section{PETER LANG}




\section{Bibliographic Information published by the Deutsche Nationalbibliothek}

The Deutsche Nationalbibliothek lists this publication in the Deutsche Nationalbibliografie; detailed bibliographic data is available in the internet at http://dnb.d-nb.de.

\section{Library of Congress Cataloging-in-Publication Data}

A CIP catalog record for this book has been applied for at the Library of Congress.

The Publication was funded by the Ministry of Science and Higher Education of the Republic of Poland as part of the National Programme for the Development of Humanities in the years 2017-2020 (project no. 21H 170259 85).

\section{DA national programme FOR THE DEVELOPMENT OF HUMANITIES}

Cover illustration courtesy of Benjamin Ben Chaim.

Printed by CPI books GmbH, Leck

ISSN 2191-3528

ISBN 978-3-631-81829-9 (Print)

E-ISBN 978-3-631-82965-3 (E-PDF)

E-ISBN 978-3-631-82966-0 (EPUB)

E-ISBN 978-3-631-82967-7 (MOBI)

DOI $10.3726 / \mathrm{b} 17291$

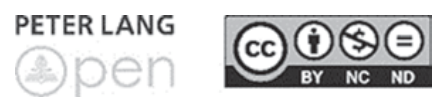

Open Access: This work is licensed under a Creative Commons Attribution NonCommercial NoDerivatives 4.0 unported license. To view a copy of this license, visit https://creativecommons.org/licenses/by-nc-nd/4.0/

(c) Zbigniew Tucholski, 2020

Peter Lang - Berlin · Bern · Bruxelles · New York · Oxford · Warszawa · Wien This publication has been peer reviewed.

www.peterlang.com 


\section{Table of contents}

INTRODUCTION 9

\section{DEVELOPING THE CONCEPT OF} MILITARY RAILWAY USE

2. RED ARMY MILITARY TRANSPORT IN THE FINAL STAGES OF THE SECOND WORLD WAR - TRANSPORTBASED SECURITY OF THE RED ARMY OPERATIONS IN BELARUS AND THE VISTULA-AND-ODRA REGION

3. RECONSTRUCTING, ORGANISING, AND DEVELOPING THE HEADQUARTERS OF MILITARY TRANSPORT IN THE YEARS 1944-1962 ………………………………………….. 55

3.1 Department of Military transport, Military District Command

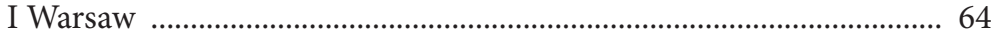

3.2 Reconstruction of Railway Units ............................................................ 66

3.2.1 The 5th Railway Troops Battalion in Darłowo ............................. 70

3.2.2 3rd Railway Troops Battalion in Pikulice near Przemyśl ............ 73

3.2.3 7th Railway Troops Battalion in Września .................................... 77

4. PREPARING THE POLISH STATE RAILWAYS NETWORK FOR A MILITARY CONFLICT AS PART OF WARSAW PACT STRATEGIC PLANS 83

4.1 Securing Transport for the Frontline Offensive Campaign .............. 142

4.2 Evacuation of the Wounded ................................................................. 159

4.2.1 Temporary Transhipment Areas ................................................... 166

4.2.2 Organisational Structure of Military Transport on the Frontline 
4.2.3 Organising Technical Protection for the Frontline Railway Network

4.3 Destruction of Railway Lines, Stations, Facilities and Rolling Stock 183

4.3.1 Bridge Destruction .................................................................. 198

4.3.2 Bridge Mining ................................................................................ 203

4.4 Temporary Reconstruction (Construction) of Railway Lines .......... 204 4.4.1 Reconstruction of Water Supply Facilities .................................. 209

4.4.2 Reconstruction of Buildings Indispensable to Railway Traffic . 210

4.4.3 Reconstruction of Railway Signalling Devices ........................... 210

4.4.4 Temporary Bridge Reconstruction ............................................. 213

4.5 Folding Railway Bridges ....................................................................... 217

4.6 Railway Bridge Crossings Built by the Road and Railway Units of the Polish Armed Forces as part of the Warsaw Pact Military Exercises and Performing Tasks to Support the National Economy

5.1 Military Transports - Typology ........................................................ 245

5.1.1 Military Rail Transport ............................................................... 245

5.1.2 Anti-Aircraft Defence of Military Transports ............................. 251

5.1.3 Anti-Tank Defence of Military Transports ................................. 253

5.1.4 Safeguarding the Confidentiality of Transports ......................... 254

5.1.5 Rolling Stock used for Military transport Purposes .................... 255

5.1.6 Loading Areas, Stations, and Sites; Loading Devices .................. 268

5.2 Transporting Soviet Army Troops in Transit by the Polish State Railways ......................................................................................... 279

5.3 Transports for Soviet Army Troops Stationed in Poland .................... 283

\section{MILITARY RAILWAY SIDINGS AND}

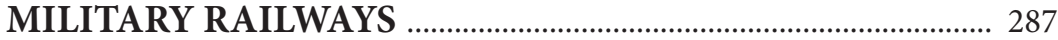

6.1 Military narrow-gauge railways ............................................................ 302 
6.1.1 Military siding no. 289 Hrubieszów (Hrubieszów narrowgauge railway)

6.1.2 Narrow-gauge military railway at the Field Artillery Research Centre in Zielonka (military siding No. 182) and standard-gauge siding No. 127

6.1.3 Rolling stock

6.1.4 Narrow-gauge $600 \mathrm{~mm}$ railway on the Hel peninsula (military siding No. 582)

6.1.5 Narrow-gauge $600 \mathrm{~mm}$ military railway Gdynia-Port Wojenny Oksywie, (military siding No. 581) JW 3643 Gdynia Port-Oksywie, siding No. 407

6.1.6 Military railway Świnoujście, military siding No. 881 (600 mm)

6.1.7 Military siding No. 181, JW 1540 Nowe Miasto and sidings for fuel re-pumping station in Piaseczno No. 101/183 (standard- and narrow-gauge)

6.1.8 Military siding in Zegrze Pomorskie and fuel re-pumping point siding in Koszalin 356

6.1.9 Military siding JW 4420 No. 180 (Mława narrow-gauge railway) 357

6.2 Military rolling stock 361

6.2.1 Locomotives 361

6.2.2 Wagon and special rolling stock 385

6.2.3 Management of military rolling stock 387

6.2.4 Road trailers for wagon transport 397

6.2.5 Narrow-gauge military tank wagons of the Ministry of National Defence 400 409 
Zbigniew Tucholski - 978-3-631-82966-0 Downloaded from PubFactory at 09/30/2020 04:51:29PM by keerthiga.m@newgen.co via Peter Lang AG and keerthiga.m@newgen.co 


\section{INTRODUCTION}

The phrase military transport first appeared in Polish military vocabulary in the late 1920s, when the Polish Armed Forces extended the existing scope of tasks of the Railway Division of the General Staff to include other modes of transport for military use, as part of an exercise aimed at re-organising its quartermaster services (to the French army model). In 1928, Headquarters for Military Transport were established as part of the General Staff. ${ }^{1}$

According to one definition, the phrase military transport shall apply to all of the following items: ${ }^{2}$

- Military forms of transport and communication (fixed and mobile) used in any organised process of moving (transferring) and carrying troops and military supplies.

- Organisational and technical ventures associated with the handling of military transport and ensuring the viability of the transport network in use during such ventures.

- Military transport service bodies responsible for the management and control of any process involving such ventures.

- Military transport units reporting to aforementioned bodies.

- Militarised bodies and units (formations) of civilian transport divisions and local forces reporting to the aforementioned bodies operationally.

Another definition of military transport references the actual communication system, which comprises a network of mutually connected roads, military transport units deployed along them, together with assorted military transport formations. ${ }^{3}$

Once thus defined, the scope of the phrase blatantly includes all modes of land and air transport employed to move troops, equipment and supplies, as well as other related matters. In this work, I have decided to limit the scope of the phrase to the issues of military use of rail transport, essentially restricting it to the operational use of the Polish State Railways network as a mode of transport for the Warsaw Pact troops.

1 Mioduszewski (1974) 1/134, 155.

2 Ministry of National Defence, Transport Command, 33/64, Komunikacja wojskowa (1965), 20.

3 Mała encyklopedia wojskowa, Vol. 2 (1970), 73. 
The fundamental purpose of this work is to present the history of the Headquarters of Military Transport of the Polish Armed Forces and of the railway units involved, and to analyse all technical issues tying in with military transport from a historical perspective. I took on a task of no lesser importance: that of describing the planned operational use of railway infrastructure on the Polish territory along the Western and Coastal Operational Directions as part of the strategic plans drafted by the parties to the Warsaw Pact.

In addition, my intention was also to create a detailed portrayal of the organisational structure and missions (during warfare and times of peace alike) of military transport bodies and railway troops, and strategic post-war use of railway transport. The narrative describing the transport of Red Army forces (operational transport and supplies) with the use of the Polish State Railways network was of no lesser importance.

Chronologically, the work spans the period of 1944-1960. The timeframe identified for the purposes of the project ties in closely with the fact that in the late 1950s, following a reduction to the armed forces, railway battalions were reformed into railway regiments, their purpose and organisational structure duly changed. For the Headquarters of Military Transport 1962 became the fundamental watershed: this was when railway transport units were integrated with the road service. In November 1962, the Headquarters of Military Transport of the General Staff of the Polish Armed Forces merged with the 15th Division of the General Staff of the Polish Armed Forces and the Headquarters of Military Transport of the Ministry of National Defence was formed. Due to the interconnectivity of technical matters associated with the preparation of the Polish State Railways network for warfare (requiring a more comprehensive approach), I described the issue up to and including the year 1990. If considered only up until 1962, the account would not have shown the size or importance of comprehensive investments on the Polish railway network.

In analysing significant investments on the Polish State Railways network, one cannot help but ask an undermining question concerning the effectiveness of the techniques used, and the organisation of military rail transport in times of a planned conflict. The usability of infrastructure developed for military purposes, as well as matters concerned with its potential use in times of peace following the Cold War, are also of vital interest. I attempted to answer these questions in individual chapters.

Considerable difficulties were encountered at the stage of collecting source material for this work, due among other things to the fact that the majority of archival materials regarding military transport have until recently been considered classified. Furthermore, given the orders to dispose of documentation 
describing operational and mobilisation exercises as well as technical documents, a considerable part of all resources has been completely destroyed. At the stage of gathering materials for the purpose of this work, it was found that only the very basic military transport service files from the 1970s and 1980s had been preserved at the Ministry of Defence Central Archives in Modlin. Additionally, issues connected with post-1945 military transports were shrouded in secrecy, which is why the few existing materials were published as classified military instructions, or as articles in restricted-access military journals of the time, such as Przeglad Kwatermistrzowski.

Reference sources for this study include technical and operational military and railway files, technical documentation related to rolling stock used for military transport, track layout plans for railway stations, military sidings, transfer routes and transhipment areas; assorted regulations and service instructions related to military transports, as well as the destruction and reconstruction of temporary and permanent railway lines (both military and civilian).

When compiling the reference list I only included the most important sources and studies.

Vital items include an extraordinarily extensive in-house study by Colonel Marian Gembora titled Wojska kolejowe, preserved at the Library of the Military Bureau for Historical Research, as well as a largely forgotten work by Captain Ryszard Strózik, Wojska kolejowe 1944-1946, [The Railway Military 1944-1946], (Master thesis under Professor Stanisław Herbst at the Department of History at Political-Military Academy) Military Office of Historical Research Archive (Military Office of Historical Research Archive), which describes the organisation and military activities of the military transport service of the 1st and 2 nd Polish Armies. Interesting items depicting the organisational structure of the military transport service include a study by the Head of Staff of the Military Transport Service of the Chief Quartermaster of the Polish Armed Forces, titled Zarys historii Szefostwa Stużby Komunikacji Wojskowej (unpublished). A valuable reference source for the description of tactical, organisational and technical matters related to warfare ("W") military transport has been provided by a Ministry of Defence Manual, Chief of Transport 33/64, Komunikacja wojskowa, Warsaw 1965.

A double-volume collective work published by the Ministry of Transport (Odbudowa mostów kolejowych, Stalowe konstrukcje składane), [Reconstruction of Railway bridges - Folding Structures], Part I, Warsaw 1966, Part II, Warsaw 1968 was the fundamental source used for the purposes of describing the structure of post-war military folding bridge facilities. A collective work titled Żheleznodorozhniki v velikoy otchestvennoy voyne, Moscow 1987, was an 
extremely interesting reference source. This is a collection of reports filed by the people involved in the Red Army railway units. Once Soviet propaganda is set aside, it is possible to use the information contained therein. In describing the system of backup crossings of the River Odra prepared for warfare I have also used the information provided by A. Kuhlmann in his study Eisenbahnen über die Oder-Neiße-Grenze, (Pürgen, 2004).

In describing the body of reference sources, one cannot fail to mention the only Polish publication discussing the military transport activities over the centuries by Professor Eugeniusz Nowak: Komunikacje i wojna, (Warsaw, 1994).

My heartiest words of thanks go to the following persons for their invaluable help and support in gathering materials and providing reviews for this work: Colonel Wiesław Bogdański, Head of the Department of Transport and Military Movement, Co-ordination Centre for the Movement of Troops; in addition, I would like to thank Lieutenant Colonel Kazimierz Balog and Professor of Engineering Henryk Bałuch, Ph. D. Hab., designer and supervisor of the Medyka transfer transhipment station and the M (Medyka) Permanent Transfer Transhipment Area in the 1950s, for their assistance in writing this work and helpful accounts; Jerzy Brych, M.Sc. Eng., former Deputy Director of the Lublin Regional State Railway Management, Wojciech Dembiński, M.Sc. Eng., Colonel Aleksander Jakimczuk, Colonel Jerzy Jarzyna, lecturer at the Faculty of Engineering of the Military University of Technology, Maciej Kucharski, M.Sc. Eng., Colonel Wacław Kuzak, retired Head of the Field Division of the Military Institute of Armament Technology (Military Institute of Armament Technology) in Zielonka, Colonel Jerzy Maj, retired Head of the Department of Military Transfer at the Regional State Railway Management in Warsaw, Aleksander Matecki, retired controller at the Regional State Railway Management in Warsaw, Bogdan Pokropiński, retired locomotive driver of the Warszawa Praga mainline locomotive depot, Krzysztof Soida M.Sc. Eng., Lieutenant Commander Stefaniak - employee of the Board of Naval Logistics in Gdynia, Jan Szponder, Colonel Józef Szwajk - former commander of the 2nd Railway Regiment in Inowrocław, Artur Weber, Colonel Jacek Wyszyński - employee of the Military Office of the Ministry for Infrastructure, and Major Jerzy Zieliński, retired Head of the Section for Internal Transport and Railways of the Institute of Military Armament Technology.

I would like to thank the following for their kindness and assistance: supervisor of my thesis Associate Professor Edward Malak, Ph.D. Hab, Professor Bolesław Orłowski, Ph.D. Hab., and Professor Leszek Zasztowt, Ph. D. Hab. 


\section{DEVELOPING THE CONCEPT OF MILITARY RAILWAY USE}

A proper description of the complex circumstances of developing the railway network in Poland requires an indispensable reference to the early use of the railways by the military.

For the first time in history, troops were carried by rail during the Palatine Uprising of $1849^{4}$, and - that same year - during the German expedition to Schleswig. Ten years later, in 1859, the French and English were already making use of rail transport. During the American Civil War, Americans carried troops by rail on a major scale. In 1866, Austrians were the first to make strategic use of this mode of transport, moving 100,000 people from Custozza to the German Front, and thus covering $700 \mathrm{~km}$ in 12 days. ${ }^{5}$

In 1851 Russian military authorities developed their first guidelines for the movement of troops by rail: Przepisy o przewozie kawalerii po PetersburskoMoskiewskiej Kolei Żelaznej [Regulations of Moving Cavalry by the PetersburgMoscow Railway], while on November 24th 1851, the Russian Ministry of War issued its first directive on the use of railways for the purposes of transferring troops. ${ }^{6}$

The progressive development of railways is connected with the 19th-century industrialisation, making it a crucial mode of transport, which was of utmost importance to the success of both individual operations and entire campaigns. In the wake of the Franco-Prussian War of 1870-71, the importance of rail transport was duly noted by the General Staff of almost all major European nations. Prussia owed its military success in the 1870 war to the efficient mobilisation and shipment of its armed forces, most certainly assisted by the strategic railway network which had at the time been under expansion in Prussia for quite a time already: Field Marshal Helmut von Moltke’s Prussian war doctrine provided for the expansion of a dense rail network, including technical infrastructure to serve the purposes of mass mobilisation and operational transfer. The efficiency of Prussia's transport system enabled swift completion of all mobilisation exercises, as well as full combat readiness three weeks ahead of the Russians.

4 Owsińska (1965), 79.

5 Koleje żelazne (1919), 4.

6 Strózik, Wojska kolejowe 1944-1946, M.A. thesis, Military Office of Historical Research Archive, Ref. No. 1036, 4. 
Geopolitical conditions determined the main directions of military movement to the west and east, across the territories lost by Poland as a result of partitioning upon the loss of its independence. Moreover, the highest concentration of fortifications in Europe clearly points to the operational importance of the Polish territory. In the 19th century, strategic crossings were fortified on major rivers at the following locations: Warszawa, Dęblin, Modlin, Toruń, Grudziądz, and Poznań. Furthermore, Russian and Prussian systems of centralised fortifications and ring fortresses (brought about by extensions to the artillery range and the invention of smokeless gunpowder after 1870) were developed on Polish territory in the late 19th century, serving identical operational purposes.

Within the Kingdom, the network of fortress roads connecting specific fortifications and points of resistance was also expanded in the 19th century.

Different concepts for the operational use of railway transport laid out by the partitioning powers became a lead factor in determining the development of the railway network on the Polish land.

In Poland under partitions, road and rail networks were constructed and operated in conformity to the operational plans drafted by the General Staffs of Prussia, Russia and Austria-Hungary. Consequently, due to the growing importance of railways to the military, from the mid-19th century onwards, the development of the railway network was largely determined by military goals. Nonetheless, the partitioning powers followed separate railway-related policies, appropriately adapted to the binding war doctrines of the time.

Railway construction in Imperial Russia was largely determined by strategic considerations. New railway routes, particularly those stretching across the River Vistula and into the pre-frontier area of the Vistula Country, were perceived as a significant strategic threat - ample proof that an extensive rail network would allow the enemy to attack swiftly and dislocate troops.

Construction of new railway lines (particularly in the western part of the Empire) was strictly controlled by the state and dependent on approval by the Department of Military Transport of the Russian General Staff, upon which the Ministry of Railways could issue a licence for the construction and operation of every single narrow-gauge or industrial line, even if tertiary in importance.

The Russo-Turkish War of 1877-1878 exposed the shortcomings of the Russian railway system, the direct cause of the Sevastopol defeat. The mobilisation capacity of the Prussian army was far greater than that of the Russian army already in the 1880s, due to the expansion of the Prussian railway network. In view of such a state of affairs, Minister of War General Dimitri Milutin decided to abandon the "wilderness strategy" in favour of railway network development, the move to a certain degree changing the Russian military doctrine. Nonetheless, 
a significant number of conservative Russian generals continued to favour the already outdated strategic concepts of Kutuzov and Suvorov. The new military doctrine became the main reason behind the changes to the Russian railwayrelated policies. A decision was made to restore the concept of construction of railway lines by the state, leading to a rush of railway line purchases from private owners at significant loss to the state treasury. In the early 20th century, twothirds of the railway network in European Russia were state-owned, strict state controls having been extended on the operation of lines in joint-stock control.

The weakness of the Russian rail transport, the Trans-Siberian railway in particular (efforts to increase the capacity of the line went as far as to setting up a special-purpose railway ferry across the Lake Baikal), was one of the main reasons for Imperial Russia’s defeat in the Russo-Japanese War.

Prior to the outbreak of the Great War, Russia developed a system of seven front-bound railway lines heading for the German border, their total capacity reaching 223 train pairs per day. The solution secured a mere 0.25 of train passage per day per frontline kilometre. Nine lines heading for the Austro-Hungarian border were routed (five double-track and four single-track lines). Their total capacity reached no more than 260 train pairs per day, securing the passage of a mere 0.4 of train per day per frontline kilometre. ${ }^{7}$ In the late 19th century, a system of low-density parallel lines was also developed in the European part of Russia and across Polish territory.

Efforts to expand the capacity of Russian railways immediately prior to the Great War took a wrong turn. No railway network to support the military was built (having been restricted to the network developed in late 19th century with no attention paid to the improvement of the organisation of railway traffic): Prior to the Great War, the Russian Staff failed to predict that warfare against Germany would be a largely railway-based war, dozens of corps being moved from one area to another for strategic purposes, sometimes across hundreds of kilometres. According to the view of the General Staff, the strategic network was mainly to consist of high-capacity mainlines designed to move troops in the shortest possible time from inland governorates to the venues of concentration. ${ }^{8}$

As the new mode of transport - the railway - developed and expanded, General Staffs of partitioning powers drafted railway policies according to their specific operational plans.

7 Nowak (1994), 35.

8 Gawroński (1930), 7. 
According to Russian military doctrine, the main theatre of war would extend along the western border of the Empire, from the Baltic Sea to the Carpathian Mountains. Such strategists assumed a specific division of the theatre of war into the following regions: the centre (near the River Vistula), the north (the Baltic Sea and Polesie region), and the south (between the Polesie region and the Carpathian Mountains). Polesie was to serve as a divide between the regions; given the Polesie marshlands, it was assumed that the area would form a natural barrier. The Vistula region incorporated the area of the Kingdom forming a major outcrop, its flanks occupied by Prussia and Austria. It was bordered by Rivers Narew and Biebrza to the north, by the River Vistula to the west, and by the San River basin to the south.

The Russian military doctrine assumed that the Vistula Country would serve as the defence boundary to the west, safeguarding the mobilisation and concentration of troops, and become a foundation, as it were, for the Russian armed forces' development on the future Western Front (with a planned strike by the Russians towards Vienna and Berlin). The area of the Kingdom (40\% of the entire future front) was to become a major mobilisation and logistical centre for the Russian army. Last but not least, the first line of Class One fortresses intended to defend the western borders of the Empire had been expanded in the early 19 th century. Consequently, the area featured considerable saturation of military infrastructure: well-developed systems of Russian fortifications warranted the protection for Russian troops' concentration in the Kingdom, the concept was followed consistently. ${ }^{9}$ As early as in the post-1915 period, the Russian General Staff decided to fortify the river crossings - in order to expand the Modlin Fortress and construct new fortifications in Warszawa and Dęblin.

Planning to carry out defence operations in such a way as to avoid providing the enemy with a favourable technical and logistics base, the Russian General Staff restricted railway construction projects on the territory of the Kingdom from the 1880s.

On the other hand, the Prussian military powers advocated an offensive railway strategy, supporting the intensive expansion of the railway network to establish a dense transport system. The goal was even supported by a specialpurpose law allowing the construction of private and self-operated local government railways: the Prussian General Staff planned for offensive railway use on enemy territory, including swift construction of temporary trench railway lines

9 Militaria polskich formacji... (1989). 
(standard- and narrow-gauge) aligned with the planned offensive directions, all works to be performed by specialist railway engineering battalions.

Prior to the outbreak of the Great War a system of thirteen double-track main lines was constructed in Germany, leading from the country's western borders towards the borders with Russia. The main line's general capacity reached 660 train pairs per day (an average of 1.8 trains per day per frontline kilometre). Ten lines were developed along the main direction of the German army attack, stretching over a distance of $160 \mathrm{~km} .{ }^{10}$ The frontline routes: Strasbourg - Stuttgart Nuremberg - Prague - Częstochowa (including the parallel Nuremberg Wrocław section), and Ulm - Munich - Vienna - Kraków crossed into Prussia and Austria-Hungary, the development arising from close co-operation between the two countries in the field of wartime operational use of the railway system. A system of high-density parallel lines was also developed in the first zone of future frontline railways, right on the Prussian - Russian border. Intense efforts to develop the railway infrastructure were also made in East Prussia, with intent to regroup and assemble troops prior to the planned flanking strike into the Russian territory.

Several years prior to the outbreak of the First World War Jan Bloch, the author of Przyszła wojna [The Future War], had emphasised the importance of Field Marshal Helmut von Moltke's operational plan, which assumed a largescale use of rail transport: "The Germans will initially decide to hurl all their might upon one of their opponents, and, once that opponent's resistance is crushed, to transfer their main forces onto the second theatre of war by rail."11 These predictions were confirmed in the course of the war in the western theatre. Bloch had also predicted the future positional nature of the war, a bold theory at the time, vastly differing from the beliefs of the majority of contemporaneous military theorists. ${ }^{12}$ "The future war - shall mostly involve a series of battles fought around defensive positions [...] practice will show that the party with the more resilient army and population, and greater means to wage the war, will come out victorious, in this respect - favourable defence conditions shall prove more important than those for attacking." ${ }^{13}$

During the First World War, the majority of operational and supply transports were performed by rail, its technical condition and carriage capacity were of key

10 Nowak (1994), 33-34.

11 Bloch (1900), vol. I, 73.

12 Wyszczelski (2001), 133.

13 Bloch (1900), vol. II, 543-546. 
importance to success at any given frontline section. Bearing in mind the nature of military transport, the First World War would ultimately be dubbed "the railway war." ${ }^{14}$ During this large-scale conflict railway military units developed wartime railway lines (standard- and narrow-gauge alike) for the purposes of operational transfers and supplies delivery to the troops in combat.

During this conflict, the development of military road transport began as well. Road transport served the purpose of moving troops, weapons and supplies directly to the frontline. In 1916 French troops managed to hold Verdun only thanks to the well-developed road network and a large number of heavy vehicles. When the German army broke through the railway lines from Verdun to Paris and Toul, the French army replaced rail transport with road transport.

At the end of the First World War an unprecedented number of troops was being moved by rail over a short period of time.

During the German offensive of March 21st 1918, when the British front was broken through near St. Quentin, it took ten days to move French reserve divisions to an under-fire section with the use of 1,376 operational transports (plus the transports used to forward supplies). ${ }^{15}$

The dubious Austrian railway policy adversely affected the construction and operation of railways in Galicia. Several shifts from private to public ownership had a negative impact on the development of the railway network. The density of the inconsistently developed Galician railways was only increased in the late 19th century once the development of the two strategically important lines began, both heading for the Russian border: the Karl Ludwig line connecting Cracow to Lviv via Przemyśl and further on to the Austrian-Russian and Austrian-Romanian borders, and a parallel line running at the foot of the Carpathian Mountains: the so-called Transversal Railway. ${ }^{16}$

A system of seven frontal railway lines (two double-track and five single-track lines) was extended on the Austro-Hungarian territory all heading for the border with Russia as the Empire's main adversary. The overall capacity of these lines reached a mere 153 pairs of trains per day, which enabled the passage of 0.22 trains per day per frontline kilometre. ${ }^{17}$

14 Bloch (1900), vol.II, 7.

15 Sikorski (1984).

16 Wielopolski (1969), 62.

17 Nowak (1994), 35. 
Austria also followed an offensive railway strategy, although - given its economic and technical restraints - it was unable to develop a railway network matching the Prussian one in expansiveness.

Once Poland regained its independence significant efforts were made during the inter-war period to integrate the three railway networks taken over from the former invaders, and establish a single uniform transport system (as the country held a combination of terminal sections of the rail networks set up by the three occupants ${ }^{18}$ ). Due to financial and technical limitations, a minimum programme of adjusting the railway system to military requirements was approved. Connecting the Warsaw-Berlin mainline with a newly built Kutno Strzałkowo railway line, and the contemporaneous development of the HerbyGdynia coal mainline built by the French-Polish Railway Society were of key importance to the Polish raison detat, for economic as well as military reasons. During the inter-war period, action was taken to prepare the railway network for the times of war - yet a bare minimum of investments was carried out due to financial constraints. The course of the September campaign served to prove that in its initial stages, both the railway troops and the militarised Polish State Railways fulfilled their roles correctly. The railway lines were destroyed in border regions; wherever the enemy had destroyed stations or junctions, rail traffic was maintained thanks to the provisional reconstruction of the surface infrastructure and installation of signalling devices in order to maintain railway traffic. Yet ever-more intense bombing and organisational chaos resulted in a quick paralysis of the mainline railway traffic. ${ }^{19}$

Leaders of the Soviet Russia also recognised the importance of railway transport. Russia's railway network was poorly developed, especially in the east. The catastrophic technical state of the railways, equipment and rolling stock in Russia as a result of the First World War and of the Revolution made operational movement of troops largely difficult. The extent of the pre-Revolution decline of the Russian railways is best proven by the following telegram: "A Telegram to the Head of the Board of the South-East Railway and the Director of the Ministry of Transport from the stationmaster of Samodurovka station. On train the No. 28 that arrived to cross with the train No. 3, there were 15 carriages with soldiers, when it came to an intersection with train No. 3. When the train stopped, the

18 Nowak (1994), 52.

19 An example of this was the Warsaw - Poznań line, following the destruction of the important Kutno station, military railway transport and evacuation trains were totally paralysed. 
soldiers surrounded me and demanded that I dispatch them immediately while apprehending the train No. 3 which was approaching me already. Upon arrival of the train No.3, they demanded that its steam engine be uncoupled from the mail train and coupled to their train. After I explained that I could not leave the mail train without an engine, they threatened me by saying that they would deal with me. I only managed to convince them by explaining that the engine uncoupled from the train No. 3 would be running backwards, reducing their speed of travel even further. Once they understood it, the soldiers grabbed me and led me to the steam engine of the train No. 28 , threatening the driver that they would throw him into the firebox if he did not go faster. Most of the discharged [soldiers] were drunk. The work is impossible and life-threatening under such conditions; please take action to protect me from such wilfulness; trains with discharged troops should be escorted by reinforced patrols - signed, Dorokhov." ${ }^{20}$

The decapitalisation of Russian railways had also resulted from the implementation of the Leninist grab nagrablonnoye [steal the stolen!] slogan, leading to the destruction of rolling stock, railway equipment, and railway property to an extent never witnessed before. The technical and transport capacity of the Russian railways was also diminished due to the shortage of skilled staff, brought about by wartime and Revolution-related losses, and the demoralisation of Russian railwaymen. All these factors contributed to the Soviet railways being plunged into chaos and corruption. It was fully realised that victory in a world revolution depended upon a properly functioning rail transport and its carrying capacity. As part of the effort to rebuild an effective transport system, Felix Dzerzhinsky was appointed Chief of Railways. The head of the Cheka quickly intimidated railwaymen with executions and repression, introducing something of a proprietary order to the Soviet railways. His excellent organisational skills were soon proven, allowing a transformation of the Soviet railways into a wellrun, totally militarised enterprise. The tsarist engineers and railway experts were put to work during the implementation of a long-term plan to modernise the Soviet railways.

The 1930s saw the implementation of the Soviet General Staff doctrine, pursuant to which the start of a war was tantamount to moving the economy onto war footing. One element of the Stalinist plan to industrialise (militarise) the entire country involved the total militarisation of railways (with military ranks introduced for railway staff). Modern rolling stock was developed in Russia at the time (a case in point involving the construction of FD and IS locomotives,

20 Gołowin (2006), 363-364. 
mainly to American designs), with electric and diesel traction brought in alongside efforts to modernise the infrastructure, signalling, permanent way and station track layouts. ${ }^{21}$

It should be noted that projects to modernise the railways involved numerous innovative technical solutions and designs for the construction of bridges and rolling stock adopted from the Americans. In the 1930s, such tendencies included the appropriation of guidelines of the American school of locomotive construction; consequently, American locomotives were in principle adapted for the purposes of Soviet railways with no major changes. Regardless of regular intelligence missions, "white intelligence" was also carried out in the field of most recent scientific and technical literature; in the 1930s all novelties in American literature on railway technology were translated into the Russian language, one example including the Moscow-based State Rail Transport Publishing House publishing in 1935 the Russian translation of a volume on the traction economy from the American railway encyclopaedia. ${ }^{22}$ American sources had major impact on the design work by Russian railway engineers.

However, broad range of activities notwithstanding, the density of the rail network was not increased to any significant extent. The insufficiently developed Russian railway network - a legacy of the defensive military politics of the Tsarist General Staff - made it very difficult to deliver supplies to the advancing German army during the last war. Nonetheless, the dire condition of roads meant that railway transport played a dominant role on the domestic front during the 194445 offensive.

In the mid-1930s, once Hitler came to power, railway modernisation and full militarisation began in Germany as well. After the war broke out, special kinds of military locomotives and wagons were developed (Kriegsdampflokomotive). This was also when major cutbacks were introduced for the use of non-ferrous and deficient materials employed in the railway sector. Notably, the importance of railway transport can be proven by the fact that the production of the rolling stock remained a priority up until the end of the war, together with the production of armaments.

While preparing to invade the USSR as part of an operation codenamed Otto, road and railway networks were expanded in Germany and across its newly

21 It is worth noting that Soviet Russia was the first country in the world to introduce mass welding technology for steel boilers in place of rivets, which had previously been most popular.

22 Tjagowoje chazjaistwo (1935). 
acquired territories. The main lines in the Reich and Poland (the Ostbahn) were modernised and expanded. As part of the efforts to carry out Operation Otto, large railway junctions together with a new Poznan Franowo marshalling yard were developed on the former Polish territory (along with a bypass and a number of connecting lines: Poznań Górczyn - Poznań Starołęka - Poznań Franowo - Swarzędz, Poznań Starołęka - Luboń, Poznań Franowo - Poznań Krzesiny, Poznań Franowo - Kobylnica), as well as the Łódź Olechów marshalling yard (along with an avoiding line Łódź Chojny - Łódź Olechów - Bedoń together with connecting lines); the following junctions and locomotive depots were expanded as well: Poznań Główna Osobowa, Poznań Franowo Towarowa, Toruń Kluczyki (one of the biggest locomotive depots in Poland, designed and built as a rectangular hall with an undercover traverser), Sierpc, Skierniewice, Skarżysko Kamienna, Dęblin, Pilawa, Łuków, Tłuszcz, Sędziszów, Suwałki, Czeremcha, Małaszewicze (pre-war Polish hangars at the Małaszewicze military airfield adapted for the purpose), Łazy, Szczakowa, Zbąszynek, Głogów, Chabówka, Żurawica, Przeworsk, Rozwadów, Nasielsk, Iłowo, Iława, and Łódź Olechów; a new depot was also built at Tomaszów Mazowiecki. ${ }^{23}$ As part of Operation Otto most railway stations were modernised and expanded along the east-west strategic lines and parallel lines.

Electromechanical (sliding) VES type signalling devices by Siemens \& Halske and Siemens electrically driven switches were installed as part of the process to modernise railway signalling devices and increase capacity of all lines at major stations.

On the eve of the German attack on the USSR, the German railways introduced an innovative method of organising and performing railway traffic with intent to increase the capacity of railway lines that had reached their limits when transporting the military and supplies. The so-called report boxes were set up at block posts; report boxes served as provisional separation check points and were fitted with wired railway communication telephones.

Pursuant to the armoured and air warfare doctrine (Fuller, Liddel Hart, Guderian, Douhet) developed over the 1930s, the efficiency of direct operational transport to the frontline would drop significantly. The motorisation of infantry and artillery units, development of armoured weaponry, and the increased ability to manoeuvre new units all meant that rail transport would be facing the

23 Within the preparations to invade the USSR the German Eastern Railways (Ostbahn) prepared a modern design of a large rectangular steam locomotive depot together with locomotive handling facilities as well as a design of a modern water tower. 
key task of supplying large amounts of ammunition, propellants and lubricants to the rear support units. In addition, railway lines in close proximity to military activities were exposed to damage due to aerial attacks; consequently, they would be basically taken out of operational use. Furthermore, the threat of small groups of sabotage guerrillas gave rise to the need for employing significant efforts to protect the railway lines. From that time on, the main task of railway transport involved the transfer of troops, equipment and supplies from the interior of the country to rear bases at the frontline, which was later proved by the experience of the Second World War.

Under operational plans of the Warsaw Pact, the Polish railway network was to be used for purposes of handling military and supply delivery transports along the Western (high-level operational reserves) and Coastal (regrouping of troops to protect naval landing operations) Operational Directions. The quickest route to Berlin led across Poland: ever since the early 19th century, both Germany and Russia had been investing in order to develop fortified (defensive) and transport (offensive) infrastructure. Transport by rail along the Western and Coastal Operational Directions to the rear of the frontline was only intended to serve the purposes of country-rear frontline transport of troops. The goal was supported through significant investment engaged in by the Polish State Railways as of the early 1950s. The railway network was undergoing modernisation and development at the time, railway lines and junction stations constructed to bypass the transport infrastructure that was impact-sensitive to conventional and nuclear weapons. Until 1956, total militarisation of the railways proceeded according to the Soviet model (the Polish State Railways had even introduced ranks resembling the military, insignia sewn onto shoulder pads). Such tendencies were also expressed in the official 1950s slogan of the Polish State Railways: "Traffic, transport, defence." In the late 1950s, once a new doctrine regarding the rear support operations in the event of a nuclear war was introduced, L-30, L-36 and REM500 folding bridges and the NZM-56 road-rail floating bridge were made part of equipment allocated to the railway military and Polish State Railways (reserve mobilisation units). Furthermore, preparations of the railway network for offensive front-end operations included the securing of appropriate technical infrastructure and rolling stock, all especially adapted for military transport purposes. 
Zbigniew Tucholski - 978-3-631-82966-0 Downloaded from PubFactory at 09/30/2020 04:51:29PM by keerthiga.m@newgen.co via Peter Lang AG and keerthiga.m@newgen.co 


\section{RED ARMY MILITARY TRANSPORT IN THE FINAL STAGES OF THE SECOND WORLD WAR - TRANSPORT-BASED SECURITY OF THE RED ARMY OPERATIONS IN BELARUS AND THE VISTULA-AND-ODRA REGION}

In July 1944, having crossed the River Bug, the Soviet Army entered the area between the Rivers Vistula, Bug, and Narew as a starting point for the offensive planned for 1945. At the operational level, the railway was the main mode of transport used by the Red Army to transfer troops and supplies to the frontline and army field bases. Direct supply deliveries from army bases to tactical frontline groups were handled by motor and horse-drawn vehicles. ${ }^{24}$ During the Second World War, the share of railway transport serving the Red Army in all forms of military transport reached $70 \%$. Due to the overall cargo volume, the military railway lines were stretched to absolute limits of transport capacity. ${ }^{25}$ The main railway directions and army base sections were outlined for attack zones of every frontline.

In order to secure the supplies for the Vistula-and-Odra and Berlin operations, one million tonnes of material resources had to be brought in over the course of each of the respective operations.

Throughout the war, the Red Army consumed 10 million tonnes of ammunition, 13.4 million tonnes of fuel, 40 million tonnes of food and around 12-15 million tonnes of other materials. All that was brought in from distant support facilities to an army in combat by rail, over a distance of many thousands of kilometres. ${ }^{26}$ Since Polish railway lines were of European track gauge $(1,435 \mathrm{~mm})$, the Soviet military authorities intended to convert the entire railway network on the Polish territory to the Russian gauge of $1,524 \mathrm{~mm}$. The project was abandoned in the course of planning and reconnaissance efforts to set up a new transport system for the future theatre of war. Such undertaking would have required a massive amount of technical and human resources; furthermore, the existing

24 Strózik, Wojska kolejowe 1944-1946, 21.

25 Antipenko (1970), 347.

26 Antipenko (1970), 348. 
standard-gauge rolling stock would have to be abandoned. The Polish railway network used a large variation of types of rails, many lines were built with metal sleepers, making it increasingly difficult to re-gauge the track. Furthermore, Polish railways followed different signalling systems and traffic regulations. Had the entire Polish railway network been converted to Russian gauge, the handover of large number of broad-gauge rolling stock to the Polish side would have had a negative impact on the efficiency and transport capacity of the Soviet railways. In case of proceeding with such a transformation of Polish railways, the Red Army operational units were to be charged with their operation, which would have left a sizeable number of Polish railwaymen without a job.

Consequently, representatives of the Lublin-based Department of Transport of the Polish Committee of National Liberation engaged in negotiations with the Soviet commanders and the Supreme Board of Military Transports with regard to the upholding of the standard gauge on the Polish railway network. The Polish party proceeded to convince the Soviet command that such a move would not be expedient. Jan Grubecki, M.Sc. Eng., Head of the Department of Transport and Postal and Telegraph Services of the Polish Committee of National Liberation handled all negotiations on behalf of the Department. ${ }^{27}$ These negotiations had some effect on the Russian leadership's decisions - ultimately, only the lines required for the delivery of supplies to the troops in combat were to be converted to the $1,524 \mathrm{~mm}$ gauge. On July 29th 1944, the Polish Committee of National Liberation resolved to agree to the partial re-gauging of railway lines on the liberated Polish territory for warfare purposes; the resolution intended to legally sanction the decision of the Red Army command. ${ }^{28}$

Tracks running in the direction of the River Vistula (in conformity to the overall direction of the offensive) were the first to be subject to conversion: Grodno Białystok - Warsaw, Vawkavysk - Czeremcha - Siedlce - Warszawa, ${ }^{29}$ Brest Łuków - Dęblin, Lubitovo -Kovel - Dorohusk - Chełm - Lublin - Dęblin, ${ }^{30}$ Pilawa - Otwock - Warszawa Praga, ${ }^{31}$ Lublin - Łuków - Siedlce, Rava

27 Zamkowska (1982), 65-75.

28 Zamkowska (1982), 41.

29 According to a report of Mr. Bogdan Pokropiński, a retired Warszawa Praga locomotive depot driver, on the Warszawa - Mińsk Maz. - Siedlce only one track was re-gauged, the standard gauge track remained disused.

30 On the Chełm - Dęblin stretch one track was regauged to $1524 \mathrm{~mm}$, traffic was retained on the second, standard-gauge track, Antipenko (1970), 227.

31 The Warsaw - Dęblin line was re-gauged together with the opening of the southern railway route. 
Ruska - Munina - Przeworsk - Rzeszów, and Munina - Przemyśl Gł. According to S. Zamkowska, as the frontline and support unit preparations proceeded, the Lublin - Klementowice ${ }^{32}$ and Lublin - Łuków $^{33}$ lines were also converted to broad-gauge.

The railway military developed a bypass of a destroyed railway tunnel, rather curious from the engineering perspective, on the 4th Ukrainian Front territory, with intent to allow the delivery of supplies for the troops entering Czechoslovakia. The circumstances of the project were the following: the Zagórz - Łupków Medzilaborce line crossing the Łupków Pass and connecting the Carpathian Mountains to Czechoslovakia was of great operational importance for 4th Ukrainian Front troops entering Czechoslovakia. An extension of the Lviv - Sambor Khyriv - Zagórz main line, it enabled the direct delivery of supplies and military equipment from the Russian interior. Meanwhile, the German troops blew up the railway tunnel in Łupków; they also destroyed in no small extent the $64 \mathrm{~km}$-long Zagórz - Łupków - Medzilaborce line.

The railway troops of the War Directorate for Railway Reconstruction No. 3 quickly rebuilt and reopened the line. Yet the tunnel in Łupków, forming a part of the line, was blown up along its central section (175 m long), its rapid reconstruction was not possible given the extent of damage and related technical difficulties. Therefore, it was decided to construct a $3.5 \mathrm{~km}$ detour across the so-called Carpathian Crest. The section - and the accompanying Pobyeda mid-station - were designed and planned by I. Ogoyev, M.Sc. Eng. The construction of a railway bypass for the destroyed tunnel required $70,200 \mathrm{~m}^{3}$ of earthworks and the development of 12 civil engineering structures, ${ }^{34}$ the incline of the detour route reached $38 \% .{ }^{35}$

Due to the extremely difficult nature of the detour, it became known as the "Devil's Loop." The detour was constructed by units of women and prisoners of war over a mere 20 days, and completed on December 4th 1944; railway traffic along the entire Zagórz - Medzilaborce line commenced on December 15th 1944. This is how a frontline railway connection opened up across the Carpathian Mountains, allowing supplies to be delivered to the 4th Ukrainian Front troops. ${ }^{36}$

32 It is most likely that the author obtained these documents (which were misinterpreted), describing a certain part of the works, because a conversion of the line only as far as Klementowice would not be based on rational reasoning. It is most probable that the entire Lublin-Dęblin section was re-gauged to broad-gauge.

33 Zamkowska (1982), 46.

34 Zheleznodorozhniki (1987), 303-304.

35 Kuczera (2007), 16.

36 Zheleznodorozhniki (1987), 303-304. 
Due to the technical and operational conditions of the detour line - the incline required trains to be re-assembled at the Pobyeda mid-station - the capacity of the Zagórz - Medzilaborce line was reduced to 8 train pairs (12 wagons per train). In the years 1945-1946, the tunnel was de-mined, all post-collapse earth and debris removed - on the Polish side, the tunnel length was reduced by approximately 50m. On November 7th 1946 rail traffic commenced through the reconstructed tunnel on the Zagórz - Medzilaborce line, which had previously been converted to standard gauge. ${ }^{37}$

At the same time - in the course of struggles for the Brest 1 railway junction a Guards Brigade of railway troops of the 1st Belarussian Front rebuilt the bridge over the River Bug in Brest. In the course of the related works, the work site had to be defended against the threat of an encircled assembly of German troops. The traffic across the reconstructed bridge recommenced on August 10th 1944..$^{38}$

The 1st Belarussian Front troops comprised War Directorates for Railway Reconstruction Nos. 1 and 20, which were charged with ensuring the safety of frontline railways reconstruction in the vicinity of the frontline operating along the Berlin direction. ${ }^{39}$

In order to secure military transports, the railway troops of the 1st Belarussian Front constructed railway bypasses of Lublin ${ }^{40}$, Dęblin" ${ }^{41}$ and Małkinia: ${ }^{42}$ "The bypass lines played a vital role. While railway junctions at Praga and Dęblin were under constant artillery fire, trains had to be continually available to carry out manoeuvres from one end of the front to another. With this in mind, troops at the front constructed a new 35km-long line, connecting Mińsk Mazowiecki and Pilawa railway stations, thus enabling an improved transfer in both directions between Warsaw and Lublin. I recall Marshall Zhukov's great satisfaction upon receiving these messages. He immediately handed over a full set of guidelines to

37 Kuczera (2007), 16.

38 Zheleznodorozhniki (1987), 297.

39 Zheleznodorozhniki (1987), 390.

40 This was probably a line bypassing the Lublin junction, connecting the Lublin - Łuków line to the Lublin - Rejowiec one.

41 This was probably the Życzyn - Stawy line, bypassing the Dęblin junction and connecting Dęblin - Pilawa to the Dęblin - Łuków line.

42 This was probably the Treblinka - Prostyń Bug rail link, which made it possible to travel to Małkinia or Tłuszcz, bypassing the destroyed bridge on the Małkinia - Treblinka section. Nonetheless, it cannot be ruled out that a rail link was installed to allow direct transfer from Białystok towards Ostrołęka, bypassing Małkinia. 
the Chief of Staff at the front, specifying additional manoeuvres and operational camouflage." 43

Railway troops on the First Belarussian Front included the following: the 1st Guardian Railway Brigade, the 29th Railway Brigade and the War Directorate for Railway Reconstruction No. 20 under the command of Major General N. Borisov. ${ }^{44}$

While one track on the Warszawa - Mińsk line was converted to broad gauge, the pre-war high-platform modernist stations were blown up, as they would not match the loading gauge of the broad-gauge rolling stock. This section was located at a distance of $12-20 \mathrm{~km}$ from the frontline head of enemy defences, whereas some rear units remained 4-6 km away; consequently, the organisation of train movements at the rear of the front had to be altered. ${ }^{45}$

Due to the close proximity of the enemy, the Rembertów junction - used as a bypass of the Warszawa Praga junction - gained considerable importance. The Russian railway troops constructed a strategic bypass for the Warszawa Praga junction in the vicinity of the junction in Rembertów. The works included the rebuilding of the Pilawa - Mińsk section, ${ }^{46}$ opened for traffic on December 15th 1944; ${ }^{47}$ the Wawer - Rembertów line was built (approximately $4 \mathrm{~km}$ in length), and commissioned on December 5th $1944 .{ }^{48}$

Pursuant to the December 21st 1944 directive of the Head of the Headquarters of Military Transport of the 1st Belarussian Front, the 1st Polish Army was positioned on the Mińsk Mazowiecki - Warszawa Praga line, between the stations Dębe Wielkie and Rembertów. The area entrusted to the 1st Polish

43 Antipenko (1970), 238-239.

44 Zheleznodorozhniki (1987), 296-297.

45 Strózik, Wojska kolejowe 1944-1946, 58.

46 The Mińsk Mazowiecki - Pilawa line was built in 1897, it handled also scheduled passenger traffic. In the 1930s official Polish State Railways documents it was described as closed; at that time the line was controlled by the Polish Armed Forces (the first paratrooper landings, destruction and rebuilding of engineering structures exercises were held there). This line was probably dismantled during the German occupation. Most probably, the construction of the strategic avoiding line of the Warszawa Praga junction described by General Antipenko only involved the laying of tracks on existing embankments. This line was most likely dismantled in the post-war period, and reconstructed again in 1970.

47 Strózik, Wojska kolejowe 1944-1946, 62.

48 Strózik, Wojska kolejowe 1944-1946, 62. The junction line was not in use after the war, but it was maintained until the 1980s as a strategic bypass of the Warsaw junction in the event of war. It was dismantled in the mid-nineties. 
Army comprised the following stations: Miłosna, Rembertów, and passenger halts: Sulejówek, Wola Grzybowska and Wesoła, as well as a siding post No. 14 in Rembertów (a branch of the military siding on the Rembertów - Wesoła line). The siding was accessible via a triangle from both directions: Rembertów and Wesoła. The depots of the 1st Polish Army (with excellent natural camouflage) were located at the former Wehrmacht armoured trains base (during the inter-war period the facility was held by the Polish Armed Forces). The operation of the Rembertów - Wesoła siding was rather difficult, as shunting on the siding was performed by line locomotives as there was no shunting locomotive available. The only watering point was located at the Miłosna station, and not an overly efficient one at that, ultimately requiring a four-hour interval before another locomotive could be watered again. Military trains were also routed on the way to the 47th Army and 3rd Assault Army across the 1st Polish Army base section area, from Rembertów to Tłuszcz via Zielonka. ${ }^{49}$

A. Kotow, one of the plenipotentiaries of the People's Commissariat for Railways and the Central Board of Military Transport at the Polish Railways Management established by the Polish Committee of National Liberation, who joined forces with a group of Soviet railwaymen to organise troop transports to the 1st Belarussian front via the main front-heading line (Brest - Łuków - Siedlce Warszawa), has included the following account in the work Zheleznodorozhniki $\mathrm{v}$ velikoy otechestvennoy voyne; my own translation follows: "During the preparations for the Warsaw - Poznań operation, the 1st Belarussian Front alone required over a thousand trains to reach the frontline, while the greatest capacity on the line allowed for the passage of 10-15 train pairs per day. For this reason, a 'live' block system ${ }^{50}$ was introduced on the line, allowing twice the number of trains to pass through. Another obstacle came up in the meantime: locomotives of the empty trains returning to Brest had to be coaled, while fuel storages at Łuków and Siedlce depots had insufficient coal resources. While coal was ultimately found at the coaling stages at the Warszawa Praga depot, it was separated from the enemy positions by the River Vistula. Provided with a favourable vantage point of the area, the Germans were able to open fire with great accuracy, which was why any daytime passage to the coaling stage was impossible. This was when the plan of operation 'Coal' was developed in collaboration with the

49 Wojska kolejowe 1944-1946, 62.

50 Live block system - a method of organising rail traffic particularly frequent on Soviet lines, involving people positioned at specified intervals along a railway line, using beacons as train signals. It allowed trains to be dispatched at several-minute intervals. 
military transport authorities. A group of railwaymen aboard a steam locomotive hauling five coal wagons and a crane reached the Warszawa Praga depot during night-time, and managed to load and transport 200 tonnes of coal until the following morning. The operation kept stretching out over time - ultimately, German artillery began firing at the coaling stage. Twelve railwaymen were killed and 32 injured at the time." 51

Other lines - secondary, tertiary, and local ones - on the Polish territory were retained as standard-gauge lines (the Polish railwaymen proceeded to take over standard-gauge lines from the Russian authorities one at a time, restoring them to traffic). The railway network was divided between the reactivated Regional State Railway Management.

The standard-gauge lines serving the Podkarpacie oil region (also earmarked for re-gauging) were of considerable strategic importance as well. Yet - while oil rigs were not fitted with storage tanks - the Soviet military had a large number of standard-gauge oil tankers at their disposal. This was why a decision was made to transport oil directly to refineries via the following standard-gauge lines: Stróże Jasło - Nowy Zagórz, Gorlice - Zagórzany, Rzeszów - Jasło - Dębica - Sobów Rozwadów, and using the single standard-gauge track on sections where the other track had been converted to 1,524 mm gauge: Rozwadów - Przeworsk, Dębica - Tarnów and Przemyśl - Przeworsk. ${ }^{52}$

As two different railway transport systems were operating using different track gauges, it was decided to implement field transhipment points at locations where standard-gauge and broad-gauge lines met. Twelve transfer points were built across the Lublin Regional State Railway Management's area: in Stawy, Dęblin, Lublin, Rejowiec, Chełm, Dorohusk, Rozwadów, Ozeta, ${ }^{53}$ Nisko, Zbydniów, Grębów, and Tarnobrzeg (the transfer capacity of these points ranging from 60 to 200 wagons per day). ${ }^{54}$ Identical transfer points were introduced on the Nasielsk - Działdowo line, and at Warszawa, Kutno, Barłogi and Poznań stations..$^{55}$ As re-gauging works proceeded in reflection of the westward shift of the frontline, the original points were decommissioned and new ones built on key railway sections directly flanking the front area.

51 Zheleznodorozhniki (1987), 394-395.

52 Zamkowska (1982), 67.

53 Former name of the Polish State Railways Stalowa Wola Południe.

54 Zamkowska (1982), 67.

55 Zheleznodorozhniki (1987), 389. 
The 1st Belarussian Front Command planned to use two primary railway traffic directions within their area of operation: the northern (Brest - Warszawa Poznan - Frankfurt an der Oder) and southern (Kovel - Lublin - Dęblin - Łódź Kalisz - Ostrów - Leszno - Węgliniec) directions. On both directions, tracks were converted to broad-gauge up to the River Vistula, as it was expected that onward transport would be made possible on standard-gauge lines using a large number of rail vehicles that were captured. For afore-specified reasons, it was considered whether lines running west of the River Vistula should be re-gauged. Had these lines remained as a standard-gauge system, immense transhipment bases would have to be constructed (with a capacity of 2,000 wagons per day, 1,000 in each direction). Any critical transhipment station would have become an easy target for the German air force; the destruction of a transhipment base would have completely paralysed the delivery of supplies to all frontline units. The implementation of such an undertaking surpassed the capabilities of frontline transport units. ${ }^{56}$

Given the above, the War Council of the 1st Belarussian Front submitted their own proposal to the State Defence Committee; according to the proposal, the northern line was to be converted to $1,524 \mathrm{~mm}$ gauge, standard-gauge track to remain on the southern line. According to the State Defence Committee's decision of October 7th 1944, the lines in both directions were to be operated as standardgauge lines. The repeated proposals of the War Council of the Front to re-gauge the Brest - Warszawa - Poznań - Frankfurt an der Oder mainline ended up with another decision of November 21st 1944 to open the line without re-gauging. ${ }^{57}$ Furthermore, the Supreme Board of Military transport of the Red Army saw the need to re-gauge at least one direction, related reasons are appropriately clarified by the words of the Chief of military transport, General I. Kovalev:

At that time, I was the head of the Supreme Board of Military transport as well as a member of the committee for transport of the State Defence Committee. The Committee members included the People's Commissar for Transport L. Kaganovich, the Secretary of the Central Committee of the Communist Party of the Soviet Union and a deputy chairman of the committee for transport A. Andreev, member of the State Defence Committee A. Mikoyan and the commander in chief of the Rear of the Red Army General A. Khrulov. J. Stalin was chairman of the committee. The committee for transport was formed on the initiative of J. Stalin, to the purpose of co-ordinating all transport systems operating across the country, and drafting proposals for the State Defence Committee with regard to the more important issues. The issue of converting tracks to

56 Antipenko (1970), 228.

57 Antipenko (1970), 228. 
specific gauge widths in view of the Red Army movement towards the western borders of the Soviet Union was of paramount importance at the time. The People's Commissariat for Transport of the USSR believed that extending the lines westwards with the use of the Soviet gauge would allow further intensification of domestic transport, particularly in view of the continued works to redevelop local economy. Maximising the use of Soviet rolling stock was considered an absolute priority at the time, its primary purpose to ultimately defeat the Fascist army. I had no doubt that without gauge conversion to the Soviet gauge in at least one direction in each of the frontline operation areas, it would be impossible to secure a significant increase in the volume of military and supply transports in the final stages of war. I motioned for the concept of the War Council of the 1st Belarussian Front to be implemented. Over the course of October and November 1944, the concept had not seen support. Only later, once transport circumstances had reached their breaking point, each front was allowed to convert a single track section to Soviet gauge. It was regrettable that this delayed decision brought a number of unfortunate consequences. ${ }^{58}$

The main arguments against line conversion included the fear of depleting railway transport far behind the frontline as a result of depriving it of sizeable rolling stock volumes, and the temptation to use large quantities of captured standard-gauge rolling stock. The War Directorate for Railway Reconstruction No. $20^{59}$ under Major General N. Borisov began works to increase the capacity of the re-gauged lines in the direction of the River Vistula, as well as preparations to rebuild bridges and railway lines to the west of the Vistula that were not to be re-gauged. ${ }^{60}$ The War and Operations Board of the People's Commissariat for Railways was formed with a view to taking advantage of foreign frontline railway lines on the Polish, Romanian, Bulgarian, Hungarian, Czechoslovak, Yugoslav, Austrian and German territories. ${ }^{61}$

The railway bridge over the River Vistula in Warszawa - destroyed by the Germans - was among the key facilities on the railway line to Berlin. The reconstruction works were performed by the 1st Railway Brigade under General

58 Antipenko (1970), 229-230.

59 The railway forces of the 1st Belorussian Front consisted of four railway brigades: the 1st brigade of the guard rail troops (commander General W. Tisson), the 29th brigade of railway troops (commander Major General W. Rogatko), the 3rd brigade of railway troops (commander D. Vasiliev), two bridge construction trains (No. 13, commander Colonel I Moskalev, No. 7 commander Major Artiemienko) and (militarized) troops of a special formation of the People's Commissariat of Communications (consisting of Soviet mobilized civil railway workers).

60 Antipenko (1970), 230.

61 Zheleznodorozhniki (1987), 390. 
W. Tisson, and the bridge reconstruction train No. 7 under N. Artemenko. Due to the extent of damage (all spans blown up, most supports destroyed), a decision was made to build a temporary bridge with the use of L-23 military folding span components, resting upon wooden supports.

Works began on the second day after the Soviet army entered Warsaw on January 18th. The new crossing, $515.7 \mathrm{~m}$ in total length, was built 25 metres upstream of the destroyed railway bridge. The significance of reconstructing this crossing - of vital importance to the delivery of supplies to the Rear of the 1st Belarussian Front - was conducive to the arrival of Marshall Zhukov, member of the War Council of the 1st Belarussian Front Lieutenant General K. Telegin, and Deputy Commander Lieutenant General N. Antipenko, all of whom intent on inspecting the construction site. Following the inspection, the War Council of the 1st Belarussian Front issued an appeal to the military workforce to complete the work in the shortest time possible. Shortly after party meetings had been arranged by political officers of the 1st Guardian Railway Brigade, the pace of work picked up significantly. Conscripted citizens of Warsaw were forced to join the bridge reconstruction works as well. The first train carrying military goods crossed the temporary bridge on January 29th at 05:30 p.m. Upon the order of the commander-in-chief, the 1st Guardian Railway Brigade was renamed the "Warsaw Brigade" in recognition of the extraordinarily quick construction of the temporary bridge across the River Vistula. ${ }^{62}$

Upon completion of the temporary bridges over the River Vistula in Warszawa and Dęblin, reconstruction of the northern (main) Warszawa - Poznań and southern Dęblin - Skarżysko Kamienna - Tomaszów Mazowiecki - Łódź Zduńska Wola - Kalisz railway lines commenced. Both lines were being returned to traffic with their standard gauge retained. Concurrently, a decision was made to build large transhipment facilities at the intersection of the two track systems in the Warsaw and Dęblin areas, with a capacity of 400-500 wagons ${ }^{63}$ each.

Construction work on the bridge across the Vistula commenced after the 1st Belarussian Front had crossed the river. The rebuilding of railway lines without their re-gauging began at the same time. The 29th Railway Brigade under General V. Rogatko was charged with reconstructing the Warsaw railway junction and the Warsaw - Poznan line. ${ }^{64}$ Due to the original idea for the lines beyond the River Vistula to remain standard-gauge, construction of transhipment depots at

62 Zheleznodorozhniki (1987), 390-392.

63 Antipenko (1970), 232.

64 Zheleznodorozhniki (1987), 392. 
Warszawa Zachodnia station and in the Dęblin region began. Over 30 kilometres of parallel transhipment tracks and 1 kilometre of high ramps were developed at Warszawa Zachodnia, roofing for goods storage facilities were also provided. On January 29th 1945 the rebuilding of the Warsaw - Poznan railway line and of the railway bridge over the Vistula River were both completed, an official decision was made to commission the use of the main northern line. That same day, an order arrived from headquarters to convert this line to $1,524 \mathrm{~mm}$ broad-gauge. ${ }^{65}$

Consequently, all work to reconstruct the line went to waste. Immense human and material resources had to be engaged to convert $300 \mathrm{~km}$ of double track mainline, and to convert the large railway junction of Warszawa Zachodnia to broad gauge. While works began at once, they were hurried and performed without proper equipment. The works ran into difficulties due to the fact that in the Soviet Union hooks were used to attach rails to sleepers - whereas the Polish system involved screws. Soviet soldiers hammered screws into sleepers, destroying them. As a result, once the line had been converted, the sleepers were damaged and trains derailed. Metal sleepers used in sidings slowed the pace of works as well. In spite of the numerous technical difficulties, the line was re-gauged and opened in February $1945 .{ }^{66}$ The 29th Railway Brigade was also renamed the "Warsaw Brigade" in recognition of the speed of all the work performed. ${ }^{67}$

The 5th Railway Brigade under Colonel T. Yatsino was dispatched to reconstruct the destroyed bridge across the River Vistula near Dęblin, on the 1st Belarussian Front territory. Over an extraordinarily brief period of eight days, the unit built a temporary rail bridge $510 \mathrm{~m}$ in length, commissioned on January 23rd $1945 .{ }^{68}$ Once the bridge was constructed, the 5th Brigade began rebuilding the southern section of the Dęblin - Łódź line, which was also soon reopened. ${ }^{69}$ By order of the Commander-in-Chief of the 5th Railway Brigade, it was renamed the "Poznan Brigade." ${ }^{70}$ The extent of damage to technical facilities on a further section of the line (Łódź to Kalisz) made rapid reconstruction impossible.

Due to the danger of the 2nd Belarussian Front being flanked by regrouped German army units in Pomerania, an urgent need arose to move troops forward towards the River Odra. The limited capacity of the Warsaw - Poznań line

65 Antipenko (1970), 261.

66 Antipenko (1970), 262-263.

67 Zheleznodorozhniki (1987), 392.

68 The bridge was completed 12 days ahead of the date planned.

69 Antipenko (1970), 263; Zheleznodorozhniki (1987), 392.

70 Zheleznodorozhniki (1987), 392. 
necessitated the reconstruction of an additional line as well. To replace the inactive southern line, military railway traffic commenced on February 2nd 1945 on the Bydgoszcz Główna - Piła - Gorzów Wielkopolski - Kostrzyn substitute route, which opened towards the right frontline wing, to the purpose of expedient troops transfer. The $5 \mathrm{t}^{\mathrm{h}}$ Railway Brigade troops under Colonel T. Yatsino was dispatched to the section.

As works progressed to open the southward line, the concept of using it as a detour route for ammunition and materials transfer developed. Munitions were transported from outposts by road to the Warsaw-Dęblin line, specially converted to the $1,524 \mathrm{~mm}$ gauge for the purpose. ${ }^{71}$ They were then reloaded in Dęblin onto standard-gauge rolling stock; 10 transports carrying ammunition and fuel were dispatched south per day. Due to the Soviet army offensive and continual changes of the frontline, trains were directed towards Gorzów and Kostrzyn. ${ }^{72}$ The opening of the line involved numerous technical difficulties; it was ultimately converted to broad gauge: "[...] From the 3rd to the 5th of February, there were over 100 trains carrying ammunition, fuel and heavy combat equipment on this line; however not a single train had yet arrived at the unloading area. [...] In fact, trains travelled slowly, encountering many obstacles on the way, including a shortage of water or fuel for steam locomotives, speed was often restricted for technical reasons. [...]."73 The perplexing and seemingly uneconomic way of delivering supplies (requiring the goods to be transhipped twice) frequently resulted in the war materials being delivered directly behind the advancing troops. An additional supply line was established at the same time. General Antipenko described the importance of opening an additional southward line: "[...] Admittedly, had the southbound line from Dęblin north and further west not been opened in the early days of the Vistula-Odra campaign, it is hard to imagine how we could have secured the frontline towards Pomerania. It is due to the usage of this line, the author of the memoirs claimed, that trains carrying ammunition and fuel arrived at the critical moment [...]." ${ }^{74}$

In February 1945, the bridge over the River Warta near Poznań Starołęka was temporarily rebuilt; a $1,524 \mathrm{~mm}$ track was installed, shortly followed by the rebuilding and re-gauging of the Poznań Franowo - Frankfurt and Poznań Franowo - Toruń Główny lines. ${ }^{75}$

71 Antipenko (1970), 264.

72 Antipenko (1970), 256.

73 Antipenko (1970), 267.

74 Antipenko (1970), 281.

75 Kroma, Sosiński (2003), 74. 
The Sandomierz - Skarżysko Kamienna line was $104 \mathrm{~km}$ long, running in the direction of the 1st Ukrainian Front. The 7th Railway Brigade handled the reconstruction of the largely destroyed line (demolished bridges, water stations, and primary and secondary tracks at railway stations). Railway traffic recommenced on January 28th; on January 30th, military trains pulled into Katowice. ${ }^{76}$

The 7th Railway Brigade, and then also the 45th Railway Brigade under Colonel A. Natalevich, rebuilt and reopened the Częstochowa - Steinau an der Oder (Ścinawa) line, $330 \mathrm{~km}$ in length. In Steinau, the bridge over the Oder had been destroyed, its reconstruction entrusted to the 28th Bridge Battalion led by Lieutenant Colonel W. Sokolov. Because of the need to provide troops in combat with immediate supplies, the War Council of the 1st Belarussian Front decided to build a lightweight wooden temporary crossing to carry wagons without locomotives near the destroyed railway bridge on the Odra. Two and a half days were allowed for works on the crossing. As the river was rather narrow at the location, it allowed the provision of a temporary lightweight wooden structure consisting of piling, frames, and frame-supported beams with turnout sleepers and rails. The bridge was ready to be used on March 9th. The wagons were pushed onto the bridge by one locomotive, and another took them over on the other river bank once the wagons were coupled onto it. A total of approximately 5,000 goods-carrying wagons were moved across the River Odra. On March 31st, the German air force destroyed the Steinau crossing; nonetheless, the 28th Battalion had it rebuilt, working three and a half days round the clock. ${ }^{77}$

The 19th Railway Brigade under General V. Miridonov, working together with bridge reconstruction train No. 7 under by A. Zhukovskyi, bridge reconstruction train No. 7 under V. Ogarkov, and water station reconstruction train No. 13 under A. Iznyarov, rebuilt the main double track line in the operational area of the 1st Ukrainian Front (Przeworsk - Dębica - Cracow - Katowice Opole), converting it to the 1,524 mm gauge. ${ }^{78}$

The War Directorate for Railway Reconstruction No. 3, responsible for activities on the 1st Ukrainian Front, handled the construction of broad-gauge sidings to industrial plants in Silesia. In the area of Katowice, Chorzów, Bytom, Gliwice and Opole, the War Directorate for Railway Reconstruction constructed broadgauge sidings to 27 mines and 40 industrial plants, totalling $300 \mathrm{~km}$ in length. ${ }^{79}$

76 Zheleznodorozhniki (1987), 392.

77 Zheleznodorozhniki(1987), 392.

78 Zheleznodorozhniki (1987), 392-393.

79 Zheleznodorozhniki (1987), 393. 
These sidings were used to ease the transport of coal and equipment plundered from industrial plants to Russia.

A sudden thaw in the spring of 1945 led to the movement of ice; railway and road bridges of the 1st Ukrainian Front were damaged or totally destroyed. On February 28th, ice floes destroyed the starlings and 10 main supports of the bridge on the Vistula near Sandomierz. The 14th and 33rd Bridge Battalions were dispatched to perform reconstruction works, with a pontoon crossing built to handle all traffic until the ice dispersed. The destruction of all frontline crossings serves to prove the temporary nature of bridge structures developed in great haste to comply with plans imposed by political officers of the Soviet military engineering units.

In order to protect the viability of frontline routes, measures were taken to defend the bridges over the River Vistula in Warsaw and Dęblin, as their destruction would have cut off the 1st Belarussian Front from its main sources of supplies ${ }^{80}$ Even the air force was used to bomb ice blockages, the defence of the bridge in Dęblin was handled by the bridge construction train No. 13 under Colonel Moskalev. ${ }^{81}$ Corridors were cut between spans to allow passage of the crushed ice. Troops of the 20th Bridge Construction Battalion - part of the 1st Railway Guards Brigade (later renamed the "Warsaw Brigade") under Colonel V. Zheltikov defended the bridge in Warsaw. During the campaign to defend that bridge, head of the frontline rear units General N. Antipenko and head of the War Board of Rail Reconstruction No. 20 General N. Borisov were both present at the crossing. When defending the bridge, sappers crushed ice with explosives. The bridge was attached to the river banks with ropes, its stability ensured with 100 rock-loaded railway flat wagons. The crossing was being defended from ice floe impact for three days. Neither bridge was destroyed - only the bridge over the Vistula in Torun (on the 2nd Belarussian Front operational territory) was ripped down by ice floes, all transports to the Front handled via a detour over the surviving bridge in Warsaw until the Torun facility was reconstructed. ${ }^{82}$

On April 16th, the Soviet Army began the "Operation Berlin" with both the 1st and the 2nd Polish Armies participating. In the early days of the strike on Berlin, the entire length of the railway network on the operational territory of all three fronts (the 1st and 2nd Belarussian and the 1st Ukrainian) totalled $11,000 \mathrm{~km}$. The main frontline railway was converted to $1,524 \mathrm{~mm}$ gauge along

80 Antipenko (1970), 282.

81 Antipenko (1970), 283.

82 Antipenko (1970), 284. 
the offensive direction of every frontline. The operation of railway traffic, as well as line maintenance, was handled by 10 War and Operations units and 5 Operational regiments. Operational regiments performed railway traffic on routes at and near the frontline, over a total length of $4,000 \mathrm{~km}$. The remaining 7,000 kilometres of operational routes were operated by Polish railwaymen. Along these lines goods were transported both on standard and broad gauge tracks. The People's Commissariat for Railways dispatched 17 columns of special railway reserve locomotives to handle the military transports on frontline railway lines, a total of 426 locomotives. Six columns were dispatched to the operational territory of the 1st Belarussian Front: Nos. 5, 13, 20, 34, 35 and 111; the 2nd Belarussian Front was supported by 4 columns: Nos. 15, 22, 33 and 43; the 1st Ukrainian Front - by 7 columns: Nos. 10, 11, 21, 31, 44, 47 and 110. ${ }^{83}$

The Kostrzyn fortress was the key to the gates of Berlin. The Germans had destroyed two railway bridges over the Rivers Odra and Warta in Kostrzyn. Shortly thereafter, Bridge Battalions began constructing temporary crossings to replace them, using Russian military L-23 spans. During heavy combat for the fort and the town of Kostrzyn, on the night of April 18th 1945, once the construction of the bridges over the Rivers Odra and Warta was completed, the German air force attacked both facilities, causing serious damage. Units of the 29th Railway Brigade and bridge construction train No. 13 under Colonel Moskalev began reconstructing both the bridges. The task was completed over the course of one week until April 25th 1945 in conditions of continuous air raids, with enormous losses suffered. The 29th Railway Brigade and the War Directorate for Railway Reconstruction No. 20 handled the reconstruction and conversion to broad gauge of the Kostrzyn - Berlin Lichtenberg railway line. At 06:00 p.m. on April 25th 1945, the first military train carrying heavy artillery arrived at Berlin Lichtenberg station, General Antipenko noting in his memoirs: "[...] The Heavens ${ }^{84}$ - War Council. I hereby report: this day April 25th at 06:00 p.m., railway traffic opened on the Kostrzyn - Berlin line as far as Berlin Lichtenberg. Antipenko, Chernyakov, Borisov." The report was duly annotated: "Brave boys. Zhukov, Telegin. April 26th [...]." ${ }^{85}$ The first train to Berlin Lichtenberg station was driven by a former Sergeant-Major of the 29th Railway Brigade A. Lesnikov. ${ }^{86}$

83 Zheleznodorozhniki (1987), 397.

84 Code name for the General Staff of the Red Army.

85 Antipenko (1970), 286-287.

86 Zheleznodorozhniki (1987), 399. 
The reconstruction of the lines along the Red Army key operational directions comprised mainly the east to west parallel lines. The following lines were converted to broad-gauge during wartime: Warszawa Gdańska Modlin - Nasielsk - Mława - Działdowo - Iława - Prabuty - Malbork, ${ }^{87}$ (Königsberg) - Elbląg - Tczew - Gdańsk - Chojnice - Szczecinek - Szczecin, ${ }^{88}$ (Insterburg) - Kętrzyn - Olsztyn - Iława - Toruń Główny - Inowrocław Gniezno - Poznań Franowo - Kunowice (Frankfurt an der Oder), Warszawa - Łowicz - Kutno - Września - Poznań (one track converted) ${ }^{89}$ Warszawa - Koluszki - Częstochowa - Opole, Koluszki - Łódź - Ostrów Wielkopolski - Krotoszyn - Leszno - Głogów - Żagań, and Dęblin - Radom Skarżysko Kamienna - Tomaszów - Koluszki - Łódź - Kutno - Toruń - Krzyż Kostrzyn..$^{90}$ In order to enable a correct rail traffic organisation in the Warsaw junction area, the Warsaw bypass line was also converted to broad gauge, forming a rail link between the left- and right-bank routes passing through Warszawa Gdańska station; ${ }^{91}$ and the line linking Warszawa Wchodnia with Warszawa Wschodnia Towarowa, including the siding of the Praga inland port. ${ }^{92}$

Both tracks on the Medyka - Przemyśl - Kraków - Szczakowa - Mysłowice Katowice line were converted to broad gauge; one track on the Katowice - Ligota line, one track on the Katowice - Hajduki - Gliwice - Kędzierzyn - Prudnik line, one track on the line from Hajduki (now Chorzów Batory) - Bytom Mikulczyce - Pyskowice - Strzelce Opolskie - Groszowice - Opole Wschód Wrocław (the other track remained standard gauge: 1,435 mm) - Bolesławiec,

87 According to a first-hand account of May 12th 2006 given by a retired locomotive driver of the Warszawa Praga locomotive depot, Mr. Bogdan Pokropiński, one track had been converted to broad gauge, while traffic continued also on the other standardgauge track; while on the bridge in Modlin a dual gauge track was installed, causing significant restrictions to overall line capacity.

88 No other sources confirm information regarding the temporary reconstruction of the bridges over the River Nogat in Malbork or on the Vistula near Tczew.

89 The locomotive depot in Sochaczew was re-gauged to $1,524 \mathrm{~mm}$, so that it could serve broad-gauge locomotives.

90 There is no absolute certainty as to track conversion on the Łódź - Kutno - Toruń - Krzyż - Kostrzyn line.

91 Paszke, Jerczyński, Koziarski, (1995), 336.

92 According to a first-hand account of given by a retired locomotive driver of the Warszawa Praga depot, Mr. Bogdan Pokropiński, the Russians had set up a field mobile power plant to supply the district of Praga with electricity on the siding leading to the harbour, prior to the capture of Warsaw. The power plant comprised approximately 10 FD and IS locomotives used to power electricity generators. 
with a branch line running towards Kluczbork, and one track on the Kraków Skawina - Spytkowice - Oświęcim - Czechowice Dziedzice - Zebrzydowice Ostrava line (the other track remained standard gauge: $1,435 \mathrm{~mm}$ ). ${ }^{93}$

The Soviet Railway troops converted a total of 5,034 km of tracks on both sides of the River Vistula on the Polish territory - $38 \%$ of tracks reopened on the so-called former Polish land (the railway lines on the Polish territory according to pre-September 1st 1939 maps)..$^{94}$

Railway line reconstruction was made considerably difficult by the extraordinarily quick and effective way of demolishing railway lines applied by the German railway troops. The Wehrmacht railway troops used special devices mounted on four-wheeled wagon chassis. The device had been given the name Schienenwolf [a railway wolf] - it was a special hook and arm hammered in between the rails. The wagon upon which the device had been mounted, hauled by two locomotives, ploughed across the tracks with great force, cutting the sleepers in half and ripping rails out of the ground along with other permanentway equipment. The Schienenwolf allowed considerable savings in terms of the volume of explosives otherwise required to destroy railway lines. The device served the purpose of destroying tracks, whereas switches and civil engineering works were blown up with TNT. ${ }^{95}$

During the work carried out in field conditions by the Red Army's railway military, one track of any double-track line would usually be re-gauged, with only the most essential, non-centralised signalling devices activated. Only single tracks intended for military train formation were subject to re-gauging at stations. At smaller stations usually only loops were re-gauged to allow the trains to pass each other. Further track reconstruction and installation of railway signalling devices took place at a later date, once the frontline had receded.

The hard work to reconstruct thousands of kilometres of tracks was handled with the use of primitive methods, both by the Russian Railway Brigades and the civilian Soviet railwaymen and workers mobilised as part of the so-called trudfront (labour battalion) campaign. German prisoners, mobilised Polish railwaymen and civilians were put to work as well. Railway line reconstruction

93 Polish State Railways railway network map (1945); History of the Katowice. . . (1997), 166.

94 Zamkowska (1984), 68; Odrodzenie (1947), 30 - the source specifies that the railway military had converted $3,518 \mathrm{~km}$ of lines, $1,159 \mathrm{~km}$ of station tracks, and 4,574 points. This discrepancy may be due to the use of incomplete data for different reporting periods.

95 In cases of sustained and long-term damage to railway lines, explosive charges were used to destroy rails as well. 
progress - which ultimately determined the timeliness of the military transports and supplies for troops in combat - was supervised by NKVD (People's Commissariat for Internal Affairs) troops.

The brutal incentive method proven "effective" in Soviet labour camps would be usually applied - the system involved food rationing based on the share of daily work norm actually delivered.

The working conditions on the re-gauging of the Warsaw - Poznań - Frankfurt line are best captured in memoirs of an eye witness to these events, a Home Army soldier and Polish railwayman Eugeniusz Macewicz:

The Soviets rapidly began converting one track to the Russian broad gauge. Polish railwaymen were not engaged. We had no work to do at the time. I had no idea whether the tracks were converted by some sapper units or by groups of civilian workers. We couldn't tell by their clothing. At one point, I tried to learn more about it. I was walking home along the tracks one evening around $10 \mathrm{pm}$. I met a lone Russian working by the light of a candle stuck into a bottle. I asked him why he was working that late. "I haven't done my share", he said, and if you don't do your share you get no food. I'm old, over 60, I can't keep up with the young ones, and I need to work at night to eat. "Are you army or railwaymen?" I asked. "Who the hell knows," he said. ${ }^{96}$

The Russian railway troops were very efficient in rebuilding and re-gauging railway lines - they would usually hand over to traffic up to $10 \mathrm{~km}$ of re-gauged tracks per day, or even $25 \mathrm{~km}$ if damage was not that great. ${ }^{97}$ Primitive track work tools would usually be employed during line conversion - occasionally, railway sleepers would even be replaced with trunks of trees felled in forests, then chiselled into shape with axes and adzes after having been laid on a rail embankment. The technical condition of such tracks rebuilt in rough conditions left much to be desired, on such sections it was not possible to reach any higher speeds, derailments were frequent. On frontline territory, rolling stock damaged in accidents was simply pushed off tracks to allow immediate restoration of rail traffic to the route.

The hasty pace of work was forced by troop movements at the time of the January offensive: Radom was captured on January 16th 1945; Skarżysko Kamienna and left-bank Warsaw on January 17th; Częstochowa on January 18th; Łowicz, Skierniewice and Kutno on January 19th; Tarnowskie Góry, Opole and Bydgoszcz on January 23rd; Katowice on January 27th; part of Poznań on January 28th; Leszno on January 31st; and Torun on February 1st. ${ }^{98}$

96 Macewicz (2000), 149.

97 Antipenko (1970), 32.

98 Paszke, Jerczyński, Koziarski (1995), 332. 
The conversion of Poland's primary transport system to broad gauge resulted in a situation when strategic broad gauge lines were operated by Soviet military transport units, with the remaining system of secondary, local, and narrow-gauge lines rebuilt by Polish railwaymen and managed by the Polish State Railways.

Supplies delivered by rail were collected according to a specific set of rules: railway lines were designated for each army as stationing areas; field depots of munitions, armaments, food, propellants, and lubricants (in conformity to goods concealment requirements) would be set up near railway stations on a pre-specified route, to receive goods arriving by rail transport. Field depots delivered supplies to individual army units with the use of horse-drawn and motor vehicles. Depots were directly connected to army unit stationing areas with roads. ${ }^{99}$ Goods were delivered directly to the frontline from rear support units by the so-called "shuttles" - compact train formations ${ }^{100}$ carrying the required supplies and escorted by transport officers. During the Belarussian Operation, for example, such compact tank wagon "shuttles" carried petrol directly from Grozny to army depots.

During the Wisła - Odra operation, 18 shuttles with a total capacity of 3,150 tons were formed for the purposes of all the 1st Belarussian Front armies. Each "shuttle" comprised two-three fuel tank wagons, one water tank wagon to refill the locomotive, and one escort and maintenance staff wagon. In the early days, these would carry fuel reloaded from broad-gauge tank wagons on the River Vistula. ${ }^{101}$

Lines of strategic importance and all railway sections on the frontline territory were serviced by railway operational regiments. Due to the shortage of qualified railway personnel, a group of Leningrad Military Transport Academy students was even dispatched as supplementary personnel to the Belarussian Front. They were called to serve in operational positions on military railway routes, mostly as train dispatchers, telegraphers, switch operators, locomotive drivers, and firemen. ${ }^{102}$ Due to the staffing issues, transport officers were occasionally relocated, serving as train dispatchers, switch operators, train guards and locomotive drivers. The re-gauged lines were staffed with Russian railway

99 Antipenko (1970), 237.

100 In railway terminology, the phrase "compact formation" applies to any train the composition of which cannot be subject to modification.

101 Antipenko (1970), 268.

102 Antipenko (1970), 266. 
military personnel (as train dispatchers and traffic control officers) reporting to the Supreme Board for Military Transports.

Furthermore, the German troops caused major damage to telephone and telegraph lines as well as to railway signalling devices on many railway routes, requiring rail traffic to recommence immediately without engaging in time-consuming tasks of rebuilding these devices. In order to restore frontline traffic the following action was taken:

[...] A certain number of motor vehicles, Po-2 aeroplanes and numerous radio station units were put at the disposal of the head of Military Transports to secure proper communication. A Military Transports officer would drive a car alongside the railway line, overtaking the train to prevent trains from approaching from the opposite direction. This is how station-to-station traffic was handled. Other officers would fly an aircraft along designated railway line sections to map train positions. Air surveillance was often obstructed by fog and drizzle, which impaired visibility and occasionally prevented takeoffs. The head of Military Transports at the frontline would receive messages twice daily via radio stations located at junction points. A special-purpose "transport division" was set up on European-gauge lines as part of the Frontline Board for Military Transports. [...] Consequently, we would receive daily data regarding the number of trains crossing the bridge in Dęblin in the western direction; we also had knowledge concerning trains on individual sections of the network [...]. ${ }^{103}$

The train operations was based on details agreed over the telephone in Russian, and in conformity to Russian rail traffic control and signalling regulations; less frequently, conditions permitting (whenever devices were operational and sufficient staff available), announcements were dispatched by telegraph. It did happen that on militarised lines Russian railway troops used a primitive yet effective method of managing traffic manually, i.e. "a token system" - a metal shield with a special-purpose handle handed over by a train guard when trains were crossing each other or at a destination station to the crew of a train dispatched in the opposite direction.

Under extraordinary warfare circumstances, Polish railwaymen fluent in Russian would be employed as train dispatchers at stations of lesser strategic importance, ${ }^{104}$ Soviet officers holding positions of station/ section commanders at

103 Antipenko (1970), 266-267.

104 Account of October 5th 2005 by a retired traffic controller of the Regional State Railway Management in Warsaw Aleksander Matecki from Mława; thanks to his excellent command of Russian language, he served in 1944 as a Soviet military train dispatcher on the Mława - Konopki section of the Warszawa Gdańska - Gdańsk Główny line. 
"junctions." Polish railwaymen would usually be employed as physical labourers, or to perform rail traffic control-related duties as signalmen, switch operators, shunting masters, or shunters.

Steam locomotive columns (parovozoviye colony) were established as early as 1941 in order to provide locomotives for military train operations; they were part of a special-purpose reserve of the People's Commissariat for Railways, all militarised, and reporting to the Red Army transport units.

The immediate reason for the formation of these columns was to provide traction to military trains under circumstances of complete destruction of servicing facilities. In order to ensure their complete self-sufficiency, these units were organised along the lines of train servicing applied on long-haul sections of Russian railways. On the Siberian railway lines living vans were coupled to locomotives to accommodate a backup locomotive crew. The solution allowed considerable extension of train crew working hours: one crew worked while the other rested in the respite van. The other condition of running frontline trains required that the parovozoviye colony be made technically independent thanks to technical equipment, field workshop facilities, and qualified rolling stock repairmen and boilersmiths assigned to them.

The process of forming first columns began in 1941, at the Ilitsa and Podmoskovskaya locomotive depots of the Moscow railway junction; these columns went on to participate in the Battle of Moscow. ${ }^{105}$ More often as not, steam locomotives assigned to a column transported troops over considerable distances. ${ }^{106}$

105 Zheleznodorozhniki (1987), 311.

106 To allow maximum-intensity of steam locomotive use, each locomotive would be coupled with bogie vans with accommodation for three locomotive crews, three conductor crews, a rolling stock fitter, and an escort. Such steam locomotive crews were self-sufficient enough to perform complex locomotive repairs, even in field conditions. On order by the State Defence Committee, the People's Commissariat for Railways formed 35 NKPS Special Reserve steam locomotive columns on railway lines at the head and rear of the frontline, operating 750 steam locomotives, with over 11,000 railwaymen troops in service. The work of every column was handled by the head and political commissar (deputy for political affairs) of the unit. Each column comprised a company of up to 5 locomotives. A brigade servicing a single locomotive comprised a platoon under the command of an experienced locomotive driver. Equipment assigned to a column included workshop tools and power generators; a column would be self-sufficient in performing all boilerworks. A standard specialpurpose reserve column consisted of 30 locomotives, although occasional ones would comprise 20 or 15.A column service was fully militarised, railwaymen were issued 
The system of using columns to perform rail traffic involved the formation of a group - a column of steam locomotives of the same type (in order to make their use in field conditions more expedient) - which was then assigned to one of the larger locomotive depots. Each column locomotive was then assigned 3 engine crews, 3 conductor crews, 3 wagon inspectors, 1 rolling stock fitter, and one wagon with two escorts to provide accommodation. Steam locomotives hauled trains according to schedule between two locomotive depots separated by a distance of $500 \mathrm{~km}$ or more, passing through stations that had their own locomotive depots on the way without stopping in these depots. The servicing of steam locomotives would be performed on station tracks or in locomotive depots, depending on conditions. Train operation began at a station adjacent to the original locomotive depot that the column had been assigned to. A steam locomotive would depart from the yard with two crews aboard - one to operate the locomotive and train, the other one resting in the van. After completing the work assignment over a specific shift, crews would rotate during a longer stopover and engine re-stoking. The third crew would remain at the locomotive yard the column was assigned to. At the final locomotive yard, the engine would undergo full servicing, and return with the train scheduled in the respective direction to the original yard it had been assigned to without stopovers. ${ }^{107}$

Broad-gauge steam locomotive of Russian classes OB, Э, Эг, Эш, Эм, C, and Cy would usually be employed to operate broad gauge military trains passing through the Warsaw junction. ${ }^{108}$ Captured standard-gauge passenger and express locomotives (coupled to passenger trains under normal circumstances), basically unsuitable for the transport of heavy military equipment, would also be employed during warfare in military rail traffic.

Field storages of coal, wood, and lubricants as well as field repair workshop facilities would be arranged to ensure uninterrupted locomotive operation. The shortage of coal (resulting in the necessity to transport it across great distances before the Soviet troops entered the Dąbrowskie Basin and Silesia) was conducive to a fuel replacement effort: railway and road military units amassed 542,000 $\mathrm{m} 3$ of wood for trains running in both directions on the Kovel and Brest lines. ${ }^{109}$ Wherever water stations had been destroyed, water for locomotive tenders

military ranks, uniforms, and weapons. A quick implementation of steam locomotive columns resulted in the NKPS establishing a special-reserve railway column branch.

107 Łaszkiewicz (1959), 58-59.

108 As told by retired locomotive driver of the Warszawa Praga depot, Mr. Bogdan Pokropiński.

109 Antipenko (1970), 231. 
would be drawn from rivers, streams or wells with the use of steam-powered suction pumps mounted on steam locomotives or in the vicinity of watercourses. Nonetheless, the limited capacity of such appliances resulted in considerable extension to the travel time of military trains.

The simplified servicing procedures - restrained only by the coal and water refill time and the need to wash-out locomotive boilers - increased the intensity of use of locomotives. Concurrently, such excess and intense use of rolling stock resulted in the rapid deterioration of all equipment, locomotive boilers in particular - yet nobody paid much attention to such a situation under wartime conditions. Service in war railway columns was extremely dangerous, frequently involving operating ammunition trains under enemy fire. Pre-war mobilised Polish railwaymen served in the Soviet steam locomotive columns as well. The 1st Belarussian Front train service lost 42 staff killed in action and 57 injured; notably, every German pilot would be decorated with an Iron Cross for destroying a locomotive. ${ }^{110}$ In an effort to eliminate air attacks on troop trains on particularly hazardous sections, single locomotives were dispatched ahead to draw enemy fire. ${ }^{111}$ In 1943, armoured steel plate came into use as protection for steam locomotive driver cabs to improve the safety of locomotive crews. ${ }^{112}$

When no Russian or Polish locomotive crews were available, an occasional German locomotive crew would be brought in, guarded by Soviet soldiers. As a retired German engine driver of the Lyck (Ełk) locomotive depot recalls: "it was a journey at the point of a Nagant." 113 Troops were issued orders under which they were required to shoot both the locomotive driver and fireman for the slightest misdemeanour or locomotive failure, considered an act of wartime sabotage and punishable by death.

After the war ended and all captured property was shipped to the USSR, locomotive columns returned to the Soviet Union, where they were demilitarised and disbanded. Former column rolling stock (locomotive and wagons) was returned to the Soviet Railways. ${ }^{114}$ The Zheleznodorozhniki w velikoy otechestvennoy voyne

110 Antipenko (1970), 233.

111 Antipenko (1970), 233.

112 Zheleznodorozhniki (1987), 323.

113 Account of May 12th 2003 by a retired driver and mechanical controller at the narrow gauge railway depot Ełk, Leszek Zumbrzycki.

114 The columns included a significant number of Polish locomotives looted by Soviet troops after the Red Army attacked Poland on September 17th 1939, as well as numerous pre-war Polish State Railways steam locomotives and locomotives seized from the Germans. 
study features an interesting note of January 22nd 1946 from Gudok, a Soviet railway weekly, describing the disbanding of railway columns:

The NKPS special reserve column No. 34 formed in 1942 at Turksib, has returned to Kazakhstan from Berlin. The frontline rail columns travelled over two million kilometres. War took them to Stalingrad, the Caucasus, the Crimea, Ukraine, Belarus and Poland; Berlin was the final destination of their victorious journey. Under enemy fire, railway columns transported over 10,000 trains to the front, carrying around three million tons of military supplies. During the period leading up to the attack on Berlin, column troops worked a ring route ${ }^{115}$ on the Warsaw - Poznań section without uncoupling locomotives or refilling water over a distance of one hundred kilometres. ${ }^{116}$

On territories not held by Poland between the wars (East Prussia, Pomerania and Lower Silesia), and in the part of Upper Silesia which had not befallen Poland post-1922, particularly intensive works were handled by Trofyeynoye Upravlenyie - Military Board for War Spoils. The special-purpose units of the Board shipped rolling stock and railway equipment out of the country, dismantling tracks and sidings. The greatest losses were sustained by East Prussia (Varmia and Mazuria) and West Pomerania, where special-purpose evacuation trains were used to dismantle a significant volume of railway lines $(1,600 \mathrm{~km}$,

115 The ring route mode with locomotives coaled and serviced on station tracks without stopping over at locomotive depots was widely used in the USA, where specialpurpose appliances were developed, designed to re-stock coal on locomotives and clean their ashpans directly on station tracks. Such servicing method was introduced to the Soviet railways in the 1930s. The ring route method was fundamentally applied on railway sections over $130 \mathrm{~km}$. The method involved locomotive refilling and servicing at the return locomotive depot, and its handover to another locomotive crew who would drive the locomotive on the return journey to its home depot. Once the home locomotive depot was reached, the locomotive would not be driven into the depot, but instead the third locomotive crew would take it over on departure tracks and drive the locomotive to another return locomotive depot. Upon reaching that station, the locomotive would not be driven into the locomotive depot either; upon refuelling and cleaning on the pit, it would be handed over to a fourth crew who would then drive it on the return journey to its home depot - and yet again, the locomotive was not driven into the depot itself, but it would be handed over to another crew tasked with the next trip, directly on station tracks. Once the scheduled distance between two boiler washouts was covered, the engine would be taken to its home locomotive depot to be cleaned and undergo periodic maintenance. While the ring route mode increased the number of active locomotives and improved route capacity, such procedures impacted the overall technical condition of locomotives.

116 Zheleznodorozhniki (1987), 316. 
including $165 \mathrm{~km}$ of narrow-gauge tracks ${ }^{117}$ ), only partly rebuilt in the 1950s. Furthermore, the Soviet units responsible for the removal of spoils of war also took Polish rolling stock and railway workshop equipment to the east; Polish railwaymen would frequently re-direct wagons carrying looted Polish property and materials useful in the reconstruction of the destroyed railway infrastructure to sidings. ${ }^{118}$

With regard to the problem of running railways on the Polish territory under the Red Army control, on November 4th 1944 the Transport Department of the Polish Committee of National Liberation issued a decree according to which the railway was to be militarised, ${ }^{119}$ reporting to the Commander in Chief of the Polish Armed Forces; all railwaymen were considered troops drafted into military transport service - yet allowed the right to wear railway uniform, to modest salaries, and to food rations. As a result of railway militarisation, former Head of the Department of Transport and Postal and Telegraph Services Jan Grubecki, M.Sc. Eng., ${ }^{120}$ was replaced by a Polish Workers' Party activist Captain Jan Rabanowski, M.Sc. Eng. (first post-war minister responsible for railways). Pursuant to the railway militarisation decree, railwaymen charged with misdemeanour in service were brought before a court-martial. According to railwaymen accounts, they were punished with custody and given bread and water only for the slightest misconduct when on duty. When serving penalty, an employee would spend the night in detention and return to duty during daytime under armed Railway Security Service escort. In the case of Torun railwaymen, for example, a special-purpose prison was established in a 19th-century fortified tower - a railway bridgehead.

Furthermore, a plenipotentiary for railway transport of the Supreme Board of Military Transports at the Polish Committee of National Liberation was appointed - General P. Rumyantsev. ${ }^{121}$ In all actuality, General Rumyantsev and Colonel Platonov were in charge of the entire department of transport of the Polish Committee of National Liberation.

On June 23rd 1945, the railway was restored to peacetime operations; on July 11th 1945 an agreement was signed with the USSR, pursuant to which the Polish State Railways were to assume control of the railways across the newly formed

117 Lijewski, Lenk, Piotrowska (1967), 5.

118 Osóbka-Morawski (1981), 49.

119 Zamkowska (1982), 65-75.

120 As Jan Grubecki opposed Russian rogue management methods involving railway equipment, he was summarily dismissed by Edward Osóbka-Morawski.

121 Zamkowska (1984), 70. 
western part of Poland by August 15th $1945 .{ }^{122}$ The actual handover process of railway lines by the Red Army was still in progress in August 1945.

In conformity with the agreement, the representative agencies of the Russian military transport authorities were established at the Polish Ministry of Transport and the regional railway management bodies.

Under the agreement concluded on August 11th $1945^{123}$ by the Polish authorities and the government of the USSR, all railway lines converted to broad gauge by the Soviet military units were to be re-converted back to standard gauge over the period of September 15th to November 30th 1945.

On October 1st 1945, the last broad-gauge Soviet troop train from Frankfurt to Brest travelled over the Warsaw - Poznań - Frankfurt railway line. ${ }^{124}$

On November 5th 1945, another agreement was entered into in Lublin by and between the Polish Committee of National Liberation and the government of the USSR concerning the operation and management of Polish railways. It granted the Red Army plenipotentiaries the right to co-decide with respect to all the matters related to railway traffic and operation of railways. In practice, this was tantamount to the railway being taken over by the Soviet authorities. ${ }^{125}$

By year-end 1945, most broad-gauge lines on the Polish territory were converted to standard gauge. Following the decision by the Soviet Minister of Defence, ${ }^{126}$ the Przemyśl - Kraków - Katowice - Wrocław line, as well as its branches to the Upper Silesian coal mines, all of strategic importance to the Soviet Army, remained converted to broad-gauge. The line served 18 trains a day, ${ }^{127}$ and was used to carry huge numbers of inhabitants of the former eastern Polish territories incorporated into the USSR to the western parts of Poland. Hard coal was the chief cargo shipped on the return journey. ${ }^{128}$ In 1946, 7.3 million tonnes of goods ( $96 \%$ of which was coal) were carried by rail along the route described.

The Upper Silesian Industrial District encompassed the longest-standing survivor of the broad-gauge network; it was used until 1947, including access to 13 coal mines (the length of the broad gauge track at railway stations reached $100 \mathrm{~km}$ ). In 1947, these facilities were used to ship 6 million tonnes of goods

122 Paszke, Jerczyński, Koziarski (1995), 335.

123 Gembora, MOHRA, Ref. No. 1138, 117.

124 Kroma, Sosiński (2003), 74.

125 Krogulski (2000), 126.

126 Zamkowska (1984), 74.

127 Zamkowska (1984), 62.

128 Krogulski (2000), 126. 
(98\% of which was coal) to the USSR. As of September 1st 1947, the overall broad-gauge network of the Regional State Railway Management in Katowice totalled a mere $31 \mathrm{~km} .{ }^{129}$

The second track on the Mamonowo - (state border) - Braniewo Bogaczewo - Elbląg line was also left as broad-gauge, serving strategic and economic purposes, the latter to a minuscule extent. In Elbląg, at the Zamech plant (the former F. Schichau Elbing factory), thousands of passenger carriages, freight wagons and steam locomotives manufactured by the H. Cegielski factory and ordered by the Soviet Railways were converted to broad gauge. Following a short test run and technical inspection by the commissioning officer for Soviet Railways in the Polish People's Republic, the rolling stock was dispatched to Kaliningrad. In the 1970s, the broad-gauge section of the Elbląg - Bogaczewo line was dismantled, the remaining part was retained for strategic reasons.

The absolute military, political, and economic enslavement of Poland by its eastern neighbour during the Stalinist times may be proven by the curious example of the permanently destroyed electric railways in Lower Silesia. Following an agreement with the Soviet government, Polish State Railways took over the slightly damaged, electrified rail network in Lower Silesia, formerly owned by the Germans, $321 \mathrm{~km}$ long (it had been subject to gradual electrification from the early 20th century until the late $1930 \mathrm{~s}, 15 \mathrm{kV}$ and $162 / 3$ $\mathrm{Hz}$ alternate current was applied). The early electrification of railways within the Eisenbahndirektion Breslau was associated with the need to operate trains on the difficult mountainous Lower Silesian railway network (inclines of up to $20 \%$, curves of $170 \mathrm{~m}$ radius), and the resulting technical difficulties with operating steam-hauled trains. Moreover, the short distances between stations and halts were detrimental to the overall economics of using steam traction (frequent starts and stops). During the period of 1912-1914, the Siemens-Schuckert Werke company constructed a power plant in Ścinawka, equipped with four sets of turbines providing power to the electric Lower Silesian railways. Coal was carried to the plant by block trains from the Nowa Ruda Słupiec mine, $12 \mathrm{~km}$ away. ${ }^{130}$

The Polish State Railways took over the following electrified railways lines from the Soviet military transport authorities: ${ }^{131}$ Wałbrzych Szczawienko - Szczawno Zdrój -Boguszów Gorce Wschód - Mieroszów - (state border) - (Mezimesti)

129 History of the Katowice (1997), 166.

130 Szynkiewicz (2004), 32.

131 Line electrification dates quoted from Lijewski, Koziarski (1995), 106.

Zbigniew Tucholski - 978-3-631-82966-0 
(June 1st 1914 ${ }^{132}$ ), Boguszów Gorce Wschód - Boguszów Gorce (July 15th 1914), Świebodzice - Szczawienko - Wałbrzych - Boguszów Gorce Wschód (January 1st 1916), Świebodzice - Jaworzyna Śląska (April 1st 1917), Boguszów Gorce Sędzisław - Marciszów - Jelenia Góra (July 15th 1920), Sędzisław - Kamienna Góra - Lubawka (August 17th 1921), Jelenia Góra - Rybnica - Gryfów Śląski Lubań (1922), Jelenia Góra - Cieplice Zdrój - Sobieszów - Piechowice Szklarska Poręba - Jakuszyce - (state border) - (Kořenov) (February 15th 1923), Lubań -Mikułowa - Zgorzelec - (state border) - (Görlitz) (September 1st 1923), Jaworzyna Śląska - Żarów - Kąty Wrocławskie - Wrocław Świebodzki (January 28th 1928), Lubań - Węgliniec (April 3rd 1928), Lubań - Leśna (June 22nd 1928), Wrocław Zachodni - Muchobór - Wrocław Świebodzki (June 25th 1928), Jelenia Góra - Mysłakowice - Kowary - Kamienna Góra (December 9th 1932), Mysłakowice - Miłaków - Karpacz (1934), Marciszów - Kamienna Góra (January 1st 1939). Furthermore, the Polish railway authorities took over numerous electric railway vehicles and state-of-the-art, very well equipped electric traction repair workshops in Lubań Śląski (Lauban).

As stated earlier, the railway network in Lower Silesia did not suffer extensive wartime damage. Only the overhead catenary of the Wrockaw junction, the Wrocław locomotive depot (completely destroyed), and the overhead catenary on the Wrocław - Jaworzyna Śląska line were damaged once heavy combat commenced during the Siege of Breslau. ${ }^{133}$ Shortly after the end of warfare, the German railway personnel - working together with the Polish railwaymen who had operated the Warsaw railway junction lines electrified between the wars and then completely destroyed by the Germans - re-commissioned electric traction on a major part of the Lower Silesian Railway Management, having removed minor damage to the overhead wires. The following lines were operational: Lubań Śląski - Leśna, later Jelenia Góra - Lubań Śląski, Jelenia Góra Zachodnia - Szklarska Poręba and Jelenia Góra - Karpacz; after several weeks of work, traffic was also restored to the Jaworzyna Śląska - Zgorzelec line. ${ }^{134}$

Unfortunately, already after the reopening of electric railways, under the agreement between the governments of the USSR and Poland of July 8th 1945, the rolling stock, machines and equipment of the Lower Silesian electrified railway network were to be shipped to the USSR (with an extraordinarily short period of three weeks allowed for disassembly). ${ }^{135}$ Consequently, the use of

132 All electrification dates listed in brackets.

133 Szynkiewicz (2004), 37.

134 Szynkiewicz (2004), 38.

135 Szynkiewicz (2004), 38. 
electric trains ceased and power was disconnected; the Soviet railway military forces proceeded to disassemble the overhead wires, equipment and sub-stations. Workshops, equipment, overhead wires, sub-stations, high-voltage power lines, power plants, rolling stock and even disassembled second tracks of double track lines, were all sent to the USSR. ${ }^{136}$ Components of the railway power plant in Ścinawka Średnia, transformer sub-stations, and equipment from electric traction workshops in Lubań Śląski were also disassembled and shipped out. The rogue plundering of electric traction equipment did not even spare thousands of traction poles, cut with torches up to the height of an upright soldier. The following equipment was shipped to the USSR: 2 E17 class electric locomotives, 3 E42 class locomotives, 2 E44 class locomotives, 2 E90 class locomotives, 5 E91 class locomotives, 11 E94 class locomotives, 2 ET31 class EMUs, 3 ET51 class railcars, and 6 ET89 class railcars. ${ }^{137}$

The rolling stock - and traction substations - were shipped to Soviet military railway equipment depots, where they remained disused for several decades. Some of the electric locomotives captured from the Polish State Railways in 1945 were presented by the Soviet authorities to East Germany after 1956, in a gesture of "brotherly assistance." Notably, the Soviet Railways used 3,000 V DC and 25,000 V AC - consequently, rolling stock seized in Lower Silesia was totally useless to the Soviet railways. ${ }^{138}$

Old, run-down steam locomotives and wagons (often dating back to the early 20th century) returned to the previously electrified railway lines of the Regional State Railway Management in Wrocław, the lines were partly re-electrified only in the 1970s and 1980s.

136 The overhead catenary on the Jelenia Góra - Jakuszyce section was left intact, probably by omission; yet this section was dismantled soon thereafter and used to rebuild the damaged catenary at the Warsaw Rail Junction.

137 Szynkiewicz (2004), 39.

138 The existence of an electric railway network in Lower Silesia became a censorshipsafeguarded secret. Even specialist publications on electric traction from the time of the Polish People's Republic contain no information concerning the electrification of these lines. It is only in the work by the notable pioneer of Polish State Railways electrification, Stanisław Kuczborski [Kuczborski (1963), 100] that we find the following

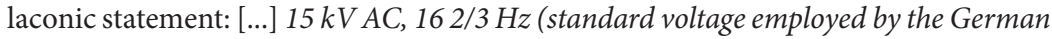
railways) electric traction was introduced already between the wars, on the Wrockaw Wałbrzych - Jelenia Góra line. Currently, the 3kV DC system adopted by the Polish State Railways is to be introduced. 
The re-electrification of the Wrocław - Wałbrzych - Jelenia Góra line was completed only in the years 1965-1966. This was a line with a particularly difficult mountainous profile. With steam traction, up to three engines were required for a single freight train. Heavy freight trains required the assistance of bankers locomotives that were pushing the trains, mainly on the particularly difficult sections of the line. The Mysłakowice - Karpacz line, on the other hand, featuring the greatest longitudinal incline on the complete Polish State Railways network (44 \%o immediately before Karpacz station), was never electrified again. 


\section{RECONSTRUCTING, ORGANISING, AND DEVELOPING THE HEADQUARTERS OF MILITARY TRANSPORT IN THE YEARS 1944-1962}

The army's transition to peacetime operations upon the end of warfare coincided with the re-organisation of the Headquarters of Military Transport and complete liquidation of the railway troops. Once the decision to disband the railway troops was made, the Headquarters of Military Transport was severely reduced, its competencies limited to military transports, reconstruction as well as the operation of sidings and military railways in military areas. The tasks assigned to military transport authorities also included the drafting of military opinions concerning the design of transport facilities and supervision of the efficient railway mobilisation and militarisation during warfare.

In the first quarter of 1945, a process of establishing military transport departments commenced at the chief of staff level of the newly formed military districts (Military District Commands) at the following locations: Warsaw, Łódź, Poznań, Lublin, and Kraków. ${ }^{139}$ The tasks of the new organisational district staff units included the co-operation with the respective Regional State Railway Management, securing military transport on railway lines within the given district, organising maintenance and reconstruction works on railway lines and facilities with the infrastructure departments of the respective Management standing in as intermediaries, and organising security services for major lines and railway facilities in co-operation with railway authorities. The organisational structure of the military transport departments included a department for military transport, as well as a department for railway maintenance and construction. Notwithstanding the above, the military transport departments were not prepared to deliver tasks under wartime mobilisation conditions, as they owned no line railway units. In practice, their work was basically limited to planning and documentary functions. In co-operation with the infrastructure departments of the Regional State Railway Managements they made records of the lines, bridges and other railway facilities for record purposes. Only under exceptional circumstances - and assisted by military engineering units - they

139 Order of the GC of the PA, No. 23/org. of February 1st 1945, in: Gembora, Ref. No. 1138, 93. 
repaired or constructed small sections of railway lines and sidings for military purposes. ${ }^{140}$

On July 18th $1945^{141}$ the General Staff was reformed as General Staff of the Polish Armed Forces. The Military Transports Board of the Chief Quartermaster of the Polish Armed Forces was dissolved. All tasks and competences of the liquidated quartermaster unit were taken over by the newly created Branch IV of Military Transport of the General Staff of the Polish Armed Forces. The purpose of separating the Military Transports bodies from the quartermaster structure and making them subordinate to the General Staff was to set up a closer operational and co-ordination format for transport bodies and operational units of the Staff in terms of planning and handling of all military operational transports.

Colonel Mikołaj Suprynowicz, M.Sc. Eng., the former head of the Military Transports Board of the Polish Armed Forces, was appointed the head of the Branch IV of Military Transport of the General Staff. He was replaced as head of the service by Colonel Michał Terlecki on December 31st $1945 .{ }^{142}$

The Branch IV of Military Transport of the General Staff included the following departments: management, department of military transport, water transport section, technical department, department of combat training, financial and control section, and secret registry. The scope of Branch IV activities also included issues of using inland waterways for military transport purposes. Branch IV employed 54 full-time soldiers, its management staff composed of the following officers seconded by the Soviet army: head of the Branch Colonel Mikołaj Suprowicz, deputy head of the Branch Colonel Grzegorz Kuźmienko, head of transport department Colonel Anatol Gaponiuk and head of the combat training department, Colonel Sergiusz Osokin. ${ }^{143}$

The main tasks of Branch IV included the following: collection and preparation of data for the General Staff (with respect to railway transport and means of transport), drafting General Staff decisions in the form of plans to prepare the railway network for army needs, preparation and training of transport officers, issuing opinions concerning the design of reconstructed railway lines and railway facilities and equipment, co-operation with the Ministry of Transport, drafting instructions and regulations with regard to the planning and

140 Gembora, Ref. No. 1138, 93.

141 Gembora, Ref. No. 1138, 93, Order of the General Command of the Polish Armed Forces, No. 177/org. of July 18th 1945.

142 Gembora, Ref. No. 1138, 93.

143 Gembora, Ref. No. 1138, 100. 
management of military transports, supervising the general military training of the Headquarters of Military Transport, military management of railway rolling stock, managing of military peacetime railway transports, and managing all financial affairs related to troops transport.

Generally, Branch IV of Military Transport of the General Staff did not undertake any work in the field of reconstruction or modernisation of railway lines or facilities. The Branch did, however, engage in intense work involving the collection and processing of data concerning the technical condition of railway lines, bridges and other railway facilities. The Branch also maintained army-purpose records of railway lines and facilities, bridges, viaducts and culverts - destroyed, under reconstruction and reconstructed.

The re-organisation and establishment of Branch IV of Military Transport coincided with the re-organisation of the Departments for Military Transports at the military district headquarters with intent to establish Departments IV of Military Transport. ${ }^{144}$ Their new organisational structure included the respective sections for transport, technical issues, control and finance, and registry. These Departments reported to the heads of staffs of the respective districts, their former tasks were fundamentally left unchanged. The Departments were also in charge of constructing a number of military sidings with assistance from civilian enterprises supplied with surface materials as required.

On December 16th 1945, the Military Railway Transport Branch Offices were established in all the state railways districts. ${ }^{145}$ The branch offices employed twofull time officers and six compulsory service soldiers. When re-organising the Headquarters of Military Transport, the Branch Offices were reformed into Local Offices of Branch IV of Military Transport, and set up to include the following sections: transport, technical issues, control and finance, and registry. Heads of Branch IV Local Offices reported directly to the head of Branch IV of Military Transport of the General Staff.

Such a solution did not prove long-standing: in 1948, the former Branch IV of Military Transport of the General Staff was renamed Board IV for Military Transport of the General Staff, Colonel Anatol Zamczyński M.Sc. Eng appointed the head of Board IV. ${ }^{146}$

Thereafter, on June 17th 1950, the Minister of National Defence Marshal Konstanty Rokossowski instructed the Chief of General Staff Lieutenant General

144 Later renamed Branches IV for MC.

145 Gembora, Ref. No. 1138, 102.

146 Gembora, Ref. No. 1138, 102. 
Władysław Korczyc to re-organise the military transport bodies ${ }^{147}$ Consequently, in the first half of 1951, the Headquarters of Military Transport of the General Staff was established in place of the current Board IV for Military Transport, the new body's competencies extended to include additional departments. ${ }^{148}$ Following the re-organisation, railway troops were formed once again to comprise three battalions (3rd, 5th and 7th railway troop's battalions, respectively).

Thus, the re-organised Headquarters of Military Transport yet again included military transport bodies and railway troops alike. The Headquarters of Military Transport had its own structures: central, line, and field (designed for wartime purposes only).

The central military transport authorities included the following: the Headquarters of Military Transport of the General Staff, the Military Transport Departments of Military District Commands, and the Military Transport Department of the Navy Staff.

The re-organised Headquarters of Military Transport of the General Staff consisted of the following branches and departments: transport department, technical branch, mobilisation department, organisation and supplies department, training department, financial and control department, military railway department, general department, and registry. The individual branches consisted of departments, and individual departments of sections.

In 1951, Colonel Herman Czerwiakow was appointed head of the Headquarters of Military Transport of the General Staff. ${ }^{149}$ The head of the Headquarters of Military Transport was also head of the Polish Armed Forces transport, reporting directly to the Chief of General Staff. Upon re-organisation, tasks of the Headquarters of Military Transport also included the planning of training and dispatching of railway troops, as well as supplying them with materials and transport equipment as required. As a result of re-organisation, the organisational structure of the Military Transport Departments of Military District Commands was also expanded to include mobilisation sections.

The head of the Military transport Department of a given Military District Command reported directly to the chief of staff of the military district, and with respect to technical and transport issues - to the chief of transport of the Polish Armed Forces.

147 Gembora, Ref. No. 1138, 102.

148 Head of the Headquarters of Military Transport, Chief Quartermaster Polish Armed Forces, 8.

149 Gembora, Ref. No. 1138, 104. 
The main tasks of Military Transport Departments of the Military District Commands included the following: knowledge of the railway network and inland waterways in the district and the possibilities of their use for military purposes, organisation, planning and execution of military transport within a given region, planning and control of training of military units with respect to railway transport, supplying military units of the district with military waybills and the control of their use, supervision over the training and operations of regional military railway units.

The headcount structure of the Military Transport Department of the Navy Staff was identical to that of the Military Transport Departments of military districts. The head of the Navy's military transport branch reported directly to the chief of staff of the Navy, and - in case of technical and transport issues - to the chief of transport of the Polish Armed Forces. The main tasks of the Navy's Military Transport Department included the use of ports and vessels for military transport purposes, organisation of military transports in harbours, planning rail and coastal transport for the Navy and supplying the naval units with military waybills and the control of their use.

The headquarters of the military transport line units were intended to manage military railway and inland waterways transport in war- and peacetime. They were deployed on the country's railway network - Headquarters of Military Transport were placed in Regional State Railway Management buildings, Military Railway Section Commands - at designated operational unit buildings; Military Station Commands - in station buildings.

The line units of railway and inland consisted of the following subdivisions of railway transport: Headquarters of Military Transport (in Regional State Railway Management), Military Railway Section Commands (at designated Operational Departments of the Polish State Railways ${ }^{150}$ ), Military Railway Section Commands (at designated Operational Departments of the Polish State Railways ${ }^{151}$ ), Military Station Commands (at designated junctions and railway stations, and at border control checkpoints of the People's Republic of Poland), Military Food Points, Military Agitation Points and Military Stage Points. With respect to the inland water transport, line authorities included the following: the Water Transport Command of the Regional Directorate of Waterways, and Military Commands of Waterway Sections and Ports (formed during wartime only).

150 Head of the Headquarters of Military Transport, Chief Quartermaster Polish Armed Forces, 10.

151 Ibid. 
The Headquarters of Military Transport at Regional State Railway Managements were established in the process of re-organising the Military Railway Transport Branch Offices. A Military Transport Command was composed of the following sections: a transport department, a technical section, a mobilisation section, a financial and accounting section, and a registry. The head of military transport at a Regional State Railway Management was a representative of the Ministry of National Defence for the respective railway management area. He reported directly to the chief of military transport of the Polish Armed Forces in matters related to the preparation of railways for army needs and the organisation and delivery of central transport service - in matters of regional transport, he reported to the head of military transport in the military district. The main tasks of a Military Transport Command included the following: knowledge of the organisation, equipment and condition of the railway network in the respective Regional State Railway Management area, control of railway preparation for army needs and of works performed on the railway as commissioned by the Ministry of Defence, drafting opinions concerning the design of railway construction and reconstruction, control of maintenance and repair works on military sidings and rolling stock at the disposal of the Ministry of National Defence, drafting military transport plans and submitting them to the Regional State Railway Management, organising and supervising their delivery, control and handling of financial settlements with the railway management for the transport of troops and military supplies, and the training of military units in the field of railway transport. The responsibilities of the Military Transport Command also included the drafting of and updates to railway network descriptions of all Regional State Railway Managements, said descriptions comprising the following data: railway track infrastructure inventory; specifications of telephone, telegram and selector communication, of train radio communication, of $\mathrm{MB}$ and $\mathrm{CB}$ service centres and teletypewriter communications; specifications of railway line and junction station capacity; railway network diagram with 3,270 mm loading gauge mapped; specification of railway border crossings; list of stations with rolling stock shunting facilities; list of rolling stock furnishing and assembly stations; list of stations where folding ramp sets and complete $\mathrm{Kl}$ wagon equipment kits were deposited; list of stations where military reserves of surface reconstruction materials were deposited; list of junction tracks operational, disused, disassembled and planned over a designated special period; network diagram with steam locomotive depots, locomotive depots, wagon depots, and Railway Rolling Stock Repair Facilities added; diagram of steam, diesel and electric traction sections; list of fuel depots with coal stages specified; network diagram with water station layout; diagram of electrified railway lines, continuous 
welded tracks and types of track infrastructure; list of coal wagon wall removal facilities; network diagram with emergency maintenance and emergency rescue train deployment mapped; network diagram with snowplough and railway crane deployment mapped; list and specification of rolling stock deactivation points on the Polish State Railways network; list of sanitary points; list of Civil Defence facilities (shelters).

Responsibilities of the Military Command of a Railway Section or station included the following: organisation and management of loading, transport and unloading of military railway transports on or at a respective section or station; preparing railway rolling stock and loading accessories for military transport; control of the technical condition of military ramps and sidings and delivering practical training for military units related to railway transport; securing all operational and sanitary services for transported military units; ensuring that the soldiers travelling by trains maintain order and comply with military discipline and railway regulations. During mass wartime transport of troops, food and agitation points were set up at larger stations. ${ }^{152}$

During wartime, the purpose of Headquarters of Military Transport was to secure the continuity of transport by railways- and waterways - transfers of troops and tactical compounds, as well as material supplies for the troops in combat. The wartime responsibilities of railway troops and militarised railway units also included reconstruction (or destruction) of railway lines.

In order to deliver all tasks as listed in wartime conditions, plans were made to establish a field Headquarters of Military Transport and to militarise the Ministry of Railways and Navigation. Military transport field bodies included the following: Military Frontline Transport Board, Military transport Branch for the Army (for each of the respective general armies), Military Commands of Frontline and Army Distribution Stations, Military Commands of Railway Sections, and Military Commands of Supply Stations.

152 The staff of a 1st Class Railway Section Military Headquarters consisted of a commander of the railway section, one senior assistant to the commander, three assistants to the commander, three dispatchers and a clerk. The staff of a 2nd CRS Military Transport consisted of a commander of the section and railway station, three dispatchers, and a clerk. The railway section military commander reported directly to the head of military transport. For all members of the military in the railway section, the railway section military commander was the acting garrison commander. A railway station commander had similar authority over his troops. 
The responsibilities of military transport field (frontline) services included the following: ${ }^{153}$

- Planning and performance of military transports domestically, and within the domestic territory-frontline area (to rear frontline bases),

- Planning the use of all types of transport,

- Securing the delivery of military transit transports for allied countries,

- Planning the use, training and supplying of transport units,

- Planning and works in areas of use, maintenance, and reconstruction of all relevant elements of transport network on home territory.

With intent to deliver all tasks as listed, the following units were organised as reporting to the head of the field (frontline) Headquarters of Military Transport: railway and road troops (railway troops brigades, ${ }^{154}$ road troops brigade, bridge brigade, railway military bridge regiment ${ }^{155}$ ) - charged with the reconstruction, maintenance, and operation of roads and railways and with the regulation of road traffic; motor vehicle - transport units (transport brigades) charged with the delivery of material and technical supplies for operational troops; transhipment units; and road and railway troop training units. ${ }^{156}$

The Head of Frontline Transport was the acting authorised representative of the Frontline command on rail- and waterways transport routes. The following units reported to the Head of Frontline Transport: the military transport bodies and railway troops forming a part of the Frontline (Army), field and line bodies and special (militarised) branches of the Ministry of Railways and Inland Navigation, serving Frontline (Army) railway and waterway sections in terms of organising and handling of military transports and reconstructing (or destroying) of railway lines and rail- and waterway facilities, and directors of Regional State Railway Managements and of Inland Navigation located in the area of Frontline operations - in the scope of military transports and reconstruction

153 Ministry of National Defence, Transport Command 33/64, Komunikacja wojskowa (1965), 27.

154 The brigade of railway troops consisted of 6 road battalions.

155 The railway military bridge regiment was charged with the protection of railway bridges. The regiment comprised the following: a pontoon bridge battalion, a folding bridge battalion and a technical battalion. The regiment's equipment included machinery and equipment for bridge works and bridge construction (1/2 of the NZM56 park and $1 / 4$ of the TMP park).

156 Ministry of National Defence, Transport Command 33/64, Komunikacja wojskowa (1965), 27-30. 
(or destruction). Under conditions of mobilisation, the Ministry of Railways and Inland Navigation units were to be militarised, the Head of Frontline Transport becoming their immediate official superior. All railwaymen were to be drafted for service in railway transport. ${ }^{157}$

In the years 1950-1957, the Headquarters of Military Transport underwent practically no re-organisation activities, except an increase to the headcount of the railway troops department and organisation and supplies department in the Headquarters of Military Transport of the General Staff of the Polish Armed Forces. The increase of officer posts in these departments tied in with the restoration and subsequent development of railway troops units. In 1956, Colonel Jan Pszennik was appointed head of the Headquarters of Military Transport of the General Staff of the Polish Armed Forces. ${ }^{158}$

The trends of comprehensive use of all modes of transport (railways, road, air and waterways) on the battlefield - becoming distinctly more profound in the 1950s and tying in with the introduction of nuclear weapons and the development of rocket artillery, transport aviation and other modern weapons and technical measures, resulted in an integration of the military transport and road services.

In November 1962, the Headquarters of Military Transport of the General Staff of the Polish Armed Forces merged with the 15th Division of the General Staff of the Polish Armed Forces; the Command of the Military Transport Service of the Ministry of National Defence was formed. In February 1964, this unit was subordinated to the Chief Quartermaster of the Polish Armed Forces. The Command of the Headquarters of Military Transports of the Chief Quartermaster of the Polish Armed Forces was thus formed. ${ }^{159}$

A unified and centralised military transport system with the capacity to secure the comprehensive use and co-ordination of all modes of transport was formed. The scope of peacetime activities of the Command of the Headquarters of Military Transport of the Ministry of National Defence included the following: ${ }^{160}$

- Planning the operational-and-mobilisation use of the transport network and means of transport across the country,

157 Gembora, Ref. No. 1138, 130.

158 Gembora, Ref. No. 1138, 130.

159 Headquarters of the Military Transport Service, Chief Quartermaster Polish Armed Forces, 11.

160 Ministry of National Defence, Transport Command 33/64, Komunikacja wojskowa (1965), 25-27. 
- Preparation of transport by rail, road, and inland waterways for railway and road troops and for motor vehicle and transport units,

- Preparation of units for the organisation of transhipment areas (points),

- Comprehensive handling and management of military transfers.

In addition, the Headquarters of the Military Transport Service of the Ministry of National Defence supervised and directed specialised activities engaged in by the heads of military transport of Military District Commands and by line bodies reporting to them, as well as by motor vehicle and transport units.

\subsection{Department of Military transport, Military District Command I Warsaw}

In the first quarter of 1945, the organisational structure of the Quartermaster Command of Military District Warsaw was expanded to include a Military Transport Department, its territory spanning the Warsaw and Białystok voivodships. ${ }^{161}$ The Department was based in Warsaw, in a building at Litewska No. 3.

In July 1945, the process of re-organising the General Staff of the Polish Armed Forces and reforming the District Command to peacetime operations as well as the coinciding expansion of its territory to include the Olsztyn voivodship (changing of the name to Military District Commands I) resulted in the establishing of Department IV of Military transport, reporting directly to the chief of staff of the District and based in a building at Solariego No. 4 in Warsaw. ${ }^{162}$

Major Stefan Ołtarzewski was appointed the first head of Department IV of Military Transport, Military District Commands I. Lieutenant Stanisław Mochnacki (military waybill reporting officer) and Second Lieutenant Adam Muzyczek (military transfer and sidings reporting officer) were in service at the Department. On May 1st 1946, Major Wacław Zydel became the head of Department IV of Military Transport. ${ }^{163}$ The importance of training in the field of loading and transferring units equipped with heavy equipment increased at the time. The department premises changed again; the unit moved to a building at 6 Sierpnia (Nowowiejska), then to the Warsaw Citadel in October 1947. The Department reported to the Chief of Staff, Military District Commands I, and

161 Traction Central Management- Co-ordination CfMM, 1.

162 Traction Central Management- Co-ordination CfMM, 1.

163 Traction Central Management- Co-ordination CfMM, 1. 
to the quartermaster of District Command I during military exercises. The repair and expansion works on sidings and military ramps at stations Muszaki, Czerwony Bór and Orzysz commenced at the time, in conjunction with the planned training of troops on training grounds, and large numbers of operational transports having been received at all stations listed.

In 1949 the subsequent stage of re-organising the armed forces involved an expansion of the district to include a part of the Regional State Railway Management. In the first half of 1950 a general re-organisation of military transport bodies was held, with Branch IV of Military Transport of District Command I set up as of January 1st $1951 .{ }^{164}$ A Red Army Colonel Konstanty Romaniuk, M.Sc. Eng. was appointed head of this unit, its headcount comprising thirteen full-time officer and ensign positions, and one civilian. New Branch headquarters were set up at the quartermaster's building at Krajewskiego. In September 1952 the location of the Branch was changed again and transferred to the Pavilion X building at the Warsaw Citadel. The area of Branch activity comprised 7 voivodships at the time.

As part of practical training of railway troops in the years 1951-1952 works were organised to rebuild a forestry railway in Cisna and Nowy Łupków; while in the period of 1952-1953 railway lines and junctions were rebuilt on the area of the Regional State Railway Management in Olsztyn, Warsaw and Lublin. 1582 kilometres of railway lines were refurbished, numerous stations and railway junctions modernised, 851 metres of railway bridges and culverts were built. The estimated cost for all works listed totalled 2,457,681,000 zloty. ${ }^{165}$

In 1954 Lieutenant Colonel Alfons Rybałtowski was appointed head of the Transport Branch after a brief period of practical internship. The Branch staff consisted of 17 officers and ensigns and 2 civilians at the time. After 1956 Soviet soldiers were recalled from their positions in the Branch, following a further reduction to the armed forces. In May 1957, Branch IV of the Military Transport shifted to new operational status, its staff reduced to 12 professional soldiers and 2 civilian employees. At that time the Branch was moved yet again to a building at Krajewskiego street. Colonel Aleksander Jaśman, M.Sc. Eng. was appointed head of the Branch in June 1959. In 1962 the Branch - which had been operating independently from 1959 as part of the quartermaster's structures - was incorporated into the Warsaw Military District Quartermaster. Also in 1962, the Road District operating independently as part of quartermaster services from 1959

164 Traction Central Management- Co-ordination CfMM, 2.

165 Traction Central Management- Co-ordination CfMM, 3. 
was made a part of the Military transport Branch. In 1963, Colonel Konstanty Świrski, M.Sc. Eng, was appointed head of the Branch, the unit itself renamed Headquarters of Military Transport Branch of the Military District in 1966. ${ }^{166}$

\subsection{Reconstruction of Railway Units ${ }^{167}$}

The 1945 liquidation of railway troops did not account for the indispensability of these units in terms of securing wartime independence of military supplies. It can well be presumed that the liquidation of railway troops was an element of the Polish Armed Forces unquestioned subordination to the Red Army operationwise, not least as the decision seemed to have been devoid of any rational premise. Notably, the significant destruction of the country's transport network and the need to reconstruct it called for the existence of railway troops - damaged to a large extent, Polish railways were rebuilt at a great cost in terms of human and financial resources; in 1946, 8,486 km of reconstructed railway lines and $52,250 \mathrm{~m}$ of railway viaducts and bridges were put back to service. ${ }^{168}$

The activities targeting the formation of railway units began with planning works and securing appropriate human resources. Immediately upon the disbanding of railway troops, an expanded railway battalion was to be formed as a mobilisation unit; the intention had to be abandoned due to staffing difficulties and material and hardware shortage. Only on July 10th 1947 did the Minister of National Defence instruct the chief of General Staff to provide preliminary insights concerning the organisation of a sapper-and-railway battalion in the first half of $1950 .{ }^{169}$ In February 1948, the head of Transport Branch IV of General Staff Colonel Michał Terlecki instructed the military transport authorities to collect and study materials related to railway troops, while Branch IV analysed the materials concerning their organisation, equipment, and operation.

166 Traction Central Management- Co-ordination CfMM, 3.

167 A work by the late Colonel Marian Gembora (Military Office of Historical Research Archive, Ref. No. 1138), was the main reference source for this chapter. The work contains detailed information on railway and road-and-railway units of the Polish Armed Forces. This work, written in the early 1980s, was classified. Declassified in the mid-1980s, it was published in three copies, in all probability just a single copy has been preserved until this day and now forms a part of the special collection of the Military Office of Historical Research Archive. Historically speaking, the material is of huge interest, the author referencing multiple documents destroyed or missing today (such as railway unit chronicles).

168 Gembora, Ref. No. 1138, 2.

169 Gembora, Ref. No. 1138, 119. 
The pre-1939 documents related to the role of the Polish Armed Forces's railway troops were collected alongside the instructions and regulations of the Soviet troops.

On February 15th 1950 the head of Branch IV of the General Staff Colonel Anatol Smaczyński presented the Head of General Staff Lieutenant General Władysław Korczyc with a report, wherein he justified the need to establish railway units, explained their war- and peacetime responsibilities, and laid out a proposition of their organisational and reporting structure. ${ }^{170}$ On June 6 th 1950 , he suggested to General Władysław Korczyc that a battalion of railway troops be organised on site of the former navy railway artillery battalion in Darłowo that was disbanded in the same year. ${ }^{171}$ Darłowo offered convenient technical and personnel support facilities, such as barracks, training grounds, and a number of officer staff. On August 8th 1950, the Minister of National Defence Marshal Konstanty Rokossowski issued a decision to form a battalion of railway troops in Darłowo. ${ }^{172}$

In the early 1950s, a development programme of the Polish Armed Forces was implemented as a consequence of the escalation of the international conflict in Korea. On October 30th 1950, the Military Commission of the Political Bureau of the Central Committee of the Polish United Workers Party approved the programme of military expansion until 1956. ${ }^{173}$ The approved plan assumed a significant increase in the number of railway troops, such an increase was intended as the most intense of all types of armed forces. The planned development of railway troops with intent to secure the engineering and logistics support for military operations was a direct derivative of the offensive nature of the contemporaneous Soviet military doctrine. Furthermore, the development of railway units arose from the need to rebuild the railway network which had suffered significant wartime damage: $38 \%$ of railway lines, $46 \%$ of bridge length (including all of the largest bridge facilities), $50 \%$ of tunnels, $37 \%$ of railway buildings, 6,000 steam locomotives and 60,000 wagons had been destroyed. ${ }^{174}$

The training of qualified specialists was of paramount importance to developing railway troops; consequently, the 30th Training Company of Railway

170 Gembora, Ref. No. 1138, 125.

171 Gembora, Ref. No. 1138, 125.

172 Gembora, Ref. No. 1138, 126.

173 Gembora, Ref. No. 1138, 126.

174 In the early 1950s, a large part of railway lines, facilities and rolling stock has still not been restored. 
Military Reserve Officers was formed in December 1950, secondary school military graduates called to service therein. ${ }^{175}$

In February 1951, works commenced to organise two training railway companies with intent to train non-commissioned officers for railway units. The subsequent non-commissioned ensign training course began on March 20th 1951, ${ }^{176}$ with intent to train non-commissioned officers called in from reserve corps to serve in lower command positions in railway units. In December 1951, upon an order of the Ministry of National Defence, a training course was organised for reserve officers of railway troops, reserve officers for new military railway units were trained within this period. ${ }^{177}$

In 1950, a training curriculum for military transport officers was also introduced at the Officers' Military Engineering Academy in Wrocław. In 1952 the Academy added a skills improvement curriculum for railway military officers. As of 1951, the process of seconding railway military officers for university studies and training courses to the Military Academy of Rear and Transport Services in the USSR began. During the same period, efforts of the Headquarters of Military Transport resulted in the launching of Higher Academic Curricula and higher-level skills improvement courses for railway and road transport unit officers at the Department of Military transport of the General Staff Academy. In 1953 a faculty of military engineering was introduced at the Military University of Technology with intent to educate highly-qualified officers for railway and road transport units.

Thanks to all the training initiatives listed, a highly qualified staff of officers and non-commissioned officers were trained for the purposes of railway military units.

Two basic concepts of establishing the railway military were forged in the process of analytical and planning works related to the reconstruction of railway troops. One assumed the creation of battalions of rail and road troops trimmed off the Ministry of National Defence resources. Their development would coincide with wartime mobilisation; related activities continued until the mid-fifties. The other plan assumed that railway units would be set up with the use of the resources of the Ministry of Transport, the Ministry would benefit from works carried out by these units as part of their practical training. The latter concept

175 Gembora, Ref. No. 1138, 126.

176 Regulation of the Ministry of National Defence No. 018/org. of March 20th 1951.

177 Course graduates were promoted to officer rank, and dispatched to the railway troops battalion as platoon commanders. 
was adopted as the basis for developing and training railway troops in the second half of the 1950s. ${ }^{178}$

The reconstruction programme of railway troops units was completed over the period of 1950-1952. The newly formed railway troops were charged with the main task of wartime use for the purposes of securing engineering and logistics support for the reconstruction and operation of the frontline railway network. In peacetime the use of railway troops involved their participation in works to reconstruct railway lines and facilities, railway equipment, and civil engineering structures. Three railway troops battalions (5th railway troops battalion in Darłowo, 3rd railway troops battalion in Pikulice near Przemyśl, and 7th railway troops battalion in Września) were organised pursuant to a Ministry of Defence directive in the military districts of Warsaw, Pomerania and Silesia. While railway troops battalions were formed centrally, the designated organisational groups encountered numerous staffing, organisational and material difficulties. In terms of operational and training matters, railway troops battalions reported to military district commanders. The Branches IV of Military Transport handled all the planning and organisational affairs associated with the training of railway troop units in military districts. The management, performing of specialist task and supervision of the use of railway troops were all within the competencies of the Headquarters of Military Transport of the General Staff of the Polish Armed Forces. Upon formation, railway troop units became a mobilisation platform when railway troop brigades were mobilised.

In the years 1955-1959, railway troops underwent a re-organisation, due in the early years to political changes directly associated with the so-called "thaw." The changes to international and domestic circumstances gave rise to three waves of armed forces headcount reduction. The 5th railway troop's battalion in Darłowo was disbanded during the first wave of 1955. The third wave of armed forces reduction in March 1957 brought the disassembly of the 7th railway troops battalion. All railway units were consequently trimmed to a bare minimum (only the 3 rd railway troops battalion in Pikulice remained). Many officers and non-commissioned officers were discharged and made part of the reserve corps, a part of the staff were retrained and assigned to other forces. The technical equipment and armaments were transferred to other units, the majority of all the barracks and training grounds were handed over to civilian authorities.

178 This concept was extremely useful to the national economy: already in the 19th century, most railway troops in European countries constructed and repaired state railway lines as part of their military exercise. 
The essence of changes to the Armed Forces of the Polish People's Republic involved the re-organisation and modernisation of the army as well as its adaptation to the new war doctrine of the Warsaw Pact. The 3rd railway troops battalion was transferred from Pikulice to Bakończyce near Przemyśl. In 1957, the battalion was re-organised, a new 2 nd railway regiment ultimately replacing it.

\subsubsection{The 5th Railway Troops Battalion in Darłowo}

The 5th railway troops battalion was formed in August $1950^{179}$ in Darłowo on the basis of the well-developed Navy railway artillery battalion, in conformity to operational status 10/7. Major Konstanty Świrski was made commander of the unit; Second Naval Lieutenant Czesław Rogala was made his deputy for political affairs. This battalion was the first railway troops unit formed upon the end of wartime hostilities. An organisational group consisting of 18 officers and non-commissioned officers and 99 sailors was assigned to the newly formed battalion. ${ }^{180}$ Many sailors had previously served in the Navy railway artillery battalion, which was disbanded in 1950. The process of assigning officers and non-commissioned officers from other types of armed forces to the battalion began soon thereafter. In October 1950, the organisational group took a barracks facility complex over from the Navy and began expanding and adjusting it to their current requirements. That same month soldiers of the draft were incorporated into the battalion for the first time. By December, the battalion headcount reached 614 soldiers.

In the years 1950-1952, the battalion served as a training unit charged with preparing command staff for the railway troops battalions that were being formed.

On May 21st 1951, ${ }^{181}$ commander of the PMD (Pomorski Okręg Wojskowy) Major General Bronisław Półturzycki was obliged to designate organisational groups from the 5th railway troops battalion to form new railway troops units in Pikulice and Września.

Over the following years, the battalion was being systematically improved with respect to the railway line and bridge construction and reconstruction skills. During wartime, the battalion's tasks also included the operation of railway

179 Order of the Ministry of National Defence No. 084/org. of August 8th 1950, in: Gembora, Ref. No. 1138, 135.

180 Order of the Navy Commander No. 022/50 of August 24th 1950, in: Gembora, Ref. No. $1138,36$.

181 Directive of the Ministry of National Defence No. 00020 of February 21st 1951, in: Gembora, Ref. No. 1138, 140. 
lines. Pursuant to the order of the Ministry of National Defence of December 1st $1952,{ }^{182}$ the 5 th railway troops battalion was expanded and reformed from operational status $10 / 7$ to $10 / 14$. The organisational structure of the battalion was partially changed; a training battalion was formed, comprising two road companies, a bridge company, an operations platoon and a service platoon. Upon reforming the headcount of the battalion, it comprised 60 officers, 146 non-commissioned officers, 655 privates, and 192 non-commissioned officers' academy cadets, totalling 1,053 soldiers. ${ }^{183}$

In October 1950, the 30th reserve officers training company was set up at the battalion for the purposes of training officers - platoon commanders for railway troops. ${ }^{184}$ Lieutenant Edmund Krawiec was appointed commander of the reserve officers training company. 121 graduates of secondary schools (especially railway schools) were assigned to the company for a period of two years. An ensign training ended with practical internship, students assuming the position of platoon commanders in railway units. Once the training was over, final examinations were held, closing with promotion to the most junior officer rankan ensign. A total of 67 graduates were promoted and remained in the military service, appropriately assigned to the 3rd railway troops battalion in Pikulice, 7th railway troop's battalion in Września, or to military transport bodies.

In 1952, a Training Curriculum for Reserve Officers of the Railway Military Forces was introduced at the battalion, the purpose of the course being to train railway troop reserves, engineering and technical staff in particular. Captain Aleksander Tarasiewicz was appointed course commander. The training of the first class of 75 reserve officers (including mostly Polish State Railways personnel) began in mid-January 1952. The curriculum covered a three-month course; upon completion all graduates were awarded an officer's rank. Approximately 360 reserve officers were trained at the 5th railway troop's battalion in Darłowo. ${ }^{185}$

On March 10th 1953, the Chief of General Staff of the Polish Armed Forces ordered the Training Curriculum for Reserve Officers of the Railway Military Forces to be transferred to the 7th railway troop's battalion in Września. ${ }^{186}$

182 Gembora, Ref. No. 1138, 140.

183 Gembora, Ref. No. 1138, 141.

184 Gembora, Ref. No. 1138, 141.

185 A special-purpose mobilisation course was also organised, graduates assigned to positions of responsibility in the army and Polish State Railways.

186 Order of the Co General Staff of the Polish Armed Forces No. 0125/org, in: Gembora, Ref. No. $1138,149$. 
In order to improve the anti-aircraft defence of military troop trains and military operational and supplies transports, an Independent Squadron of AntiAircraft Defence of Military Transports was formed at the 5th railway troops battalion as of December 31st 1952, to operational status 10/15. The Squadron comprised anti-aircraft defence platoons from the 5 th, $3 \mathrm{rd}$ and 7 th railway troops battalions; the overall headcount comprised 11 officers, 22 non-commissioned officers and 73 privates (including 20 cadets) for a total of 106 soldiers. Lieutenant Stanisław Skurtys was appointed commander of the Squadron. ${ }^{187}$

The practical training of the battalion was performed while constructing and refurbishing railway lines, belonging to the military or the state railway.

The 5th railway troops battalion was dispatched for its first field camp in Olszanica in 1951. As part of their practical training the soldiers of the battalion worked to support the reconstruction of the Uherce - Olszanica - Ustianowa Krościenko railway line. In 1952 the companies of the battalion were dispatched for practical training to field camps in Skandawa, Braniewo and Mordy, their training involving construction of sidings, station tracks and fixed ramps. In 1953, the battalion was dispatched to Nurzec, Zielonka, and Słupsk camps, where it built military sidings and refurbished station tracks. ${ }^{188}$ In 1954, the companies of the battalion were dispatched to Nurzec and Koszalin field camps and performed works associated with the construction of a military railway siding and refurbishment of station tracks. In 1955, the battalion was dispatched to a field camp in Skandawa, where it carried out work associated with the construction of sidings and permanent ramps for army purposes.

In conjunction with a resolution passed by the Polish People's Republic government with regard to the reductions in the numbers of the Polish People's Republic Armed Forces, on September 26th 1955, the commander of the PMD ordered the battalion to be disbanded by December 15 th $1955 .{ }^{189}$

Consequently, the 5th Railway Troops Battalion disappeared after 5 years of existence; nonetheless, the personnel trained in the battalion went on to organise new railway units. Twenty-eight officers and 3 professional non-commissioned officers were transferred to the $3 \mathrm{rd}$ and 7 th railway troop's battalions and military transport authorities respectively, the remaining part of professional personnel

187 Gembora, Ref. No. 1138, 150.

188 The construction of the military siding at Nurzec was handled jointly with the 7th railway troops battalion.

189 Order of the Headquarters of the Pomeranian Military District of September 26th 1955; in: Gembora, Ref. No. 1138. 
assigned to other military units or discharged and included in the reserve corps; the 196 draft privates were released early as reserve troops. Pursuant to an order of October 8th 1955, the Independent Squadron of Anti-Aircraft Defence of Military Transfers ${ }^{190}$ was relocated to the 7 th railway troop's battalion in Września. The technical and railway equipment was transferred to the 3rd and 7th railway troop's battalions. Rolling stock - an armoured steam locomotive, armoured wagons and armoured trolleys - were handed over to the 3rd railway troops battalion in Bakończyce. The barracks facility in Darłowo (including all equipment) was re-transferred to the Navy.

\subsubsection{3rd Railway Troops Battalion in Pikulice near Przemyśl}

On July 17th $1951,{ }^{191}$ pursuant to an order by the Minister of National Defence, the 5th railway troops battalion was formed in Pikulice near Przemyśl with a headcount of 632 , in conformity to operational status $10 / 7$. The 3rd railway troops battalion was the second military railway unit to be established upon the end of wartime hostilities. In September, the battalion was joined by an organisational group of 6 officers and 120 soldiers from the 5th railway troops battalion. By October 20th 1951, the group took over and adapted the barracks complex in Pikulice to their purposes. In late October, the first draft soldiers were recruited for the battalion. Also that month, a complement of 28 ensigns arrived (mostly graduates of the ensign course in Darłowo), appropriately assuming positions of platoon commanders. In early November, the battalion was joined by personnel from the 5th railway troops battalion, by graduates of the Officers' Military Engineering Academy in Wrocław, and by officers and noncommissioned officers from other types of armed forces.

Lieutenant Colonel Konstanty Świrski (former commander of the 5th railway troops battalion) was appointed the commander of the battalion, Captain Jan Borowiecki his deputy for political affairs. ${ }^{192}$

From November 1951, the battalion conducted intensive training and restored the barracks facilities, adapting them for railway troops requirements. On January 18th January 1952, the first military oath ceremony was held at the battalion, battalion commander Lieutenant Colonel Konstanty Świrski receiving

190 Order of the Headquarters of the Pomeranian Military District No. 00573/oper of October 8th 1955.

191 Order of the Ministry of National Defence No. 063/org. of July 17th 1951 (10/7), in: Gembora, Ref. No. 1138, 155.

192 Gembora, Ref. No. 1138, 156. 
the oath taken by 235 junior troops. ${ }^{193}$ In October 1952, another complement was added to the battalion: graduates of the 30th Training Company of Railway Military Reserve Officers were appointed platoon commanders. On January 1st 1952, the 3rd railway troops battalion headcount reached 506. The battalion was charged with the construction and reconstruction of railway lines and facilities, culverts and bridges, and with the operation of militarised railway lines.

The battalion comprised two permanent way companies, a bridge company, a technical company and an operations platoon. The permanent way company was charged with the construction of trackbed and tracks. The bridge company's responsibilities included the construction and reconstruction of wooden bridges and temporary culverts. The tasks assigned to soldiers of the operations company included the handling of heavy equipment: S-100 bulldozers, KU 1201 excavators, standard-gauge Tw1-98 locomotive and PS-15 generator ( $15 \mathrm{kVa})$ with the devices it powered: cross-cut saws, drills, saws, lathes, column drilling machine, and spotlight masts used as construction site lighting. The tasks of the operations platoon included the operation of the permanent-way maintenance train during tracks overhaul and securing telegraph and telephone communication. ${ }^{194}$

The Tw1-98 locomotive was leased in the 1950s from the Regional State Railway Management in Warsaw, and used to haul work trains. Shortly after the battalion had been reformed as the 2nd railway regiment, the locomotive was returned to the Polish State Railways (in March 1958). ${ }^{195}$

On December 3rd 1952, ${ }^{196}$ the battalion's operational status was changed from $10 / 7$ to $10 / 14$. In order to continue the training in the field of anti-aircraft defence, on December 3rd 1952, 3 anti-aircraft defence platoons were dispatched from the 3rd railway troops battalion to the Independent Squadron of Anti-Aircraft Defence of Military Transfers at the 5th railway troops battalion in Darłowo. ${ }^{197}$

In order to add to the full-time personnel of the 3rd railway troops battalion, a further 180 soldiers were recruited for the permanent-way companies on February 12th $1953 .{ }^{198}$ They took the military oath in late March 1953, upon completion of the basic training.

193 Gembora, Ref. No. 1138, 159.

194 Pociagi pancerne (1999), 107.

195 Polish State Railways General Management, Central Traction Management, Księga inwentarzowa parowozów.

196 Order of the Ministry of National Defence No. 00415/org. of December 3rd 1952, in: Gembora, Ref. No. 1138, 160.

197 Gembora, Ref. No. 1138, 162.

198 Gembora, Ref. No. 1138, 162. 
In the autumn of 1953, once all subdivisions returned from their practical training, the 3rd railway troops battalion was relocated from Pikulice to the barracks in Przemyśl-Bakończyce. The facility was a much larger one, with a railway siding with capacity for further expansion on site.

On November 11th 1955, upon order by the commander of the Warsaw Military District, the battalion's operational status was changed from 10/14 to $10 / 16$, with a headcount of 655 soldiers. ${ }^{199}$

In April 1956, the 3rd railway troops battalion was relocated again, from Bakończyce to the new barracks facility of Przemyśl Zasanie. The barracks in Bakończyce remained at the disposal of the battalion, for use as a reserve troops training facility. This was also where the Railway Equipment Depot was organised at the time, reporting directly to the Headquarters of Military Transport of the General Staff of the Polish Armed Forces.

From 1952, the battalion also provided military and railway training for the students of the Warsaw, Cracow and Silesian Universities of Technology for military railway purposes. The technical skills of the battalion upon the completion of training were tested during works performed for the purposes of both the army and the national economy, organised annually at field camps (during the period of May to September).

The battalion was dispatched to its first field camp in Ustrzyki Dolne in 1952. The 3rd railway troops battalion engaged in works associated with the reconstruction of the Ustrzyki Dolne - Krościenko railway line, ${ }^{200} 12 \mathrm{~km}$ long. The line was converted from $1,524 \mathrm{~mm}$ broad gauge to $1,435 \mathrm{~mm}$ standard gauge. The reconstruction of the line also involved full length rail and track replacement as well as bridge and culvert reconstruction. Apart from delivering the aforementioned tasks, the battalion (assisted by reserve troops) completed an intermediate-level repair project on a $20 \mathrm{~km}$ section of the Zagórz - Komańcza Łupków railway line at a field camp in Zagórz. Additionally, the battalion was involved in the construction of a railway siding leading to the military barracks at the Pikulice garrison - the project had to be discontinued as a result of the battalion having been relocated from Pikulice to Bakończyce in 1953.

In 1953, the battalion left for a field camp in Bezwola near Łuków, a military railway siding had been constructed during its term. The works involved the construction of a $9 \mathrm{~km}$ section of a siding access track, branching off from Polish State Railways station in Bezwola. Due to on-site difficulties the development

199 Gembora, Ref. No. 1138, 164.

200 Gembora, Ref. No. 1138, 169. 
of the access track embankment required extensive earthworks (half of the 9 kilometre access track ran upon a 1,5m high embankment, the other half routed in a $2 \mathrm{~m}$ deep cutting). Furthermore, the siding construction project involved the construction of 7 side tracks (each $6 \mathrm{~km}$ long); trees were felled and stumps grubbed on site as well. During the same year, the battalion performed railway station expansion works at a field camp in Tarnobrzeg.

At the Polish State Railways station in Żurawica, the battalion carried out track repairs, and engaged in the practical training of non-commissioned officer cadets in the field of railway operation.

In 1954, the battalion was dispatched to another field camp in Bezwola for the purpose of continued siding development. The investment was completed 12 days ahead of time, in conformity to the commitment to commemorate the 10th anniversary of the founding of the Polish People's Republic. That same year the battalion subdivisions engaged in bridge construction works at a field camp in Wyszków, the project coinciding with the battalion's bridge company having joined forces with the 63rd road troops battalion to reconstruct and refurbish road bridges across the River Vistula in Wyszogród and Płock.

In 1955, upon an order by the head of the Headquarters of Military Transport of the General Staff of the Polish Armed Forces, the battalion was engaged in works at the Hurko-Medyka field camp, to expand the Dry Transhipment Port in Medyka and local sidings for army purposes.

In the same year, the battalion (having joined forces with the permanent-way company) also worked on an intermediate-level repair project of the Siedlce Czeremcha railway line, at a field camp in Mordy. The non-commissioned officers academy, in turn, worked together with the permanent-way company to expand the Dry Transhipment Port in Medyka. The operations company of the non-commissioned officers academy provided training in the field of handling rail traffic signalling devices at the Polish State Railways station Żurawica.

In February 1955, the bridge company of the battalion commanded by Second Lieutenant Zygmunt Leciak - having joined forces at a field camp in Iskań with the 83rd road troops battalion - completed the construction of a high-water road bridge (187 m long) across the River San.

On April 3rd 1956, by order of the Chief of General Staff, ${ }^{201}$ the battalion began constructing the Cisna - Przysłup - Kalnica - Wetlina narrow-gauge forestry railway line, during a field camp in Przysłup near Cisna. The purpose

201 Order by the Co-General Staff of the Polish Armed Forces No. 00592 of April 3rd 1956, in: Gembora, Ref. No. 1138, 173. 
of extending the existing Nowy Łupków - Cisna narrow-gauge line towards Wetlina was to foster economic recovery of the Bieszczady Mountains and increase timber shipments. While constructing the narrow-gauge railway in 1956 at the field camp in Przysłup the battalion constructed $13.5 \mathrm{~km}$ of railway embankments (as an undeveloped structure) and 32 culverts. All works were performed in difficult technical conditions in a mountainous area. The value of all works carried out totalled 9 million zloty. The $3 \mathrm{rd}$ railway troops battalion was joined by subdivisions of the 7th railway troops battalion from Września for the purposes of works to construct the narrow-gauge railway line in the Bieszczady Mountains. The 3rd railway troops battalion (thereafter the 2 nd railway regiment) continued working on the narrow-gauge railway line until 1959.

In 1957 the battalion continued (together with the 7th railway troops battalion) works associated with the construction of a narrow-gauge railway in the Bieszczady Mountains - the actual railway line was developed on previously prepared embankments. At the same time the battalion subdivisions engaged in works associated with the modernisation of the Polish State Railways station in Szczakowa ${ }^{202}$ and the electrification of the Trzebinia - Szczakowa railway line.

Pursuant to the resolution of the Council of Ministers of the Polish People's Republic of March 25th $1957^{203}$ and the Order of the Minister of National Defence of April 19th $1957^{204}$ concerning the reductions to army numbers, on April 26th 1957 the commander of the Warsaw Military District ordered the operational status of the battalion to be changed from 10/16 to $10 / 19$, the battalion itself renamed the 2 nd railway regiment. The battalion was to be reformed by June 15 th $1957 . .^{205}$

\subsubsection{7th Railway Troops Battalion in Września}

Upon the order of the Minister of National Defence of July 17th 1951, ${ }^{206}$ the 7 th railway troops battalion was formed in Września to operational status 10/7 with

202 As of July 1957, 7th railway troops battalion subdivisions were working to modernise station Szczakowa; they were replaced with 2 nd railway troops regiment subdivisions at a later time.

203 Regulation of the Council of Ministers No. 109/57 of March 25th 1957.

204 Order of the Ministry of National Defence No. 031/org. of April 19th 1957.

205 Gembora, Ref. No. 1138, 178.

206 Order of the Ministry of National Defence No. 063/org. of July 17th 1951, in: Gembora, Ref. No. 1138, 178. 
an overall headcount of 632 soldiers. The battalion was the third railway unit to be formed upon the end of wartime hostilities in Poland.

An organisational group of 12 officers and non-commissioned officers and 90 privates from the 5th railway troops battalion arrived to the newly formed battalion on August 18th 1951. ${ }^{207}$ Major Eugeniusz Majer was appointed commander of the 7th railway troops battalion with Lieutenant Antoni Piszczyk as his deputy for political affairs. By October 20th 1951, the group had taken over and developed the barracks facility complex. In November 1951, the battalion began training and adapting the barracks facility to meet the purposes of railway troops. In late October, the first group of draft junior troops was incorporated into the battalion. In early November, the battalion was joined by a supplement from the 5th railway troops battalion (command personnel) and by graduates of the Officers' Military Engineering Academy in Wrockaw. The officers and non-commissioned officers dispatched from other types of armed forces of the Silesian Military District arrived to the battalion as well. In October 1952, graduates of the 30th Training Company of Railway Military Reserve Officers in Darłowo joined the battalion, appropriately appointed platoon commanders or assigned as bridge technicians to the Technical Section, for example. ${ }^{208}$

On January 1st 1952, the headcount of the 7th railway troops battalion reached 538 soldiers; ${ }^{209}$ on January 10th, the first military oath ceremony was held at the battalion, Lieutenant Colonel Włodzimierz Godek receiving the oath taken by 448 junior troops. ${ }^{210}$

To secure anti-aircraft defence training, two full-time anti-aircraft defence platoons were dispatched from the 7 th railway troops battalion to the 5 th railway troops battalion in Darłowo on December 3rd 1952. ${ }^{211}$ Both platoons were incorporated in the Independent Squadron of Anti-Aircraft Defence of Military Transports.

On December 3rd 1952, ${ }^{212}$ the operational status of the battalion was changed from 10/7 to 10/14. Upon the order by the Chief of General Staff of the Polish Armed Forces, the Training Curriculum for Reserve Officers of the Railway Military Forces was relocated from the 5th railway troops battalion in

207 Gembora, Ref. No. 1138, 179.

208 Lieutenant Colonel Kazimierz Balog's account of December 10th 2006.

209 Gembora, Ref. No. 1138, 179.

210 Gembora, Ref. No. 1138, 185.

211 Order of the Ministry of National Defence No. 00415/org. of December 3rd 1952, in: Gembora, Ref. No. 1138, 185.

212 Gembora, Ref. No. 1138, 187. 
Darłowo to the 7th railway troops battalion on April 30th 1953, ${ }^{213}$ All Training Curriculum personnel were quartered in the barracks of the non-commissioned officers academy. ${ }^{214}$

Following the disbandment of the 5th railway troops battalion upon the order by the commander of the PMD of October 8th 1955, ${ }^{215}$ the Independent Squadron of Anti-Aircraft Defence of Military Transports was relocated to the 7 th railway troops battalion. In October 1956, the Squadron was dispatched out of railway troops structures to Zgorzelec. ${ }^{216}$ On November 8th $1955,{ }^{217}$ the operational status of the 7th railway troops battalion was changed again from 10/14 to $10 / 16$, with a headcount of 655 soldiers.

The 7th railway troops battalion was dispatched to its first field camps in Mordy and Platerów in 1952; the practical training of the battalion subdivisions involved works associated with full-length railway surface replacement on the Mordy - Siemiatycze section. That same year, the battalion was dispatched to a field camp in Zielonka, where the troops engaged in works to construct seven temporary wooden bridges for the purposes of the narrow-gauge railway line being built at that time at the Centre for Ballistic Research. ${ }^{218}$ In 1954, battalion subdivisions continued working on the line. The battalion was dispatched to a field camp in Nurzec in the same year with intent to join the 5th railway troops battalion from Darłowo in constructing a military railway siding.

The battalion also engaged in the construction of a railway siding to the barracks in Września for in-house purposes. The siding (approximate length: $5 \mathrm{~km}$ ) was enlarged to form a small railway station at battalion barracks. It was fitted with rail traffic signalling devices (including manual semaphores). A 25-metre long bridge and two culverts were built as part of the construction project; the siding was to be used in the training of operation subdivisions and for in-house service purposes.

In 1954, the battalion was dispatched to field camps in Nurzec, Srem and Poznań. At the training camp in Nurzec - having joined forces with the 5th

213 Order of the Chief of General Staff of the Polish Armed Forces No. 0125/org. of March 10th 1953, in: Gembora, Ref. No. 1138, 187.

214 The full-time variable headcount at the course totalled 100 students.

215 Order by the Commander of the PMD No. 00537/oper of October 8th 1955, in: Gembora, Ref. No. 1138, 188.

216 Gembora, Ref. No. 1138, 188.

217 Order by the Commander of the Silesian Military District No. 0172 of November 8th 1955, in: Gembora, Ref. No. 1138, 90.

218 In the 1960s, the Centre was renamed the MIoAT in Zielonka. 
railway troops battalion from Darłowo - it continued works to construct a military siding. At the field camp in Srem, assisted by bridge companies and jointly with the 78th road troops battalion from Torun, the battalion constructed a 150metre long road bridge across the River Warta in Śrem. The bridge was commissioned for traffic on July 22nd for propaganda-related reasons. At the field camp in Poznań, supported by its permanent-way company, the battalion refurbished tracks at the Polish State Railways station in Poznań. The battalion also provided practical training for non-commissioned officer academy cadets in the field of railway operations at PKP stations in Września and Poznań. In 1954 the battalion continued to expand and modernise its own siding in Września; the works were performed by the subdivisions that remained in the garrison.

In 1955, the battalion was dispatched to field camps in Waliły, Chwalibogowo and Kuryłówka. At the Waliły camp a military siding was constructed; 7 kilometres of track were constructed and 53,000 $\mathrm{m}^{3}$ of soil were displaced; local works also included felling trees and grubbing up stumps.

In August, at the Chwalibogowo field camp, the battalion constructed two road bridges (15 and $22 \mathrm{~m}$ in length, respectively), for purposes of the Września county. At the camp in Kuryłówka, supported by two bridge companies and together with the 63rd road troops battalion from Płock, the battalion constructed a 252-metre long road bridge over the River San in Kuryłówka.

In 1956, the battalion was dispatched to field camps in Skandawa, Przysłup near Cisna, and Poznań.

At the Skandawa camp, assisted by two permanent-way companies and three reserve troops companies, together with the 5th railway troops battalion from Darłowo, the battalion engaged in works to construct a military siding, and the second track of the Sątopy Samulewo - Korsze railway line (length: $15 \mathrm{~km}$ ).

At the camp in Przysłup, upon the order by the Chief of General Staff, ${ }^{219}$ the battalion engaged in works to construct the Cisna - Przysłup - Kalnica - Wetlina narrow-gauge forestry railway line, jointly with the 3rd railway troops battalion from Bakończyce. The battalion constructed 8 kilometres of tracks and 4 small bridges (total length: $100 \mathrm{~m}$ ). The earthworks in difficult mountainous terrain involved moving of 54,000 $\mathrm{m}^{3}$ of soil. At the field camp in Poznan, the battalion renovated 17 kilometres of station tracks at the Polish State Railways station in Poznań.

219 Order of the Commander of General Staff of the Polish Armed Forces No. 00592 of April 3rd 1956, in: Gembora, Ref. No. 1138, 198. 
In 1957, the battalion was dispatched to their subsequent field camp in Przysłup; using first-year junior troops, together with the 3rd railway troops battalion from Bakończyce, the battalion continued to construct the narrow-gauge Cisna - Przysłup - Kalnica - Wetlina railway. On June 15th 1957, the subdivisions of these battalions ${ }^{220}$ were incorporated into the 2 nd railway regiment.

Furthermore, the battalion participated in combating the effects of natural disasters, soldiers protecting bridges from ice floes, taking part in flood prevention action, and clearing snow from railway lines, stations and roads.

The 7th railway troops battalion completed its training on April 24th 1957. On May 2nd 1957, first-year troops were dispatched to field camps in Przysłup and Szczakowa to modernise and expand the marshalling yard. ${ }^{221}$

Acting upon the Resolution of the Council of Ministers of March 25th 1957 and the order of the Ministry of National Defence of April 19th 1957 concerning the reductions to army numbers, and pursuant to the order of the commander of the Silesian Military District of April 30th 1957, the 7th railway troops battalion was disbanded, the disbandment period set for May 1st until July 20th 1957. All the technical and railway equipment owned by the battalion was transferred to the 2nd railway regiment that was being formed in Przemyśl. ${ }^{222}$

All the officers and non-commissioned officers were reassigned to military transport authorities and to other Silesian Military District units; some were released as part of the reserve corps. Some personnel (24 officers and 15 noncommissioned officers) were transferred to the 2 nd railway regiment under formation. Once the battalion had been disbanded, the second-year draft troops were granted early release into the reserve corps. The barracks were handed over to the Municipal National Council in Września, some facilities placed at the disposal of the Soviet Army (transport battalion of the Soviet Army). ${ }^{223}$

220 Order of the Commander of the Silesian Military District No. 08/org. of April 30th 1957, and order of the Commander of the Warsaw Military District No. 026/org. of April 26th 1957, in: Gembora, Ref. No. 1138, 203.

221 Gembora, Ref. No. 1138, 213.

222 Gembora, Ref. No. 1138, 213.

223 Lieutenant Colonel Kazimierz Balog's account of December 10th 2006. 
Zbigniew Tucholski - 978-3-631-82966-0 Downloaded from PubFactory at 09/30/2020 04:51:29PM by keerthiga.m@newgen.co via Peter Lang AG and keerthiga.m@newgen.co 


\section{PREPARING THE POLISH STATE RAILWAYS NETWORK FOR A MILITARY CONFLICT AS PART OF WARSAW PACT STRATEGIC PLANS}

The re-gauging of the majority of the main railway lines on the Polish territory back to standard-gauge did not, however, end the time of close supervision of the Polish State Railway operations by the Soviet military authorities.

The transit layout of railway lines along the East-to-West axis on the Polish territory was far too important for the Soviet war plans. In view of the country's geopolitical circumstances, already the tsarist military doctrine had assumed the operational use of the shortest route to Berlin, which cut across the Kingdom of Poland, impacted by a single water obstacle: the River Odra. Conversely, an assault along the left bank of the River Vistula could cut off the strongly fortified German border of the lower Vistula and East Prussia. ${ }^{224}$

After 1945 the Polish railway network was charged with two fundamental peacetime responsibilities: performing army troop transports and transports of supplies for the units of the Polish Armed Forces units, delivering supplies and carrying rotation personnel for the Soviet troops stationed in Poland, and handling related transit transfers for the troops stationed in the Soviet occupation zone in Germany. During the initial post-war years, prisoners of war, prisoners, and huge volumes of spoils of war were also shipped east.

Delegations of the Supreme Board of Military Transport of the Red Army were established at the General Staff of the Polish Armed Forces, Ministry of

224 The war doctrine of tsarist Russia underwent considerable modifications with every change in the minister of war position. The Russian Empire's railway policy was based on the premises resulting from defensive strategic plans, which is why the Russian General Staff opposed the expansion of a number of strategic railways located on the left bank of the River Vistula. These lands were written off with a defensive concept of destruction of railway lines and withdrawal of railway rolling stock east of the River Vistula demarcation line (the line of withdrawal and evacuation), in case of an enemy attack. The first line of the 1st class fortresses was treated as a strategic shield for the mobilisation of the Russian army, which was much more lengthy than in case of other European countries due to the poor railway network development. These plans resulted from the fear of the flanking of the first-wave mobilisation of Russian troops. Cf. Bochenek (1996), introduction. 
Transport, Polish State Railways General Management, and Regional State Railway Managements, in order to deliver all scheduled transport services for the Soviet Army. ${ }^{225}$ Similar facilities operated at the vital stations and railway line sections. ${ }^{226}$ The structure was mirrored by the Polish military transport units of the Polish Armed Forces, which was set up in parallel to the Russian structure.

During wartime, the railway network in Poland was to be charged with relocating second-wave Soviet troops to regroup the deep operational reserves, and shipping ammunition, equipment and supplies onto the Western Operational Direction. Other plans included railway network to be used for the purposes of regrouping troops along the Coastal Operational Direction.

The technical infrastructure developed by the Germans as part of their plan (codename Otto) to build a transport system for the purposes of invading the USSR played a significant part in the Russian plans of using the existing railway network on the Polish territory.

The layout of railway lines on the Polish territory was of great importance to the offensive war doctrine of the Warsaw Pact, as the strategic Małaszewicze Siedlce - Warsaw - Kutno - Poznań - Zbąszynek - Kunowice - Frankfurt mainline, other major transport lines, as well as numerous parallel lines ran through Poland.

The new Soviet doctrine of rear operations in nuclear war conditions assumed a balanced employment of all types of transport (by road, rail, air, and sea) alongside large-scale air and sea landings. ${ }^{227}$ Attention was also paid at the time to the need of securing railway network viability and adequate rail transport capacity in the nuclear weapon attack conditions. The 1950s brought about another qualitative change resulting from the technical development of rocket missiles (capable of transferring warheads with conventional and nuclear charges), which became the dominant element of the battlefield. The Soviet art of military operations (founded upon the experience of the Second World War) assumed

225 Final delegations of the Supreme Board of Military Transport of the Soviet Army at the General Polish State Railways Management and Regional State Railway Managements were liquidated only upon the final withdrawal of the Soviet troops from Poland in 1992.

226 In the area of Regional State Railway Warsaw Management, these units were located at the Regional State Railway Management in Warsaw, and at stations Czeremcha and Kutno.

227 The construction of assault vessels in the Polish shipyards and the forming of landing and assault divisions were both determinants of such trends in the Polish Armed Forces. 
that a success in modern warfare could be secured through large operational compounds: armoured armies, mechanised corps, and the air force. In the mid1950s, unique thermonuclear war conditions enforced the need to design combat vehicles and tanks adapted for operations under conditions of radioactive contamination (the T-55 was the first tank adapted for operation on the nuclear war battlefield).

The Komunikacja Wojskowa handbook drafted by the Ministry of National Defence reads:

[...] The potential contemporary war the capitalist countries bloc has begun preparations for will be a global, coalitionist, and intercontinental war, involving massive use of nuclear and missile weapons, as well as the use of outer space for military purposes. The early period of a contemporary war will be of particular importance, its trademark feature would be that of deep and decisive operations with a daily rate of 80 to $100 \mathrm{~km}^{228}$ and more, active and manoeuvre-based combat operations, and brief operational breaks [...]. The mobilisation of armed forces or concentration of all tactical and operational compounds under such conditions, followed by augmented efforts by all types of troops, supplying them, or manoeuvres with force and measure, will all be impossible without extensive use of assorted modes of transport.

In the course of the military operations, transport will be the basic solution for manoeuvring troops, transporting material resources, and evacuating the wounded, the sick, and all unnecessary assets from the frontline area to homeland. The success of the contemporary combat operations and of the sustainability of the operational rear will largely depend on the technical-and-operational condition of the modes of transport, and the efficiency of their use. Therefore, transport will be among the main targets of the enemy's attack. Attacks with the use of weapons of mass destruction will destroy important transport objects located at any distance from the front line, radioactive agents will contaminate entire regions and sections of the transport network, long-term traffic interruptions will affect the railway, roads, and inland waterways. ${ }^{229}$

Given the dependence of all types of land transport on the potential nuclear attack-caused destruction which would completely paralyse the manoeuvrability of operational and tactical compounds, peacetime preparations of the transport network for work under war conditions became an unquestioned focus. It was also assumed that an enemy attack on the railway network might cause

228 The rate of attack as quoted was extremely high, and rather optimistic in assuming complete success of the offensive operation. Notably, the average daily rate of attack for units of the 1st Belarussian Front and 1st Ukrainian Front during the VistulaOdra Operation reached 17 to $40 \mathrm{~km}$, Cf. Ministry of National Defence, GS 181/56, Rozgromienie wojsk (1956), 115.

229 Ministry of National Defence, CC 33/64, Komunikacja wojskowa (1965), 18-19. 
significant damage and contamination, as a result of which only isolated sections and areas of strategic importance would preserve their transport capacity. It was highlighted that the impact of an adverse mass destruction attack might result in the complete annihilation of the capacity of certain modes of transport, road sections, and transport objects (especially rail) to operate for the Armed Forces.

It was assumed that once the following conditions regarding the transport network were met, they would ensure mobility and continuity of transport in wartime conditions: $:^{230}$

- Possession of a dense, high-capacity transport network,

- Ensuring the possibility to perform quick manoeuvres with transfers and means of transport,

- Ensuring the viability and continuity of transport in vital directions under enemy impact.

The organisation of military transports was also adapted (according to the prevalent theory) to nuclear war conditions. In view of the danger of an enemy using nuclear weapons against transport facilities of greater importance, the rule of dispersing transport flows was adopted already at the mobilisation stage. The stations that were to be used for the loading and unloading of mobilisation resources were located outside of the areas of large junctions and junction stations, always at a distance of 20-30 km from venues of forming or developing military units and military plants. Contingency loading and unloading stations were designated, too. ${ }^{231}$

In the course of the planning works over the new Warsaw Pact military doctrine, the concept of employing wartime rear operations experience combined with the use of state-of-the-art military technological achievements was adopted. It was duly noted that, during the Second World War, rail traffic interruptions due to enemy air force operations would usually last 6 to 8 hours, whereas contemporarily, the air force and missiles were capable of destroying transport objects at any point on enemy territory. Destruction-caused interruptions could last much longer; consequently, the transport capacity of railway lines could decrease by about $50-60 \% .{ }^{232}$ 
In the conclusions laid out in the summary of his work Na głównym kierunku, ${ }^{233}$ General Antipenko described the basic tendencies associated with adapting the railway network and transport activities to the conditions of a nuclear war:

[...] Therefore, the question is not which mode of transport to recognise as a priority at the Frontline, but how to most effectively use all types of transport - in isolation or jointly. The comprehensive use of all modes of transport is one of the cornerstones of the rear Frontline operations, largely determining the so-called viability of the rear. The timely transition from one mode of transport to another, the use of available alternative routes or their early preparation - all such solutions improve the viability of the rear.

During the recent war we discovered the importance of railway detours of large hubs or administrative and political centres. Even during peacetime, detours can be practically justified in terms of national interest. While road and railway detour construction is currently attracting increased attention, much more should be done in the field than has been done thus far. Deliberations concerning the desirability of military use of the surviving sections of railway lines bring the thought of steam locomotive to mind: steam locomotives, not diesel or electric ones. A primitive locomotive - such as the steam locomotive indubitably is - may indeed prove to be the single available mode of transport once wood and similar readily-accessible fuels become the only option. The scrapping of steam locomotives should not be rushed. Comprehensive use of all modes of transport and communication routes is most definitely a capacity of an integrated rear system. With such an integration, the other side of the problem - comprehensive recovery of transport-related damage - may be resolved properly as well [...]. ${ }^{234}$

Due to all of the above, the basic assumption for the rear operations involved the organisation of a single transport network consisting of railways, frontline roads, inland waterways, ${ }^{235}$ field pipelines, and airfields. Attention was also paid to securing uniform solutions of rapid troops and military cargo transition from one transport mode to another. ${ }^{236}$ The need for troops and rear support structures to be quickly regrouped, and the increased demand for operational troops supplies gave rise to the need for maximum mobility and flexibility in transport, and for the reduction in its sensitivity to the impact of modern means of destruction. ${ }^{237}$

233 Antipenko (1970), conclusions.

234 Antipenko (1970), 350-351.

235 While inland waterways were of marginal significance to military transport, during the Red Army offensive campaigns in the Second World War, inland waterway stock and facilities on major Polish and German rivers were used to carry supplies and ship war spoils to Russia.

236 Ministry of National Defence, Transport Command 33/64, Komunikacja wojskowa (1965), 19.

237 Ministry of National Defence, Transport Command 33/64, Komunikacja wojskowa (1965), 191. 
Already in the 1950s, preparations were in progress on the Soviet railway network with intent to secure uninterrupted operations in nuclear war conditions, not least as on the USSR territory the railway network density was rather limited in comparison to other European countries. Strategic bypasses were constructed at the time on most railway junctions (their destruction upon first nuclear impact was assumed) beyond the range of tactical nuclear warheads, as well as new parallel and reserve lines. The simulations of a nuclear attack involved an assumption that power plants, traction substations, and the power grid would all be destroyed. To secure railway operability in thermonuclear warfare conditions, significant investments connected with organising special purpose steam locomotive bases were carried out; hundreds of decommissioned, yet overhauled and properly preserved steam locomotives were collected at such depots. The technical infrastructure required to operate steam traction (water stations, coal refuelling equipment, ash pits, steam locomotive repair workshops) was maintained in operational standby condition; significant volumes of traction coal were stored and preserved at depots for warfare purposes as well.

The Polish State Railways engaged in similar activities, albeit on a significantly less expansive scale; yet in view of the considerable railway network density on territories under former Prussian and Austrian partitioning, numerous local railway lines could be used as bypasses.

On territories under former Russian partitioning, where the tsarist defensive military doctrine inhibited any railway network development, the need arose to supplement the railway network for strategic purposes. The construction of the Skierniewice - Pilawa - Łuków line ${ }^{238}$ (length: $161 \mathrm{~km}$, built over the years 1952-1953) became the flagship investment targeting the continuity of railway line viability along the Western Operational Direction, the project's immediate justification involving the need to secure a latitudinal bypass for military transports in transit between the USSR and East Germany and for transfers planned along the Western Direction, should the Warsaw junction be destroyed in a nuclear attack (the minimum distance from the Warsaw Railway Junction, in the vicinity of Czachówek station - $30 \mathrm{~km}$ ). The great importance of this investment is demonstrated by the fact that it formed part of the main East-to-West strategic transit network: (state border near Terespol) - Małaszewicze - Łuków Skierniewice - Łowicz - Kutno - Poznań - Zbąszynek - Kunowice - Frankfurt. ${ }^{239}$

238 Significant increase in military transit traffic gave rise to the need to build a second track, completed on this section in 1965, see: Pisarski (1974), 127.

239 Pisarski (1974), 124. 
The importance of the line increased with its electrification, the project was completed in $1971 .{ }^{240}$

With warfare in mind, two strategic rail links were to be constructed on the Skierniewice - Łuków line, in order to secure the connection to the Warsaw Dorohusk line: allowing access from the Góra Kalwaria direction to station Pilawa with the passenger section of Pilawa station bypassed, and allowing direct access from Ruda Talubska station to Parysów. ${ }^{241}$ The planned rail links would enable direct passage of troop trains from the USSR via transport line No. 7 (Dorohusk - Lublin) and via the front mainline (state border near Terespol) Małaszewicze - Łuków - Skierniewice - Łowicz - Kutno - Poznań - Zbąszynek Kunowice - Frankfurt.

As an add-on to the set-up of the old Russian parallel lines ${ }^{242}$ - Brest - Chelm (1887), Siedlce - Małkinia (1887), Małkinia - Ostrołęka (1893), Ostrołęka Łapy (1893), Pilawa -Mińsk (1893), Mińsk - Tłuszcz (1897), Tłuszcz - Ostrołęka (1897), Lublin - Łuków (1898), Grodno - Olita (1899) ${ }^{243}$ - the following new parallel lines and strategic bypasses of railway junctions were developed in the 1950s: Tomaszów Mazowiecki - Radom (Tomaszów Mazowiecki - Drzewica opened for traffic on May 9th 1948, Drzewica - Radom opened for traffic on January 9th 1949). ${ }^{244}$ The construction of the Warszawa Gdańska - Warszawa Odolany rail link (opened for traffic on October 17th $1951^{245}$ ) was also intended to secure greater railway network efficiency within the Warsaw Railway Junction. In the 1950s and 1960s a series of bypasses and rail links were built to increase the network's lifespan and strategic frontline and parallel lines capacity. Second tracks were built and railway signalling devices were modernised on numerous rail sections as well.

Attention was drawn at the time to the need of maintaining rail links to enable bypassing of critical railway junctions, should these be destroyed. Working jointly with the military offices of the Regional State Railway Management,

240 Following electrification, the line capacity increased and journey times decreased yet electrification remained marginal to military purposes. Due to the high destruction sensitivity of the overhead wires, traction substations, transmission lines and the power system, plans were made to switch to steam and diesel traction in wartime.

241 Regional State Railway Management Warsaw, Wojskowo-techniczny opis (1972), 2.

242 Line opening dates in parentheses.

243 Wojasiewicz (1982), 50.

244 After the war, the German wartime investment forming part of the Otto plan was completed, opening dates as indicated in Lijewski, Koziarski (1995), 100.

245 Lijewski, Koziarski (1995), 100. 
Headquarters of Military Transport drafted the regularly updated Wojskowotechniczne opisy łacznic kolejowych [Military-technical description of rail links] for all Regional State Railway Management, the register including operational, disused, and dismantled sidings (with specifications of track infrastructure, as well as of the general condition of trackbeds, civil engineering structures, and railway signalling devices), as well as sidings planned for construction or reconstruction during warfare.

The list of rail links (existing, dismantled and planned in case of warfare) within the area of the Warsaw Regional State Railway Management in $1972^{246}$

\begin{tabular}{|l|l|}
\hline Name of the rail link & Line sections linked \\
\hline $\begin{array}{l}\text { junction post }{ }^{1} \text { Jagiellonka - junction } \\
\text { post Targówek }\end{array}$ & $\begin{array}{l}\text { Warszawa Gdańska - Warszawa } \\
\text { Wschodnia }\end{array}$ \\
\hline $\begin{array}{l}\text { junction post Targówek - station } \\
\text { Warszawa Wileńska Marki }\end{array}$ & $\begin{array}{l}\text { Warszawa - Działdowo } \\
\text { Warszawa - Białystok }\end{array}$ \\
\hline $\begin{array}{l}\text { Warszawa Wschodnia } \\
\text { Osobowa - Michałów }\end{array}$ & $\begin{array}{l}\text { Warszawa -Działdowo } \\
\text { Warszawa - Terespol }\end{array}$ \\
\hline $\begin{array}{l}\text { Michałów - Warszawa Wschodnia } \\
\text { Towarowa }\end{array}$ & $\begin{array}{l}\text { Warszawa - Działdowo } \\
\text { Warszawa Wschodnia Towarowa - } \\
\text { Warszawa Wschodnia Rozrządowa }\end{array}$ \\
\hline $\begin{array}{l}\text { Michałów - Warszawa Wschodnia } \\
\text { Rozrządowa }\end{array}$ & $\begin{array}{l}\text { Warszawa - Działdowo } \\
\text { Warszawa - Terespol }\end{array}$ \\
\hline $\begin{array}{l}\text { Warszawa Wileńska Marki - Warszawa } \\
\text { Wschodnia Rozrządowa }\end{array}$ & $\begin{array}{l}\text { Warszawa - Białystok } \\
\text { Warszawa - Terespol }\end{array}$ \\
\hline $\begin{array}{l}\text { Warszawa Szczęśliwice - Warszawa } \\
\text { Czyste }\end{array}$ & $\begin{array}{l}\text { Warszawa Zachodnia - Warszawa } \\
\text { Bema }\end{array}$ \\
\hline Warszawa WCz 6 - Warszawa Czyste & Internal freight rail link \\
\hline Pruszków - Komorów & $\begin{array}{l}\text { Warszawa Śódmieście - Grodzisk } \\
\text { WKD }\end{array}$ \\
\hline
\end{tabular}

246 Regional State Railway Management, Wojskowo-techniczny opis (1972), 2.

Zbigniew Tucholski - 978-3-631-82966-0 


\begin{tabular}{|l|l|}
\hline Name of the rail link & Line sections linked \\
\hline junction post Prostyń Bug - Treblinka 2 & $\begin{array}{l}\text { Ostrołęka - Siedlce - Warsaw - } \\
\text { Białystok }\end{array}$ \\
\hline $\begin{array}{l}\text { Warszawa Antoninów - Warszawa } \\
\text { Gocławek }\end{array}$ & $\begin{array}{l}\text { Warszawa Wschodnia } \\
\text { Rozrządowa - Rembertów } \\
\text { Warszawa Wschodnia } \\
\text { Osobowa - Dęblin }\end{array}$ \\
\hline $\begin{array}{l}\text { junction post Stojadła - junction post } \\
\text { Kędzierak }\end{array}$ & $\begin{array}{l}\text { Warszawa Centralna - Terespol } \\
\text { Krusze - Pilawa }\end{array}$ \\
\hline junction post Ca 5 - junction post Ca 6 & $\begin{array}{l}\text { Siedlce - Czeremcha } \\
\text { Czeremcha - Brest }\end{array}$ \\
\hline $\begin{array}{l}\text { junction post Jasienica Mazowiecka - } \\
\text { junction post Krusze }\end{array}$ & $\begin{array}{l}\text { Mińsk Mazowiecki - Tłuszcz } \\
\text { Legionowo - Tłuszcz }\end{array}$ \\
\hline $\begin{array}{l}\text { Warszawa Odolany - junction post } \\
\text { Józefinów }\end{array}$ & $\begin{array}{l}\text { Warszawa Odolany with the } \\
\text { Warszawa } \\
\text { Centralna - Katowice line }\end{array}$ \\
\hline $\begin{array}{l}\text { Warszawa Odolany - Warszawa } \\
\text { Gdańska } \\
\text { (old circumferential line) }\end{array}$ & $\begin{array}{l}\text { Warszawa - Kutno } \\
\text { Warszawa - Działdowo }\end{array}$ \\
\hline Chotomów - Łajski & $\begin{array}{l}\text { Legionowo - Tłuszcz } \\
\text { Warszawa - Działdowo }\end{array}$ \\
\hline Warszawa Odolany - Gołąbki & $\begin{array}{l}\text { Warszawa - Kutno } \\
\text { Warszawa - Koluszki }\end{array}$ \\
\hline Warszawa Odolany - Warszawa Czyste & Internal freight rail link \\
\hline $\begin{array}{l}\text { Warszawa Odolany - Warszawa } \\
\text { Gdańska }\end{array}$ & $\begin{array}{l}\text { Warszawa - Kutno } \\
\text { Warszawa - Działdowo }\end{array}$ \\
\hline Warszawa Odolany - junction post & $\begin{array}{l}\text { Warszawa - Kutno } \\
\text { Warszawa - Koluszki } \\
\text { Warszawa - Radom }\end{array}$ \\
\hline Skierniewice - Łuków - Warszawa - \\
Radom
\end{tabular}




\begin{tabular}{|c|c|}
\hline Name of the rail link & Line sections linked \\
\hline Czachówek Wsch. - Czachówek Płd. & $\begin{array}{l}\text { Skierniewice - Łuków - Warszawa - } \\
\text { Radom }\end{array}$ \\
\hline Czachówek Zach. - Czachówek Płd. & $\begin{array}{l}\text { Skierniewice - Łuków - Warszawa - } \\
\text { Radom }\end{array}$ \\
\hline Czachówek Płn. - Czachówek Zach. & $\begin{array}{l}\text { Skierniewice - Łuków - Warszawa - } \\
\text { Radom }\end{array}$ \\
\hline Rembertów - Zielonka & $\begin{array}{l}\text { Warszawa - Białystok } \\
\text { Warszawa - Terespol }\end{array}$ \\
\hline junction post Siwki - km. 19.204 & $\begin{array}{l}\text { Warszawa - Białystok to the } \\
\text { Rembertów - Zielonka rail link }\end{array}$ \\
\hline junction post Poligon - km. $13.807^{4}$ & $\begin{array}{l}\text { Warszawa - Terespol to the } \\
\text { Warszawa - Białystok line via the } \\
\text { Rembertów - Zielonka rail link }\end{array}$ \\
\hline Rembertów - Wawer ${ }^{5}$ & $\begin{array}{l}\text { Warszawa - Terespol } \\
\text { Warszawa - Dęblin }\end{array}$ \\
\hline Papiernia - Las Suwalski & $\begin{array}{l}\text { Suwałki - Olecko } \\
\text { Suwałki - Augustów }\end{array}$ \\
\hline $\begin{array}{l}\text { Rail link on the former of Śniadowo - } \\
\text { Łomża line, near station Śniadowo }\end{array}$ & $\begin{array}{l}\text { Ostrołęka - Łapy } \\
\text { Śniadowo - Łomża }\end{array}$ \\
\hline Doły - Ujrzanów & $\begin{array}{l}\text { Czeremcha - Siedlce } \\
\text { Siedlce - Łuków }\end{array}$ \\
\hline Trzaskoniec - Poważe 6 & $\begin{array}{l}\text { Siedlce - Łuków } \\
\text { Łuków - Dęblin }\end{array}$ \\
\hline Rail link near Suwałki station ${ }^{7}$ & $\begin{array}{l}\text { Sokółka - Suwałki } \\
\text { Suwałki - Trakiszki } \\
\end{array}$ \\
\hline Rail link near Białystok station ${ }^{8}$ & $\begin{array}{l}\text { Czeremcha - Białystok } \\
\text { Białystok - Głomno }\end{array}$ \\
\hline Jaźwiny - Żołnierka & $\begin{array}{l}\text { Krusze - Pilawa } \\
\text { Skierniewice - Łuków }\end{array}$ \\
\hline
\end{tabular}




\begin{tabular}{|c|c|}
\hline $\begin{array}{l}\text { Planned for wartime conditions - rail } \\
\text { link allowing traffic from the direction } \\
\text { of Góra Kalwaria to Pilawa station, } \\
\text { the passenger section of Pilawa station } \\
\text { bypassed }\end{array}$ & $\begin{array}{l}\text { Warszawa - Dorohusk } \\
\text { Skierniewice - Łuków }\end{array}$ \\
\hline $\begin{array}{l}\text { Planned for wartime conditions - rail } \\
\text { link designed to allow train passage } \\
\text { from Ruda Talubska station to Parysów } \\
\text { station }\end{array}$ & $\begin{array}{l}\text { Skierniewice - Łuków } \\
\text { Warszawa Wschodnia - Dorohusk }\end{array}$ \\
\hline $\begin{array}{l}1 \text { The term "junction post" as defined in } \\
{ }^{2} \text { Siding built by Soviet troops during the } \\
\text { destroyed bridge on the River Bug. } \\
{ }^{3} \text { Rail link disused since the } 1960 \text { s, main } \\
\text { purposes. Not maintained since the } 1980 \\
{ }^{4} \text { Rail link disused since the } 1960 \text { s, main } \\
\text { purposes. Not maintained since the } 1980 \\
{ }^{5} \text { Rail link disused since the } 1960 \text { s, main } \\
\text { purposes. Not maintained since the } 198 \\
{ }^{6} \text { Rail link dismantled, trackbeds reconst } \\
\text { over the years } 1970-1971 \text {, culverts inclu } \\
\text { involved the restoration of track surface } \\
{ }^{7} \text { Rail link dismantled, track existed in se } \\
\text { the years } 1974-1975 \text { pursuant to an orde } \\
{ }^{8} \text { Rail link dismantled, trackbed damage } \\
\text { restoration works planned for the forese }\end{array}$ & $\begin{array}{l}\text { ilway vocabulary. } \\
\text { inecond World War as a bypass of the } \\
\text { inedy for potential warfare } \\
\text { ined onty for potential warfare } \\
\text { Dismantled in the mid-1990s. } \\
\text { ined only for potential warfare } \\
\text { Dismantled in the mid-1990s. } \\
\text { icted and prepared for operation } \\
\text { d. In case of warfare, the plan } \\
\text { nd rail signalling devices. } \\
\text { tions; rebuilding works planned over } \\
\text { by the Ministry of Transport. } \\
\text { p to } 20 \% \text { on some sections; } \\
\text { ble future. }\end{array}$ \\
\hline
\end{tabular}

The potential enemy impact on the deep rear made all transport lines and facilities more sensitive than during the Second World War. It was predicted that strategic railway crossings on large water obstacles, railway junctions and main stations and permanent transhipment areas would be destroyed under the initial NATO strike. ${ }^{247}$

As proven by previous conflicts, rebuilding complex track layouts, complicated switches and railway signalling devices would pose significant difficulties whenever it was attempted to restore railway traffic at main junction stations. In

247 Headquarters of Military Transport at Regional State Railway Management in Warsaw, Ogólna charakterystyka (1984), 6. 
view of the above, and in order to maintain railway operational efficiency and longevity, peacetime preparation of emergency-use rail links and strategic railway junction detours for warfare was identified as an operation less demanding in terms of effort and resources alike. When designing such reserve rail links and military purpose bypasses a rule was applied for these to diverge directly from mainline tracks (rather than extensive station track systems).

The need to secure an east-side bypass of the Warsaw Railway Junction was highlighted as well. Should the Warszawa Wschodnia Rozrządowa station be destroyed, plans were made to use the Rembertów - Zielonka rail link (length: $9 \mathrm{~km}$, opened on September 2nd 1933 ${ }^{248}$ ) alongside two short rail links kept on standby in case of war: junction post Siwki - km 19.204 connecting the Warsaw - Białystok line to the Rembertów - Zielonka rail link, and junction post $^{249}$ Poligon - km 13.000 connecting the Warsaw - Terespol line to the Warsaw - Białystok line via the Rembertów - Zielonka rail link. Neither of the two rail links were connected to the railway system. In case of war, it was planned to connect the junction post Siwki - km 19.204 with the railway network by a switch-free slide on to the Rembertów -Zielonka rail link and to track No. 1 of the Warszawa Wileńska - Tłuszcz line. The junction post Poligon - km 13.807 was to be connected with the network by a switch-free slide on to the Rembertów - Zielonka rail link, and to track No. 2 of the Mińsk Mazowiecki Warszawa Wschodnia line. Rail traffic control would involve the setup of a link for traffic control officers at stations Miłosna and Warszawa Wileńska Marki, on existing cable or overhead lines. The rail link was to be incorporated into traffic in less than 24 hours. ${ }^{250}$

The Rembertów - Wawer rail link built by the Soviet military in 1944 was a further section of the Warsaw Railway Junction bypass to be used in the event of the destruction of the Warszawa Wschodnia Rozrządowa station; not used for commercial purposes and kept on standby in case of war, it connected the Warsaw - Terespol line to the Warsaw - Dęblin section.

The Pilawa - Mińsk Mazowiecki - Tłuszcz section was rebuilt in the early 1970s ${ }^{251}$ (Pilawa - Mińsk Mazowiecki in 1970, Mińsk Mazowiecki - Tłuszcz

248 Lijewski, Koziarski (1995), 98.

249 Junction post.

250 Regional State Railway Management Warsaw, Wojskowo-techniczny opis (1972).

251 The line was reconstructed by a battalion of the 2 nd railway regiment in Inowrocław (stationed in Tłuszcz near the steam locomotive depot) and by Permanent Way Work Company No. 15. 
opened on December 29th 1971 ${ }^{252}$ ). The line allowed direct transfer (bypassing the Warsaw Railway Junction) of military troop transports - reloaded at Permanent Transhipment Areas Kuźnica Białostocka, Zubki Białostockie and Siemianówka - to the main front mainline (state border near Terespol) Małaszewicze - Łuków - Skierniewice - Łowicz - Kutno - Poznań - Zbąszynek Kunowice - Frankfurt. Together with the Tłuszcz - Legionowo line, the Pilawa - Mińsk Mazowiecki - Tłuszcz section also became the eastern bypass of the Warsaw Railway Junction. ${ }^{253}$

In order to secure wartime transport continuity, substitute sections were prepared on high-sensitivity junctions on the Western Operational Direction's main frontline railway lines. Folding railway bridge components were stored at major emergency water obstacle crossings, railway connections appropriately secured to reach storage locations. On the Polish territory railway bridges along the Rivers Vistula (width: 400-1,900 m, depth: 1.8-8 m) and Odra (width: 200$400 \mathrm{~m}$, depth: $2.5-10 \mathrm{~m}$ ) were most sensitive to destruction. Essentially, all railway bridge crossings were prepared to secure transport viability in the operational rear, for the purposes of delivering supplies and second-line units to deployment areas. The railway network in Poland was divided along the lines of areas most exposed to destruction: Permanent Transhipment Areas, Substitute Transhipment Areas, and Temporary Transhipment Areas, the latter developed during wartime on destroyed obstacles of Rivers Vistula and Odra.

List of permanent railway bridges on the River Vistula line $e^{254}$

\begin{tabular}{|l|l|l|}
\hline $\begin{array}{l}\text { Railway route or section, other } \\
\text { location }\end{array}$ & Design & Length / Width \\
\hline Wisła Uzdrowisko - Wisła Obłaziec & $?$ & $?$ \\
\hline Skoczów - Pierściec/ Pogórze & $?$ & $?$ \\
\hline Drogomyśl - Pruchna & $?$ & $?$ \\
\hline Zabłocie Czuchów - Strumień & $?$ & $?$ \\
\hline
\end{tabular}

252 Lijewski, Koziarski (1995), 101-102.

253 Lijewski, Koziarski (1995), 33.

254 Own study based on materials owned by the Polish State Railways General Management. 


\begin{tabular}{|c|c|c|}
\hline $\begin{array}{l}\text { Railway route or section, other } \\
\text { location }\end{array}$ & Design & Length / Width \\
\hline $\begin{array}{l}\text { Junction post Wisła Bridge - } \\
\text { Goczałkowice Zdrój }\end{array}$ & steel structure & $175 \mathrm{~m}$ \\
\hline Oświęcim - Nowy Bieruń & $?$ & $178 \mathrm{~m}$ \\
\hline Gorzów Chrzanowski - Oświęcim & 5 spans & $178 \mathrm{~m}$ \\
\hline Miejsce - Okleśna & 5 spans & $215 \mathrm{~m}$ \\
\hline Kraków Główny - Kraków Zabłocie & $\begin{array}{l}\text { steel structure, } 8 \\
\text { spans }\end{array}$ & $189.5 \mathrm{~m}$ \\
\hline \begin{tabular}{|l} 
junction post Kraków Nadwiśle - \\
Kraków Prokocim Towarowy
\end{tabular} & $\begin{array}{l}\text { steel structure, } 8 \\
\text { spans }\end{array}$ & $342.5 \mathrm{~m}$ \\
\hline $\begin{array}{l}\text { junction post Wisła - junction post } \\
\text { Kościelnik }\end{array}$ & $\begin{array}{l}\text { steel structure, } 10 \\
\text { spans }\end{array}$ & $246 \mathrm{~m}$ \\
\hline LHS Wola Baranowska - Staszów & $\begin{array}{l}\text { steel through truss } \\
\text { bridge, } 6 \text { spans }\end{array}$ & $?$ \\
\hline $\begin{array}{l}\text { Stary Łążek - Chmielów near } \\
\text { Tarnobrzeg }\end{array}$ & $\begin{array}{l}\text { road-rail bridge, } \\
\text { steel structure, } 9 \\
\text { spans }\end{array}$ & $\begin{array}{l}425 \mathrm{~m} \\
\text { width: } 8 \mathrm{~m} \\
\text { height: } 6.2 \mathrm{~m} \\
\text { load bearing } \\
\text { capacity: } 30 \\
\text { tonnes } \\
\end{array}$ \\
\hline $\begin{array}{l}\text { junction post Zalesie Gorzyckie - } \\
\text { Sandomierz }\end{array}$ & $\begin{array}{l}\text { steel structure, } 8 \\
\text { spans }\end{array}$ & $455 \mathrm{~m}$ \\
\hline $\begin{array}{l}\text { Zajezierze near Dęblin - } \\
\text { Wisła junction post }\end{array}$ & $\begin{array}{l}\text { steel structure, } 9 \\
\text { spans }\end{array}$ & $445 \mathrm{~m}$ \\
\hline Góra Kalwaria - Warszówka & $\begin{array}{l}\text { steel structure, } 9 \\
\text { spans }\end{array}$ & $445 \mathrm{~m}$ \\
\hline Warszawa Powiśle - Warszawa Stadion & $\begin{array}{l}\text { steel structure, } 11 \\
\text { spans }\end{array}$ & $495 \mathrm{~m}$ \\
\hline Warszawa Gdańska - Warszawa ZOO & $\begin{array}{l}\text { steel structure, } 10 \\
\text { spans }\end{array}$ & $514 \mathrm{~m}$ \\
\hline
\end{tabular}




\begin{tabular}{|c|c|c|}
\hline $\begin{array}{l}\text { Railway route or section, other } \\
\text { location }\end{array}$ & Design & Length / Width \\
\hline Płock Radziwie - Płock & $\begin{array}{l}\text { road-rail bridge, } 15 \\
\text { spans }\end{array}$ & $\begin{array}{l}716 \mathrm{~m} \\
\text { width: } 6.1 \mathrm{~m} \\
\text { load bearing } \\
\text { capacity: } 30 \\
\text { tonnes }\end{array}$ \\
\hline Toruń Główny - Toruń Miasto & 19 spans & $973 \mathrm{~m}$ \\
\hline Bydgoszcz Fordon - Ostromecko & $\begin{array}{l}\text { road-rail bridge, } \\
\text { steel structure } 13 \\
\text { spans }\end{array}$ & $\begin{array}{l}1,010 \mathrm{~m} \\
\text { load bearing } \\
\text { capacity: } 80 \\
\text { tonnes }\end{array}$ \\
\hline Grudziądz - Dragacz & $\begin{array}{l}\text { road-rail bridge, } 11 \\
\text { spans }\end{array}$ & $\begin{array}{l}\text { 1,098 m } \\
\text { width: } 7.1 \mathrm{~m} \\
\text { height: } 5 \mathrm{~m} \\
\text { load bearing } \\
\text { capacity: } 30 \\
\text { tonnes }\end{array}$ \\
\hline Malbork & 2 spans & $249.5 \mathrm{~m}$ \\
\hline Tczew - Lisewo & $\begin{array}{l}\text { steel structure, } 12 \\
\text { spans }\end{array}$ & $1,039 \mathrm{~m}$ \\
\hline Bridge on Martwa Wisła in Gdańsk & 5 spans & $120 \mathrm{~m}$ \\
\hline
\end{tabular}

The advancing primary units were to regroup in a circular way. Large water obstacle crossings were to be handled with the use of combat bridges (Lenta), light floating tanks and tracked personnel carrier fleets, tanks were to cross the rivers on river beds, the speed of crossing rivers was to be identical to the speed of the strike on the ground.

Held during the period of October 5th until October 10th 1962, the BALTICODRA bilateral army exercise served to prove the effectiveness of crossing the obstacle posed by the River Odra:

In observing the 211th Motorised Regiment of the Soviet Army crossing the River Odra, we have identified a real opportunity to significantly reduce the time required to cross a large water obstacle. Owing to the use of floating tracked carriers and the LENTA park, as well as tanks crossing the river directly on the river bed, the regiment crossed the river 
in 15 minutes. A LENTA bridge was constructed in 9 minutes; the tank battalion crossed the river in 4 minutes, that is at a rate of $35 \mathrm{~km}$ per hour. The ferrying equipment employed during the exercise has proven that rivers can be crossed by the military at a rate typical for army action beyond water obstacles. ${ }^{255}$

Due to the low number of permanent railway crossings along the River Vistula and considerable distances separating the existing bridges (approximately $60 \mathrm{~km}$, on average; a particularly long distance of $120 \mathrm{~km}$ without any railway crossings separated Warsaw and Płock), two substitute railway crossings were developed on the Vistula: at Nowy Dwór Kwidzyński and Wysokie Koło. The wartime construction of temporary crossings with the use of folding railway bridge components and the setting up of Temporary Transhipment Areas were also planned on the River Vistula in the vicinity of the destroyed permanent crossings.

A permanent railway bridge over the River Vistula was built on the Prabuty Szlachta railway line, on the $23 \mathrm{~km}$-long Smętowo - Opalenie Tczewskie - Nowy Dwór Kwidzynski-Kwidzyn section (line opened on September 1st 1909256).

This line was severed by the Polish-German state border which ran along the Vistula, a border river at the time. ${ }^{257}$ In 1944, following the destruction of the railway bridge near Tczew, the Russian railway troops built a provisional bridge to replace it (type L-23 spans arranged on wooden supports). In 1947, the bridge collapsed under the weight of a passing train. Shortly after the accident, the remains of the temporary bridge were pulled down. In the 1960s, however, a decision was made to use the Smętowo - Opalenie Tczewskie - Nowy Dwór Kwidzyński - Kwidzyn line as a substitute bypass of the existing permanent railway crossings: on the Nogat in Malbork (Warsaw - Gdańsk line), on the Vistula at Tczew (Malbork - Tczew line), and on the Vistula near Grudziądz (Jabłonowo Pomorskie - Laskowice Pomorskie line). The wartime contingency plans provided for the construction of a REM-500 overpass and a NZM-56 folding floating road-rail bridge. Both overpass and bridge components were stored at Opalenie Tczewskie station; NZM-56 bridge pontoons were collected at the Nowy Dwór Kwidzyński river port.

255 Ministry of National Defence, General Staff, Doświadczenia i wnioski (1962), 126.

256 Lijewski, Koziarski (1995), 86.

257 In 1929, the bridge across the River Vistula was dismantled, spans transported on barges down the Vistula to Toruń. In Torun, these components were used to construct a road bridge over the River Vistula. 
On September 7th and 8th 1965, as part of a rear-operations transport exercise (codename OPAL-65), the 2nd railway regiment, 3rd bridge brigade, and 1st railway troops battalion constructed piers and ferry crossings on the River Vistula at Nowy Dwór near Kwidzyn, with the use of NZM-56 bridge park components. ${ }^{258}$ The 3rd Warsaw Bridge Regiment and 12th Folding Bridge Battalion built a road bridge over the Vistula with the use of an MS-2280 folding structure set upon wooden supports; length: $391.7 \mathrm{~m}$; load-bearing capacity: 40 tonnes. ${ }^{259}$

In May 1969 the railway bridge battalion of the 2nd railway regiment from Inowrocław used the REM-500 structure to construct a railway bridge approach (length: $280 \mathrm{~m}$ ) in Nowy Dwór near Kwidzyn, as part of tactical and transport bridge regiment exercises ${ }^{260}$ the approach was connected (with the use of adjustable supports) to a single span of a NZM-56 pontoon bridge used as a ferry. While an overpass was later re-constructed as part of subsequent military exercises, a complete NZM-56 floating bridge had never been assembled on the Opalenie Tczewskie - Nowy Dwór Kwidzyński section. ${ }^{261}$

The reserve railway section (with appropriately prepared bridge and overpass components) were retained until the late 1990s. As late as in 1995 the D-29, List of Railway Lines, Rail Links, and Connecting Lines issued by the Polish State Railways General Management continued to feature the Prabuty - Szlachta line (length: $121.628 \mathrm{~km}$ ) (along with the Smętowo - Opalenie Tczewskie - Nowy Dwór Kwidzynski - Kwidzyn section). ${ }^{262}$

Another reserve crossing was to be built in the south of Poland, in the Dęblin area. Two railway lines running from the border with the USSR met there: Małaszewicze - Łuków - Dęblin, and Dorohusk - Lublin - Dęblin. The significance of the railway junction in Dęblin was demonstrated by the war activities during the Red Army's Vistula - Odra Operation, the main front railway line having passed through Dęblin. The Dęblin - Radom - Koluszki - Łódź - Ostrów Wielkopolski - Leszno - Głogów - Gubin - Berlin line crossed the River Vistula to its other side.

258 Gembora, Ref. No. 1138, 384, 397.

259 Gembora, Ref. No. 1138, Attachment No. 8, 2.

260 Gembora, Ref. No. 1138, Attachment No. 8, 3.

261 Account of June 15th 2006 by Colonel Józef Szwajka, and Gembora, Ref. No. 1138, 379.

262 Polish State Railways, D 29, Wykaz linii (1995), 17. 


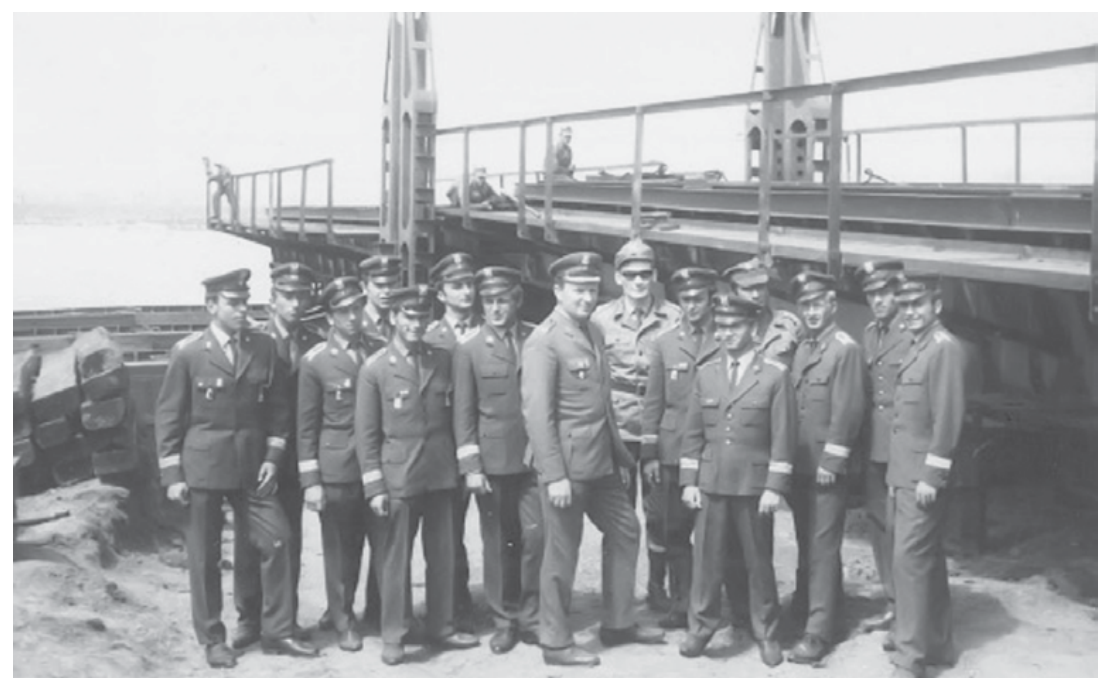

The Nowy Dwór near Kwidzyn crossing, 1969. A platoon of ensign cadets of the Officers' Military Engineering Academy in Wrocław, adjustable NZM-56 bridge support connected to the ferry via NZM-56 park structure components in the background (photo courtesy of Colonel Józef Szwajka)

In the 1970s, a decision was made to construct the Wysokie Koło - Puławy Azoty bypass, with intent to bypass the well-developed Dęblin junction with a permanent railway bridge across the River Vistula.

In 1975, the 12th railway regiment from Tarnowskie Góry constructed approaches to both River Vistula river banks. A station siding was built from the Wysokie Koło station to the western bank of the Vistula on the Bąkowiec Wysokie Koło Polish State Railways line. The eastern bank of the river, in turn, was connected via a siding developed from the Polish State Railways station Puławy Azoty. On September 15th and 16th 1975, during the VISTULA 75 military coalition exercise, a REM-500 overpass crossing was developed on both sides of the river, connected to the NZM-56 floating road-rail bridge. ${ }^{263}$ A REM500 overpass (length: $214.37 \mathrm{~m}, 17$ spans $12.61 \mathrm{~m}$ each and 16 supports) was assembled on the right bank. The 8th road and railway bridge regiment from Grudziądz constructed the overpass and the floating road-rail bridge, assisted

263 Colonel Jerzy Jarzyna’s account of September 4th 2006. 
by the 12th road and operations regiment and 12th railway regiment. ${ }^{264} \mathrm{~A} 360 \mathrm{~m}$ access track was constructed on the left bank, comprising 24 rail lengths made with the use of S-49 rails (length: $15 \mathrm{~m}$ ) set upon INBK-3 sleepers. The roadrail bridge assembled with the use of NZM-56 park components was $379.47 \mathrm{~m}$ long; the SEK-500-based overpass was $214.37 \mathrm{~m}$ long. ${ }^{265}$ A military train of tankloaded flat wagons hauled by Ty2-1089 locomotive from MD Dęblin depot used the structure to cross the River Vistula.

The temporary road-rail crossing in Wysokie Koło was re-assembled in the course of the VISTULA 85 exercise. Approaches made using the SEK-500 overpass structure connected to the road-rail bridge were developed on both sides of the river, the bridge was assembled with the use of appropriately adapted BP-150 barges. Large-diameter piling with caps was used to construct the bridgeheads at overpass-barge joints, an ice floe offset structure set up below the minimum water level. The access track from Puławy Azoty station was approximately 1,600 m long; an overpass leading directly to the river bank was assembled (approximate length: $500 \mathrm{~m}$, approximate incline: $16 \%$ ). An excavation was made in the River Vistula embankment along the access path from station Wysokie Koło for the duration of the crossing, to ease the profile of the access track. The embankment was dug to a depth of about $3 \mathrm{~m}$, upon which the SEK-500 overpass was assembled (approximate length: $300 \mathrm{~m}$, approximate incline: $7 \%$ ). Passing loops were constructed on access tracks on both sides of the river, with intent to increase the number of trains waiting to cross (the capacity of the crossing allowed a quick passage of three trains). In view of the threat of the crossing being rapidly located by enemy satellites, it was assumed that the crossing would remain active for a period of $1.5 \mathrm{hrs}$, upon which it would be dismantled, crossing components towed away by tugboats. Access roads were developed on both sides of the crossing, a viaduct of corrosion-resistant steel (manufactured by Railway Steel Structures Plant in Starosielce) built on the railway approach of the DęblinPuławy road. ${ }^{266}$

The BP-150 barges were adapted for the purposes of the crossing by the Wrocław River Shipyard, to a design by the Navicentrum Inland Navigation Design Office in Wrocław. S-49 rails were screwed directly onto the barges using

264 Colonel Aleksander Jakimczuk's account of December 12th 2006. The Colonel was involved in the preparations for the VISTULA 75 coalition exercises.

265 Gembora, Ref. No. 1138, Attachment No. 8, 4.

266 Account of September 3rd 2006 by Jerzy Brych, M.Sc. Eng, former deputy manager of the Regional State Railway Management in Lublin. 
steel chairs, the rails were flexibly joined using fishplates (fishplates screwed together using two bolts only). The barges provided three traffic routes - a single railway track and one road section on each side of the track. The overall approximate length of the barge crossing reached $500 \mathrm{~m} .{ }^{267}$

Before a complete military train was allowed onto the bridge test rides of a single locomotive (ST44) and a locomotive with a train of empty flat wagons were performed. During the VISTULA 85 exercise, a heavy military train loaded with tanks hauled by an ST44 locomotive crossed the river via the ferry structure from the direction of Puławy-Azoty station, the train was top-and-tailed by an identical locomotive in case of any difficulties with ascending the incline. While a speed of $15 \mathrm{~km} / \mathrm{h}$ was set as allowable for the crossing, a considerably higher speed of $28 \mathrm{~km} / \mathrm{h}$ was reached during the official demonstration ride. Artillery subdivisions and a sapper unit (motor vehicles loaded with pontoon boats) regrouped in opposite directions on the road sections of the bridge, while the train was crossing it as well. Chief of the General Staff of the Polish Armed Forces General Florian Siwicki witnessed the demo passage from a stand. Jerzy Brych, M.Sc., Deputy Manager of the East Regional State Railway Management at the time, was the acting co-ordinator for the crossing construction project for the Polish State Railways. ${ }^{268}$ The crossing was constructed by the 4 th, 8 th, 10th, and 11th railway regiments and the 5th railway bridge regiment. ${ }^{269}$ During the VISTULA 85 exercise, field point of rolling stock deactivation was organised at Wysokie Koło as well.

267 Account of September 3rd 2006 by Jerzy Brych.

268 Account of September 3rd 2006 by Jerzy Brych.

269 Colonel Jacek Wyszyński's account of August 28th 2006. 


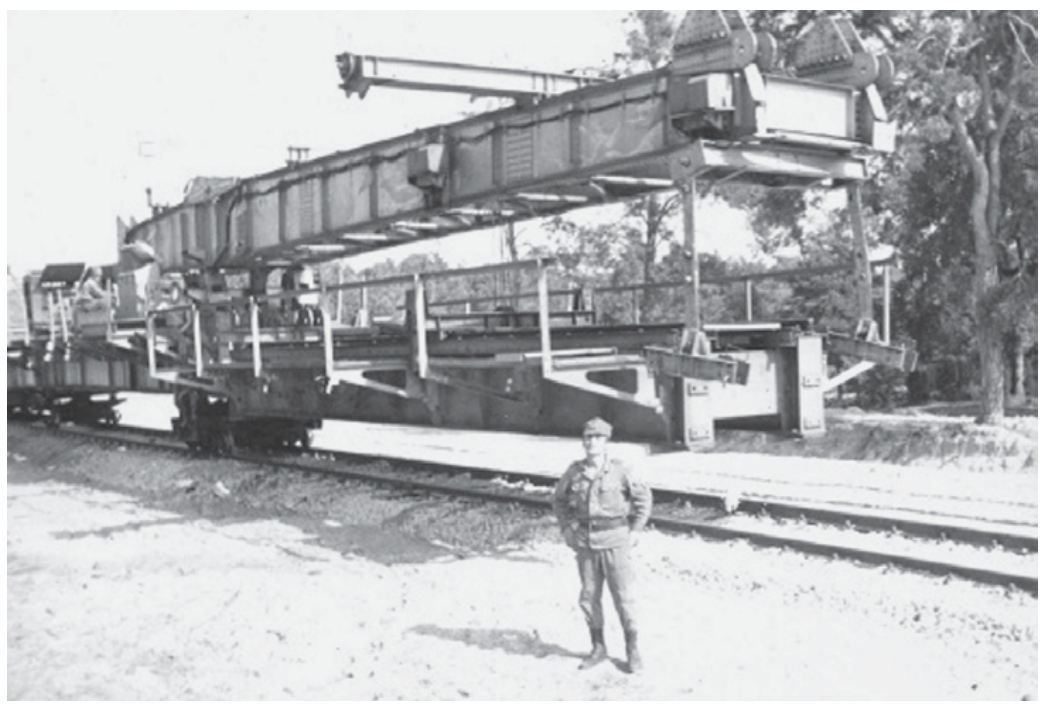

An SRK 20 railway crane used during the VISTULA 75 exercise, photo by Colonel J. Jarzyna (courtesy of Colonel J. Jarzyna)

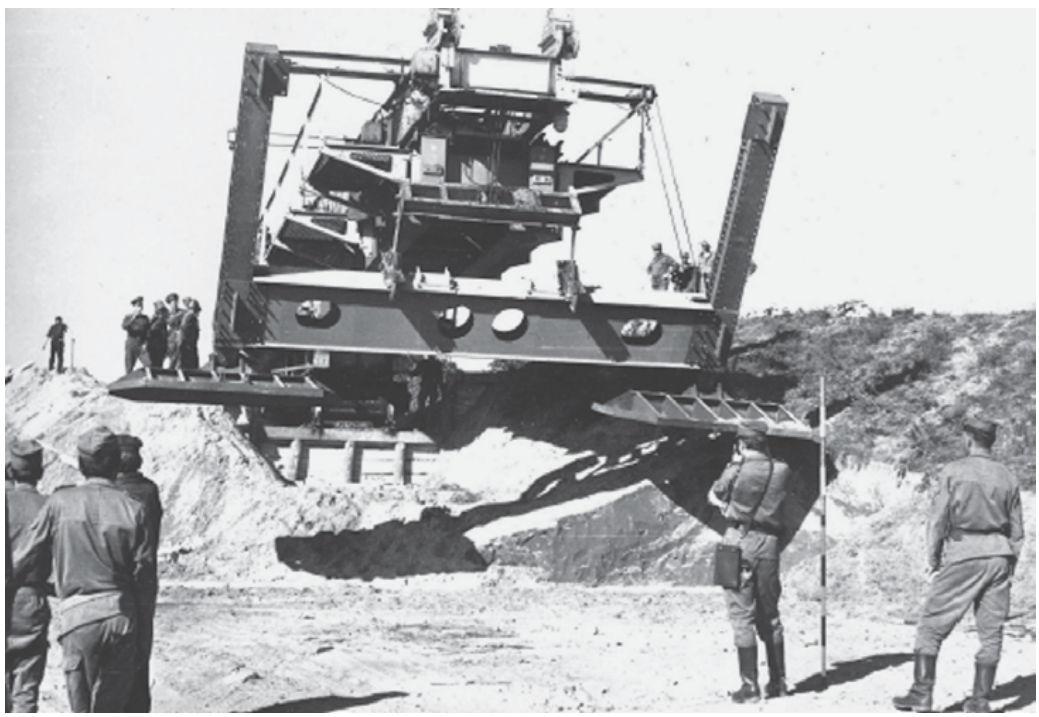

The assembly of a REM-500 overpass during the preparations for the VISTULA 75 exercise, photo by Colonel J. Jarzyna (photo courtesy Colonel J. Jarzyna). The required

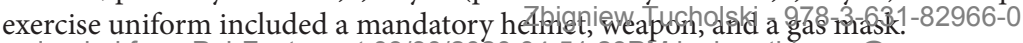
Downloaded from PubFactory at 09/30/2020 04:51:29PM by keerthiga.m@newgen.co 


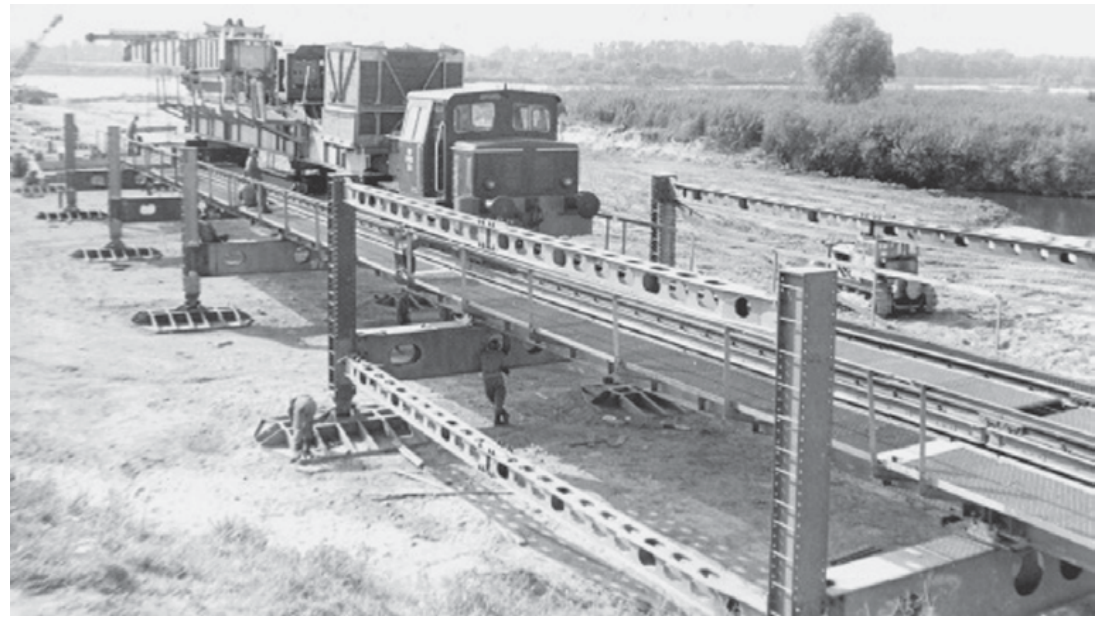

The assembly of a REM-500 overpass during the VISTULA 75 exercise. An SM03 locomotive from the Ammunition Depot in Stawy near Dęblin in the foreground, photo by Colonel J. Jarzyna (courtesy of Colonel J. Jarzyna)

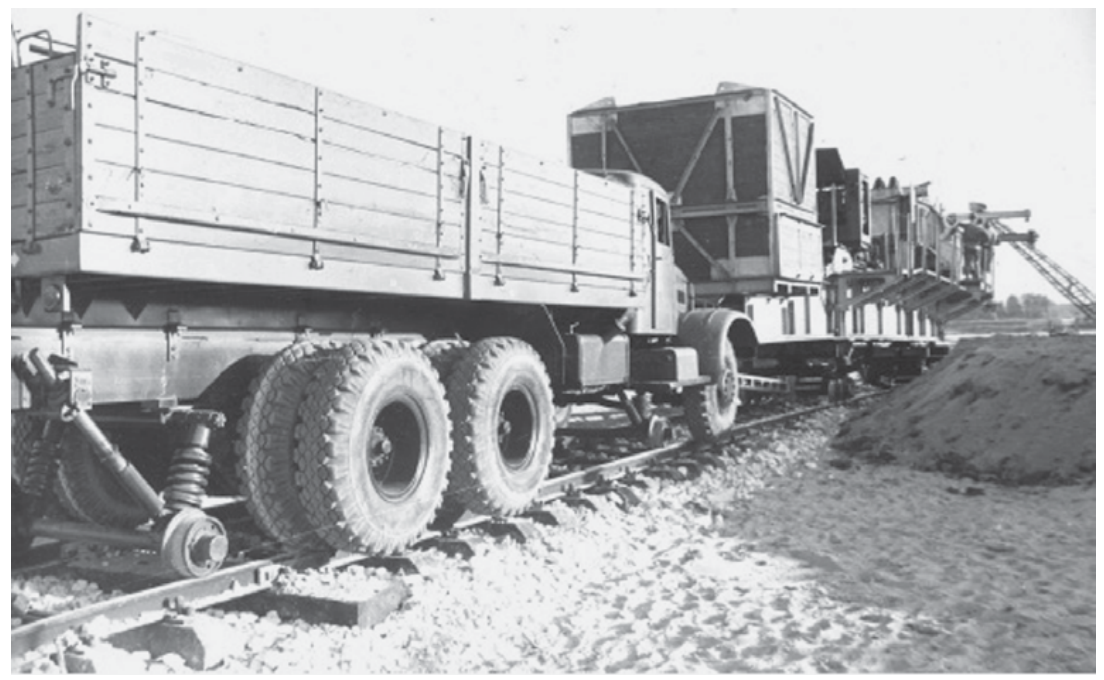

A KrAZ 218 lorry adapted for railway operation, with an SRK 20 crane, during the VISTULA 75 exercise, photo by Colonel J. Jarzyna (courtesy of Colonel J. Jarzyna) 


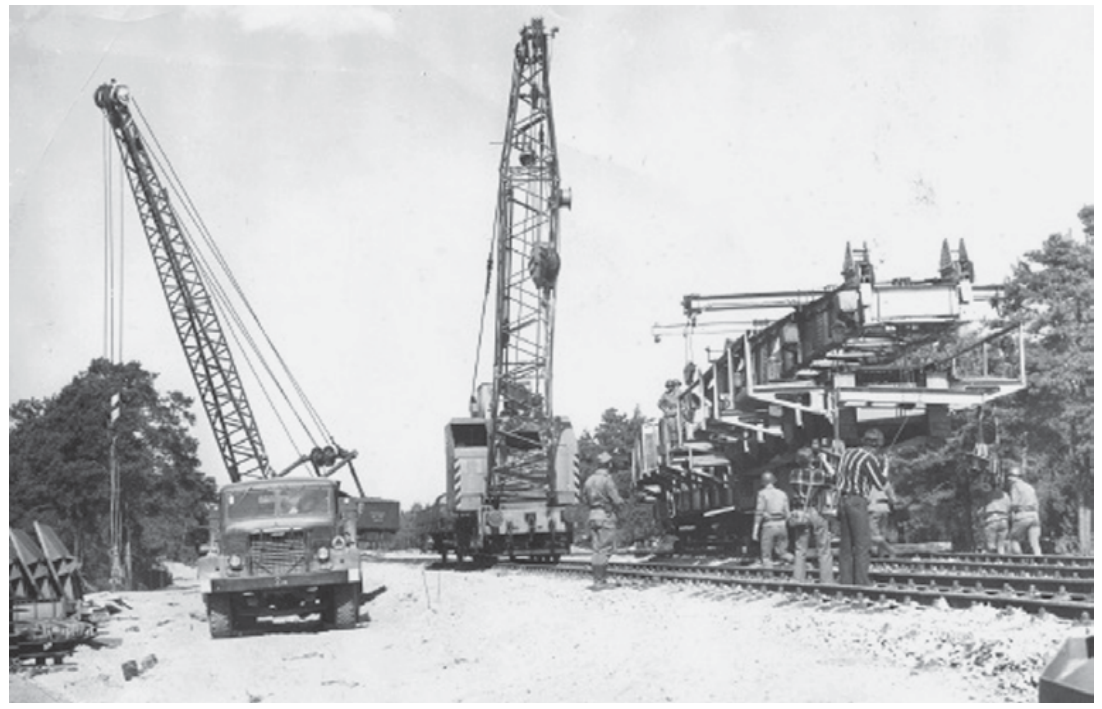

An assembly base during the VISTULA 75 exercise, photo by Colonel J. Jarzyna (courtesy of Colonel J. Jarzyna)

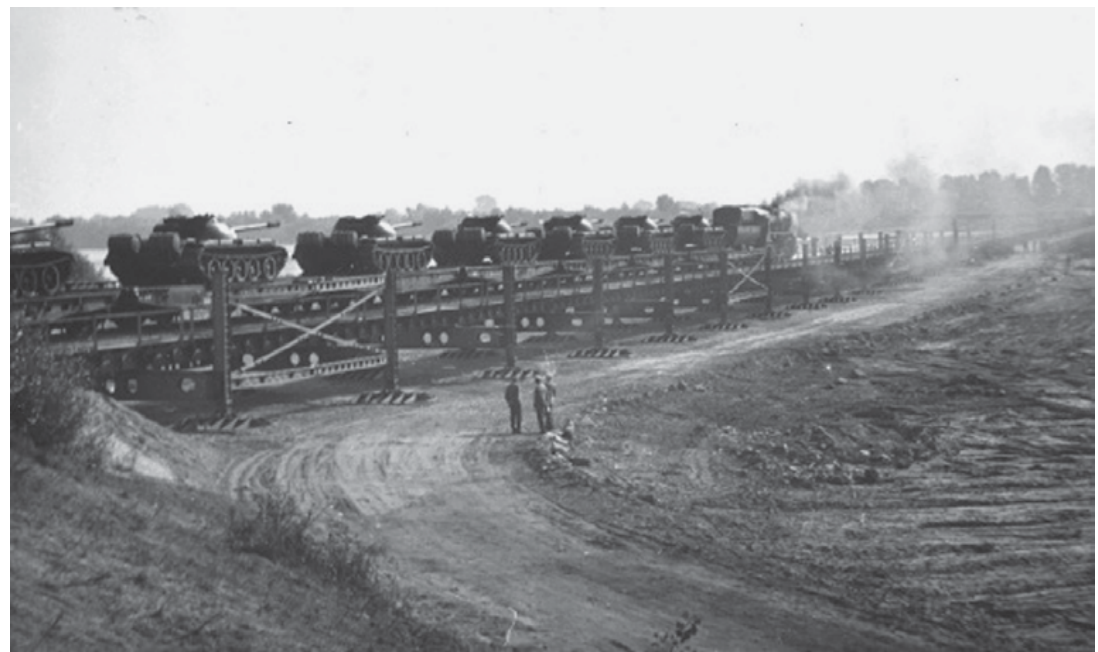

A troop train passing over the River Vistula during the VISTULA 75 exercise, photo by Colonel J. Jarzyna (courtesy of Colonel J. Jarzyna) 


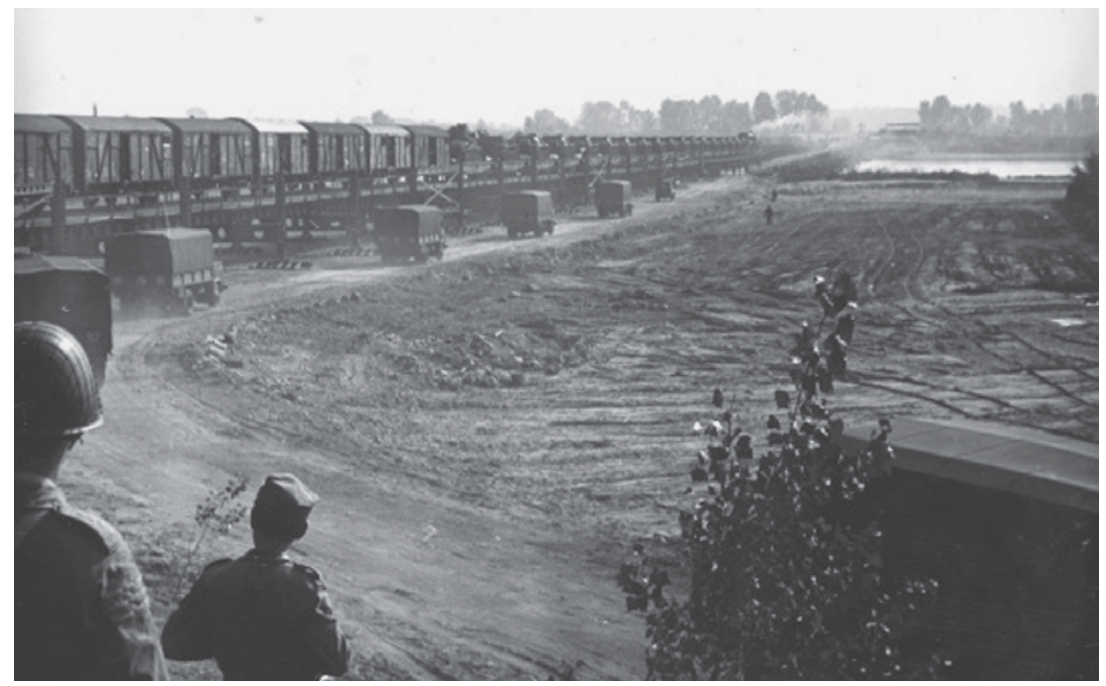

A troop train passing over the River Vistula during the VISTULA 75 exercise, photo by Colonel J. Jarzyna (photo courtesy Colonel J. Jarzyna)

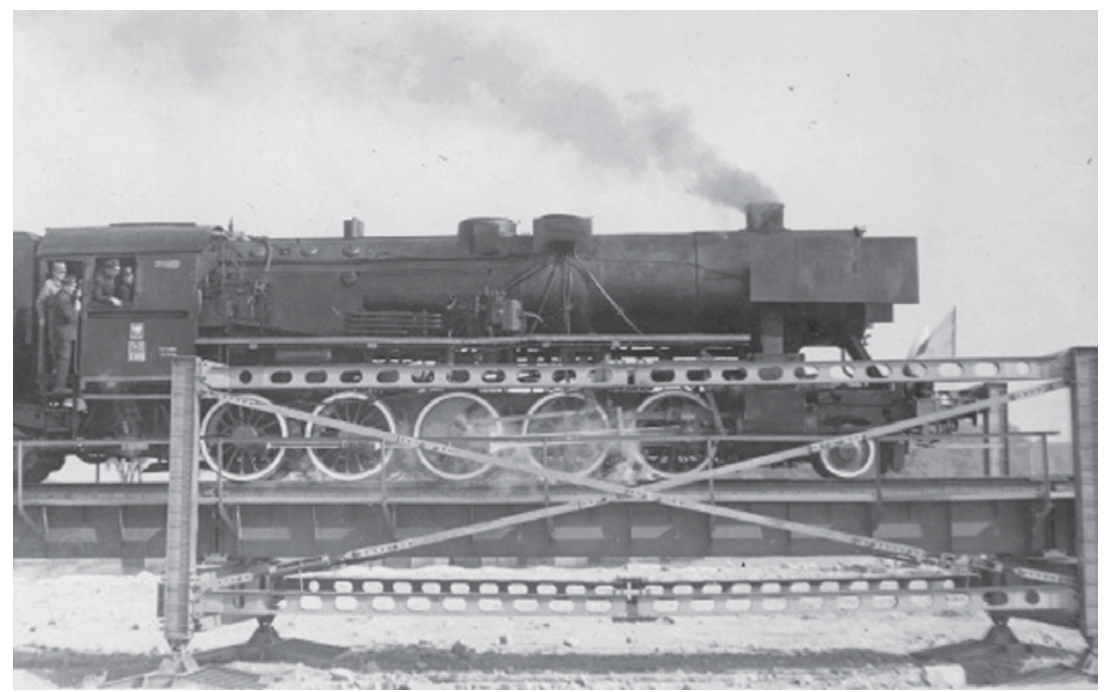

A Ty2-1089 steam locomotive from MD Dęblin depot hauling a heavy troop train entering a REM-500 overpass, VISTULA 75 exercise, photo by Colonel J. Jarzyna (photo courtesy Colonel J. Jarzyna) 


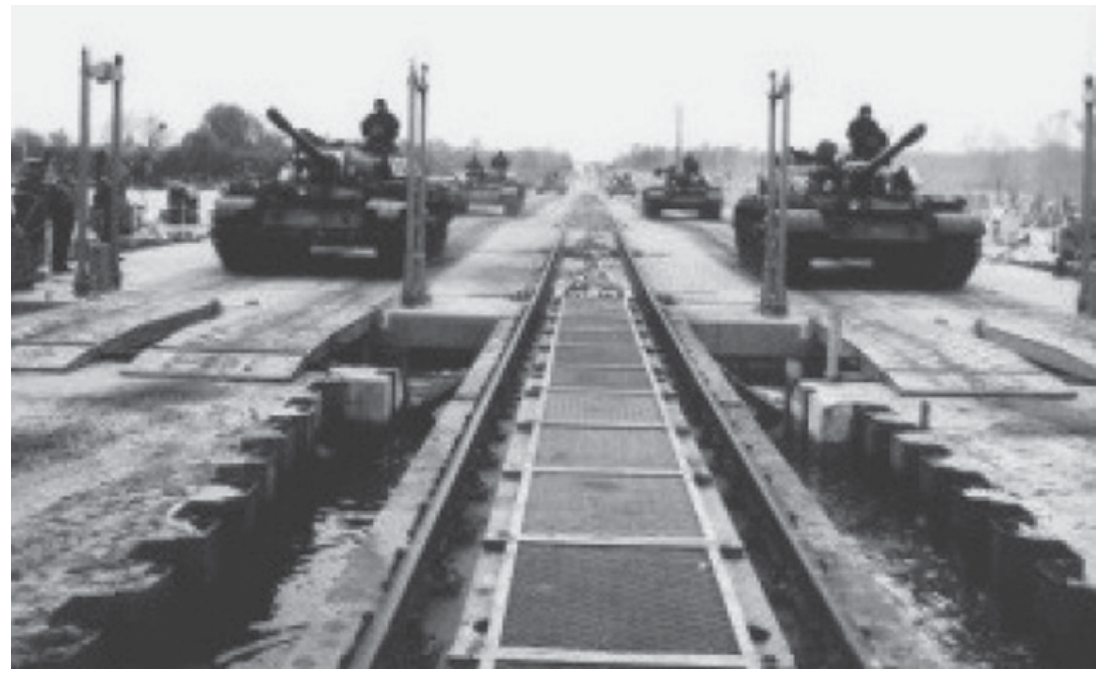

A modern road-rail crossing constructed in Wysokie Koło with the use of BP-150 barges during the VISTULA 75 exercise (courtesy of Colonel J. Jarzyna)

With the changes to the defence doctrine, the Wysokie Koło crossing lost operational significance and has been out of service for several years.

Given their hydrographic properties, the Rivers Lausitzer Neiße, Odra, Dźwina and Świna, Lake Dąbie and the Szczecin Lagoon were the second mostimportant obstacles for troops on Polish territory. In order to secure the efficiency of the main front railway lines along the Western Operational Direction, a decision was made to construct reserve railway sections with intent to bypass strategic railway crossings and junctions on the Polish - German border should the permanent crossings be destructed.

The Węgliniec railway junction was of great strategic importance, as proven by the 1945 military operations. Two reserve sections were constructed in the 1970s in order to bypass the junction, one planned on the Horka - Rothenburg Steinbach - bridge on the River Nysa - Sanice - Przewóz line, the bridge over the Nysa on this line was blown up during the war. The bridge was not rebuilt after the war, as the railway line was cut by the Polish - German border that was set along the Neiße/ Nysa - yet in the early 1970s, a decision was made to use the line during wartime as a reserve section to bypass the Węgliniec junction. The bridgeheads of the permanent bridge that was blown up during the war were to be reused for the construction of a REM-500 overpass folding bridge. 
A temporary bridge was assembled during a military exercise in the early 1970s. In the autumn of 1988 units of the Soviet Army and the East German National People's Army re-assembled a 200 m REM-500 overpass bridge as part of a joint military exercise. A KrAZ 219B lorry (adapted for operation on railway tracks) and SRK 20 railway crane were used during the construction project.

Due to the changes of the military doctrine and reunification of Germany, the railway section on the German side was taken out of service on April 22nd 1993. ${ }^{270}$

List of permanent railway bridges on the Lausitzer Neiße - Odra - Dźwina line ${ }^{271}$

\begin{tabular}{|l|l|l|l|l|}
\hline Location & Railway line & Design & $\begin{array}{l}\text { Length / } \\
\text { Width }\end{array}$ & $\begin{array}{l}\text { Number } \\
\text { of tracks }\end{array}$ \\
\hline Porajów - Pieńsk & Zittau - Liberec & $\begin{array}{l}\text { stone arch } \\
\text { structure }\end{array}$ & 1100 & 1 \\
\hline Porajów & $\begin{array}{l}\text { Trzciniec } \\
\text { Zgorzelecki - } \\
\text { Hirschfelde }\end{array}$ & $\begin{array}{l}\text { steel through } \\
\text { truss bridge }\end{array}$ & 50 & 1 \\
\hline Trzciniec & $\begin{array}{l}\text { Mikułowa - } \\
\text { Bogatynia }\end{array}$ & $\begin{array}{l}\text { steel through } \\
\text { arch bridge }\end{array}$ & 60 & 1 \\
\hline Trzciniec & $\begin{array}{l}\text { Mikułowa - } \\
\text { Bogatynia }\end{array}$ & $\begin{array}{l}\text { steel through } \\
\text { arch bridge }\end{array}$ & 60 & 1 \\
\hline Trzciniec & $\begin{array}{l}\text { Ręczyn - } \\
\text { steel through } \\
\text { girder bridge }\end{array}$ & 22 & 1 \\
\hline Radomierzycerder & $\begin{array}{l}\text { Wrocław } \\
\text { Stone arch } \\
\text { Zriebodzki - }\end{array}$ & 420 & 2 \\
\hline Zgorzelec & Zgorzelec & & \\
\hline Pieńsk - Zasieki section & &
\end{tabular}

270 Kuhlmann (2004), 171-172.

271 Study based on instruction Inż. 470/81, Ministry of National Defence, Charakterystyka (1982), 12-29. Based also on the record of bridges kept by the RA of the Regional State Railway Management Wrocław and Szczecin. 


\begin{tabular}{|c|c|c|c|c|}
\hline Location & Railway line & Design & \begin{tabular}{|l} 
Length / \\
Width
\end{tabular} & $\begin{array}{l}\text { Number } \\
\text { of tracks }\end{array}$ \\
\hline Bielawa Dolna & $\begin{array}{l}\text { Węgliniec - } \\
\text { Horka }\end{array}$ & $?$ & 100 & 1 \\
\hline Łęknica & \begin{tabular}{|l|} 
junction post \\
Stary Raduszec - \\
state border
\end{tabular} & $\begin{array}{l}\text { steel deck arch } \\
\text { bridge (13 } \\
\text { spans) }\end{array}$ & 150 & 1 \\
\hline Zasieki & \begin{tabular}{|l|} 
Łódź \\
Kaliska - Tuplice
\end{tabular} & beam bridge? & 150 & 1 \\
\hline \multicolumn{5}{|c|}{ Zasieki - Kostrzyn section } \\
\hline Gubinek & $\begin{array}{l}\text { Wrocław } \\
\text { Muchobór - } \\
\text { Gubinek }\end{array}$ & truss bridge? & 180 & 1 \\
\hline Gubin & $\begin{array}{l}\text { Zbąszynek - } \\
\text { Gubin }\end{array}$ & $?$ & 150 & 1 \\
\hline Świecko & $\begin{array}{l}\text { Warszawa } \\
\text { Zachodnia - } \\
\text { Kunowice } \\
\end{array}$ & truss bridge & $?$ & 2 \\
\hline \multicolumn{5}{|c|}{ Kostrzyn - Widuchowa - Szczecin section } \\
\hline Kostrzyn & Tczew - Kostrzyn & truss bridge & $?$ & 2 \\
\hline Siekierki & \begin{tabular}{|l} 
Stargard \\
Szczeciński - \\
Siekierki \\
\end{tabular} & truss bridge & $334.2 / 3.6$ & 1 \\
\hline $\begin{array}{l}\text { Szczecin } \\
\text { (Odra Zach.) }\end{array}$ & $\begin{array}{l}\text { junction post } \\
\text { Szczecin } \\
\text { Wstowo - } \\
\text { junction post } \\
\text { Dziewoklicz } \\
\end{array}$ & $\begin{array}{l}\text { steel through } \\
\text { truss bridge }\end{array}$ & - & 2 \\
\hline $\begin{array}{l}\text { Szczecin } \\
(\text { Odra Zach. }))\end{array}$ & \begin{tabular}{|l} 
Szczecin \\
Główny - \\
Szczecin Port \\
Centralny \\
\end{tabular} & $\begin{array}{l}\text { steel through } \\
\text { girder bridge } \\
\text { with rotating } \\
\text { span }\end{array}$ & - & 2 \\
\hline
\end{tabular}




\begin{tabular}{|l|l|l|l|l|}
\hline Location & Railway line & Design & $\begin{array}{l}\text { Length / } \\
\text { Width }\end{array}$ & $\begin{array}{l}\text { Number } \\
\text { of tracks }\end{array}$ \\
\hline $\begin{array}{l}\text { Szczecin } \\
\text { (Parnica) }\end{array}$ & $\begin{array}{l}\text { Szczecin } \\
\text { Główny - } \\
\text { Szczecin Port } \\
\text { Centralny }\end{array}$ & $\begin{array}{l}\text { steel girder } \\
\text { bridge }\end{array}$ & - & 2 \\
\hline $\begin{array}{l}\text { Szczecin } \\
\text { Odra Wsch.- } \\
\text { Regalica) }\end{array}$ & $\begin{array}{l}\text { junction post } \\
\text { Regalica - } \\
\text { junction post } \\
\text { Szczecin Zdroje }\end{array}$ & $\begin{array}{l}\text { steel through } \\
\text { truss bridge }\end{array}$ & - & 2 \\
\hline $\begin{array}{l}\text { Szczecin } \\
\text { (Odra Wsch.- } \\
\text { Regalica) }\end{array}$ & $\begin{array}{l}\text { Szczecin Port } \\
\text { Centralny - } \\
\text { Szczecin } \\
\text { Podjuchy }\end{array}$ & $\begin{array}{l}\text { Steel through } \\
\text { truss bridge } \\
1 \text { vertical } \\
\text { lift span, } \\
\text { length: } 17.5 \mathrm{~m}\end{array}$ & $\begin{array}{l}\text { approximately } \\
262 \mathrm{~m}\end{array}$ & 1 \\
\hline
\end{tabular}

Another reserve section was prepared as a bypass of the Görlitz - Zgorzelec junction. On the German side, sidings were developed from the station Charlottenhof $(\mathrm{O} / \mathrm{L})$ to the bank of the River Neiße; while a siding diverging from a mainline track was developed down to the River Neiße on the Polish side, branching in the junction post Lasów area. To overcome the obstacle of the Neiße plans were made to construct a bridge with REM-500 or ESB-16 spans (manufactured in East Germany). Due to the changes of the military doctrine and reunification of Germany, the section on the German side was taken out of service on April 22nd 1993. ${ }^{272}$

In order to maintain wartime efficiency of the (state border near Terespol) Małaszewicze - Łuków - Skierniewice - Łowicz - Kutno - Poznań - Zbąszynek Kunowice - Frankfurt - Berlin railway line, a decision was made to provide a reserve section for the Frankfurt (Oder) ${ }^{273}$ railway junction, alongside the

272 Study based on instruction Inż.470/81, Ministry of National Defence, Charakterystyka (1982), 172.

273 The Frankfurt (Oder) railway junction was of great military significance during the Franco-Prussian War of 1870. The Red Army's Berlin Operation also showed that the strategic Frankfurt (Oder) junction was the gateway to Berlin. Blowing up the railway bridge on the River Odra and heavy fighting for Frankfurt delayed the delivery of supplies to troops in combat (all factors of significant impact to the course of the Operation Berlin itself). 
permanent bridge over the River Odra. In the 1970s, a siding was constructed to the River Odra on the German side, branching off at km. 92.750 between stations Finkenheerd and Wiesenau. On the Polish side a siding branching off at Maczków (Urad) station to the River Odra bank (Kunowice - Cyblinka line).

The wartime construction of a folding railway bridge with the use of REM-500 overpass components was planned on the River Odra. Folding bridge components were deposited at the Soviet army depot in Ziltendorf. During the military exercises in 1979 units of the National People's Army of East Germany assembled a bridge across the River Odra in Kunice. A military train loaded with tanks rode across the bridge, hauled by a BR120 diesel locomotive of the Deutsche Reichsbahn/German National Railways; the train returned to East Germany the following day. In 1988 a Frankfurt (Oder) junction bypass was added for military purposes. ${ }^{274}$

The Kostrzyn - Küstrin Kietz section (on the strategic Kostrzyn - Berlin railway line) was particularly vulnerable to destruction, as it included three railway bridges across the Rivers Warta, Odra and the Odra flood plains, which significantly limited its potential wartime lifespan. Already in the 1890s in recognition of the operational significance of the Berlin - Kostrzyn - Krzyż railway, the Prussian General Staff took on an action to build a military reserve line. In 1899 railway brigades of the Prussian army constructed railway connections to the River Odra from stations Reitwein and Göritz (Górzyca), and constructed a fortified 650 long railway bridge (set upon a wooden structure). ${ }^{275}$

In the 1960s, short sections reaching both banks of the River Odra were provided with intent to bypass the Kostrzyn - Küstrin Kietz section. On the Polish side, a siding (approximate length: $3 \mathrm{~km}$ ) was built, branching off near the station at Ługi Górzyckie. In order to allow the passage of military trains directly off the mainline from both directions (Kostrzyn and Rzepin), the siding approach was built in a form of a triangle. On the German side, an approx. $1 \mathrm{~km}$ long siding was constructed, branching off at kilometre 3.502 of the Küstrin Kietz Frankfurt (Oder) line before Neu Manschnow station (located on km 3.8). Plans involved wartime construction of a folding railway bridge with the use of REM-500 overpass components on the River Odra. The Neu Manschnow - Eugi Górzyckie reserve section allowed direct transit of military trains from Rzepin and Kostrzyn to Berlin with the Kostrzyn - Küstrin Kietz section bypassed, as it was vulnerable to destruction due to its' three bridges. ${ }^{276}$

274 Kuhlmann (2004), 124-125.

275 Kuhlmann (2004), 94.

276 Kuhlmann (2004), 94. 
The joint 1969 exercises of the Polish Armed Forces, Soviet Army and East German Army comprised the construction of a folding road-rail bridge with the use of REM-500 overpass components (on the Polish side) and folding ESB-16 spans (on the German side). Due to the changes to the military doctrine and reunification of Germany, the Neu Manschnow - Oder West section was taken out of service on April 22nd 1993.277

In the 1970s, a decision was made to build a strategic bypass of the railway bridge over the River Odra on the Godków - Siekierki ${ }^{278}$ - state border - Wriezen railway line (the section allowing direct passage of military trains from Szczecin and Kostrzyn to Berlin). It was assumed that any permanent railway bridge on the section would be destroyed by a NATO strike, hence the plans to develop a reserve bypass of the existing bridge. Wartime plans assumed that the River Odra would be crossed via the REM-500 overpass and the NZM-56 floating road-rail bridge.

As early as 1976, a siding branching off at kilometre 10.895 (Abzweigung Nra) between station Neurüdnitz and the bridge over the River Odra (approximate length: $1.5 \mathrm{~km}$ ) was developed down to the riverbank. Construction works on the siding codenamed "Object-83" proceeded in extremely difficult wet terrain. The embankment of the siding was connected to the floodbank below its head, which is why the floodbank had to be traversed with special-purpose flood gates accommodating the final section of the siding on the floodplain (temporary crossing construction was possible only at low water levels). ${ }^{279}$

During a Warsaw Pact exercise codenamed "BARIERA 79" held on October 18 th - 24th 1979, the railway bridge battalion of the 2nd railway regiment from Inowrocław (JW 1523) joined forces with the units of the Soviet and East German

277 Kuhlmann (2004), 94.

278 On April 16th 1945, the 1st Polish Army proceeded to cross the River Odra near Siekierki and Stare Łysogórki. On April 17th 1945 a waterway manoeuvre was attempted with the use of a pontoon bridge (width: $16 \mathrm{~m}$, length: $220 \mathrm{~m}$ ), which was floated in sections with the use of five cutters from Gozdowice, and re-assembled in the area of Stare Łysogórki. On April 18th 1945, the 9th battalion of the 1st Sapper Brigade, 11th battalion of the 1st Sapper Brigade, 2nd road battalion, and 3rd bridge construction battalion built a low-water wooden bridge (width: $4.5 \mathrm{~m}$, length: $220 \mathrm{~m}$, load-bearing capacity: 30 tonnes) over 71 hours, near the village of Siekierki (in front of the railway bridge). Based on Ministry of National Defence, SG 118/53, Zbiór przykładów (1953), 65-66.

279 Colonel Józef Szajka's account of June 15th 2006. German railways allocated DM 9.4 million to the construction of the siding in difficult terrain conditions. 
armies to construct a bridge with the use of REM-500 and SEK-500 overpass components, and a NZM-56 road-rail bridge across the River Odra (practical part of the exercise). ${ }^{280}$

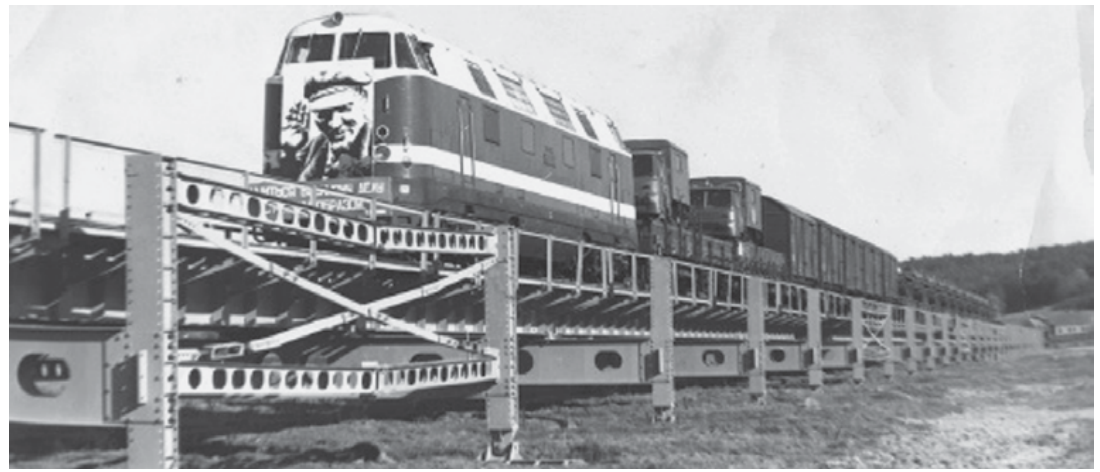

A troop train passing over the River Odra during the "BARIERA 79" exercise, hauled by a DR diesel locomotive - BR 118 374-8, photo by Colonel J. Jarzyna (photo courtesy Colonel J. Jarzyna)

Due to the changes of the military doctrine and reunification of Germany, all sidings connecting the River Odra on the German side were taken out of service on April 22nd 1993; on December 31st 1993, traffic on the Wriezen - Neurüdnitz line was discontinued. The entire line, including the siding connecting the River Odra, was dismantled in 2001. ${ }^{281}$

During the planning works to secure the technical support for the railway network, the Headquarters of Military Transport at individual Regional State Railway Managements drafted lists of the local bridge and railway junction bypasses in case of destruction of a given bridge or junction. As it was assumed that the modern weapons' striking force will have the capacity to cause total destruction to railway crossings, bypass crossings were to be provided in new locations upstream, at distances allowing obstacle-free construction of temporary bridges.

Within the area managed by the Regional State Railway Management in Warsaw, the plan involved the replacement of the railway bridges listed below with folding structures: River Vistula, Góra Kalwaria, km. 75.915 (Skierniewice - Łuków line,

280 Colonel Józef Szajka’s account of June 15th 2006.

281 Kuhlmann (2004), 82. 
single track steel bridge); River Narew, Łapy, km. 155.989 (Warsaw - Białystok line, double track steel bridge); River Narew, Grabowo, km. 5.229 (Ostrołęka Wielbark line, single track steel bridge); River Narew, Strabla, km. 48.500 (Czeremcha - Białystok line, single track steel bridge); River Bug, Małkinia, km. 84.502 (Warsaw - Białystok line, single track steel bridge); River Narew, Modlin, km. 43.264 (Warsaw - Działdowo line, single track steel bridge); River Bug, Fronołów, km. 54.871 (Siedlce - Hajnówka line, double track steel bridge); River Pilica, Tomaszów Mazowiecki, km. 57.688 (Koluszki - Skarżysko line, double track steel bridge); River Warta, Teklinów, km. 195.082 (Warsaw - Katowice line, double track steel bridge); River Narew, Siemianówka, km. 148.851 (Siedlce Narewka line, single track steel bridge). According to the wartime plan, all bridges were to be rebuilt by the militarised Bridge Reconstruction Trains of the Ministry of Transport: (Bridge Reconstruction Train-4, Bridge Reconstruction Train-5, Bridge Reconstruction Train-11, Bridge Reconstruction Train-12).

The wartime plans of the Regional State Railway Management in Warsaw further included the provision of a close bypass for Białystok station (junction station for the Ełk - Czeremcha - state border direction). ${ }^{282}$ The planned $1 \mathrm{~km}$ link was to connect the Czeremcha - Białystok line to the Białystok - Ełk section (bypassing station Białystok, classified as exposed to destruction). The wartime construction of the bypass was to be performed by Track Reconstruction Train-13 with the use of military reserve surface materials deposited at the station in Strabla. ${ }^{283}$

Given the insufficient number of permanent road crossings on large and medium-sized water obstacles, railway bridges had to be adapted to allow tracked vehicles to use them, by providing access roads and reinforcing their construction.

Within the area managed by the Regional State Railway Management in Warsaw, the following railway bridges were adapted in this way: River Vistula, km. 75.915, Góra Kalwaria (Skierniewice - Łuków line), River Bug, km. 18.658, Wyszków (Tłuszcz - Ostrołęka line), River Bzura, km. 81.338, Łowicz (Warsaw Poznań line), River Narew, km. 5.229, Grabowo (Ostrołęka - Wielbark line), River Bug, km. 54.871, Fronołów (Siedlce - Hajnówka line). ${ }^{284}$

282 In general, related plans involved reconstruction of a rail link dismantled in the 1950 s or 1960s.

283 Headquarters of Military Transport at Regional State Railway Management in Warsaw, Ogólna charakterystyka (1984), 21-22.

284 Headquarters of Military Transport at Regional State Railway Management in Warsaw, Ogólna charakterystyka (1984), 10. 
Additionally, Temporary Transhipment Areas were to be established to secure the reloading of materials and technical supplies from rail to other modes of transport (road and waterway), should crossings on large water obstacles be destroyed (until the bridges affected were to be provisionally reconstructed) ${ }^{285}$

The international military exercises of the Warsaw Pact (BARIERA and Vistula) were charged with the responsibility of constructing temporary crossings across water obstacles: the Rivers Vistula and Odra. According to the operational plans, both rivers would remain the greatest water obstacles to any attack of mechanised military formations, once permanent bridges were destroyed by tactical nuclear weapons in the first phase of the war (it should be remembered that a significant attack rate of $80-100 \mathrm{~km}$ was assumed).

Since the 1940s, the development of the infrastructure of the Polish State Railways had to accommodate for military transport along the Western Operational Direction. In the 1950s, the nuclear war doctrine changed the concept of using the railway network on the USSR and Polish territory (as an intersection of two gauges: 1,524/1,435 mm). The need for significant acceleration of an offensive and a change in the general nature of military operations gave rise to the construction of a transhipment system and the necessity to secure a large number of standard-gauge rolling stock to transfer troops along the Western Operational Direction. In light of the above, the concept of re-gauging the front mainlines in the first stage of the war was abandoned in the 1950s.

In 1951, Commander-in-Chief of Polish Armed Forces Marshal Konstanty Rokossovsky received specific instructions during a meeting of the General Staff of the USSR in Moscow: he was instructed to develop six transfer areas in Poland as departure termini for five frontline-bound railway lines running across Poland from the USSR to East Germany. ${ }^{286}$

Aimed at ensuring an uninterrupted wartime transfer of the Soviet troops, works to develop a system of transhipment bases (broad-gauge to standard-gauge transfer) began in the 1950s, all bases located directly on the border between the Polish People's Republic and the USSR. All facilities were constructed a mere few kilometres from the state border, usually in dense forest stands to ensure proper camouflage. Broad-gauge sidings were provided from the Soviet side into the transhipment bases, all facilities equipped with reloading equipment, cranes and gantries, ramp systems and complex track systems (arrival/departure, transfer,

285 Ministry of National Defence, Transport Command, Komunikacja wojskowa (1965), 30-33.

286 Kwiatkowski (No. 8), 51. 
stabling and traction tracks). All equipment at the individual bases was properly serviced and kept in sound technical condition. Mechanical railway signalling devices (interlocking control signal boxes, mechanical semaphores, track closing signals and shunting signals) were provided in selected areas. Some were also fitted with technical infrastructure allowing for the handling of steam traction servicing points equipped with ash pits, water cranes and coal loading facilities. Furthermore, a system of roads (tank roads) and access roads to loading ramps for heavy tracked vehicles loading were developed at transhipment areas. The Red Army road vehicles were also taken into account in terms of their direct transfer from the Permanent Transhipment Areas onto regular roads leading to ferry crossings over water. In all transhipment areas, individual facilities were appropriately adapted to reload light and heavy technological devices, fuel and lubricant storage included; heavy- and lightweight ramps and fuel transfer stations were employed as required. Some transhipment areas were also used for the purpose of transferring civilian commodities between the Polish and Soviet railways, respectively. During peacetime, all fuel and lubricant storage facilities in transhipment areas were operated by the state-owned CPN company.

The transhipment areas were located at the intersection of all broad-gauge railway lines from the USSR to Poland, in Braniewo, Bartoszyce, Skandawa, Kuźnica Białostocka, Zubki Białostockie, Siemianówka, Małaszewicze, Dorohusk, Werchrata, Żurawica and Przemyśl. ${ }^{287}$

The track layouts of the transhipment areas were designed in such a way as to ensure the doubling of the particular loading facilities and particularly vulnerable tracks at stations and sidings, with intent to secure the viability of respective areas should its components be destroyed. In order to make the destruction of an area more difficult, individual loading facilities were located in dense forest complexes.

The transfer and arrival/departure tracks were developed into groups at the transhipment areas in order to increase the capacity of each area. Such a track layout allowed military trains to await reloading on approach in an arrival/departure holding area while two other trains were being reloaded simultaneously.

To increase the transhipment capacity of individual areas and enhance the organisation of all reloading works, a technologically interesting solution was applied: standard- and broad-gauge track combinations in the ramp area

287 Large transhipment stations (with significant reloading capacity) that were developed since the 1960s in Przemyśl, Medyka, Żurawica and Małaszewicze on main railway lines were used for military purpose as well. 
(quadruple dual-gauge track system). Standard-gauge tracks adjacent to ramps incorporated a broad-gauge track, offset by $192 \mathrm{~mm}$ against the standard-gauge axis. The inner rail of the broad-gauge track would be coupled with the outer rail of the standard-gauge track section with the use of a typical junction crosshead.

In general, two types of track layouts were built at all transhipment areas: tracks branching off from pass-through peripheral routes, and sidings leading directly into the area.

A number of independent branches connecting the transhipment areas to the railway network and substitute loading stations were also provided with intent to extend the service life of transhipment areas. In case of wartime destruction of the Permanent Transhipment Areas, Substitute Transhipment Areas were to be developed at stations on frontline railway routes, directly behind the Permanent Transhipment Areas. Substitute Transhipment Areas were to secure $50 \%$ of the Permanent Transhipment Area reloading capacity, access to Substitute Areas was to be possible by road transport and enable loading of road vehicles onto railway wagons. The transfer areas were also mirrored on the Russian side by additional transhipment areas. The Russian transhipment bases were rather primitive in structure: earth reloading ramps reinforced with wooden logs on the loading side were common. ${ }^{288}$ The use of a dual reloading area system (in the USSR and Poland alike) and possible transition to Substitute Transhipment Areas in case of the permanent bases being destroyed served the purpose of securing transports to the Western Operational Direction in conditions of a massive air attack. ${ }^{289}$

After the end of the war, some standard-gauge railway lines were retained in the Kaliningrad area for strategic reasons. In the 1950s, extensive standard- and broad-gauge siding systems and Military Transhipment Bases of the USSR Ministry of Defence were established in the border region on the Russian side: Mamonovo II (Świętosław), Bagratyonovsk (Iława Pruska), Krasnovka (Birkenfeld), and Zheleznodorozhniy (Gierdawy). The transhipment bases were set up on the three main railway lines leading towards Poland, on the following sections: Mamonovo II - (state border) - Bogaczewo - Braniewo - Elbląg (after the war, the second track of the line was retained as broad-gauge); Bagratyonovsk Bartoszyce (a 16km long dual gauge 1,524 $\mathrm{mm}$ and 1,435 $\mathrm{mm}$ section, allowing the passage of standard- and broad-gauge trains); Zheleznodorozhniy Skandawa (also broad-gauge 1,524 mm track). Several hundred standard-gauge

288 Account of October 20th 2006 by Colonel Jerzy Maj, retired head of the Head of Military Transport at the Regional State Railway Management in Warsaw.

289 Individual areas were equipped with field anti-aircraft defence stations. 
$\mathrm{T} €$ steam locomotives (German wartime class 52) allocated to long-term storage were kept at the military transhipment base Zheleznodorozhniy - Mamonovo II. All locomotives were regularly inspected and repaired until the mid-1990s. They were retained with intent to haul Russian military trains on the standard-gauge Polish State Railways network in a future war. ${ }^{290}$

Throughout the 1950s, a system of Permanent Transhipment Areas under development on the Polish territory (in the area managed by the Regional State Railway Management in Gdańsk), along the section bordering with the Kaliningrad area.

The first Permanent Transhipment Area in Skandawa was constructed over the years 1952-1956, comprising a system of local standard- and broad-gauge tracks in and around Skandawa. The investment was performed by the Railway Works Company No. 12 from Gdańsk, with about 3,000 troops employed at the construction site, alongside the Stużba Polsce [Service to Poland] paramilitary cadets and members of local population. ${ }^{291}$ The constructed track layout with a length of approx. 20 kilometres comprised the following railway sidings: (state border) - Wielewo - Anielin - Gradowo (broad-gauge track), length: 11.282; Skandawa - Kotki ramp, approximate length: $3.2 \mathrm{~km}$; Anieliny Gradowo Gradowo ramp, approximate length: $2.2 \mathrm{~km}$; Kotki - km. 52.5 (broad-gauge track), approximate length: $1.2 \mathrm{~km}$; Drogosze - Krymławki ramp, approximate length: $2.2 \mathrm{~km} .{ }^{292}$ The individual transhipment facilities of the Skandawa Permanent Transhipment Area were located along the peripheral 1,524 mm track (reloading facilities and ramps: Kotki, Gradowo, Krymławki). At the point where tracks of two different gauges met a station in Wielewo was built (six broad-gauge tracks, four $1,435 \mathrm{~mm}$ tracks), together with a broad-gauge traction servicing point (fitted with a fuel depot, coal crane, gantry, and water cranes ${ }^{293}$ ), all with intent to re-assemble and dispatch broad-gauge military troop trains arriving from the USSR for reloading. The linear arrangement of the reloading points at the Skandawa Permanent Transhipment Area allowed four trains to be reloaded simultaneously at Kotki, Gradowo and Krymławki, and to be later dispatched from standard-gauge stations: Skandawa, Anielin and Drogosze.

290 In view of the significant acceleration of military operations with the use of the newly developed types of weapons and the doctrine of thermonuclear war, re-gauging railway lines from standard-gauge to broad-gauge was too time-consuming, and would unnecessarily involve significant resources and technical means.

291 Kwiatkowski (No. 8), 57.

292 Ministry of Transport, D 29, Wykaz linii (1985), 30.

293 A water tower was constructed to feed water cranes at station mid-length of the station. 
Signal boxes and mechanical signalling devices with mechanical semaphores were installed at individual points of the area. Due to changes to the military doctrine the Skandawa Permanent Transhipment Area lost its strategic importance; in the early 1990s, part of the broad-gauge tracks was dismantled, followed by all the facilities later in the 1990s. The facility in Kotki was the only one converted for civilian purposes, a gas terminal was developed on that site.

After the end of the war broad-gauge tracks were retained on the Elblag Braniewo - Mamonovo section for strategic purposes, the section was used to build the Permanent Transhipment Area in the 1950s.

The next Permanent Transhipment Area was constructed in Braniewo over the years 1953-1957, comprising stations and a system of standard- and broadgauge sidings located along the standard- and broad-gauge lines (second track) on the Mamonovo - (state border) - Bogaczewo - Braniewo - Elbląg sections.

The development of the area was supervised by the Head of Military Transport at the Regional State Railway Management in Olsztyn. The construction works of the area were performed by Railway Works Company No. 12 from Gdańsk; sidings north of Kurów Braniewski were built by Kablobeton, a company based in Warsaw. Members of the local population were also employed - in a corvée labour system - for the purposes of handling construction material deliveries. ${ }^{294}$

The following traffic posts, transfer facilities and modernisation works were provided and/or completed as part of the project described: ${ }^{295}$

- A broad-gauge track layout at the Braniewo station was built, including a steam locomotive turning triangle and a small locomotive depot, with technical facilities;

- A passing loop at Bemowizna (broad-gauge);

- Junction post "Bos" - Wielewo (broad-gauge);

- A passing loop at Wielewo (standard-gauge); in all probability, the local prewar block post Pettelkau was used to construct the loop;

- Transhipment facility "Bo" - "Autostrada" - a broad-gauge siding was built to the facility from junction post "Bos" - Wielewo, a standard-gauge siding continued onwards from the passing loop in Wielewo. The standard- and broadgauge sidings were located at both sides of the ramp (approx. 700m long and $1 \mathrm{~m}$ high),including passing loops. The facility allowed concurrent reloading of two trains (one standard- and one broad-gauge) only. A paved access road was built, leading from road 508 to the facility;

294 http://www.starejuchy.pl/kolej/wrpbran/wrpbraniewo.htm [access: 18.10.2019].

295 http://www.starejuchy.pl/kolej/wrpbran/wrpbraniewo.htm [access: 18.10.2019]. 
- Chruściel station - Area construction works involved the provision of a broad-gauge track layout and a broad-gauge passing loop; a broad-gauge siding was built as well, leading from the station to the "Be" Rucianka transhipment facility;

- Transhipment facility "Be" Rucianka - a broad-gauge railway siding was constructed to the facility from the station in Chruściel; a standard-gauge siding was built in the direction of Wielkie Wierzno. The following solutions were employed at facility the "Be" Rucianka: a dual-gauge $(1,435 \mathrm{~mm} /$ $1,524 \mathrm{~mm}$ ) transfer track system; two paved reloading ramps allowing the simultaneous reloading of two military trains, and loading/unloading of a single train at the side ramp on the standard-gauge track. The facility offered transfer capacity of 6 train pairs per day, and the transition of 6 trains per day from/to road transport;

- Station in Wielkie Wierzno - built from the foundations up as part of the effort to build the Braniewo Permanent Transhipment Area, it was the largest station in the area, featuring an extra broad-gauge loading facility. Broad-gauge sidings were built from the station to "By" Piórkowo transhipment facility; the "Be" CPN-operated fuel transfer station and standard-gauge siding to transhipment facility "Be" Rucianka;

- Fuel transfer station "Ba" CPN - two separate (standard- and broad-gauge) track layouts were developed at the CPN fuel depot premises; both track systems were intended to deliver tank wagons to fuel transfer points, and to store the empty trains. The facility was connected with a broad-gauge siding to the station in Wielkie Wierzno, and a standard gauge siding to Kurowo Braniewskie. The base could reload two trains per 24 hours. The base was constructed by Kablobeton, a company based in Warsaw;

- The "By" Piórkowo transhipment facility - located on the eastern side of the Braniewo - Elbląg line, connected to station Wielkie Wierzno with a broadgauge siding and to station Kurowo Braniewskie with a standard-gauge siding. At the "By" Piórkowo facility two separate track layouts $(1,435 \mathrm{~mm} / 1,524 \mathrm{~mm})$ and two paved loading ramps were provided. An access road was constructed, connecting the facility to road 506;

- Station Kurowo Braniewskie - during the construction of the Area improvements to the station included a loading ramp and standard-gauge siding connecting the station to the "By" Piórkowo facility, as well as the "Ba" CPN fuel transfer station;

- Station Młynary - the Area incorporated the standard-gauge track layout of the station; 
- Station Elbląg - a broad-gauge track was built to connect the station to the Railway Rolling Stock Plant in Elbląg (part of Zamech, before the war: German Schichau Elbing factory); a broad-gauge track layout was developed at the Elbląg station; a broad-gauge siding was constructed to connect the station to the plant. A broad-gauge TKt48 locomotive was stationed at the plant's in-house locomotive shed.

The track system developed at the Braniewo Permanent Transhipment Area of an approximate length $\mathrm{h}$ of $12 \mathrm{~km}$ comprised the following railway sidings: Wielewo/ Pierzchały - "Autostrada", length: 2.5 km; Chruściel/Wlk. Wieżno - "Rucianka", length: $3.1 \mathrm{~km}$; Kurowo/Wlk. Wieżno - "CPN", length: $2.3 \mathrm{~km}$; Kurowo/Wlk. Wieżno - "Piórkowo", length: $3.6 \mathrm{~km} .{ }^{296}$ The Braniewo Permanent Transhipment Area offered a transfer capacity of 20 military trains per day, additionally it was possible to load/unload 12 trains with transition to/from road vehicles. ${ }^{297}$

As a general rule, the Military Transhipment Base Mamonovo II of the USSR Ministry of Defence was designated for troop transfer purposes in case of war, with an extensive system of standard- and broad-gauge tracks developed on site. The Braniewo Permanent Transhipment Area was to be charged with mirroring the Soviet base in case of its destruction.

The significance of the Mamonovo II base may be proven by the fact of the Soviet troops having been transferred at the location during the intervention of the Warsaw Pact troops in Czechoslovakia. ${ }^{298}$ Today, the transhipment facilities of the Braniewo Permanent Transhipment Area are used for commodity reloading purposes by the privately held Chem-Trans Logistic Północ, whereas fuel transfer station "Ba" CPN Fuel Base No. 12 Chruściel/Braniewo is managed by Naftobaza Sp. $z$ o.o. (Co. Ltd.). ${ }^{299}$

Another Permanent Transhipment Area was developed in Bartoszyce over the years 1956-1957, comprising the Głomno - Molwity - Lejdy siding (approximate length: $2 \mathrm{~km})$, and a dual-gauge $(1,524 \mathrm{~mm} / 1,435 \mathrm{~mm})$ track on the Bartoszyce Bagratyonovsk section (Bartoszyce, km. 225.650 - Głomno, km. 235.111 - (State Border), km. 241.289300), overall section length: $16 \mathrm{~km} \cdot{ }^{301}$

296 According to data of the Infrastructure Administration Authority, Regional State Railway Management Gdańsk.

297 http://www.starejuchy.pl/kolej/wrpbran/wrpbraniewo.htm [access: 18.10.2019].

$298 \mathrm{http}: / /$ www.starejuchy.pl/kolej/wrpbran/wrpbraniewo.htm [access: 18.10.2019].

299 http://www.starejuchy.pl/kolej/wrpbran/wrpbraniewo.htm [access: 18.10.2019].

300 Official-purpose map, Regional State Railway Management Gdańsk.

301 According to the data of the Infrastructure Administration Authority, Regional State Railway Management in Gdańsk. 
Four Permanent Transhipment Areas of the Regional State Railway Management in Warsaw were developed in the 1950s: Kuźnica Białostocka, Zubki Białostockie, Narewka and Terespol. With the viability of the Area in mind, the standard- and broad-gauge layouts were designed in such a way as to enable the mirroring of the Permanent Transhipment Area: duplicate track systems $(1,524 \mathrm{~mm} / 1,435 \mathrm{~mm})$ and loading facilities were provided as Substitute Transhipment Areas, should the Permanent Transhipment Areas be destroyed. Both Permanent and Substitute Transhipment Areas were located across an area of $1,500 \mathrm{~km}^{2}$; the standard-gauge network (length: $537 \mathrm{~km}, 750$ points) and the broad-gauge track network (length: $239 \mathrm{~km}, 307$ points), 9 heavy ramps, 10 light ramps, 6 proximity tracks (length: $3,652 \mathrm{~km}$ ) were constructed. ${ }^{302}$

The Permanent Transhipment Area in Kuźnica Białostocka was set up on the standard-gauge line Białystok - Sokółka - Kuźnica Białostocka - State Border - (Łosośna).

A broad-gauge siding was built along the Białystok - Kuźnica line: (State Border) - Kuźnica Białostocka - Sokółka - Geniusze Wsch. - Geniusze Machnacz passing loop - transfer facility Machnacz, length: $9.360 \mathrm{~km}$ $(36,124 \mathrm{~m}) .{ }^{303}$ The individual transfer facilities on the broad-gauge siding were constructed in tangent to standard-gauge track layouts of the Polish State Railways stations at Machnacz, Geniusze, Sokółka, and Kuźnica Białostocka.

At the border station of Kuźnica Białostocka two separate track layouts were constructed for standard- and broad-gauge. A broad-gauge siding branched off from the broad-gauge layout leading to all the transfer facilities across the Area. The station in Kuźnica was designed in a way that it could receive military troop trains from the USSR, re-assemble them and dispatch them on broad-gauge tracks to the correct transhipment points. A system of eight broad-gauge arrival/ departure tracks and a layout of four standard-gauge tracks were provided at the station to handle the Area-related railway traffic (the station itself was fitted with four signal boxes). In addition, the platform at Kuźnica station could be used as a transfer ramp, the main track of the broad-gauge siding and an additional track were constructed to the right side of the platform.

A locomotive servicing point was also set up at Kuźnica station, comprising of two standard- and two broad-gauge tracks (including ash pits) and a turntable (with a dual-gauge $1,435 \mathrm{~mm} / 1,524 \mathrm{~mm}$ track). The station was also fitted with

302 Headquarters of Military Transport at Regional State Railway Management in Warsaw, Ogólna charakterystyka (1984), 5.

303 Polish State Railways, D 29, Wykaz linii (1995), 43. 
a water station and coal storage. The broad-gauge locomotives assigned to the Kuźnica traction facility were intended to serve the entire transhipment Area. Broad-gauge Ty23 locomotives (pre-war Polish freight steam locomotives converted to broad-gauge) were stationed in Kuźnica until the late 1970s, when they were replaced with broad-gauge SM48 (TEM2) diesel locomotives produced in the USSR.

A siding (length: $1.120 \mathrm{~km}$ ) branched off the broad-gauge main line between stations the Kuźnica and Sokółka, leading to a fuel transfer station. ${ }^{304}$ Two facilities were set upon it: station Bufałowo Wsch. (two broad-gauge tracks) and handling facility Bufałowo - two broad-gauge tracks, a short siding, and a hoisting track as an extension of the main track (connecting to a standard-gauge siding branching off the station in Sokółka).

A reloading track layout $(1,435 \mathrm{~mm} / 1,524 \mathrm{~mm})$ and a reloading ramp (length: $600 \mathrm{~m}$ ) were also provided at Sokółka. A standard-gauge siding (length: $2.790 \mathrm{~km}$ ) connecting the $\mathrm{CPN}$-operated fuel transfer station at Bufałowo and the Polish State Railways Sokółka - Kamienna Nowa line both branched off the standard-gauge layout at Sokółka. ${ }^{305}$

A system of reloading tracks $(1,435 \mathrm{~mm} / 1,524 \mathrm{~mm})$ and two reloading ramps (length: $612 \mathrm{~m}$ each) were provided at Geniusze station. A layout of five broadgauge arrival tracks and five standard-gauge departure tracks were built in front of and behind the Geniusze handling facility, respectively. The transfer facility in Geniusze enabled five military trains on two ramps to be quickly reloaded. Furthermore, a passing loop Machnacz Wschód was located at the end of the main broad-gauge siding (one loading track built close to the main BiałystokKuźnica line), and the last handling facility of the Machnacz Area (connecting with the standard-gauge siding branching off the Polish State Railways station at Machnacz, length: $3.548 \mathrm{~km}$ ), the broad-gauge main track and one tack adjacent to a loading ramp. ${ }^{306}$ The main siding track, one additional track and a short dead-end track were located on the other side of the ramp.

The Permanent Transhipment Area at Zubki Białostockie was constructed around 1955, close to the standard-gauge Białystok - Zubki Białostockie State Border - (Berestowica) line. A broad-gauge track (length: $944.6 \mathrm{~m})^{307}$ was built from the state border to Zubki Białostockie station. A dual-gauge

304 Polish State Railways, D 29, Wykaz linii (1995), 37.

305 Polish State Railways, D 29, Wykaz linii (1995), 37

306 Polish State Railways, D 29, Wykaz linii (1995), 37.

307 Polish State Railways, D 29, Wykaz linii (1995), 43.

Zbigniew Tucholski - 978-3-631-82966-0 
$(1,524 \mathrm{~mm} / 1,435 \mathrm{~mm})$ track layout was provided, partly dual-gauge in the station area. The station in Kuźnica Białostocka was designed to receive military trains from the USSR, re-assemble and dispatch them on broad-gauge tracks to the appropriate transhipment facilities. A group of three broad-gauge tracks was built at the station: a broad-gauge siding (length: $2.903 \mathrm{~km}$ ) connected the broad-gauge track No. 12 to transfer facility Grzybowiec; ${ }^{308}$ whilst from broad-gauge track No. 8 a siding diverged with a crossover intersecting the standard-gauge Białystok Zubki line and on to the transfer facility in Straszewo (length: $3.362 \mathrm{~km}$ ). ${ }^{309}$ Furthermore, a track branched off from the arrival/departure broad-gauge track group leading to the stabling point for broad-gauge locomotives. It was built in a form of a triangle in order to allow steam locomotives to be turned. A stabling track and a short siding for refuelling and disposing of ash from locomotives branched off from the outer arm of the triangle. One standard-gauge track was also leading to the locomotive stabling point. Standard-gauge locomotives could access the stabling point via two crossovers, which diagonally traversed three broad-gauge tracks.

A group of four standard-gauge tracks was set up across the broad-gauge track layout. It was possible to reload goods in the area between broad-gauge track No. 8 and standard-gauge track No. 6 (no permanent ramp was provided between the tracks). Furthermore, also the broad-gauge track No. 10 was constructed along the Białystok - Zubki Białostockie line, as far as the junction post Waliły Las (reloading operations could be handled at the standard-broad gauge intersection).

Transfer facilities Straszewo and Grzybowiec were connected with standardgauge sidings (length: $3.325 \mathrm{~km}^{310}$ - Straszewo, and $2.224 \mathrm{~km}^{311}$ - Grzybowiec), which branched off the Białystok - Zubki Białostockie line near the junction post Waliły Las. A junction post was located at the point where the two lines diverged, the exit from both sidings secured with dead-end tracks (further secured by key locks).

The Grzybowiec transhipment point had two broad-gauge tracks: the main siding track and a loop track, one permanent reloading ramp and three tracks which lead to the place in which standard-gauge tracks ended: main siding track, a loop track, and a dead-end track.

308 Polish State Railways, D 29, Wykaz linii (1995), 72.

309 Polish State Railways, D 29, Wykaz linii (1995), 72.

310 Polish State Railways, D 29, Wykaz linii (1995), 71.

311 Polish State Railways, D 29, Wykaz linii (1995), 71.

Zbigniew Tucholski - 978-3-631-82966-0 
The following facilities were provided at the Straszewo transhipment point: two broad-gauge transfer points, one (main siding track and a loop track) allowing the reloading (without a permanent ramp) directly onto the standard-gauge siding, and another on the site proper, as a broad-gauge track system: the main siding track, a loop track, a hoisting dead-end track (an extension to the main siding track); a permanent reloading ramp, and a group of standard-gauge tracks: main siding track, a loop track and a dead-end track (branching off the western head of the transhipment station). The Permanent Transhipment Area in Zubki Białostockie allowed the transfer of 12 broad-gauge troop trains per day at four loading stations.

The Permanent Transhipment Area in Narewka was located close to the standardgauge Hajnówka - Siemianówka - State Border - (Świsłocz) line. A broad-gauge siding was constructed parallel to the Hajnówka - Siemianówka (Nowosady Siemianówka) line: (state border) - Siemianówka - Miklaszewo - Zabłotczyzna Skupowo - Chryzantów (length: 27.155 km). ${ }^{312}$ The station in Siemianówka was designed to receive military troop trains from the USSR, and later re-assemble and dispatch them onto the broad-gauge sidings to the correct transhipment facilities. A group of ten broad-gauge and four standard-gauge tracks was provided at the station. A front and side fixed transhipment ramp was provided between the outer broad-gauge track No. 118 and the standard-gauge track No. 5 (a track connected to the front of the ramp from the western head of the standard-gauge part of the station). A standard-gauge track No. 9 was directed (from the eastern head of the standard-gauge part of the station) in between the broad-gauge tracks Nos. 118 and 116, allowing direct transfers (without the use of the permanent ramp) from a broad-gauge to the standard-gauge track.

The main Siemianówka - Chryzanów siding as well as the Siemianówka Więcków station siding branched off directly from the broad-gauge track group. Two broad-gauge side tracks Nos. 226 and 228 and a dead-end hoisting track No. 230 were set up in the branching area of the two sidings. A broad-gauge locomotive turning triangle with a stabling track No. 219 was constructed across the site. The station in Siemianówka was fitted with three signal-boxes: dispatching box $\mathrm{Sm}$, and executing boxes $\mathrm{Sm} 1$ and $\mathrm{Sm} 2$.

A $3.931 \mathrm{~km}$-long broad-gauge siding connected the Więcków transhipment point with Siemianówka ${ }^{313}$ as well as a $5.376 \mathrm{~km}$-long standard-gauge siding to Narewka station. ${ }^{314}$ The transfer facility was fitted with both broad- and

312 Polish State Railways, D 29, Wykaz linii (1995), 43.

313 Polish State Railways, D 29, Wykaz linii (1995), 71.

314 Polish State Railways, D 29, Wykaz linii (1995), 71.

Zbigniew Tucholski - 978-3-631-82966-0 
standard-gauge side tracks destined for troop trains awaiting transhipment. The main broad-gauge transfer tracks were built further down the transhipment point, comprising the main siding (transhipment) track, a loop track, a deadend hoisting track, and permanent reloading ramp; the standard-gauge track group comprised the main siding (transhipment) track, a loop track, a deadend hoisting track, and a side dead-end track branching off the western head of the transhipment tracks. The transhipment point was fitted with four signalboxes: the dispatching box Wc, and executing boxes Wc1, Wc2, and Wc3.

Three broad-gauge stations were constructed on the main Siemianówka Chryzanów siding, in order to serve the following transhipment points:

- Miklaszewo - a five-track group, transit track, two signal-boxes: the dispatching box Mk and executing box Mk1. A $2.538 \mathrm{~km}$-long broad-gauge Miklaszewo - Planta siding branched off the western head of the station; ${ }^{315}$

- Zabłotczyzna - a three-track group, two signal-boxes: the dispatching box $\mathrm{Zb}$ and executing box Zb1. The $1.777 \mathrm{~km}$-long broad-gauge Zabłotczyzna Oskierki siding branched off the western head of the station; ${ }^{316}$

- Skupowo - a three-track group, a dead-end hoisting track on the extension of track No. 1, two signal-boxes: dispatching box Sk and executing box Sk1.

A transhipment facility was set up at the Planta station, with a broad-gauge siding (Miklaszewo - Planta) and standard-gauge (Narewka - Planta, length: $2.501 \mathrm{~km}$ ) siding connection. ${ }^{317}$ The transhipment facility comprised the following: a broad-gauge main (transfer) siding, bypass track, short protective hoisting trap, permanent reloading ramp, and a standard-gauge track system: main (transfer) siding, a loop track, a short hoisting dead-end track, and a short dead-end track branching off the eastern head of the standard-gauge station section. The station was fitted with two signal-boxes: a dispatching box Pl and an executing box Pl1.

A transhipment facility was set up at Oskierki station, with a broad-gauge siding (Zabłotczyzna - Oskierki) and standard-gauge (Bernardczyzna - Oskierki, length: $4.559 \mathrm{~km}$ ) siding connection. ${ }^{318}$ The transhipment facility comprised the following: a broad-gauge layout of three transfer tracks and a short transfer track with two dead-end tracks; and a standard-gauge layout of three transfer tracks,

315 Polish State Railways, D 29, Wykaz linii (1995), 71.

316 Polish State Railways, D 29, Wykaz linii (1995), 71.

317 Polish State Railways, D 29, Wykaz linii (1995), 71.

318 Polish State Railways, D 29, Wykaz linii (1995), 71.

Zbigniew Tucholski - 978-3-631-82966-0 
a hoisting (reloading) track, hoisting (reloading) track two, and three communication tracks between the standard-gauge tracks No.1 and No.3.

A transhipment facility was set up at Chryzantów - the final station of the broad-gauge main siding, with a standard-gauge siding (length: $3.707 \mathrm{~km}$ ) connection. ${ }^{319}$ This facility comprised a group of three broad-gauge tracks and a short dead-end hoisting track. The group of tracks was located between the standard-gauge tracks. Two reloading ramps (No. 1 and No. 2) were built in the proximity of the outer broad-gauge transfer tracks. Two standard-gauge tracks, complete with dead-end hoisting tracks, were provided across the two ramps. The station was fitted with two signal-boxes: dispatching box Chr and an executing box Chr1.

The track layouts at the Nowosady, Bernardczyzna and Narewka stations (on the Hajnówka - Siemianówka line) were expanded as well in order to secure a proper reloading capacity for the Permanent Transhipment Area in Narewka. The Area construction works involved an increase in the number of tracks at all stations, modernisation of railway signalling devices, and the construction of standard-gauge sidings leading to the reloading facilities at Chryzanów, Oskierka, Planta and Więcków.

The Terespol Permanent Transhipment Area was located in the area of the standard-gauge Biała Podlaska - Małaszewicze - Terespol - State Border (Brest) line. A broad-gauge track combined with standard-gauge tracks (length: $8.088 \mathrm{~km}$ ) was constructed along the State Border - Terespol - Kobylany standard-gauge line. ${ }^{320}$

At Terespol station, a layout of three broad-gauge tracks was constructed in order to accommodate trains from the USSR, with a further group of six standard-gauge tracks (one standard-gauge track section combined with broadgauge tracks), and four standard-gauge stabling tracks dedicated for shunting locomotives. The station incorporated four signal-boxes and 29 mechanical semaphores.

Wartime plans involved the construction of a 2 kilometre railway link intended to replace the permanent (destruction-vulnerable) border railway bridge across the River Bug with a folding structure. A floodbank embankment was erected near the existing bridge. ${ }^{321}$

319 Polish State Railways, D 29, Wykaz linii (1995), 71.

320 Polish State Railways, D 29, Wykaz linii (1995), 43, 60.

321 Account of October 20th 2006 by Colonel Jerzy Maj, retired head of the Head of Military Transport at the Regional State Railway Management in Warsaw. 
The broad-gauge marshalling yard at Kobylany was the focal point of the Area, comprising a layout of 19 marshalling yard tracks and 10 side and transhipment tracks. Four tracks connected with two permanent reloading ramps, three with an ore reloading hopper, and one (broad-gauge) - to a coal reloading hopper; standard-gauge tracks connected station Małaszewicze to all the transhipment facilities.

The broad-gauge track layout of the Kobylany station branched out into the main broad-gauge Transhipment Area circular line: Kobylany - Zaborze - Osypisko Karaczewo - Podsędków - Wólka - junction post Bogdanów - Popiel - Kobylany (length: $27.333 \mathrm{~km}$ ), ${ }^{322}$ and a broad-gauge siding connecting the CPN-operated depot at Małaszewicze. The broad-gauge marshalling yard in Kobylany was fitted with six signal-boxes, and 41 colour-light semaphores and shunting signals. The standard-gauge stations at Małaszewicze and Małaszewicze Południowe were located further down the Transhipment Area. The facilities of the Małaszewicze station included standard-gauge and broad-gauge locomotive depots, locomotive stabling equipment, as well as standard- and broad-gauge steam locomotive turning triangles. A standard-gauge siding to the CPN-operated Małaszewicze fuel base also branched off the track layout of the Małaszewicze station.

Two track systems (standard- and broad-gauge) were provided at the CPNoperated Małaszewicze fuel base. Storage tracks branched off the access tracks of both sidings, intended to accommodate tank wagons awaiting reloading or transfer to the Polish State Railways. The broad-gauge siding system comprised the following: main siding, two transfer tracks, five short communication tracks, three dead-end hoisting tracks, and two locomotive stabling tracks. The standard-gauge siding track system comprised the following: main siding, three reloading tracks, six short communications tracks, three dead-end hoisting tracks, one dead-end track, and two locomotive stabling tracks. A steam locomotive depot (with one broad- and one standard-gauge track) and two rolling stock repair workshops (with one broad- and one standard-gauge track) were provided on the siding site.

Two inner broad-gauge sidings were provided within the Terespol Permanent Transhipment Area inside the peripheral line: station Popiel - station Raniewo junction post Zaborze (length: $3.730 \mathrm{~km}$ ), ${ }^{323}$ and junction post Bogdanów - station Kowalewo - station Osypisko (length: $3.115 \mathrm{~km}$ ). ${ }^{324}$ The following stations and traffic posts were provided on the peripheral line:

322 Polish State Railways, D 29, Wykaz linii (1995), 60.

323 Polish State Railways, D 29, Wykaz linii (1995), 60.

324 Polish State Railways, D 29, Wykaz linii (1995), 60. 
- Junction post Zaborze, km. 7.06 - main siding track, secondary track, short communications track. The junction post Zaborze - Popiel siding branched off the additional track; station Osypisko, km. 9,450 - main siding track, secondary track. The Osypisko station - junction post Bogdanów siding branched off the main siding;

- Karaczewo station, km. 11,373 - main siding track, two secondary tracks, two signal-boxes, four mechanical semaphores: one arrival semaphore (on approach from Kobylany station) and three departure semaphores (towards Podsędków station);

- Podsędków station, km. 13.102 - six broad-gauge tracks (including one siding branching off the Wólka station track system), two permanent reloading ramps (600 m x $7 \mathrm{~m}$ ). A standard-gauge track system was constructed across the site from both ramps, comprising six standard-gauge tracks and two dead-end tracks of a siding branching off the Chotyłów station. The broadgauge station section was fitted with two signal-boxes and five mechanical semaphores - two arrival semaphores (on approach from Karaczewo), and three departure semaphores towards Wólka. The standard-gauge station section was fitted with one signal-box and four semaphores - one arrival semaphore on approach from Chotyłów, and three departure semaphores towards Chotyłów;

- Wólka station, km. 15.366 - a system of four broad-gauge tracks (one track placed on an overpass track used for gravity-based unloading), overpass and permanent handling ramp; a siding towards Podsędków station branched off the eastern head of the track system (broad-gauge track). The standard-gauge station section comprised a system of eight standard-gauge tracks. The station in Wólka was connected to a standard-gauge siding branching off the station in Chotyłów, and to another standard-gauge siding branching off the main track of the Bór station - Kowalewo station siding. The station was fitted with three signal-boxes (including two on the broad-gauge section) and four semaphores: one arrival semaphore (on broad-gauge track, on approach from Podsędków station to junction post Bogdanów), one departure semaphore (on a broad-gauge track) towards Kobylany, one arrival semaphore on the approach from Bogdanów (on standard-gauge track), and one departure semaphore on the standardgauge track, towards Chotyłów;

- Junction post Bogdanów, km. 16.757 - junction post building;

- Block post Mętraki, km. 18.847 - block station building;

- Popiel station, km. 19.694 - three broad-gauge tracks, two signal-boxes, six mechanical arrival and departure semaphores. A broad-gauge Popiel 
station - Raniewo station - junction post Zaborze siding branched off the eastern head of the station's track system.

Moreover, a Popiel station (km. 1.656) was provided on the inner broad-gauge Popiel - junction post Zaborze siding, with a layout of four broad-gauge tracks (main transhipment siding track, two storage and reloading tracks, short deadend track, and two permanent reloading ramps [length: $229 \mathrm{~m} \mathrm{x} 8 \mathrm{~m}$ and $790 \mathrm{x}$ $10 \mathrm{~m}$ ], including one end-to-end). A standard-gauge siding from the Mętarki block post - Raniewo station (km. 1.656) was constructed on the other side of the ramp, with a layout of eight tracks - two loading tracks, one loop track, main siding track, two side tracks, short communication track and a short dead-end track. The station was fitted with two signal-boxes and five semaphores - one arrival semaphore on the approach from junction post Zaborze (on a broadgauge track), one arrival semaphore on approach from block post Mętraki (on a standard-gauge track), and three departure semaphores towards block post Mętraki (on standard-gauge track).

The Kowalewo station $(\mathrm{km} .1 .531)$ was constructed on the inner broad-gauge siding from junction post Bogdanów - to Osypisko station, with a layout of five broad-gauge tracks, three loading ramps, and a group of six standard-gauge tracks of a siding branching off the Bór station. The station was fitted with two signal-boxes and four semaphores - one arrival semaphore (on a broad-gauge track) on approach from station Osypisko, one departure semaphore (on a broad-gauge track) towards Bogdanów station, one departure semaphore (on standard-gauge track) towards Bogdanów station, and one arrival semaphore (on a standard-gauge track) on the approach from Bogdanów station.

The well-developed track layout of the station in Biała Podlaska was used as an additional facility to handle the standard-gauge siding system of the Terespol Permanent Transhipment Area. A standard-gauge siding handling the Chotyłów - Bór - Mętraki block post section of the Area branched off track two of the Biała Podlaska - Małaszewicze line near Chotyłów, further sidings branching out to connect individual reloading facilities of the Area.

In order to serve the Terespol Permanent Transhipment Area, the steam locomotive depot in Małaszewicze operated broad-gauge Ty23 steam locomotives. In the late 1970s, these were replaced by SM48 (TEM2) diesel locomotives produced in the USSR. 
Technical and rail traffic specification of the Terespol Permanent Transhipment Area $^{325}$

\begin{tabular}{|l|l|l|l|l|l|l|}
\hline Line section & $\begin{array}{l}\text { Capacity } \\
\text { (number } \\
\text { of trains) }\end{array}$ & $\begin{array}{l}\text { Number } \\
\text { of axles } \\
\text { permitted }\end{array}$ & $\begin{array}{l}\text { Maximum } \\
\text { train weight } \\
(\mathbf{T})\end{array}$ & $\begin{array}{l}\text { Maximum } \\
\text { axle-load } \\
\text { permitted } \\
\text { (T) }\end{array}$ & $\begin{array}{l}\text { Minimum } \\
\text { curve } \\
\text { radius (m) }\end{array}$ & $\begin{array}{l}\text { Section } \\
\text { length } \\
(\mathbf{k m})\end{array}$ \\
\hline $\mathbf{1 , 5 2 4}$ mm gauge tracks
\end{tabular}

325 Diagram of the Terespol Permanent Transhipment Area (undated, probably the 1970s). 


\begin{tabular}{|l|l|l|l|l|l|l|}
\hline Line section & $\begin{array}{l}\text { Capacity } \\
\text { (number } \\
\text { of trains) }\end{array}$ & $\begin{array}{l}\text { Number } \\
\text { of axles } \\
\text { permitted }\end{array}$ & $\begin{array}{l}\text { Maximum } \\
\text { train weight } \\
(\mathrm{T})\end{array}$ & $\begin{array}{l}\text { Maximum } \\
\text { axle-load } \\
\text { permitted } \\
(\mathrm{T})\end{array}$ & $\begin{array}{l}\text { Minimum } \\
\text { curve } \\
\text { radius }(\mathbf{m})\end{array}$ & $\begin{array}{l}\text { Section } \\
\text { length } \\
(\mathbf{k m})\end{array}$ \\
\hline $\begin{array}{l}\text { Bór- } \\
\text { Kowalewo }\end{array}$ & 18 & 120 & 1200 & 18.4 & 200 & 1.58 \\
\hline $\begin{array}{l}\text { Wólka- } \\
\text { Chotyłow }\end{array}$ & 18 & 120 & 1200 & 18.4 & 200 & 2.63 \\
\hline $\begin{array}{l}\text { Bogdanów- } \\
\text { Wólka }\end{array}$ & 18 & 120 & 1200 & 18.4 & 200 & 5.25 \\
\hline
\end{tabular}

General specification of the Permanent and Temporary Transhipment Areas within the Regional State Railway Management in Warsaw (Headquarters of Military Transport, Warsaw) ${ }^{326}$

\begin{tabular}{|c|c|c|c|c|c|c|c|c|c|}
\hline \multirow{2}{*}{$\begin{array}{l}\text { Military } \\
\text { Transport } \\
\text { Command }\end{array}$} & \multirow[t]{2}{*}{ Area type } & \multirow{2}{*}{$\begin{array}{l}\text { Area } \\
\text { designation }\end{array}$} & \multirow{2}{*}{$\begin{array}{l}\text { Number } \\
\text { of } \\
\text { transfer } \\
\text { facilities }\end{array}$} & \multicolumn{6}{|c|}{ Handling capacity: trains per day } \\
\hline & & & & $\mathrm{CT}$ & LT & A & MR & MPS & Total \\
\hline Białystok & $\begin{array}{l}\text { Permanent } \\
\text { Transhipment } \\
\text { Area }\end{array}$ & "Kuźnica" & 4 & 6 & 3 & 2 & - & 1 & 12 \\
\hline Białystok & $\begin{array}{l}\text { Permanent } \\
\text { Transhipment } \\
\text { Area }\end{array}$ & “Zubki” & 2 & 3 & 3 & - & - & - & 6 \\
\hline Warsaw & $\begin{array}{l}\text { Permanent } \\
\text { Transhipment } \\
\text { Area }\end{array}$ & "Narewka" & 5 & 8 & 4 & 3 & 3 & 2 & 20 \\
\hline Warsaw & $\begin{array}{l}\text { Permanent } \\
\text { Transhipment } \\
\text { Area }\end{array}$ & “Terespol” & 6 & 13 & 9 & 3 & 5 & 4 & 34 \\
\hline
\end{tabular}

326 Headquarters of Military Transport at Regional State Railway Management in Warsaw, Ogólna charakterystyka (1984), 8. 


\begin{tabular}{|c|c|c|c|c|c|c|c|c|c|}
\hline \multirow{2}{*}{$\begin{array}{l}\text { Military } \\
\text { Transport } \\
\text { Command }\end{array}$} & \multirow[t]{2}{*}{ Area type } & \multirow{2}{*}{$\begin{array}{l}\text { Area } \\
\text { designation }\end{array}$} & \multirow{2}{*}{$\begin{array}{l}\text { Number } \\
\text { of } \\
\text { transfer } \\
\text { facilities }\end{array}$} & \multicolumn{6}{|c|}{ Handling capacity: trains per day } \\
\hline & & & & CT & LT & A & MR & MPS & Total \\
\hline Białystok & $\begin{array}{l}\text { Temporary } \\
\text { Transhipment } \\
\text { Areas }\end{array}$ & "Kuźnica” & 5 & 9 & - & 2 & - & 1 & 12 \\
\hline Białystok & $\begin{array}{l}\text { Temporary } \\
\text { Transhipment } \\
\text { Areas }\end{array}$ & “Zubki” & 2 & 6 & - & - & - & - & 6 \\
\hline Warsaw & $\begin{array}{l}\text { Temporary } \\
\text { Transhipment } \\
\text { Areas }\end{array}$ & "Narewka" & 7 & 9 & 2 & 5 & 4 & - & 20 \\
\hline Warsaw & $\begin{array}{l}\text { Temporary } \\
\text { Transhipment } \\
\text { Areas }\end{array}$ & “Terespol” & 6 & 11 & 4 & 3 & 3 & 3 & 24 \\
\hline
\end{tabular}

In 1958, the Permanent Transhipment Area in Dorohusk was constructed within the area managed by the Regional State Railway Management in Lublin. As all the related works were classified, the project was codenamed Area " $\mathrm{D}$ ", and all the respective transhipment facilities encrypted as "Daniel", "Damazy", "Dominik", and "Dionizy". A broad-gauge line (length: $31.258 \mathrm{~km}$ ) was constructed along the standard-gauge Rejowiec - Chełm - Dorohusk - (State Border) - Yagodin section: (State Border, km 0.000) - Dorohusk, km. 2.031 - Wólka Okopska, km. 7.722 - "Dominik" siding, Chełm Wschodni, km. 20.922 - Chełm, km. 23.120 Uherka passage loop, km. 24.967 - junction post Uherka - Zawadówka, km. 31.258. ${ }^{327}$ This line ran to the left of the standard-gauge Lublin - Dorohusk line; the broad-gauge line intersected with the standard-gauge line in a level near the junction post Uherka, with a concurrent transition to the right side of standardgauge tracks. Three reloading facilities were constructed on the line: "Dominik" (at the Chełm Wschód station), Dorohusk, and (CPN-operated) fuel and lubricant transfer station in Zawadówka ("Dionizy").

327 Official-use map of Regional State Railway Management Lublin and Polish State Railways, D 29, Wykaz linii (1995), 43; also Polish State Railways, Regional State Railway Management East, Dodatek 5 (1990), 24. 
In the 1950s, further two Permanent Transhipment Areas (Werchrata and Medyka) were constructed on the area managed by the Regional State Railway Management in Cracow.

The Werchrata Permanent Transhipment Area was built close to the standardgauge Munina - Werchrata - Hrebenne line. As all the related works were classified, the project was codenamed Area "W", the three respective transhipment facilities encrypted as "Waldemar", "Wiktor", and "Weronika".328 A short standard-gauge track section (length: $4.316 \mathrm{~km}$ ) was constructed from the station at Basznia to the reloading facility at Kaplisze. ${ }^{329}$ The broad-gauge line (Rava Ruska) - (State Border, km. 0.000) - Werchrata, km. 2.972 - Horyniec Zdrój, km. 16.770 - Kaplisze, km. 24.253 was also built to connect to Kaplisze. ${ }^{330}$ This line branched off in the USSR from the track layout of the Rava Ruska station and entered the Polish territory, running mostly in parallel to the standard-gauge line Munina - Werchrata - Hrebenne (Werchrata, km. 2.972 - Horyniec Zdrój, km. 16.770).

In 1953, a Permanent Transhipment Area at Medyka was developed as well, the investment associated with the expansion of the border reloading facilities in Żurawica, Przemyśl and Medyka. The second track of the Żurawica Przemyśl - Medyka line was retained as broad-gauge, as converted during the war. The construction works were performed by the Railway Works Company No. 9 from Cracow. The preparatory works involved blowing up two Austrian reinforced-concrete forts, and replacing them with a new track layout of the Medyka station. ${ }^{331}$

As all the related works were classified, the Permanent Transhipment Area in Medyka was codenamed Area " $M$ ", the respective transhipment facilities encrypted as "Michalina" (reloading facility at Torki ${ }^{332}$ ) and "Mikołaj" (reloading

328 Polish State Railways, Regional State Railway Management East, Dodatek 5 (1990), 24.

329 Polish State Railways, D 29, Wykaz linii (1995), 64.

330 Official-use map of Regional State Railway Management Cracow and Polish State Railways, D 29, Wykaz linii (1995), 45.

331 Account of September 11th 2006 by professor Henryk Bałuch, Ph.D, M.Sc. Eng.; in the 1950s, he designed and supervised the construction of reloading station Medyka and Permanent Transhipment Area M (Medyka).

332 At a later date, Torki was renamed Chałupki Medyckie. 
facility at Krówniki). The following facilities were constructed as part of the project: ${ }^{333}$

- Reloading facility Torki "Michalina" (Chałupki Medyckie) - a broad- and standard-gauge track branch was provided from the dual-gauge track system at Medyka station. Broad-gauge (length: 2,327 m) and standard-gauge $(2,894 \mathrm{~m})$ sidings were built. ${ }^{334}$ The standard-gauge track to the facility crossed the broad-gauge Medyka - Przemyśl line, crossing the line at a level and at a non-standard angle;

- Reloading facility Krzyniki "Mikołaj" - a broad- and standard-gauge track branch was routed directly to the Medyka-Przemyśl line at km. 250.589 near the Hurko loop, the broad-gauge track intersecting with the standard-gauge line at a level. Broad-gauge (length: 3,571 m) and standard-gauge $(3,143 \mathrm{~m})$ sidings were built; ${ }^{335}$

- Reloading facility Małkowice - a broad- and standard-gauge track branch was constructed from the dual-gauge track system at Zurawica station. Broadgauge (length: 3,679 m) and standard-gauge (3,554 m) sidings were built.

A fuel and lubricant transfer station was also built near the station at Zurawica (CPN Żurawica), both standard- and broad-gauge sidings branching off the station layout.

A double-track Żurawica - Hurko rail link (with broad-gauge length: 7,617 m; standard-gauge length: 6,399 m) was constructed over the years 1959-1960 with intent to improve the technical and rail traffic capacity of the Area " $M$ ", and to bypass the track system at station Przemyśl, susceptible to destruction during wartime. ${ }^{336}$ The rail link was also constructed by the Railway Works Company No. 9 from Cracow, the project was greatly labour- and resource-consuming. The rail link construction included the building of high-rise embankments and welded steel bridge across the River San (approximate length: $63 \mathrm{~m}$ ). The link branched off Żurawica station, while on the Medyka - Przemyśl line a new standard-gauge and broad-gauge layouts at Hurko were built. The technical acceptance procedure for the rail link coincided with the dismantling of the broad-gauge track two on the Przemyśl - Zurawica section. As a result of faulty construction of the

333 Account of September 11th 2006 by professor Henryk Bałuch, Ph.D, M.Sc. Eng.; in the 1950s, he designed and supervised the construction of reloading station Medyka and Permanent Transhipment Area M (Medyka).

334 Polish State Railways, D 29, Wykaz linii (1995), 45.

335 Polish State Railways, D 29, Wykaz linii (1995), 45.

336 Polish State Railways, D 29, Wykaz linii (1995), 64. 
link, land subsided in the early stages of operation, giving rise to considerable maintenance issues. The design of the Medyka Permanent Transhipment Area had assumed the wartime upkeep of two reloading facilities. ${ }^{337}$

Already in the 1960s, Area "M" was also used for commercial purposes - the reloading of Russian grain arriving in broad-gauge wagons. Wheat was mainly reloaded at Hurko station and at the reloading facility in Małkowice. ${ }^{338}$ The use of Area "M" for grain handling allowed substantial relief of the reloading facility in Medyka. ${ }^{339}$

Broad-gauge Ty23 locomotives (pre-war Polish freight steam locomotives converted to broad-gauge) from the Żurawica depot were used to handle the Medyka and Area "M" transfer facility traffic. In the late 1970s, they were replaced with broad-gauge SM48 (TEM2) diesel locomotives produced in the USSR.

The investments associated with the development of the Area were carried out in strict confidence by battalions of railway troops, the Polish State Railways, and civilian enterprises. In operational terms, transhipment bases were in all actuality used only once: to transfer the Soviet troops to standard-gauge trains during the intervention in Czechoslovakia. All Areas were managed by military transport authorities of the Polish Armed Forces, supervision over the operation, repair and maintenance of all tracks, equipment and facilities remaining with the Commands of Military Transport. Track and equipment renovation was handled by the Polish State Railways infrastructure maintenance division pursuant to a contract with the Ministry of National Defence. The areas were kept fully operational until the early 1990s.

The strategic reserves of steam locomotives allocated for long-term storage, together with the infrastructure required to operate steam traction, were also maintained on the Polish State Railways network ${ }^{340}$ - yet in principle, a different concept from that prevalent in the USSR was adopted, with preference for an active reserve of steam locomotives operated by the Polish State Railways for

337 Account of September 11th 2006 by professor Henryk Bałuch, Ph.D, M.Sc. Eng.; in the 1950s, he designed and supervised the construction of reloading station Medyka and Permanent Transhipment Area $M$ (Medyka).

338 Account of September 11th 2006 by professor Henryk Bałuch, Ph.D, M.Sc.Eng.

339 Account of September 11th 2006 by professor Henryk Bałuch, Ph.D, M.Sc.Eng.

340 Plans for wartime use of steam locomotives by the Polish Armed Forces were abandoned only in the early 1990s, the last strategic military inventory of Ty51 heavy freight locomotives was still in stock at the Polish State Railways station Zarzeka near Dęblin in the early 1990s. In the early 1990s, ST44 diesel locomotives were dispatched to long-term storage (for military purposes). 
auxiliary work purposes: light freight traffic, shunting at stations, or hauling maintenance or permanent-way trains. Until the early 1990s, steam traction was frequently used on the Polish State Railways network, solely as a strategic reserve and with no economic justification. ${ }^{341}$

Even on lines electrified by the early 1990s, as it were, railway water stations, water cranes, fuel depots with coal-refuelling devices, and ash pits were all kept in sound technical condition. Heavy ST44 diesel locomotives (2,000 horsepower) imported from the USSR since 1965 with a total of 1128 imported locomotives were also largely intended to serve military purposes in conditions of Polish State Railways wartime mobilisation.

While no plans were provided for the re-gauging of the Polish mainline railways to broad-gauge in modern-time war conditions, from the 1950s onwards all rolling stock produced in Poland (with the single exception of steam locomotive) had to be designed in such a way that it was to be easily re-gauged to broad-gauge $1,524 \mathrm{~mm}$; all design work was subject to Soviet regulations and technical standards, as well as the Soviet Railways broad-gauge loading gauge.

Full resurfacing to heavy S-49 and S-60 rails was carried out on multiple local and secondary lines categorised as strategic bypasses and/or parallel lines. Continuous resurfacing works and efforts to adapt the strategic railway lines for the passage of military troop trains weighing 1,500-2,000 tonnes were in progress as well. Railway signalling devices were also modernised and railway track layouts were being rebuilt, in order to improve the capacity of the strategic railway lines.

The responsibility for supplying the resources to allow the reconstruction of railway lines in order to provide the continuity of traffic in case of strategic railway line destruction rested primarily with the Ministry of Transport. Polish State Railways were obliged to secure the resources required to reconstruct railway lines, facilities and equipment at special-purpose mobilisation depots.

341 The Polish concept of maintaining active steam locomotives stock for wartime purposes differed from the Soviet principles, one example of the trend was the retaining of steam locomotives in the Skierniewice locomotive depot until 1990. From the 1970s onwards steam locomotives operated in Skierniewice were employed for auxiliary work purposes, the depot in Skierniewice served no non-electrified track sections at the time. Steam traction was also maintained at numerous other PKP locomotive depots (e.g. at Kielce Herbskie and Sędziszów) located on completely electrified lines. Heavy freight Ty51 steam locomotives - originally designed to haul also heavy military trains - remained in operation as well. 
In order to ensure the continuity of railway operations under wartime conditions emergency stocks of Zazulak system key interlocking boards ${ }^{342}$ and of field switching facilities were collected. Should signal-boxes and railway signalling devices be destroyed, they were to be replaced with the Zazulak system interlocking boards and with mechanical signalling devices. Should the operation of any damaged mechanical, electromechanical and/or relay signalling devices be discontinued, the existing interdependencies and centralised switch and catch-traps drives would also be removed by switching to non-centralised mode, and to simple key interdependencies of switches and catch-traps.

The emergency stocks of surface materials, sleepers and rail accessories was also kept on inventory (close to areas of predicted damage to front- and parallel railway lines).

The responsibility for maintaining wartime storage of surface materials rested with the Ministry of Transport. It was assumed that resources for the purposes of securing traffic continuity would be supplied with the aid of reserves established during peacetime. With the gradual meltdown of such supplies, materials were to be secured by dismantling local railway lines and seldomly-used access tracks and dead-end tracks. Commands of the Military Transport drafted evidence lists of tracks and junctions designated for wartime disassembly.

Storage facilities of surface and material supplies of the Warsaw Regional State Railway Management ${ }^{343}$

\begin{tabular}{|l|l|l|l|l|}
\hline $\begin{array}{l}\text { Military } \\
\text { Transport } \\
\text { Command }\end{array}$ & Station & Rails (m) & $\begin{array}{l}\text { Railway sleepers } \\
\text { (units) }\end{array}$ & $\begin{array}{l}\text { Railway } \\
\text { switches } \\
\text { (units) }\end{array}$ \\
\hline Białystok & $\begin{array}{l}\text { Czarna } \\
\text { Białostocka }\end{array}$ & 3,600 & 2,812 & 8 \\
\hline Białystok & Kuriany & 3,840 & 3,048 & 6 \\
\hline Białystok & Ełk (Prostki) & 300 & 260 & 2 \\
\hline Warsaw & Strabla & 1,140 & 980 & 11 \\
\hline
\end{tabular}

342 The railway signalling devices operated by mechanical lockdown of horizontal and vertical sliders, used to block train passage and manage traffic interdependencies.

343 Headquarters of Military Transport at Regional State Railway Management in Warsaw, Ogólna charakterystyka (1984), 23. 


\begin{tabular}{|l|l|l|l|l|}
\hline $\begin{array}{l}\text { Military } \\
\text { Transport } \\
\text { Command }\end{array}$ & Station & Rails (m) & $\begin{array}{l}\text { Railway sleepers } \\
\text { (units) }\end{array}$ & $\begin{array}{l}\text { Railway } \\
\text { switches } \\
\text { (units) }\end{array}$ \\
\hline Warsaw & Czeremcha & 6,000 & 4,698 & 12 \\
\hline Warsaw & Międzyrzec Podl. & 12,800 & 11,008 & 30 \\
\hline Warsaw & Błonie & 300 & 26 & 2 \\
\hline Warsaw & Tłuszcz & 1,200 & 1,030 & 15 \\
\hline Warsaw & Siedlce & 3,170 & 2,722 & 10 \\
\hline Warsaw & Pilawa & 3,230 & 2,194 & 18 \\
\hline Łódź & Skierniewice & 6,000 & 5,160 & 10 \\
\hline Łódź & Koluszki & 5,050 & 4,300 & 12 \\
\hline Łódź & Łódź Olechów & 900 & 774 & 14 \\
\hline Łódź & Żychlin & 5,000 & 4,300 & 7 \\
\hline Total & & 52,430 & 43,546 & $157 / 164$ \\
\hline
\end{tabular}

As of late 1950s, railway troops were equipped with increasingly modern mechanised technical solutions intended for the reconstruction of railway lines. The technology was developed in association with the use of mechanised trains for rapid resurfacing with the use of components pre-assembled at special-purpose track span depots. A significant number of railway track assembly depots and specialised bridge-building plants were set-up on the Polish State Railways network. The mobilisation plans involved the conversion of specialised Special Polish State Railways track maintenance, overhead wire maintenance, as well as signalling and communications divisions were to be turned into militarised resurfacing trains, bridge reconstruction trains, communications restoration trains, and overhead catenary reconstruction trains. All trains as listed were charged with the task of technical protection of railway lines (critical bridges, junctions, and other railway facilities and devices). The technical protection of the railway network in wartime conditions was to be secured by the railway units of the Polish Armed Forces and by militarised railway troops.

Ministry of Transport militarised units of the Warsaw Regional State Railway and their wartime responsibilities 


\begin{tabular}{|c|c|c|c|c|}
\hline Train designation & Location & Base & $\begin{array}{l}\text { Predicted } \\
\text { operational } \\
\text { area }\end{array}$ & Capacity per day \\
\hline $\begin{array}{l}\text { PON-11 } \\
\text { resurfacing train }\end{array}$ & Tłuszcz & DOM Warsaw & Tłuszcz & $\begin{array}{l}\text { Type B: } 100 \mathrm{~m}^{3} \text { of } \\
\text { earthworks, } 600 \mathrm{~m} \\
\text { of track, } 1 \text { standard } \\
\text { railway switch }\end{array}$ \\
\hline $\begin{array}{l}\text { PON-12 } \\
\text { resurfacing train }\end{array}$ & Błonie & DOM Warsaw & Gałkówek & $\begin{array}{l}100 \mathrm{~m}^{3} \text { of earthworks, } \\
100 \mathrm{~m} \text { of track, } 4 \\
\text { standard railway } \\
\text { switches }\end{array}$ \\
\hline $\begin{array}{l}\text { PON-13 } \\
\text { resurfacing train }\end{array}$ & Ełk & DOM Białystok & Szepietowo & $\begin{array}{l}100 \mathrm{~m}^{3} \text { of earthworks, } \\
100 \mathrm{~m} \text { of track, } 4 \\
\text { standard railway } \\
\text { switches }\end{array}$ \\
\hline $\begin{array}{l}\text { POŁ-01 } \\
\text { communications } \\
\text { restoring train }\end{array}$ & Zielonka & $\begin{array}{l}\text { Railway Plant for } \\
\text { Communication } \\
\text { and Signalling } \\
\text { Zielonka }\end{array}$ & Zielonka & $\begin{array}{l}\text { Setting up } 2 \\
\text { semaphores, } \\
\text { reconstructing } 0.5 \mathrm{~km} \\
\text { telephone cable and } \\
4 \text { km electrical wire } \\
\text { sections }\end{array}$ \\
\hline $\begin{array}{l}\text { POM-1 bridge } \\
\text { reconstruction } \\
\text { train }\end{array}$ & Żyrardów & \begin{tabular}{|l} 
Bridge \\
Construction \\
Plant \\
Warsaw \\
\end{tabular} & $\begin{array}{l}\text { Góra } \\
\text { Kalwaria }\end{array}$ & \\
\hline $\begin{array}{l}\text { POM-4 bridge } \\
\text { reconstruction } \\
\text { train }\end{array}$ & $\begin{array}{l}\text { Kraków } \\
\text { Bieżanów }\end{array}$ & $\begin{array}{l}\text { KZM } \\
\text { Kraków }\end{array}$ & Warka & $\begin{array}{l}\text { Type A: reconstructing } \\
30 \mathrm{~m} \text { of temporary } \\
\text { bridge structure } \\
\text { (single-track): } \\
\text { standard spans or } \\
\text { beams on wooden } \\
\text { or steel folding } \\
\text { supports. } 1,300 \mathrm{~m}^{3} \\
\text { of earthworks on the } \\
\text { original axis, including } \\
\text { the dismantling of } \\
\text { the destroyed bridge } \\
\text { (capacity then reduced } \\
\text { to } 20 \mathrm{~m} \text { ). }\end{array}$ \\
\hline
\end{tabular}




\begin{tabular}{|c|c|c|c|c|}
\hline Train designation & Location & Base & $\begin{array}{l}\text { Predicted } \\
\text { operational } \\
\text { area }\end{array}$ & Capacity per day \\
\hline $\begin{array}{l}\text { POM- } 5 \text { bridge } \\
\text { reconstruction } \\
\text { train }\end{array}$ & $\begin{array}{l}\text { Białystok } \\
\text { Starosielce }\end{array}$ & $\begin{array}{l}\text { KZKS } \\
\text { Białystok }\end{array}$ & $\begin{array}{l}\text { Sokołów } \\
\text { Podlaski }\end{array}$ & $\begin{array}{l}\text { Type } \\
\text { A: reconstructing } \\
30 \mathrm{~m} \text { of } \\
\text { temporary bridge } \\
\text { structure (single- } \\
\text { track): standard spans } \\
\text { or beams on wooden } \\
\text { or steel folding } \\
\text { supports. } 1,300 \\
\mathrm{~m}^{3} \text { of earthworks } \\
\text { on the original } \\
\text { axis, including the } \\
\text { dismantling of a } \\
\text { destroyed bridge } \\
\text { (capacity then } \\
\text { reduced to } 20 \mathrm{~m} \text { ). } \\
\end{array}$ \\
\hline $\begin{array}{l}\text { POM-11 bridge } \\
\text { reconstruction } \\
\text { train }\end{array}$ & Legionowo & DOM W-wa & Legionowo & $\begin{array}{l}\text { Reconstructing } 100 \mathrm{~m} \\
\text { of temporary bridge } \\
\text { structure (single- } \\
\text { track): standard spans } \\
\text { or beams on wooden } \\
\text { or steel folding } \\
\text { supports. } 100 \mathrm{~m}^{3} \text { of } \\
\text { earthworks. }\end{array}$ \\
\hline $\begin{array}{l}\text { POM-12 bridge } \\
\text { reconstruction } \\
\text { train }\end{array}$ & Ełk & $\begin{array}{l}\text { DOM } \\
\text { Białystok }\end{array}$ & Ostrów Maz. & $\begin{array}{l}\text { Reconstructing } 100 \mathrm{~m} \\
\text { of temporary bridge } \\
\text { structure (single- } \\
\text { track): standard spans } \\
\text { or beams on wooden } \\
\text { or steel folding } \\
\text { supports. } 100 \mathrm{~m}^{3} \text { of } \\
\text { earthworks. }\end{array}$ \\
\hline $\begin{array}{l}\text { POS-1 network } \\
\text { reconstruction } \\
\text { train }\end{array}$ & Słotwiny & $\begin{array}{l}\text { MOR } \\
\text { Słotwiny }\end{array}$ & Słotwiny & $\begin{array}{l}\text { Reconstruction and } \\
\text { repair of overhead } \\
\text { wires and power } \\
\text { supply devices. }\end{array}$ \\
\hline
\end{tabular}




\subsection{Securing Transport for the Frontline Offensive Campaign}

On the Western Theatre of War Activities, railway transport was charged with the fundamental responsibility of securing large-scale military transfer over medium and long distances from the interior of the country (and the USSR) to the rear of the frontline. The frontline railway network of the rear was intended to become the primary structure for the transport system. Railway transport connecting rear frontline bases to the frontline bases and their subdivisions (and the whole country) to the frontline was of paramount importance. Transferring complete tactical groups and units by rail became reasonable at distances of $500 \mathrm{~km}$ and above. In the case of lesser distances, troops were usually transferred by intermodal transport: heavy equipment (tanks, self-propelled guns, missile units, and engineering equipment) were transported by rail, light equipment - by road. ${ }^{344}$ In conditions of operational continuity, the railway could cover approximately $50-70 \%$ of overall frontal transport requirements. Notwithstanding the above, given its inherent lack of flexibility and manoeuvrability - in confrontation with a powerful enemy armed with nuclear and conventional weapons - the railway's contribution to general frontline transport could well be reduced to a mere $20-25 \%$. The experience of the Second World War has proven that groups of saboteurs and guerrillas operating far behind enemy lines could effectively limit the capacity of mainlines serving the frontline. The improvement to the operational lifespan of rail transport required options of transport adjustment, and the use of technical solutions allowing rapid crossing of obstacles (destroyed bridges, junctions or stations) on railway lines. The continuity and timeliness of military transport at the operational rear was achievable only with the parallel and linear use of other modes of transport, notably motor vehicles and field pipelines. Given that the planned intensity of military attack well surpassed any rate of railway reconstruction, road transport remained the only option as a military delivery link; when combined with other modes of transport, it became an extension of the railway system ${ }^{345}$ as well as a means of transferring troops by road.

Railway lines with the greatest capacity, equipped with all technical infrastructure required and least-used for other purposes were selected for the handling of military transports. Attention was paid to the susceptibility of lines to nuclear and conventional weapons impact (large and medium-sized bridges, tunnels, major railway junctions, industrial centres). Equally important was the ability

344 Ministry of National Defence, Transport Command 33/64, Komunikacja wojskowa (1965), 262.

345 Ministry of National Defence, Transport Command 33/64, Komunikacja wojskowa (1965), 198. 
to disperse the transports and the presence of devices and measures to secure transport continuity (bypass lines for bridges and junctions, rail links, crossings, Temporary Transhipment Areas prepared prior to the outbreak of war). ${ }^{346}$

The schematic map on the next page shows the structure of a transport network along the offensive campaign frontline. The offensive warfare doctrine of the Warsaw Pact presumed the use of large volumes of armoured weapons, aircraft and mechanised divisions.

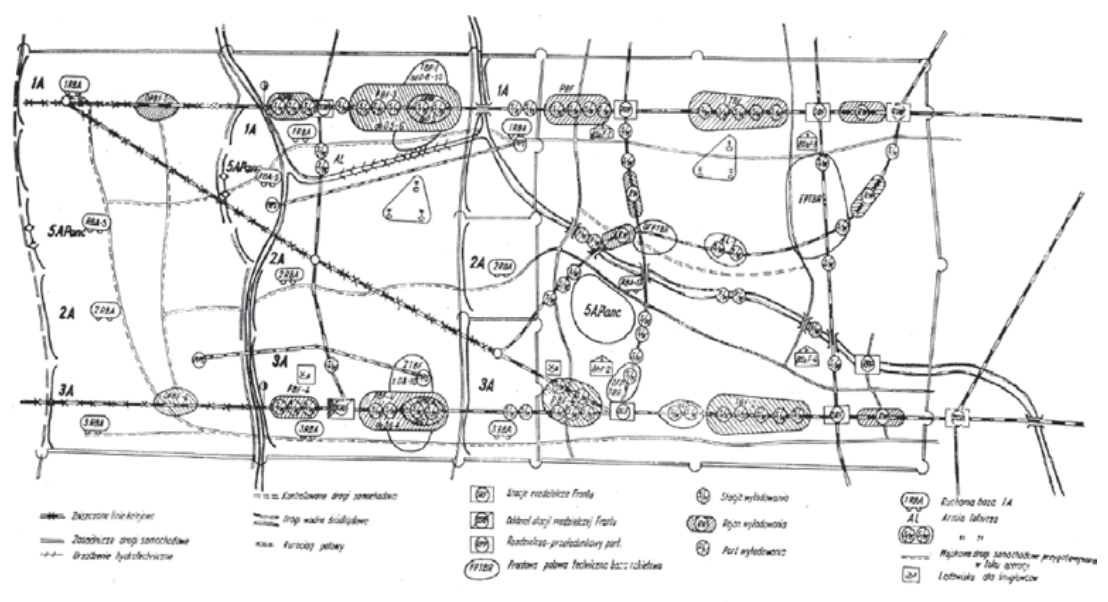

Struktura sief komunikacyjnej $\mathrm{w}$ operacji zaczepnej frontu (wariant)

Structure of the transport network in the frontal offensive operation (option). Source: Ministry of National Defence, Head of Com. 33/64, Military Transport, Warsaw 1965

Consequently, any planned rapid attack would require the delivery of large quantities of supplies, ammunition, propellants and lubricants. The aforementioned diagram shows an integrated network of transport networks in the operational rear of any frontline zone: railway lines, military roads, regular roads adapted for military operations as required, inland waterways, and helicopter airfields. The fundamental assumption for any transport system of the kind would involve its density, and an option of rapid transition from one mode of transport to another, once critical system components were eliminated or destroyed. The doctrine of continuous operability of transport and communications in nuclear warfare conditions was developed in the 1960s. Notably, the Worldwide Web was developed thanks

346 Ministry of National Defence, Transport Command 33/64, Komunikacja wojskowa (1965), 262. 
to the efforts by the United States Army to secure uninterrupted operability of military data communication networks in the event of a nuclear war.

The introduction of radio communication to the Polish State Railways in the 1960s continued to improve the reliability of railway traffic control systems (eliminating their dependence on destruction-susceptible overhead telephone lines). While automatic and semi-automatic station and line locks offered significant improvement to railway line capacity, all such devices were vulnerable and easily destroyed.

As shown by the past conflicts, mechanical railway traffic control devices are by far the most reliable, although they do extend the time needed to set and release a road for a train to pass. Furthermore, wartime plans involved special methods of train operation, should technical infrastructure and railway traffic control devices be destroyed.

Significant destruction of transport lines and facilities by thermonuclear and/ or conventional weapons could cause disruption to rail transport for periods extending over one to several days. The continuity of military transport was to be secured by dispatching military troop trains to bypass routes; unloading troops (or cargo) on approach to rail traffic disruption areas; bypassing these areas by march followed by re-transfer onto rolling stock; and improving railway line capacity through the use of odd-numbered timetables, ${ }^{347}$ use of packet timetables ${ }^{348}$ combined with the deployment of additional block posts (including mobile block posts), use of live block posts, ${ }^{349}$ organising unidirectional ${ }^{350}$ or shuttle $\mathrm{e}^{351}$ train traffic, and introducing caravan railway traffic mode..$^{352}$

347 Odd-numbered timetables could only be used on lines with well-developed track layouts.

348 A packet of several trains could pass through a given section in one direction, then a number of trains could pass through in the opposite direction.

349 Temporary block posts fitted with telephone communication devices were deployed along the line. Semaphores were replaced with D1 stop signs. Trains would be allowed to pass through a block post upon the All Clear signal given by the signal officer manning the given post.

350 Two lines were essentially selected whenever unidirectional traffic was set up: one used by loaded trains, the other - by empty ones on return.

351 Shuttle train operation comprised unidirectional traffic cycles on a single line (train passage would be allowed in alternate directions for pre-specified periods of time). Such method was employed if no other option for the return of empty wagons was available, or if the need arose to dispatch trains for unloading at night.

352 Caravan rail traffic involved train dispatching over minimum separation intervals of 3-4 minutes at $20 \mathrm{~km}$ per hour, in general with the train before being constantly in 
Plans of preparing materials to secure equipment on railway flat wagons were drafted with intent to ensure maximum safety during the loading and unloading of troops at stations. Furthermore, train shuttles and/or motor vehicle columns were to be kept on standby in the vicinity of vital railway facilities and large water courses, to assure access to appliances used to secure equipment on railway flat wagons, water and fuel resources, and other facilities. Railway rolling stock reserves allowing the formation of 1-2 trains were to be kept on approaches to large facilities at any given time.

The following distances were assumed as bypass route lengths for facilities destroyed by a ground explosion under conditions of radioactive clouds shrouding railway lines: in case of a small-calibre nuclear bomb strike - approximately $0-80 \mathrm{~km}$; in case of a mid-calibre nuclear bomb strike - approximately $100-120 \mathrm{~km}$; in case of a large-calibre nuclear bomb strike - approximately $150-180 \mathrm{~km}$. It was further noted when planning bypasses for damaged facilities that troops marching along the road were a solution far less economical than rail transport, involving high consumption of propellants and lubricants. Approximate fuel consumption per $100 \mathrm{~km}$ of a marching mechanised division totalled 254 tonnes, of an armoured division - 488 tonnes; of a general army (4 divisions, 2 armoured divisions and army units) - almost 2,340 tonnes, the latter tantamount to four trains with a net weight of nearly 650 tonnes each. ${ }^{353}$

In view of the anticipated nuclear attack on the frontline railway network, plans were made to deploy rolling stock decommissioning facilities across a 150$200 \mathrm{~km}$ radius. In principle, fixed facilities were to be deployed at Polish State Railways wagon depots (fitted with carriage-cleaning appliances), while field facilities were to be set up at stations with access to railway water mains (water stations for locomotive supply purposes). Contingency plans involved rolling stock decommissioning with the use of hot water from locomotive boilers.

Two main front railway lines (each with a capacity of 24-46 pairs of trains per day) were designated for the purposes of handling transfers to the Western Front assault operations: (state border near Terespol) - Małaszewicze - Łuków Skierniewice - Łowicz - Kutno - Poznań - Zbąszynek - Kunowice - Frankfurt, and Białystok - Łapy - Ostrołęka - Wielbark - Działdowo - Toruń - Bydgoszcz -

sight. Due to safety requirements for such traffic mode, the permitted train speed was significantly reduced. Caravan mode with steam traction was permitted on sections up to $60 \mathrm{~km}$ in length, for periods no longer than one day.

353 Ministry of National Defence, Transport Command 33/64, Komunikacja wojskowa (1965), 286-287. 
Piła - Krzyż - Kostrzyń. ${ }^{354}$ A Wielbark Las -Suchy Las rail link was constructed on the latter, with intent to bypass the vulnerable Wielbark junction (the rail link was disused and kept on standby for wartime purposes, complete with signalboxes). A rail link was also built to bypass the Działdowo junction (junction post Działdowo Wschód - junction post Działdowo Zachód), routed from Nidzica towards Brodnica. This rail section was also used for commercial purposes. Both front mainlines ran from the operational rear of the front to the bases at its very head. The front mainlines were also connected to the selected railway lines leading from Permanent Transhipment Areas to the state border. During wartime priority would be given to the reconstruction of front-bound railway lines as well as major parallel lines.

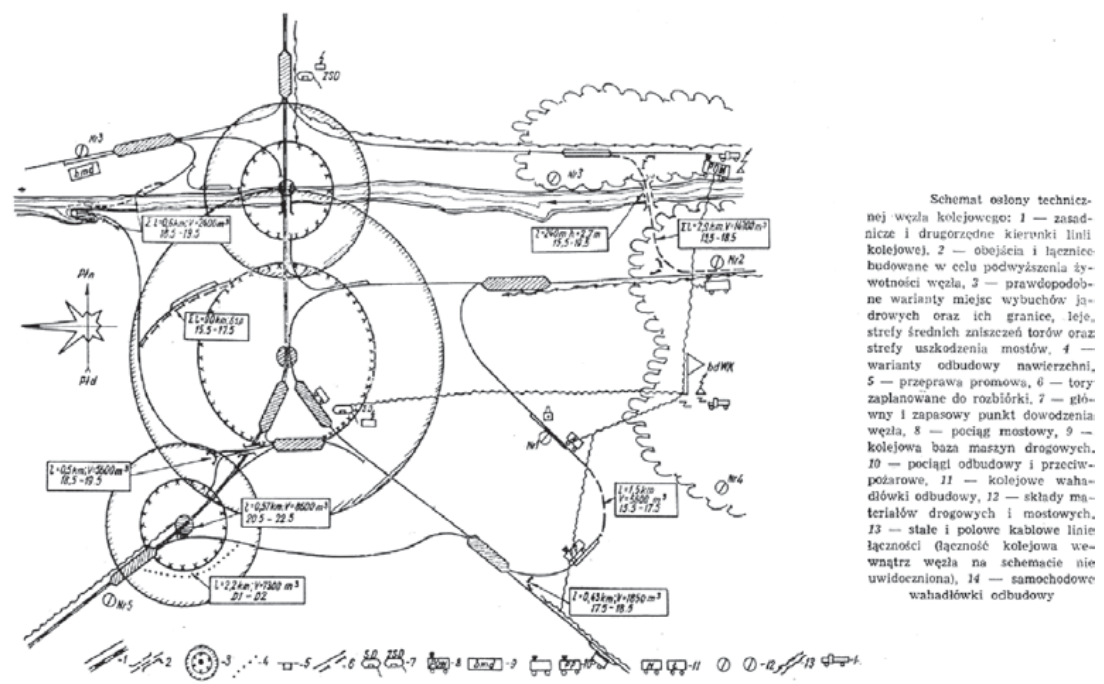

Diagram of technical solutions for a railway junction.

Source: Ministry of National Defence, Transport Command 33/64, Komunikacja wojskowa (1965)

354 And two front parallel lines (with a capacity of 8-14 train pairs per day). 
List of rolling stock decommissioning points within the Regional State Railway Management in Warsaw ${ }^{355}$

\begin{tabular}{|c|c|c|c|c|c|}
\hline \begin{tabular}{|l} 
Military \\
Transport \\
Command
\end{tabular} & $\begin{array}{l}\text { Station } \\
\text { designation }\end{array}$ & Location & \begin{tabular}{|l} 
Time to \\
open a \\
facility \\
upon signal \\
reception
\end{tabular} & $\begin{array}{l}\text { Water } \\
\text { source }\end{array}$ & $\begin{array}{l}\text { Daily capacity } \\
\text { of wagon } \\
\text { decommissioning }\end{array}$ \\
\hline \multicolumn{6}{|c|}{ Permanent facilities } \\
\hline Warsaw & $\begin{array}{l}\text { Warszawa } \\
\text { Wschodnia } \\
\text { Rozrządowa } \\
\end{array}$ & $\begin{array}{l}\text { tracks } 36 \\
38\end{array}$ & 24 hours & $\begin{array}{l}\text { municipal } \\
\text { water mains }\end{array}$ & 250 \\
\hline Łódź & Kutno Azory & track 357 & 24 hours & \begin{tabular}{|l} 
railway \\
water mains
\end{tabular} & 120 \\
\hline Łódź & \begin{tabular}{|l|l} 
Łódź \\
Karolew
\end{tabular} & track 17 & 24 hours & $\begin{array}{l}\text { railway } \\
\text { water mains }\end{array}$ & 120 \\
\hline \multicolumn{6}{|c|}{ Field facilities } \\
\hline Warsaw & Pruszków & $\begin{array}{l}\text { station } \\
\text { tracks }\end{array}$ & 24 hours & \begin{tabular}{|l} 
railway \\
water mains \\
\end{tabular} & 480 \\
\hline Warsaw & Mszczonów & $\begin{array}{l}\text { station } \\
\text { tracks }\end{array}$ & 24 hours & \begin{tabular}{|l} 
railway \\
water mains \\
\end{tabular} & 480 \\
\hline Warsaw & \begin{tabular}{|l} 
Stoczek \\
Eukowski
\end{tabular} & $\begin{array}{l}\text { station } \\
\text { tracks }\end{array}$ & 24 hours & \begin{tabular}{|l|} 
railway \\
water mains \\
\end{tabular} & 480 \\
\hline Warsaw & Mrozy & $\begin{array}{l}\text { station } \\
\text { tracks }\end{array}$ & 24 hours & \begin{tabular}{|l} 
railway \\
water mains \\
\end{tabular} & 480 \\
\hline Łódź & \begin{tabular}{|l} 
Piotrków \\
Trybunalski
\end{tabular} & $\begin{array}{l}\text { station } \\
\text { tracks }\end{array}$ & 24 hours & \begin{tabular}{|l} 
railway \\
water mains \\
\end{tabular} & 540 \\
\hline Łódź & Rogów & \begin{tabular}{|l} 
station \\
tracks
\end{tabular} & 24 hours & $\begin{array}{l}\text { railway } \\
\text { water mains }\end{array}$ & 440 \\
\hline Łódź & Radomsko & \begin{tabular}{|l} 
station \\
tracks
\end{tabular} & 24 hours & oil pipeline & 540 \\
\hline
\end{tabular}

355 Headquarters of Military Transport at Regional State Railway Management in Warsaw, Ogólna charakterystyka (1984), 26, 28. 


\begin{tabular}{|c|c|c|c|c|c|}
\hline $\begin{array}{l}\text { Military } \\
\text { Transport } \\
\text { Command }\end{array}$ & \begin{tabular}{|l} 
Station \\
designation
\end{tabular} & Location & $\begin{array}{l}\text { Time to } \\
\text { open a } \\
\text { facility } \\
\text { upon signal } \\
\text { reception }\end{array}$ & $\begin{array}{l}\text { Water } \\
\text { source }\end{array}$ & $\begin{array}{l}\text { Daily capacity } \\
\text { of wagon } \\
\text { decommissioning }\end{array}$ \\
\hline Łódź & Zgierz & $\begin{array}{l}\text { station } \\
\text { tracks }\end{array}$ & 24 hours & \begin{tabular}{|l} 
railway \\
water mains
\end{tabular} & 400 \\
\hline Białystok & \begin{tabular}{|l} 
Bielsk \\
Podlaski
\end{tabular} & $\begin{array}{l}\text { station } \\
\text { tracks }\end{array}$ & 24 hours & $\begin{array}{l}\text { railway } \\
\text { water mains }\end{array}$ & 480 \\
\hline Białystok & $\begin{array}{l}\text { Ostrów } \\
\text { Mazowiecka }\end{array}$ & $\begin{array}{l}\text { station } \\
\text { tracks }\end{array}$ & 24 hours & $\begin{array}{l}\text { railway } \\
\text { water mains }\end{array}$ & 480 \\
\hline Białystok & Łochów & $\begin{array}{l}\text { station } \\
\text { tracks }\end{array}$ & 24 hours & $\begin{array}{l}\text { railway } \\
\text { water mains }\end{array}$ & 550 \\
\hline Białystok & Czyżew & $\begin{array}{l}\text { station } \\
\text { tracks }\end{array}$ & 24 hours & \begin{tabular}{|l} 
railway \\
water mains
\end{tabular} & 550 \\
\hline Białystok & Olecko & $\begin{array}{l}\text { station } \\
\text { tracks }\end{array}$ & 24 hours & \begin{tabular}{|l} 
railway \\
water mains
\end{tabular} & 390 \\
\hline Białystok & Sokółka & $\begin{array}{l}\text { station } \\
\text { tracks }\end{array}$ & 24 hours & \begin{tabular}{|l} 
railway \\
water mains
\end{tabular} & 550 \\
\hline Białystok & Żednia & $\begin{array}{l}\text { station } \\
\text { tracks }\end{array}$ & 24 hours & \begin{tabular}{|l} 
railway \\
water mains
\end{tabular} & 380 \\
\hline Białystok & Knyszyn & $\begin{array}{l}\text { station } \\
\text { tracks }\end{array}$ & 24 hours & \begin{tabular}{|l} 
railway \\
water mains
\end{tabular} & 450 \\
\hline Białystok & Grajewo & $\begin{array}{l}\text { station } \\
\text { tracks }\end{array}$ & 24 hours & \begin{tabular}{|l} 
railway \\
water mains \\
\end{tabular} & 490 \\
\hline Białystok & Parciaki & $\begin{array}{l}\text { station } \\
\text { tracks }\end{array}$ & 24 hours & \begin{tabular}{|l} 
railway \\
water mains \\
\end{tabular} & 510 \\
\hline Łódź & Łęczyca & $\begin{array}{l}\text { station } \\
\text { tracks }\end{array}$ & 24 hours & \begin{tabular}{|l} 
railway \\
water mains \\
\end{tabular} & 600 \\
\hline Łódź & Lask & $\begin{array}{l}\text { station } \\
\text { tracks }\end{array}$ & 24 hours & $\begin{array}{l}\text { railway } \\
\text { water mains }\end{array}$ & 320 \\
\hline \multicolumn{5}{|l|}{ Total } & 10,080 \\
\hline
\end{tabular}


The plan for regrouping the Soviet Army and Polish Armed Forces troops in the Western Operational Direction assumed the use of Permanent Transhipment Areas in Braniewo, Skandawa, Kuźnica Białostocka, Zubki Białostockie, Narewka, Terespol, Dorohusk, Werchrata and Medyka, followed by the transfer of tactical units via the eight transport lines along the east-west direction according to a standard latitudinal layout: ${ }^{356}$ No. 1: Braniewo - Malbork - Tczew - Chojnice - Piła - Krzyż - Kostrzyn - Berlin (or Szczecinek - Stargard - Szczecin); No. 2: Skandawa - Korsze - Olsztyn Iława - Toruń - Poznań - Rzepin - Berlin; No. 3: Trakiszki ${ }^{357}$ - Suwałki $\left(\right.$ Olecko $\left.^{358}\right)$ - Ełk - Korsze - Iława - Toruń; No. 4: Kuźnica Białostocka Białystok - Łapy Ostrołęka - (Wielbark ${ }^{359}$ ) - Nidzica - Brodnica; No. 4a: Zubki Białostockie - Białystok Łapy - Małkinia - Tłuszcz - $\left(\right.$ Legionowo $\left.^{360}\right)$ - Nasielsk Sierpc - Toruń; No. 5: Siemianówka - Czeremcha - $\left(\right.$ Siedlce $\left.^{361}\right)$ - $\left(\right.$ Łuków $\left.^{362}\right)$ Pilawa - Skierniewice; No. 6: Terespol - Łuków -Pilawa - Skierniewice; No. 7: Dorohusk - Lublin - $\left(\right.$ Dęblin $\left.^{363}\right)$ - Tomaszów Mazowiecki - Łódź Olechów Ostrów Wielkopolski - Leszno - Głogów - Żagań - Cottbus; No. 8: Werchrata/ Medyka - Przeworsk - Kraków - Katowice - Wrocław - Legnica - Żagań/ Węgliniec. The loading operations were to be handled by the Permanent Transhipment Areas at the state border, all trains to be unloaded at stations ahead of River Odra.

This diagram of military Soviet troop transfer across the Polish territory shows two main frontline-bound railway lines.

356 Reconstruction of the location of the lines according to indirect sources.

357 In Trakiszki, the standard-gauge track entered USSR territory where a Permanent Transhipment Area had been developed; standard-gauge military trains were to enter Polish territory upon reloading.

358 Via rail link Łęgówek - Lesko.

359 Via rail link Suchy Las - Wielbark Las.

360 Via rail link Legionowo Piaski - Chotomów.

361 Via rail link Doły - Ujrzanów.

362 Via rail link Trzaskoniec - Poważe.

363 Via rail link Wieprz - Wisła. 


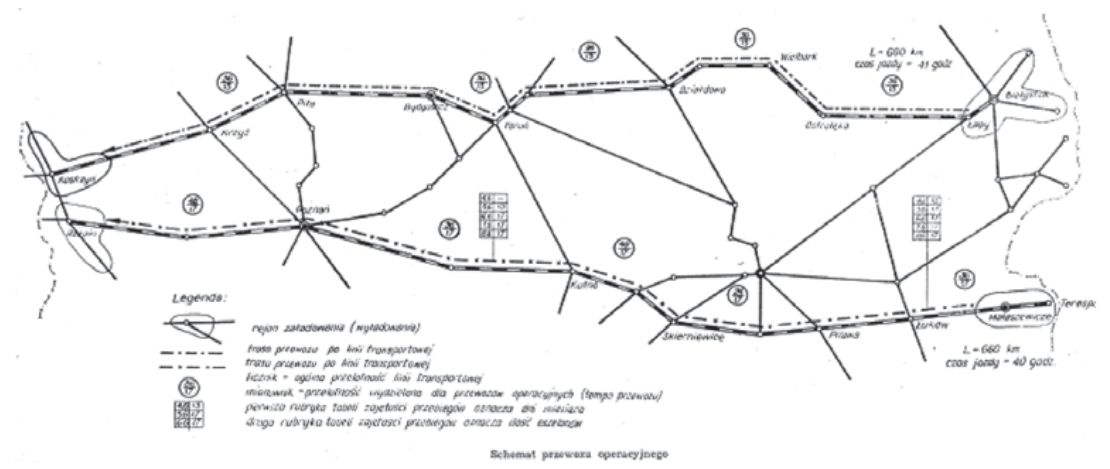

Diagram of an operational transport.

Source: Ministry of National Defence, Transport Command 33/64, Komunikacja wojskowa (1965)

When drafting forecasts of damages to the railway transport network, the Warsaw Military District of the Bureau of Military Transport conducted an "analysis of predicted damages caused by conventional weapons to the transport network of the Warsaw Military District area." ${ }^{364}$ Pursuant to mobilisation plans, reforming Headquarters of Military Transport into a single field unit would take place within two days prior to the outbreak of war, whilst reforming militarised railway (Polish State Railways) units would take one day. Damage analyses proved that railway bridges over large and medium-sized water courses, stations and junctions, as well as Permanent and Temporary Transhipment Areas were the most vulnerable railway structures of all, and most difficult to rebuild. In the wake of mobilisation plan scrutiny, it was found that railway bridge reconstruction during the first stage of war would be impossible due to the shortage of human and material resources. ${ }^{365}$ Consequently, railway bridges over the following rivers were omitted in the reconstruction schedule for the first stages of warfare: Góra Kalwaria (Vistula), Tomaszów Mazowiecki (Pilica), Małkinia (Bug), Terespol (Bug), Osowiec (Biebrza), Łowicz (Bzura), Modlin (Narew), Grabowie (Narew), Warsaw, near the Citadel (Vistula), Warsaw, crosscity (Vistula), Skierniewice (Rawka), Permanent Transhipment Area Dorohusk

364 Command of the Military Transports Service, Warsaw Military District, Analiza (1978), 4.

365 Command of the Military Transports Service, Warsaw Military District, Analiza (1978), 4. 
(Bug), Dęblin (Wieprz), Nagnajów (Vistula), Sandomierz (Vistula), Lubartów (Wieprz), Hrubieszow (Bug), Podłęże (Vistula), and Kraków (Vistula). ${ }^{366}$ The following works were planned for the main front- and transport lines near the River Vistula: development of bridges as bypass routes for destroyed permanent crossings; organisation of Substitute Transhipment Areas; and the use of two substitute crossings at Wysokie Koło and Nowy Dwór Kwidzyński.

In view of the labour-intensive nature of all reconstruction works it was planned to switch railway operation to diesel and steam tractions should the overhead catenary of the electrified lines be destroyed. ${ }^{367}$

The permanent Transhipment Areas in Kuźnica, Zubki, Narewka, Terespol, Dorohusk, Werchrata and Medyka were most vulnerable to destruction, all recognised as vital components of connecting the two railway systems with different gauges. In case of destruction to the Permanent Transhipment Areas in Zubki, Terespol and/or Dorohusk, a Substitute Transhipment Area was to be used. ${ }^{368}$

It was also assumed that in order to prevent troops from regrouping, the enemy would destroy bridges over Rivers Vistula, Bug and Narew, on transfer lines leading from the Permanent Transhipment Areas in Kuźnica, Zubki, Narewka and Terespol to the River Vistula. Should permanent crossings over the Vistula be destroyed, Temporary Transhipment Areas were to be developed in Toruń, Płock, Karczew, and Góra Kalwaria, all traffic switched to the zonal mode. ${ }^{369}$

366 Command of the Military Transports Service, Warsaw Military District, Analiza (1978), 9.

367 Command of the Military Transports Service, Warsaw Military District, Analiza (1978), 9.

368 Command of the Military Transports Service, Warsaw Military District, Analiza (1978), Appendix No. 1 - map.

369 Headquarters of Military Transport at Regional State Railway Management in Warsaw, Ogólna charakterystyka (1984), 5. 


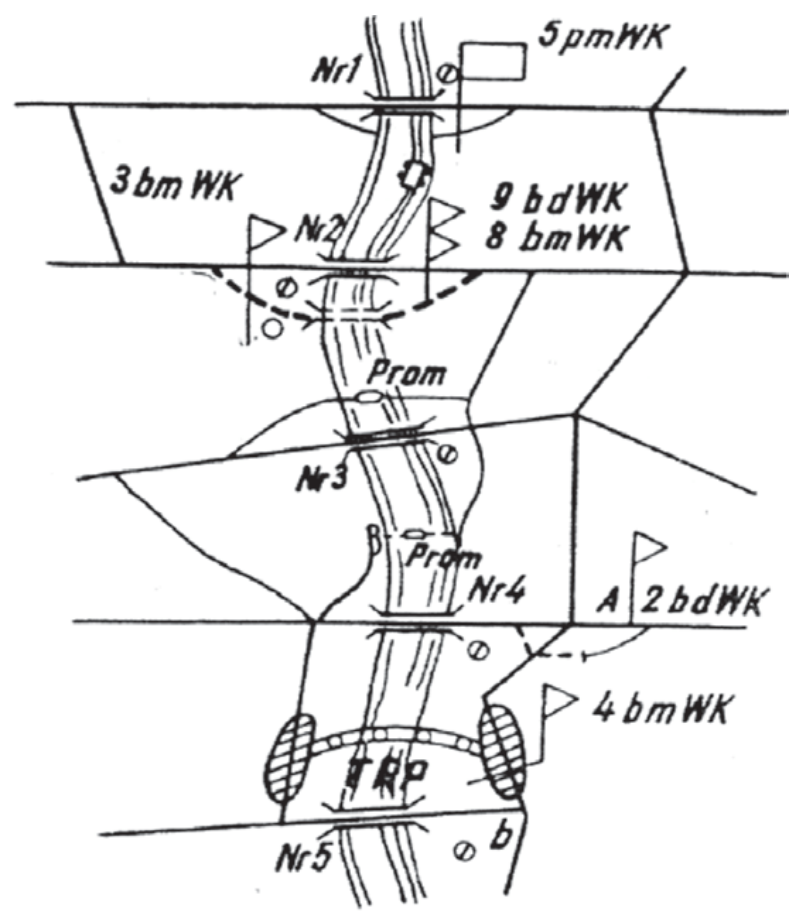

\section{Wariant organizacji osłony technicznej przejść mostowych przez dużą przeszkodę wodną}

Option for organisation of technical solutions for bridges over a large water obstacle. Source: Ministry of National Defence, Transport Command 33/64, Komunikacja wojskowa (1965)

The planning of frontline offensive campaigns involved an assumption of regrouping the Soviet and Polish Armed Forces units by rail (the operation to be completed prior to the outbreak of war), to be followed by heavy equipment transfer only, via the Permanent Transhipment Areas and the front mainlines. It was assumed as part of the original estimates that the initial attack would cause major disruptions to moving troops by rail, in view of the destruction to bridges over the River Vistula (with two bridges remaining open). The capacity of transit lines was to enable the regrouping of a maximum of 1 tactical compound per day. Should 4 axes of the Temporary Transhipment Areas be made operational for the 
purposes of crossing the Vistula, however, the capacity could be increased to 2 tactical compound per day. ${ }^{370}$

Apart from the main transfer lines, parallel and reserve lines were to be put to use as well to secure manoeuvrability in case of the destruction to large railway facilities causing long-term disruption to rail traffic. Capacity reserves were pre-specified for the boundaries of all main lines, ${ }^{371}$ meaning large bodies of water and railway junctions, frontline rear demarcation lines, state borders, and Transhipment Areas. ${ }^{372}$

Furthermore, 40-50 unloading stations were set out as part of the frontline railway network: for troops, material and technical supplies, evacuation of the wounded, disinfection, and rolling stock decommissioning. The remaining front railway lines (parallel and support lines) and rail links were to be used for the purposes of regulating operational traffic density, and as bypasses of large junctions and transport facilities.

It was assumed that the destruction of railway objects by nuclear weapons would lead to the following disruptions in service: 1-6 days if railway hubs were destroyed, 6-8 days if bridges were destroyed, 20-60 days if tunnels were destroyed. ${ }^{373}$ Reconstruction of mainlines (at a rate of $30-40 \mathrm{~km}$ per day), reconstruction of railway bridges on permanent supports (at an approximate rate of 50 metres per day), and reconstruction of road-rail bridges on floating supports (NZM56, at an approximate rate of 250 metres per day) was to be handled by railway troops brigades assisted by militarised railway (Polish State Railways) divisions specialised in the reconstruction of railway structures (infrastructure reconstruction trains, bridge reconstruction trains, communications reconstruction trains). ${ }^{374}$

Strategic bridge component reserve list, Regional State Railway Management in Warsaw $^{375}$

370 Command of the Military Transports Service, Warsaw Military District, Analiza (1978), 4.

371 The reserve was established at $10-20 \%$ of the total railway line capacity.

372 Ministry of National Defence, Transport Command 33/64, Komunikacja wojskowa (1965), 263.

373 Ministry of National Defence, Transport Command 33/64, Komunikacja wojskowa (1965), 202.

374 Ministry of National Defence, Transport Command 33/64, Komunikacja wojskowa (1965), 194.

375 Headquarters of Military Transport at Regional State Railway Management in Warsaw, Ogólna charakterystyka (1984), 29. 


\begin{tabular}{|l|l|l|l|l|l|l|}
\hline \multirow{2}{*}{$\begin{array}{l}\text { Military } \\
\text { Command }\end{array}$} & Station & \multicolumn{3}{|l|}{ Bridge components } & \multirow{2}{*}{ Allocation } \\
\cline { 3 - 6 } & & $\begin{array}{l}\text { SEK- } \\
\mathbf{5 0 0} \\
\text { (sets })\end{array}$ & $\begin{array}{l}\text { L-36 } \\
\text { units/m }\end{array}$ & $\begin{array}{l}\text { Supports } \\
\text { (sets) }\end{array}$ & $\begin{array}{l}\text { NP-559 } \\
\text { Units/m }\end{array}$ & \\
\hline Warsaw & Legionowo & -- & $2 / 216$ & 20 & -- & 200 \\
\hline Warsaw & Pilawa & $1 / 500$ & -- & 1 & $14 / 175$ & 200 \\
\hline Warsaw & $\begin{array}{l}\text { Góra } \\
\text { Kalwaria }\end{array}$ & $1 / 500$ & -- & 1 & -- & \\
\hline Warsaw & Platerów & -- & -- & -- & $17 / 212,5$ & 300 \\
\hline Białystok & Gucin & -- & -- & -- & $10 / 125$ & 300 \\
\hline Łódź & $\begin{array}{l}\text { Łowicz } \\
\text { Suburb }\end{array}$ & -- & -- & -- & $41 / 512$ & 800 \\
\hline Łódź & Sierpc & -- & -- & -- & $14 / 175$ & 200 \\
\hline Total & $2 / 100$ & $2 / 216$ & 22 & $96 / 1199.5$ & 2,000 \\
\hline${ }^{9}$ Double T-profile beams used in temporary bridge reconstruction \\
\hline
\end{tabular}

The rear military transport was categorised as serving the following purposes: operational/military, supplementary, supplies, evacuation, reconstruction materials, and general support. Military exercise-related experience has proven that regular transfer of the units of a general army (three mechanised divisions, one armoured division, standard army units) would require between 200 and 250 trains (mechanised divisions - 50 trains, armoured division - 50-55 trains, army units - 30 trains, operational rear units and divisions -20 trains). The mechanisation of tactical compound gave rise to a significant increase in the volumes of heavy (tank) flat wagons required for operational/military transport (whenever mechanised or armoured divisions were transferred, flat wagons comprised approximately $80-83 \%$ of the rolling stock). ${ }^{376}$ Due to the shortage of such wagons during wartime, the army decided to set up special-purpose side-wall removal facilities for coal wagons.

376 Ministry of National Defence, Transport Command 33/64, Komunikacja wojskowa (1965), 260. 
List of wagon side wall removal facilities within the Regional State Railway Management in Warsaw (Command of Military Transport Warsaw) ${ }^{377}$

\begin{tabular}{|c|c|c|c|c|c|c|}
\hline $\begin{array}{l}\text { Military } \\
\text { Transport } \\
\text { Command } \\
\text { Warsaw } \\
\end{array}$ & Facilities & $\begin{array}{l}\text { Side wall } \\
\text { removal } \\
\text { location } \\
\text { (station) } \\
\end{array}$ & \begin{tabular}{|l|} 
Track \\
number for \\
wagon side- \\
wall removal
\end{tabular} & Manual & Mechanical & Emergency \\
\hline Warsaw & $\begin{array}{l}\text { Wagon } \\
\text { workshop }\end{array}$ & \begin{tabular}{|l} 
Szczęśliwice \\
wagon \\
workshop \\
\end{tabular} & 159 & $40 / 32$ & & \\
\hline Warsaw & $\begin{array}{l}\text { Wagon } \\
\text { workshop }\end{array}$ & $\begin{array}{l}\text { Odolany } \\
\text { wagon } \\
\text { workshop }\end{array}$ & $814-815$ & $59 / 47$ & & \\
\hline Warsaw & Okęcie station & Okęcie & $510-514$ & & 119 & \\
\hline Warsaw & $\begin{array}{l}\text { Warszawa } \\
\text { Wschodnia } \\
\text { Rozrządowa } \\
\end{array}$ & $\begin{array}{l}\text { Warszawa } \\
\text { Praga }\end{array}$ & $13-15$ & $29 / 23$ & & \\
\hline Warsaw & $\begin{array}{l}\text { Wagon } \\
\text { workshop }\end{array}$ & $\begin{array}{l}\text { Warszawz } \\
\text { Praga }\end{array}$ & $400-401$ & & 116 & \\
\hline Warsaw & $\begin{array}{l}\text { Wagon } \\
\text { workshop }\end{array}$ & Siedlce & 482 & $67 / 53$ & & \\
\hline Warsaw & $\begin{array}{l}\text { Małaszewicze } \\
\text { station }\end{array}$ & Małaszewicze & 22 & 77 & & \\
\hline Warsaw & $\begin{array}{l}\text { Wagon } \\
\text { workshop }\end{array}$ & Małaszewicze & $154 a$ & & 23 & 50 \\
\hline Warsaw & $\begin{array}{l}\text { Wagon } \\
\text { workshop }\end{array}$ & Małaszewicze & $240-242$ & $77 / 61$ & $50 / 40$ & \\
\hline Warsaw & $\begin{array}{l}\text { Rolling Stock } \\
\text { Repair Plant } \\
\text { in Pruszków } \\
\end{array}$ & Pruszków & plant tracks & & 30 & \\
\hline Warsaw & $\begin{array}{l}\text { Rolling Stock } \\
\text { Repair Plant } \\
\text { in Mińsk } \\
\text { Mazowiecki } \\
\end{array}$ & Mińsk Maz. & plant tracks & & 54 & \\
\hline
\end{tabular}

377 Headquarters of Military Transport at Regional State Railway Management in Warsaw, Ogólna charakterystyka (1984), 27. 


\begin{tabular}{|c|c|c|c|c|c|c|}
\hline $\begin{array}{l}\text { Military } \\
\text { Transport } \\
\text { Command } \\
\text { Warsaw } \\
\end{array}$ & Facilities & $\begin{array}{l}\text { Side wall } \\
\text { removal } \\
\text { location } \\
\text { (station) }\end{array}$ & $\begin{array}{l}\text { Track } \\
\text { number for } \\
\text { wagon side- } \\
\text { wall removal }\end{array}$ & Manual & Mechanical & Emergency \\
\hline Białystok & $\begin{array}{l}\text { Wagon } \\
\text { workshop }\end{array}$ & $\begin{array}{l}\text { Białystok } \\
\text { Fabr. }\end{array}$ & $12-13$ & $104 / 26$ & & \\
\hline Białystok & $\begin{array}{l}\text { Rolling Stock } \\
\text { Repair Plant } \\
\text { in Łapy }\end{array}$ & Łapy & plant tracks & & 23 & \\
\hline Łódź & $\begin{array}{l}\text { Wagon } \\
\text { workshop }\end{array}$ & $\begin{array}{l}\text { Łódź } \\
\text { Olechów }\end{array}$ & 246 & $199 / 157$ & $124 / 99$ & \\
\hline Łódź & $\begin{array}{l}\text { Wagon } \\
\text { workshop }\end{array}$ & Piotrków & 58 & & $18 / 16$ & \\
\hline Łódź & $\begin{array}{l}\text { Wagon } \\
\text { workshop }\end{array}$ & \begin{tabular}{|l} 
Łódź \\
Karolew
\end{tabular} & 22 & & $14 / 11$ & \\
\hline Łódź & $\begin{array}{l}\text { Wagon } \\
\text { workshop }\end{array}$ & $\begin{array}{l}\text { Łódź } \\
\text { Żabieniec }\end{array}$ & 20 & $30 / 24$ & & \\
\hline
\end{tabular}

In the period prior to the opening of the Permanent Transhipment Areas, it was planned to efficiently transfer wagons with side walls removed ${ }^{378}$ to Temporary and Permanent Transhipment Areas at the intersection of the Polish and Soviet railway networks. Securing adequate standard-gauge rolling stock and its smooth delivery was of great importance to the timely transfer of Soviet and Polish Armed Forces units along the West European Operational Direction. Plans involved the use of railway transport for heavy combat and technical equipment purposes only (40$45 \%$ of all general army units). Approximately 100 to 120 trains were allocated to the purpose (infantry - 18 trains, armoured divisions - 20 trains, army units 15-20 trains, rear units - 10-20 trains). Exercise-related experience has proven the average operational transport volume during the preparatory phase to be reaching approximately 50-70 trains, with 20-30 trains at the operational stage. Analyses suggested that nearly 120,000 tonnes of supplies should be delivered to the frontline. These would include the following: fuels and lubricants [50-55\%], ammunition

378 Due to the shortage of flat wagons capable of transporting tanks, a decision was made to mobilise a significant number of coal wagons as part of the mobilisation effort, and remove their side walls with the use of acetylene torches. 
[20-25\%], food and equipment [15-20\%], bombs [3-5\%], missile propellants [nearly $1 \%$ ], others [1-4\%]. Notably, approximately $75-80 \%$ of all supplies have to be delivered at the preparations phase of the military campaign. ${ }^{379}$ An average of 100 trains would be required to carry materials for the reconstruction, maintenance and operation of railway lines during the operational stage. ${ }^{380}$

According to the operational plans, over 100,000 tonnes of material and technical supplies would be required to secure military operations over the first 6-8 days of war. The planned amount of cargo was to be moved using an average of 40 trains and around 2,000 road vehicles per day. ${ }^{381}$

The frontline rail network was divided into three zones, depending on the location of the unloading facility and the amount of cargo to be transported: ${ }^{382}$

- Zone One (I), 40-60 km wide, included railway sections in the army's operational rear area;

- Zone Two (II), 10-150 km wide, included railway sections at the frontline rear in the vicinity of the army's operational rear, comprising unloading areas for operational troops, frontline bases, and other frontline rear units and plants.

- Zone Three (III), 200-250 km wide or wider, included all other railway sections concerned with railway deployment at the rear of the frontline. This zone comprised rear frontline bases, air force depots, frontline field technical missile base, and all other frontline rear units and plants.

The frontline railway network was intended to handle all centrally planned and intrafront transfers associated with the operational and tactical regrouping. Military trains carrying light equipment were to be unloaded on approaches to frontline distribution stations, troops dispatched to march to reach designated regrouping areas.

In the area adjacent to the rear frontline area, a parallel and linear method of using the different modes of transport was to be employed. Railway lines and roads in the area were exposed to mass destruction - which is why only heavy tracked vehicles were to be transferred by front railway lines. ${ }^{383}$ Trains carrying

379 Ministry of National Defence, Transport Command 33/64, Komunikacja wojskowa (1965), 260.

380 Ministry of National Defence, Transport Command 33/64, Komunikacja wojskowa (1965), 203.

381 Ministry of National Defence, Transport Command 33/64, Komunikacja wojskowa (1965), 192.

382 Ministry of National Defence, Transport Command 33/64, Komunikacja wojskowa (1965), 205.

383 Under favourable road conditions, road vehicles could be regrouped using their own transport, even over distances of 400-500 km. 
heavy equipment for tactical groups and units were to be routed via designated points of entry, and unloaded in unloading areas located $100-150 \mathrm{~km}$ from the frontline. ${ }^{384}$ It was assumed that military trains carrying heavy equipment would be allowed in immediate frontline vicinity in exceptional cases only: roads and railway equipment were exposed at all times to enemy attack and destruction. ${ }^{385}$

The mechanisation of tactical compounds and the increased number of tanks and APCs increased their transfer capacity to up to $200-250 \mathrm{~km}$ per day. ${ }^{386}$ Their significant marching ability secured troop transfer continuity for extended periods in the areas where railway lines were to be destructed for a longer period of time. It was assumed that the combination of moving troops by rail and marching would allow operational continuity in nuclear warfare conditions. ${ }^{387}$

The effective use of all modes of transport required a special transport reserve to be set up. The transport reserve could not drop below $25 \%$ of the daily carriage volume in the operating zone of railways charged with the delivery of supplies. When operating within the rear frontline base - head frontline base transport diagram, with its daily transfer volume of $25,000 \mathrm{t}$, railway transport had to be mirrored by road vehicles (carrying approximately 4,000 tonnes of goods per day) and pipelines (with an approximate transfer capacity of 2,500 tonnes of fuels and lubricants per day). ${ }^{388}$ Transport reserves were to be dispersed whilst ensuring their seamless involvement if required.

When planning frontline offensive campaigns, staying ahead of the enemy in terms of troops regrouping was of paramount importance, to that end, the quickest possible deployment of operational transport became a priority focus. Plans involved high-speed transfer with parallel regroupings on several railway lines, as well as the use of other forms of transport. ${ }^{389}$

384 Plans involved the preparation of heavy equipment loading and unloading stations.

385 Ministry of National Defence, Transport Command 33/64, Komunikacja wojskowa (1965), 207.

386 Theoretical capacity.

387 Ministry of National Defence, Transport Command 33/64, Komunikacja wojskowa (1965), 261.

388 Ibid., 196. These numbers were inflated: transport reserve plans assumed lower carriage capacity.

389 Ministry of National Defence, Transport Command 33/64, Komunikacja wojskowa (1965), 260. 


\subsection{Evacuation of the Wounded}

The evacuation of the wounded and the sick from frontline hospital bases to hospitals and evacuation sites in the interior should primarily rely on railway transport. Special-purpose hospital trains were to be organised to transport the wounded and the sick, and to provide medical assistance and perform surgical procedures while in transit. Furthermore, medical emergency trains were to be temporary used as field hospitals. ${ }^{390}$

A hospital train was to comprise (permanent) staff carriages and mobilisation carriages. Staff carriages were built (rebuilt) and equipped to accommodate special needs. Designated Polish State Railways carriage depots kept all wagons on permanent standby. Staff carriages were designed and built for ambulance purposes; mobilisation carriages (for general purposes and to carry baggage) were adapted as required by the Ministry of Transport. ${ }^{391}$ During peacetime, mobilisation carriages were operated by the Polish State Railways for regular purposes.

Furthermore, Ministries of Transport and Defence prepared and stocked equipment and goods required to furnish mobilisation wagons in a properly designated mobilisation storage. In peacetime, staff carriages were made available to the Ministry of Transport, and they could be used for their primary purpose. In times of mobilisation, staff carriages (that only had to be re-fitted) would be dispatched by their home depots directly to the pre-specified assembly stations, mobilisation carriages to be taken out of operation and delivered to a Rolling Stock Repair Plant for adaptation. In order to form a hospital train the following were to be dispatched to a Rolling Stock Repair Plant: ${ }^{392}$

- Three Dhxt (Fhxt) luggage cars, for use by train staff, and for food and uniform storage,

- Eight Bhixt passenger carriages to be used for moving the severely injured,

- One Ahuxzt carriage for medical and General Staff use as a sleeping carriage.

390 Ministry of Transport, $P k-31$ (1970), 3.

391 Ministry of Transport, $P k-31$ (1970), 3-4.

392 Ministry of Transport, $P k-31$ (1970), 4.

Zbigniew Tucholski - 978-3-631-82966-0 


\title{
Ustawienie wagonón w skTadzie wojskowego pociagu sanitarnego.
}

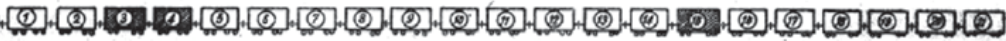

\author{
Oznaczenie: \\ 1. STuzbary mod. serï Dhxt (Fhxt) \\ 2 Magaryn ziymnosciowy-skierowany przeozialen stuzbowym \\ do wagoni przykuchennego mob. serï Dhxt (Fhxt) \\ 3 Przykuchenny-spegialny kadrawy \\ 4 Kuchnio-specjainy kadrony \\ 6 sypiainy dla personelu pociagu mab. serï Bhuxzt. \\ s Sppiathy dla kadry pociagu i hanceflaria mok seri Ahuxzt.
}

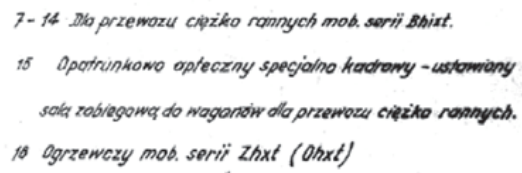

Location of wagons and carriages in a military hospital train.

Source: Ministry of Transport, $P k-31$ (1970)

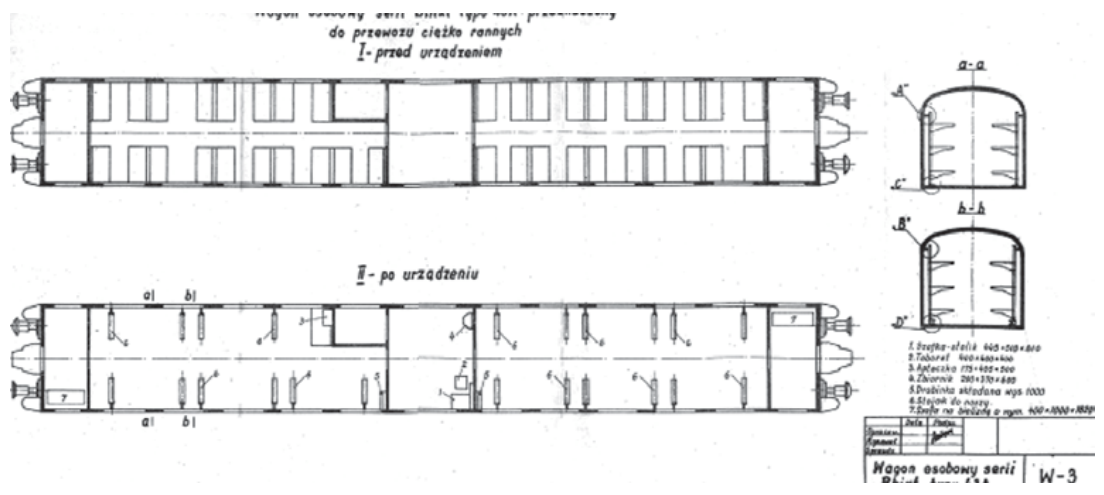

A passenger carriage adopted for the transport of the heavily wounded.

Source: Ministry of Transport, $P k-31$ (1970)

The Ministry of Transport designated a specific Rolling Stock Repair Plant charged with the complete re-fitting of mobilisation carriages, and assembly stations as venues for hospital train formation by Polish State Railways staff. ${ }^{393}$

393 Ministry of Transport, $P k-31$ (1970), 5. 
Hospital trains were to be equipped with the following: an MB internal field telephone communications system (a telephone to be also installed on a locomotive) connected to the general railway $\mathrm{CB}$ network (including a CB-20 switching station); $; 94$ an electrical system powered by a PAD-30-3/400/X-324-Ei-J/ 38 kVA power generator; ${ }^{395}$ an $\mathrm{M}-800$ fire protection pump; ${ }^{396}$ and a motorcycle with a trailer. ${ }^{397}$

Carriages designated for military ambulance purposes were appropriately marked with additional exterior signage in addition to Polish State Railways: ${ }^{398}$

1) Red Cross emblem on the roof and side panels,

2) Carriage sequential number in the hospital train assembly - on side panels,

3) Carriage sequential number in the hospital train assembly - in the interior,

4) Red Cross emblem on the front panel of the first and last carriage. ${ }^{399}$

Use of the Red Cross emblem as part of hospital train signage

394 Ministry of Transport, $P k-31$ (1970), 46.

395 Ministry of Transport, $P k-31$ (1970), 50

396 Ministry of Transport, $P k-31$ (1970), 17.

397 Ministry of Transport, $P k-31$ (1970), 20.

398 Ministry of Transport, $P k-31$ (1970), 6-7.

399 If the front panel of the first or last carriage was fitted with a door, the Red Cross emblem would be replaced with a $500 \times 500 \mathrm{~mm}$ Red Cross identification flag, suspended from a wooden stick (approximate length: 1,500 $\mathrm{mm}$ ) allowing the flag to be slid over the stick. 

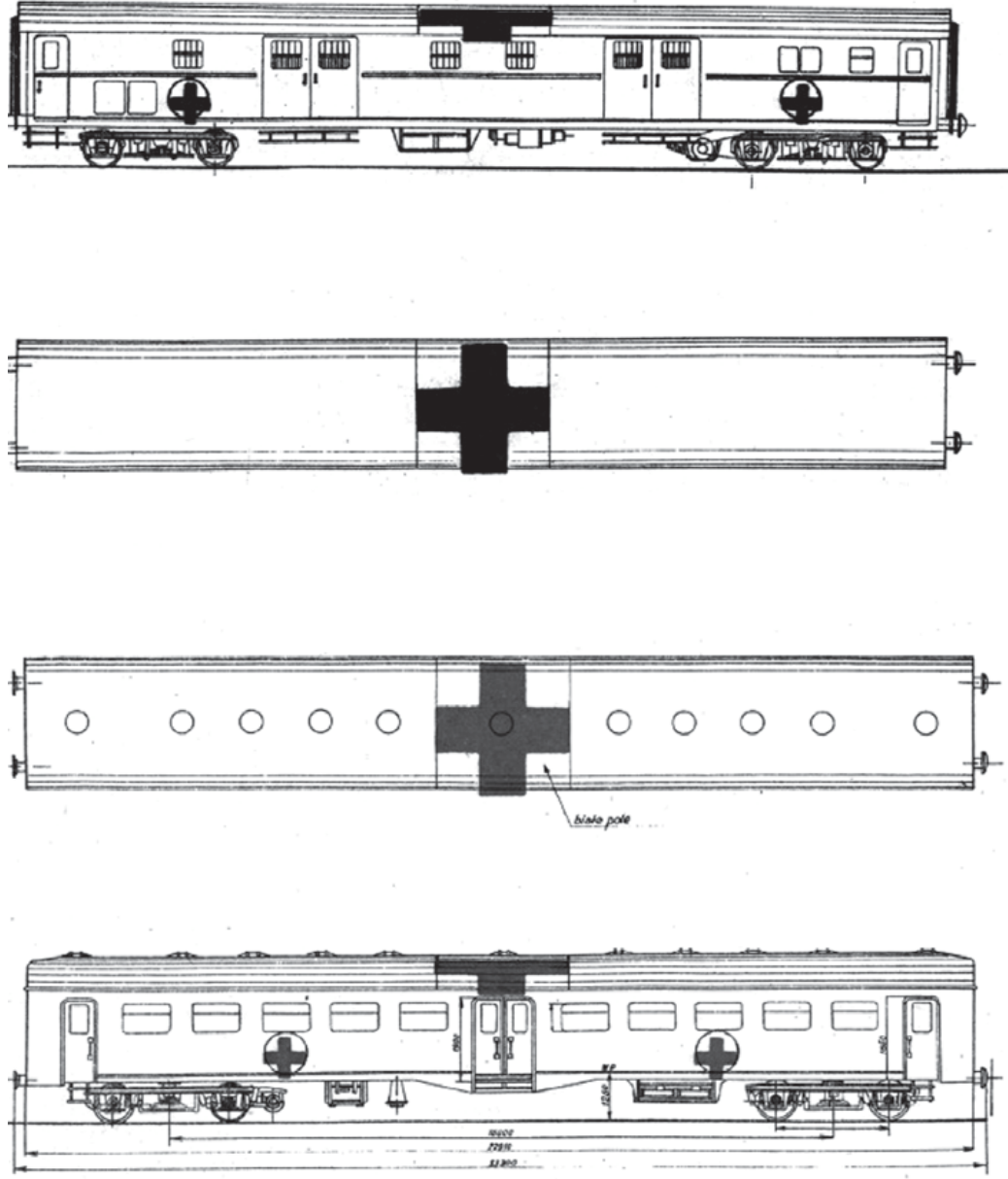

Source: Ministry of Transport, $P k-31$ (1970)

Planned wartime railway staffing of hospital trains involved the following permanent staff required for the technical operation of a military hospital train: 1 carriage/wagon inspector, 1 electrician, 1 fitter/plumber, and 2 firefighters for heating vans. ${ }^{400}$

400 Ministry of Transport, $P k-31$ (1970), 8. 
In case of wartime destruction to staff carriages, the following vehicles could serve as their replacement: ${ }^{401}$

- Staff kitchen support carriage - Dhxt (Fhx) luggage van,

- Staff wound dressing/pharmacy carriage - lhxt bar car,

- Staff kitchen carriage - Dhxt (Fhxt) luggage van.

The Ministry of National Defence would be charged with fitting-out all vehicles.

The total length of a hospital train reached nearly $465 \mathrm{~m}$, approximate gross weight 760 tonnes. ${ }^{402}$ During the heating season, Polish State Railways would be obliged to provide a Zhxt (Ohxt) heating van, together with its firemen, on request by hospital train commander. ${ }^{403}$

Hospital train organisation and operation was supervised by the military transport authorities, and the Health Services Bureau of the Ministry of National Defence. The railway section (station) military commander was responsible for the direct supervision of hospital train operation..$^{404}$

On the frontline, hospital trains would be classified as either Permanent or Temporary Military Hospital Trains, or military hospital shuttle trains assembled in pre-specified conditions, with intent to transfer the sick and the wounded within the operational rear of the frontline, and on isolated railway sections. ${ }^{405}$

The Permanent Military Hospital Trains were designed to evacuate the sick and the wounded from the frontline sick bays to inland hospitals and evacuation areas. Permanent Military Hospital Trains were assembled as follows, with the use of vehicles listed below:

\begin{tabular}{|l|l|l|}
\hline Carriage type and purpose & \multicolumn{2}{|l|}{ Number of carriages } \\
\cline { 2 - 3 } & Total & $\begin{array}{l}\text { Including } \\
\text { carriages with } \\
\text { staff }\end{array}$ \\
\hline Kitchen carriage (special-purpose carriage) & 1 & 1 \\
\hline $\begin{array}{l}\text { Wound dressing/ pharmacy carriage (special-purpose } \\
\text { carriage) }\end{array}$ & 1 & 1 \\
\hline
\end{tabular}

401 Ministry of Transport, $P k-31$ (1970), 8.

402 Ministry of Transport, $P k-31$ (1970), 12.

403 Ministry of Transport, $P k-31$ (1970), 12.

404 Ministry of Transport, $P k-31$ (1970), 13.

405 Ministry of Transport, $P k-31$ (1970), 295-296. 


\begin{tabular}{|l|l|l|}
\hline Carriage type and purpose & \multicolumn{2}{|l|}{ Number of carriages } \\
\cline { 2 - 4 } & Total & $\begin{array}{l}\text { Including } \\
\text { carriages with } \\
\text { staff }\end{array}$ \\
\hline $\begin{array}{l}\text { Carriage for the severely wounded (special-purpose } \\
\text { carriage or Bhixt) }\end{array}$ & 4 & 4 \\
\hline Power generator van (special-purpose carriage) & 1 & 1 \\
\hline Carriage for the lightly wounded (Bhuxzt carriage) & 6 & --- \\
\hline Refrigerated van (S1) & 1 & --- \\
\hline Uniform storage van (Kpt) & 1 & --- \\
\hline Food storage van (Kdt) & 1 & --- \\
\hline Sleeping car for officers and registry office (Ahuxzt) & 1 & --- \\
\hline $\begin{array}{l}\text { Carriage for non-commissioned officers and } \\
\text { paramedics (Bhuxzt) }\end{array}$ & 1 & --- \\
\hline Quarantine carriage (for contagious \\
patients - Bhuxzt)
\end{tabular}

On special request, a carriage for patients with mental disorders (Bhuxzt) could be included as part of a Permanent Military Hospital Train. The evacuation capacity of a Permanent Military Hospital Train was 520-640 persons (including 160 severely wounded, 360 lightly wounded or (in higher-occupation rate conditions, 8 persons per compartment) - 480 persons). ${ }^{406}$

Temporary Military Hospital Trains (comprising variable and fixed components) were assembled with the use of the following carriages:

406 Ministry of National Defence, Transport Command 33/64, Komunikacja wojskowa (1965), 296. 


\begin{tabular}{|l|l|l|}
\hline \multirow{2}{*}{ Carriage type and purpose } & \multicolumn{2}{|l|}{ Number of carriages } \\
\cline { 2 - 4 } & Total & $\begin{array}{l}\text { Including } \\
\text { carriages with } \\
\text { staff }\end{array}$ \\
\hline A. Fixed component: & \multicolumn{2}{|l|}{} \\
\hline Kitchen carriage (special-purpose carriage) & 1 & 1 \\
\hline $\begin{array}{l}\text { Wound dressing/ pharmacy carriage (special-purpose } \\
\text { carriage) }\end{array}$ & 1 & 1 \\
\hline Carriage for the severely wounded (Bhixt carriage) & 2 & 2 \\
\hline Power generator van (special-purpose carriage) & 1 & 1 \\
\hline B. Variable component & \multicolumn{2}{|l|}{} \\
\hline Refrigerated van (S1) & 1 & --- \\
\hline Uniform, bed sheet and equipment storage van (Kpt) & 1 & --- \\
\hline Carriage for officers and office (Ahuxzt) & 1 & --- \\
\hline $\begin{array}{l}\text { Carriage for non-commissioned officers and } \\
\text { paramedics (Bhux) }\end{array}$ & 2 & --- \\
\hline Carriage for wounded officers (Ahuxzt) & 1 & --- \\
\hline Carriage for the severely wounded (Bhixt) & 8 & --- \\
\hline Crew (service) carriage (Ft) & 1 & --- \\
\hline Heating van (O) & 1 & ---- \\
\hline $\begin{array}{l}\text { Box van for the lightly wounded (Kdt) included as } \\
\text { required }\end{array}$ & 16 & ---- \\
\hline Total: & 37 & 5 \\
\hline
\end{tabular}

The evacuation capacity of a Temporary Military Hospital Trains was 720 persons, including 400 severely wounded and 352 lightly wounded (20 wounded per box van). Military shuttle trains were planned to be operated with the following composition - fixed component: 1 kitchen carriage, 1 pharmacy carriage, 4 carriages for the severely wounded, 1 uniform storage van, 1 food storage van, 2 train service crew carriage (all covered freight vans); variable component: assembled with 
the use of freight covered vans, their number determined on a case by case basis depending on current needs and on technical and operational capabilities. The average evacuation capacity of military hospital shuttle trains was approximately 500 persons, including 150 severely wounded and 320-350 lightly wounded. The variable component of Temporary Military Hospital Trains and military hospital shuttle trains could be uncoupled at unloading stations, their fixed component (train crews and equipment included) dispatched to a loading or storage station according to schedule. In conditions of increased transfer demand, both train components would upon unloading be dispatched for reloading to loading stations. All hospital trains were to be assigned a permanent number, which would not change throughout their operational life. ${ }^{407}$

\subsubsection{Temporary Transhipment Areas}

During the Second World War, the destruction of bridges over wide water obstacles and of large railway junctions was common as part of mass destruction of railway lines. As the reconstruction of such facilities was highly labour- and time-consuming, the so-called isolated railway sections were formed on areas between the destroyed bridges or junctions, operational rolling stock frequently remaining on these sections. For the reasons mentioned above, the concept of putting such sections to use was developed, involving the use of other modes of transport (by road or water) in areas with destroyed bridges or junctions this is how double transhipment had to be employed in such areas. Over time, locations in which such reloading operations were being carried out began to be referred to as Temporary Transhipment Areas. Temporary Transhipment Areas were organised for the first time by the German troops on the Eastern Front in 1941. The Soviet Army began organising Temporary Transhipment Areas by using an isolated railway section on the Tula - Aleksin - Kaluga route during the counterattacks near Moscow. The retreating German troops blew up a bridge on the River Oka on the route. Temporary Transhipment Areas were organised to allow the use of this section and rolling stock located upon it, in the area of Rurikovo and Aleksin. An ice crossing was developed across the River Oka at the time; the section continued to operate as an ice crossing until the permanent railway bridge was rebuilt in the spring of $1942 .{ }^{408}$

407 Ministry of National Defence, Transport Command 33/64, Komunikacja wojskowa (1965), 296-297.

408 Nowak (1994), 56-58. 
Also after the war plans were drafted to switch to Temporary Transhipment Areas in case of wartime destruction of permanent crossings on Rivers Vistula and Odra on the main frontline, with intent to secure transport for frontline offensive campaigns.

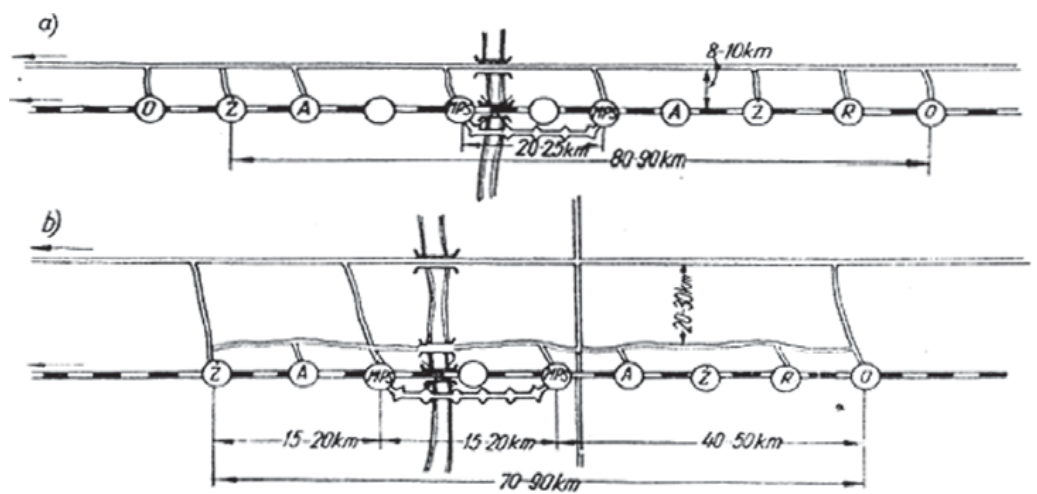

Schemat TRP na zasadniczym kierunku dofrontowym $\mathrm{z}$ dwiema grupami stacji rozmieszezonymi po obu stronach przeszkody wodnej

A diagram of a Temporary Transhipment Area on the primary frontal direction with two station groups placed on the two sides of a water obstacle.

Source: Ministry of National Defence, Transport Command, Komunikacja wojskowa (1965)

In case of equipment or resources shortage, or insufficient time to properly construct a temporary crossing or detour, Temporary Transhipment Areas would be organised on main railway lines, on approaches to major obstacles (bridges, tunnels or critical railway junctions). In these areas, military transports and supplies would be reloaded from railway wagons to other modes of transport (by road or waterway) with intent to cross the obstacle. Troops and goods would be transferred and reloaded in the Area with the use of the following: low- and underwater road bridges on fixed floating supports, floating bridges developed with the use of pontoon parks or inland waterway stock, ferry and ice crossings, motor vehicle roads (detours of railway junctions, tunnels and other transport facilities), and transfer pipelines (used to transfer fuel and/or lubricants). Transfer by air was planned as well, with intent to deliver all cargo directly to the recipients. ${ }^{409}$

409 Ministry of National Defence, Transport Command 33/64, Komunikacja wojskowa (1965), 343-344. 
It was assumed that the use of section-based shuttle traffic, i.e. re-introduction of rail transport (once the damaged section was passed) would be justified for distances over 100-120 km. Under exceptional circumstances, such transport could be employed for shorter distances ( $40-50 \mathrm{~km})$. In case of shorter distances, the goods would be transferred by road within the Area, or from the Area directly to the frontline, to military depots, or to the Division Supply Points. ${ }^{410}$

The following scenarios were adopted for the transfer of goods within the Area as part of an Area's technological process: ${ }^{411}$

- goods arriving at an unloading station - direct transfer by road to recipients,

- goods arriving at an unloading station - transhipment from railway to road vehicles, then transfer to a loading station located on the other side of the obstacle,

- goods arriving at an unloading station - transfer by road to a temporary storage yard, then reload onto motor vehicles according to availability and transfer to loading station for re-transfer onto rail transport,

- goods arriving - to be transferred by road to loading station transfer yards, then loaded onto rail transport according to rolling stock availability.

The Temporary Transhipment Areas included the following: railway sections with specially-developed loading and unloading stations, areas of troops assembly and holding, holding areas for transfer by road and forming motor vehicle columns, temporary goods storage sites, motor vehicle roads and motor vehicle access roads, field fuel and lubricant pipelines, airfields (airstrips and landing areas), and (in some cases) ports (marinas and ferry crossings). ${ }^{412}$

410 Ministry of National Defence, Transport Command 33/64, Komunikacja wojskowa (1965), 344.

411 Ministry of National Defence, Transport Command 33/64, Komunikacja wojskowa (1965), 357-358.

412 Ministry of National Defence, Transport Command 33/64, Komunikacja wojskowa (1965), 344. 
a) przed zniszczeniami

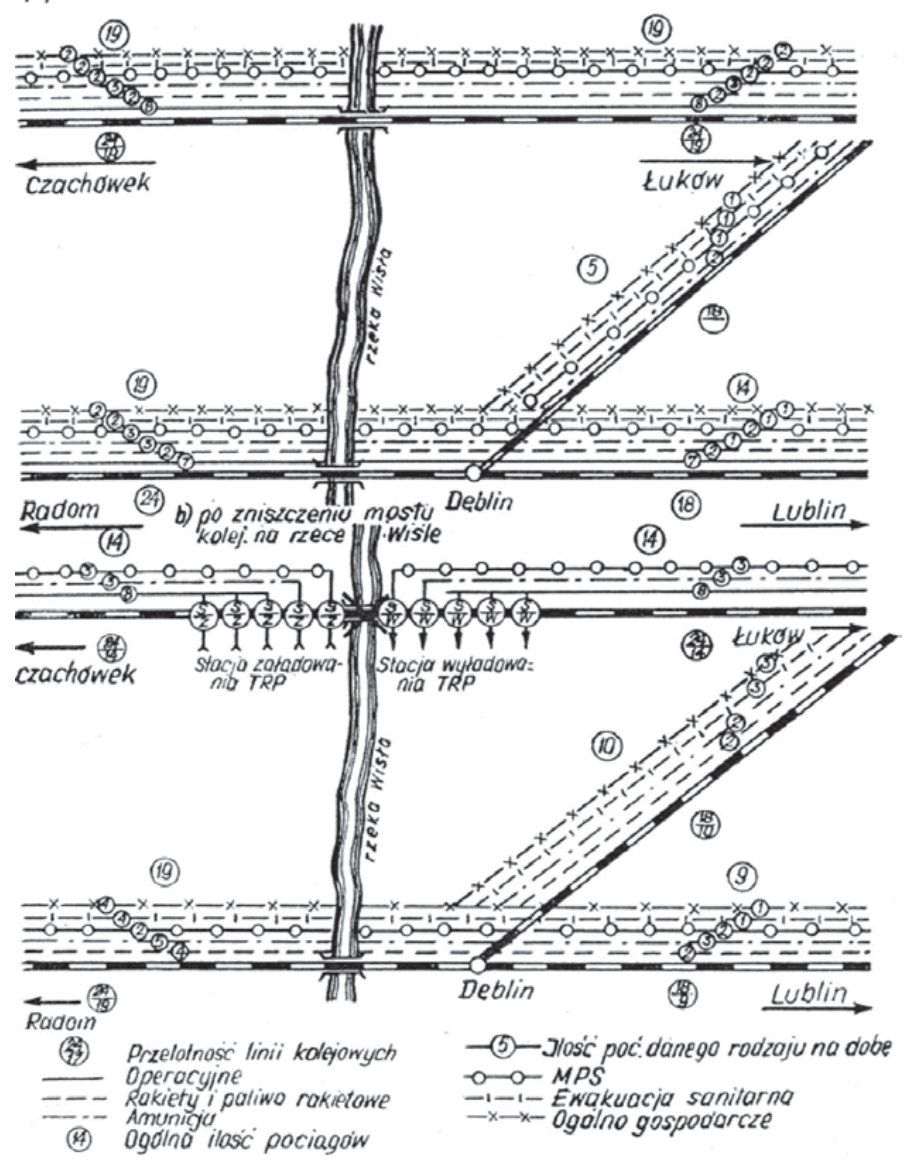

An option for the regulation of military traffic with the use of a Temporary Transhipment Area.

Source: Ministry of National Defence, Transport Command 33/64, Komunikacja wojskowa (1965) 


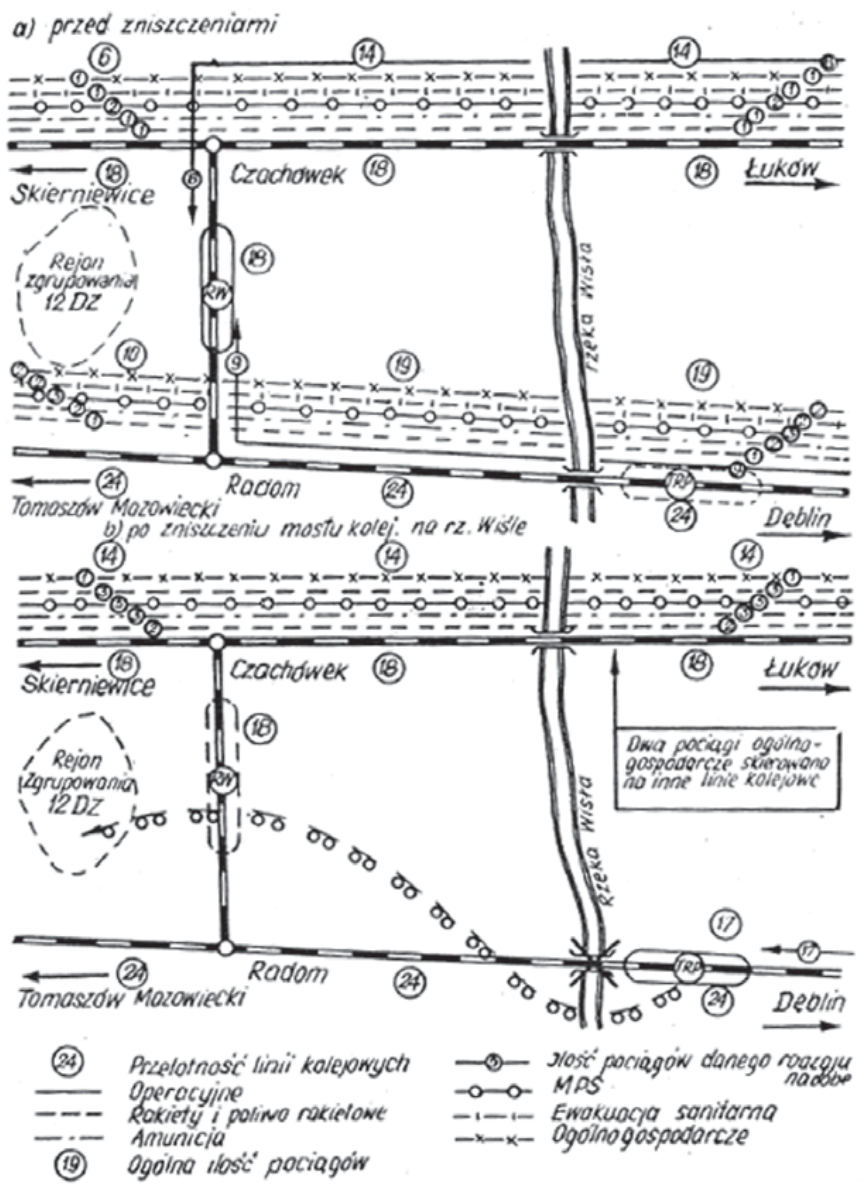

Wariant regulacji przewozbow wojskowych z wykorzystaniem zapasowego rejonu wyladowania

An option for the regulation of military traffic with the use of a reserve unloading area. Source: Ministry of National Defence, Transport Command 33/64, Komunikacja wojskowa (1965)

On large river obstacles, Temporary Transhipment Areas were to be provided as access roads, floodbank crossings, inclined ramps and reinforced concrete marinas - this is how access roads and marinas were developed for Temporary Transhipment Areas Góra Kalwaria. Water Engineering and Construction 
Companies secured transport by inland waterways across the river ( $\dot{\mathrm{ubbr}}$ pushers and barges). ${ }^{413}$

Longitudinal type Temporary Transhipment Areas were developed with the use of a single frontline-bound rail section. Upon destruction of a bridge or a railway junction, the section was to be divided into two parts. In the case of single-track lines with a capacity of 18-20 train pairs a day, the length of a longitudinal Area could reach $70-90 \mathrm{~km}$, the average transfer distance (from an unloading station to a loading station) reaching $40-60 \mathrm{~km}$. It was assumed that should two main railway bridges located at an average distance of 50-80 km from one another be destroyed, the operation of the section located between them would be considered inexpedient. A system of frontline roads (connecting individual loading and unloading stations in the Area), crossings and field fuel and lubricant transfer pipelines would be employed for all Temporary Transhipment Areas types. Should a bridge within the boundaries of a large city be destroyed, motor vehicle bypass roads would be constructed in the Temporary Transhipment Areas, complete with a crossing and field fuel and lubricant transfer pipeline. On parallel railway lines, transverse Temporary Transhipment Areas would be developed in case of destruction to railway bridges. In such Areas, distances between unloading and loading stations would be smaller than in the case of longitudinal Areas. The general principle of developing bypass roads complete with crossings and field fuel and lubricant transfer pipelines was adopted. Mixed-type Temporary Transhipment Areas were to be developed with the use of primary and parallel railway lines. Thanks to the deployment of loading and unloading stations along the frontline-bound and parallel lines, high railway network density on the West European Theatre was to allow a shortening of the overall depth of an Area. ${ }^{414}$

The length of a rail section within a Temporary Transhipment Areas depended on the number of loading and unloading stations for trains carrying assorted goods. One train could be unloaded at any station at any given time. It was assumed that each Area would comprise 3-6 loading and unloading stations for missiles, ${ }^{415}$ military troop trains, ammunition and explosives, fuels and

413 Account of October 20th 2006 by Colonel Jerzy Maj, retired head of the Head of Military Transport at the Regional State Railway Management Warsaw.

414 Ministry of National Defence, Transport Command, Komunikacja wojskowa (1965), 345-348.

415 2-3 primary and 2-3 backup unloading stations were to be developed for the unloading of missiles. The unloading of missiles and missile rocket propulsion materials at the same station was forbidden. A missile unloading station would be fitted with 2-3 
lubricants, and missile propulsion materials as well as food and other commodities. ${ }^{416}$ It was assumed that the average loading and unloading station capacity should be as follows: ammunition and fuels and lubricants $-4-5$ trains per day; military trains carrying heavy equipment $-3-4$ trains per day; other military trains - 5-6 trains per day. It was further assumed that an unloading station should be fitted with the following (apart from the essential main tracks): 2-3 arrival/departure tracks, 1 hoisting track (length: 300-350 m), and 2 unloading tracks. Groups of fuel tanks, field pipelines, and tank wagon unloading track systems were to be developed at fuel and lubricant transfer and unloading stations. ${ }^{417}$
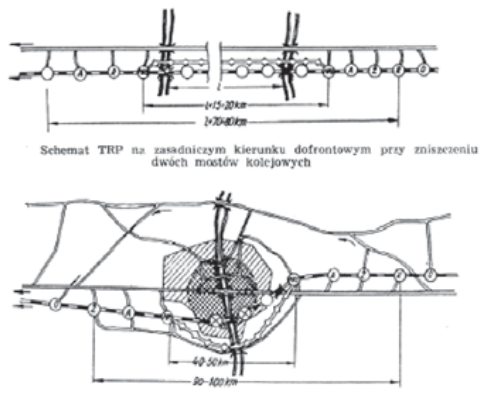

సั

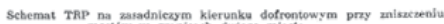

Zrodlo: MON, Szef. Kom. 33/64, Komunikacja wojskowa, Warszawa 1965.

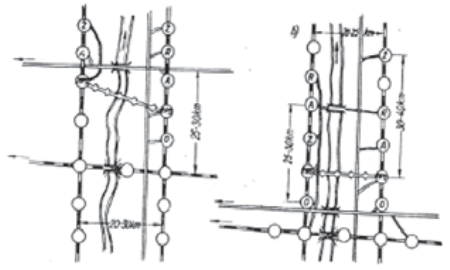

Schemat TRP na dwdeh kierunkach rokadowycb przy miezezeniu mostu na zasadniczym kicrunku dofrontowym

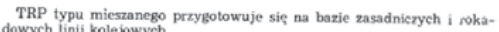
dowych linil kolejowych

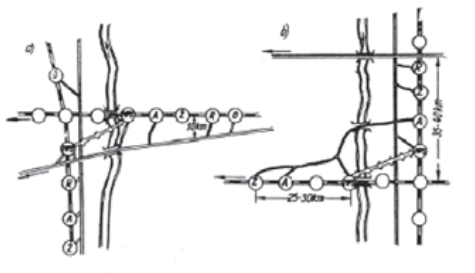

z roumieszerneniem stacji zabdowezy
liniach rokadouych i dofrontowyeb

1. A diagram of a Temporary Transhipment Area on the primary frontal direction with two railway bridges destroyed.

2. A diagram of a Temporary Transhipment Area on the primary frontal direction with bridges within a big city destroyed.

tracks (in addition to the primary one) and 1 unloading track (siding) located at a distance from the arrival/ departure tracks.

416 Stations for the unloading of rail and road reconstruction materials and for militarised resurfacing and bridge reconstruction divisions were to be developed as well, if required.

417 Ministry of National Defence, Transport Command 33/64, Komunikacja wojskowa (1965), 348-352. 
3. A mixed-type Temporary Transhipment Area is to be prepared on the basis of mainlines and parallel railway lines.

Fast-track reloading within a Temporary Transhipment Areas would involve mechanised loading appliances (lifts, forklifts, conveyors, hoists and road cranes). ${ }^{418}$

Militarised divisions of the Ministry of Transport (Polish State Railways line units) were to be charged with the operation and technical protection of railway sections in Temporary Transhipment Areas.

Mobilisation plans provided for Temporary Transhipment Areas to be organised on the water obstacles of Rivers Vistula and Odra, on strategic bridges, and on other railway facilities. The following Temporary Transhipment Areas were planned for the River Vistula (within the Regional State Railway Management in Warsaw): ${ }^{419}$

\begin{tabular}{|l|l|l|l|l|}
\hline \multirow{2}{*}{$\begin{array}{l}\text { Area } \\
\text { designation }\end{array}$} & \multirow{2}{*}{$\begin{array}{l}\text { Unloading } \\
\text { stations }\end{array}$} & Loading stations & \multicolumn{2}{|l|}{$\begin{array}{l}\text { Loading capacity } \\
\text { per 24 hours }\end{array}$} \\
\cline { 4 - 5 } & & & unloading & loading \\
\hline $\begin{array}{l}\text { Góra } \\
\text { Kalwaria }\end{array}$ & Warszówka & Góra Kalwaria & 2 & 8 \\
\hline & Osieck & Czachówek Wschód & 4 & 2 \\
\hline & Garwolin & Czachówek Południe & 4 & 4 \\
\hline & Pilawa & Tarczyn & 4 & 4 \\
\hline & Parysów & Mszczonów & 4 & 4 \\
\hline & & Puszcza Mariańska & & 4 \\
\hline Karczew ${ }^{10}$ & Legionowo & Warszawa Gdańska & 3 & 6 \\
\hline & Warszawa Praga & Warszawa Okęcie & 6 & 4 \\
\hline & Rembertów & Piaseczno & 6 & 3 \\
\hline & Falenica & Ożarów & 3 & 3 \\
\hline & Tłuszcz & Płochocin & 4 & 2 \\
\hline
\end{tabular}

418 Ministry of National Defence, Transport Command 33/64, Komunikacja wojskowa (1965), 358.

419 Headquarters of Military Transport at Regional State Railway Management in Warsaw, Ogólna charakterystyka (1984), 9. 


\begin{tabular}{|l|l|l|l|l|}
\hline \multirow{2}{*}{$\begin{array}{l}\text { Area } \\
\text { designation }\end{array}$} & \multirow{2}{*}{$\begin{array}{l}\text { Unloading } \\
\text { stations }\end{array}$} & & \multicolumn{2}{|l|}{$\begin{array}{l}\text { Loading capacity } \\
\text { per 24 hours }\end{array}$} \\
\cline { 3 - 5 } & & unloading & loading \\
\hline & Wołomin & Grodzisk Mazowiecki & 4 & 3 \\
\hline & Wawer & Pruszków & 2 & 2 \\
\hline & Beniaminów & Szymanów & 3 & 2 \\
\hline Płock & Sierpc & Płock Radziwie & 5 & 3 \\
\hline & Gozdowo & Ląck & 3 & 2 \\
\hline & $\begin{array}{l}\text { Proboszczewice } \\
\text { Płockie }\end{array}$ & Gostynin & 2 & 5 \\
\hline & Płock & Kutno & 6 & 3 \\
\hline & Zawidz & Żychlin & 2 & 3 \\
\hline & Ostrowy & 67 & 2 \\
\hline
\end{tabular}

\subsubsection{Organisational Structure of Military Transport on the Frontline}

The following military transport units and railway troops were to be formed, mobilised and developed to secure frontline railways operability:

- Military transport branch for the army,

- Two railway troops brigades,

- Field railway equipment storage depot,

- Military command for the frontline dispatching station,

- Military command for railway frontline sections,

- Military command for unloading stations,

- Military railway management.

Military Railway Brigades were charged with technical protection of railway lines and bridges, and with the temporary operation of the main reconstructed 
railway sections. Railway troops brigades could be assisted by Resurfacing Trains and Bridge Reconstruction Trains. The primary responsibilities of a railway troops brigade included the following: construction of new railway lines, rail links on railway junctions, obstacle bypasses, additional sidings, station tracks and bridges; reconstruction of damaged tracks and railway structures on existing railway lines, and destruction of railway lines and facilities during retreat. Railway brigades comprised the following: 3 permanent-way battalions, 2 bridge battalions, 1 technical battalion, 1 railway signalling and communication battalion, 1 motor vehicle-and-tractor battalion, 1 water facility reconstruction company, 1 sapper company, 1 operational company, and 1 technical reconnaissance unit. Railway troops brigades were to be supplied with machinery, equipment and materials used in railway permanent way and bridge works. ${ }^{420}$

The field railway equipment storage depot was charged with providing the military railway brigade with equipment and with the permanent way and bridge materials required for bridge and railway reconstruction works. The field railway equipment storage depot comprised the following: an equipment warehouse, construction materials warehouse, explosives warehouse, repair workshop, and service and command subdivision. The following materials and equipment were to be stored in a field railway equipment storage depot: $30 \mathrm{~km}$ of railway track (including accessories and sleepers), 50 single switches, 10 double switches, $500 \mathrm{~m}$ of folding bridges (spans), $500 \mathrm{~m}$ of bridge structures (20-30 m spans), as well as lifts, trolleys, gantry cranes, and hoists. ${ }^{421}$

The railway frontline dispatching station was charged with dispatching military transports arriving from the domestic territory to the frontline rear operational area, and re-assembling evacuation trains and dispatching them back to Poland. The responsibilities of the military command of the frontline dispatching station involved the following: handling trains in transit; support and sanitary services for the passing military trains, groups and individual soldiers; preparing and assembling trains used for operational/military, sanitary, and evacuation purposes; and rolling stock cleaning, sanitation, and decommissioning. Two frontline dispatching stations and a dispatching station division were to be organised as well. . $22^{2}$

420 Ministry of National Defence, Transport Command 33/64, Komunikacja wojskowa (1965), 373.

421 Ibid., 373.

422 Ibid., 373-374. 
The military command for railway frontline sections was charged with securing adequate transfers on the front railway line sections. Military commands for railway frontline sections were to be organised in areas with no line military transport authorities. The military command for unloading stations was charged with the following: ${ }^{423}$

- accepting military trains and transports dispatched to respective loading stations and sites,

- dispatching loaded or re-directed supply transfers to unloading stations,

- dispatching evacuation transports,

- dispatching empty trains.

Military commands for unloading stations were to be set up in Front Field Base and Army Housing Areas.

In order to provide rations and hot food to military troop trains, soldiers and prisoners were to be grouped into Mobile Railway Food Points within the frontline railway network, with the use of carriages adapted to the purpose and basically deployed within the frontline dispatching station. ${ }^{424}$

The Military Railways Management that was to be formed during the war was an independent organisational unit of the Polish State Railways, responsible for managing railway operations in a designated area (rear frontline territory). It reported directly to the Minister of Transport; in operational terms - to the head of frontline military transport. Primary responsibilities of the Military Railways Management included the following: organising and managing railway traffic on the supervised railway network; securing transport resources as required; securing efficient organisation and delivery of transport; and reconstruction and maintenance of railway lines, facilities and equipment. The following units reported to the Management: ${ }^{425}$

- 4 military railway transport divisions,

- 2 Bridge Reconstruction Trains,

- 2 Track Reconstruction Trains,

- 2 Mechanised Permanent-Way Trains,

- 2 Railway Traffic and Communication Appliance Reconstruction Trains,

- 2 Water Facility Reconstruction Trains,

- 1 Steam Locomotive Repair Train,

423 Ministry of National Defence, Transport Command 33/64, Komunikacja wojskowa (1965), 374.

424 Ibid., 374.

425 Ibid., 374-375. 
- 1 Wagon Repair Train,

- 12 steam locomotive columns.

The military division of military transfers was charged with managing transport and commercial operations on a designated railway line (approximate length: $200 \mathrm{~km}$ ). The following line units were to report to the division (staff): 1 marshalling yard, 5 junction stations, 15 transition stations, 1 communication section. ${ }^{426}$

The Bridge Reconstruction Train was charged with wartime technical protection of railway bridges. The Train was to be assisted by the following teams reporting to it: construction team, assembly team, mechanics and electricians team, and operators team, workshop team, and a motor vehicle-and-tractor column. The Bridge Reconstruction Train was to be issued machines, equipment, and materials required for the first reconstruction phase (initial 1,5 days). ${ }^{427}$

The Track Reconstruction Train was charged with wartime technical protection of railway lines, culverts, and small bridges. The Train was to be assisted by the following teams reporting to it: earth- and track-works team, culverts and bridges team, construction and installation team, workshop team, mechanics and electricians team, operators team, and a motor vehicle-and-tractor column. The Track reconstruction Train was to be issued machines, equipment, and materials required for the first reconstruction phase (initial 6 hours). ${ }^{428}$

The Mechanised Permanent-Way Train was charged with wartime construction and reconstruction of railway lines. The Train was to be assisted by assembly and track laying teams reporting to it. The Mechanised Permanent-Way Train was to be issued machines, equipment, and materials required for the first phase of works. ${ }^{429}$

The Railway Traffic and Communication Appliance Reconstruction Train was charged with wartime technical protection of appliances securing railway traffic and railway line communications. In all works, the Train was to be assisted by the following departments reporting to it: telecommunications line works department (with 3 construction sections), railway traffic protection line department (with 2 construction sections), and workshop department (railway traffic and communications). The Railway Traffic and Communication Appliance Reconstruction Train was to be issued equipment for the purposes of railway

426 Ministry of National Defence, Transport Command 33/64, Komunikacja wojskowa (1965), 375.

427 Ibid., 375.

428 Ibid., 375.

429 Ibid., 375-376. 
traffic control and communications-related work, materials allowing the reconstruction of railway traffic control and communications appliances at 2 stations, mechanical semaphore wire, lines, locks for 4 stations, materials sufficient for 4 days of telecommunication works, and catenary poles stock sufficient for 1 workday. The Railway Traffic and Communication Appliance Reconstruction Train was to be fitted with a power generator van.

The Water Facility Reconstruction Train was charged with wartime technical protection of water facilities on railway lines. The Train was to be assisted by the following departments reporting to it: road department with a water intake construction and installation team, and an electromechanical department with electro-technical and mechanical teams. The Water Facility Reconstruction Train was to be issued equipment and materials required to reconstruct water facilities (installation materials for water towers, pumping stations, water cranes, etc.).

The Steam Locomotives Repair Train was charged with wartime running maintenance of steam locomotives, and with the repair and maintenance of workshop and support equipment placed in wagons. The Train was to comprise a production department consisting of a technical branch and repair teams. The Steam Locomotives Repair Train was to be issued machines, equipment and spare parts allowing steam locomotives to be repaired.

The Wagon Repair Train was charged with wartime running repairs and periodic inspections of freight wagons. The Train was to comprise the following teams: chassis team, body team, and workshop and support team. The Wagon Repair Train was to be issued equipment and spare parts allowing wagons to be repaired and inspected.

Steam Locomotive Columns were to be formed during wartime, in order to provide traction to military trains. The Column was to include dispatchers, train section engineers, steam locomotive crews (drivers and firemen), and auxiliary staff. Each Column was to be issued 16 steam locomotives (15 active and 1 undergoing maintenance), as well as equipment, materials and spare parts required for repairs. ${ }^{430}$

Material resources that were to be made available were of great importance to the timely reconstruction of railway lines and facilities: material storage warehouses were to be established near all the facilities and close to all large bridges. Storage facility bases with materials required to reconstruct railway junctions and adjacent rail sections were to be set up in the proximity of the largest railway junctions, at a maximum separation distance of 100-150 km.

430 Ministry of National Defence, Transport Command 33/64, Komunikacja wojskowa (1965), 376. 
Each storage base was to hold approximately $5 \mathrm{~km}$ of rails, 50 tonnes of rail fittings, 5 thousand sleepers, 10 switch sets, $200 \mathrm{~m}^{3}$ of timber and wooden support structures, 10 tonnes of fittings, 2 portable water stations, $2 \mathrm{~km}$ of pipes, 4 hydrophores, 1 set of fast-access water supply appliances, $20 \mathrm{~km}$ of telegraph and telephone lines, $10 \mathrm{~km}$ of four-core cable, and two sets of communications devices and railway traffic control devices each. Wherever the railway network was dense, resources in stock could be reduced by an order of two or three. Lines, sidings and tracks earmarked for dismantling and of no strategic importance could be accounted for as one-half of all resources in stock.

In predicting the necessity to eliminate minor damage, mobile stocks of permanent way materials were to be carried by railway and motor vehicle shuttles. Due to the threat of destruction to storage depots, they were to be deployed at a distance of $10-15 \mathrm{~km}$ from the facilities that were being covered. ${ }^{431}$

\subsubsection{Organising Technical Protection for the Frontline Railway Network}

Technical protection for the frontline railway network was to be provided by frontline railway troops and with the use of Military Railways Management measures. The main railway line sections were to be protected by railway troops and auxiliary militarised divisions. Two scenarios were developed for the purposes of technical protection of the frontline railway network. Under the first scenario, technical cover for the frontline railway network was to be provided by the Military Railways Management, designated railway troops units dispatched to defend large facilities. Under the second scenario, technical protection for the frontline railway network and damage removal were to be handled by railway troops. Any sections and facilities not protected by the technical protection provided by railway troops were to be shielded by forces and resources of the Military Railways Management. ${ }^{432}$

A railway troops brigade was assigned to perform all tasks related to the technical protection and the removal of damage to facilities and sections of the frontline railway network. Each railway troops brigade was charged with providing technical protection for a single $300-400 \mathrm{~km}$ railway line, together with its facilities and infrastructure. Each permanent-way battalion was to provide technical protection for 1-2 large junctions together with approaches, or for a section up

431 Ministry of National Defence, Transport Command 33/64, Komunikacja wojskowa (1965), 428-431.

432 Ibid., 421-423. 
to $150 \mathrm{~km}$ in length. A bridge battalion could protect 1-2 large or 2-3 mediumsized bridges, separated by a distance not greater than $40-50 \mathrm{~km}$.

The mechanisation battalion was to be used for the purposes of major earthworks when reconstructing facilities. The transport and technical battalions were not charged with protecting specific facilities either. The technical battalion's crane company was to be used to form 2-3 reconstruction trains charged with track cleaning. Motor vehicle and railway reconstruction shuttle trains were to be organised for the purposes of transferring forces and resources across the works area. ${ }^{433}$

Units of railway troops or militarised divisions assigned to the technical protection of railway junctions were mainly charged with the task of rapid rail traffic restoration, should a junction be destroyed in a nuclear attack. The technical protection of a railway junction involved the following early action: setting up of concealed points of command in the area of the protected facility and in the deployment area of the unit; organising a system of communications; developing variant scenarios of reconstructing the junction; collecting building materials allowing the reconstruction works for no less than 2 days under the most difficult damage scenario; developing bypasses of communication lines; constructing short railway links to increase the capacity of train passage without entering the junction station; or building an extensive bypass if it was so stipulated in the frontline network technical protection plan.

Basic stationing (dislocation) sites for units of railway troops or militarised divisions were to be located at a minimum distance of $10-15 \mathrm{~km}$ from the facilities identified as likely targets for nuclear strikes. The works aimed at eliminating major damage to railway junctions were divided into two stages: Stage I - prevention of damage spreading (dispersion of burning wagons, extinguishing fires, liquidating unexploded bombs) and restoring transit rail traffic on main railway lines converging at the junction; Stage II - reconstruction of damaged facilities and equipment to an extent securing the junction's traffic and processing capacity as required. Reconstruction of railway junctions destroyed by a nuclear attack involved the following works: connecting broken communication lines with the use of heavy field cable or by radio communication means; restoring direct rail traffic on main railway lines converging at the junction and securing minimum speed of $15 \mathrm{~km} / \mathrm{h}$ (on some locations, such as freshly built embankments: $5 \mathrm{~km} / \mathrm{h}$ ); adapting surviving stations of the junction or stations located before the junction for the purposes of technical handling of trains

433 Ministry of National Defence, Transport Command 33/64, Komunikacja wojskowa (1965), 423-424. 
passing through the junction in transit. The second stage of works as planned involved the following: track repair to increase train speed to $30 \mathrm{~km} / \mathrm{h}$ and higher; opening temporary passing loops and traffic control posts; constructing second tracks for bypass purposes; reconstruction of junction stations or prejunction stations, or extension of surviving junctions stations or pre-junction stations. ${ }^{434}$ "Reconstruction shuttles" (road vehicle- or rail vehicle based) with divisions, equipment and materials assigned were to be employed to eliminate major damage to the junction.

The basic assumption related to the protection of large bridges in nuclear warfare conditions involved the protection of all strategic bridge crossings over water obstacles, and the development of new crossings: it was assumed that at least some would prove operational. Increasing the number of crossings would boost the viability of the frontline railway network. Large bridge reconstruction was to involve two stages: during stage one, works were aimed at restoring rail traffic as quick as possible. The second stage of the reconstruction works was intended to secure the required traffic capacity at a speed of $30 \mathrm{~km} / \mathrm{h}$, restore and maintain navigation on the river, and allow passage of high water and ice. The rate of reconstructing temporary bridges with the use of ready-made components was defined as follows: for a bridge length of $500 \mathrm{~m}$ or greater - 150-200 m/day; for a bridge length of 300 to $500 \mathrm{~m}-100-150 \mathrm{~m}$ /day; for a bridge length of 100 to $300 \mathrm{~m}-3$ days per bridge; for a length of 25 to $100 \mathrm{~m}-2$ days per bridge. The rate of short-term reconstruction or securing a bridge onto floating supports was set at $500 \mathrm{~m} /$ day (without the construction of bridge approach). Plans to organise technical protection for large bridges involved the drafting of detailed reconstruction plans (with varying destruction scenarios), as well as collecting material resources. Due to strict deadlines for bridge reconstruction (at the first stage), the reconstruction of bridges over major water obstacles was to involve floating bridge NZM-56 components and the SEK500 overpass, and to prepare railway river approaches at crossings within frontline territory. In case of equipment and/ or materials shortage, ferry crossings would be developed (with the use of NZM56 bridge spans). Should it prove impossible to quickly reconstruct the bridges or to destroy them once again, a Temporary Transhipment Areas was to be set up. ${ }^{435}$

In principle, it was assumed that the overhead catenary on electrified railway lines is extremely susceptible to destruction under conventional or nuclear

434 Ministry of National Defence, Transport Command 33/64, Komunikacja wojskowa (1965), 424-426.

435 Ibid., 427-428. 
attack, mainly due to the dependence of the energy supply system from the source of energy. Nonetheless, the experience of previous conflicts has proven that the use of demolition and crumble bombs causes limited-area damage, most frequently to the lines supporting the overhead wires. On the other hand, a nuclear explosion may cause damage to the catenary poles; the overhead wire would be torn with one to three tension sections, or at a station and on adjacent tension sections. ${ }^{436}$

The wartime technical protection was planned for electrified railway lines. Specialised subdivisions, shuttles and power restoration trains were to be charged with repairing and rebuilding the overhead catenary and traction substations. The temporary reconstruction of the overhead catenary assumed construction simplifications, such as: the use of one contact wire instead of two; reduction to the number of carrying wires; replacement of double-chain suspension and flexible hangers with single-chain suspension and ordinary hangers; use of standard chainless suspension on secondary station tracks, doubling the length of tension sections and distances between hangers; and one-sided contact wire compensation.

Furthermore, contact wire could be lowered (once temperatures were accounted for) to $4,850-4,900 \mathrm{~mm}$ (at operating voltage $3.3 \mathrm{kV}$ ) or to $5,600 \mathrm{~mm}$ (at $25 \mathrm{kV}$ ); the distance of the live wire from earthed structures could be reduced to $150-300 \mathrm{~mm}$, respectively. Reducing the distance of the catenary support poles from the track axis along straight rail sections to $2,450 \mathrm{~mm}$ was allowed as well. Contact terminals were to be used for the purposes of connecting wire and steel cables damaged or shredded by shrapnel. The reconstruction of the destroyed support poles involved the use of temporary standard poles (attached to the track) as well as temporary wooden poles. The second stage of works was to involve the replacement of the simplified construction solutions with regular structures, standard poles to be replaced with wooden or permanent ones (of metal and/ or reinforced concrete). In case of the destruction to traction substations, they were to be replaced with mobile substations. ${ }^{437} \mathrm{~A}$ minimum reserve of two mobile substations was to be stored in the area of every electrified line. ${ }^{438}$ Concurrently,

436 An analysis of nuclear bomb explosion effects in Japan confirms the nature and extent of all predicted damages; catenary poles withstood the impact of the shockwave on Japanese railways due to their flexibility and small size.

437 Ministry of National Defence, Transport Command 33/64, Komunikacja wojskowa (1965), 433-438.

438 Ministry of National Defence, Transport Command 33/64, Komunikacja wojskowa (1965), 444. 
the Military Railways Management was obliged to prepare sections of electrified lines for transition to steam or diesel traction with intent to secure the continuity of transport on the railway network. ${ }^{439}$

Due to the novel nature of any future conflict (thermonuclear war), particular attention was paid to securing railway operability under conditions of radioactive contamination. Attention was also paid to securing transport viability in conditions of chemical and biological contamination. Plans involved the deactivation of rolling stock, structures, stations and railway devices, as well as the soldiers of the transferred units, their equipment and materials. Permanent and temporary sites of rolling stock decontamination were to be deployed across the frontline railway network. ${ }^{440} \mathrm{~A}$ special-purpose disinfectant solution, and hot water or steam supplied by steam locomotives were to be used as decontaminants. Guidelines on the passage of military trains through radioactive contamination zones were drafted as well. ${ }^{441}$ These rules were merely to preserve the morale of the transported troops (the use of personal protection equipment and gas masks was recommended).

\subsection{Destruction of Railway Lines, Stations, Facilities and Rolling Stock}

Destruction and reconstruction of railway lines, stations, facilities and rolling stock had been among the main responsibilities of sapper divisions from the early days of railway use for military purposes.

The first known case of railway line destruction involved was an episode of the final stage of the Palatine Uprising of 1849 under General Ludwik Mierosławski: "Thanks to the defence of Durlach, Mierosławski managed to evacuate the gun powder warehouse from Ettingen, war supplies from Karlsruhe, and dismantle the railway tracks on the line of his retreat. On June 26th, the revolutionary army found itself at the destination of its march - at the Rastatt Fortress. Consequently, the flank march - proceeding under the pressure of three enemy corps - was successfully completed." 442

The majority of contemporaneous staff members held General Mierosławski’s retreat march from Heidelberg to Rastatt in great esteem. Furthermore, thanks

439 Ministry of National Defence, Transport Command 33/64, Komunikacja wojskowa (1965), 444.

440 Ibid., 458.

441 Ibid., 469-472.

442 Owsińska (1965), 96. 
to the destruction of transport lines, he managed to free nearly the entire army of the threat of encirclement. As a result of these activities, the Prussian elaborate operational plan of Generals Peucker and Hirschfeld's corps uniting behind the Baden failed utterly. ${ }^{443}$

Also during the 1863 uprising in Poland, the Russians used the railways for the purposes of massive troops transfer from within Russia. The insurgents engaged in regular struggle for the railway to counteract the dislocation of the Russian troops, having fought in as many as 61 skirmishes. ${ }^{44}$ In all probability, this was the first case of operational use of railways for military purposes on the Polish territory.

Beginning with the Franco-Prussian War of 1870, which served to prove the great strategic importance of rail transport, the formation of specialised railway engineering and sapper units began in all significant European armies, their responsibilities involving the construction, reconstruction and destruction of railway lines, as well as operating the railways along frontline sections of railway lines, by means of operational battalions.

The Polish sappers' manual drafted between the wars contained a detailed description of methods of destroying railway lines. The first Miners' Manual published by Branch VII (scientific) of the General Staff of the Polish Armed Forces in 1919, after Poland had regained independence, ${ }^{445}$ included a brief description of the destruction of railway lines and appliances:

[...] Rails shall be blown up on curves, in deep pits, or at high-rise embankment or tunnel locations. Blowing up operations shall be carried out every $1 / 2 \mathrm{~km}$. Bursting charges comprise $1 / 2$ of crumble ammunition, or $1 \mathrm{~kg}$ at rail intersections. Tracks can also be damaged by rail removal and concealment. Railway station destruction may involve the following: breakage to telegraph and telephone devices; blowing up of switches (bursting charge - $1 \mathrm{~kg}$ ); destruction of water supply facilities, pumps, boilers and steam cylinders. Switch crossovers shall be blown up with $4 \mathrm{~kg}$ charges. Wagons and carriages shall be destroyed by blasting axles with $3 \mathrm{~kg}$ charges, or axle boxes with $1 / 2 \mathrm{~kg}$ charges. With regard to locomotives, pistons and steam cylinders shall be blown up with a $1 \frac{1}{2} \mathrm{~kg}$ charge, the boiler with $1-1.5 \mathrm{~kg}$ charges. Telegraph and telephone lines shall be destroyed by cutting wires and destroying insulators, also by connecting wires with a thin cable to the ground or by switching on the incorrect wire $[\ldots] .{ }^{446}$

443 Owsińska (1965), 96-97.

444 Łaniec (1974), 269.

445 General Staff, Instrukcja (1919).

446 General Staff, Instrukcja (1919), 62-63. 
Chapter 4 (Destroying Railways) of the Sappers' Manual for Use by all Types of Armed Forces $^{447}$ published in 1930 by the Ministry of Military Affairs also described various methods of destroying railway lines, facilities, equipment, and rolling stock.

Railway track was destroyed outside stations by blasting rail joints, destroying curved sections and cutting rails as such. A $0.3-0.5 \mathrm{~kg}$ charge was used to cut a rail, joints blown up with the use of a $1 \mathrm{~kg}$ charge. ${ }^{448}$ Yet the best effect was achieved by blasting rails with a $1 \mathrm{~kg}$ charge: it destroyed the rail as well as the sleepers. Major destruction of selected railway line sections involved the use of $20 \mathrm{~kg}$ charges placed at 4-5 m intervals: when detonated, such major charges gouged craters $2-2.5 \mathrm{~m}$ deep. ${ }^{449}$

Railway tracks were also damaged mechanically by disassembling and removal of rails, by cutting hook and bolt heads (connecting rails to sleepers) on selected railway line sections, or by widening the railway track by several centimetres. Railway track sections were also destroyed mechanically (using locomotive pulling force) with the use of special chains and handles, attached to a locomotive. Such a solution allowed for quick and efficient destruction of railway lines of considerable length. To rip out longer railway track sections, loops and a special-purpose hook were attached to the rear hook of a train comprising a locomotive and 2-3 tightly coupled wagons. Loops were made of two straight rails and one curved rail, the hook - of two rails, the end of one curved into a hook. Before rails were to be torn, a crowbar was used to pull rail-fixing nails on 8-10 sleepers, one joint opened, and the loop inserted under the rails. After the train moved, the loop pulled rails out of sleepers; the hook was attached to the loop and arranged outside the track, catching onto one of the sleepers. With the train in motion, the hook rotated all loosened the sleepers. ${ }^{450}$

Engineering-miner trains fitted with mechanical railway track destruction appliances were used to destroy railway lines in areas of retreat in the early days of the September 1939 campaign (once border area fighting ceased). ${ }^{451}$

Telegraph and telephone lines were destroyed by cutting and entangling the wires; by cutting, burning or blasting poles on sections up to $2 \mathrm{~km}$ in length; and by breaking insulators. ${ }^{452}$ Telephones and telegraph devices and batteries were destroyed by shattering them.

447 Ministry of Military Affairs, Instrukcja (1930).

448 Ministry of Transport, Podręcznik (1939), 20.

449 Ministry of Transport, Podręcznik (1939), 212-213.

450 Ministry of Transport, Podręcznik (1939), 213-215.

451 Żolnierze (1988), 34.

452 Ministry of Military Affairs, Instrukcja (1930), 215. 
Before any railway station was destroyed, all rolling stock was removed, or destroyed if time restrictions did not allow for the removal. All railway station assets were destroyed: telegraph and telephone lines, switches, signalling and block devices, rolling stock, wells, buildings, and other station equipment. Switches were destroyed with $0.6 \mathrm{~kg}$ charges placed between the blade and the rail, and a $1 \mathrm{~kg}$ charge placed next to the second blade adjacent to the rail. ${ }^{453}$ Frogs were destroyed with a $2 \mathrm{~kg}$ charge placed between the frog and the rail (or with a $4 \mathrm{~kg}$ charge placed under the frogs for more effective destruction). ${ }^{454}$

Arrival switches were usually destroyed first, followed by the damage to the other switches and more double slip switches (centred and fitted with spring blades). ${ }^{455}$ Semaphores and stop signals were also blown up. Block apparatus at signal-boxes were destroyed with $2-3 \mathrm{~kg}$ charges. ${ }^{456}$

Water towers were destroyed with 1-1.5 kg charges lowered to the bottom of the tank; the water tower pipe could also be damaged with a $400 \mathrm{~g}$ charge, or the entire tower could be blasted with a cluster charge (usually $25 \mathrm{~kg}$ of TNT or $100 \mathrm{~kg}$ of gunpowder) placed at the tower's centre. ${ }^{457}$ All window and door openings were blocked to boost explosion force. Water cranes were destroyed with charges applied to the crane pipe in the valve area (in the well). Turntables were destroyed with $4 \mathrm{~kg}$ charges placed low near the bearing pivot, or with 1-2 kg charges placed at rail-ends on the running board, and at the axles of support wheels. ${ }^{458}$

Wagons were destroyed with $0.40 \mathrm{~kg}$ charges applied to springs or axle boxes (should explosives be unavailable, axle boxes were to be filled with sand or ash).

Steam locomotives were destroyed with $1 \mathrm{~kg}$ charges applied to connecting rods, cylinders, steam dome and boiler; if locomotive was cold, boiler tubes inside the boiler were destroyed - on the tubeplate or in the firebox. ${ }^{459}$ Tenders

453 Ministry of Military Affairs, Instrukcja (1930), 215-216.

454 Ministry of Military Affairs, Instrukcja (1930), 216.

455 Ministry of Transport, Podręcznik (1939), 21.

456 Ministry of Military Affairs, Instrukcja (1930), 217.

457 Ministry of Military Affairs, Instrukcja (1930), 217-218.

458 Ministry of Military Affairs, Instrukcja (1930), 219.

459 A practice common during the Second World War involved extremely effective destruction of steam locomotives by blasting a charge placed inside a cold engine's firebox; according to an account by railwaymen, this was how retreating Germans destroyed locomotives at the Myszyniec locomotive depot (Ostrołęka Narrow-gauge Railway). This method was also used by guerrillas - they destroyed a narrow-gauge steam locomotive on the Zwierzyniec-Biłgoraj narrow-gauge line with a bunch of grenades thrown into the firebox. 
were destroyed with an $0.8 \mathrm{~kg}$ charge applied to the lower section of the water tank. ${ }^{460}$

The Sapper's Manual also recommended the "trapping" of armoured trains by blasting both sides of a railway track with the use of mines fitted with special self-activating devices. ${ }^{461}$

The Manual of Railway Damage Reconstruction ${ }^{462}$ published in 1939 by the Ministry of Transport describes railway line destruction as well. Three fundamental destruction types were identified: ${ }^{463}$

- Damage - dismantling, disassembly and removal of pumping station equipment, main track switches at stations, workshop equipment and machining tools, railway signalling devices and telecommunications appliances; dismantling of several track spans, track destruction on bridges;

- Partial destruction - track damage along certain sections by joint blasting; gradual dismantling of several track spans and track removal at intervals; dismantling railway signalling devices; blasting switches at main track (if time constraints disallowed the complete switch and frog disassembly and removal), cutting parts of telegraph poles; partial bridge destruction by blowing charges on the first, second or third section of the lower flange or cross-brace; destruction of one span on multi-span bridges; destruction of crossbars or stringers in one or two sections; potential disassembly and removal of girders (in case of time constraints, blowing girders up with charges placed in several locations of the lower flange at the connection points to crossbars and wind guards);

- Mass destruction - blowing up buildings, bridges with pillars, and tracks joints along longer sections; setting fire to wooden buildings and bridges; destroying railway tracks with a loop dragged by a steam locomotive or a tracked tractor and steel cable (riding on a lineside); cutting all telegraph poles; flooding tracks artificially; recommendations for mass railway bridges destruction involved blasting of all spans, bridgeheads and pillars, charges placed in a few bridge sections, preferably in the second and third section from the span-end; ${ }^{464}$ cross-sections of structural parts to be destroyed should

460 Ministry of Military Affairs, Instrukcja (1930), 219-221.

461 Ministry of Military Affairs, Instrukcja (1930), 221-222.

462 Ministry of Transport, Podręcznik (1939).

463 Ministry of Transport, Podręcznik (1939) 4-7.

464 With intent to destroy all structural elements of a section: upper and lower flanges, crossbars, stringers and wind braces. 
be located in a single section and at an incline towards the centre of the bridge; recommended single-span bridge destruction included the cutting along two sections (fields) and blowing up bridgeheads; in case of multi-span bridges, as many spans as possible were to be destroyed, together with bridgeheads and pillars; bridge approaches were to be destroyed at the length of at least 60-80 m;

- it was also recommended to cause masked railway track damage so as to derail enemy trains by expanding the track width by a few centimetres; cutting sleepers inside curved tracks (along one or more rail lengths); removing hooks or bolts on several outer curved lengths and concealing them with preassembled short $(2-3 \mathrm{~cm})$ hooks or bolts; by nailing the groove between the rail and guard rail;

- rail traffic along a specific railway line could be brought to a complete standstill by blocking it with derailed rolling-stock; the method could be employed in tunnels or deep cuttings, and was particularly effective at locations where rolling stock could not be retracted.

The afore-described damage and methods of destroying railway lines and facilities were applied depending on the intended purpose. In cases of momentary retreat from a home territory (in anticipation of a quick return, slight damage was caused only), the following action was planned to make enemy advancement difficult: the dismantling and removal of machinery, equipment, switch components, telecommunication equipment, and materials; destroying tracks along specific sections; blowing up rail joints; destroying individual bridges. If there was no time to dismantle and dispose of equipment and/or materials, damage was caused to station facilities, tracks and structures with intent to hinder enemy advancement: switches in primary tracks, bridges and communication devices, waterworks and fuel depots. In the case of longer-term retreat, mass destruction was planned. ${ }^{465}$

When destroying railway stations, the order of destruction was predetermined, priority assigned to devices whose reconstruction would enable rail traffic to be restored and be most time-consuming. Prior to destruction, it was recommended to remove any rolling stock potentially useful to the enemy. The following sequence of destruction was planned: main track switches, siding switches, communication devices, pumping stations and water towers, fuel depots, signalling equipment, main tracks, additional and side tracks, turntables, wells, buildings and other structures. If a station featured any artificial structures 
(bridges, viaducts, tunnels - platform tunnels, for example), they were to be destroyed as a priority, together with switches. ${ }^{466}$

Just before the outbreak of the war, in August 1939, special-purpose engineering-miner trains were formed, staffed with mobilised railwaymen troops as part of the effort to militarise the Polish State Railways. Similarly to emergency trains, these trains were fitted with specialised permanent-way equipment and mines with accessories, train crews comprising sappers and qualified employees of the Polish State Railways permanent -way departments. Engineering-miner trains were charged with reconstructing railway lines destroyed by the enemy, and destroying railway lines in troop retreat areas. Using mechanical appliances an engineering-miner train under the command of reserve Lieutenant Colonel Wacław Wojter completely destroyed the border Zbąszyń - Poznań railway line between September 1st and 2nd 1939. ${ }^{467}$

Also after the war, great importance was attached to the destruction of railway lines and infrastructure when organising and training railway engineering units. The Sappers' Manual - Explosives and Destruction published by the Ministry of National Defence in $1947,{ }^{468}$ based largely on the aforementioned pre-war Sappers' Manual and on Soviet regulations in the field, ${ }^{469}$ described technical and mining measures employed to destroy tracks, switches, facilities and rolling stock. The Manual also described effective and economical (low explosiveconsuming) methods of destroying such facilities during retreat operations.

The extent of damage depended on the time for which an area was to be abandoned. In case of short-term retreat, the railway line was to be only slightly damaged; conversely, if longer-term retreat was planned, considerable damage was caused to the permanent-way, rolling stock and infrastructure of the line. The same principle applied to all devices, facilities and rolling stock, and was duly reflected in contemporaneous sapper guidelines.

With mass destruction of the railway track, each rail length of $12.5 \mathrm{~m}$ and longer was cut into three parts, two charges placed on each side of the rail. Charges on both rails were arranged in a chessboard pattern. Rails below the length of $12 \mathrm{~m}$ (and all rails, should explosives not be available) were cut in two. Charges were applied to the neck of the rail just below the head. For better adhesion, the charge was sealed with soil or pressed with a special-purpose wire clamp.

466 Ministry of Transport, Podręcznik (1939), 7-8.

467 Żotnierze (1988), 33-34.

468 Ministry of National Defence, Instrukcja (1947).

469 The manual includes engravings from Russian wartime sappers' handbooks.

Zbigniew Tucholski - 978-3-631-82966-0 
Charges were ejected with long-delay fuse igniters (fitted with smouldering wicks, burning time: 6 minutes). A 200-400 g closely-fitting TNT charge was sufficient to cut a rail of any type. ${ }^{470}$ In view to destroy railway tracks between two stations as fast as possible, work was performed by several platoons simultaneously, 2.5-4 km section assigned to each. Sections of such length were destroyed over a time of 1.5 to 2 hours. ${ }^{411}$

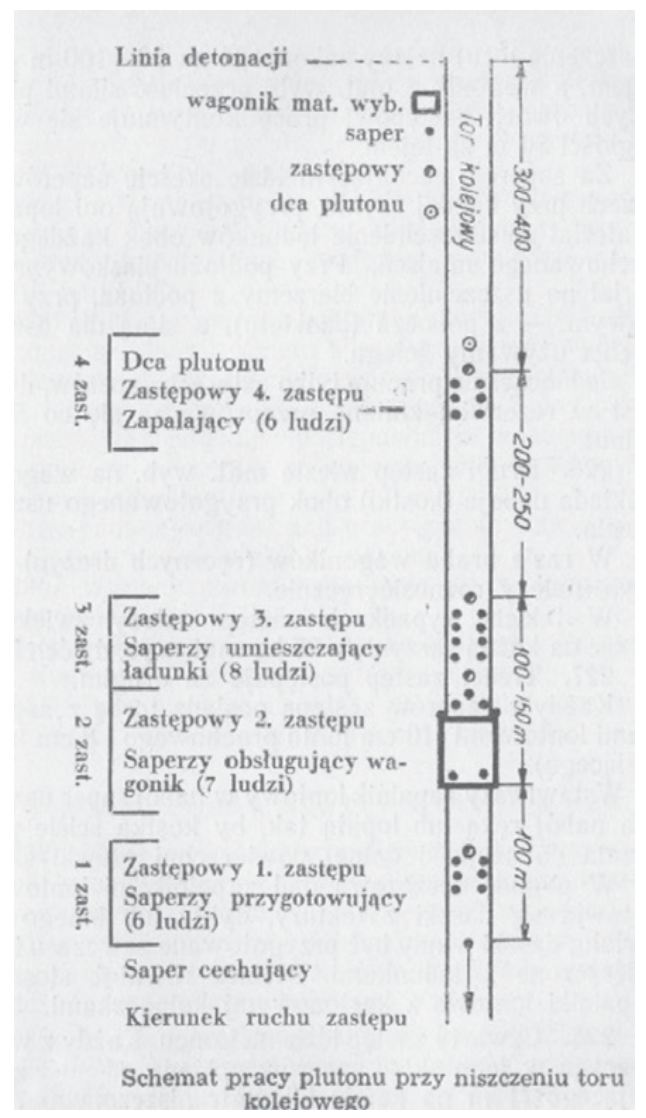

Work diagram for a platoon when destroying railway tracks.

Source: Ministry of National Defence, Instrukcja (1947)

470 Resistance movement soldiers recalled that an S- 49 rail (running meter weight: $49 \mathrm{~kg}$ ) could be effectively cut with the use of a single $200 \mathrm{~g}$ TNT brick.

471 Ministry of National Defence, Instrukcja (1947), 244. 


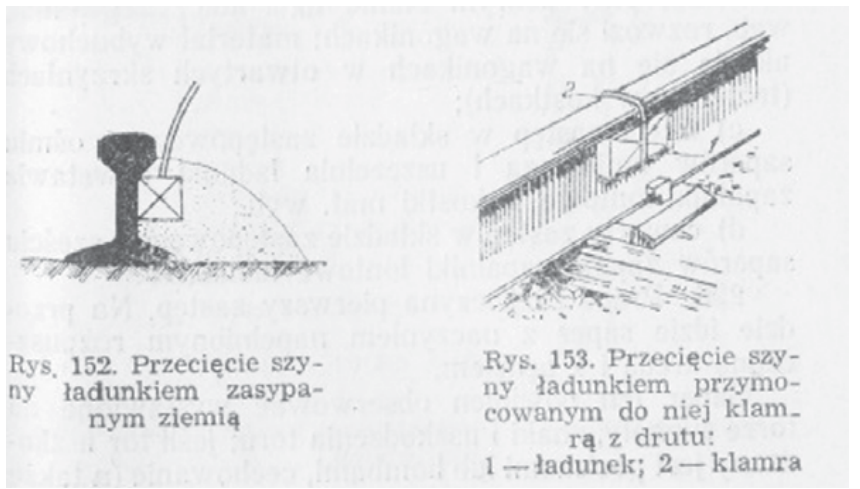

Cutting rails with explosives.

Source: Ministry of National Defence, Instrukcja (1947)

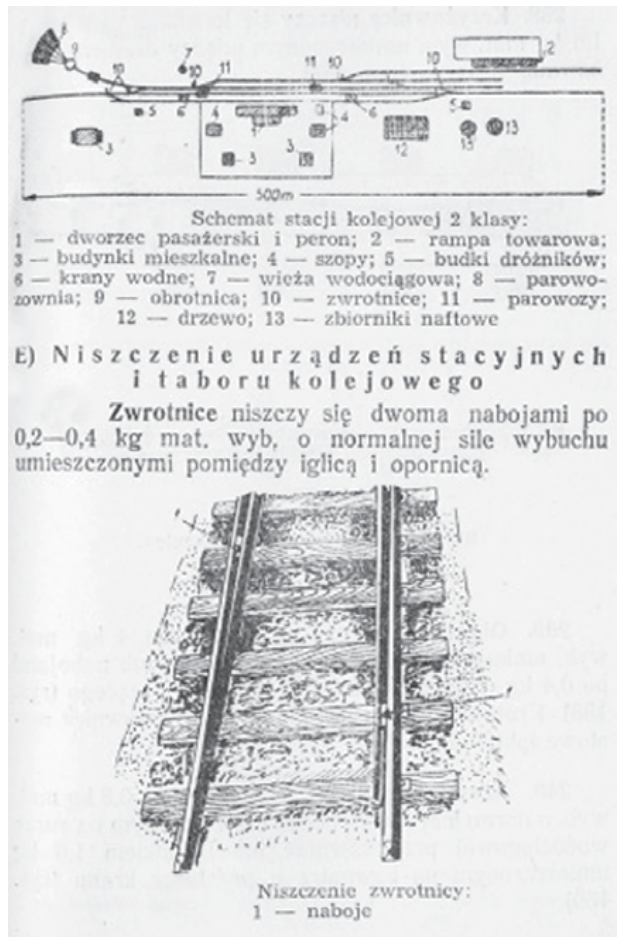

Destroying of railway station devices and rolling stock.

Source: Ministry of National Defence, Instrukcja (1947) 
All major railway station technical infrastructure facilities were destroyed: water towers, water cranes, coal-fuelling equipment, tracks, switches, turntables, semaphores, telegraph and telephone devices, pumping station machines, ramps, railway workshops, materials suitable for reconstruction, rolling stock, and fuel.

Switches were destroyed with two rounds of $0.2-0.4 \mathrm{~kg}$ of TNT placed between the needle and the resistor. Switch crossbars were destroyed with a $0.8-1.6 \mathrm{~kg}$ TNT charge placed between the frog and the rail. ${ }^{472}$
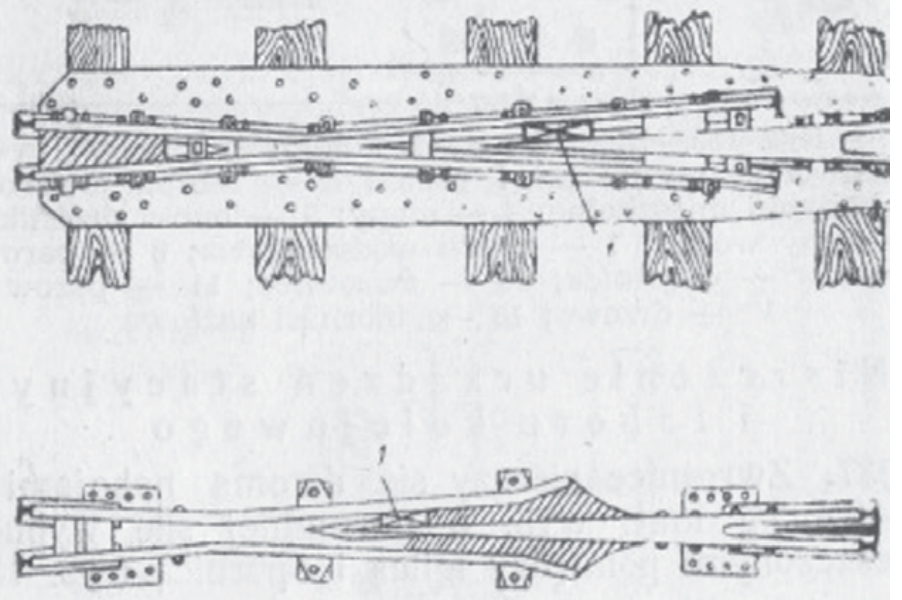

Niszczenie krzyżownicy:

1 - ladunek

Destroying switch crossbars.

Source: Ministry of National Defence, Instrukcja (1947)

Railway turntables were destroyed with $4 \mathrm{~kg}$ TNT charges placed low next to the turntable pin, or with the use of $0.4 \mathrm{~kg}$ cartridges placed at the axis of a running wheel. Turntable trusses were destroyed as well. ${ }^{473}$

472 Ministry of National Defence, Instrukcja (1947), 252.

473 Ministry of National Defence, Instrukcja (1947), 252.

Zbigniew Tucholski - 978-3-631-82966-0 
Water cranes were destroyed with $0.8 \mathrm{~kg}$ TNT charges placed on the water pipe next to the valve, or with a $1.6 \mathrm{~kg}$ charged placed outside the structure, at the base of the crane. ${ }^{474}$

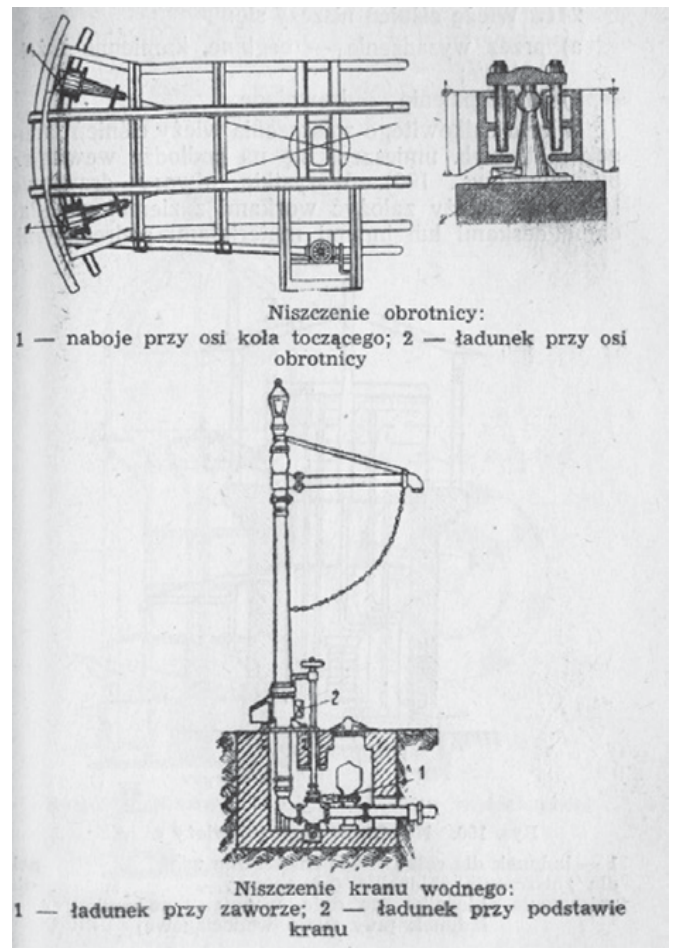

Destroying turntables and water cranes.

Source: Ministry of National Defence, Instrukcja (1947)

Water towers were destroyed by blowing them up (brick, stone and reinforced concrete structures) or by burning (wooden towers). Complete water tower destruction required the charge to be placed on the floor inside the building. All door and window openings were blocked with bags of soil, sleepers, and wooden planks. Skeleton-type water towers were destroyed by blowing up their support pillars. Slight damage to the tower involved blasting the tank, pipelines, and accessories only. Water-filled towers were destroyed with a $1.2 \mathrm{~kg}$ TNT charge 
dropped to the bottom of the tank. Empty tanks would be destroyed with a $1.2 \mathrm{~kg}$ charge placed on the outer tank wall, near its bottom panel.

Valves and pipes were destroyed mechanically or with $0.2 \mathrm{~kg}$ charges. Steam pumps would be destroyed with $0.4 \mathrm{~kg}$ charges placed on steam and water pipes and cylinders (near the pump valves); a centrifugal pump would be destroyed with a $0.4 \mathrm{~kg}$ charge placed on the body of the pump. In the case of mechanical destruction, cylinders, valves, steam pipes and transmission boxes would be damaged in piston pumps; in centrifugal pumps, their bodies and bearings would be damaged. ${ }^{475}$

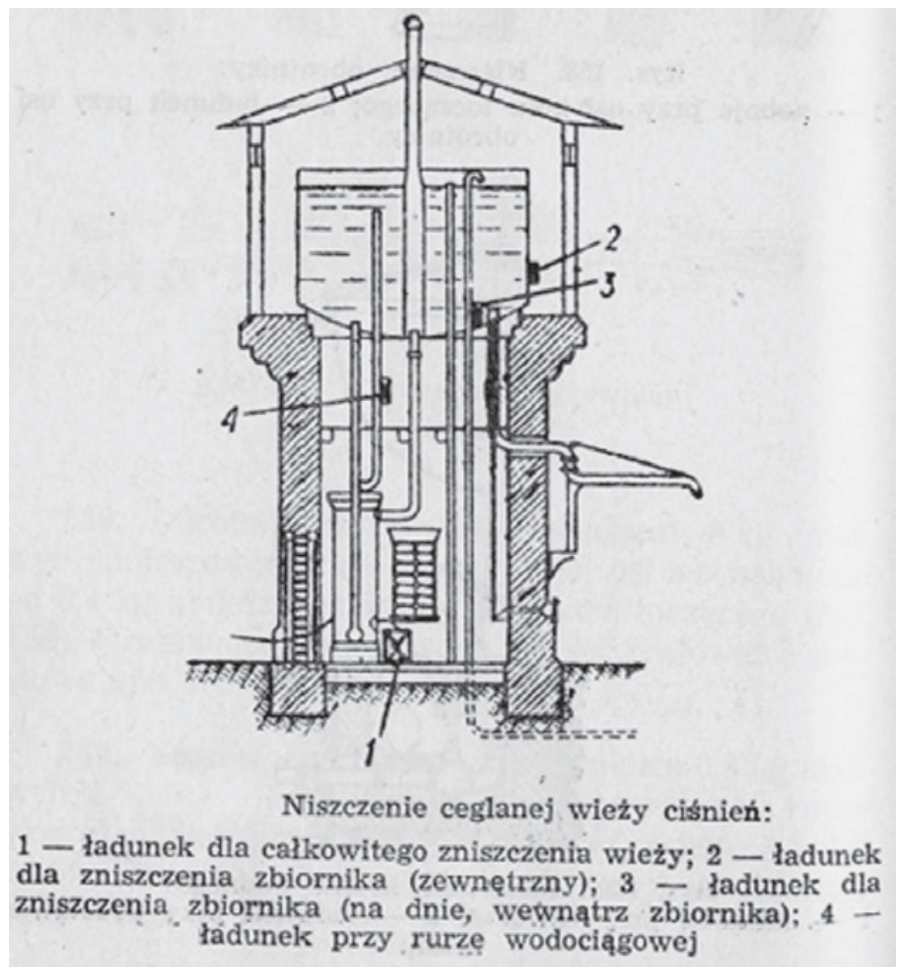

Destroying a brick water tower.

Source: Ministry of National Defence, Instrukcja (1947)

475 Ministry of National Defence, Instrukcja (1947), 257. 


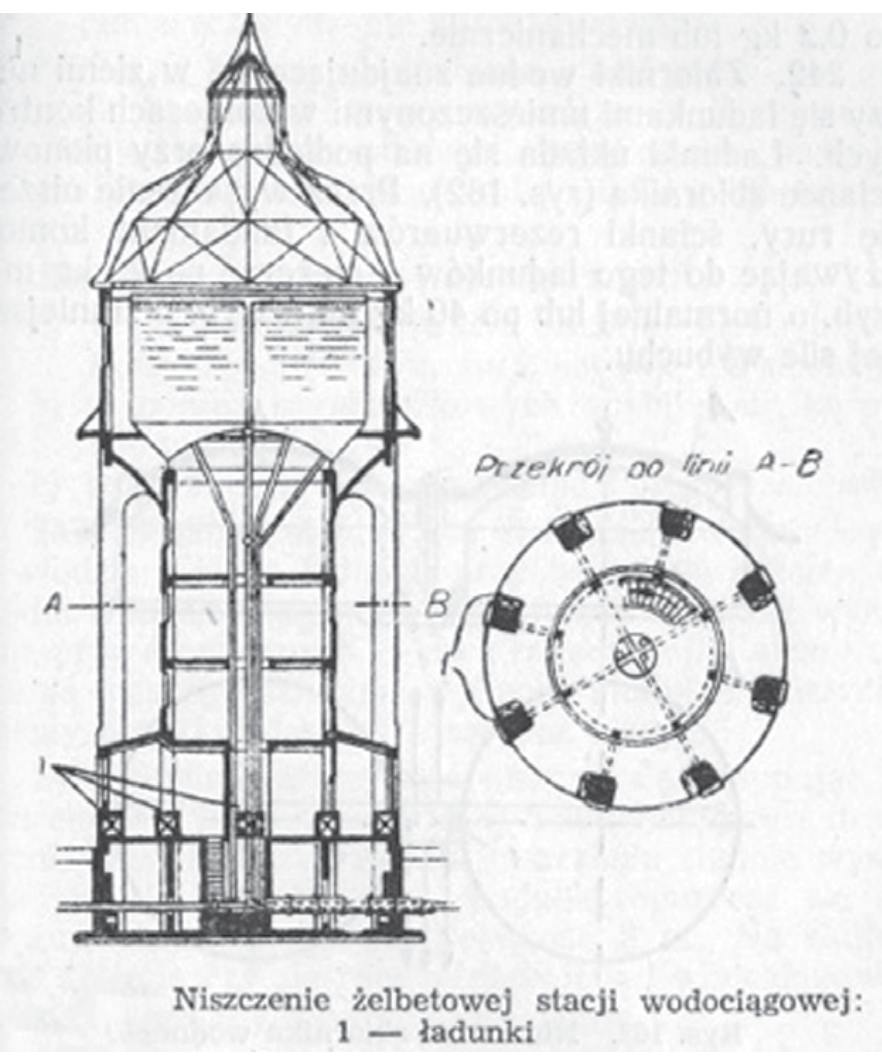

Destroying of a reinforced concrete water tower.

Source: Ministry of National Defence, Instrukcja (1947)

Wells were destroyed with water-immersed charges. In the case of concrete well walls, $16 \mathrm{~kg}$ charges were used; in the case of wooden ones, the charge could be reduced by half. For better explosion effect, topside well openings would be sealed with wooden planks and covered with dirt. ${ }^{476}$

Steam locomotives were destroyed to a greater or lesser extent, depending on charge location. Slight damage would be achieved by placing a $0.4 \mathrm{~kg}$ charge next to the connecting rods or valve gear. Significant damage was caused by a $1.2 \mathrm{~kg}$ TNT charge placed next to a cylinder or steam dome, near boiler walls or in the 
smokebox next to the rear tubeplate, the latter possible in the case of cold steam locomotives only. ${ }^{477}$ In case of mechanical destruction, the following accessories would be removed or destroyed by hammer: regulator, pressure gauge, water gauge, test cocks, and other fittings and control elements. Tenders were destroyed with an $0.8 \mathrm{~kg}$ charge applied to the lower part of the water tank wall. ${ }^{478}$

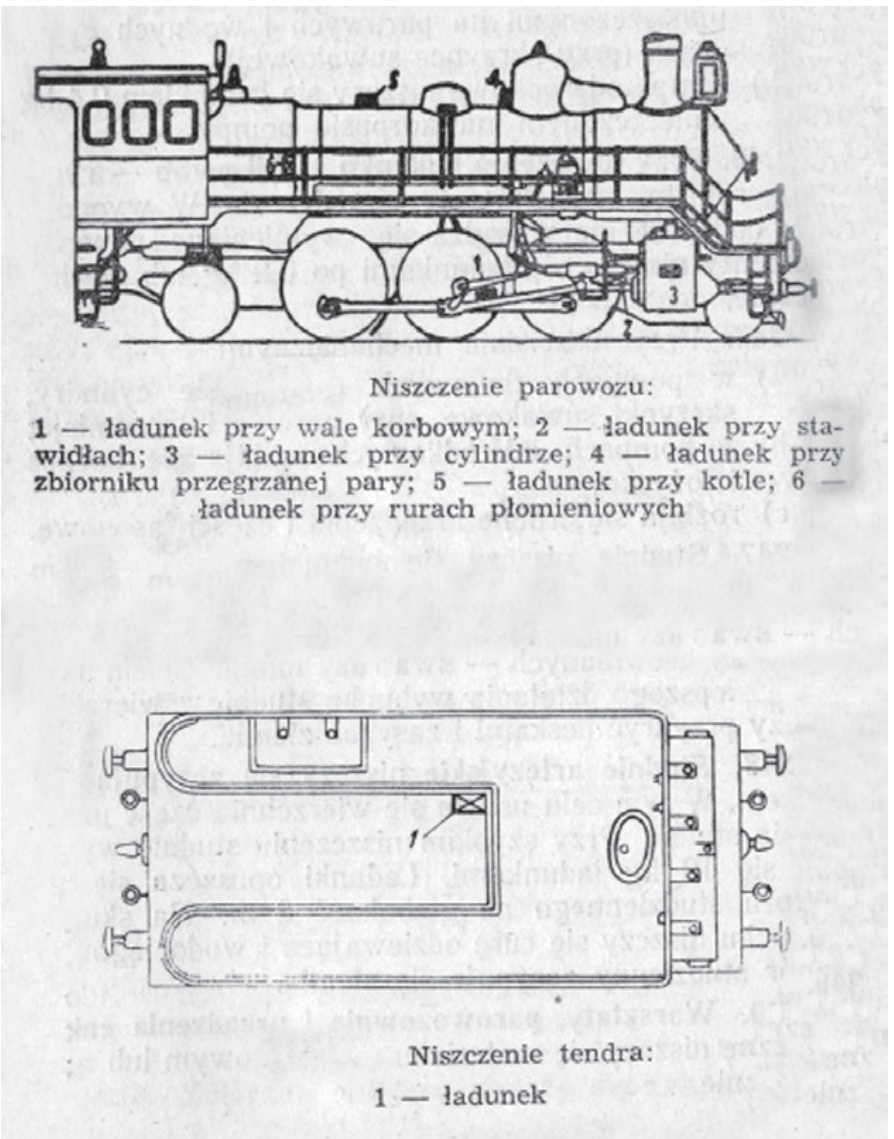

Destroying of steam locomotives and tenders.

Source: Ministry of National Defence, Instrukcja (1947)

477 Blowing up the firebox of a hot locomotive would lead to a locomotive boiler explosion with effect of unpredictable proportions.

478 Ministry of National Defence, Instrukcja (1947), 259.

Zbigniew Tucholski - 978-3-631-82966-0 
Wagons were destroyed with $0.4 \mathrm{~kg}$ TNT charges placed next to the narrower part of their springs or the wheels. If more wagons were standing on the same track, they were destroyed by blasting the track beneath them at several locations. ${ }^{479}$

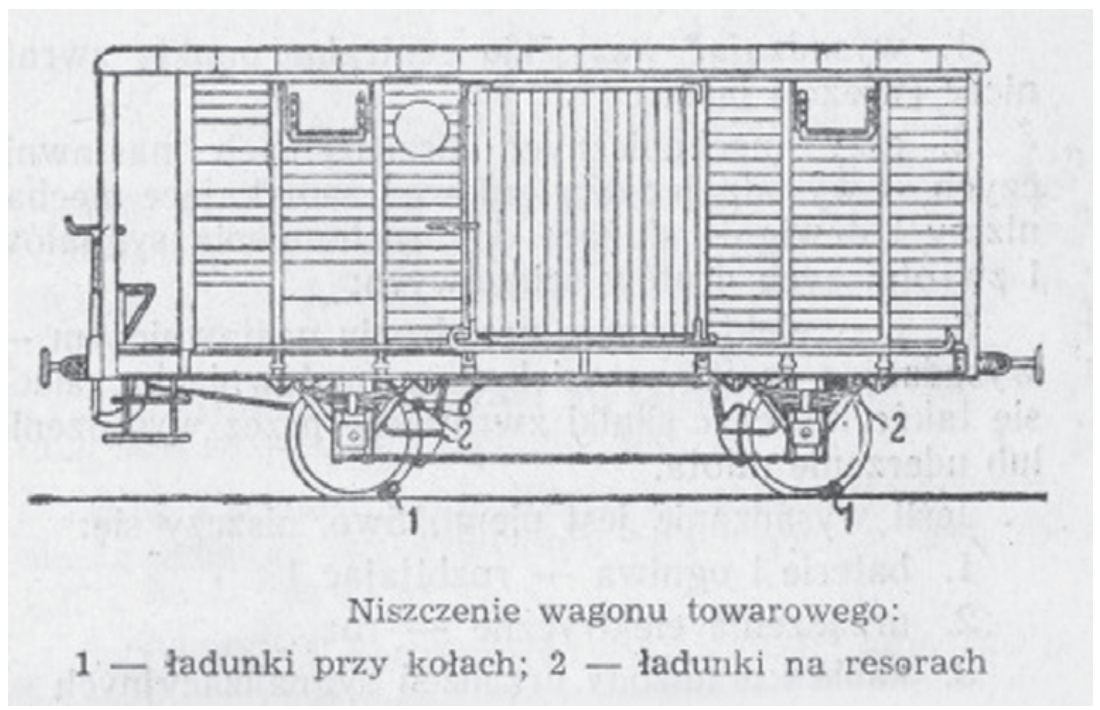

Destroying of a box van.

Source: Ministry of National Defence, Instrukcja (1947)

In case of mass destruction, railway rolling stock was destroyed in the following order: axles were blasted in the first and last wagon; vital steam engine components were blasted; rails beneath the train were damaged at several locations; finally the train was burned.

In the case of telegraph and telephone lines, telegraph poles with wiring leading into the station building as well as internal and external lead routings were destroyed with $0.4 \mathrm{~kg}$ charges. ${ }^{480}$

When destroying signalling and block devices, central devices as well as switches and signalling equipment were blown at the same time. In the case of mechanical switch operating devices, devices at a signal-box were blasted,

479 Ministry of National Defence, Instrukcja (1947), 259.

480 Ministry of National Defence, Instrukcja (1947), 260.

Zbigniew Tucholski - 978-3-631-82966-0 
together with wires and tensioners. In the case of electric switch operating devices, devices at a signal-box were blasted, together with switch motors. Signalling devices were destroyed with $0.8-1.6 \mathrm{~kg}$ charges; signal levers - with $0.4 \mathrm{~kg}$ charges; semaphores and mechanical shunting discs - with $0.8-1.6 \mathrm{~kg}$ charges. ${ }^{481}$

\subsubsection{Bridge Destruction}

The chapter on Destroying roads and Communications of the first Miners' Manual published by Branch VII (scientific) of the General Staff of the Polish Armed Forces in 1919, after Poland had regained independence, included a brief description of the destruction of wooden and iron bridges: ${ }^{482}$

[...] The blasting of wooden bridges: achieved by blowing up of the piling of several bridge pillars and beams, and spans adjacent to the blown-up pillars. Under conditions of time constraints, bridge spans shall be blasted with longitudinal crossarranged charges. Damaged bridge sections shall not be shorter than $20 \mathrm{~m}$. Other wooden bridge destruction methods shall involve the following: dry-season burning by planting explosives beneath pillars and beams, or finally, dismantling. Wooden bridges on enemy-occupied territory can be damaged by floating river mines, stoneloaded fire-ships, etc. [...] Destruction of iron bridges shall be achieved by blowing up bridge spans, less often by blasting pillars. Spans shall be destroyed near the padding, at the deepest point of the river bed. Continuous beams shall be blasted along two penetration cross-sections. If an iron bridge is to be destroyed, all relevant structural parts shall be blown up. Both sections, lower and upper main girders, auxiliary longitudinal beams, crossbars. Blast cross-sections shall be located within a single grating, and be inclined downwards, towards the centre of the bridge. Charges shall be placed on weaker structural parts. Charges should lie flush against penetration locations, with close attention paid to strong lacing and wedging. Under circumstances of ammunition shortage, we shall limit all action to the blasting of vital and easily accessible sections with intent to damage the bridge. In such case, the optimum solution shall be to blow up the lower section (crossbars) to hinder railway traffic. If possible, one shall also attempt to blast longitudinal auxiliary beams, causing the bridge to warp under its own weight. In the case of brick bridges, pillars and adjacent spans shall be blasted. Bridgeheads shall only be blasted in the case of small-width singlespan bridges. Tunnels shall be destroyed by obliterating 20-30 m sections; the location of the tunnel passing through brittle rock shall be identified, with intent to cause further landslides upon blasting [...] If possible, mine chambers shall be set up in tunnel side walls. Damage to the tunnel shall be caused by blowing up entrances, by

481 Ministry of National Defence, Instrukcja (1947), 261.

482 General Staff, Instrukcja (1919). 
barricading longer or shorter tunnel sections, or by derailing a train of stone-filled wagons. [...]..$^{483}$

Bridge and railway viaduct destruction had been among the main responsibilities of sapper and railway engineering divisions from the early days of railway use for military purposes.

Another set of instructions - the Sappers' Manual for Use by all Types of Armed Forces published in 1930 by the Ministry of Military Affairs ${ }^{484}$ - read under item 257 (Blowing up Iron Bridges) as follows:

[...] There are three types of devastation: total destruction, partial destruction, and damage. Total destruction shall consist of blowing up all bridge supports and cutting the spans. Partial destruction shall consist of blowing one or several spans or two adjacent supports at the deepest point, relevant spans included.

Damage. Under circumstances of ammunition shortage, destruction may be limited to the blasting of vital and easily accessible span sections only, such as the lower section, or cross-braces. In such cases, attempts shall be made to induce bridge warping under its own weight $[\ldots] .^{485}$

This was a very brief description of bridge destruction methods. No provisions were made with regard to the destruction of stone and concrete bridges, or pillars and bridgeheads. It did, however, discuss the destruction of individual materials indirectly affecting the destruction of bridges of other design.

The Manual of Railway Damage Reconstruction published by the Ministry of Transport in 1939 described railway bridge destruction as well. Bridges were to be destroyed by the following patrols: preparatory patrol (6 people) - charged with preparing access to cross-sectional areas, digging shelters for squads ${ }^{486}$ for actual bridge-blasting, and other small works; cross-sectional patrol - charged with arming pillars and bridgeheads or drilling mine chambers within, attaching pre-calculated charges to cross-sections, and jamming mine chambers upon charging; ${ }^{487}$ fire system patrols (12 people) - acting upon command of the patrol or squad commander. ${ }^{488}$

483 General Staff, Instrukcja (1919) 58-62.

484 Ministry of Military Affairs, Instrukcja (1930).

485 Ministry of Military Affairs, Instrukcja (1930) 210-211.

486 Shelters (deep shooting ditches) were developed no less than $300 \mathrm{~m}$ from a bridge along its longitudinal axis.

487 Patrol composition depended on the construction of bridge elements; girder box section - 3 persons; single or double T-profile beams - 2 persons; single-layer steel sheet - 1 person.

488 Ministry of Transport, Podręcznik (1939), 19-20 (methods employed also after the Second World War). 
Bridges could be destroyed by air bombing, artillery or missile attack, and/ or on the ground by retreating troops, or by sabotage. Bridges were destroyed with intent to develop obstacles preventing the enemy from using open transport routes. Obstacles and destruction-causing damage in the field and on transport routes were referred to as "damming" in military terminology. The following damming types were employed for bridge-related purposes: ${ }^{489}$

- Bridge destruction (mechanically, by fire and explosives);

- Bridge mining (immediate- or delayed-action mines).

Wooden bridges were usually destroyed by burning or blasting; in some cases by sawing supports and on-bridge roads. Steel spans on wooden supports were destroyed by burning supports or blasting the fundamental structure - piling and girders. Steel, reinforced concrete and stone bridges were destroyed by blasting. Bridge destruction by artillery fire or air bombing caused partial object destruction only (e.g. span breakage or demolition to the upper support). Burning wooden bridges was time-consuming in terms of preparing and burning the object, and required large quantities of flammable materials. Furthermore, the effect was largely dependent on weather conditions; this is why burning, while highly effective, was considered an auxiliary means of destruction.

Timber cribs potentially identified in reconstructed bridges ${ }^{490}$ were blown up with the use of explosives deposited in mine wells excavated in cribs along their axes.

Should time not allow mine wells to be dug, timber cribs were blown up with explosives placed on the outside along longitudinal crib walls, at points of intersection with the lateral walls.

Explosives were the most effective and least time-consuming bridge destruction measure. The extent of damage to the bridge depended on the period for which the area was to be abandoned. In case of short-time retreat, bridges were to be only slightly damaged; in case of longer-term retreat, bridges were damaged significantly - or destroyed outright. The following bridge destruction methods by blasting were applied: ${ }^{491}$

489 Odbudowa mostów (1966), 12.

490 Timber cribs - special-purpose bridge supports of wooden design, comprising around a dozen or several dozen horizontal layers of corner-notched logs, forming a frame stabilised from within with transverse and in some cases also longitudinal walls. Crib cavities are filled with stones or gravel.

491 Odbudowa mostów (1966), 13. 
- damage to spans (without collapse),

- damage to supports and foundations (without collapse),

- span destruction,

- support destruction,

- total destruction of a bridge, or of one or several spans.

Damage to steel bridge spans without it collapsing was achieved by cutting vital components, twisting, bending or ripping. In the case of reinforced concrete bridges, while damage did not usually cause the structure to collapse, cracks, punctures to the slab, or even piercing to the main girder could be induced. Steel bridge spans were destroyed by cutting the main structure components. In the case of plate girder bridges, girders and stringers supporting the surface were cut. On truss spans, upper and lower sections, posts and cross-braces were cut. Upon collapse, bridge spans were further deformed. With intent to enhance steel bridge span destruction in truss-design bridges, the rods of both girders were cut in different sections, causing spans to twist upon collapse. Blowing out supports could cause damage to the upper section, or complete destruction. Upon total support blasting, all that remained was debris, bridge spans deviating from the bridge axis and significantly warped. Upon the blasting of one support, the bridge span would plummet with an incline along the vertical axis. Upon blasting both supports along a single bridge face, bridge spans collapsed and twisted. Total bridge destruction was caused by the concurrent blasting of supports and bridge spans. As a result, span reconstruction would be impossible, bridge aperture significantly reduced by span collapse and resulting debris; consequently, the bridge could not be risen again at the original location.

The extent of damage could increase considerably once rolling stock loaded with flammable materials and ammunition was pushed onto damaged spans.

Reinforced concrete bridges were destroyed by blowing out supports or spans. In the case of reinforced concrete multi-span bridges with continuous beams, all spans were destroyed upon blasting selected supports only.

Stone (arched) bridges were destroyed by blowing up vaults and supports. Vault blasting was rather rare, as the results were unsatisfactory. Stone bridge supports were blown up - this would cause vault destruction, debris effectively blocking the riverbed.

Should time or resource constraints disallow the destruction of the entire bridge, the longest span over the navigable part of the river (or over a deep ravine) or the span with the highest supports would be blasted.

In the case of wooden bridge which would have to be destroyed, two charging methods were applied: large volumes of small charges would be placed at basic 
bridge components (piling, main beams); alternately, larger charges destroying several adjacent design components could be used.

When destroying steel bridges, charges were applied to the basic elements of the span. Charges would be placed in trusses along an inclined downward line to ensure freefall of the cut girders. Stone and concrete supports were destroyed by charges placed in fixed mine devices developed during the construction of the bridge or preparatory works. ${ }^{42}$ The type of fixed mine equipment used depended on support thickness. In the case of the supports being over 3 metres thick, mine chambers would be provided, complete with wells (manholes) and passages. The chamber size depended on the size of the charge calculated for a given support. In the case of supports $2-3 \mathrm{~m}$ thick, circular or square mine pipes (slots) were developed. In the case of supports less than $2 \mathrm{~m}$ thick, niches or furrows sufficed, their floor $0.5 \mathrm{~m}$ above the highest water level. ${ }^{493}$

If time allowed and in conditions of suitable mine device shortage, sleeves or niches were developed to $1 / 3-1 / 2$ of support thickness, at the bottom of the support, $0.5 \mathrm{~m}$ above the highest water level. Sleeves were developed by personnel operating from platforms, rafts or boats, with the use of manual or mechanical tools. In the case of longitudinal charges and pillars less than $2 \mathrm{~m}$ thick, a furrow (or two furrows separated by a distance of $0.5 \mathrm{~m}$ ) no shorter than one-half of pillar length would be provided. ${ }^{494}$ For greater explosive force effect, furrows and mine sleeves were sealed with available materials. Support destruction with outside charges was rare, as this required large volumes of explosives. Should time disallow adequate preparation, supports were destroyed by randomly-placed clustered or longitudinal charges, tightly attached to the support $0.5-1 \mathrm{~m}$ above water level. ${ }^{495}$ In the absence of fixed mine devices, support destruction charges could be placed in one of the following: ${ }^{496}$

- wells dug directly behind bridgehead rear walls,

- sleeves chiselled in bridgeheads to a depth of $2 / 3$ of their thickness,

- sleeves chiselled in intermediate supports (pillars) to a depth of $1 / 3-1 / 2$ of their thickness,

492 The provision of niches, pipes, wells and mine chambers in supports and bridgeheads of newly built railway bridges in case of war was common practice. These devices were usually masked with steel covers or stones with the appearance and colour of the support surface.

493 Odbudowa mostów (1966), 17-18.

494 Ministry of National Defence, Instrukcja (1947), 191-192.

495 Ministry of National Defence, Instrukcja (1947), 190-191.

496 Ministry of National Defence, Instrukcja (1947), 18-19. 
- niches chiselled in supports,

- furrows chiselled in supports.

The provision of special-purpose mining appliances, in stone or reinforced concrete structures in particular, was extremely difficult, and not always possible in field conditions. Whenever such solutions were missing, bridges had to be destroyed with the fast-track method of exploding open-air large charges placed at specific components of the bridge.

Bridgeheads missing pre-developed mine placement devices were destroyed with cluster charges arranged (conditions pending) in one of the following: wells dug in the bridgehead's peripheral section (their depth greater than the thickness of the bas $\mathrm{e}^{497}$ ), or in sleeves drilled across the entire support section, or to $2 / 3$ of its thickness. ${ }^{498}$

Arched stone and concrete bridges were destroyed with cluster or longitudinal charges. Cluster charges could be placed on both sides of the vault keystone at $1 / 6$ to $1 / 12$ of span clearance length; above the supports; on the vault keystone - for quick destruction. ${ }^{499}$ Longitudinal charges were placed along the vault keystone and along the bridge. Whenever charges were placed on the bridge surface, wells or furrows were provided for cluster or longitudinal charges, respectively (at a depth allowing a charge to be placed directly against the vault or its backfill). ${ }^{500}$

In the course of the Second World War, the destroyed bridges would be additionally mined with immediate- or delayed-action devices being set upon debris and surviving supports, with intent to cause additional damage and hinder reconstruction works.

\subsubsection{Bridge Mining}

Mining bridges was a method of damming railway lines with intent to blow up the facility during subsequent reconstruction. Delayed-action mining was employed prior to the use of other damming types on railway lines. If the nature of destruction to a large bridge and its location suggested that the enemy would try to rebuild it along the original axis, delayed-action mines would be set up

497 In case of arched bridges, charges were placed below the bearing stone or the foot of the vault.

498 Ministry of National Defence, Instrukcja (1947), 196-197.

499 Should charge placement in supports prove difficult, stone or reinforced concrete bridges could be destroyed with charges placed above supports or vaults, on both sides of the keystone.

500 Ministry of National Defence, Instrukcja (1947), 197-199. 
on approaches thereto. Delayed explosion time would be set according to the predicted dates of bridge reconstruction by the enemy. Unless interfering with bridge defence, delayed-action mines would also be placed at locations potentially useful to the enemy as construction sites or depots. The remains of damaged spans and supports were mined with immediate-action devices with intent to hinder the reconstruction works.

\subsection{Temporary Reconstruction (Construction) of Railway Lines}

Ever since the railway had been used for military purposes, rapid reconstruction of railway lines destroyed by the enemy was among the fundamental responsibilities of railway troops. Chapter V (Removing Effects of Damage to Tracks on Lines and at Stations) of the Manual of Railway Damage Reconstruction published in 1939 by the Ministry of Transport describes the methods of removing damage to railway lines and facilities.

Air bombing of railway tracks gouged large craters in the trackbed: in the case of bombs containing 50-100 kg of explosives - 1-5 $\mathrm{m}$ deep, and 2-10 $\mathrm{m}$ in upper rim diameter. ${ }^{501}$ The removal of the effect of an air attack involved the crater to be filled with dirt (an estimated $70 \%$ of soil blown into banks around craters could be refilled back into the crater). In case of complete track destruction craters could also be filled with crate structures of railway sleepers, once the crater bottom was landfilled, levelled, and compacted. Crates were used as auxiliary devices to facilitate crater landfilling and as load-bearing structures reducing the volume of earthworks required. In case of significant damage to a railway embankment, tracks were to be repaired by partial covering of the bottom of the crater, positioning two sleeper crates as abutments, and covering the hole with rails or iron beams. Should significant damage (e.g. a sequence of craters) extend the reconstruction time considerably, a detour would have to be developed. ${ }^{502}$

In case of destruction to railway tracks by joint or rail blasting or both, another reconstruction technology would be applied at the same time: in principle, it was recommended to replace damaged rails with rails of the same length. Such a method warranted the fastest restoration rate, allowing the time-consuming cutting and drilling of damaged rails to be avoided. Such a reconstruction method should guarantee the following approximate reconstruction rate: $8 \mathrm{~km}$ a day in case of a $50 \%$ share of damaged rails; $16 \mathrm{~km}$ a day in case of a $25 \%$ share of

501 Ministry of Transport, Podręcznik (1939), 78-79.

502 Ministry of Transport, Podręcznik (1939), 78-84.

Zbigniew Tucholski - 978-3-631-82966-0 
damaged rails..$^{53}$ Under conditions of insufficient spare rail stock, damaged railends would have to be cut off, and holes drilled on site. Pursuant to regulation $D 3$, the length of rails installable in regular operational conditions was to be no less than $9 \mathrm{~m}$. Under conditions of fast-track railway line reconstruction in wartime conditions, rails no shorter than $6 \mathrm{~m}$ would be used. ${ }^{504}$ During rail-cutting attempts were made to limit the number of different-length rails, and to use samelength rail pairs for repair purposes. Should a need to reconstruct a double-track line arise upon damage by rail blasting, material from track two could be used to reconstruct track one. Materials to rebuild track two could be carried on track one once restored. Damaged rail ends were cut and rail holes were drilled manually with the use of chisels or rail saws, and hand drills or oxy-acetylene torches.

When a railway line was destructed by means of a loop set significant warping to rails occurred (especially to screw-mounted track). Once such a method was used, only some accessories could be recovered. In case of rails fastened by nails, up to $50 \%$ of sleepers could be recovered; in the case of rails mounted with screws, only around $20 \%$. Reconstructing of a loop set-damaged line basically involved the removal of most of the damaged surface, and the construction of a new track with the use of new material brought in. ${ }^{505}$

Warfare damage to railway junctions could be caused by air attack (bombing), artillery fire, or by blasting with explosives. Air bombs and missiles would usually cause damage to junction components (switches, frogs, connecting tracks) only, while blasting would destroy the entire switch. Repair of damaged switches was one of the most urgent jobs during rapid train traffic restoration. ${ }^{506}$

If spare parts were available on site or obtainable from side tracks, they were as a rule used to replace the damaged components. If no replacement switches or frogs were available, the need to use temporary devices (the so-called American switches) arose. During assembly, a frog was replaced by two standard rails, plateconnected on joints before the point rails to the main track, and moved towards a straight or curved track at the point where the point track guides would usually be located. Rails were kept in position by special-purpose hard-timber inserts. Additionally, bolts (or hooks) were inserted into switch sleepers to limit lateral rail sliding, angled flat joint plates used as rail head supports. ${ }^{507}$

503 Ministry of Transport, Podręcznik (1939), 91.

504 Ministry of Transport, Podręcznik (1939), 91.

505 Ministry of Transport, Podręcznik (1939), 96.

506 Ministry of Transport, Podręcznik (1939), 98.

507 Ministry of Transport, Podrecznik (1939), 98.

Zbigniew Tucholski - 978-3-631-82966-0 
Destroyed frogs were replaced with two rails connected with inserts (iron or hard timber) and bolts, rails slidable at one end, in semblance of switches. Portable hard-timber inserts and screws were used to keep the rails in position, angled flat joint plates serving as rail head supports. Frogs could also be constructed with the use of two regular rail sections, connected diagonally at a correct angle. Rails could be adapted by torch-cutting and grinding. ${ }^{508}$

The following repair recommendations applied to defective switch components: point rails damaged at the thin end would be filed or cut; in the case of stock rails with damaged ends - if planed, a stock rail would be moved forward upon cutting, if non-planed, it would be replaced with a rail of the correct type and length.

Spare switch parts (point rails, frogs, stock rails) were stocked at stations for fast-track repair purposes. Plans to acquire such components from the lesserused side tracks were also made. It was further recommended that a single type of main track switch be used to facilitate spare parts supply. ${ }^{509}$

Roundhouses were particularly vulnerable to destruction. ${ }^{510}$ Destruction to the turntable would frequently render many locomotives inoperational, as they could not leave the depot building. Two methods were developed to allow locomotives to leave a roundhouse with a damaged turntable.

If a roundhouse with a destroyed or damaged turntable housed one or two steam locomotives, the turntable pit was landfilled and a provisional track was laid, one end connected to the station track layout, the other would be movable to connect to the particular track of the locomotive depot as required. ${ }^{511}$

However, should the need to release more locomotives arise, multiple changes to the shape and length of the makeshift track would be too burdensome. Moreover, insufficient space at numerous stations would disallow temporary track to be curved along the correct radii. In such cases, a uniform method of steam locomotive release with the use of a movable four-rail track was recommended: once the pit of the damaged turntable was landfilled, a combination of two tracks on switch sleeper (4 rails) was developed, with curved rails with $\mathrm{R}=180 \mathrm{~m}$ radius, the length corresponding to the diameter of the turntable.

508 Ministry of Transport, Podręcznik (1939), 101.

509 Ministry of Transport, Podręcznik (1939), 104.

510 This is why the Germans constructed rectangular and stepped locomotive depots when implementing the Otto plan to prepare the transport system to invade the USSR. In case of such locomotive depots the damage to particular depot tracks was easily removable.

511 Ministry of Transport, Podręcznik (1939), 105. 
A protective dead-end track connected to the 4-rail track, its length allowing accommodation of at least one steam locomotive. The released steam locomotive would make a number of shunting movements, moving from the depot track to the dead-end track and backing beyond the 4-rail track towards the depot. During shunting intermissions, the 4-rail track as well as the dead-end track would be moved; upon performing each pair of movements, depending on the way in which the 4-rail track was shaped, the locomotive would proceed to the next road (type I), or two roads further (type II). ${ }^{512}$

After the war, when technical specifications for wartime reconstruction of damaged railway lines were drafted, they were largely modelled on the Manual of Railway Damage Reconstruction published in 1939 by the Ministry of Transport. In 1965, the Ministry of Transport developed the Technical Specifications for the Design and Construction or Reconstruction of Temporary Railway Infrastructure, their stipulations basically comprising nothing but technical parameters for the reconstruction of railway lines and facilities (with exemptions to peacetime railway regulations), and methods of provisional repair of railway switches.

The planned reconstruction of railway surface in field conditions involved exemptions to regulations in force at the Polish State Railways at the time: Regulations Concerning the Construction and Maintenance of Standard Gauge Railway Track (D1 $)^{513}$ and Technical Regulations of Railway Operation (PET). ${ }^{514}$

Reconstruction and construction of railway infrastructure under special conditions was classified by two categories: interim and temporary.

The purpose of interim reconstruction (construction) was to restore railway traffic on a specific line section as soon as reasonably possible, the time of reconstruction (construction) reduced at the expense of the technical condition of infrastructure, the number of station tracks (it was permitted to dismantle track layouts), and other railway equipment. During interim reconstruction (construction) works, technical conditions should allow trains to run at maximum speed of $10 \mathrm{~km} / \mathrm{h}$. The purpose of temporary reconstruction (construction) was to allow rail traffic operation for a relatively long period of time (over two years), as well as permanent reconstruction during such time if required. The technical condition of railway lines and devices during temporary reconstruction (construction) should allow trains to run at maximum speed of $30 \mathrm{~km} / \mathrm{h} .{ }^{515}$

512 Ministry of Transport, Podręcznik (1939), 105-108.

513 Polish State Railways, D1, Przepisy budowy (1957).

514 Ministry of Railways, Przepisy eksploatacji (1956).

515 Ministry of Transport, Warunki techniczne (1965), 5-6. 
In the case of interim and temporary reconstruction (construction) works, deviations from the standard track gauge against the prevalent regulations were allowable. Requirements concerning the geometry of track curves and track inserts ${ }^{516}$ used by trains to pass between two reverse curves were eased as well. Under low-speed conditions during interim reconstruction (construction) works, refraining from the use of cants, cant ramps and transition curves was allowed. During temporary reconstruction (construction) works, the cant use was not mandatory, if the rail incline on curves was correct and if rails were appropriately fixed to the sleepers. Otherwise, a tilt as stipulated by the table for maximum speed of $30 \mathrm{~km} / \mathrm{h}^{517}$ was to be used. Furthermore, requirements regarding profile deflection and ballast thickness were considerably eased under both reconstruction (construction) scenarios: for interim reconstruction (construction) on lines and main station tracks $-13 \mathrm{~cm}$, side tracks could be reconstructed without ballasting; for temporary reconstruction (construction) on lines and main station tracks $-16 \mathrm{~cm}$, on side tracks $-10 \mathrm{~cm} .{ }^{518}$ The use of ballast composed of any material available was allowed, including crushed stone, gravel, sandy gravel, sand and blast-furnace slag. The use of traffic signalling and indicators were also suspended for both reconstruction (construction) scenarios.

Both in the case of interim and temporary reconstruction (construction), the use of standard rails with minimum weight of $33 \mathrm{kG} / \mathrm{m}^{519}$ was recommended. For lightweight track material and high axle load scenarios, the number of sleepers per $1 \mathrm{~km}$ of track was to be appropriately increased. ${ }^{520}$ Damaged rail sections could be cut with oxy-acetylene torches; plate bolt holes were to be burned with a torch or drilled with a powder-actuated punch tool. The technical specifications for track joints were eased as well. Under interim and temporary reconstruction conditions, the use of rails with pre-specified defects and worn-out rails was allowed, as was the direct attachment of rails to sleepers with nails and without the use of rail chairs. All available sleeper types were permitted.

During interim reconstruction of a wooden sleeper track, regular sleepers could alternate with $90 \mathrm{~cm}$ short sleepers (single short sleeper beneath each rail) made of damaged sleepers. ${ }^{521}$ Should the majority of sleepers in a given track be

516 Reverse curves could be joined without a straight insert or cant, provided that curve radii were greater than or equal to $1,200 \mathrm{~m}$.

517 Ministry of Transport, Warunki techniczne (1965), 11.

518 Ministry of Transport, Warunki techniczne (1965), 15.

519 Ministry of Transport, Warunki techniczne (1965), 18.

520 Ministry of Transport, Warunki techniczne (1965), 22.

521 Ministry of Transport, Warunki techniczne (1965), 23. 
mechanically damaged or decayed, alternate sleeper shift and re-attachment to rails at other locations was allowed.

In case of destruction to switches these could be replaced with rails connected to the main track with plates at rail joints before the point rails. Such rails were used as point rails and as such were movable. Rails were kept in position by correct hard-timber wood inserts. Steel spacers attached to switch sleepers facilitated rail shifting. Angled flat plates supported rail heads.

Frogs were replaced with two rail sections connected with steel or wooden inserts. At one end, rails were flexibly connected, as in the case of makeshift switches. Interim reconstruction (construction) also allowed mechanical machining of damaged switch components. Switches thus repaired could be passed at maximum speed of $10 \mathrm{~km} / \mathrm{h} .{ }^{522}$ The use of significantly worn switch components was also permitted. Track intersections could be replaced with two rail sections of correct length, plate-connected to rails and attached to a switch sleeper with nails or screws.

On steel bridges, rails could be installed on railway sleepers. For bridges with a span over $60 \mathrm{~m}$, the use of joint-plates with oval apertures was allowed if there were no expansion joints available. Temporary reconstruction (construction) required no check-rails to be used..$^{523}$

\subsubsection{Reconstruction of Water Supply Facilities}

Some steam locomotive types (mostly narrow-gauge) were originally fitted with water lifters - steam ejectors designed to take water from rivers or other reservoirs. Nonetheless, efficiency of water lifters was poor, watering significantly extending train travel time. Due to the above, fixed high-efficiency water lifters were developed near rivers or water reservoirs already during the First World War, these devices were powered by steam from a steam locomotive.

The Manual of Railway Damage Reconstruction published in 1939 by the Ministry of Transport described methods of reconstructing water supply facilities as well. In case of destruction to water towers, a makeshift wooden tower of one of the three types listed would have to be constructed: ${ }^{524}$

- water tower with a wooden water tank (capacity: $10 \mathrm{~m}^{3}$ ), mounted on a special-purpose wooden structure or on a sleeper-based structure,

522 Ministry of Transport, Warunki techniczne (1965), 30.

523 Ministry of Transport, Warunki techniczne (1965), 34-35.

524 Ministry of Transport, Warunki techniczne (1965), 314-319. 
- water tower with a tank made of a railway tank wagon (capacity: $11.5 \mathrm{~m}^{3}$ ), mounted upon a special-purpose structure,

- locomotive tender tank (capacity: $12 \mathrm{~m}^{3}$ ), mounted upon a sleeper crate.

In case of significant damage to water station facilities and/or waterworks, water lifters were to be set up near an existing water source (a water lifter could be positioned near a river or on a bridge). However, if there was no nearby river yet groundwater or surface water resources were available, it was recommended to dig water intake wells, with a water lifter mounted in one of the wells. ${ }^{525}$

\subsubsection{Reconstruction of Buildings Indispensable to Railway Traffic}

Already during the First World War, Prussian railway troops developed standardised temporary wooden station buildings designs. The Manual of Railway Damage Reconstruction published in 1939 by the Ministry of Transport described methods of constructing temporary station buildings. Between the wars the following designs were recognised as a standard solution: temporary single-storey wooden station buildings, adapted freight wagon bodies to be used as a temporary station building, a hut and a block shelter made of railway sleepers. ${ }^{526}$

\subsubsection{Reconstruction of Railway Signalling Devices}

Appropriate railway signalling devices were indispensable to secure smooth and regular railway traffic as well as adequate railway line capacity. Any damage or destruction to railway signalling devices resulted in restricted capacity of railway lines. The efficiency of railway traffic depended on a maximum speed permitted on a given section, determined by the degree of security provided by the signalling equipment, and on the duration of activities associated with route preparation and resolution, also dependant on the type of signalling devices. The $R 1$ Traffic Regulations for General Railway Lines determined respective standards for the first element of railway traffic device efficiency.

The maximum permitted speed for railway signalling devices with manual switch setting was identical to that allowed for centralised switch setting. The benefits arising from the use of centralised switch setting became visible only at the second stage of railway traffic operability and efficiency rates, when preparing the road for a given train.

525 Ministry of Transport, Podręcznik (1939), 306.

526 Ministry of Transport, Podręcznik (1939), 310-314. 
The maximum permitted speed of a freight train was determined by travel direction (straight or diverging). When signalling clear road with the use of a single-arm semaphore, route distinction could not be indicated. Double-arm semaphores were used to discern directions, yet only in combination with switch interdependency. In order to allow maximum permitted train speed (both for straight and diverging traffic directions), making double-arm semaphores switchdependent was sufficient, and required no further appliances. Nonetheless, making one semaphore arm switch-dependent for straight-directional travel allowed the highest maximum speed in this direction to be achieved.

The second element of rail traffic efficiency involved the duration of activities associated with route preparation and resolution in conjunction with the operation of traffic control posts. The efficiency of signalling devices was classified as follows: ${ }^{527}$

a) centralised switch and signal setting;

b) centralised signal setting and local switch setting (with bolt setting control);

c) centralised signal setting and local switch setting (with key lock setting control);

d) local signal and switch setting with key lock control.

Upon direct destruction of signalling devices and tensioner chambers, or major damage to the devices transferring the lever motion (signalling wires in mechanical devices; wiring in electrical devices) complete transition to manual switch setting was required, followed by the provision of temporary signalling devices. ${ }^{528}$ When substitute and temporary traffic control devices were to be made operational in wartime conditions and immediate restoration of rail traffic became a priority, manual rather than centralised switch control was employed. To reduce the time required to prepare and resolve routes by manual switch setting, the efficiency of a given traffic control post was improved by introducing the following solutions: ${ }^{529}$

1) rational division of centralised switch setting areas to switch setting post/station areas for manual switch setting,

2) installation of adequate telephone connection devices at those posts.

Key locks (or, in their absence, switch point locks) were used to secure manually operated switches. Key interdependencies were introduced for several switches

527 Ministry of Transport, Podręcznik (1939), 229.

528 Ministry of Transport, Podręcznik (1939), 241.

529 Ministry of Transport, Podręcznik (1939), 230.

Zbigniew Tucholski - 978-3-631-82966-0 
and catch points to secure proper handling sequences. Moreover, interdependencies facilitated switch setting control, and simplified devices (key control panels, key interlocking frames, field control panels with interlocking locks). Double locks were used to achieve such interdependencies; should these be unavailable, two single locks (one main and one interdependency lock) would be used. Compound locks (comprising a regular and a catch point lock) were used as well. For a large number of locks, the number of regular key registers was increased, exceeding the usual $24 .{ }^{530}$

Catch points were used to protect transit tracks from intersection collisions with wagons uncoupled from locomotives. Catch points were usually dependant on the switch leading to the track upon which it was mounted. Catch point interdependency involved the use of two locks, one intended to lock the catch point in a track closing position (clamped on the rail), the other - in a track opening position (removed from the rail). A section of loading track or other station side track were secured with a catch point along $150 \mathrm{~m}$ sections (tracks used as dead-end track). ${ }^{531}$ During temporary reconstruction, destroyed catch points were replaced with wooden ones. ${ }^{532}$

When manual switch setting was used, switch bolts were used to secure the proper switch setting, and their required dependence on semaphore signalling. Using bolts rather than key locks to control switch settings allowed major time savings in terms of preparations for train passage. The bolt-locking of switches (the position of which frequently changed) was of key importance to speed-up trains crossing or passing each other. Bolt-locking was facilitated by including bolts into a signalling wire, and having a number of bolts combined into a joint bolt wire. The maximum permitted length of a separate bolt wire including a tensioner, was $500 \mathrm{~m}^{533}$

Key control panels were the simplest system of facilitating correct switch setting control and key-locking them for train passage as required. A more complex device used in conditions of destruction to permanent devices were key interdependence boxes. Such boxes were designed to make signal settings dependent on the correct setting and closure of switches corresponding to the relevant train course and passage. Simple-version key boxes were most suitable for the purposes of the fast setting of interdependencies, as they were not fitted with

530 Ministry of Transport, Podręcznik (1939), 231-232.

531 Ministry of Transport, Podręcznik (1939), 233-234.

532 Ministry of Transport, Podręcznik (1939), 263.

533 Ministry of Transport, Podręcznik (1939), 234-235. 
interdependency key sliders, mutual contradictory signal exclusion systems, or station block dependency systems. Yet such boxes featured a number of structural limitations in terms of the number of train passages they could handle. Should signal-boxes and traffic posts be destroyed, field signal interlocks, structurally designed for indoor or outdoor placement (as required) would be applied. Such interlocks were connected to station block systems with the use of key interdependencies. In case of outdoor field interlock use, they were secured with tents or wooden shelters. Upon transition to manual switch setting, key interdependencies were applied to field interlocks directly. Signalling, switch and catch point interdependencies were applied on field interlocks. ${ }^{534}$

In case of complete destruction to railway signalling devices, train traffic had to be managed without them. The first condition involved outpost (location) protection with the use of D1 stop signs and DO warning signs. The next move involved securing semaphore operability to allow trains to enter a given post (location) without stopping. If semaphores were destroyed, makeshift wooden semaphores and stationary warning signs were set up. Should a need arise, provisional wooden semaphores could be adapted to be manually set. ${ }^{535}$

\subsubsection{Temporary Bridge Reconstruction}

Fundamental responsibilities of all sapper and railway engineering units included rapid reconstruction of the damaged railway bridges. As steel truss and girder bridges became more common in the late 19th century, railway engineering units were trained to lift the blown up and damaged spans on wooden crates. Furthermore, bridge reconstruction included the replacement of damaged spans with makeshift structures. During both world wars, battalions of railway engineers and sappers of all the fighting armies rebuilt a significant number of field wooden bridges. The Prussian army went as far as to design special-purpose high-rise wooden field bridges. The Bridge Repair and Reinforcement chapter of the Sappers' Manual for Use by all Types of Armed Forces published in 1930 by the Ministry of Military Affairs briefly described the methods of building and reconstructing wooden field bridges. ${ }^{536}$

The Manual of Railway Damage Reconstruction published in 1939 by the Ministry of Transport also described the methods of provisional railway bridge reconstruction. Essentially, damaged bridge and culvert reconstruction works

534 Ministry of Transport, Podręcznik (1939), 236-239.

535 Ministry of Transport, Podręcznik (1939), 257-258.

536 Ministry of Military Affairs, Instrukcja (1930). 
followed the rule that the reconstruction shall proceed along the destroyed bridge axis (with the option of using the remains of the old bridge structures, pillars, and bridgeheads). The reconstruction would involve the following solutions: filling the openings in; covering the openings with temporary structures; supporting the damaged spans; elevating the spans and setting them upon existing or makeshift supports; developing structures set upon the damaged spans; dividing the openings into smaller spans; and building track detours and detour bridges. ${ }^{537}$

The openings were filled only at smaller structures (culverts and small bridges) where the water flow was insignificant. Earth, sand, gravel, stones, and timber were used as opening fillers. Stone drainage and concrete pipes were applied to allow watercourse passage. In case of a greater water flow openings were blocked with structures constructed with the use of sleepers (with triangular culvert openings) and backfilled with dirt, or filled with sleepers completely (leaving a watercourse opening as required). In case of partial destruction to a culvert or bridge, it was to be reconstructed with the use of wooden beams and railway sleepers. ${ }^{538}$

Openings were covered with makeshift structures when the water flow was strong enough to prevent complete opening to be filled. Temporary supports were constructed with makeshift load-bearing structures set upon them. Temporary supports could be built using the following methods: crates made with railway sleepers; ${ }^{539}$ wooden pillar frame structures set upon the ground; wooden pillars driven into the soil; timber cribs. ${ }^{540}$ Temporary supports were protected with starlings against the impact of ice floes or logs carried by flood waters. Provisional load-bearing structures made of wooden beams, rail bundles, I-beams and folding structures were laid on wooden supports. Mixed structures were also provided with the use of wooden beams and steel I-beam girders. Short-span I-beam girders (less than $4 \mathrm{~m}$ ) were slid onto supports with ropes and a lift placed on the opposite bridgehead. In the case of larger spans (over $5 \mathrm{~m}$ ), additional supports (rotational pillars) were set up beneath the span mid-sections.

In case of a partial damage to the span load-bearing structure (breakage of individual truss components, partial carriageway damage), the structure remaining on

537 Ministry of Transport, Podręcznik (1939), 139.

538 Ministry of Transport, Podręcznik (1939), 140-142.

539 Maximum permitted sleeper crate support height reached 10-12 m.

540 Cribs were used when piling intended as pillar frame support could not be driven into rocky or stony ground. 
supports but was unable to carry any traffic load, additional girder supports were developed at the damaged locations with the use of sleeper crates or piling span pillars. Damaged longitudinal and/or lateral beams in one or several span sections were replaced with rail bundles or rolled girders; the section in question could also be filled in with sleepers. ${ }^{541}$

Spans destroyed and collapsed into watercourses were elevated. Entire spans or their usable sections were lifted. Rapid reconstruction works involved the most common lifting method of levers placed against sleeper crates. In the case of lowweight structures and insignificant elevation (10 $\mathrm{m}$ or less), this was the fastest way to lift the collapsed spans. Levers ${ }^{542}$ (hydraulic, bolt, crank levers), lifts, pulleys and special-purpose suspension appliances were used in such an operation. In case of the use of a hydraulic lift, single or multiple lifting points were applied. In case of complete destruction of the span intended for elevation, structural truss components were reinforced with wooden beams, steel rods, or flat bar ties; concrete encasement would be applied as well. ${ }^{543}$

If a collapsed span was unusable or could not be easily lifted, it was used as a support for the new makeshift structure to facilitate rapid bridge reconstruction, usually limited to developing the bridge superstructure on the collapsed span; a fill of timber (timber crates) would be used; alternately, crate or wooden frame supports would be set upon the damaged structure, wooden beam girders, with steel I-beam girders or rail beams arranged on top. ${ }^{544}$

Should a larger-span bridge be completely destroyed and unsuitable for reconstruction - yet allow easy and swift removal of the damaged components the bridge opening would be divided into smaller sections, depending on girder availability. The supports would be constructed with the use of crates or frames, with new girders set upon them. If bridge reconstruction was to be permanent rather than provisional (and thus require a detour bridge for the time of reconstruction anyway), or if reconstruction works at the exact destroyed bridge location could prove difficult due to the old structure being impossible to be removed, excess support height, and/or poor riverbed conditions, the concept of bridge reconstruction along the old axis was to be abandoned, rebuilding works involving developing a track detour and detour bridge construction. ${ }^{545}$

541 Ministry of Transport, Podręcznik (1939), 178-180.

542 If no levers were available, low-elevation lifting could even involve the use of hardtimber wedges.

543 Ministry of Transport, Podręcznik (1939), 180-198.

544 Ministry of Transport, Podręcznik (1939), 199.

545 Ministry of Transport, Podręcznik (1939), 200-201. 
Railway troops were also trained in constructing wooden bridges. Such structures involved piling-, frame-, and piling-and-frame-based supports and abutments. Other solutions included crib pillars and supports as well as criband-frame supports (cribs used as a foundation to construct frame supports). Sleeper-built crate supports were used as well (maximum permitted height was 4-8 m, due to significant spring deflection). Wooden starlings were used as protection for temporary wooden bridges, which induced unfavourable water flow conditions.

The following temporary railway bridge span types were fairly common: beamed, stayed, trapeze-stayed, arched, framed, and Howe truss (steel frame). Fundamentally, wooden bridges developed since the 1950s were all beamed, ${ }^{546}$ framed bridges were built only on narrow-gauge lines. ${ }^{547}$

Soft timber (pine, spruce, fir) would be the common choice for wooden bridge construction, timber felled in wintertime was the optimum option.

During the previous wars, rolled beams would be a common choice in reconstructing small-span bridges. Rolled girders offered a number of advantages, such as easy storage, transport, and span assembly; disadvantages included insignificant beam length (30 m or less) and considerable weight. Span clusters were a simple and feasible solution for field conditions. Rolled-beam spans would be assembled on the riverbank, and slid onto supports in whole or in sections. ${ }^{548}$ Regular-flange and wide-flange rolled beam spans were developed with the use of rolled beams, longitudinal and lateral clusters, and railway track components.

The First World War experience served to prove beyond any doubt that the use of folding steel spans allowed the quickest restoration of rail traffic across major water obstacles. The development of technical battlefield solutions and modern weapons, not to mention the huge volumes of ammunition, supplies and fuels that had to be delivered to the operational rear of troops in combat, showed irrefutably that the use of folding steel bridges produced optimum effect. Such bridges were highly durable and highly resistant to destruction; they were designed and calculated to meet specific rolling stock load standards; truss assembly with the use of standard components was much faster and less complicated than the construction of wooden bridges. Furthermore, the construction of such crossings did not depend on the delivery of large volumes of timber which required pre-processing with field

546 In beamed bridge design, main beams carried the entire weight of the bridge, and were set upon support saddles. Bridge girders comprised single, multiple and composite beams.

547 Odbudowa mostów (1966), 266.

548 Odbudowa mostów (1966), 301. 
sawmills. In addition, steel bridges did not carry the risk of fire caused by sparks from locomotive ashpans. Yet due to the shortage of steel folding bridges and the need for quick reconstruction of crossings, the sapper units of the fighting armies constructed numerous wooden bridges during the Second World War as well.

\subsection{Folding Railway Bridges}

If a water obstacle required a large-span crossing, and in the case of bridge reconstruction over deep ravines in mountainous terrain or over large rivers in high water or ice floe conditions, folding structures were applied for temporary reconstruction purposes whenever the use of indirect supports (piling- or crib-based pillars) was not feasible. ${ }^{549}$

From a military point of view, folding bridges were considered the second and more permanent way of securing bridge crossing-related technical measures, pontoon bridges and accompanying mechanised bridges classified as first solution measures. ${ }^{550}$

In the second half of the 19th century, as the economic and military importance of railways increased, the first military-purpose folding bridges were introduced, their practical use becoming more common in the wake of the Franco-Prussian war in France. ${ }^{551}$ The technological changes in metallurgy and the development and popularisation of riveted joint technology - were of great significance to the progress in the field of folding bridges. The first folding railway bridges were made part of regular equipment issued to the engineering and railway troops in European countries in the 1890s. At the 1900 Exposition Universelle in Paris, railway and road folding bridges designed by Eiffel and a Polish engineer Brochocki were on display. ${ }^{552}$ At the turn of the 19th and the 20th centuries, the following folding railway bridge designs were introduced: Eiffel (French spans were also made part of regular equipment for the Russian army railway battalions), Harkot (Prussian railway folding bridge with a span of $30 \mathrm{~m}$ ), and Roth-Waagner (Austrian spans). In 1910, professor Paton designed a folding bridge structure, made part of regular production during the First World War. ${ }^{553}$ The design became hugely popular during the Great War; towards its end, armies

549 Ministry of Transport, Podręcznik (1939), 168-169.

550 Białobrzeski (1978), 8.

551 Białobrzeski (1978), 8.

552 Wrześniowski (1955), 217.

553 Wrześniowski (1955), 217. 
of the European countries involved in warfare owned several dozen kilometres of folding bridges. ${ }^{55}$

In Russia, dismountable bridges were used as temporary crossings during the construction of the strategic East China Railway.

Between the wars, the Polish Armed Forces Railway Sapper Units were issued steel Roth-Waagner ${ }^{55}$ and $(\mathrm{K})$ type folding rail bridges. ${ }^{556}$ Sapper companies handled folding span assembly.

The Roth-Waagner spans were designed by the Austrian officer Roth before the First World War, and manufactured at the Waagner plant. Prior to the First World War, they were commonly used by the Austrian army. The Roth-Waagner spans later became a design reference for the Wehrmacht's $\mathrm{R}$ system, and the British army's Everall Sectional Train Bridge folding span system. ${ }^{557}$

The versatility of the Roth-Waagner bridges offered numerous options of adapting them to the local conditions - spans could support top-, central- and bottom-deck carriageway bridges. ${ }^{558}$ The Roth-Waagner bridges could also be constructed on curved tracks. ${ }^{59}$ Adapting a bridge to the height involved the assembly of regular and elevated sections, as Roth-Waagner spans were available in single- and double-storey versions. The breadth could be increased by reinforcing bridge components, with conversion into double- and triple-walled sections. Single-walled girder spans were only applied for the purposes of narrow-gauge railway and road bridges. Conversely, the following components were used in the case of standard-gauge railway bridges: single-storey spans with double-walled girders and double-storey spans with double- or triple-walled girders. ${ }^{560}$ The Roth-Waagner bridge main beams were calculated according to standards I and II of the Austrian KKStB railway bridge load rates (from the year 1904). ${ }^{561}$

554 Białobrzeski (1978), 8.

555 Roth-Waagner folding spans were referenced as Type 1 by the Polish Armed Forces of the interwar period.

556 Ministry of Military Affairs, Budowa (1926).

557 Odbudowa mostów (1968), 11.

558 The improved German $R$ version of Roth-Waagner spans was used during the last war by the sapper units of the Wehrmacht. The considerable durability of this successful design is evidenced by the fact that even in the late 1960s, several Roth-Waagner spans continued to be in use on secondary lines of the Polish State Railways network.

559 Ministry of Military Affairs, Budowa (1926), 18.

560 Ministry of Transport, Podręcznik (1939), 173.

561 Ministry of Military Affairs, Budowa (1926), 4. 
The span breadth for mobile loads according to load standard C (in force on the Polish State Railways as of 1923) ranged from 18 to $84 \mathrm{~m}:{ }^{562}$

- single-storey double-walled spans - up to $45 \mathrm{~m}$,

- double-storey double-walled spans $-46.5 \div 72 \mathrm{~m}$,

- double-storey triple-walled spans $-72.5 \div 84 \mathrm{~m}$.

According to standard I loading rates of the Austrian KKStB railways (from the year 1904), the maximum permitted Roth-Waagner span breadth (top-deck carriageway) was $63 \mathrm{~m} .{ }^{563}$ Standard type I span truss sections were $3 \mathrm{~m}$ long consequently, the total main span width was a multiple of 3 . If so required, short sections could be installed at span-ends (so-called half-sections, $1.5 \mathrm{~m}$ in length). ${ }^{564}$

The Roth-Waagner spans were developed as lattice beams with parallel riveted sections, individual lattice (frame) components were connected using bolts. Roth-Waagner span components were made of open-hearth steel. ${ }^{565}$

The Roth-Waagner spans were assembled on scaffoldings, with the use of a special-purpose crane and the semi-cantilever or cantilever method. A cantilever Roth-Waagner span assembly involved the use of ballast, or ballast-free counterweights (longer spans). A semi-cantilever assembly involved the development of an additional support beneath the span, used when a suitable counterweight was not available, or whenever the limiting length of the cantilever was greater than the span width. A dismountable Roth-Waagner crane moving along the upper sections of the installed span was used for the purposes of span component assembly. The crane was fitted with winches and pulleys with a lifting capacity of 1.5 tonnes; the crane's front extension allowed span assembly over a frontal distance of $6 \mathrm{~m}^{566}$

One linear meter of a single-storey span could be assembled within 1 hour. One linear meter of a double-storey span took about 1 hour and 30 minutes to assemble. The assembly of a double-storey tripled-walled span required approximately 2 hours. ${ }^{567}$

562 Odbudowa mostów (1968), 12; Ministry of Transport, Podręcznik (1939), 175.

563 Ministry of Military Affairs, Budowa (1926), 5.

564 Ministry of Transport, Podręcznik (1939), 171.

565 Ministry of Military Affairs, Budowa (1926), 1.

566 Ministry of Military Affairs, Budowa (1926), 15.

567 Ministry of Transport, Podręcznik (1939), 176.

Zbigniew Tucholski - 978-3-631-82966-0 
The span's heaviest component (end section) weighed $627 \mathrm{~kg}$ (length: $6.5 \mathrm{~m}$ ); Roth-Waagner span dead weights were as follows: ${ }^{568}$

- double-storey double-walled spans: 3.0 tonnes $/ \mathrm{m}$,

- double-storey double-walled spans: 4.2 tonnes $/ \mathrm{m}$,

- double-storey triple-walled spans: 6.2 tonnes $/ \mathrm{m}$.

The other system $(\mathrm{K})$ of folding railway bridges made part of regular equipment carried by Railway Sapper units of the Polish Armed Forces between the wars was basically intended to replace the damaged spans of permanent bridges. $\mathrm{K}$-type bridges could also be used as temporary crossings developed in field conditions on railway lines or roads, whenever time disallowed the provision of a permanent bridge. ${ }^{569}$

The bridge structure comprised the main lattice beam and lateral carriageway and wind brace components. The rivetted components of K-type bridges could be square, triangular, rod-shaped, or latticed. The extended bridge crossbeam was the structure's heaviest component ( $650 \mathrm{~kg})$; a $6 \mathrm{~m} \mathrm{sec}$ tion was its longest element. ${ }^{570} \mathrm{~K}$-type bridges could be assembled as single-, double-, or triple-storey structures. Single-storey bridges were assembled as single or double-walled.

K-type bridges were installed for the purposes of crossing obstacles with the use of the following: $:^{571}$

1. standard-gauge railway (Polish State Railways load standard D), single-storey structure; double traction - maximum span breadth: $24 \mathrm{~m}$ span, single locomotive - maximum span breadth: $30 \mathrm{~m}$;

2. narrow-gauge railway (two military steam locomotives) single-storey, doublewalled - span breadth: $24 \mathrm{~m}-36 \mathrm{~m}$,

3. narrow-gauge railway (single military steam locomotive) single-storey, singlewalled - maximum span breadth: $27 \mathrm{~m}$,

4. roads, single-walled - maximum span breadth: $33 \mathrm{~m}$; double-walled - maximum span breadth: $42 \mathrm{~m}$.

K-type bridges were built on a scaffolding, with the use of the cantilever or mixed method (on scaffolding, partly with the use of cantilevers). A crane moving along

568 Odbudowa mostów (1968), 15.

569 Ministry of Military Affairs, Budowa (1926), 61.

570 Ministry of Military Affairs, Budowa (1926), 64.

571 Ministry of Military Affairs, Budowa (1926), 62-63. 
the main section-mounted track was used for the purposes of cantilever assembly of double-walled single-or double-storey K-type bridges. ${ }^{572}$

During the Second World War, Wehrmacht sapper troops were issued six folding railway bridge systems: $\mathrm{V}$ - four-girder and six-girder; Roth-Waagner - single- and double-storey; $\mathrm{MZ}$ - single- and double-storey; $\mathrm{R}$ - single-, double-, and triplestorey; SZ - single- and double-storey; SKR 6 - single-, double-, and triple-storey. ${ }^{573}$ Using the aforementioned spans, the German troops rebuilt the damaged railway bridges on the Polish territory. Other equipment employed by Wehrmacht sapper troops on the Polish territory included the captured French Bonneta-Schneider (BS) railway spans, and the seized Czechoslovak Skoda-Faltus (SF) spans. ${ }^{574}$ After the war, the UNRRA aid included the delivery of heavy English ESTB ${ }^{575}$ system spans to Poland (span breadth: $36.5 \div 21.92 \mathrm{~m}$ ), used to reconstruct the damaged Polish State Railways network (i.e. the railway bridges in Tczew on the Vistula and in Malbork on the River Nogat). ${ }^{576}$

Equipment issued to the railway troops ${ }^{577}$ of the Red Army at the time included non-dismountable top-deck carriageway L-23 lattice spans (theoretical breadth: $23.04 \mathrm{~m}$, span height: $2.67 \mathrm{~m}$ ). ${ }^{578}$ Main parallel-section span girders were fitted with triangular lattice and support posts. Upper and lower wind braces (and lateral bracing on supports and each post) were installed between the girders. Due to their considerable weight (28 tonnes), the spans could only be transported by railway flat wagons. Spans were placed on wooden supports with the use of special-purpose wagon cantilever cranes. The use of such bridge reconstruction technology by the Red Army allowed extremely fast assembly of temporary bridges.

During the Vistula-Odra Offensive, the Russian forces rebuilt most of the railway bridges across the major rivers on the Polish territory with the use of

572 Ministry of Military Affairs, Budowa (1926), 76.

573 Odbudowa mostów (1968), 11.

574 Three types of Skoda-Faltus spans were designed: Aa, Ab and Ac - for railway bridges, types $\mathrm{B}$ and $\mathrm{C}$ - for narrow-gauge railway bridges and road bridges, and $\mathrm{D}-$ for road bridges.

575 Everall Sectional Train Bridge.

576 EVERALL SECTIONAL TRAIN BRIDGE spans in Tczew were moved from the railway bridge to the road bridge in 1958 .

577 Soviet brigades of railway troops employed special-purpose bridge reconstruction trains. These trains featured appropriate mechanical equipment and wagon cantilever cranes for the installation of temporary railway spans. Soldiers assigned as crews to bridge reconstruction trains were quartered in living vans.

578 Odbudowa mostów (1968), 28. 
L-23 spans: over the River Vistula near Opalenie, at the Warsaw Citadel, over the River Odra near Szczecin, over the River Narew near Modlin, and near Dęblin and Sandomierz. ${ }^{579}$

The single track bridge near the Warsaw Citadel was elevated 15 meters above the destroyed abutments. Twenty five L-23 steel frames were placed on wooden supports and abutments, the total bridge length was $510 \mathrm{~m} .{ }^{580}$ The bridge was reconstructed over a period of 10 days with the use of L-23 spans. ${ }^{581}$

After the war, Polish Armed Forces troops were issued L-23 spans as well, most were withdrawn from use in the 1950s and 1960s for reasons of their low strength rating and poor design. Static calculations for L-23 spans proved that (in dynamic coefficient terms) they usually did not even conform to load standard $\mathrm{C}$ in force during the previous period ${ }^{52}$ (17 tonnes/ axle load). In view of the load standard NL having been introduced for the Polish State Railways rolling stock in 1955 (20 tonnes/ axle load), limits for rolling stock passage were adopted in conformity to the new standard. When crossing L-23 span bridges, trains had to reduce their speed to $5 \mathrm{~km} / \mathrm{h}$ when hauled by a single locomotive. ${ }^{583}$ A single Russian L-23 span was left for training purposes on a military training ground of the 2nd railway regiment in Łojewo near Inowrocław. ${ }^{584}$

In the mid-1950s, new L-30 folding spans (designed and produced in Poland to the $\mathrm{NL}^{585}$ load standard) were introduced as an equipment issued to bridge battalions of railway troops (the L-30 span design was modelled on Second World War Russian L-23 spans). The L-30 type lattice span was partly dismountable, with a top-deck carriageway and theoretical maximum span breadth of $30 \mathrm{~m}$. L-30 spans comprised two parallel-section lattice girders and a rectangular truss with support posts and crossbars. The extreme cross-braces converged with the upper section, forming the basic trapezoidal truss outline. The carriageway comprised rails and bridge sleepers or sleepers, arranged directly on the main girder's upper section. In an effort to reduce the dead weight, the span structure was designed with high-quality $18 \mathrm{G} 2 \mathrm{~A}$ steel, the posts, bracing and wind braces with standard St3S steel (with riveted main girders). The total weight of an L-30 span was 42 tonnes.

579 Odrodzenie (1947), 30.

580 Sterner (1960), 145-146.

581 Odbudowa mostów (1968), 29.

582 Bridge load standard was in force for PKP from 1923.

583 Odbudowa mostów (1968), 30.

584 Colonel Józef Szajka's account of June 11th 2006.

585 All spans manufactured by the Railway Bridge Production Plant Białystok-Starosielce. 

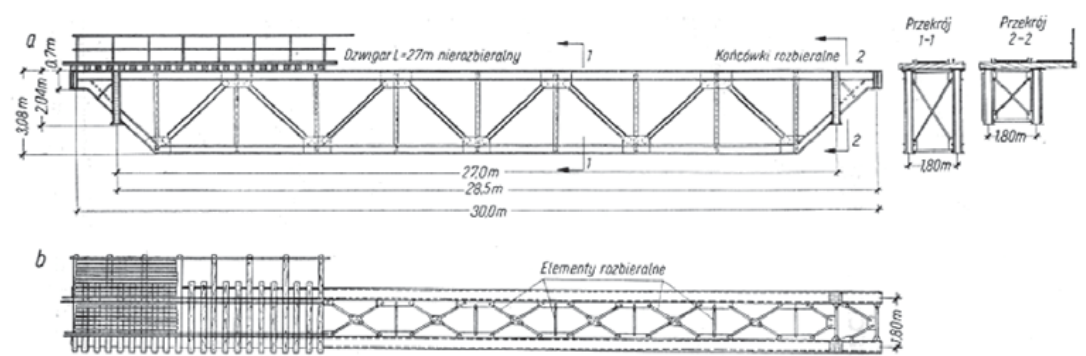

Schematyczny rysunek przęła $\mathrm{L}-30 \mathrm{z}$ rozbieralnymi końcowikami a - widok z boku, b - wldok z góry

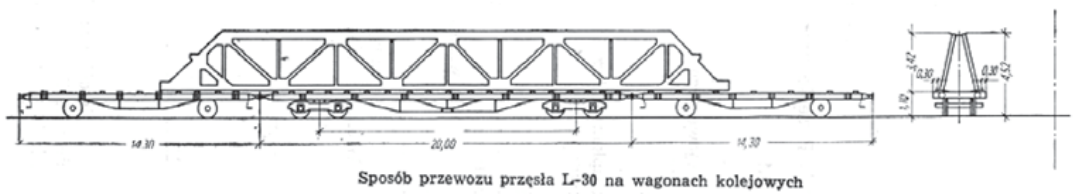

1. A diagram of an L-30 span with removable ends. 2. Transport of an L-30 span on railway wagons.

Source: Odbudowa mostów (1968)

The L-30 spans were transported upon assembly by heavy railway flat wagons, as an out of gauge load. The main span girders were transported by three railway flat wagons: the central wagon upon which the span rested (load-bearing capacity: 42 tonnes, length: $20 \mathrm{~m}$ ), and two backup flat wagons to support the span-ends. ${ }^{586}$ The girders were unloaded onto sleeper-built crates by crane or, if unavailable, using a manual lift. The span assembly involved the embedding of upper wind braces and lateral bracing between the girders. L-30 girders were fitted with dismountable girder-ends (length: $1.5 \mathrm{~m}$ ), allowing a theoretical span width adjustment to $27.0 \mathrm{~m}$ or $28.5 \mathrm{~m}$ by removing one or both ends. ${ }^{587}$ The main girders were supported by fixed and mobile tangent bearings. ${ }^{588}$

586 Odbudowa mostów (1968), 33.

587 Odbudowa mostów (1968), 34.

588 Two methods of setting an assembled L-30 span on supports were used. The first method involved their placement on the track on special-purpose trolleys, upon which they were moved to the outer bridge support. Once lifting beams were in place, two KR-36 gantry cranes were brought in, the span suspended thereon. After the span was hoisted by the KR-36 cranes, it was hung on the gantry crane, moved onto the bridge 
The second method involved the transport of pre-assembled spans onto the bridge axis, and lowering them onto supports with the use of SRK (Sborno Razbornyj Kran) 30/40 railway cranes.

The L-36 span (width: $36 \mathrm{~m}$ ) was more modern, also designed and produced in Poland. ${ }^{589}$ The span was a parallel-section double-girder ${ }^{590}$ truss, with a topdeck carriageway. The L-36 span design was largely modelled on the English ESTB wartime folding spans. To facilitate transport and assembly, a span $36 \mathrm{~m}$ long ${ }^{591}$ was composed of six independent 6 -metre bolt-connected truss sections (weight: $2890 \div 2951 \mathrm{~kg}$ ). The span was assembled with the use of 20 different components.

In an effort to reduce the dead weight to the extent possible, the main span structural components were designed with high-quality $18 \mathrm{G} 2 \mathrm{~A}$ steel, secondary components constructed with the use of St3M steel. ${ }^{592}$ Structural span components were welded; the use of welding technology and adequate materials allowed an overall span weight of 48.349 tonnes - or 1.34 tonnes $/ \mathrm{m} .{ }^{593}$

axis, and lowered by lift. Placed on trolleys, the span was moved with the use of a puller winch and a brake winch. After lowering the span onto supports, the KR-36 gantry cranes were moved backwards to suspend the next span. Bridge sleepers, tracks, and footpaths were constructed on the span after it had been aligned on the bridge axis.

589 All spans manufactured by the Railway Bridge Production Plant Białystok-Starosielce.

590 Trusses with multiple statically indeterminate lattice.

591 Smaller-breadth spans were used as well, with fewer lattice elements (length: $30 \mathrm{~m}$, weight: 40.581 tonnes, i.a. 1.34 tonnes $/ \mathrm{m}$; and length: $24 \mathrm{~m}$, weight: 32.828 tonnes, i.a. 1.36 tonnes $/ \mathrm{m}$. The use of spans shorter than $24 \mathrm{~m}$ was not economically viable in view of the inability to use the remaining elements to assemble an independent span.

592 Odbudowa mostów (1968), 37.

593 Odbudowa mostów (1968), 37. 

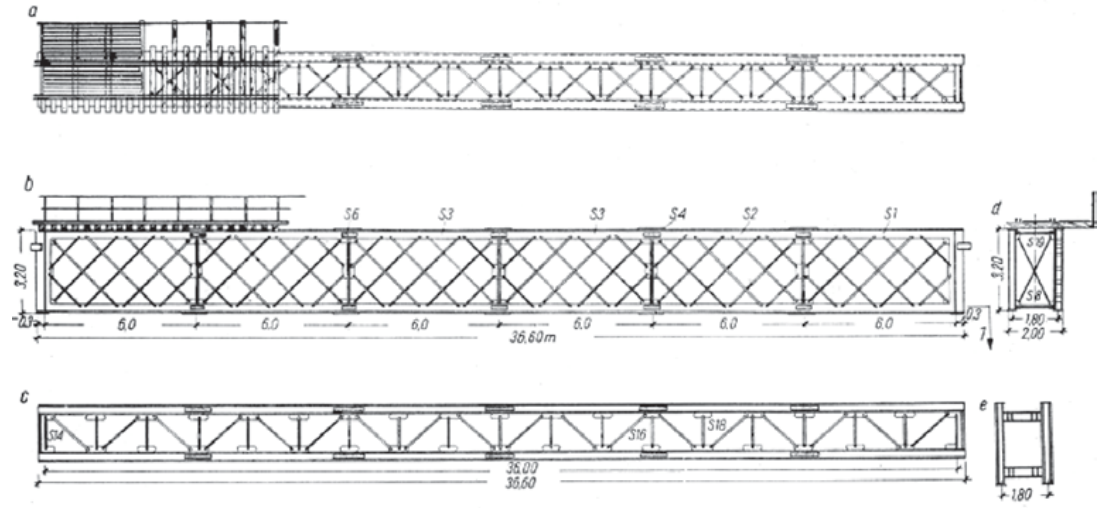

Rysunek zestawieniowy przęsła L-36

c - widok z göry, b - widok z boku, $c-$ wiatrownice dolne, przekró $1=1, d-$ steżenle poprzeczne, $e-$ widok od czoła

An L-36 span.

Source: Odbudowa mostów (1968)

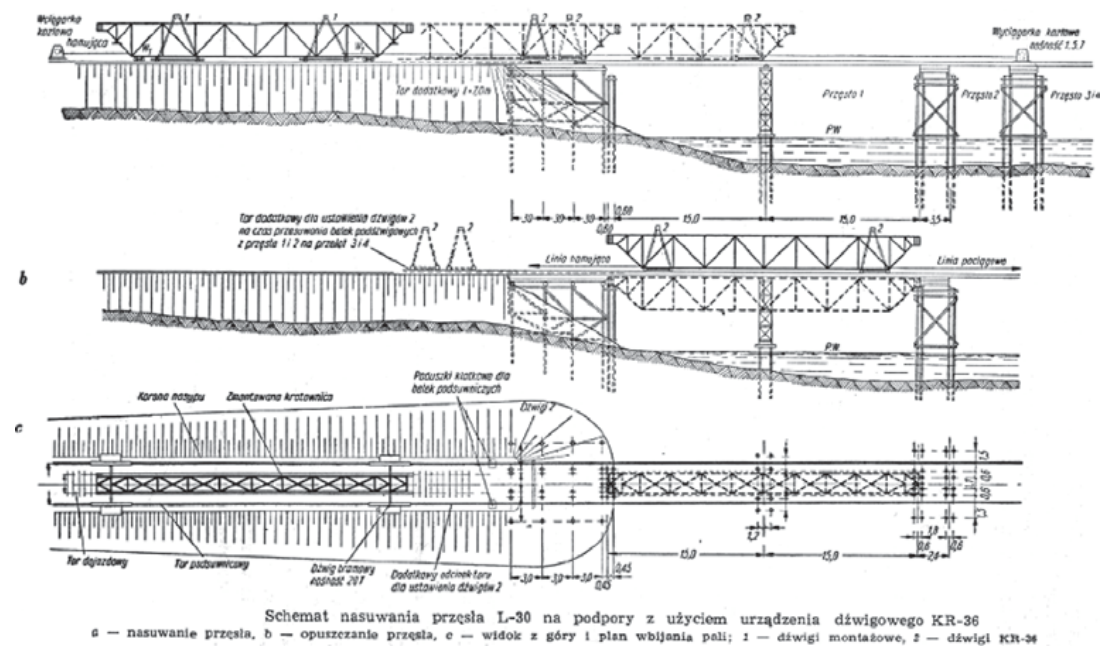

A diagram of sliding an L-30 span onto piers using a KR-36 crane device.

Source: Odbudowa mostów (1968)

A carriageway of bridge sleepers or IB sleepers was constructed on the span's parallel sections (on main girder sections directly). S42 or S-49 rails, with accessories, were laid upon the bridge sleepers or bridge sleepers. Check-rails were 
installed between the rails. A one-sided footpath (for railway service crews) with a handrail was installed on the span. Mobile and fixed tangent bearings were used on the L-36 span. ${ }^{594}$

The option of multi-section span assembly allowed component transport by rail and by road (on low-floor trailers with a load-bearing capacity rating over 8 tonnes). Six-metre spatial blocks were transported on a railway flat wagon, 2 per wagon. As such components were slightly wider than the rolling stock loading gauge, they could only be carried as out-of-gauge loads.

The L-36 span assembly required unloading and assembly sites to be organised near the bridges undergoing reconstruction. K-104 lorry-mounted cranes (installed on KrAZ219 lorry chassis), K-162 lorry-mounted cranes, and SRK 50 railway cranes (designed to transport and assemble the L-36 trusses) were used to unload the span sections from railway flat wagons on assembly sites. Once assembled, spans were transported to the bridge on tracks, by special-purpose railway trolley or by a SRK 50 railway crane.

Once assembled, the span could be positioned on supports using a KR-36 device (as in the case of the L-30 spans); by moving the span over the watercourse and lowering it onto bearings with the use of KR-36 gantry cranes; or by arranging the span with the use of floating measures or an SRK50 railway crane.

In the 1950s foldable steel supports were developed in the USSR for military purposes, with intent to reconstruct or build damaged railway bridge supports. These supports were developed up to a maximum height of $20 \mathrm{~m}$, to construct top-deck carriageway railway spans (breadth: $23 \div 36 \mathrm{~m}$ ), and bottomdeck carriageway spans (breadth: $36 \div 72 \mathrm{~m}$ ). The Russian project was modified to reflect the Polish technical conditions of bridge design, and Polish State Railways load standards. The folding steel supports were made of the following steel grades: 18G2A (main structural elements) and St3M ${ }^{595}$ (other elements), and used to carry L-30 and L-36 spans. Supports were placed on a piling cap and grating, comprising piling bundles driven into watercourse beds with the use of pile drivers.

In the late 1950s, a military-purpose folding railway overpass was designed in the USSR, intended for the rapid railway bridge reconstruction and to cross shallow water obstacles. This state-of-the art universal structure was labelled REM-500 (Rasbornyi Estakadnyi Most, single set length: 500 m). Russian documentation was later used to develop a variant of this overpass; its production

594 Odbudowa mostów (1968), 50.

595 Odbudowa mostów (1968), 128. 
commenced in Poland, the structure labelled SEK-500 (Składana Estakada Kolejowa - Folding Railway Overpass). The Polish design involved lowerstrength steel; consequently, the cross-sections of its structural elements were increased. ${ }^{596}$ The overpass was produced by the Railway Bridge Production Plant Białystok-Starosielce. ${ }^{597}$ An overpass version modelled on the Russian design was also developed in East Germany and labelled ESB-16 (Eisenbahnbrücke length: $16 \mathrm{~m}$ ). The design and production commencement of folding railway overpasss in the Warsaw Pact armies was associated with the changes to the battlefield technical solutions, arising from the development of the nuclear warfare doctrine. The operational plans predicted that the initial NATO tactical nuclear warhead strike would destroy the permanent strategic crossings on the Rivers Odra and Vistula, on main railway lines along the Western Operational Direction. The REM-500 overpass (modified) and that NZM-56 floating railand-road bridge would be used to quickly develop substitute crossings for the damaged railway bridges over the Rivers Vistula and Odra.

Consequently, the SEK-500 overpass components were introduced as equipment issued to railway and road units (railway bridge battalion of the 2nd railway regiment in Inowrocław).

The overpass could also be used to cross floodplains, on approaches to floatingsupport bridges, and to cross breakages in railway embankments. It could also be employed on approaches to high-rise detour bridges, allowing the elimination of time-consuming embankment construction. In shallow water and weak current conditions, the overpass could also be used to cross standing and running water.

The SEK-500 overpass was a steel structure, its components used to assemble spans and bridge supports alike. An NL standard train, its full dynamic coefficient increased by $10 \%$, was adopted as the mobile load benchmark (in view of the fact that rails were laid directly on the main span beams). The maximum permitted speed for trains crossing the overpass was set at $30 \mathrm{~km} / \mathrm{h}$, the maximum longitudinal gradient at $30 \% 0 .{ }^{598}$

The theoretical span of individual spans was constant (length: $12.51 \mathrm{~m}$ ). The greatest structural height of the overpass (bottom of the foundation footing to span rail heads) reached $14.0 \mathrm{~m}$ (lowest height: $3.06 \mathrm{~m}$ ). while the overpass was adapted for construction along straight and curved lines alike, a single radius rating ( $R=400)$ was permitted. The design of the overpass involved two steel

596 Colonel Józef Szajka’s account of June 11th 2006.

597 Colonel Józef Szajka’s account of June 11th 2006.

598 Odbudowa mostów (1968), 72. 
grades: high-quality 18G2A steel for support structures and support pillars, and St3M steel for other components. All structure joints were welded, individual components bolt-connected during assembly. The overpass set comprised 40 spans and 39 supports (length: $500 \mathrm{~m}$ ). The total weight of the set was 825.5 tonnes, i.e. 1.63 tonnes/ $\mathrm{m}$ across the entire structure. Each overpass span was assembled with the use of 14 assorted repetitive components, supports requiring 19 repetitive components. ${ }^{599}$ The size of individual overpass components allowed for transport by rail and by road, without exceeding the loading gauge.

S-49 rails were connected to the upper overpass section with bolts and washers. A footpath (for railway service crews) was provided along the external span girders. A service platform was periodically suspended on chain hoists from overpass support structures (supports), to allow adjustment works and bolt connection checks.

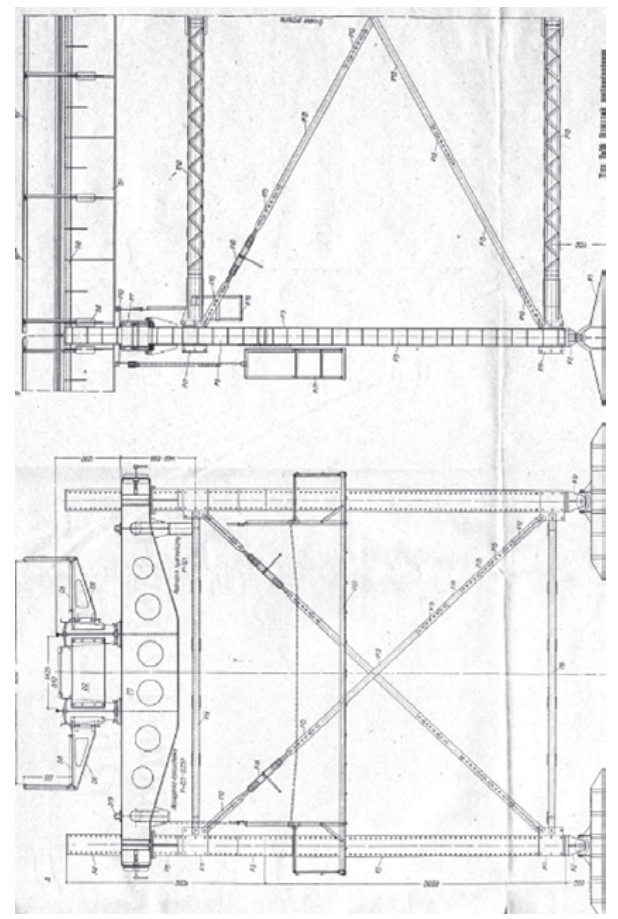

Source: Odbudowa mostów (1968)

Construction drawings of a Folding Railway Overpass (SEK-500).

599 Odbudowa mostów (1968), 78. 


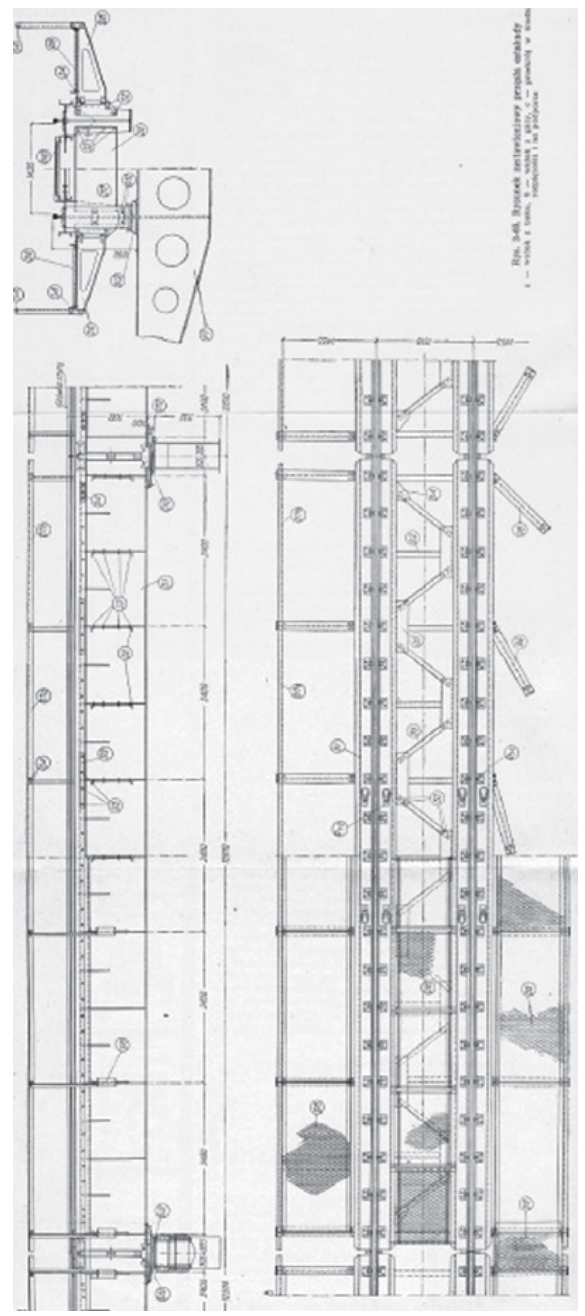

The main overpass girder supports were assembled with the use of a K-104 lorrymounted crane (installed on a KrAz-219 lorry chassis), K-162 lorry-mounted crane, or SRK 20 railway crane, or with the use of the cantilever method involving a trolley to slide the span and a winch-fitted rolling crane. ${ }^{600}$ Upon assembly

600 Assembly supports were made of piles driven into soil, or sleeper crates.

Zbigniew Tucholski - 978-3-631-82966-0

Downloaded from PubFactory at 09/30/2020 04:51:29PM by keerthiga.m@newgen.co

via Peter Lang AG and keerthiga.m@newgen.co 
of the entire overpass, it would be levelled and adjusted along the vertical and horizontal axis.

Since the 1960s, railway cranes of Soviet design and manufacture had been used for the purposes of assembling and transporting folding bridge spans and SEK-500 overpasss components. The SRK-20 crane (lifting capacity: 20 tonnes) was designed to transport and align the SEK-500 overpass elements. It had a light-alloy structure to account for the need to enter the temporarily developed overpass sections during assembly. The SRK 30/40 crane (lifting capacity: 30 tonnes) was used to transport and align the L-30 lattice spans along the bridge geodetic axis, while the SRK-50 crane (lifting capacity: 50 tonnes) was designed to transport and align the assembled L-36 trusses (weight: 48 tonnes) along the bridge geodetic axis.

The cranes were not self-propelled - they were moved by a diesel locomotive or a KrAZ 256 lorry (fitted with rollers allowing it to be used on railway track). The cranes were transported to the assembly site on seven freight wagons, and assembled over a single day. The cranes were fitted with the following accessories: a power generator, a counterweight, and a system of three electric winches to raise and lower the transported trusses and supports. Two winches were mounted on the crane's operating arm. The winches were controlled from the panels located on the platforms provided on both sides of the crane. The crane was equipped with small four wheel bogies (with an option to replace them with broad-gauge 1,524 $\mathrm{mm}$ bogies). Not fitted with regular coupling devices, the crane was connected to a locomotive or a KrAZ lorry with a special-purpose beam and pin. The crane was operated by a crane team of ten soldiers and a non-commissioned officer operator.

The SRK-30/40 folding crane could be installed on rails or floating vessels according to three different procedures. The assembly following the first scheme meant that the crane could be used on the broad Soviet Railway loading gauge. The assembly according to the second scheme allowed the crane to operate within the standard gauge loading gauge. The third way of assembling the crane meant that it could be used on floating vessels (NZM-56 pontoon bridge) - following a number of improvements, this version enabled the crane lifting capacity of 40 tonnes.

The crane design enabled the negotiating of curves with a radius not less than $150 \mathrm{~m}$.

The railway bridge battalion of the 2nd railway regiment in Inowrocław had three railway cranes: the SRK 20, SRK 30/40, and SRK 50. The 12th railway regiment in Tarnowskie Góry (JW 4117) operated one SRK20 crane as well. ${ }^{601}$

601 Colonel Józef Szajka’s account of June 11th 2006. 
The NZM-56 (Naplavnoy Zheleznodorozhnyi Most) folding floating rail-androad bridge of Russian design and production (design: mid-1950s) allowed the provision of crossings of a maximum length of $500 \mathrm{~m}$ over 2 to 4 days. ${ }^{602}$ The bridge was adapted for assembly together with the SEK-500 overpass. The NZM-56 set comprised floating bridge supports (pontoons) and a span structure which included road and rail lengths, bank and elevation supports, and auxiliary equipment.

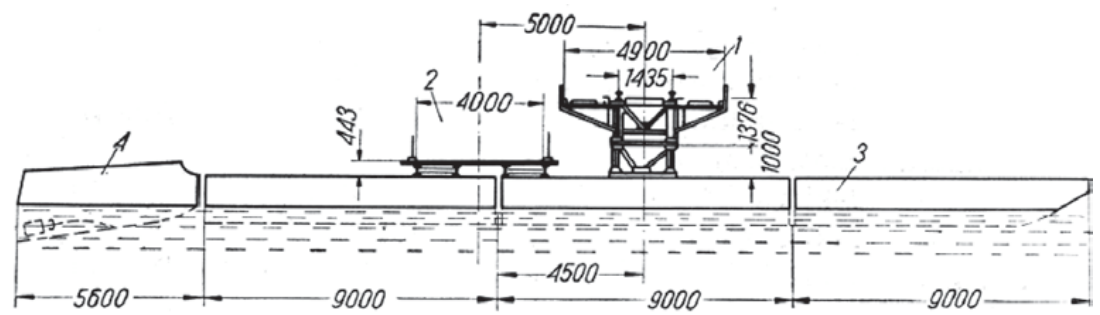

Przekrój poprzeczny mostu pontonowego NżM-56

A cross-section of a NZM-56 floating bridge.

Source: Odbudowa mostów (1968)

Welded railway bridge spans were $6.25 \mathrm{~m}$ long. A footpath was provided along both sides of the spans. The bridge allowed the laying of $1,524 \mathrm{~mm}$ and $1,435 \mathrm{~mm}$ tracks. Main railway span girders comprised two welded I-beams connected with lateral and longitudinal braces. Four I-beams were installed in the carriageway cross-section. These beams were aligned on pontoon bulwarks. Beams were paired with the use of struts mounted above the pontoon side boards. Struts were also used to attach beams to the pontoon side boards. The road surface was built with the use of double wooden logs, arranged laterally. ${ }^{603}$

Pushers were used to connect the bridge sections. The floating component comprised sections; a typical bridge section of 6 pontoons was $37.5 \mathrm{~m}$ long. Each bridge section was provided with three pushers. A complete NZM-56 bridge set could be used to develop 13 ferry crossings with a load-bearing capacity of 300 tonnes reach. Upon transition from a shore to a floating component, a hoisting

602 Odbudowa mostów (1968), 228.

603 Odbudowa mostów (1968), 229. 
support was used, adjustable depending on water level conditions, connected with an articulated span-joint above it. ${ }^{604}$

The riverbank spans were developed to connect the shore to the carriageway of the floating bridge section, one end connected to the carriageway on the floating support, the other - resting upon a crate of railway sleepers on the bank. Navigation was enabled by a drawbridge section, the clearance between the drawbridge section components and the connected pontoon bridge reaching $300 \div 500 \mathrm{~mm}$. Such a solution warranted unrestricted attaching and detaching of the drawbridge section. ${ }^{605}$

\subsection{Railway Bridge Crossings Built by the Road and Railway Units of the Polish Armed Forces as part of the Warsaw Pact Military Exercises and Performing Tasks to Support the National Economy}

In 1962, the 2nd railway regiment (as part of a field camp in Rybienko near Wyszków), working together with the bridge company of the 1st road and bridge battalion and the bridge company of the 2 nd road and bridge battalion, built a permanent railway bridge over the River Bug (length: $446 \mathrm{~m}$ ) in Rybienko Leśne near Wyszków (riveted steel frame, bottom-deck carriageway). ${ }^{606}$

In the years 1962-1963, the 2nd railway regiment (as part of field camps in Łojewo), working together with the bridge company of the 2 nd road and bridge battalion, constructed a railway siding (length: $3.5 \mathrm{~km}$ ), bridgeheads and a bridge across the Noteć Channel (single-track, steel frame, bottom-deck carriageway, length: $38 \mathrm{~m}) .{ }^{607}$

In 1964, on the military training site of the 2nd railway regiment in Łojewo, a presentation of the NŻM-56 bridge construction was performed for PMD officers. ${ }^{608}$

On July 11th-13th 1964, a model procedure of constructing a NZM-56 roadand-rail bridge (length: $142 \mathrm{~m}$ ) on the Lake Szarlej, together with railway and road approaches, was organised on the bridge military training site of the 2 nd railway regiment in Łojewo, as part of a tactical and communications exercise. ${ }^{609}$

604 Odbudowa mostów (1968), 229.

605 Odbudowa mostów (1968), 230.

606 Gembora, Ref. No. 1138, 437.

607 Gembora, Ref. No. 1138, 446, 451.

608 Gembora, Ref. No. 1138, 455.

609 Gembora, Ref. No. 1138, Attachment No. 8, 2. 
The presentation was witnessed by Marshal Marian Spychalski, and by Chief of General Staff of the Polish Armed Forces General Jerzy Bordziłowski. ${ }^{610}$

On September 7th-8th 1965, the 2nd railway regiment constructed piers and ferry crossings with the use of NZM-56 bridge components on the River Vistula in Nowy Dwór near Kwidzyn, as part of the military exercise codename OPAL-65. ${ }^{611}$

On October 1st-2nd 1965, the 2nd railway regiment constructed piers and ferry crossings with the use of NZM-56 bridge components on the River Vistula in Topólno, as part of the military exercise codename BAZA-66. ${ }^{612}$

Also in 1966, during a visit by Chief Quartermaster of the Polish Armed Forces Lieutenant General Wiktor Zieminski, accompanied by the Minister of Transport Piotr Lewiński, a procedure of constructing a NZM-56 bridge was organised on the military training site of the 2nd railway regiment in Łojewo. ${ }^{613}$

In May 1967, the 2nd railway regiment constructed an L-30 structure-based railway bridge (to the NL load standard, length: $60 \mathrm{~m}$, with wooden supports) on the River Nysa Kłodzka in Gracze as part of a regiment tactical and communications exercise for the reserve corps. ${ }^{614}$

In May 1969, the railway bridge battalion of the 2nd railway regiment from Inowrocław assembled a number of SEK-500 overpass spans sections, which were connected with an adjustable support to a single ferry of the NZM56 floating railway bridge, as part of a military exercise in Nowy Dwór near Kwidzyn. The facility was partially built on site of the planned strategic railway crossing over the River Vistula, on the Smętowo - Opalenie Tczewskie - Nowy Dwór Kwidzyński - Kwidzyn railway line. ${ }^{615}$ The overpass spans and supports were transported by an SRK crane pushed by a diesel locomotive - a significant advantage over lorries operated by the Soviet Army, adapted for rail operation. ${ }^{616}$

610 Gembora, Ref. No. 1138, 384.

611 Gembora, Ref. No. 1138, 384, 397.

612 Gembora, Ref. No. 1138, 397.

613 Gembora, Ref. No. 1138, 384.

614 Gembora, Ref. No. 1138, 397.

615 Colonel Józef Szajka's account of June 11th 2006.

616 Lieutenant Colonel Kazimierz Balog's account of December 10th 2006.

Zbigniew Tucholski - 978-3-631-82966-0 


\section{"BARIERA 70" Military Exercise of the Allied Forces, Lugi Górzyckie}

In October 1970, a bridge crossing was constructed over the River Odra near Kostrzyn with the use of a REM-500 overpass (length: $570 \mathrm{~m}$, to the NL load standard), as part of the "BARIERA 70" military exercise of the Warsaw Pact Allied Forces. ${ }^{617}$ The railway bridge battalion of the 2 nd railway regiment in Inowrocław under Captain Janusz Oraczewski's command constructed a railway siding (approximate length: $3 \mathrm{~km}$ ) during the preparatory period; the siding branched near Ługi Gorzyckie, securing a connection to Odra floodbanks.

A triangular siding entrance was constructed so that the siding could be entered directly from the mainline from both directions (Kostrzyn and Rzepin/ Górzyca).

On the German side, a siding diverging at kilometre 3.502 of the Küstrin Kietz - Frankfurt (Oder) line of an approximate length of $1 \mathrm{~km}$ was constructed, branching off the line before the Neu Manschnow station (located on km. 3.8). Plans involved wartime construction of a folding railway bridge with the use of REM-500 overpass components on the River Odra. The Neu Manschnow - Ługi Górzyckie reserve section allowed the direct transit of military troop trains from Rzepin and Kostrzyn to Berlin, bypassing the Kostrzyn - Küstrin Kietz section, which was vulnerable to destruction. ${ }^{618}$

A temporary road-rail crossing was developed over the River Odra with the use of REM-500 overpass components (on the Polish side and directly on the Odra) and ESB-16 folding spans (on the German side) as part of the 1970 "BARIERA 70" International Joint Military Exercise (of the Polish Armed Forces, the Soviet Army and the East German National People's Army). The overpass spans and supports were transported by an SRK crane shunted by a diesel locomotive. ${ }^{619}$

On the flood embankment - riverbank section the overpass was assembled by the railway bridge battalion of the 2 nd railway regiment from Inowrocław; a railway bridge battalion of the Soviet Army constructed the overpass on the river proper. The railway bridge battalion of the 2 nd railway regiment used lorrymounted cranes to assemble overpass supports along the axis of the crossing (they were positioned vertically with the use of winch trimmers); an SRK 20 type railway crane was used to carry and align spans along the bridge geodetic axis. The railway bridge battalion of the Soviet Army used an SRK 20 crane to align

617 Gembora, Ref. No. 1138, Attachment No. 8, 4.

618 Kuhlmann (2004), 94.

619 Lieutenant Colonel Kazimierz Balog's account of December 10th 2006. 
the overpass components and supports on the river. Two SRK 20 cranes were used to build the crossing. ${ }^{620}$

\section{Railway Bridge Construction in Małkinia (1971)}

In 1971, the 2nd railway regiment in Inowrocław constructed a new permanent road-rail bridge on the River Bug in Małkinia (Siedlce - Małkinia - Ostrołęka line) as part of a task to support the national economy. The L-36 folding military spans were appropriately adapted for the purpose, extended to a length of $48 \mathrm{~m}$ by adding two sections (each $6 \mathrm{~m}$ long). Following the extension, spans had to be reinforced from the outside (to the left and right) with additional girders; consequently, quadruple-sided bridge spans were developed, their load-bearing capacity was significantly increased. Standard bolt connections on span sections and other structural elements were replaced with rivets. ${ }^{621}$

\section{Construction of a High-Water Temporary Bridge on the River Nogat in Malbork (1972)}

In 1972 in view of the planned construction of a new reinforced-concrete bridge to replace an old bridge on its old site, ${ }^{622}$ a temporary detour bridge crossing was developed with the use of military folding railway bridge components. According to contemporaneous assumptions, the substitute bridge would be operated for a period of five years. The bridge was constructed by the railway bridge battalion of the 2nd railway regiment in Inowrocław (JW 1523) as part of a task to support the national economy. The bridge construction works were supervised by Major Kazimierz Balog. The temporary railway bridge was constructed with the use of REM 500 overpass components on approach to the crossing, and L-30 steel frames over the River Nogat.

The L-30 bridge spans on the river were aligned on folding steel supports resting upon a wooden pile grating. Assembly base No. 1 developed for the

620 Colonel Józef Szajka's account of June 11th 2006.

621 Colonel Józef Szajka's account of June 11th 2006.

622 After the war, the destroyed railway bridge over the River Nogat in Malbork (WarsawGdańsk line) was temporarily reconstructed with the use of heavy folding spans of the English ESTB system. The increased rail traffic and the declining technical condition of old-type spans gave rise to the need of developing a new bridge in the early 1970s. Since a bridge was necessary to secure uninterrupted train traffic, a decision was made to set up a provisional bypass bridge. 
purposes of assembling the steel supports and the treatment of wooden piles to be used for pile grating was set up $1.5 \mathrm{~km}$ upstream. Piling to be driven into the riverbed was floated down the river by boat, three KDM $2 \mathrm{M}$ pile drivers used. Upon assembly steel frames and steel supports were transported as complete units by a PRK 50 floating crane $^{623}$ and placed on pre-arranged pile grating. Pushers were used to transport the crane (positioned on an NZM-56 bridge ferry) down the river with all bridge sections. The assembly base No. 2 set up in order to assemble the REM-500 overpass sections and L-30 steel frame girders was set up at the Malbork freight station. Upon assembly at the base, the bridge span components were carried to the bridge axis by SRK 20 and SRK 30/40 railway cranes. ${ }^{624}$

\section{“BARIERA 79” Military Exercise, Siekierki n. Odrą (1979)}

The railway bridge battalion of the 2nd railway regiment from Inowrocław (JW 1523), having joined forces with troops of the Red Army and the National People's Army of East Germany, constructed a bridge crossing on the River Odra in Siekierki as a part of the practical coalition test of the Warsaw Pact Allied Forces Military Exercise, codename "BARIERA 79", ${ }^{25}$ held during the period of October 18th until October 24th 1979. The battalion was commanded by Captain Józef Szwajka, M.Sc. Eng.

Throughout the mission the railway bridge battalion was staffed according to wartime requirements (approximately 500 soldiers), and supported by a rail crane company of the Soviet Army, stationed in Międzyrzecze and reporting to the battalion commander (two SRK 20 cranes and three KrAZ lorries adapted for operation on rails; the Polish Armed Forces had one SRK 20 crane).

The Soviet battalion assembled NZM-56 spans upstream at the assembly base; these spans were then carried by BMK 90 cutters onto the location, and connected with two pre-assembled overpasses (both from the Polish and German sides) with the use of adjustable NZM-56 bridge supports.

623 The PRK 50 crane (Plavayushchyi Rasbornyi Kran), lifting capacity: 50 tonnes, was designed to position steel frames and steel supports along the bridge axis. The crane was assembled on NZM-56 road-rail bridge ferry pontoons..

624 Colonel Józef Szajka’s account of June 11th 2006.

625 The "BARIERA 79" Exercise involved the construction of other bridges as well, including a folding road bridge in Cedynia on the River Odra (wooden supports, length: $89 \mathrm{~m}$, load-bearing capacity: 40 tonnes). 
The railway bridge battalion of the 2 nd railway regiment constructed a part of the crossing with the use of REM-500 overpass components (approximate length: $820 \mathrm{~m}$ ) on the River Odra marsh territory, while the Soviet Army troops worked on the crossing's mid-section on the river using an NZM-56 floating road-rail bridge (length: $255 \mathrm{~m}$ ). Subdivisions of the National People's Army of East Germany assembled the bridge section terminus on the German side using REM-500 overpass components (length: $150 \mathrm{~m}$, component assembly along the bridge axis with the use of a lorry-mounted crane). ${ }^{626}$

Upon assembly the crossing (constructed over 3 days) reached an approximate length of $1,200 \mathrm{~m}$. The railway section was developed to the NL load standard; the road section - to a 40 tonne load standard. ${ }^{627}$ The crossing was given an informal name, Tadeusz Bridge, after Colonel Tadeusz Hanowski, commander of the 2 nd railway regiment in Inowrocław.

In preparation for the military exercise, the Military Unit JW 1523 constructed an embankment, ${ }^{628}$ together with a track connecting the Siekierki station to the overpass bridgehead (approximate length: $9 \mathrm{~km}$, average height: $4 \mathrm{~m}$ ), it set up the assembly base at the Siekierki station, stocked two overpass sets, and completed surveying, design and carried out coordination works in co-operation with the "BARIERA" Exercise Training Command, for the purposes of resolving issues of military exercise collaboration and the connection of the two different bridge structures (the final overpass girder with the mobile support of the NZM56 floating bridge, adjustable to river water level).

626 In view of the plans to develop a wartime reserve crossing, a siding branching off at km. 10.895 (Abzweigung Nra) between station Neurüdnitz and the bridge over the River Odra (approximate length: $1.5 \mathrm{~km}$ ) was developed down to the riverbank as early as 1976. Construction works on the siding codenamed "Object-83" proceeded in extremely difficult wet terrain. The embankment of the siding was connected to the floodbank below the head, which is why the floodbank was secured with specialpurpose flood gates housing the final section of the siding on the floodplain. Gates were opened at low water, temporary crossing construction possible in low water conditions only. The East German Deutsche Reichsbahn/German National Railways allocated 9.4 million East German Marks to the construction of the siding in difficult terrain conditions.

627 Gembora, Ref. No. 1138, Attachment No. 8, 5.

628 Siding construction works involved the construction of a gravel embankment in rough wet terrain; gravel was transported from the Chojna gravel pit with a dumpcar wagon shuttle hauled by a ST44 locomotive. 
The REM-500 overpass was connected to the NZM-56 floating bridge with the use of a transitional span of railway sleepers, $550 \mathrm{~mm}$ I-sections and S-49 rails fixed to the bridge.

The railway bridge battalion of the 2 nd railway regiment assembled the REM500 rail overpass (length: $820.43 \mathrm{~m}$ ), including its initial $334.72 \mathrm{~m}$ section along a curve (radius: $400 \mathrm{~m}$ ) from support No. 2 to support No. 27; the overpass was built with a ruling gradient $3.82 \%$ along its entire length. The SEK-500 and REM-500 structures respectively were applied along the curved and straight section. The overpass was assembled with the use of 65 spans (length: $12.61 \mathrm{~m}$ ) resting on 64 S-6, S-7 and PN supports of different heights. The overpass was reinforced with the use of 12 brace clusters. The entire project was completed over a very brief period of 68 hours, with the use of three SRK 20 railway cranes and a triple-shift system (approximately 150-170 soldiers per shift). The overpass assembly involved the transport and assembly of entire overpass spans and supports.

The project owed its significant construction speed to the uninterrupted work of three SRK 20 assembly crane units (one crane provided by JW 1523, with an SM30 locomotive; two SRK 20 cranes coupled with rail mounted KrAZ 256 lorries. The two SRK20 cranes and KrAZ lorries, crews included, were dispatched by the Soviet Army railway unit stationed in Międzyrzecze. The average rate of bridge construction from the REM-500 overpass on the riverbank reached approximately $12.05 \mathrm{~m} / \mathrm{h}$ (around $290 \mathrm{~m}$ per day). 

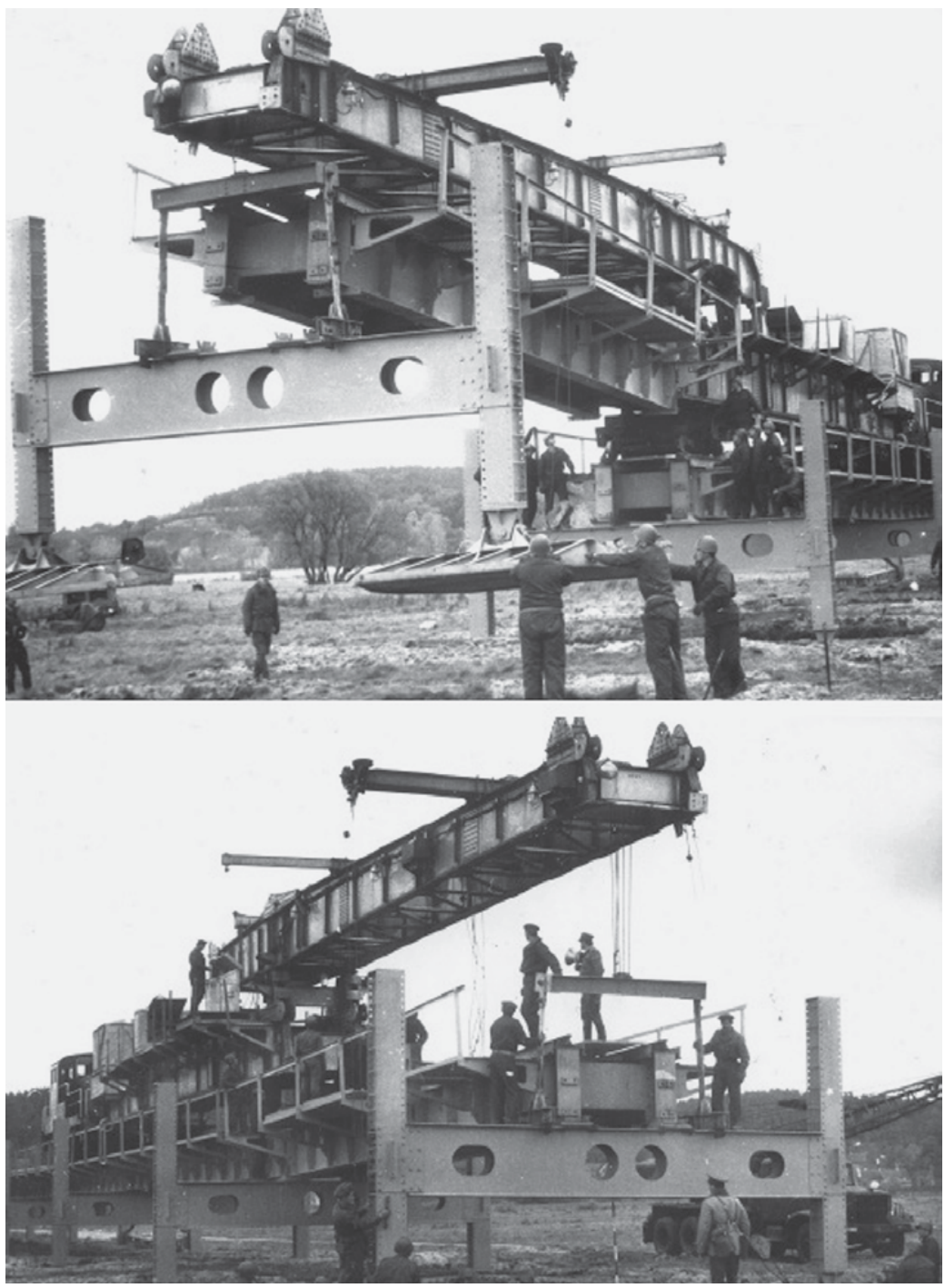

Above: Siekierki 1979, “BARIERA 79” Military Exercise. Overpass span with supports being lowered onto the bridge geodetic axis by SRK 20 crane, SM30 locomotive visible in the background, photo by Colonel J. Jarzyna (photo courtesy Colonel J. Jarzyna) Below: Siekierki 1979, "BARIERA 79” Military Exercise. Overpass span with supports being lowered onto the bridge geodetic axis by SRK 20 crane, SM30 locomotive visible in the background, photo by Colonel J. Jarzyna (photo courtesy Colonel J. Jarzyna) 


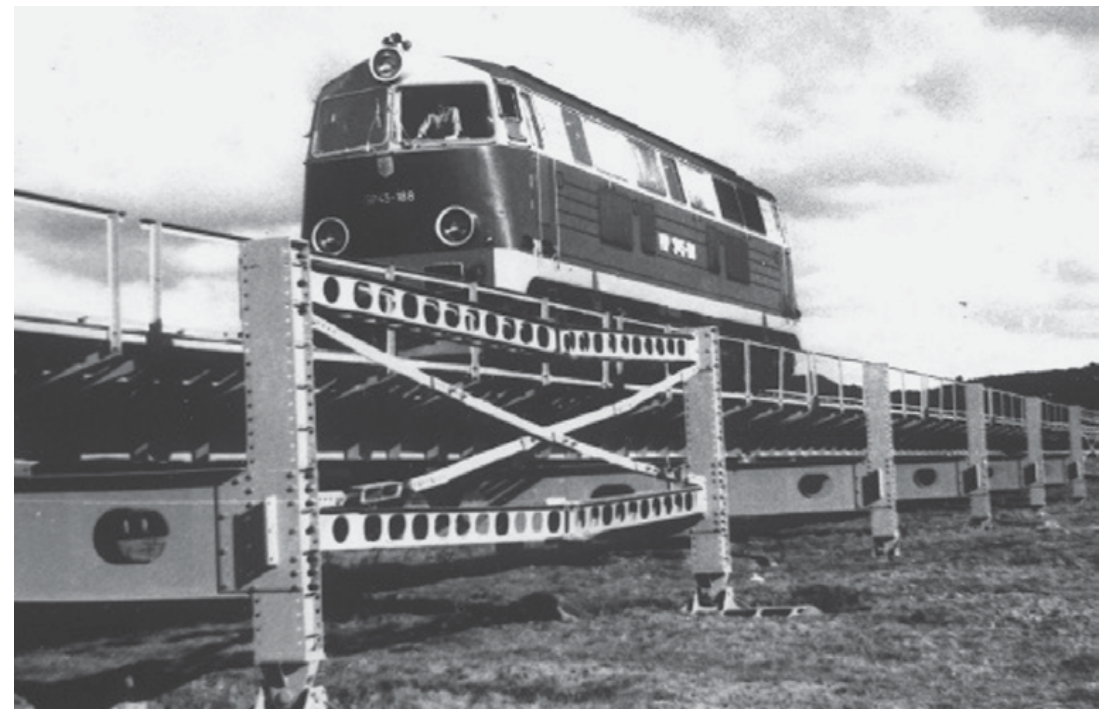

Load test of the overpass with an SP45-188 locomotive during the "BARIERA 79" Military Exercise, Siekierki 1979, photo by Colonel J. Jarzyna (photo courtesy Colonel J. Jarzyna)

The bridge crossing constructed during the "BARIERA 79" Military Exercise was load-tested with a single SP45-188 locomotive, followed by the passage of a heavy military troop train with a company of medium-sized tanks of the National People's Army of the East Germany on heavy Saap flat wagons (18 tanks $+\mathrm{Kl}$ vans for the transport of soldiers), hauled by a Deutsche Reichsbahn/German National Railways BR 118 374-8 diesel locomotive. Upon arrival at Siekierki station running round its train, the locomotive hauled the train back to East Germany to Bienenwerder station. The commander of the battalion responsible for the construction of the crossing, Captain Józef Szwajka, remained standing beneath the span of the bridge throughout the passage of the train, a common custom for tests under load.

In order to construct the bridge at the required rate of $290 \mathrm{~m}$ per day the following equipment was used during the bridge overpass assembly: three SRK 20 railway cranes; one SM30 diesel locomotive; three KrAZ 256 road-rail lorries, five K164 and K104 lorry-mounted cranes used for assembling the structure on the assembly base; two power generation units; EO 1, PAB 4, PAB 8, and PAD 16 generators; 3 bulldozers to prepare the foundations for the overpass supports; 2 excavators to dig the support foundations; 4 tipper lorries to prepare 
the foundations; 1 wheel loader to prepare the support foundations; 20 lorries of different types; 5 trailers; 4 off-road vehicles; 2 ambulance vehicles; 3 fuel tanker vehicles with dispensers; 1 set of surveying instruments (levellers, theodolites, geodesic surveys, rangefinder), one R 118 car-mounted radio station, portable radio stations supporting the communications between the construction site, assembly base, and crane commanders; battalion commander's staff car; steel structure assembly tools; 2 rail impact wrenches.

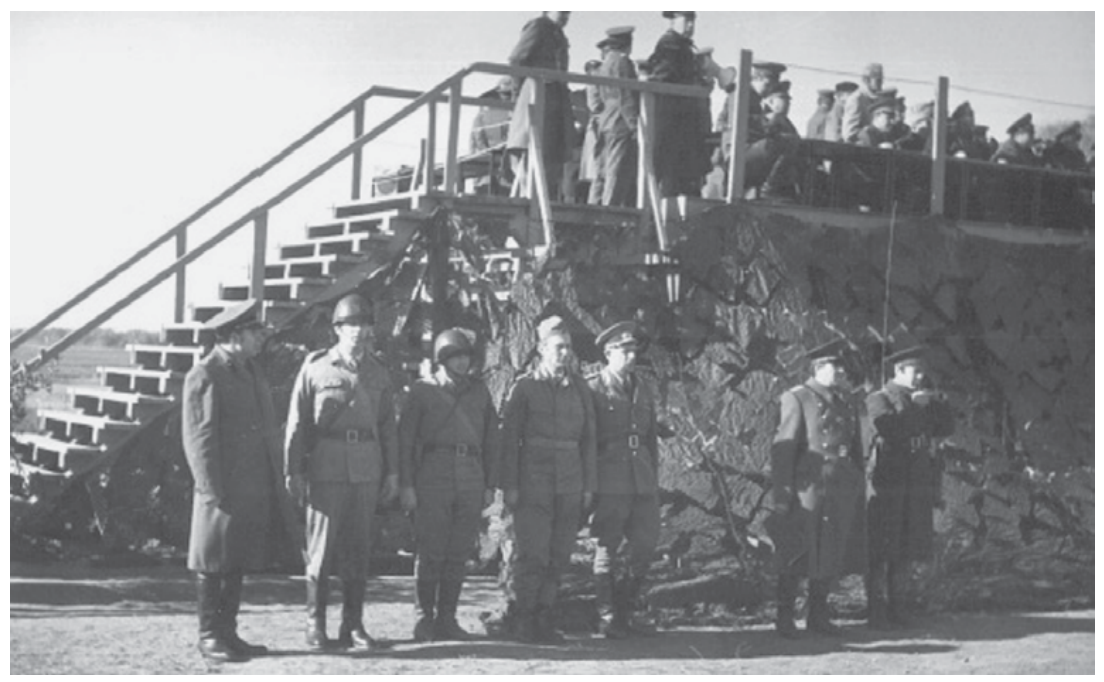

1979, "BARIERA 79" Military Exercise. On the German side - the main stand for observers from the Command of the Allied Forces of the Warsaw Pact. Bottom row, standing - representatives of troops of the Soviet Army, the Polish Armed Forces and the National People's Army of East Germany taking part in the Exercise (photo courtesy Colonel Józef Szwajka) 


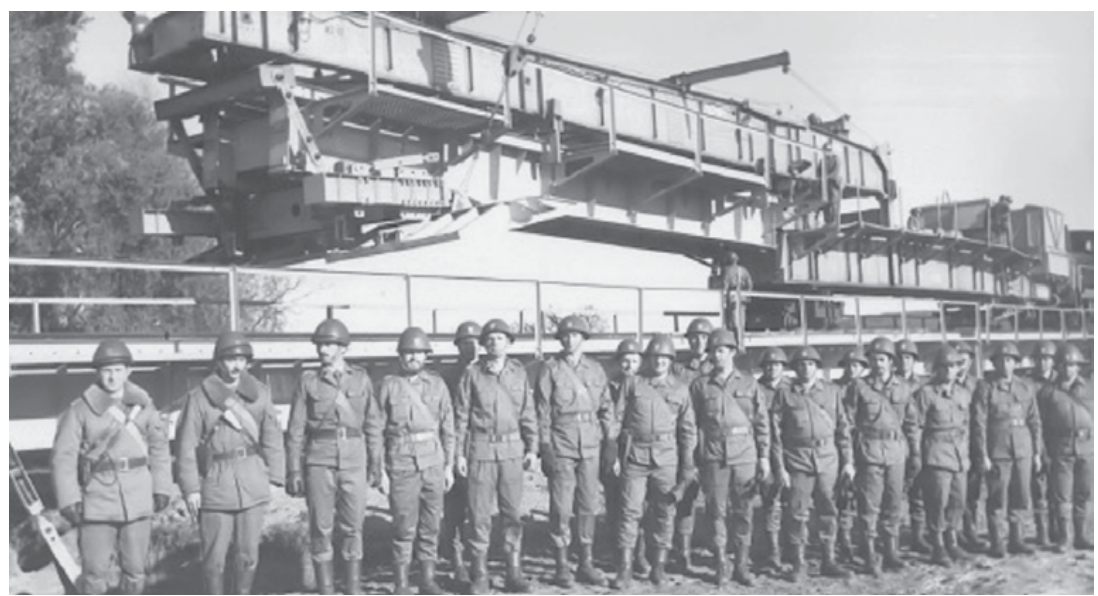

1979, Siekierki, the"BARIERA 79" Military Exercise. An SRK20 railway crane and an SM30 locomotive with a support and span attached; in the foreground - bridge company of the bridge battalion, with commander.

(photo courtesy Colonel Józef Szwajka)

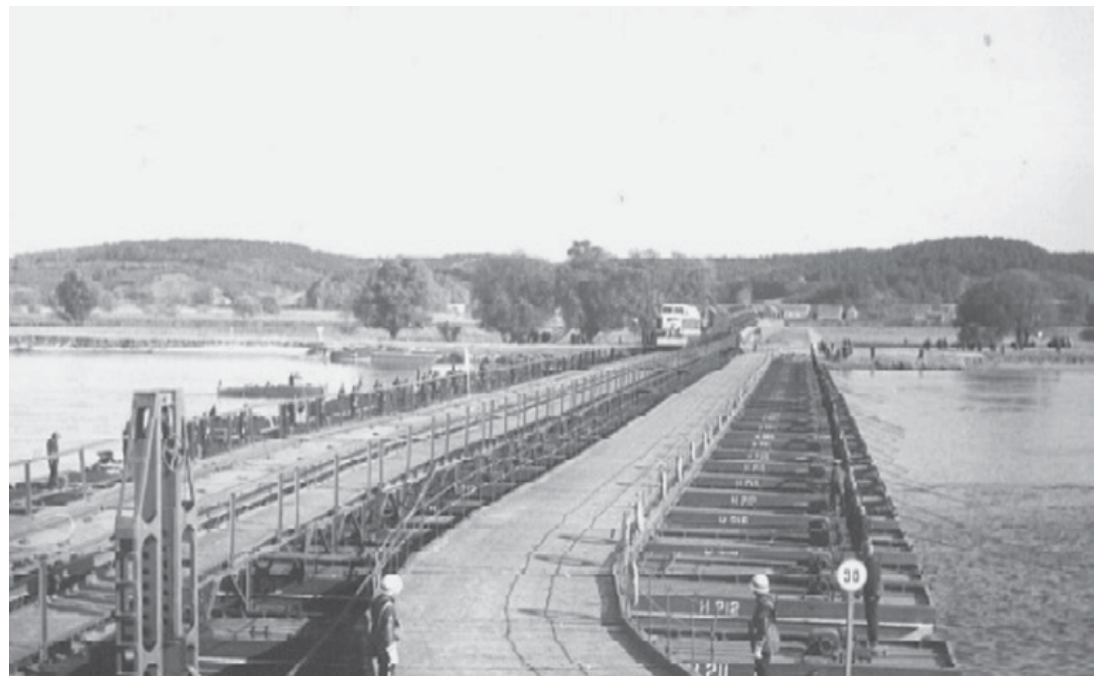

1979, Siekierki, the "BARIERA 79" Military Exercise. A military troop train with a regrouping tank company of the National People's Army of East Germany enters the crossing (photo courtesy Colonel Józef Szwajka) 


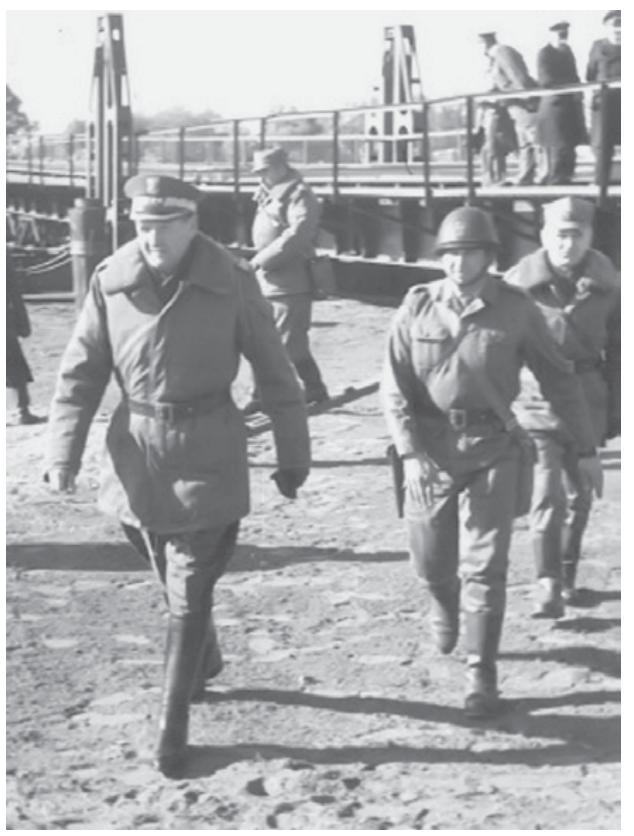

1979, Siekierki, “BARIERA 79” Military Exercise. Chief Quartermaster of the Polish Armed Forces General Mieczysław Obiedziński, Colonel Józef Szwajka, and commander of the 2nd railway regiment Colonel Pacyna against the connection point of SEK-500 and NZM-56 bridge structures (in the background) (photo courtesy Colonel Józef Szwajka) 
Zbigniew Tucholski - 978-3-631-82966-0 Downloaded from PubFactory at 09/30/2020 04:51:29PM by keerthiga.m@newgen.co via Peter Lang AG and keerthiga.m@newgen.co 


\section{MILITARY TRANSPORTS}

\subsection{Military Transports - Typology}

\subsubsection{Military Rail Transport}

The definition of military rail transport comprised the transfer of military units, military plants, subdivisions and groups of soldiers (individual soldiers), and military cargo, all conforming to military transport documents as drafted by the Ministry of National Defence. Military transfers were a process of relocating troops and military cargo, comprising their loading, transport, and unloading, and (in some cases) transhipment. ${ }^{629}$ Military rail transfers included the following: mobilisation-related transfers; deployment of troops to the war theatre; delivery of material and technical resources and army supplies to the troops in combat; the regrouping of troops and supplies; transports associated with peacetime army training and supplies; and evacuation. ${ }^{630}$

Nature and purpose pending, transports were classified as follows: ${ }^{631}$

- operational transfers, i.e. the transfer of military units and plants deployed for operational mission purposes to new stationing, military exercises and camp venues;

- mobilisation-related transfers, i.e. the transfer of personnel supplementation, armaments, combat equipment, motor vehicles, and material-and-technical supplies intended to staff and secure military divisions and plants throughout the mobilisation period;

- transfer of supplies, i.e. of military equipment, material-and-technical supplies, construction materials and other cargo;

- evacuation transfers, i.e. the transport of wounded and sick soldiers by special-purpose military hospital trains;

- resource evacuation-related transfers, i.e. the transport of military equipment intended for repair or stocking at military bases and depots, and equipment under transfer for national economy purposes.

629 Ministry of National Defence, Transport Command 33/64, Komunikacja wojskowa (1965), 251.

630 Ibid., 249.

631 Ibid., 250. 
Military transports were also classified by planning format, as centrallyplanned - by the command of Headquarters of Military Transports of the Ministry of National Defence (carried out on the territory of several military districts or frontlines), and district (frontline)-planned by the Headquarters of Military Transport authorities of the district or frontline; carried out within the boundaries of a single military district (frontline). Depending on the delivery period, military transports were classified as peacetime or wartime transports.

Peacetime operational transports served the following purposes: participation of the military units in military exercises; deployment to military training grounds; changing the dislocation sites, and protection of major strategic objects on domestic territory, appropriately supervised by the National Defence Committee under the conditions of an exacerbated international situation and/ or risk of an armed conflict; transfers of groups of soldiers, individual troops, and draft conscripts; transport of supplies; mobilisation transports associated with the initiated armed forces mobilisation - such transports were to continue as a rule in the early days of war. ${ }^{632}$

The wartime plans included the following: operational transports to support specific operational or strategic missions; transport of supplies; transfers of groups of soldiers or individual soldiers and supplement personnel; evacuation of the wounded; evacuation of materials; and transfers of prisoners of war. Wartime military transfers were classified as: transfers on domestic territory with intent to support the domestic Territorial Defence (military districts), to secure the newly formed divisions and tactical compounds, and to disperse and manoeuvre Territorial Defence resources; or frontline transfers to secure the troops in combat. Depending on the size and volume, military transports were classified as mass transfers requiring the preparation of railway equipment and large volumes of rolling stock; or routine transfers, requiring no special-purpose preparation of significant volumes of rolling stock. ${ }^{633}$

Due to its inherent nature, military railway transport featured a number of typical and specific properties. Reprogramming the economy and industry for wartime operation involved a complete militarisation of railways. The mass nature and significance of wartime military transports gave rise to the need to abandon all civilian passenger and freight transport on some of the main railway routes. The timeliness of transfer of tactical compounds and the delivery of supplies was of vital importance, operational success often as not determined

632 Ministry of National Defence, Transport Command 33/64, Komunikacja wojskowa (1965), 250.

633 Ibid., 250-251. 
by how quickly personnel and supplies could be transported. The transport of hazardous goods (missiles, ammunition, explosives, rocket fuel, propellants and lubricants, corrosive and poisonous materials) imposed the need to apply special conditions of shipping such materials, in conformity to special-purpose official regulations. The carriage of operational transports was associated with sanitary, medical, veterinary and material supplies (food, cooking and potable water, water for wartime washing and partial facility deactivation, candles and fuel); the necessity to secure the loading devices and rolling stock for the purposes of troops transfer; and the need to secure the transfer of out-of-gauge loads (missile launchers, tanks, aircraft, cutters, etc.). The need to protect information concerning troops deployment against intelligence infiltration enforced strict confidentiality of transport. ${ }^{634}$

The military railway transport involved the use of military troop trains and military transfers. ${ }^{635}$ The phrase "military troop train" would apply to a complete train sets of wagons, groups of wagons, or single wagons used to transport military units together with their equipment (military units, subdivisions, groups of soldiers, horse groups). The phrase was also used to describe the transfer of armoured, hospital, bath, and disinfection trains, including crews, equipment and work tools, or of military railway rolling stock (empty or loaded) supervised by the Ministry of National Defence. ${ }^{636}$ The transfer of the military took place using passenger, freight, or special-purpose wagons owned by the Polish State Railways and/or the Ministry of National Defence.

The term "transport" would apply to complete train sets of wagons, groups of wagons, or single wagons used to carry military supplies of armaments, ammunition, food, fodder, fuels, lubricants, military equipment, etc., and to ship military and civilian property of persons employed in the military institutions, prisoners of war, and bodies of the fallen soldiers.

The use of block trains of refrigerated vans was planned for the purposes of carrying bodies of soldiers from the future wartime battlefields. Polish State Railways were obliged to maintain a large number of such wagons as fully operational. ${ }^{637}$

634 Ministry of National Defence, Transport Command 33/64, Komunikacja wojskowa (1965), 249.

635 In earlier days, classification of military operational transports carrying military units / supplies and transports carrying ammunition, equipment and military materials was used. Ministry of National Defence, Tymczasowa instrukcja (1947), 6.

636 Ministry of Transport, Instrukcja o organizacji (1958), 14.

637 After 1989 and upon modifications to the warfare doctrine, large numbers of these wagons were removed from the Polish State Railways lists and scrapped. 
Pursuant to the amendments to the Instructions Concerning the Organisation and Delivery of Military Railway Transports, ${ }^{638}$ military troop trains and military transports comprising sets no greater than 30 four-wheeled wagons were classified as incomplete train sets; military troop trains and military transports comprising sets greater than 30 wagons (up to 120 axles), including match wagons and guards vans, were classified as complete train sets. Train sets with fewer wagons were also classified as military troop trains and complete train sets, providing their approximate gross weight was between 800 and 1,200 tonnes.

Military waybills were issued as shipment orders for each transfer by a military troop train and/or military transport. When planning transfer operations, military transport authorities assigned individual numbers (and passwords, under specific circumstances) to military troop trains and military transports. A military troop train and transport numbers remained unchanged throughout the journey, from a loading station to an unloading station. Military troop train/ military transport numbers and potential passwords were used by military transport bodies and Polish State Railways employees in the planning and performance of the military rail transfers.

The military rail transports were delivered with the use of the following:

a) - Scheduled trains, included in the railway timetable, running daily and/or on pre-specified days;

b) - Non-scheduled trains operated pursuant to special orders; these included:

- Additional trains, listed in the train timetable, run as required;

- Extraordinary trains, not listed in the train timetable, run strictly as required, operating according to a particular, special-purpose schedule.

Military troop trains and military transports not forming a complete train were operated as scheduled or additional trains; in an effort to use rolling stock in an economical way, if possible these were supplemented with other cargo or empty wagons.

Complete military troop trains and military transports were operated according to a special timetable. Military troop trains and military transports not defined as military trains and operated as freight trains could also be attached to passenger trains, technical-and-operating conditions of the railway line and rolling stock permitting.

Military transports comprising complete trains were operated according to the general transport rules, or (if the train, station of departure, and/or station 
of arrival were classified as strictly confidential) to Kostap password (name derived from the Polish acronym for "next destination"). In the case of a train thus dispatched, the station of departure would only enter the term Kostap in the station of arrival field of all transfer and commercial documentation of the train. Stationmasters of loading stations and stations designated en-route for Kostap trains would use data in sealed envelopes (the exact date of opening marked on the envelope) or issued by the Main Dispatching Service of the Polish State Railways as the basis to notify (in person) the commander of the military troop train or transport of the subsequent Kostap destination, and/or of any connecting inter-operational stations, and of the estimated time of arrival and/or hold at such a station.

Extraordinary precautions were taken for the purposes of carrying military explosives (ammunition, explosives, incendiary agents), poisonous agents (poisonous/venomous liquids and gases), or propellants and lubricants. In an effort to warrant the safety of carrying any such cargo, the Regulations of the Polish State Railways Peacetime Proceedings Regarding Military Transports of Ammunition, Explosives, Incendiary Substances and Poisonous (Venomous) Materials ${ }^{639}$ were approved in 1950. These regulations applied to the entire Polish State Railways network, for the purposes of Polish Armed Forces and the Soviet Army transports alike. ${ }^{640}$ Throughout the journey, transports of explosives, ammunition and poisonous materials remained under the protection of armed military escorts. Whenever hazardous or poisonous goods were carried, it was forbidden to specify cargo by name in any documentation or on wagon stickers; Hazardous Cargo or Poison warnings were used. Whenever group of wagons carrying hazardous goods were operated, they would be separated from other wagons with 4 empty match wagons. Furthermore, the simultaneous carriage of hazardous and poisonous goods by a single train was forbidden. Such wagons could only be transported in wagons equipped with 50 tonne- or 65 tonnereinforced couplings, with a minimum wheelbase of $4.5 \mathrm{~m}$, and axle boxes free of oil leaks. ${ }^{641}$ The wagons intended for the carriage of hazardous goods were subject to particularly detailed technical inspections by wagon inspectors. Hazardous goods were loaded and unloaded on military sidings or commission-designated station tracks, at a minimum distance of $125 \mathrm{~m}$ from residential and production buildings, and $50 \mathrm{~m}$ from main tracks, under surveillance by military post

639 Polish State Railways, Przepisy o postępowaniu (1950).

640 Polish State Railways, Przepisy o postępowaniu (1950), 5.

641 Polish State Railways, Przepisy o postępowaniu (1950), 9. 
personnel. ${ }^{62}$ Steam locomotives without operational spark arresters, with closed firebox doors, ashpans flaps, and closed blowers were prohibited from passing in the vicinity of hazardous goods unloading sites. Explosives and poisonous goods could only be carried in goods or pick-up goods trains. Whenever hazardous goods were carried, locomotive crews were issued firefighting equipment.

Particularly hazardous goods included missiles, warheads, rocket fuel, and missile equipment. Missiles were transported from the bases and central depots to unloading stations of operational and tactical compounds, rocket missile troops, territorial defence forces, naval bases, and (during wartime) to frontline dispatch stations. On the frontline railway network, missiles would be delivered from the frontline dispatch station to unloading stations of rocket squadrons or to frontline technical missile bases. Rail transport of assembled (without warheads) or disassembled missiles was allowed. Maximum train speed of $70 \mathrm{~km} / \mathrm{h}$ was permitted. Tactical missile squadrons of armoured or mechanised divisions were carried by a single train; rocket missile brigades were carried by 6 trains. ${ }^{643}$ Missiles (upon disassembly) could be carried in containers, in coal wagons or on flat wagons Missiles were secured and camouflaged with watertight material for rail transfer purposes. Air-to-air missiles were loaded (in 25 unit batches) onto four-wheeled vans, or (in 50 unit batches) into bogie covered wagons. Missile warheads fitted with nuclear charges were transported separately, in special airtight containers. Each missile transport, irrespective of the number of wagons, was issued a special number. Railway cranes (lifting capacity: 5-10 tonnes), or lorry-mounted 5 tonne cranes (K-102, K-112, K-104) were used for loading the missiles (at sidings belonging to material depots or missile units). Hump shunting of wagons carrying missiles at marshalling yards was prohibited. Shunting of missile-carrying trains was handled at pre-junction stations, at a minimum distance of 5-7 km from the major facilities and railway junctions. It was forbidden for military troop trains and trains carrying missiles and/or rockets to be held in one station. In case of destruction to railway facilities and in view of a hindered missile reloading, missile-carrying trains would be routed onto obstacle-bypassing lines; in case of destruction to bridges on major water obstacles, missile-carrying wagons were to be transferred via ferry crossings and railway bridges on floating supports. A standard time of 20-30

642 Polish State Railways, Przepisy o postępowaniu (1950) 12.

643 Ministry of National Defence, Transport Command 33/64, Komunikacja wojskowa (1965), 284. 
minutes was approved for the unloading of a single missile from a coal wagon by a team of $5 .^{644}$

Intermediate stations were designated as loading stations for missile troops; such stations had to meet the following requirements: location at a minimum distance of $5 \mathrm{~km}$ from large settlements and locations of potential nuclear weapon impact; 2-3 additional tracks (in addition to the main track) and a loading track with a capacity to accommodate complete train sets; loading yards no less than 200-350 in length and $25-30 \mathrm{~m}$ in width. A single station had the capacity to load/unload 3-4 military troop trains per day. One or two reserve loading (unloading) stations were designated for every two or three primary stations.

Units were dispersed at deployment (assembly) locations, individual squadrons dispatched to locations separated by a distance of 3-4 km. Military trains carrying rocket missile units were loaded at stations (or on sidings) at 2-3 locations simultaneously. Launchers and semi-trailers for transporting missiles were loaded and camouflaged separately, the remainder of the unit was loaded at a station. Such military troop trains were as a rule loaded and unloaded during night-time. Shunting was performed by the train locomotive. Actual missile transports were paralleled with mock missile transports planned with intent to confuse the enemy. ${ }^{645}$

\subsubsection{Anti-Aircraft Defence of Military Transports}

The threat of wartime enemy air attack required the use of anti-aircraft defence for military transports and for loading (unloading) stations. The main purposes of enemy air strikes and paratrooper landings involved the destruction of railway lines, facilities, and devices, as well as direct attacks on military troop trains and military transports. A permanent state of anti-aircraft defence emergency alert was introduced for all areas under threat of attack by the enemy's air force. During night-time loading of troops, total blackout was ordered in the event of an anti-aircraft emergency; whenever a military transport was required to cross a danger zone, a total train blackout was ordered as well. ${ }^{646}$ Armaments carried on flat wagons and coal wagons were camouflaged with canvas tarpaulins or wagon

644 Ministry of National Defence, Transport Command 33/64, Komunikacja wojskowa (1965), 288-290.

645 Ibid., 284-285.

646 Special-purpose slot diaphragms were in common wartime use as devices to obscure beacons fitted on switches, derailers, and other light signalling appliances. 
tarpaulins. ${ }^{647}$ Permanent local air defence was planned for larger railway stations and junctions.

Loading (unloading) sites were pre-specified for any divisions loaded or unloaded in danger zones. Anti-aircraft defence commanders were appointed for all sites.

Small-calibre anti-aircraft artillery batteries were assigned to military transports with intent to provide them with proper anti-aircraft defence en-route. Anti-aircraft defence of military transports were supervised by their commanders, charged with the appointment of air defence units comprising surveillance and alert teams, and machine gun fire groups. The following armaments were assigned to military transport air defence units: for divisions issued low volumes of heavy machine guns (no more than 6) - all machine guns; for divisions issued greater volumes of heavy machine guns $-1 / 2$ to $3 / 4$ of armaments issued, and in any case a minimum of 6 heavy machine guns. ${ }^{648}$

The following air raid alert signalling system was employed at railway stations, and during train travel, pursuant to the Polish State Railways Signalling Regulations: Air raid alarm - long uninterrupted tone (1-2 minutes) emitted by a steam engine whistle or horn; End of alarm - intermittent tone (1-2 minutes) comprising 3-5 second signals at 3-5 second intervals.

In the event of an air attack, enemy aircraft were fought with the use of antiaircraft artillery and machine guns in firing positions. Anti-aircraft defence units assigned to military transports were deployed before the transport was moved from the loading site to departure tracks. Only low-height equipment was loaded onto flat wagons carrying machine guns, and properly positioned so as not to interfere with machine gun operation. Surveillance and alert teams, each comprising two observers and one telephonist issued a field telephone, were deployed at the head, mid-section, and end of the train, respectively (frontal team - at the engine tender; mid-section team - at the brake box adjacent to the train commander's van; rear team - at the brake box at the end of the train). In air raid conditions, the train did not stop; it continued to move while the train was being defended.

647 Wagon tarpaulins - special-purpose tarpaulins made to standard size of open freight wagons.

648 Ministry of National Defence, Tymczasowa instrukcja (1947), 89. 

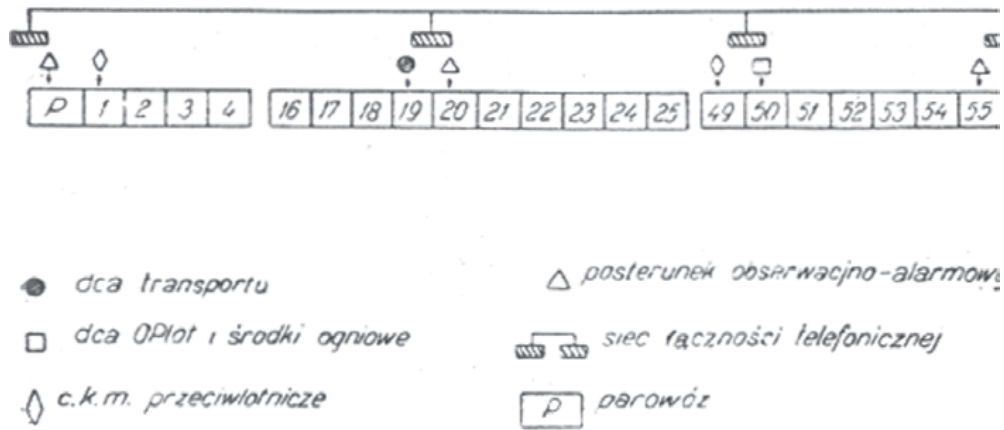

Schemat organizacji OPlot. transportu

Diagram of anti-aircraft defence of a transport.

Source: Ministry of National Defence, Tymczasowa instrukcja (1947)

\subsubsection{Anti-Tank Defence of Military Transports}

Wartime anti-tank defence was also planned for military transport loading (unloading) yards. ${ }^{649}$ Anti-tank defence armaments unloaded as a priority were to be used for that purpose. In order to defend the individual sites (areas) against tanks, each unit was expected to secure its own anti-tank defence with the use of all measures available. Anti-tank guns, anti-tank heavy machine guns, and light artillery were to be deployed as area defence measures along the predicted enemy attack direction. Instructions further provided for the use of anti-tank mines on the territory surrounding the loading (unloading) sites, along the predicted enemy attack direction. ${ }^{650}$ Anti-tank defence involved firing continuity - a part of all armaments were to remain in position until the military transport was fully loaded, ensuring immediate firing readiness for all weapons upon loading onto flat wagons.

On a territory under threat by enemy tank attack, plans involved all transports in motion to remain in continuous anti-tank defence readiness. Effective defence involved the use of anti-tank guns, machine guns with anti-tank ammunition, and (in exceptional conditions) light artillery.

Preparations for anti-tank defence of rail transport included the following: anti-tank armaments positioned to allow firing from railway flat wagons

649 Ministry of National Defence, Tymczasowa instrukcja (1947), 96.

650 Ministry of National Defence, Tymczasowa instrukcja (1947), 96. 
(adequate field of fire warranted by untethered gun loading and positioning); surveillance and anti-tank emergency posts set up in anti-tank armament positions.

Should a military transport be surprised by an enemy tank attack once moving, the train was not to stop. If a transport had to be stopped for the reasons of damage to railway tracks, the transported unit was expected to repel the attack on site by unloading troops and equipment, or retreat to a location providing natural protection against the enemy tanks. According to instructions, transports carrying no anti-tank weapons were to increase speed to ensure separation from enemy tanks, and seek refuge behind a natural obstacle.

\subsubsection{Safeguarding the Confidentiality of Transports}

A number of protective measures were taken to safeguard the confidentiality of the military transports, and counteract the intelligence infiltration. Pursuant to regulations concerning state secrets and their safeguarding, the dissemination of military transport-related information carried criminal liability. In wartime conditions, any troops or railwaymen found guilty of violating the rule of military transport confidentiality were to be brought to justice.

Restrictions in access to classified information were applied according to the scope of responsibilities of persons involved in the military transport handling. All ordinances and documentation describing military railway transport were drafted in limited format, to contain information concerning a specific service unit only. Only personnel directly involved in the handling of a specific military transport were notified of the related planning and delivery decisions, and only within such time and scope as was required to perform the respective activities. At service units of the Ministry of Transport and the Polish State Railways, the flow of military transport-related documents was handled between individual military offices and Headquarters of Military Transport, and other military transport authorities. Soldiers were forbidden to send private correspondence during transport.

Whenever additional or special trains were operated, respective telegrams could only specify the necessary data concerning the train (data, train number, schedule). The use of any terms such as "military troop train", "transport", "military", "special", etc. in telegrams was prohibited, as was any mention of numbers or passwords.

The Ministry of Transport issued guidelines (specifying all abbreviations and the correct order of disseminating data) to secure the proper form and manner of providing relevant railway units with information concerning the situation of military transports. 
If the route of a military troop transport or military transport was classified as strictly confidential, trains were commissioned to Kostap password (name derived from the Polish acronym for "next destination").

Whenever operational transports requiring strict confidentiality were organised, orders and excerpts from the transfer plans could also be delivered to military transport authorities in person by staff participating in the transport handling (staff members would report to the Headquarters of Military Transport of the Ministry of National Defence); liaison officers or operational groups could also be dispatched from the Headquarters of Military Transport of the Ministry of National Defence to the institutions concerned. ${ }^{651}$

In an effort to safeguard the confidentiality of explosives and poisonous materials carriage, waybills issued for wagon loads did not specify the actual name of the goods carried - only the terms Explosives or Poisonous Materials were used, always red-bordered in pencil or ink. Specification of explosives and poisonous materials was required in view of the different regulations applying to the carriage of such materials. Furthermore, no documents allowing the identification of goods were attached to the goods shipment waybills. Wagons carrying explosives or poisonous materials were not marked by any stickers typical for commercial shipments allowing cargo identification.

Files regarding the transfer of special military shipments were forwarded to the files storage depot within a term of one month of the transport mission. ${ }^{62}$

\subsubsection{Rolling Stock used for Military transport Purposes}

Already in the late 19th century, the Prussian State Railways (KPEV) introduced troops transfer by standard goods vans, appropriately adapted for the purpose of transporting the military by the use of special-purpose standard mobile wagon components (benches, bunks, rifle, and personal equipment stands, etc.). ${ }^{653}$ As part of the first effort to standardise the wagons used by the Prussian railways (1878), all newly-constructed vans were built in such a way as to enable swift conversion for military purposes. Soon thereafter, railways in other countries also adopted such system of converting goods vans for use by the military.

651 Ministry of National Defence, Transport Command 33/64, Komunikacja wojskowa (1965), 127.

652 Polish State Railways, R 57, Przepisy o przewozie (1980), 6.

653 It remains unclear whether individual German states carried troops in covered wagons prior to the unification of Germany. 
While equipment used to furnish troops-carrying goods vans on the Russian railways had been approved as early as $1870,{ }^{654}$ it was considered far from suitable:

Freight wagons would usually accommodate 36 people or 8 horses. Wagon furnishings on vehicles used to transport troops consisted of planks and slats, nailed to the van's walls. There were no solutions to make boarding easier. Whenever horses or artillery were loaded, devices referred to as "bridges" were applied: at too great an incline, too narrow, very inconvenient in use. In wintertime, two iron stoves were assigned to each vans; heat was never distributed evenly. Such heated wagons were called "tyeplushki" ("heated places"). "Tyeplushki" were also used to carry the sick and the lightly wounded, patient headcount $10-15$ per van $[\ldots] .655$

Between the wars, four-wheel Polish State Railways vans fitted with different wagon furnishings were used for the military transport of people and animals. Specific types of covered vans adapted for the purposes of carrying people or horses were fitted with fixed wagon furnishings. Fixed wagon furnishings included the following: frames with airing flaps to ventilate the van; lantern suspension devices; support slats for sitting/ sleeping boards; support slats to hang personal equipment; stand-fixing clamps; rod-fixing rings used to tie horses and prevent people from falling out of the wagons. Mobile furnishings included the following: boards, rods, lanterns, rifle stands, stand slats, and stoves. ${ }^{656}$

654 Tchaplin (1895), 385.

655 Gawroński (1930), 15.

656 Furnishings designed for vans intended to carry privates comprised the following: 18 boards, 1 lantern, 2 sets of rifle racks ( 1 set of rails with notches for rifle barrels, slats to secure barrels, and a slat to support rifle butts), 2 rods - untethered BARIERAs preventing people from falling out of the wagon; in the winter season (October 15th until April 15th) - 1 stove. Furnishings for vans intended to carry horses and cattle included 3 rods and 1 lantern. 

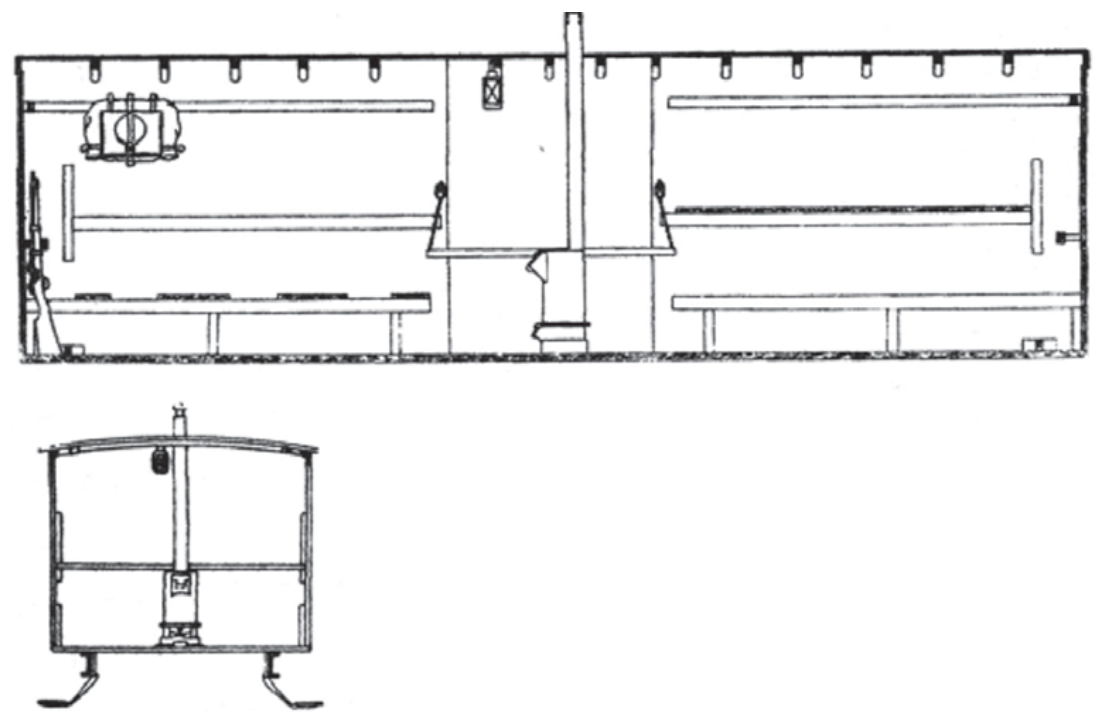

A furnished box van.

Source: Ministry of Military Affairs, Instrukcja (1932) 

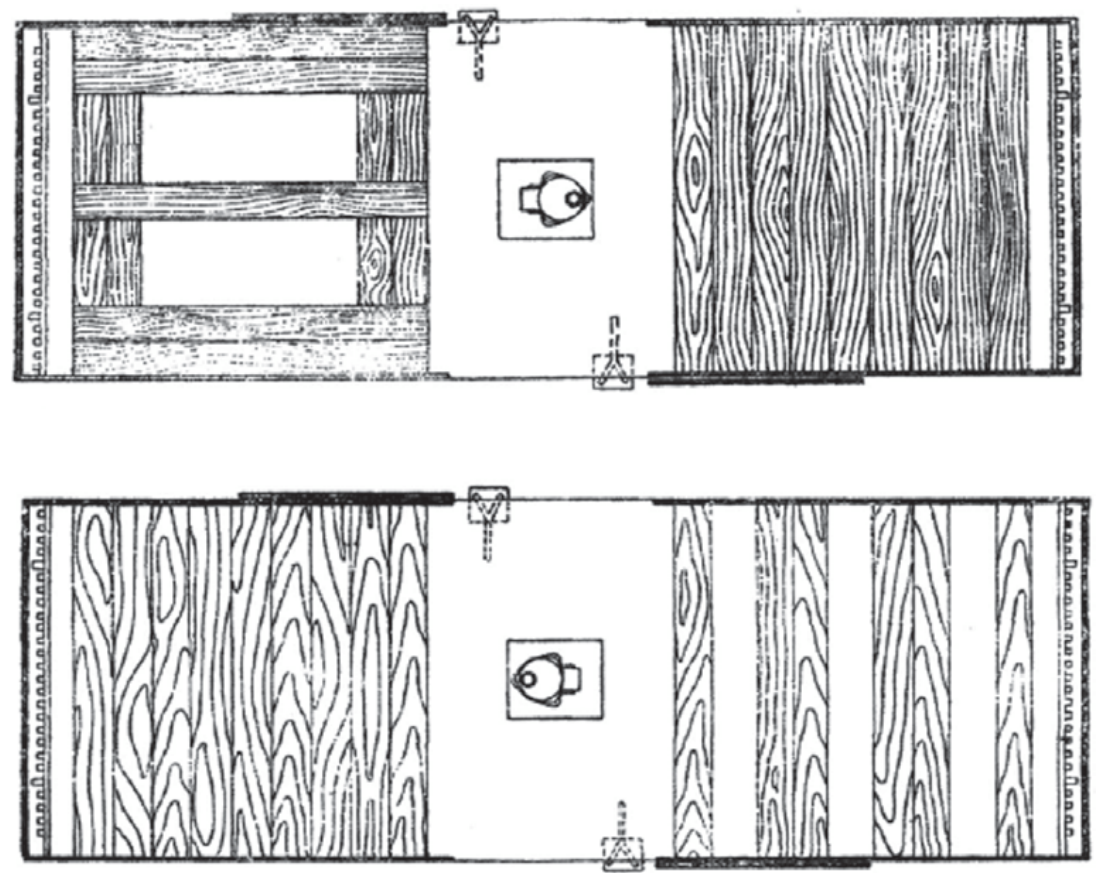

A furnished box van.

Source: Ministry of Military Affairs, Instrukcja (1932)

Passenger carriages, covered freight wagons, flat wagons, coal wagons, tank wagons, and special-purpose wagons meeting pre-specified technical conditions were used to carry military equipment and materials on the Polish State Railways network after the war. ${ }^{67}$ According to a list contained in the Instructions Concerning the Organisation and Delivery of Military Railway Transports, ${ }^{658}$ the following Polish State Railways rolling stock was used for military transport purposes: bogie carriages - Ahuxz (1st class) and Bhuxz (2nd class); fourwheeled vans: Kddt, Kddet, Kdt, Kdst, Kpt (door aperture width: 699-200 mm), four-wheeled flat wagons: Pd 21, Pdk 31, Pddk 31, Pddk 41, bogie flat wagons: PP

657 In general, Ministry of National Defence military rolling stock was limited to on-site transport at bases, depots, and military units. Only special-purpose wagons and armoured trains were used on the PKP network.

658 Ministry of Transport, Instrukcja o organizacji (1958), 186-187. 
421, PPuk 511, PPyk 203; six-axle bogie flat wagons: PPPzk 303; four-wheeled coal wagons: Wdo, Wddo, Wddt; bogie coal wagons: WWy; four-wheeled tank wagons: R; bogie tank wagons: RR. Should shipment by a regular flat wagon be impossible for reasons of excessive width of the load to be carried, specialpurpose well wagons (PPg) were employed. ${ }^{659}$

Covered vans and coal wagons were adapted for the purposes of military transfer of soldiers, horses, and field kitchens and as anti-aircraft defence positions. As a rule, passenger carriages on military trains were reserved for officers. Should such wagons be unavailable, or should they preclude the option of heating in the winter season, covered vans were also used to carry officers.

Covered vans were used to carry privates, non-commissioned officers, horses, field kitchens, equipment and supplies. Polish State Railways wagons that were marked with the letter " $\mathrm{t}$ " were used to carry people. ${ }^{660} \mathrm{Kpw}$ and Kdsw freight wagons (door aperture width: $2 \mathrm{~m}$ ) were used to carry operational field kitchens (galleys). Flat wagons were used to carry vehicles, equipment and supplies. Coal wagons were used to carry supplies and to provide anti-aircraft defence positions.

Covered vans were fitted with the following fixed wagon furnishings intended for military transport purposes: hatches with windows to ventilate the vans; upper internal support slats for rifle beds and personal equipment; internal wall rings allowing protective barrier rods to be suspended (for horses) or seat board shackles; overhead guides allowing flashlights or lanterns; wagon boarding steps. ${ }^{661}$

Special-purpose storage depots supervised by the Polish State Railways Mechanical Services Division were used to store mobile wagon furnishings used in the fitting of wagons intended for troops transfer: seat boards, stands, shackles, rifle beds, horse protective barrier rods, wagon flashlights, stove sets, smoke extractors for operational field kitchens, anti-aircraft defence position equipment, water boilers, potable water tanks, candle lanterns ${ }^{662}$ and carbide lanterns. German, Soviet, Polish (pre-war) and American UNRRA wagon furnishings were used. The Polish State Railways Mechanical Services Division was charged with the inventory and maintenance of all wagon appliance, loading devices, and lighting equipment stock (intended for ongoing and emergency use). The

659 Ministry of Transport, Instrukcja o organizacji (1958), 137.

660 Ministry of Transport, Instrukcja o organizacji (1958), 47.

661 Some old-type box vans were fixed with iron stanchions at both doors, normally lifted up and hooked under the roof.

662 Special-purpose candle lanterns (suspended from the wagon's overhead guide strip) were used to light up provisional troops-carrying wagons. 
ongoing use stock was managed by traffic services; the emergency-use stock was at the disposal of the Military Offices of Regional State Railway Managements.

Selected assembly and furnishing locations within the Regional State Railway Management in Warsaw ${ }^{663}$

\begin{tabular}{|c|c|c|c|c|}
\hline \multirow[t]{3}{*}{ Station } & \multicolumn{4}{|c|}{ Maximum daily capacity per station } \\
\hline & \multicolumn{2}{|c|}{$\begin{array}{l}\text { Wagon furnishing } \\
1 \text { day } \\
2 \text { days }\end{array}$} & \multicolumn{2}{|c|}{$\begin{array}{l}\text { Train set assembly } \\
1 \text { day } \\
2 \text { days }\end{array}$} \\
\hline & summer season & $\begin{array}{l}\text { winter } \\
\text { season }\end{array}$ & $\begin{array}{l}\text { summer } \\
\text { season }\end{array}$ & $\begin{array}{l}\text { winter } \\
\text { season }\end{array}$ \\
\hline Warszawa Praga & $\begin{array}{r}84 \\
114 \\
\end{array}$ & $\begin{array}{l}48 \\
76 \\
\end{array}$ & $\begin{array}{l}7 \\
9 \\
\end{array}$ & $\begin{array}{l}4 \\
6 \\
\end{array}$ \\
\hline $\begin{array}{l}\text { Warszawa Gł. } \\
\text { Towarowa }\end{array}$ & $\begin{array}{l}108 \\
114 \\
\end{array}$ & $\begin{array}{r}84 \\
108 \\
\end{array}$ & $\begin{array}{r}9 \\
12 \\
\end{array}$ & $\begin{array}{l}9 \\
6 \\
\end{array}$ \\
\hline Łódź Kaliska & $\begin{array}{l}114 \\
156 \\
\end{array}$ & $\begin{array}{r}96 \\
144 \\
\end{array}$ & $\begin{array}{r}9 \\
13 \\
\end{array}$ & $\begin{array}{r}7 \\
11 \\
\end{array}$ \\
\hline Łódź Widzew & $\begin{array}{r}66 \\
122 \\
\end{array}$ & $\begin{array}{r}49 \\
108 \\
\end{array}$ & $\begin{array}{r}6 \\
18 \\
\end{array}$ & $\begin{array}{l}5 \\
9 \\
\end{array}$ \\
\hline Kutno & $\begin{array}{r}56 \\
117 \\
\end{array}$ & $\begin{array}{l}38 \\
96 \\
\end{array}$ & $\begin{array}{l}5 \\
8 \\
\end{array}$ & $\begin{array}{l}3 \\
5 \\
\end{array}$ \\
\hline $\begin{array}{l}\text { Białystok } \\
\text { Fabryczny }\end{array}$ & $\begin{array}{l}120 \\
180\end{array}$ & $\begin{array}{r}95 \\
148 \\
\end{array}$ & $\begin{array}{r}7 \\
10 \\
\end{array}$ & $\begin{array}{l}5 \\
8 \\
\end{array}$ \\
\hline Ostrołęka & $\begin{array}{l}140 \\
190 \\
\end{array}$ & $\begin{array}{l}105 \\
150 \\
\end{array}$ & $\begin{array}{l}6 \\
9 \\
\end{array}$ & $\begin{array}{l}5 \\
7 \\
\end{array}$ \\
\hline Siedlce & $\begin{array}{l}144 \\
168\end{array}$ & $\begin{array}{l}108 \\
132 \\
\end{array}$ & & \\
\hline Czeremcha & & & $\begin{array}{r}9 \\
14\end{array}$ & $\begin{array}{r}6 \\
11\end{array}$ \\
\hline
\end{tabular}

663 Headquarters of Military Transport at the Regional State Railway Management in Warsaw, Ogólna charakterystyka (1984), 25. 
Furnishing wagons for army relocation purposes required a large number of personnel to be employed, as well as the upkeep of large mobilisation warehouses containing wagon furnishing sets. The table above indicates the theoretical maximum capacity per train set assembly station.

Wagons earmarked for the transport of soldiers as part of rail military transports were furnished by fitting out box vans and converting them into "people-carrying" wagons allowing passengers to sit or lie down (marked "Kl"), or only to sit (marked "Kls"). The K1 people-carrying box vans were used to carry the soldiers over longer distances. ${ }^{664}$

The K1s people-carrying box vans were used to carry the military over shorter distances; they were also used to carry convoy escorts of supply transports, distance and time of passage notwithstanding. ${ }^{665}$

664 A typical Kl "people-carrying" van featured the following: 8 stands, 48 boards, 2 rifle beds, 2 BARIERA rods, 1 candle lantern, and 1 stove set (during the winter season of October 15th until April 15th).

665 A typical Kls "people-carrying" van featured the following: 12 shackles, 14 boards, 2 rifle beds, 2 BARIERA rods, 1 candle lantern, and 1 stove set (during the winter season of October 15th until April 15th). 
Kryty ludzki „Kl.“ do Leżenia

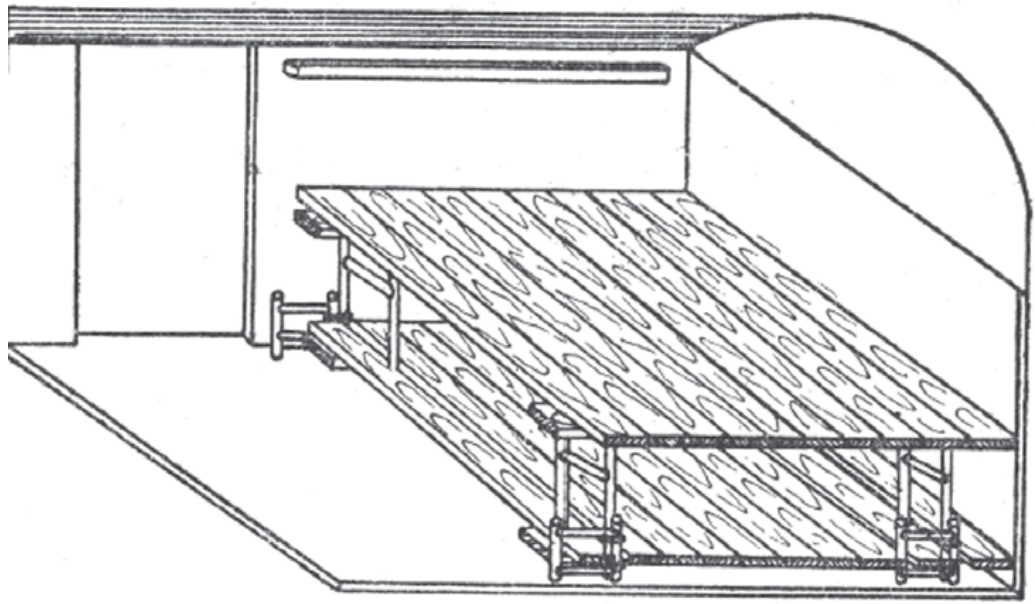

Kryty ludzhi „Kls“ do siedzenia

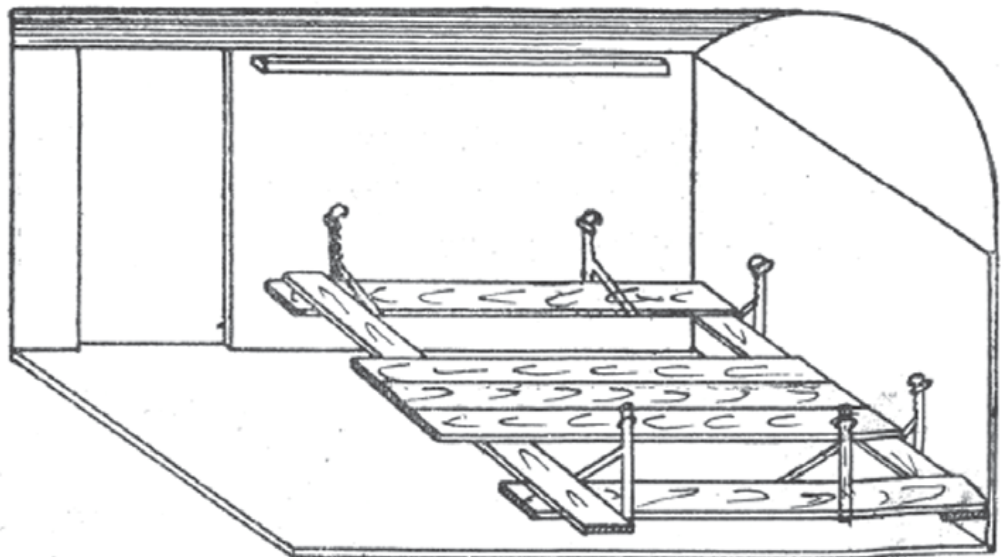

$\mathrm{Kl}$ vans with lying and sitting places.

Source: Polish State Railways, Instrukcja o stosowaniu (1949) 
Racks made of locomotive boiler tubes were used to arrange K1 "peoplecarrying" van as sitting space, reclining space (double-decked), and office space. The wagon stove exhaust was discharged with the use of a pipe system and special-purpose door and window inserts (to avoid damage to the wagon).

\section{Kryty ludzki „Kl“ do siedzenia}

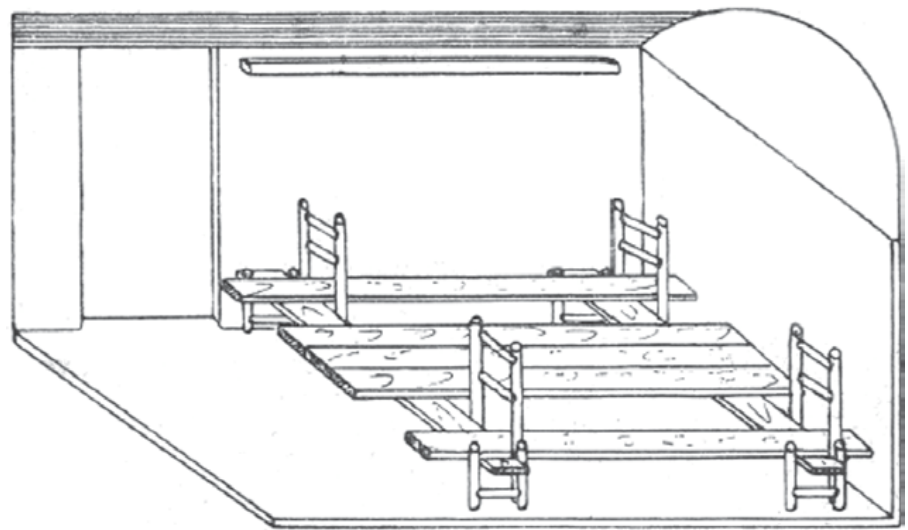

A Kl van with sitting places.

Source: Polish State Railways, Instrukcja o stosowaniu (1949)

Wdd type coal wagons with high-rise wooden side walls were equipped to allow the fitting of anti-aircraft defence positions. Such wagons were adapted by mounting an indoor platform and outdoor railing. ${ }^{666}$

666 Anti-aircraft defence position sets included the following: 1 set of platform suspension appliances ( 4 girders with stoppers, 4 handrails, 2 bridge girders), 1 gallery with three wooden sections, fixing wedges included, 2 longitudinal bridging girders, 2 lateral railings, 1 set of platform boarding steps, 1 wagon boarding ladder. 


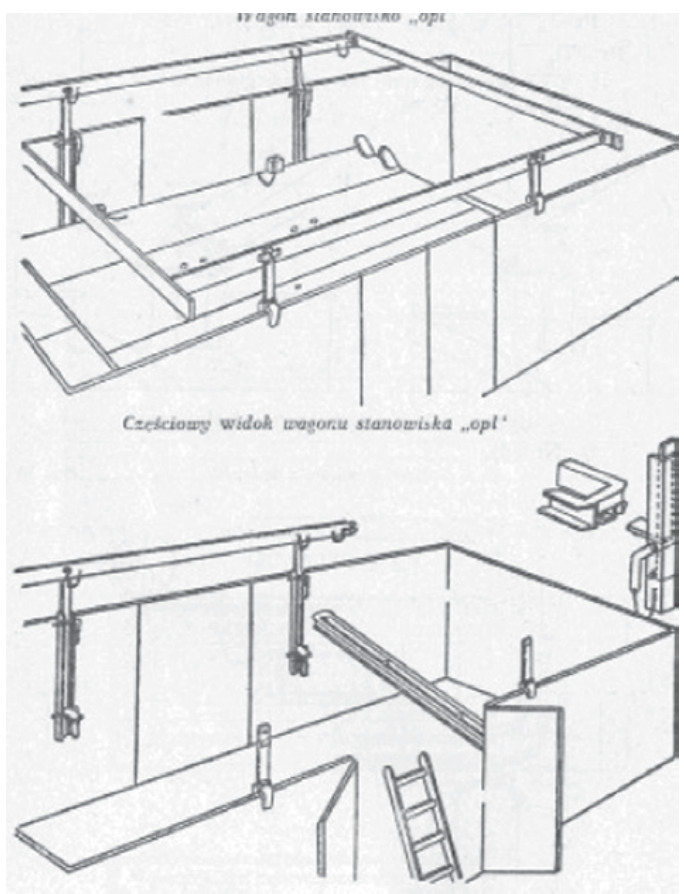

Anti-aircraft wagon converted from a coal wagon.

Source: Polish State Railways, Instrukcja o stosowaniu (1949) 
Kryfy ludzki ,Kl" hancelaria

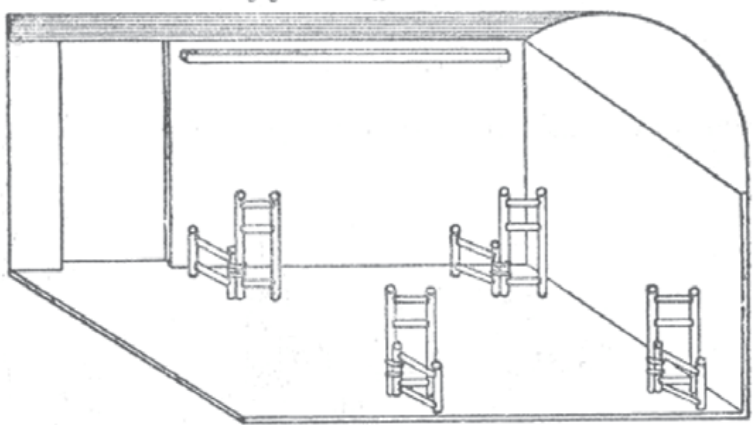

Ustawianie stojaków

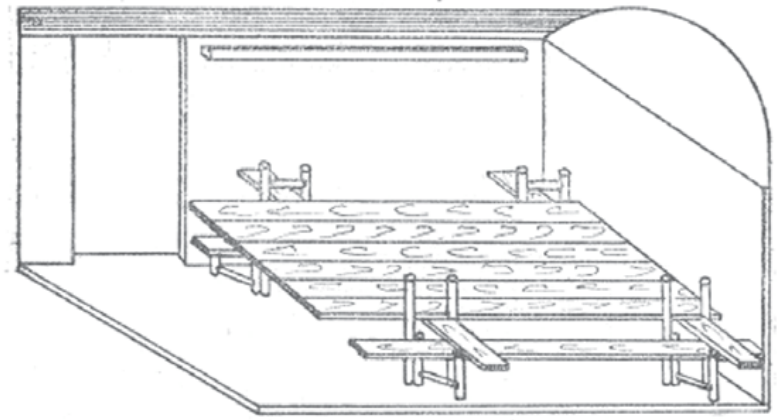

Uhladanie desek legarowych

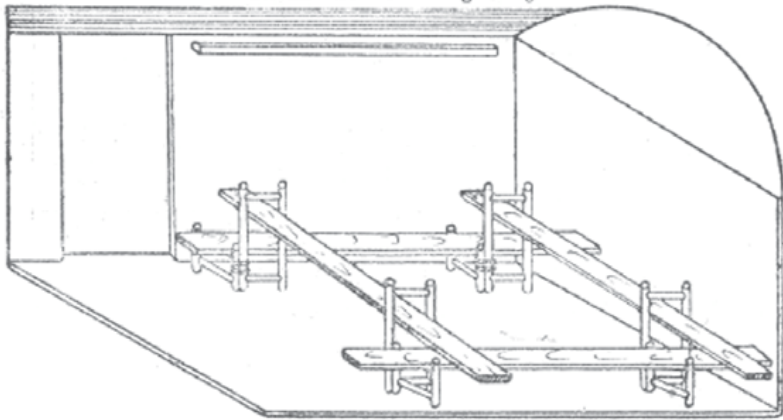

Furnishing of $\mathrm{Kl}$ vans.

Source: Polish State Railways, Instrukcja o stosowaniu (1949) 

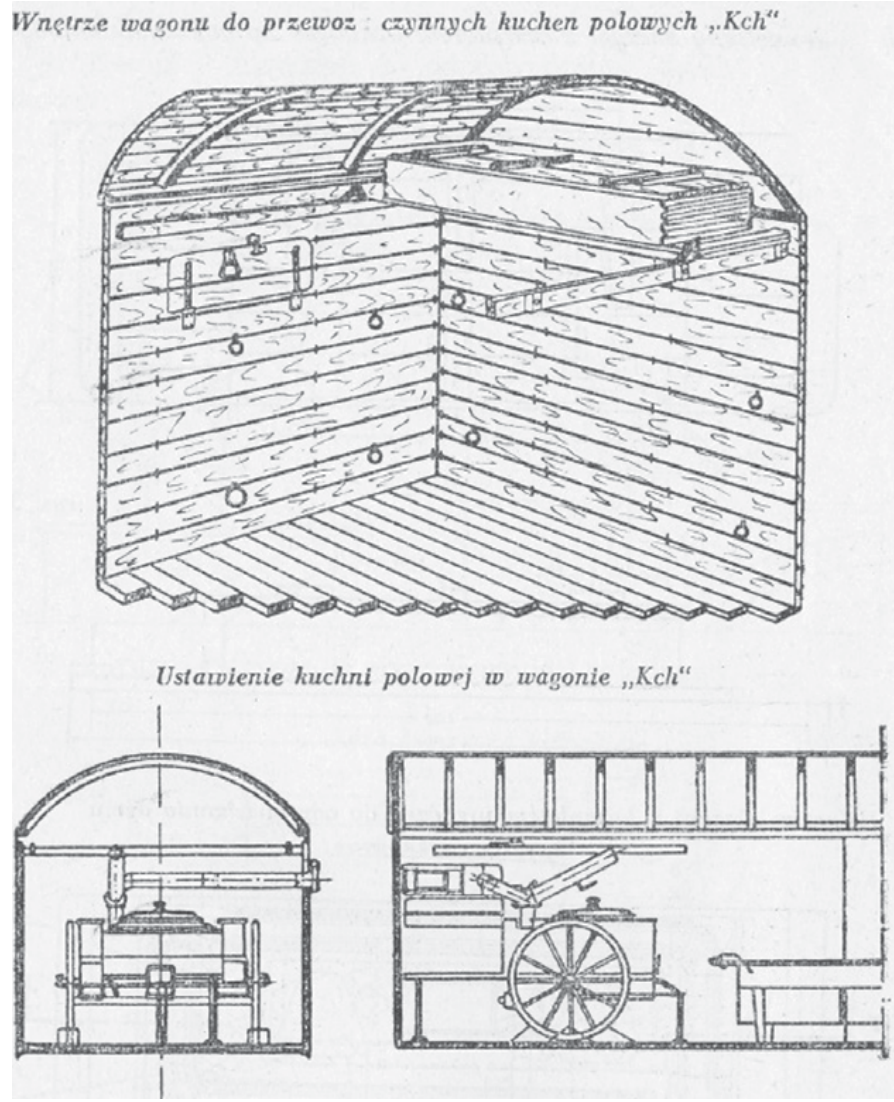

Field kitchens transported in a van.

Source: Polish State Railways, Instrukcja o stosowaniu (1949)

Box vans could also be fitted as "Kn" wagons intended to carry horses. A Kn horsecarrying van was fitted with 3 protective BARIERA rods and 1 lantern. "Kdsw" and "Kpw" box van (door opening width: $2 \mathrm{~m}$ ) were designed to transport of operational field kitchens (galleys). Each wagon could carry two operational field kitchens.

Upon adaptation for field kitchen carrying purposes, Kdsw and Kpw vans were labelled "Kch". 667

667 The equipment of a wagon with active field kitchens included: a box with a set of smoke extraction devices for 2 field kitchens, 1 door insert, 2 barrier bars, 1 candle lantern. 
The works to adapt wagons for mass military transport were performed at stations with warehouses stocking the mobile wagon furnishings. Wagon furnishing and train set assembly stations were designated by the given Regional State Railway Management in coordination with the Ministry of Transport. Such stations were fitted with separate tracks for wagon cleaning, washing and furnishing, and for train set assembly. Train sets were assembled according to a diagram presented to the station master by the military commander of the railway section (station).

If necessary, coal wagons could be used as substitute wagons to carry people and horses over short distances during summer season. Coal wagons used as substitute wagons to carry people were not furnished. Should such wagons be used to carry horses, they were fitted with 2 barrier rods nailed to the wagon upon loading, and used as horse ties.

In the case of journeys of a duration greater than 2 days, any military troop train with no less than 10 people-carrying wagons was expanded to include one sick bay wagon (with appropriate furnishings for carrying people) with intent to isolate patients until such time as they could be delivered to a medical centre.

Military troop trains or military transport trains were assembled along the following rules:

a) passenger carriages and box vans (carrying people and operational field kitchens) were placed in the train mid-section, loaded vans and flat wagons coupled on both sides of the wagons transporting people;

b) during the heating season, passenger carriages were placed directly behind the staff car, with intent to use locomotive heating;

c) wagons carrying people were separated from the locomotive by no less than one wagon; they were separated from the train-end by no less than six axles of wagons not occupied by people;

d) wagons carrying ammunition, explosives and incendiary materials, and/or chemical and flammable materials issued to a respective military troop train or military transport, were located in the rear train section;

e) wagons carrying propellants were separated from the wagons carrying people with no less than 6 axles of neutral-load wagons;

f) wagons carrying chemical materials were located in the rear train section, behind the wagons carrying people and animals;

g) wagons with anti-aircraft defence positions were placed in the front and rear train sections.

In general, similar rolling stock continues to be in use for military transport purposes today; the only difference involves the fact that the designated rolling 
stock maintenance depots are charged with the maintenance and repairs of the adapted Kl type vans upon commission by the Ministry of National Defence.

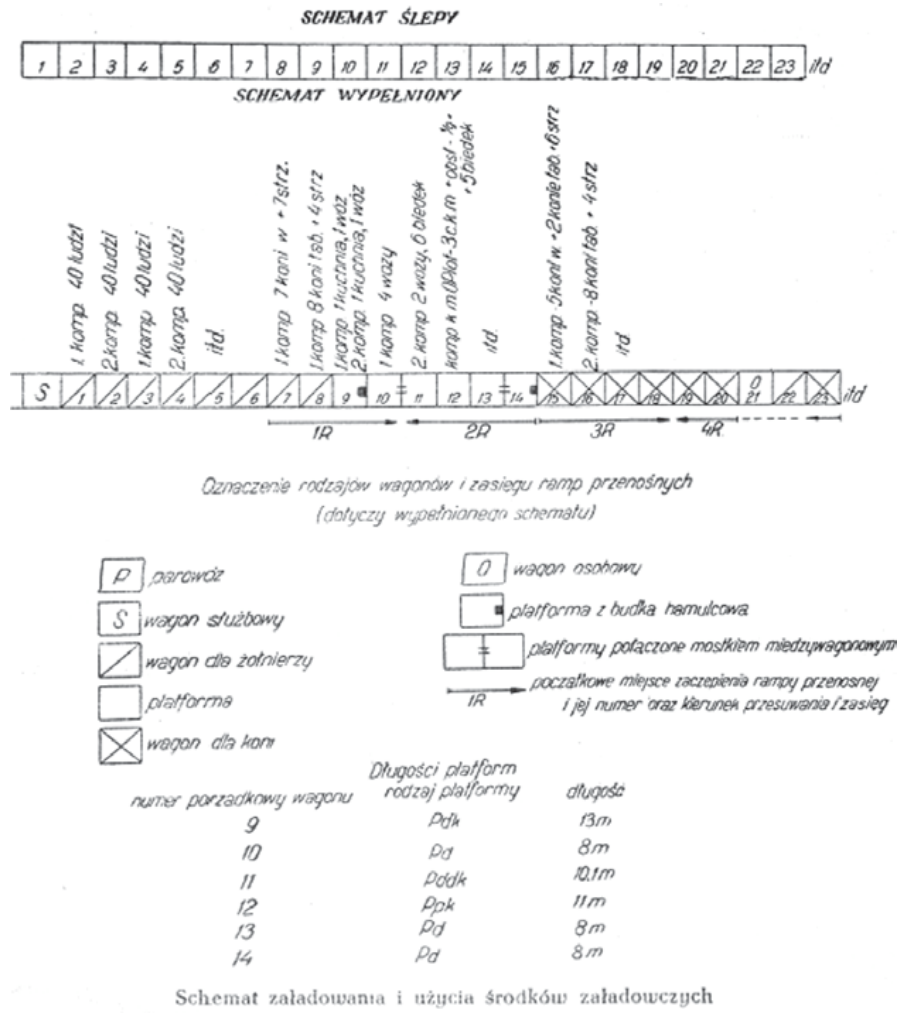

Loading diagram and the use of loading devices.

Source: Ministry of National Defence, Tymczasowa instrukcja (1947)

\subsubsection{Loading Areas, Stations, and Sites; Loading Devices}

Securing the proper loading and unloading of transported units had been among the main responsibilities of the Headquarters of Military Transport from the early days of railway use for military purposes in the 19th century. The introduction of armoured weapons and aviation, development of artillery, and gradual mechanisation of armed forces during the Great War gave rise to the need for 
appropriate loading/unloading appliances designed to load and unload heavy equipment.

Passenger train platforms, Polish State Railways commercial ramps, permanent military ramps and loading sites were used in the inter-war period as permanent stationary facilities serving the purposes of loading and unloading transported units and their equipment. ${ }^{668}$ Military ramps built between the wars were mostly designed as end-to-end ramps. The following temporary stationary facilities were in use as well: provisional military ramps (constructed in field conditions from wood as side, frontal, or end-to-end ramps), portable ramps ${ }^{669}$ (used for loading or unloading directly from the ground level), improvised ramps $^{670}$ (made of any material available, mostly with the use of rails and railway sleepers, if portable ramps were unavailable), horse transfer bridges ${ }^{671}$ (used to load and unload horses from ramps levelled with wagon floors) and cross-wagon bridges $^{672}$ (used to shunt rolling stock from platform to platform). ${ }^{673}$

Also after the war, when the Headquarters of Military Transport was planned and organised, great importance was attached to the proper securing and delivery of military transport. Tymczasowa instrukcja o wosjkowych transportach kolejowych [Temporary Instructions Regarding Military Railway Transports] were published in $1947,{ }^{674}$ based largely on the 1931 Instrukcji o wojskowych transportach kolejowych [Instructions Regarding Military Railway Transports]. ${ }^{675}$ In 1958, the Ministry of Transport published Instrukcje o organizacji wykonywania wojskowych przewozów kolejowych [Instructions Concerning the Organisation and Delivery of Military Railway Transports]. ${ }^{676}$

668 Ministry of Military Affairs, Instrukcja (1932), 17.

669 The Polish Armed Forces was issued a mobile platform, 1931 design, steel and wood structure.

670 Improvised ramps were available in two basic variations: light ramps (up to 1,800 kg) for infantry, cavalry, and light artillery; and heavy ramps (up to 6,000 kg) for heavy artillery and tanks.

671 Horse transfer bridges could also be used to roll cannons from ramps to platforms and vice versa.

672 Bridges used between the two world wars were made of riveted metal sheets.

673 Ministry of Military Affairs, Instrukcja (1932), 19-30.

674 Ministry of National Defence, Tymczasowa instrukcja (1947).

675 Ministry of Military Affairs, Instrukcja (1932).

676 Ministry of Transport, Instrukcja o organizacji (1958). 
Pursuant to new regulations, the loading (unloading) area was defined as a site comprising ten to twenty stations simultaneously handling the loading (unloading) of a large number of military troop trains or military transports. ${ }^{677}$

The approximate number of stations required to load and unload of individual operational and tactical compounds in the primary and supplementary loading areas has been shown in the table below: ${ }^{678}$

\begin{tabular}{|l|l|l|}
\hline \multirow{2}{*}{ Name of tactical unit or division } & \multicolumn{2}{|l|}{$\begin{array}{l}\text { Estimated number of } \\
\text { stations required in an area }\end{array}$} \\
\cline { 2 - 3 } & basic area & auxiliary area \\
\hline General army & up to 12 & $6-8$ \\
\hline Armoured army & up to 8 & $4-6$ \\
\hline Mechanised or armoured division & up to 3 & up to 2 \\
\hline Artillery brigade & $1-2$ & 1 \\
\hline Independent brigades, all types of armed forces & up to 2 & 1 \\
\hline Mechanised or armoured regiment & 1 & 1 \\
\hline Rocket missile troops & up to 2 & $1-2$ \\
\hline
\end{tabular}

Loading (unloading) areas were set up as close as possible to troops location. The phrase "loading (unloading) station" was used in reference to a railway station were troops or military transports were loaded (unloaded). ${ }^{679}$

The process of selecting and organising loading (unloading) areas involved the following basic requirements: dispersing and doubling of all essential loading and unloading area components (stations, holding and assembly areas, military units) to preserve the area viability and develop reserves; organising combat security and area camouflaging against enemy attack with the use of nuclear weapons and other weapons of mass destruction. ${ }^{680}$ Main troop loading areas were provided on railway lines of lowest traffic intensity, on parallel and bypass lines, with intent to secure loading continuity and allow one-way railway traffic. Basic military

677 Ministry of Transport, Instrukcja o organizacji (1958), 60-61.

678 Ministry of National Defence, Transport Command 33/64, Komunikacja wojskowa (1965), 277.

679 Ministry of Transport, Instrukcja o organizacji (1958), 60-61.

680 Ministry of National Defence, Transport Command 33/64, Komunikacja wojskowa (1965), 273. 
unloading areas were set up on approaches to large railway junctions, bridges, tunnels and other important facilities, the destruction of which could cause longterm interruptions to rail traffic. ${ }^{681}$ The purpose of such areas was to quickly unload troops in case of destruction to an obstacle, and then bypass it.

The railway authorities were obliged to organise and co-ordinate the loading and unloading of military transports. Heads of Traffic and Trade Departments appointed personnel charged with related duties: station masters or loading point managers. Military authorities appointed loading or unloading officers as persons in charge.

Railway employees responsible for the managing of loading and unloading of military railway transports during mass transport and military-and-railway exercises wore red-and-white armbands on the left arm, with a railway emblem and the seal of Branch IV of the General Staff of the Polish Armed Forces. The officers responsible for loading and unloading, and officers and noncommissioned officers of military units transported by rail, wore white armbands with a red lateral strip on the left arm. ${ }^{682}$

Whenever required, technical emergency service staff with adequate tools and equipment were appointed from among the infrastructure, mechanical and maintenance service personnel to assist the loading point managers. The loading or unloading of equipment and materials, hammering wedges, and wiring of vehicles were all responsibilities of the troops that were being loaded or unloaded. ${ }^{683}$

Furthermore, the Polish State Railways maintained a significant number of military loading locations ${ }^{684}$ (loading yards, permanent military ramps), no less than $8 \mathrm{~m}$ wide, ${ }^{655}$ as well as loading roads designed for military purposes. Whenever new loading yards were constructed, nearby holding (assembly) areas were set up wherever feasible (sheltered, if possible) to accommodate military units awaiting loading. ${ }^{686}$ Given the strategic use of ramps and loading facilities,

681 Ministry of National Defence, Transport Command 33/64, Komunikacja wojskowa (1965), 274.

682 Ministry of National Defence, Tymczasowa instrukcja (1947), 8.

683 Ministry of National Defence, Tymczasowa instrukcja (1947), 8.

684 According to the definition included in the Polish State Railways, Instrukcja o stosowaniu (1949), 25: In the military sense, the term "loading yard" shall refer to a railway station site developed on a siding or railway route, adjacent to a track, enabling the loading or unloading of military transports.

685 Pursuant to Ministry of Transport, Instrukcja o organizacji (1958), the width of newlybuilt loading yards was increased to $10-15$ meters, 61

686 Typical examples of military loading yards include loading facilities located near loading tracks of PKP Modlin and Chotomów stations. 
the Military Transport Board kept updated records of all such facilities available on the domestic railway network.

A loading yard - in the military sense of the term - is a railway station site provided on a siding or railway route, adjacent to the track, enabling the loading or unloading of military transports. Loading yards had to meet specific conditions: location on outer tracks, sidings or protective traps - possibly far from station facilities, such locations allowed camouflage and concealment. ${ }^{67}$ Notably, due to the wartime threat of bombing or artillery fire, individual loading yards had to be developed at approximate intervals of $1.5-2 \mathrm{~km}$, should several be set up at a single station. In the process of loading yard selection, attention was also paid to the use of natural terrain for camouflage purposes (land undulation, forest cover, weirs, ravines, small settlements, etc.) ${ }^{688}$ It was also important for loading yards to be placed on tracks allowing trains to be received/dispatched directly to correct routes, without the need to cross complex track systems, particularly vulnerable to wartime destruction.

Depending on their length, loading yards were classified as allowing full or partial train unloading (loading). ${ }^{69}$ It was also assumed that the approximate length of a loading front allowing the simultaneous loading of an entire military train should be $600 \mathrm{~m}$ (minimum length of the track at the loading front: $650 \mathrm{~m}^{690}$ ).

Loading or unloading of military trains at yards unable to accommodate full trains involved trains having to be divided in sections.

The following loading yards are classified as partial train unloading facilities: ${ }^{691}$

1) half-train yards, minimum required length: $300 \mathrm{~m}$;

2) 1/3-train yards: minimum required length: $230 \mathrm{~m}$;

3) yards less than $230 \mathrm{~m}$ long, used only when necessary.

687 Ditches (150-600 $\mathrm{m}$ long, depending on the headcount of subdivisions transported) were dug at loading (unloading) stations with intent to conceal transported troops.

688 Ministry of National Defence, Transport Command 33/64, Komunikacja wojskowa (1965), 274.

689 It was estimated that a full train loading (unloading) yard shall have the capacity to handle 6-8 military troop trains a day, and that partial loading (unloading) yards shall have the capacity to handle 4 military troop trains a day.

690 Polish State Railways, Instrukcja o stosowaniu (1949), 26, and Ministry of Transport, Instrukcja o organizacji (1958), 61.

691 Polish State Railways, Instrukcja o stosowaniu (1949), 26. 
The following loading facilities were used to handle loading activities: improvised ramps, transportable ramps, platform ramps, wagon connecting ramps and loading bridges.

Permanent, provisional and improvised ramps were used for military purposes. Depending on the loading method applied, ramps were classified as side ramps, frontal ramps, or end-to-end ramps; under exceptional circumstances, temporary ramps could be provided directly on the route.

Fixed ramps were made of durable materials (stone, concrete or brick retaining walls), entrances developed along their entire length or at several locations (minimum length: $230 \mathrm{~m}$ ).

Whenever required, commercial ramps were also used for the purposes of loading (unloading) of tactical compounds, as were passenger train platforms (under exceptional circumstances, and if levelled with wagon floors). Level crossings could also be used for the frontal loading or unloading of military units, with the use of transportable ramps or ramp platforms.

Provisional makeshift ramps were built as a temporary solution (side, front, end-to-end), operated as separate loading yards or extensions of the existing permanent ramps. Furthermore, Polish State Railways stored emergency-use supplies of materials intended for the construction of makeshift military ramps.

Improvised ramps were built with the use of sleepers and rails, as lightweight (maximum capacity: 12 tonnes) or heavy structures (maximum capacity: 60 tonnes) as side perpendicular, side oblique, frontal perpendicular or frontal oblique versions. The improvised side oblique ramps could be constructed on loading platforms at stations, loading points, on sidings, and on railway routes proper. Heavy side oblique and frontal improvised ramps were developed for the purposes of unloading particularly long or heavy vehicles.

Depending on the type of equipment or vehicles intended to be loaded or unloaded and on loading site width, lightweight and heavy improvised ramps could be provided as side perpendicular and double frontal version.

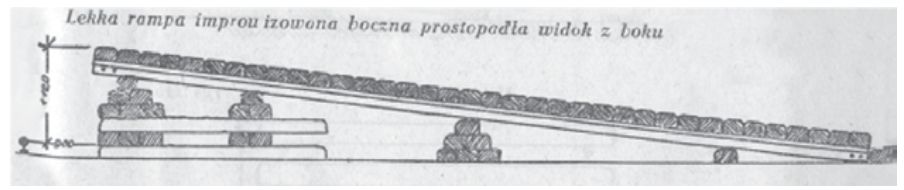

Light improvised perpendicular side ramp, side view.

Source: Polish State Railways, Instrukcja o stosowaniu (1949) 


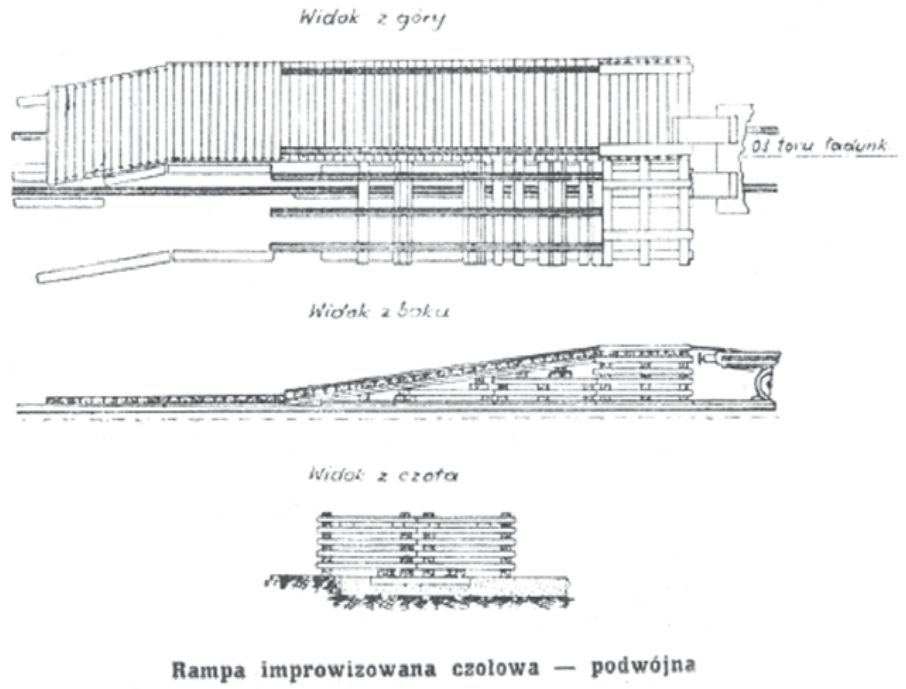

Improvised frontal double ramp.

Source: Ministry of Transport, Instrukcja o organizacji (1958)

Mobile ramps (side or frontal) of the following two types were used for loading purposes as well: heavy transportable ramp (two iron wheels, load-bearing capacity: 10 tonnes); lightweight transportable ramp (two wooden wheels, load-bearing capacity: 8 tonnes). When loading or unloading vehicles, two or more interconnected mobile ramps of a single type could be used together. 
Wiolok z goiry

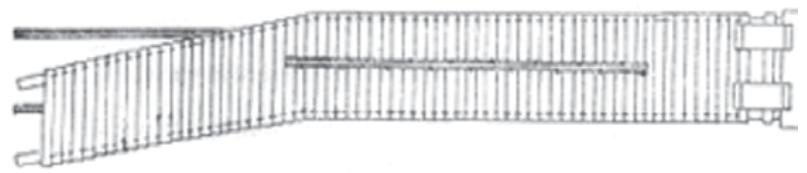

Wiolok $z$ bokes

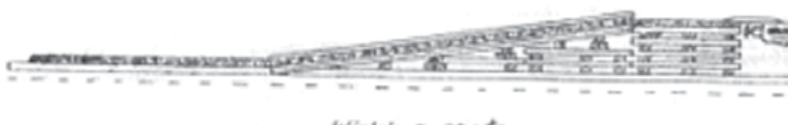

Widok a czota

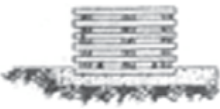

Rampa improwizowana czolowa - pojedyitcza

Wioled a gony
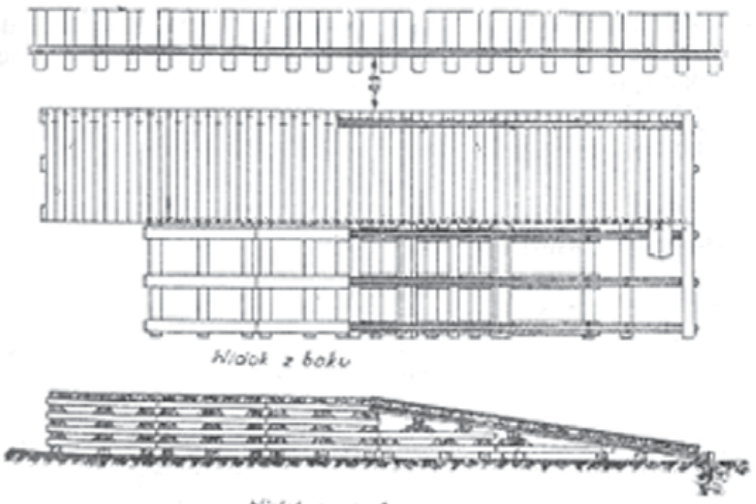

Wided z czors

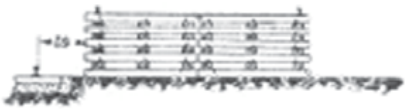

Rampa improwizowasa rownolegla $z$ jedna pochytnla zjardowa

Improvised frontal single ramp/ Improvised parallel ramp with a single incline. Source: Ministry of Transport, Instrukcja o organizacji (1958) 


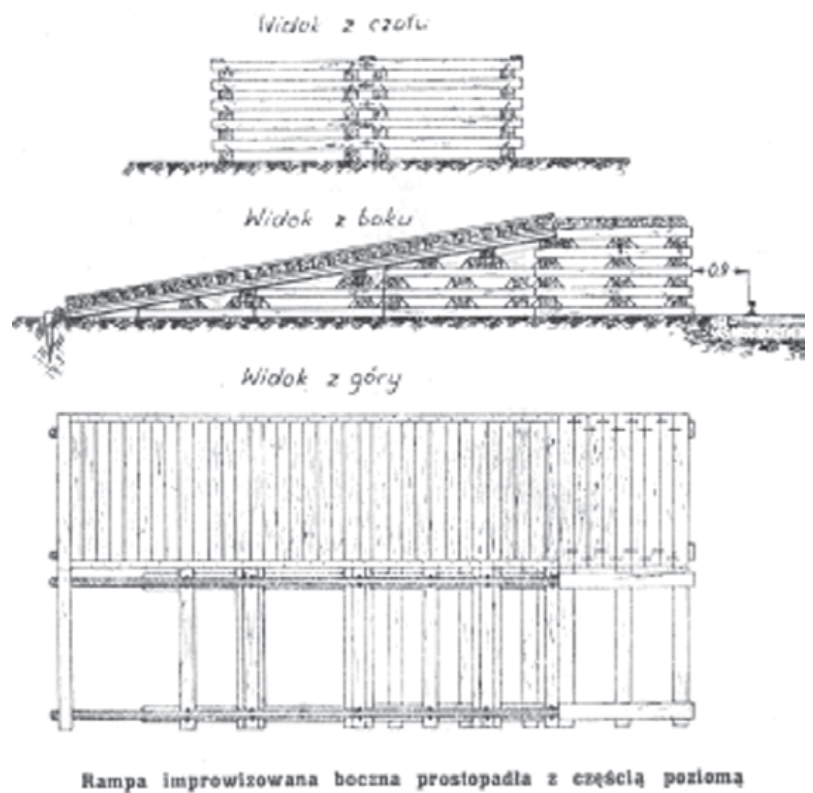

Improvised side perpendicular ramp with a horizontal section.

Z-type portable ramps were also used, comprising three girders, several wooden platform sections, and one wedge-shaped section with steel sheet protection and welded iron non-slip hinges.

Already between the wars heavy-duty railway flat wagons (intended for heavy equipment transport) were fitted with special-purpose consoles placed on their buffer beams. They were used to attach safety supports or wagon bridges to the buffers during the frontal loading and unloading procedures, or for the passage of tracked and wheeled vehicles from one flat wagon to another. Such loading bridges were used to secure the space between the side ramp edges and wagon flooring.

In the late 1940s, special bogie flat wagons were introduced: the PPwwp type ramps. ${ }^{692}$ They were coupled at the end of the train that was to be loaded/ unloaded, a special lever was provided in the mid-section of the wagon; upon detaching the outer bogie and elevating the platform with the use of a lift, the bogie was rolled out, the flat wagon lowered to the rail head level. This is how a massive front loading ramp was provided for the purposes of loading heavy 
armoured equipment onto railway flat wagons. Such ramp flat wagons were owned by the military as special-purpose rolling stock.
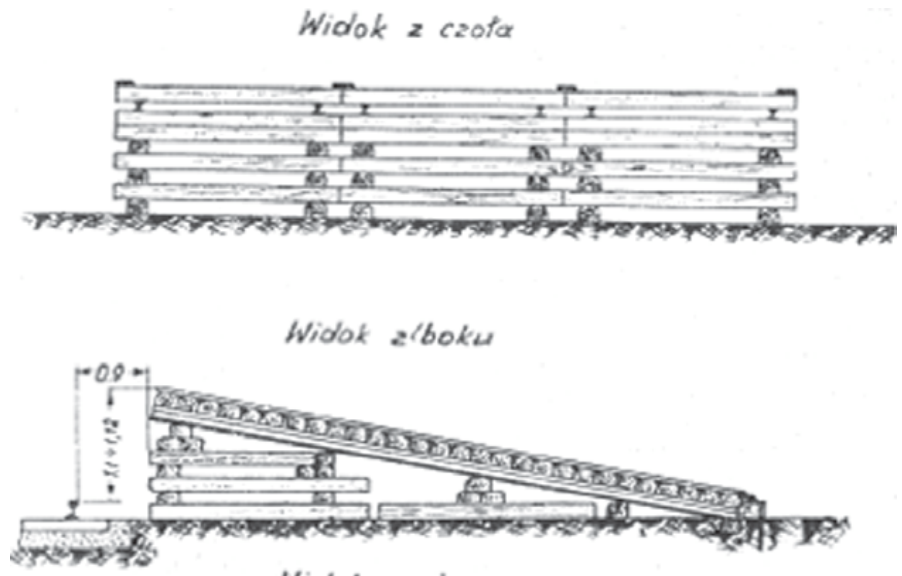

Widak $z$ goiry

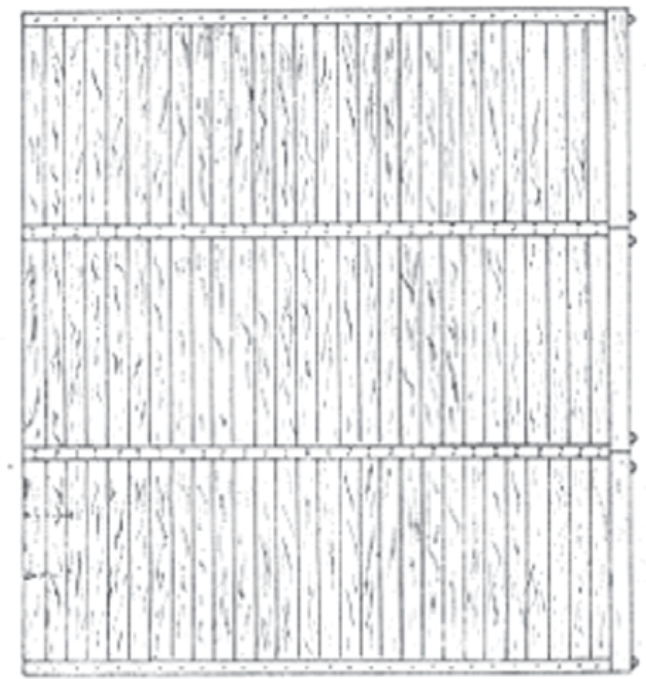

Rampa Improwizowana bocza prostopadla bez częsci poziomej

Improvised side perpendicular ramp without a horizontal section.

Source: Ministry of Transport, Instrukcja o organizacji (1958) 

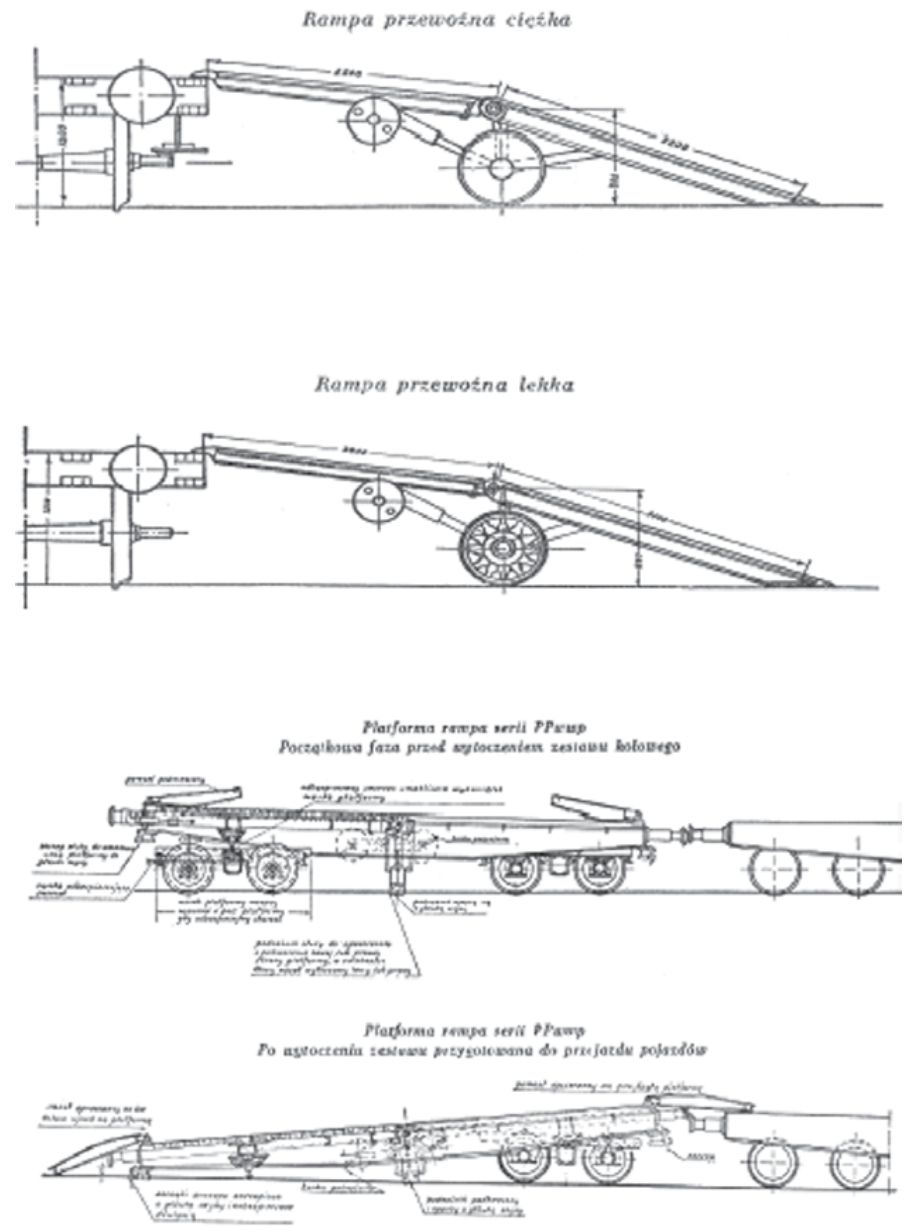

Ppwwp ramp flat wagon.

Source: Polish State Railways, Instrukcja o stosowaniu (1949)

Location of steel ramps and resources deposited for the purposes of improvised ramp construction in DOKP Warsaw ${ }^{693}$

693 Headquarters of Military Transport at Regional State Railway Management in Warsaw, Ogólna charakterystyka (1984), 13. 


\begin{tabular}{|l|l|l|}
\hline Location & $\begin{array}{l}\text { Number of improvised } \\
\text { ramps }\end{array}$ & $\begin{array}{l}\text { Number of folding } \\
\text { ramps }\end{array}$ \\
\hline Station Siedlce & 1 set & 3 sets \\
\hline Station Skierniewice & 1 set & \\
\hline Station Łomża & 1 set & \\
\hline Station Ełk & 1 set & \\
\hline Station Warszawa Odolany & & 3 sets \\
\hline Station Warszawa Praga & & 2 sets \\
\hline Station Białystok & & 2 sets \\
\hline Station Ostrołęka & & 2 sets \\
\hline Station Lódź & & 3 sets \\
\hline Station Kutno & & 3 sets \\
\hline Total & 4 sets & 18 sets \\
\hline
\end{tabular}

\subsection{Transporting Soviet Army Troops in Transit by the Polish State Railways}

Temporary Regulations on the Use of the Polish Railways by USSR Trains ${ }^{694}$ were approved as of October 30th 1946 (with two subsequent amendments).

Russia and Poland entered into the Agreement Regarding Polish-Soviet Direct Railway Communication and the Polish-Soviet Railway Agreement as late as 1950, with intent to formally legalise the extra-territorial transit carriage of Soviet Army military transports, and of travellers, luggage and shipments in both directions between East Germany and USSR, by Soviet trains and with the use of the Polish State Railways network. ${ }^{695}$

Pursuant to the respective agreements, ${ }^{696}$ the carriage of goods and luggage by Soviet trains on the Polish State Railways network was free of customs duties, and was exempt from customs clearance and inspections by the Polish Customs Service. ${ }^{67}$

694 Ministry of Transport, Przepisy tymczasowe (1946).

695 Polish State Railways, Polsko-Radziecka (1950).

696 Polish State Railways, Polsko-Radziecka (1950), 15.

697 Polish officers were not allowed to board the Soviet military trains; they were only authorised to inspect the carriages of the train crew and steam locomotives. 
Transit trains travelled across the Polish territory unchecked. In the 1940s and 1950s, they were used to smuggle huge volumes of industrial goods, other materials, and food. Transit was handled by block ${ }^{698}$ trains assembled pursuant to regulations governing technical operation of Soviet Railways (SZD).

These trains were operated by steam locomotives and train staff of the Soviet or German (East Germany) railways. Russian and East German train crews operating transit trains in Poland were specially selected, also for their loyalty. Nonetheless, German express steam locomotives that hauled transit passenger trains were manned by Russian crews, freight trains handled by Deutsche Reichsbahn/ German National Railways locomotives and crews, which goes to show that Russians did not trust East German citizens. The secret service paid close attention to preventing people from escaping to West Germany in the guise of transit train crewmembers. Every Soviet military train commander was obliged to present a complete list of train crew members at the entry and exit stations of the Polish State Railways, and at the entry stations of the Soviet or East German railways, respectively, to secure the full checks of train crew identities.

The Soviet military train traffic was managed by the appropriate Polish State Railways divisions, under strict supervision by the Soviet military transport authorities, and the plenipotentiary of the Soviet Ministry of Transport at the Polish Ministry of Transport.

Train documentation in the form of special orders, official Russian transit train timetables, and all train traffic charts were drawn up in three languages (Polish, Russian and German). The train crews of the Soviet Railways (SZD) and the Deutsche Reichsbahn/ German National Railways operating transit trains were trained in the use of the Polish railway signalling regulations. However, should a specific crew be not familiar with the Polish signalling or route, Polish State Railways would assign Polish locomotive drivers with the command of the Russian or German language to the transit train locomotives.

Furthermore, the re-forming of train sets, uncoupling or coupling of wagons or carriages or their groups to the USSR block trains on the Polish railway lines was strictly forbidden, unless a damaged vehicle was to be uncoupled.

Should the need arise to reload goods from a damaged wagon, a specialpurpose report was drafted whenever such wagon was to be opened, in the

698 The phrase "block train" references a train set returning in an unchanged composition to its original station of departure. Such solution was intended to prevent any attempts to re-marshal the Soviet trains on the Polish territory. 
presence of a representative of the Supreme Board of Military Transport of the Soviet Army.

The composition of USSR block trains was set at 100-120 axles. As a rule, these trains were hauled by Soviet or East German steam locomotives, Polish State Railways locomotives taking over only in case of the original locomotive being damaged. The transit trains were hauled by German railway express locomotives (classes BR 01, 03) and freight locomotives (BR50 and BR52). ${ }^{699}$ However, an analysis of archival official timetables from the 1950s has shown that BR 01 and BR 52 steam locomotives were assigned to passenger transit trains and freight trains, respectively. The SZD and Deutsche Reichsbahn/ German National Railways locomotives were supplied with fuel and lubricants for a fee, while watering and cleaning on ash pits were free of charge.

Polish State Railways would take over a minimum of 25 transit trains per day from the East German railways, dispatching an identical number in the opposite direction. The following border crossing stations were used as listed below: ${ }^{700}$
1. Szczecin Gumieńce
-1 train
2. Kostrzyn
-6 trains
3. Frankfurt / Oder
-10 trains
4. Gubin
-8 trains

These trains would pass between the Polish and Soviet state railway systems using the following border crossing stations:

1. Bagratyonovsk

2. Zheleznodorozhnyi

3. Łosośna (auxiliary station)

4. Berestovica

5. Brest (via Czeremcha)

6. Brest (via Terespol)

7. Jagodzin

8. Mostiska Nizhankovice
-2 trains

-4 trains

-1 train

-3 trains

-5 trains

-7 trains

-3 trains

-4 trains

On the Polish territory, the USSR trains would as a rule take the following routes in transit:

699 As reported by a retired locomotive driver of the MD Warszawa-Praga depot, Mr. Bogdan Pokropiński.

700 Polish State Railways, Polsko-Radziecka (1950). 
1. Szczecin Gumieńce - Stargard - Krzyż - Piła - Bydgoszcz - Toruń - Iława Olsztyn - Korsze - Bagratyonovsk - $524 \mathrm{~km}$.

2. Kostrzyn - Bydgoszcz - Toruń - Iława - Olsztyn - Zheleznodorozhnyi $546 \mathrm{~km}$, or via Bagratyonovsk (524 km).

3. Frankfurt / Oder - Poznań - Warsaw - Berestovica - $724 \mathrm{~km}$, or via Brest $(715 \mathrm{~km})$ or Vysokolitovsk $(690 \mathrm{~km})$.

4. Frankfurt / Oder - Poznań - Ostrów Wielkopolski - Łódź - Tomaszów Mazowiecki - Radom - Rejowiec - Hrebenne - Rava Ruska - 870 km, or via Jagodzin $(771 \mathrm{~km})$.

5. Gubin - Ostrów Wielkopolski - Łódź - Tomaszów Mazowiecki - Radom Rejowiec - Hrebenne - Rava Ruska - $871 \mathrm{~km}$, or via Jagodzin $(772 \mathrm{~km})$.

6. Gubin - Ostrów Wielkopolski - Łódź - Skarżysko Kamienna - Przeworsk Nizankowice $-730 \mathrm{~km}$, or via Mościska $(732 \mathrm{~km})$.

A term of three days was adopted as the time it would take a USSR transit train to cross the Polish territory as of the moment of take-over from the Soviet Railways/ SZD until the hand-over to the Deutsche Reichsbahn/ German National Railways, or in the reverse direction.

A passenger train (Brest - Warsaw - Berlin) connecting with the Moscow Brest train, requiring train change in Brest, and two trains from Brest to Frankfurt am Oder, were designated to carry passengers and luggage from the USSR to East Germany (and from East Germany to USSR). These trains were assembled with the use of rolling stock (steam locomotives and carriages) provided by the Deutsche Reichsbahn/ German National Railways, and operated by a Russian train and conductor crew jointly with a conductor crew staffed by the Polish State Railways. Passengers and Russian train crews were obliged to remain within the station area whenever the train stopped. The carriage of passengers was subject to the SZD railway regulations and fares.

The USSR Ministry of Transport (Board of International Communications) paid fees to the Ministry of Transport of the Polish People's Republic for the transit of Soviet trains on the Polish State Railways network, for supplying steam locomotives with fuel and lubricants, and for the repairs of damaged rolling stock. The Polish State Railways Central Bureau for Foreign Clearance in Bydgoszcz handled all financial settlements with the Soviet partner for the Polish side. The extremely low tariff rate of 0.0042 tariff unit per axle-kilometre of rolling stock in transit on the Polish State Railways network was adopted, yet changed to 0.03 roubles in 1951 already. ${ }^{701}$ Notably, the method of calculating

701 Polish State Railways, Wykaz zmian (1951), 8. 
fees per axle-kilometre rather than according to the weight of shipments carried also precluded any control of the quantity or type of commodities and military goods transported. The USSR Ministry of Transport began to pay higher fees for the train transit on the Polish State Railways network only in the mid-1980s, and only following tough negotiations by Poland. ${ }^{702}$ Around 1953, the operation of Soviet trains in transit and of the deliveries to the Soviet Army troops stationed on the Polish People's Republic territory was transferred to the Polish State Railways.

\subsection{Transports for Soviet Army Troops Stationed in Poland}

The Soviet military transports were basically operated across the entire Polish State Railways network, depending on the deployment location of the military units.

In light of the high numbers of Soviet troops stationed in Lower Silesia (headquarters of the North Military Group of the Soviet Army stationed in Legnica), the railway line leading from the state border near Przemyśl via Kraków and Katowice to Wrockaw was the longest-remaining broad-gauge route on the Polish territory, allowing military troop trains and supply transports to be carried without transhipment at the border. The line was converted to standard gauge only around $1947 .^{703}$

Upon conversion, military supplies, other cargo and military troop trains were reloaded at the Border Transhipment Bases operated by the USSR Ministry of Defence, or with the use of reloading equipment available at the SZD Russian

702 According to accounts by advisor to the Ministry of Transport, the late Jerzy Wasilewski, the USSR Ministry of Transport began paying higher fees for transit operations on the Polish State Railways only in the mid-1980s, following tough negotiations by Poland.

703 As late as a few years ago the Rolling Stock Repair Plant's Opole workshop was using a boiler originally installed on a broad-gauge FD (Felix Dzerzhynski) steam locomotive - built in Voroshillovgrad with No. 7774/1940, operated at reduced pressure of 10 Atm, the boiler was taken off the frames and positioned on foundations. According to the accounts by employees of the Chief Mechanical Department of the Rolling Stock Repair Plant in Opole, the boiler was set up by the Soviet military authorities after the war as the original boiler room was damaged. It was impossible to identify the number of the steam locomotive originally carrying the boiler. The boiler was carried on a steam locomotive which arrived to Opole at the time when Soviet troops re-gauged the Wrocław - Opole mainline to broad-gauge. 
border stations and Polish Military Transhipment Areas, from broad-gauge to standard-gauge wagons, or from standard-gauge to broad-gauge ones. ${ }^{704}$

Depending on the equipment available at the transhipment areas, military troop trains could be reloaded with the use of the following measures and facilities: an island ramp (loading site), directly from one wagon to another; unloading followed by loading at the same ramp (site); unloading at one ramp (site), followed by a transfer to another ramp (site) and loading. The SZD used bogie vans to carry people, horses and operational field kitchens (galleys). A single bogie van was used to carry 72-80 people; in case of transfers of a maximum daytime duration of 12 hours, such wagons would carry 100 people, or 14 saddle or haulage horses, or 10 artillery horses, or 2 operational field kitchens. ${ }^{705}$ Since the standard-gauge Polish State Railways vans had a lower carrying capacity, larger numbers of wagons had to be provided for transhipment.

A scheduled passenger train (Legnica - Brest), closed to domestic travellers, was introduced in the early 1950s to carry the Soviet soldiers and their luggage. The train continued running until the early 1990s.

On November 23rd 1945, the Ministry of Transport of the Republic of Poland and the USSR People's Commissariat of Communication Routes agreed to adopt the Regulations Concerning Military Transfers for the USSR ${ }^{706}$ (valid as of December 15th 1945). On July 1st 1954, the Ministry of Transport approved the Regulations Concerning Military Transports Operated by Polish Railways for Soviet Army Troops Temporarily Stationed in Poland. ${ }^{707}$

The transports operated for the Soviet troops stationed in Poland included the following: transports of military troop trains, transports of military materials and supplies, military mail transport (by SZD or Polish State Railways mail carriages, or in separate compartments), transport of passengers, luggage and express consignments, and USSR staff saloon wagons. The organisation and handling of Russian military transports was supervised by the Representation of the Supreme Board of Military Transports of the Red Army at the General Staff of the Polish Armed Forces, in co-operation with the Military Transports Directorate of the Polish Armed Forces. Delegations of the Supreme Board of Military Transports of the Red Army at the Central Polish State Railways Management and the individual Regional Managements were recognised as line transport management

704 At border stations, bogies were replaced on passenger carriages and saloon cars only. 705 Ministry of Transport, Instrukcja o organizacji (1958), 105.

706 Ministry of Transport, Przepisy o przewozach (1945).

707 Ministry of Transport, Przepisy o wojskowych (1954). 
units, working closely with the Headquarters of Military Transport and Military Bureaux of the Central and Regional State Railway Managements. The transports of the Red Army soldiers and officers were also operated by Polish State Railways passenger trains, the military carrying military tickets issued by the authorised ticket offices on the Polish territory in exchange for special-purpose military orders.

The following Polish State Railways stations (not included in the Agreement on International Passenger Transport by Rail Tariff) located near major Soviet Army garrisons were designated to carry military personnel and luggage from the Polish People's Republic to the USSR and East Germany: Białogard, Borne Sulinowo, Brzeg, Chojna, Chojnów, Chocianów, Gorzów, Jawor, Kluczewo Pomorskie, Kołobrzeg, Kutno, Lubin Legnicki, Międzyrzecz, Nowa Sól, Odra Port, Oława, Siedlce, Świdnica, Świętoszów, Szczecinek, Szprotawa, Stargard Szczeciński, Toruń Central, Tarnów Opolski, Tomaszów Mazowiecki, Zbąszynek, and Żagań. ${ }^{708}$

On the Polish People's Republic territory, military troop trains were assembled using the standard Polish State Railways rolling stock used in troops transfer - Kl vans to carry soldiers, and passenger carriages for the officers. Bogie flat wagons were used to carry heavy equipment. On the Polish territory, Soviet military troop trains were escorted by the Soviet military security troops. Polish State Railways supplied the military troop trains with fuel, oil lanterns, hot drinking water, and medical assistance if required. Polish State Railways were also obliged to deliver and made available mobile lifting devices, materials to construct portable ramps, official premises to accommodate Delegations of the Supreme Board of Military Transports of the Red Army, means of railway radio communications, and staff saloon carriages for the delegates of the Supreme Board of Military Transports of the Red Army at the General Staff of the Polish Armed Forces.

Uncoupling and removal of wagons from the military troop trains and military transports was only allowed in case of their damage.

The following rolling stock was available to the North Military Group of the Soviet Army stationing in Poland: USSR staff saloon cars to carry officers of the command of the Soviet troops in the Polish People's Republic, USSR mail vans (to carry military mail), and standard-gauge Russian shunting locomotives to operate sidings at the Soviet bases and military units. ${ }^{709}$ The Polish State Railways

708 Ministry of Transport, Instrukcja o organizacji (1958), 29.

709 The railway siding of the military unit in Rokitki was the location of the only TGK2 shunting locomotive (Kaluga 7492/86, renumbered as Ls250) left by the Soviet Army on the Polish territory. 
also operated Soviet railway tank wagon block trains, intended to carry fuels and lubricants for the Soviet troops.

Until December 31st 1946, all block military trains dispatched to the Soviet Union were operated free of charge. In 1945, a tariff rate for the carriage of the Soviet military personnel (and their families) was set at 2.95 zloty per $100 \mathrm{~km}$. Under the regular Polish State Railways tariff (2nd class), a fee of 32.4 zloty was charged for the same distance ${ }^{710}$ - eleven times higher for Polish citizens than for Soviet soldiers and their families. ${ }^{711}$ Military transports for the Soviet troops stationed in Poland operated on credit. All financial settlements with the Command of the Soviet Army in Poland were handled by the Polish State Railways Central Bureau for Foreign Clearance in Bydgoszcz. Military transport fees were paid by the Supreme Board of Military Transports of the Red Army in Moscow. Fees for the military transport were calculated at the extremely low rate of 0.29 rouble $^{712}$ per axle-kilometre of rail carriage.

The passage of empty Soviet tank wagons operated by the Red Army across the Polish territory to loading (transhipment) sites was not subject to any transport charges. In case of oversized loads, the rate was raised by $100 \%$. Fees for the travel of military passengers, luggage, express consignments, and mail were subject to a special military tariff.

710 The Ministry of Transport of the Republic of Poland unsuccessfully tried to introduce a military tariff identical to that applying to the Polish Armed Forces; only as of June 10th 1954 did the USSR government renounce the practically free-of-charge transit between East Germany and USSR. On July 1st 1954, a tariff much more favourable for Poland was eventually introduced.

711 Krogulski (2000), 128.

712 Ministry of Transport, Instrukcja o organizacji (1958), 16. 


\section{MILITARY RAILWAY SIDINGS AND MILITARY RAILWAYS}

The fundamental tasks of military transport authorities of the Polish Armed Forces included the management and supervision of sidings and military railways at bases, units, depots, and military establishments (plants): at all major facilities, military operated standard-gauge sidings as well as internal narrow-gauge lines. Records of Board IV of the General Staff included approximately 200 military sidings with a total length of over $800 \mathrm{~km}$; most transports of armaments, ammunition, materials, and fuels and lubricants were delivered by rail.

Initially, pursuant to a definition as per military regulations, lines were classified as military sidings branching off public tracks, and/or military railways independent narrow-gauge lines operated internally, at Ministry of National Defence facilities. ${ }^{713}$ Military sidings were grouped by construction period:

a) owned and operated by the army until September 1st 1939, and sidings built for the military purposes during the war, taken over by the Polish Armed Forces upon liberation;

b) built after the war to the military and railway works plan of the Military Transports Board of the General Staff;

c) built as part of investment plans, or using internal methods making use of credit lines opened by the Department of Accommodation and Construction Services of the Polish Armed Forces, Investment and Construction Board of the Ministry of National Defence, Air Force Command and Anti-Aircraft Defence Command, Navy Command, and central institutions of the Ministry of National Defence and other military units - and made part of the military railway sidings inventory;

d) built or operated by civilian institutions and taken over for military purposes due to their nature, under inter-ministerial agreements and resulting orders issued by the Chief of the General Staff.

Following the introduction of the Regulations Concerning the Management of Military Railways and Military Railway Rolling Stock ${ }^{714}$ by the Ministry of National Defence, a new definition of military railways was adopted as well,

713 Ministry of National Defence, Przepisy o eksploatacji (1960), 5.

714 Ministry of National Defence, Przepisy o gospodarce (1975), 7. 
extending to and including sidings and on-site railway tracks operated by military units, institutions, plants and enterprises. Sidings were defined as railway tracks intended for on-site (in-house) transport service, branching directly or indirectly off railway lines that were in public use via internal railway lines operated by a specific entity, not connected to the public railway network. Sidings and internal railway tracks would by definition not be distinguished as standard- or narrow-gauge facilities.

The users of military railways users were required to observe all regulations issued by the Ministry of Transport in the field of railway construction, maintenance and technical operation. Surface materials and railway equipment were kept on user records, and under supervision authorities by the Headquarters of Military Transport. The land on which military railways were built was appropriately evidenced by the authorities of the accommodation and construction services; land occupied by state-owned enterprises reporting to the Ministry of National Defence was evidenced by such enterprises.

Military railways were managed by the following entities: Military Transports Board of the General Staff, Military Transports Branches of the military districts, Navy, Ground Forces, National Air Defense (peer entities), military transport commands assisted by Military Transports units reporting to them, and military units (as users).

General supervision over military railways was performed by the head of the Military Transport service via line authorities reporting to him. Military railways on individual military district territory were managed by the heads of Military Transports at respective military districts.

The direct management of military railways operated by all users stationing on the areas of the given Regional State Railway Managements was entrusted to the respective military transport commands, assisted by the military transport authorities reporting to them. Professional soldiers and civilian employees were responsible for operating railways and managing related rail traffic at military units (defined as military railway users).

Military railways were constructed, extended and reconstructed according to investment plans drafted by the Ministry of National Defence. The respective Polish State Railways regulations applied to the design and construction of military railways. ${ }^{715}$ State Railway Managements exercised substantive and technical supervision over the construction of military railways.

715 On 17 January 1963 the Ministry of Transport issued regulation No. 21, on the principles for maintenance and operation of non-public railways used by the Ministry of National Defence and Ministry of Internal Affairs. 
Upon construction, military railways were listed on record pursuant to a respective decision by the Transport Board of the General Staff of the Polish Armed Forces. Military railways had to meet all technical requirements for nonpublic use railways.

The registration of military railways was handled by a commission comprising representatives of the Military Transfer Command, Military Service of Accommodation and Construction, Polish State Railways, the party submitting the facility for registration, and the user. Upon registration, military transport authorities categorised the given military railway in recognition of its purpose and technical condition. The investor was obliged to remove any defects that were identified within the deadlines defined by the commission, prior to the final acceptance of the given railway for operation. Upon takeover of a facility comprising a railway siding from another ministry, authorities of the Headquarters of Military Transport would only inspect the siding and siding-related facilities remaining facility assets (land included) would be inspected and approved by competent military authorities. Military railways approved by military transport authorities and entered into the army stock-lists were handed over to the military unit concerned. All military railways managed and operated by the Ministry of National Defence were listed on record as part of registers managed by the respective Military Transport Commands. They drafted military siding registration cards containing all the basic technical data as required.

A number of the respective military railway on the list was assigned by the Military Transport Command. The following numbering rules were adopted: $:^{716}$

Each number comprised three digits. The first digit corresponded to the Regional State Railway numbering. Ordinal numbers were applied as the second and third digits for standard-gauge railways.

Conversely, narrow-gauge railway numbering involved the digit " 8 " as the second one, the third digit was an ordinal one.

Railway numbering further involved slash-followed railway category designation, and a letter to reflect the main user category, as follows:

a) railways operated by military units of the:

- Warsaw Military District, "W"

- Pomorze Military District, "P"

- Silesian Military District, "S" 
Railways operated by military units reporting to the:

- Central institutions of the Ministry of National Defence, "C"

- Naval Command, "MW"

- Air Force Command, "L"

- Command of the Polish Air Defence Forces, "O"

Letter markings of military railways operated by units reporting to the central institutions of the Ministry of National Defence, the Air Force Command, and the Command of the Polish Air Defence Forces were preceded by a letter designation of the military district on whose territory the railway was located. Users kept files for all military sidings and/or on-site railway tracks, comprising all documents concerning the respective railway facility. Whenever a facility changed hands, files were appropriately forwarded to the new user.

Pursuant to a special order of the Ministry of Transport, all works associated with the repair and maintenance of buildings and equipment on military railways ${ }^{717}$ were provided by the Polish State Railways infrastructure service. ${ }^{718}$

The following criteria applied to the process of military railways categorisation:

- Category One: military railways or groups of tracks used by central or district depots (plants) of hazardous materials;

- Category Two: military railways or groups of tracks used by other central depots and military railways, the number of wagons that were loaded/ unloaded exceeding 1,000 per annum;

- Category Three: all other military tracks and railways.

Category One and Two military railways could comprise track groups or individual tracks classifiable as lower-category assets due to their nature.

Depending on the individual requirements and their technical condition, military railways and/or tracks could be re-classified annually. Maintenance works on military railways included, following the Polish State Railways rules: ${ }^{719}$ ongoing maintenance, running repairs, medium repairs, complete reinstatement, and other works.

717 Okólnik (1957).

718 The renovation of military sidings was mainly based on materials coming from surface replacement during renovation and modernisation of the Polish State Railways network.

719 Polish State Railways, D1, Przepisy budowy (1957), 50. 
Polish State Railways were responsible for the delivery of all repair works and ongoing maintenance on narrow- and standard-gauge military railways not classified as internal railway systems, the user responsible for the repair and maintenance of the latter. Materials required for the purposes of such works were delivered by the Polish State Railways, on order and commission by the Headquarters of Military Transport. The scope of works required to secure the proper technical condition of all military railways temporarily excluded from operation (such as back-up airports) or tracks temporarily excluded from operation yet expected to be used in the future, would be defined by the Headquarters of Military Transport in co-operation with the Polish State Railways representatives.

The Headquarters of Military Transport submitted proposals concerning the use of military railways classified for liquidation (for reasons of limited workload and shortage of specific tasks) to the respective military transport authorities. Decisions concerning partial military railway liquidation (upon performing all arrangements as required) were made by the Headquarters of the Military Transport Service of the respective military district. Decisions concerning the transfer or a complete liquidation of military railways were made by the head of the Military Transport Board of the General Staff of the Polish Armed Forces.

Track layouts forming part of ammunition and explosives depots had to meet special security-related requirements. Such depots were usually located in large forest areas. Siding track systems were constructed according to specific camouflaging requirements and shunting technology rules. Two fundamental track system types were employed at ammunition and explosives depots: circuit track system (Regny, Stawy); and groups of parallel tracks (ending with buffer stops) branching off primary track layouts. Examples of such track systems include depots in Bezwola (constructed in the early 1950s) and in Nurzec.

Sidings at ammunition depots developed since the early 20th century would usually comprise an internal track group (siding station track layout) together with technical facilities and locomotive depot, and a communication track connecting circuit the tracks with high-length loops. 


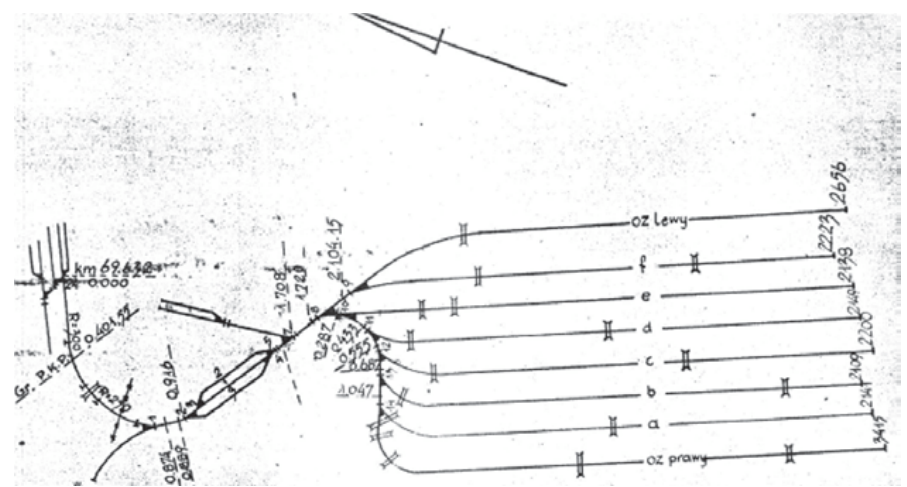

Track layout of military railway siding No. 143 M.U. 3748, Nurzec, 1959. The diagram shows tracks arranged in a group of eight parallel storage tracks

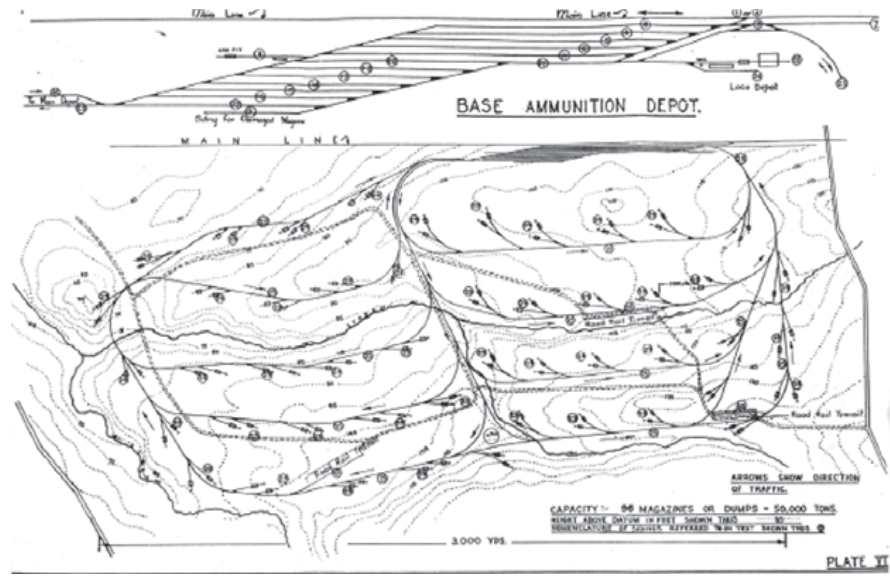

Sample standard railway siding track layout for ammunition storage facilities

A significant distance between the adjacent sidings and the decentralisation of warehouses at a safe distance with respect to the range of possible explosion of materials stored in the individual warehouses, were to prevent the potential explosion of one warehouse to be transferred to other facilities. Two types of access to particular warehouses were usually designed, in the form of short fins branching off from peripheral tracks (the English system was not used in Poland) or warehouses were built directly at the peripheral tracks. The second system facilitated the shunting works in the storage depots. 
According to these assumptions, as early as in the 1930s the construction of two modern central ammunition depots of the Polish Armed Forces in Palmiry and Stawy near Dęblin has been completed.

Railway sidings on the premises of special importance were in some cases designed with independent connections to the Polish State Railways network. ${ }^{720}$ Track layout of the military siding No. 161, Military Unit No. 1530 Regny, as of 1959. The layout shows the peripheral tracks within the storage facility and three independent connections with the Regny, Mikołajów, and Koluszki railway stations

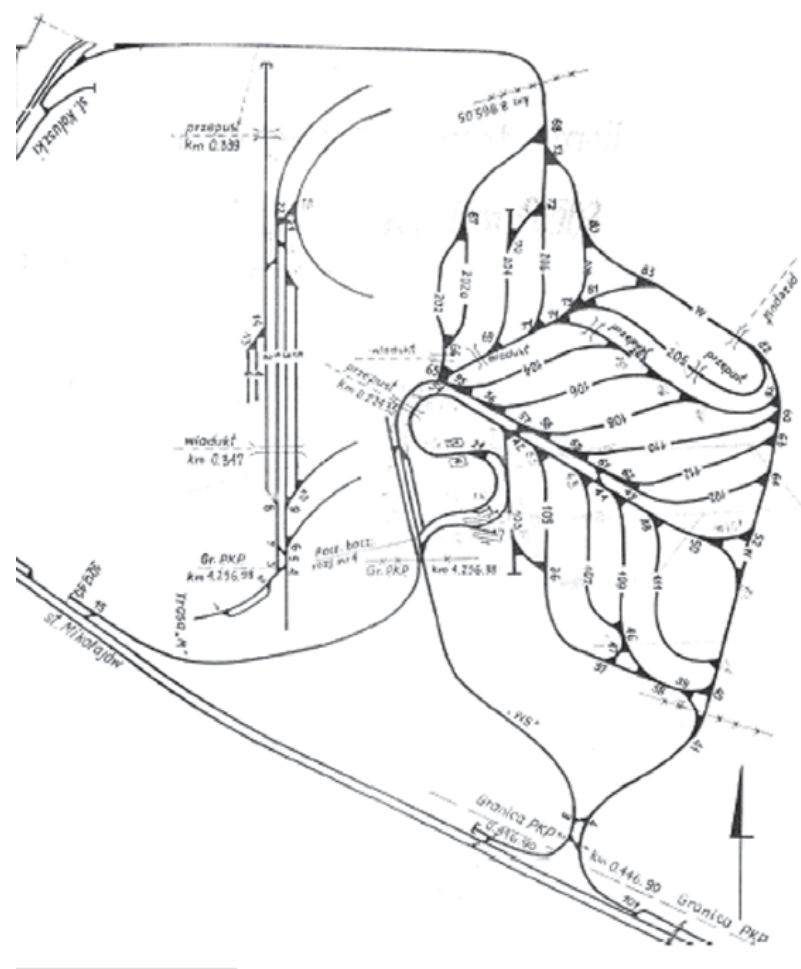

Source: Files of the Warsaw State Railway Regional Management

720 An example of these tendencies was the siding of the warehouse site in Regny and the siding of the "Pronit-Erg" Plastics Plant explosives production plant in Pionki, which had two independent transport tracks connected with the track system of the Pionki and Jedlnia railway stations. 
Track layout of military siding No. 145, Military Unit No. 2186 Hajnówka, as of 1959. The diagram shows a group of warehouse, storage and traction tracks branching out from the main siding track

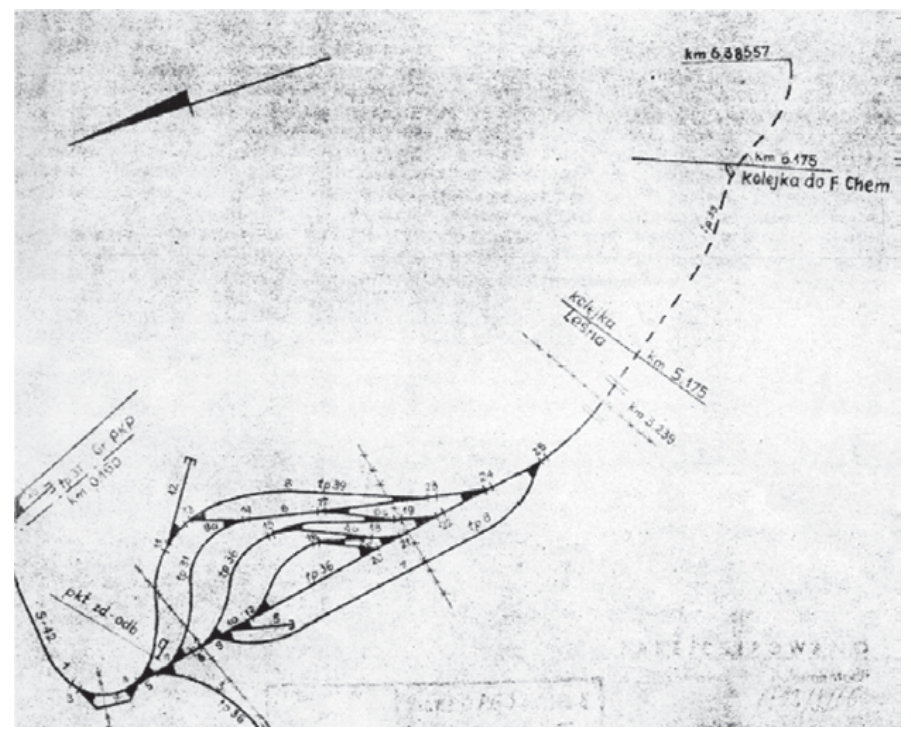

Source: Files of Warsaw State Railway Regional Management

The technology of shunting work on the sidings of ammunition depots included reloading of materials at the internal station area to the internal rolling stock (in order to ensure timely return of the wagons owned by the Polish State Railways as well as an independence from the Polish State Railways rolling stock). On the sidings of the storage sites transport was carried out with own rolling stock which was usually not allowed to operate on the Polish State Railways network.

Locally operated switches were usually used on military sidings. In principle, no other signalling devices were used. Only on the siding of the Osowiec site several manual stop signal shunting discs were installed in the 1950s.

On the few more extensive military sidings, employees and soldiers were transported to work stations in freight wagons adapted to transport people (TOWOS - freight wagons adapted for passenger transport) and old passenger carriages that were withdrawn from the Polish State Railways books since the 
1950s. Such transport procedures were performed: on the siding of the ammunition depot in Stawy (until 1970s), the siding of the military Mechanical Works in Głowno, the siding leading to the airport in Bielice ${ }^{721}$ and the military narrowgauge railway in the Zielonka training area.

List of military sidings in the area of the Head of Military Transport in Warsaw, from 1959 (narrow-gauge sidings were not included, see the list of military narrow-gauge sidings $)^{722}$

\begin{tabular}{|c|c|c|c|c|}
\hline $\begin{array}{l}\text { Siding } \\
\text { no. }\end{array}$ & User & Branch & $\begin{array}{l}\text { Overall } \\
\text { length }\end{array}$ & Remarks \\
\hline 101 & Piaseczno & Piaseczno & & \\
\hline 102 & $\begin{array}{l}\text { Warszawa } \\
\text { Wschodnia }\end{array}$ & & $2277 \mathrm{~m}$ & \\
\hline 103 & \begin{tabular}{|l} 
30th \\
Quartermaster's \\
Warehouse \\
Warszawa - \\
Utrata \\
\end{tabular} & $\begin{array}{l}\text { Warszawa } \\
\text { Wschodnia? }\end{array}$ & $4257 \mathrm{~m}$ & \\
\hline 104 & $?$ & ? & & \\
\hline 105 & $\begin{array}{l}\text { Warszawa } \\
\text { Gdańska }\end{array}$ & & $1930 \mathrm{~m}$ & \\
\hline 106 & $\begin{array}{l}\text { Warszawa } \\
\text { Gdańska }\end{array}$ & Warszawa Gdańska & $1405 \mathrm{~m}$ & \\
\hline 107 & $\begin{array}{l}\text { Warszawa } \\
\text { Gdańska }\end{array}$ & $\begin{array}{l}\text { from communication } \\
\text { track to military } \\
\text { railway siding No. } 108, \\
109\end{array}$ & $?$ & \\
\hline
\end{tabular}

721 The transports were carried out on the Sochaczew - Bielice section, according to a special schedule (seven train pairs) with four Kd wagons (freight wagons adapted for passenger transport) hauled by an SM03 locomotive.

722 Elaborated on the basis of: data by Military Transport Command as well as the Register of railway sidings, Warsaw Regional State Railway Management. 


\begin{tabular}{|c|c|c|c|c|}
\hline $\begin{array}{l}\text { Siding } \\
\text { no. }\end{array}$ & User & Branch & $\begin{array}{l}\text { Overall } \\
\text { length }\end{array}$ & Remarks \\
\hline 108 & $\begin{array}{l}\text { Warszawa } \\
\text { Gdańska }\end{array}$ & & $5140 \mathrm{~m}$ & \\
\hline 109 & $\begin{array}{l}\text { JW } 1136 \\
\text { Warszawa } \\
\text { Gdańska } \\
\end{array}$ & $\begin{array}{l}\text { from military railway } \\
\text { siding No. } 108\end{array}$ & $1297 \mathrm{~m}$ & \\
\hline 110 & $\begin{array}{l}\text { Warszawa } \\
\text { Gdańska }\end{array}$ & & $249 \mathrm{~m}$ & \\
\hline 111 & Rembertów & Warszawa Rembertów & $3629 \mathrm{~m}$ & \\
\hline 112 & Rembertów & Warszawa Rembertów & $9726 \mathrm{~m}$ & \\
\hline 113 & \begin{tabular}{|l} 
JW 2212 \\
Rembertów
\end{tabular} & & $8.701 \mathrm{~m}$ & \\
\hline 114 & Warszawa Jelonki & $\begin{array}{l}\text { from communication } \\
\text { track of the "Warszawa" } \\
\text { steelworks railway } \\
\text { siding }\end{array}$ & $920 \mathrm{~m}$ & \\
\hline 115 & Warszawa Jelonki & & $4435 \mathrm{~m}$ & \\
\hline 116 & $\begin{array}{l}\text { JW } 1391 \\
\text { Celestynów }\end{array}$ & Celestynów & $2882 \mathrm{~m}$ & \\
\hline 117 & Szlakowa & $\begin{array}{l}\text { Arrival in Nasielsk } \\
\text { departure in Modlin }\end{array}$ & $1121 \mathrm{~m}$ & \\
\hline 118 & Rembertów & $\begin{array}{l}\text { from railway siding } \\
\text { No. } 12\end{array}$ & $4465 \mathrm{~m}$ & \\
\hline 119 & Legionowo & & $1091 \mathrm{~m}$ & \\
\hline 120 & $\begin{array}{l}\text { JW } 2396 \text { Zegrze } \\
\text { (Legionowo) }\end{array}$ & & $398 \mathrm{~m}$ & \\
\hline 121 & Modlin & & $820 \mathrm{~m}$ & \\
\hline 122 & Modlin & Modlin & $5650 \mathrm{~m}$ & \\
\hline 123 & Modlin & & $3909 \mathrm{~m}$ & \\
\hline
\end{tabular}




\begin{tabular}{|l|l|l|l|l|}
\hline $\begin{array}{l}\text { Siding } \\
\text { no. }\end{array}$ & User & Branch & $\begin{array}{l}\text { Overall } \\
\text { length }\end{array}$ & Remarks \\
\hline 124 & Modlin & $\begin{array}{l}\text { at km 1.624 from the } \\
\text { communication track } \\
\text { to military siding No. } \\
122,123\end{array}$ & $3677 \mathrm{~m}$ & \\
\hline 125 & Modlin & $\begin{array}{l}\text { at km 1.956 to military } \\
\text { siding No. 124 }\end{array}$ & $2974 \mathrm{~m}$ & \\
\hline 126 & Beniaminów & Beniaminów & $446 \mathrm{~m}$ & \\
\hline 127 & $\begin{array}{l}\text { Military Institute } \\
\text { of Armament } \\
\text { Technology }\end{array}$ & & & \\
\hline Zielonka & $\begin{array}{l} \\
\\
\text { Sochaczew }\end{array}$ & & $7227 \mathrm{~m}$ & \\
\hline 128 & Bielice) & & $6604 \mathrm{~m}$ & \\
\hline 129 & $?$ & & & \\
\hline 130 & $?$ & & & \\
\hline 131 & $?$ & & & \\
\hline 132 & $?$ & & & \\
\hline 133 & $?$ & & & \\
\hline 134 & $?$ & & & \\
\hline 135 & $?$ & & & \\
\hline 136 & $?$ & & & \\
\hline 137 & $?$ & & & \\
\hline 138 & $?$ & & & \\
\hline 139 & $?$ & & & \\
\hline 140 & Biała Podlaska & Biała Podlaska & \\
\hline 141 & Biała Podlaska & & & \\
\hline 142 & JW 1583 Mienia & Mienia & & \\
\hline
\end{tabular}




\begin{tabular}{|c|c|c|c|c|}
\hline $\begin{array}{l}\text { Siding } \\
\text { no. }\end{array}$ & User & Branch & $\begin{array}{l}\text { Overall } \\
\text { length }\end{array}$ & Remarks \\
\hline 143 & Nurzec & Nurzec & 22548.80 & \\
\hline 144 & Pilawa & & $1049 \mathrm{~m}$ & \\
\hline 145 & Hajnówka & & 15163.95 & \\
\hline 146 & JW 3425 Życzyn & Życzyn & $3975 \mathrm{~m}$ & \\
\hline 147 & Siedlce & & $1006 \mathrm{~m}$ & \\
\hline $\begin{array}{l}148 \mathrm{ex} \\
220\end{array}$ & Bezwola & Bezwola & $17845 \mathrm{~m}$ & \\
\hline 149 & $?$ & & & \\
\hline 150 & Suwałki & Suwałki & $753 \mathrm{~m}$ & \\
\hline 151 & $\begin{array}{l}\text { JW } 2009 \\
\text { Białystok }\end{array}$ & Białystok Fabryczny & 3857.0 & \\
\hline 152 & Łomża & & & \\
\hline 153 & JW 124 Osowiec & & 12165.22 & \\
\hline 154 & Ełk & $\begin{array}{l}\text { from railway siding to } \\
\text { gravel excavation pit }\end{array}$ & $561,00 \mathrm{~m}$ & \\
\hline 155 & JW 2199 & $\begin{array}{l}\text { Ostrów Maz. km. } \\
33.220\end{array}$ & 11847 & \\
\hline 156 & $\begin{array}{l}\text { Track No. } 1 \text { of } \\
\text { railway siding } \\
156 \text { Ełk }\end{array}$ & $\begin{array}{l}\text { from gravel pit railway } \\
\text { siding }\end{array}$ & 0.536 .70 & \\
\hline $\begin{array}{l}156 \mathrm{ex} \\
507\end{array}$ & JW 2430 & Szeroki Bór? & 12259.07 & \\
\hline 157 & Białystok & & & \\
\hline 158 & $?$ & & & \\
\hline 159 & $?$ & & & \\
\hline 160 & Skierniewice & & $449 \mathrm{~m}$ & \\
\hline 161 & Regny & & & \\
\hline
\end{tabular}




\begin{tabular}{|c|c|c|c|c|}
\hline $\begin{array}{l}\text { Siding } \\
\text { no. }\end{array}$ & User & Branch & $\begin{array}{l}\text { Overall } \\
\text { length }\end{array}$ & Remarks \\
\hline 162 & Kutno & & 3308.89 & \\
\hline 163 & Łódź Chojny & & & \\
\hline 164 & Gałkówek & & & \\
\hline 165 & Łódź Teodory? & & & \\
\hline 166 & Łęczyca & & & \\
\hline 167 & Płock & & $\begin{array}{l}1.324 \\
0.119 .6 \\
\end{array}$ & \\
\hline 168 & WZM Głowno & & & since 1968 \\
\hline $\begin{array}{l}169 \text { ex } \\
224 ?\end{array}$ & $\begin{array}{l}\text { Tomaszów } \\
\text { Mazowiecki }\end{array}$ & $\begin{array}{l}\text { branching off } \\
\text { Tomaszów Maz. - } \\
\text { Spała line at 6.010th } \\
\text { km }\end{array}$ & $1.954 \mathrm{~m}$ & \\
\hline
\end{tabular}

List and basic characteristics of railway sidings in the Silesian Military District

\begin{tabular}{|l|l|}
\hline \multicolumn{2}{|l|}{ List of Military Railway Sidings in the Silesian Military District area ${ }^{11}$} \\
\hline Railway siding number & Operating station \\
\hline $401 /$ III/SOPK & Mierzęcice \\
\hline $402 /$ III/S & Gliwice Port \\
\hline $403 /$ III/SIG & Siemianowice \\
\hline $404 /$ III/SOPK & Cykarzew \\
\hline $405 /$ III/S & Zebrzydowice \\
\hline $601 /$ III-S & Wrocław Popowice \\
\hline $603-$ III-S & Wrocław Swojczyce \\
\hline $604-$ III-S & $\begin{array}{l}\text { Namysłów } \\
\text { (Jastrzębie Śl.) }\end{array}$ \\
\hline $605-$ III-S & Brzeg \\
\hline
\end{tabular}




\begin{tabular}{|c|c|}
\hline \multicolumn{2}{|c|}{ List of Military Railway Sidings in the Silesian Military District area ${ }^{11}$} \\
\hline 606-III-S & Brzeg \\
\hline 607-III-S & Brzeg \\
\hline 610-III-S & Komprachcice \\
\hline 611-III-S & Komprachcice \\
\hline 612-III-SIC & Krapkowice \\
\hline $613-S$ & Opole Zachód \\
\hline 614-III-S & Wrocław Klecina \\
\hline 616-III-S & Czernica Wrocławska \\
\hline 702/III/S & Czerwieńsk \\
\hline 703/III/S & Poznań Gł. \\
\hline 705/III/3 (S?) & Gubin \\
\hline 709/III/S & Trzemeszno Lubuskie \\
\hline 710/III/S & Poznań Gł. \\
\hline 712/III S & Gorzów Wlkp. \\
\hline 713/II SIC & Przewóz \\
\hline 715/III/S & Kostrzyn \\
\hline 716/III/S & Kunowice \\
\hline 717/III/S & Poznań Gł. \\
\hline 718/II/S & Żagań \\
\hline 719 & Krzystkowice \\
\hline $\begin{array}{l}720 \text { (removed, register number } \\
\text { changed to 609) }\end{array}$ & Głogów \\
\hline $\begin{array}{l}721 \text { (removed, register number } \\
\text { changed to } 715 \text { ) }\end{array}$ & Radnica \\
\hline $\begin{array}{l}722 \text { (removed, register number } \\
\text { changed to 707) }\end{array}$ & Poznań Wola \\
\hline
\end{tabular}




\section{List of Military Railway Sidings in the Silesian Military District area ${ }^{11}$}

723 (removed, register number

Wałowice

changed to 704)

${ }^{11}$ Based on photocopies of schematic plans and characteristics of military railways from the archives of the Transport Division of the Silesian Military District.

Inventory of military rolling stock used on the military sidings of the Silesian Military District from the $1970 \mathrm{~s}^{723}$

\begin{tabular}{|c|c|c|c|c|}
\hline Post No. & Siding No. & Military Unit & Locomotives & Wagons \\
\hline $\begin{array}{l}\text { Post No. } \\
52 / 026\end{array}$ & 601-III-S & $\begin{array}{l}\text { 4th District } \\
\text { Equipment Depot }\end{array}$ & $\begin{array}{l}\text { Ls40-4196 } \\
\text { Ls40-5087 }\end{array}$ & \\
\hline $\begin{array}{l}\text { Post No. } \\
54 / 620\end{array}$ & 603-III-S & $\begin{array}{l}\text { 5th District fuel } \\
\text { stock }\end{array}$ & Ls40-4555 & \\
\hline $\begin{array}{l}\text { Post No. } \\
61 / 613\end{array}$ & 604-III-S & $\begin{array}{l}\text { 9th District } \\
\text { Weapons Depot }\end{array}$ & Ls150-369 & $\begin{array}{l}820247 \text { flat wagon } \\
30 \mathrm{~km} / \mathrm{h} \\
870510 \text { van } 30 \mathrm{~km} / \mathrm{h} \\
858084 \text { tender } \\
05729 \text { flat wagon }\end{array}$ \\
\hline $\begin{array}{l}\text { Post } \\
\text { No.? }\end{array}$ & 612-III-SIC & $\begin{array}{l}\text { 3rd District } \\
\text { Explosives Depot }\end{array}$ & $\begin{array}{l}\text { Ls180 } \\
?-112 \\
\end{array}$ & \begin{tabular}{|l}
$870385 \mathrm{Kd}$ \\
$870534 \mathrm{Pd}$ \\
\end{tabular} \\
\hline $\begin{array}{l}\text { Post No. } \\
61 / 013\end{array}$ & 713/II SIC & JW 3303 Potok & $\begin{array}{l}\text { Ls40-4061 } \\
\text { Ls40-4557 }\end{array}$ & $\begin{array}{l}858085 \text { tender } \\
858087 \text { tender }\end{array}$ \\
\hline $\begin{array}{l}\text { Post } \\
\text { No.? }\end{array}$ & 719/III/SIC & $\begin{array}{l}\text { JW } 1951 \\
\text { Krzystkowice }\end{array}$ & Ls40-4593 & $\begin{array}{l}\text { XK } 870416 \\
\text { Xp } 870532 \\
\end{array}$ \\
\hline $\begin{array}{l}\text { Post } \\
\text { No.? }\end{array}$ & \begin{tabular}{|l|}
$721 / \mathrm{II} / \mathrm{S} 721$ \\
to 715
\end{tabular} & JW 4013 Radnica & $\begin{array}{l}\text { Ls300-885 } \\
350 \mathrm{KM}\end{array}$ & \\
\hline
\end{tabular}

723 Listed on the basis of data from the Silesian Military District. 


\subsection{Military narrow-gauge railways}

In the post-war period, the Polish Armed Forces managed and operated several military narrow-gauge railways and sidings branching off from Polish State Railways narrow-gauge lines, on the internal areas of Navy bases, airports, warehouses and military training areas. Determining the exact number of such lines is extremely difficult given the scarcity of archival material (most of the technical files from the 1940s and 1950s in military archives are missing). In the case of some lines only partial information was found - excerpts from factory lists or rolling stock delivery records are the only indirect sources documenting their existence. The table below summarises all collected information on narrow-gauge railways and sidings operated by the Polish Armed Forces in the post-war period. List of narrow-gauge military railways 


\begin{tabular}{|c|c|c|c|c|}
\hline 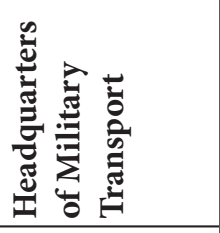 & 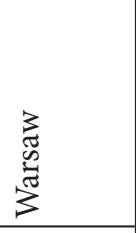 & 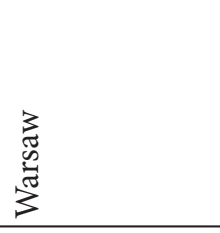 & 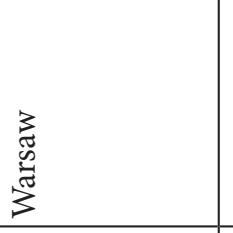 & 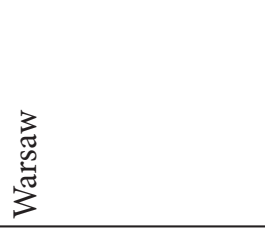 \\
\hline 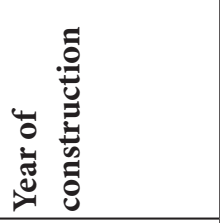 & $\stackrel{2}{2}$ & 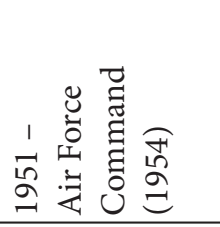 & $\stackrel{\text { ڤn }}{2}$ & 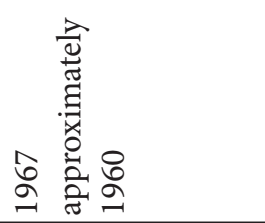 \\
\hline 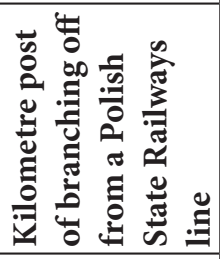 & 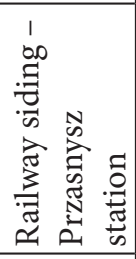 & 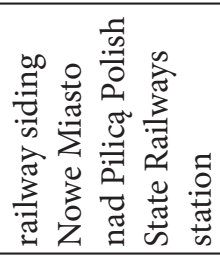 & $i$ & 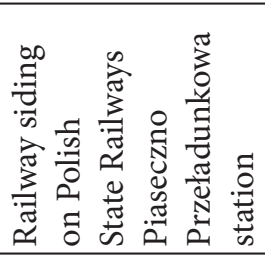 \\
\hline 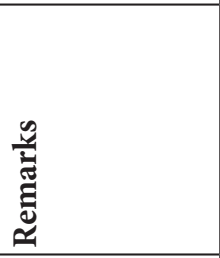 & 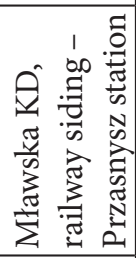 & 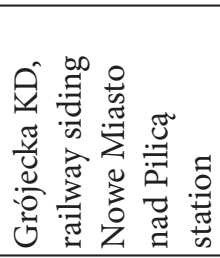 & 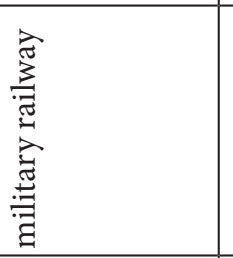 & 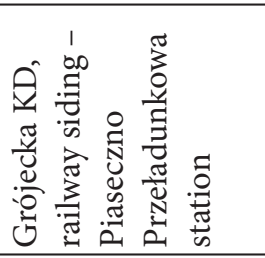 \\
\hline 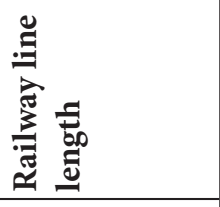 & $\begin{array}{l}\frac{\dot{\Xi}}{8} \\
\stackrel{\Xi}{\sim} \\
\end{array}$ & \begin{tabular}{l}
$\dot{\xi}$ \\
\multirow{G}{*}{} \\
$\hat{\sim}$ \\
\end{tabular} & 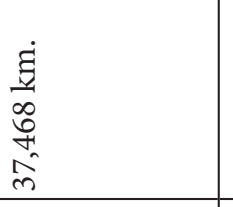 & $\begin{array}{l}0 \\
\hat{6} \\
-1 \\
-1\end{array}$ \\
\hline 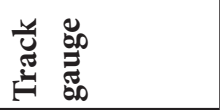 & $\begin{array}{l}\uparrow \\
8 \stackrel{1}{\circ} \\
8\end{array}$ & $\stackrel{8}{8}$ & $\stackrel{\circ}{1}$ & $\stackrel{8}{\circ}$ \\
\hline : & 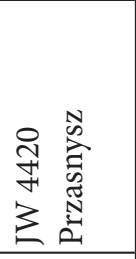 & 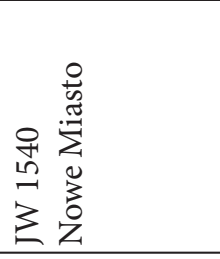 & 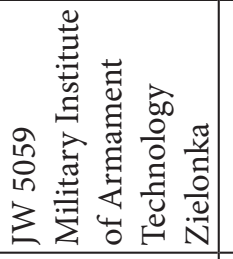 & 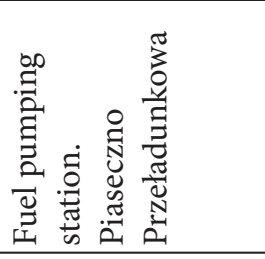 \\
\hline 疍 & $\stackrel{\infty}{-1}$ & $\stackrel{\infty}{=}, 3$ & $\stackrel{\infty}{\rightarrow}$ & $\stackrel{\infty}{\sim}$ \\
\hline
\end{tabular}




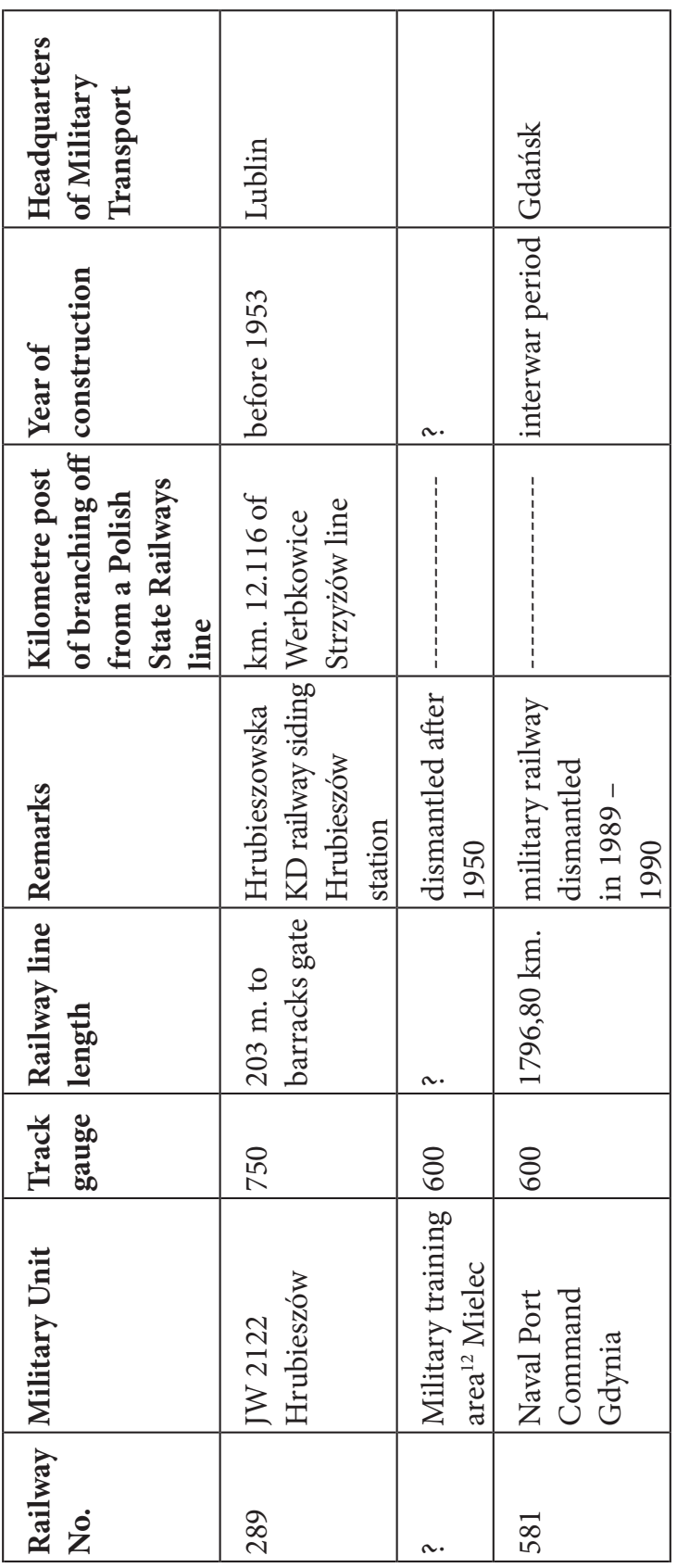

Zbigniew Tucholski - 978-3-631-82966-0 


\begin{tabular}{|c|c|c|c|c|}
\hline 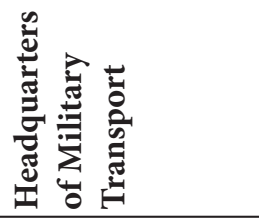 & 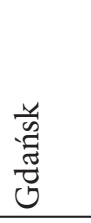 & 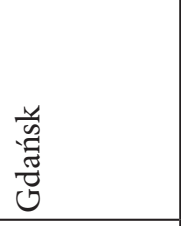 & 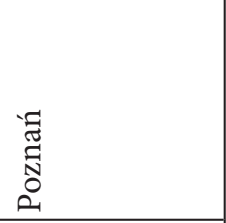 & 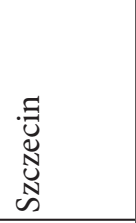 \\
\hline 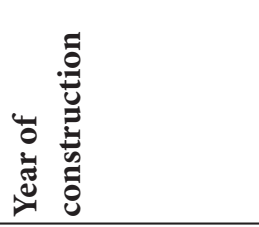 & à & $\sim$. & 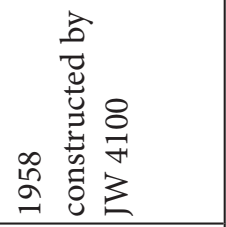 & 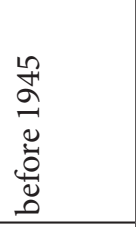 \\
\hline 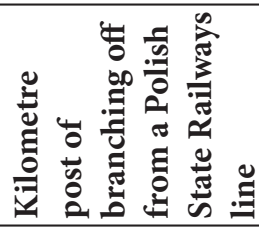 & & & 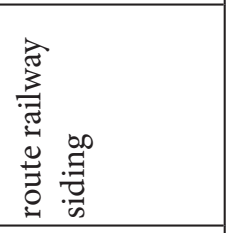 & \\
\hline 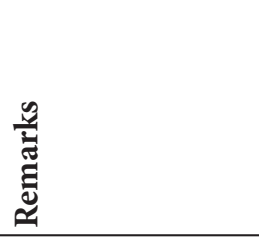 & 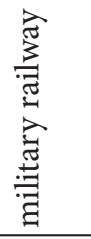 & 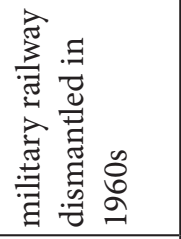 & 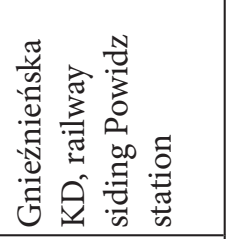 & 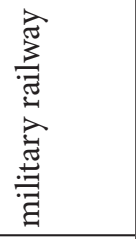 \\
\hline 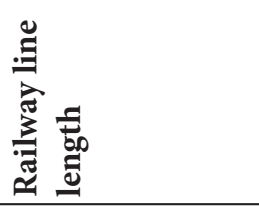 & 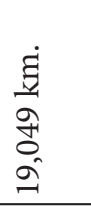 & $\sim$. & 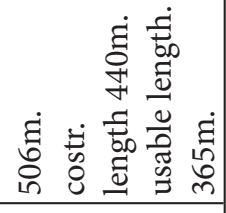 & $\begin{array}{l}1 \\
\stackrel{1}{\xi} \\
\stackrel{\Xi}{n} \\
\stackrel{\Xi}{=}\end{array}$ \\
\hline 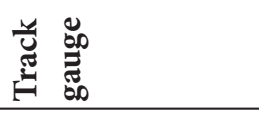 & 8 & $\begin{array}{l}\tilde{0} \\
\stackrel{8}{\circ} \\
\wedge\end{array}$ & $\begin{array}{l}\uparrow \\
8 \\
8\end{array}$ & 8 \\
\hline 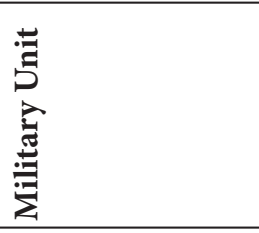 & 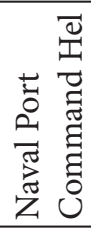 & 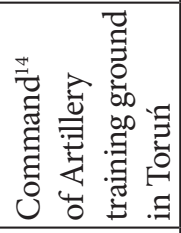 & 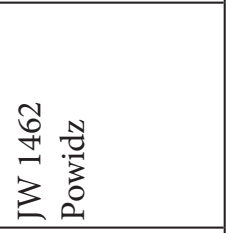 & 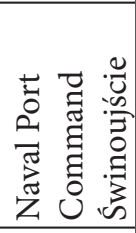 \\
\hline 氧 & in & & $\stackrel{\infty}{\wedge}$ & $\infty$ \\
\hline
\end{tabular}

Zbigniew Tucholski - 978-3-631-82966-0 


\begin{tabular}{|c|c|c|c|c|}
\hline 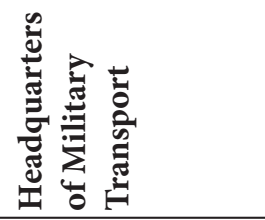 & 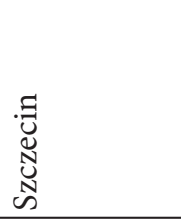 & $\begin{array}{l}\text { ज्ञ } \\
\text { Nू } \\
\text { ஸू }\end{array}$ & $\sim$ & 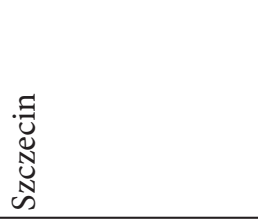 \\
\hline 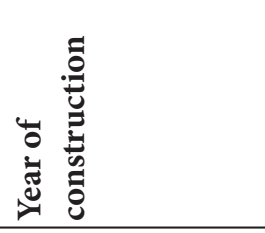 & 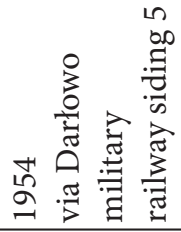 & $\stackrel{\curvearrowright}{\widehat{\Xi}}$ & $\sim$ & $\sim$. \\
\hline 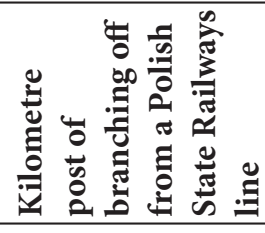 & 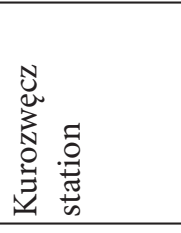 & 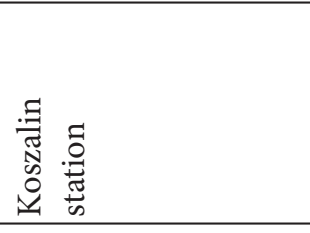 & $\sim$. & 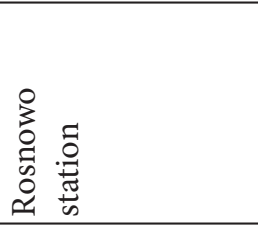 \\
\hline 荘 & 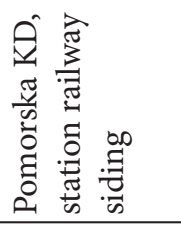 & 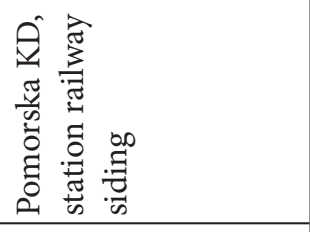 & $\sim$. & 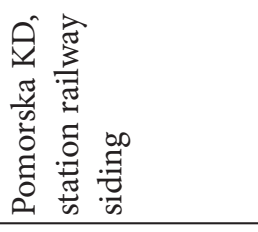 \\
\hline 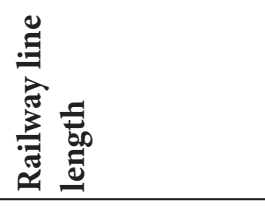 & 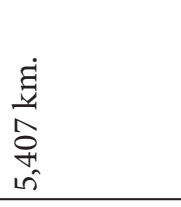 & 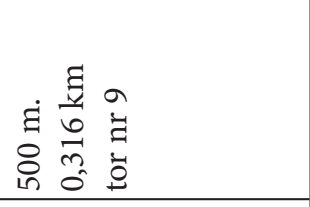 & $\sim$. & \begin{tabular}{l}
$\stackrel{+}{10}$ \\
\multirow{2}{*}{$\Xi$} \\
0
\end{tabular} \\
\hline 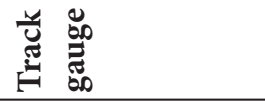 & ¿ & \& & $\sim$. & ¿ \\
\hline 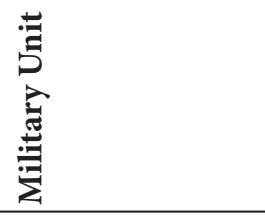 & 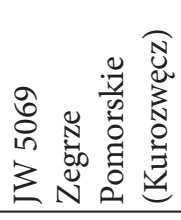 & 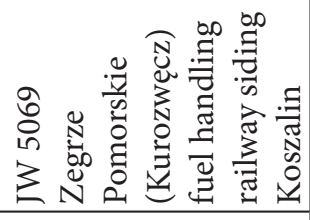 & $\sim \cdot$ & 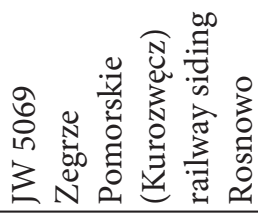 \\
\hline$\stackrel{\vec{\pi}}{\tilde{\pi}}$ & $\infty$ & $\infty$ & $\begin{array}{l}+ \\
\infty \\
\infty\end{array}$ & $\begin{array}{l}10 \\
\infty \\
\infty\end{array}$ \\
\hline
\end{tabular}

Zbigniew Tucholski - 978-3-631-82966-0

Downloaded from PubFactory at 09/30/2020 04:51:29PM by keerthiga.m@newgen.co 

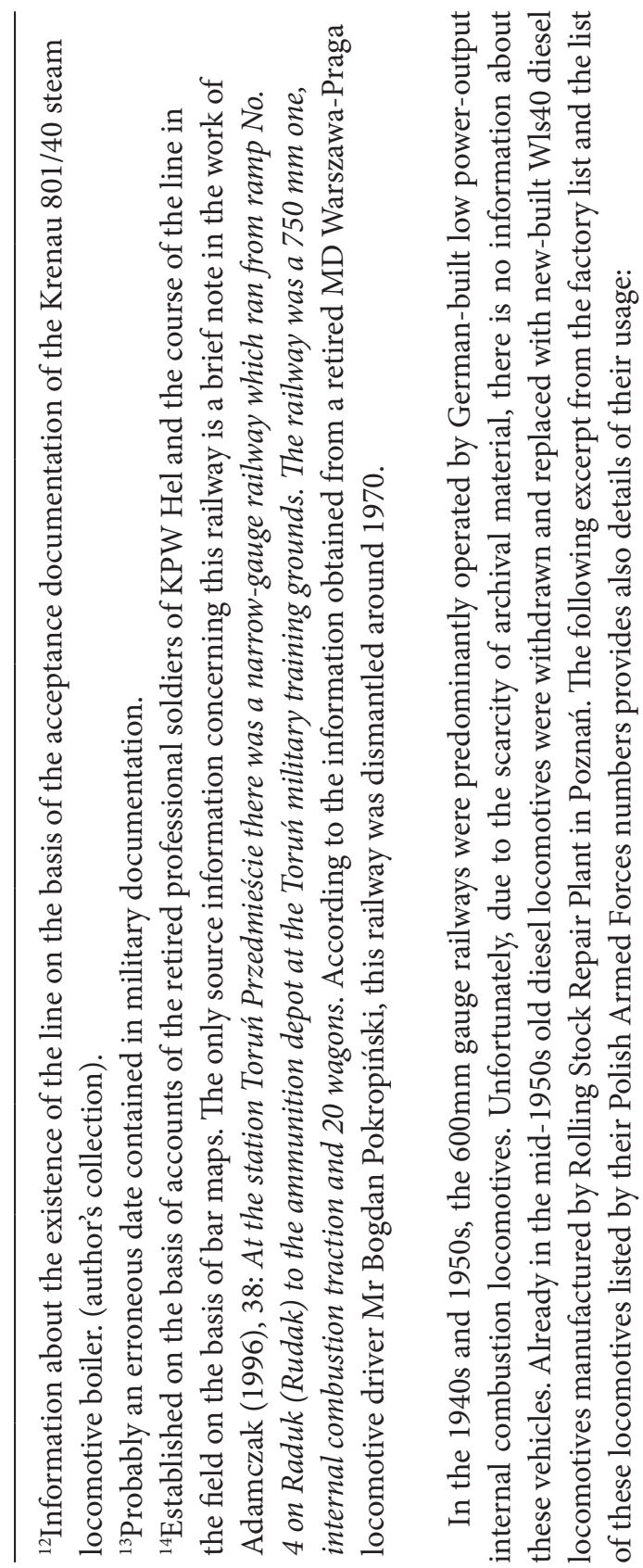

Zbigniew Tucholski - 978-3-631-82966-0 
List of military narrow-gauge diesel locomotives of WLs 40/50 type e $^{724}$

\begin{tabular}{|c|c|c|c|}
\hline $\begin{array}{l}\text { Type and } \\
\text { Polish Armed } \\
\text { Forcesnumber } \\
\end{array}$ & $\begin{array}{l}\text { Factory } \\
\text { number, year of } \\
\text { production }\end{array}$ & Service record & Remarks \\
\hline WP-11-40361 & $\begin{array}{l}\text { Rolling Stock } \\
\text { Repair Plant } \\
\text { Poznań 120/53 r. }\end{array}$ & $\begin{array}{l}\text { 2.06.53 JW } 3127 \text { Dęblin } \\
\rightarrow \text { Naval Port Command } \\
\text { Gdynia 4.02.91 } \rightarrow \text { Naval Port } \\
\text { Command Świnoujście }\end{array}$ & $\begin{array}{l}\text { defective } \\
+1996 \text { r. }\end{array}$ \\
\hline WP-11-40362 & $?$ & $?$ & \\
\hline WP-11-40363 & $\begin{array}{l}\text { Rolling Stock } \\
\text { Repair Plant } \\
\text { Poznań 289/55 r. } \\
\end{array}$ & $\begin{array}{l}\text { 5.04.55 JW 2454 Przytor, } \\
\text { renamed: Naval Port } \\
\text { Command Świnoujście }\end{array}$ & \\
\hline WP-11-40364 & $\begin{array}{l}\text { Rolling Stock } \\
\text { Repair Plant } \\
\text { Poznań 291/55 r. }\end{array}$ & $\begin{array}{l}\text { 5.04.55 JW } 3643 \text { Gdynia } \\
\text { Port-Oksywie, railway siding } \\
\text { No. 407, renamed: Naval Port } \\
\text { Command Gdynia } 1991 \rightarrow \\
\text { Naval Port Command Hel }\end{array}$ & \\
\hline WP-11-40365 & $\begin{array}{l}\text { Rolling Stock Repair } \\
\text { Plant Poznań?/55 }\end{array}$ & Naval Port Command Hel & \\
\hline WP-11-40366 & $?$ & $?$ & \\
\hline WP-11-40367 & \begin{tabular}{|l} 
Rolling Stock \\
Repair Plant \\
Poznań 402/56 \\
\end{tabular} & $\begin{array}{l}\text { 15.02.56 JW } 24 \text { Odra Port } \\
\rightarrow \text { Naval Port Command } \\
\text { Świnoujście }\end{array}$ & \\
\hline WP-11-40368 & $\begin{array}{l}\text { Rolling Stock } \\
\text { Repair Plant } \\
\text { Poznań 329/55 } \\
\end{array}$ & $\begin{array}{l}\text { 18.07.55 JW } 2224 \text { Darłowo } \\
\rightarrow \text { Naval Port Command } \\
\text { Świnoujście }\end{array}$ & \\
\hline WP-11-40369 & $\begin{array}{l}\text { Rolling Stock } \\
\text { Repair Plant } \\
\text { Poznań 330/55 }\end{array}$ & $\begin{array}{l}\text { 18.07.55 JW } 2655 \text { Września } \\
\rightarrow \text { Naval Port Command } \\
\text { Świnoujście }\end{array}$ & $\begin{array}{l}\text { defective } \\
+1996 \text { r. }\end{array}$ \\
\hline
\end{tabular}

724 Prepared on the basis of records of military rolling stock of the Headquarters of the Military Transport Service of the General Quartermaster of the Polish Armed Forces, Headquarters of Military Transport, and documentation (vehicle logbook) of the individual military locomotives. Z Zbigniew Tucholski - 978-3-631-82966-0 


\begin{tabular}{|c|c|c|c|}
\hline $\begin{array}{l}\text { Type and } \\
\text { Polish Armed } \\
\text { Forcesnumber } \\
\end{array}$ & $\begin{array}{l}\text { Factory } \\
\text { number, year of } \\
\text { production }\end{array}$ & Service record & Remarks \\
\hline WP-11-40370 & $?$ & $?$ & \\
\hline WP-11-40371 & $\begin{array}{l}\text { Rolling Stock } \\
\text { Repair Plant } \\
\text { Poznań 436/36 } \\
1956\end{array}$ & $\begin{array}{l}\text { 18.04.56 JW } 2655 \text { Września } \\
\rightarrow \text { Navy Harbour Command } \\
\text { Hel }\end{array}$ & \\
\hline WP-11-40372 & $\begin{array}{l}\text { Rolling Stock } \\
\text { Repair Plant } \\
\text { Poznań 437/56 }\end{array}$ & $\begin{array}{l}\text { 29.05.56 JW 2655 Września } \\
\rightarrow \text { Navy Harbour Command } \\
\text { Hel }\end{array}$ & \begin{tabular}{|l} 
sidelined \\
as spare \\
parts \\
donor \\
\end{tabular} \\
\hline WP-11-40373 & $\begin{array}{l}\text { Rolling Stock } \\
\text { Repair Plant } \\
\text { Poznań 688/57 }\end{array}$ & $\begin{array}{l}\text { 9.01.58 Military Equipment } \\
\text { Stock Przemyśl } \rightarrow \text { Naval Port } \\
\text { Command Hel }\end{array}$ & $\begin{array}{l}\text { defective } \\
+ \\
20.10 .93 \mathrm{r} .\end{array}$ \\
\hline
\end{tabular}

WLs 40/50 diesel locomotives built for Polish Armed Forces ${ }^{725}$

\begin{tabular}{|l|l|l|l|l|}
\hline $\begin{array}{l}\text { Factory } \\
\text { No. }\end{array}$ & $\begin{array}{l}\text { Year of } \\
\text { production }\end{array}$ & Type & Locomotive user & Track gauge \\
\hline 120 & 1953 & WLs40 & $\begin{array}{l}\text { 2.06.53 Polish Armed Forces } \\
\text { JW 3127 Dęblin }\end{array}$ & $600 \mathrm{~mm}$ \\
\hline 121 & 1953 & WLs40 & $\begin{array}{l}\text { 2.06.53 Polish Armed Forces } \\
\text { JW 3127 Dęblin }\end{array}$ & $600 \mathrm{~mm}$ \\
\hline 289 & 1955 & WLs40 & $\begin{array}{l}\text { 5.04.55 Polish Armed Forces } \\
\text { JW 2454, railway siding at } \\
\text { Przytor station }\end{array}$ & $600 \mathrm{~mm}$ \\
\hline 290 & 1955 & WLs40 & $\begin{array}{l}\text { 5.04.55 Polish Armed Forces } \\
\text { JW 5027, Hell station - } \\
\text { railway siding No. 409 }\end{array}$ & $600 \mathrm{~mm}$ \\
\hline
\end{tabular}

725 Prepared on the basis of the WLs40/50 Rolling Stock Repair Plant Poznań locomotive factory list. 


\begin{tabular}{|l|l|l|l|l|}
\hline $\begin{array}{l}\text { Factory } \\
\text { No. }\end{array}$ & $\begin{array}{l}\text { Year of } \\
\text { production }\end{array}$ & Type & Locomotive user & Track gauge \\
\hline 291 & 1953 & WLs40 & $\begin{array}{l}5.04 .55 \text { Polish Armed Forces } \\
\text { JW 3643, Gdynia Port - } \\
\text { Oksywie station, railway } \\
\text { siding No. 407 }\end{array}$ & $600 \mathrm{~mm}$ \\
\hline 329 & 1955 & WLs40 & $\begin{array}{l}18.07 .55 \text { Polish Armed Forces } \\
\text { JW 2224, Darłowo station }\end{array}$ & $600 \mathrm{~mm}$ \\
\hline 330 & 1955 & WLs40 & $\begin{array}{l}18.07 .55 \text { Polish Armed Forces } \\
\text { JW 2655 Września, Września } \\
\text { station }\end{array}$ & $600 \mathrm{~mm}$ \\
\hline 331 & 1955 & WLs40 & $\begin{array}{l}18.07 .55 \text { Polish Armed } \\
\text { Forces JW 1523 Bakończyce, } \\
\text { Przemyśl station }\end{array}$ & $600 \mathrm{~mm}$ \\
\hline 402 & 1956 & WLs40 & $\begin{array}{l}15.02 .56 \text { Polish Armed Forces } \\
\text { JW 24 Odra Port }\end{array}$ & $600 \mathrm{~mm}$ \\
\hline 436 & 1956 & WLs40 & $\begin{array}{l}\text { 18.04.56 Polish Armed Forces } \\
\text { JW 2655 Września }\end{array}$ & $600 \mathrm{~mm}$ \\
\hline 437 & 1956 & WLs40 & $\begin{array}{l}29.05 .56 \text { Polish Armed Forces } \\
\text { JW 2655 Września }\end{array}$ & $600 \mathrm{~mm}$ \\
\hline 688 & 1957 & WLs40 & $\begin{array}{l}9.01 .58 \text { Polish Armed Forces, } \\
\text { Military Equipment Stock } \\
\text { Przemyśl, Przemyśl station } \\
\text { Navy Harbour Command } \\
\text { Hel) }\end{array}$ & $600 \mathrm{~mm}$ \\
\hline
\end{tabular}

The above list also requires some commentary: locomotives built for the battalions of railway troops - JW 2224 Darłowo, JW 2655 Września, and JW 1523 Bakończyce were probably used as construction equipment on makeshift construction and training narrow-gauge railways. About locomotives built for JW 3127 Dęblin and JW 6066 Ełk there is no information as for their intended use. 


\begin{tabular}{|l|l|l|l|l|}
\hline $\begin{array}{l}\text { Factory } \\
\text { No. }\end{array}$ & $\begin{array}{l}\text { Year of } \\
\text { production }\end{array}$ & Type & Locomotive user & Track gauge \\
\hline 863 & 1959 & WLs40 & $\begin{array}{l}24.02 .59 \text { Polish Armed Forces, } \\
\text { Military Equipment Stock } \\
\text { Przemyśl station (Naval Port } \\
\text { Hel 1974 } \rightarrow \text { Polish State } \\
\text { Railways Białośliwie Ld1-3) }\end{array}$ & $600 \mathrm{~mm}$ \\
\hline 1102 & 1960 & WLs50? & $\begin{array}{l}\text { 6.01.61 Polish Armed Forces } \\
\text { JW 6066 Ełk, Ełk Towarowa } \\
\text { (freight) station }\end{array}$ & $600 \mathrm{~mm}$ \\
\hline 1103 & 1960 & WLs50? & $\begin{array}{l}\text { 6.01.61 Polish Armed Forces } \\
\text { JW 6066 Ełk, Ełk Towarowa } \\
\text { (freight) station }\end{array}$ & $600 \mathrm{~mm}$ \\
\hline 1709 & 1965 & WLs50 & $\begin{array}{l}\text { Naval Port Command Hel } \\
6.09 .77 \rightarrow \text { Polish State } \\
\text { Railways Ld1-2 Warsaw } \\
\text { Military District Białośliwie } \\
\rightarrow \text { Myślęcinek No. 1 }\end{array}$ & $600 \mathrm{~mm}$ \\
\hline
\end{tabular}

Technical specification of WLs40/50 locomotives l26 $^{726}$

\begin{tabular}{|l|l|}
\hline Track gauge & $\begin{array}{l}\mathbf{6 0 0} \mathbf{~ m m} \text { gauge standard } \\
\text { construction }\end{array}$ \\
\hline Weight in working order & $7,8 \mathrm{t}$ \\
\hline Own weight & $7,0 \mathrm{t}$ \\
\hline Number of powered axles & 2 \\
\hline Wheel-base & $1000 \mathrm{~mm}$ \\
\hline Driving wheel diameter & $550 \mathrm{~mm}$ \\
\hline
\end{tabular}

726 WLs40 stands for a narrow-gauge diesel locomotive with $40 \mathrm{HP}$ power output or WLs50 with 50 HP power output, depending on the type of S64L or S-324 HL engine 


\begin{tabular}{|l|l|}
\hline Track gauge & $\begin{array}{l}\mathbf{6 0 0} \mathbf{~ m m} \text { gauge standard } \\
\text { construction }\end{array}$ \\
\hline Locomotive length & $4380 \mathrm{~mm}$ \\
\hline Locomotive width & $1440 \mathrm{~mm}$ \\
\hline Locomotive height & $2200 \mathrm{~mm}$ \\
\hline Minimum curve radius & $10 \mathrm{~m}$. \\
\hline Number of gears & 4 \\
\hline Speed on the respective gears & $\begin{array}{l}\mathrm{I}-4, \mathrm{II}-7, \mathrm{III}-11, \\
\mathrm{IV}-17 \mathrm{~km} / \mathrm{h}\end{array}$ \\
\hline Maximum speed & $17 \mathrm{~km} / \mathrm{h}$ \\
\hline Maximum train weight on horizontal track & $100 \mathrm{t}$ \\
\hline $\begin{array}{l}\text { Standard version: Hand-screw brake, manual bidirectional sanding gear, } \\
\text { electric lighting, signal bell and exhaust fume whistle. }\end{array}$ \\
\hline
\end{tabular}

used. Prepared on the basis of: Rolling Stock Repair Plant Poznań, Technical and operating documentation for the WLs40/50 diesel locomotive and Andrychów Diesel Engine Factory, Operating instructions for the S-64L and s-324HL engines. 
Characteristics of S64L type engine (WLs40 locomotives)

\begin{tabular}{|l|l|}
\hline 4-cylinder, 4-stroke, line Diesel engine, no compressor \\
\hline Manufacturer & Andrychów Diesel Engine Factory \\
\hline Engine power-output & $44 \mathrm{HP}$ \\
\hline RPM & $1200 \mathrm{rpm}$ \\
\hline $\begin{array}{l}\text { Fuel consumption including } 10 \% \\
\text { tolerance }\end{array}$ & $210 \mathrm{~g} / \mathrm{HPh}$ \\
\hline Oil consumption & $8 \mathrm{~g} / \mathrm{HPh}$ \\
\hline Fuel tank capacity & 751 \\
\hline Lubrication & Circulating \\
\hline Cooling & forced circulation, water cooled \\
\hline $\begin{array}{l}\text { Engine start-up } \\
\text { The test consumption of fuels per hour of normal operation is } 4.9 \mathrm{~kg} \text { of diesel } \\
\text { oil and 320 g of engine oil. }\end{array}$ \\
\hline
\end{tabular}

Characteristics of S-324 HL type engine (WLs50 locomotives)

\begin{tabular}{|l|l|}
\hline 4-cylinder, 4-stroke, line Diesel engine, no compressor \\
\hline Manufacturer & Andrychów Diesel Engine Factory \\
\hline Nominal power-output & $50 \mathrm{HP}$ \\
\hline RPM & 1200 \\
\hline $\begin{array}{l}\text { Fuel consumption including } 10 \% \\
\text { tolerance }\end{array}$ & $190 \mathrm{~g} / \mathrm{HPh}$ \\
\hline Oil consumption & $4 \mathrm{~g} / \mathrm{HPh}$ \\
\hline Fuel tank capacity & 1361 \\
\hline Lubrication & Circulating \\
\hline Cooling & forced circulation, water cooled \\
\hline Engine start-up & electric starter \\
\hline
\end{tabular}


4-cylinder, 4-stroke, line Diesel engine, no compressor

The test consumption of fuels per hour of normal operation is $4.9 \mathrm{~kg}$ of diesel oil and $320 \mathrm{~g}$ of engine oil.

\subsubsection{Military siding no. 289 Hrubieszów (Hrubieszów narrow- gauge railway)}

Military siding No. 289 "Barracks" (750 mm gauge) branched at $12.113 \mathrm{~km}$ of the Polish State Railways narrow-gauge Werbkowice - Matcze line (Hrubieszów narrow-gauge railway) from track No. 1 with switch No. 201 and led to the area of JW 2122 Hrubieszów. The entrance to the siding was secured with a derailer, its single track was 823 meters long.

The siding was built in the inter-war period for the delivery of supplies to the barracks of the 2nd Horse Rifle Regiment in Hrubieszów. In the post-war period the track layout of the siding remained unchanged, the siding was operated with the use of Polish State Railways train locomotives. The operation of the siding was discontinued at the end of the 1980s.

\subsubsection{Narrow-gauge military railway at the Field Artillery Research Centre in Zielonka (military siding No. 182) and standard- gauge siding No. $127^{727}$}

In the post-war period, the Field Artillery Research Centre (JW 5059) was organised in Zielonka, and at the beginning of the 1950s, the adaptation of the training area for the needs of the military research facility began. A military narrow-gauge railway was built in the area of the Zielonka training ground in the interwar period. During the occupation years the Germans built a field airport in Zielonka - it's area is currently used as military allotments. The narrow-gauge railway was probably used to transport materials for the construction of the field airport from Zielonka station. ${ }^{728}$ The pre-war narrow gauge railway was dismantled by the Soviet army in 1944. In connection with the organisation of artillery

727 At the end of the 1950s the name of the Field Artillery Research Centre was changed to the Ordnance Research Centre, and in the 1960s the name was changed once again to the Military Institute of Armament Technology.

728 The embankment of this railway (running from the area of the institute parallel to the later railway track) was levelled during land redevelopment for the allotments. 
research stations and departments in the training area of a significant size (several dozen square kilometres), it was necessary to transport the equipment and employees to the research stations. It was then decided to construct a $750 \mathrm{~mm}$ narrow gauge railway. It was mostly built on the existing embankments of the pre-war narrow-gauge military line Zielonka - Rembertów (750 mm).

In 1952, the 7th Railway Troops Batallion from Września began the construction of a narrow-gauge railway for the needs of the Field Artillery Research Centre at the Zielonka field grouping. In 1953-1954, the 5th Railway Troops Batallion from Darłowo at the field grouping in Zielonka continued further work on the construction of the railway. In 1954, the 7th Railway Troops Batallion also carried out the construction works at another field grouping.

In 1951, the training company of the 7th Railway Troops Batallion built a standard gauge siding from Zielonka railway station to the unit ${ }^{729}$ (it was given number $127^{730}$ ). It had a total length of $3,744 \mathrm{~m}$, and from the main siding track

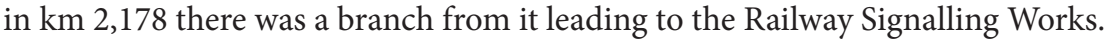

On the area of the unit, on the right side of the main siding track No. 1a, a loading track No. 2 and a $70 \mathrm{~m}$ long front and side platform (narrow-gauge track no. 14 was also connected to the front of the ramp) were provided, while on its left side a dead-end track no. 3 with a $174 \mathrm{~m}$ long ramp was built. The main siding track ended with a buffer stop in front of which a protective dead-end track No. 4 was constructed. The standard-gauge siding was located near the narrow-gauge railway system - at the intersection of both track gauges a transhipment point was created from the siding to the narrow-gauge railway. The $30 \mathrm{~m}$ long transhipment ramp was located between the standard-gauge track of the siding and the narrow-gauge track, also the connecting loading track No. 2 was laid parallel to the narrow-gauge track No. $3 .^{731}$

In the area of the military unit, narrow-gauge railway maintenance facilities were constructed in the form of a single-road, red brick rectangular locomotive shed (equipped with one inspection pit and a gable roof) ${ }^{732}$ and a two-road brick

729 Account dated 23rd Oct. 2006 of Major Jerzy Zieliński, retired head of the Internal Transport and Railway Section.

730 The siding ran in the middle of its length next to the Rembertów - Zielonka railway line.

731 Head of Military Transport at the Polish State Railways, Plan schematyczny nr 127 (1959), and Head of Military Transport at the Polish State Railways, Plan schematyczny nr 182.

732 This locomotive depot was built in the 1950s. 
rolling-stock repair workshop ${ }^{733}$ (equipped with two inspection pits, a building with an arched roof), a transhipment ramp, a system of maintenance and stabling tracks and a dead-end track leading to the strict area of the T-1 laboratory (department of ammunition and artillery). A system of storage tracks and dead-end tracks leading to equipment and armament warehouses was created on the premises of the workshop. The track system in this area had many tight curves of 30 and $35 \mathrm{~m}$, and a WLs150 locomotive had to negotiate these curves at a low speed because they were prone to derailments. A WLs75 locomotive on the other hand would pass through all the sharp curves due to the shorter wheelbase. At the end of the siding's communication track, a loop was located close to the ammunition depots, which was also used to turn the rolling stock if necessary. ${ }^{734}$ Two railway crossings within the unit were initially equipped with manually operated traffic lights. ${ }^{735}$ The remaining crossings on the narrow-gauge railway network in Zielonka were not secured.

Within the training area a narrow-gauge railway network was built in the form of the following lines: ${ }^{736}$

a) the Zielonka - Pustelnik main line, 21,300 m long,

b) the Okuniew - Michałów perimeter line branching off from the main line in the area of the armoured centre at $\mathrm{km} .8,500$ in $\mathrm{km} \mathrm{7,132}$ and connecting with the main line in the area of Krubki just after km 15,000 with a length of $10,550 \mathrm{~m}$,

c) a branch starting in the ' 0 ' point area, $920 \mathrm{~m}$ long, leading to the premises of the T-1 laboratory (on the premises of the institute),

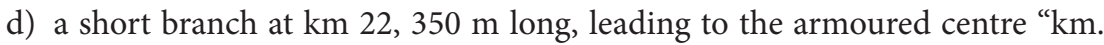
8,500 " (track 114).

Both on the main and the peripheral lines, in the area of artillery research and observation stations, the following loops were provided: "km. 3,500", Zabraniec, Michałów, Łęka. In addition, near the branch leading to the area of the armoured

733 According to Major Jerzy Zieliński's account of 23rd Oct. 2006, it was a narrow-gauge railway locomotive depot from the interwar period, the shed housed two roads (pits) as well as a forge and a workshop equipped with a grinding machine and a lathe.

734 Head of Military Transport at the Polish State Railways, Plan schematyczny nr 182.

735 In accordance with the amendment of 27th Dec. 1962 to the Technical Regulation, the traffic lights have been removed and the crossings were equipped with gates (blocking, as appropriate, the track or the road) operated by the driver or shunter.

736 Regional State Railway Management in Warsaw, Regulamin obstugi (1962), 2. 
centre "km. 8,500" and at the end of the line in Pustelnik dead-end tracks with front-and-side loading ramps were built. ${ }^{737}$

The tracks were laid on a sand trackbed (in some places the track was laid directly on the ground) with $\mathrm{H} 90$ and $\mathrm{H} 93$ rails (rail length from 7 to $12 \mathrm{~m}$ ), on narrow-gauge wooden sleepers type II and standard gauge sleepers $(1.2-1.3 \mathrm{~m}$ long). In total $34 \mathrm{H} 93$ switches (right and left with a 1:7 diagonal) without locks, equipped with non-standard switch lamps that did not indicate the position of the switch, were built into the main tracks, station and depot tracks. ${ }^{738}$ Due to the lack of switch locks, the provisions of the regulations ordered the locomotive crew to stop the train or single locomotive before entering each switch, in order to check the switch points' condition. ${ }^{739}$ The highest longitudinal incline on the line was $8 \%$ and the smallest curve radius on the line was $75 \mathrm{~m}$. The surface used allowed the rolling stock with the highest axle load of $6 \mathrm{t}$ to be used. ${ }^{740}$

In 1953, eight temporary wooden bridges with a wooden surface on piles were built along the entire line: at $\mathrm{km} 6,500 \mathrm{~L}=24 \mathrm{~m}$, at $\mathrm{km} 6,550 \mathrm{~L}=20 \mathrm{~m}$, at $\mathrm{km}$ $8,050 \mathrm{~L}=16 \mathrm{~m}$, at $\mathrm{km} 11,050 \mathrm{~L}=5 \mathrm{~m}$, at $\mathrm{km} 11,150 \mathrm{~L}=10 \mathrm{~m}$, at $\mathrm{km} 15,500$ $\mathrm{L}=16,8 \mathrm{~m}$, at $\mathrm{km} 16,800 \mathrm{~L}=15 \mathrm{~m}$ and at $\mathrm{km} 17,600^{741} \mathrm{~L}=8,5 \mathrm{~m} \cdot{ }^{742} \mathrm{In}$ addition, next to the narrow-gauge railway track at $\mathrm{km} \mathrm{9,200} \mathrm{and} \mathrm{12,000,} \mathrm{concrete} \mathrm{bunkers}$ were located to protect the observers during shooting.

Five permanent loading ramps and platforms (four wooden and one paved) were also built on the narrow-gauge railway network in Zielonka: ${ }^{743}$

\begin{tabular}{|l|l|l|l|}
\hline Track/km & Ramp type and purpose & $\begin{array}{l}\text { Length of the } \\
\text { loading end in } \mathbf{~ m}\end{array}$ & $\begin{array}{l}\text { Ramp } \\
\text { width }\end{array}$ \\
\hline $1 / 0$ & $\begin{array}{l}\text { End and side handling ramp with } \\
\text { exit on both sides - wooden surface. }\end{array}$ & 70 & 9 \\
\hline $111 / 0,300$ & $\begin{array}{l}\text { Side ramp with no exists, low for } \\
\text { use by people - wooden surface. }\end{array}$ & 15 & 2 \\
\hline
\end{tabular}

737 Regional State Railway Management in Warsaw, Regulamin obstugi (1962), 2-5.

738 Head of Military Transport at the Polish State Railways, Plan schematyczny nr 182 and Regional State Railway Management in Warsaw, Akta kolei.

739 Regional State Railway Management in Warsaw, Regulamin obstugi (1962), 4.

740 Regional State Railway Management in Warsaw, Regulamin obstugi (1962), 2.

741 The bridge at $\mathrm{km} \mathrm{17,600} \mathrm{was} \mathrm{located} \mathrm{on} \mathrm{the} \mathrm{Łęka} \mathrm{-} \mathrm{Pustelnik} \mathrm{section,} \mathrm{which} \mathrm{was} \mathrm{closed}$ down in October 1963.

742 Regional State Railway Management in Warsaw, Regulamin obstugi (1962), 6.

743 Regional State Railway Management in Warsaw, Regulamin obstugi (1962), 6. Zbigniew Tucholski - 978-3-631-82966-0 


\begin{tabular}{|l|l|l|l|}
\hline Track/km & Ramp type and purpose & $\begin{array}{l}\text { Length of the } \\
\text { loading end in } \mathbf{~ m}\end{array}$ & $\begin{array}{l}\text { Ramp } \\
\text { width }\end{array}$ \\
\hline $111 / 3,600$ & $\begin{array}{l}\text { Side ramp with no exists, low for } \\
\text { use by people - wooden surface. }\end{array}$ & 15 & 2 \\
\hline $111 / 21,300$ & $\begin{array}{l}\text { End and side handling ramp } \\
\text { with exit } \\
\text { - paved surface } 15\end{array}$ & 15 & 5 \\
\hline $112 / 22,000$ & $\begin{array}{l}\text { End and side handling ramp } \\
\text { with exit } \\
\text { - wooden surface }\end{array}$ & 40 & 8 \\
\hline
\end{tabular}

Along the line an over-ground $\mathrm{MB}$ system telephone line on concrete poles was also built. At the following points on the line sockets were provided for connection of field telephone apparatus: at $\mathrm{km} 0.700, \mathrm{~km} 1.000, \mathrm{~km} 1.500, \mathrm{~km} 2.000$,

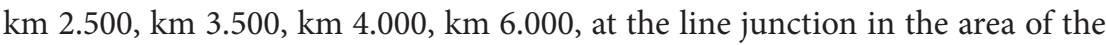
armoured centre "km. 8,500," on the Zabraniec passing loop, on the fire observation towers no. $15,16,17,18$, on the dead-end track by the bunkers ${ }^{744}$ in $\mathrm{km}$ 9,200 and $\mathrm{km} \mathrm{12,000.745746}$ Maintenance of the telephone network within the training ground was carried out by the field communication team. ${ }^{747}$ In 1954 , the 5th Railway Troops Battalion completed the construction of the railway, the total length of the line and all tracks reached $37.468 \mathrm{~km} .{ }^{748}$

Due to the fact that the complete line was located within the internal area of the training area, the complete military railway line was formally considered as station tracks.

On June 30th 1954, the Director of the Regional State Railway Management in Warsaw approved the Technical Regulations for Railway Operation prepared by

744 The bunkers were designed for the observers and measurement engineers during shooting.

745 This line was not only intended for train communication, it was also used for communication between the institute's directional officer and arms research posts and guards of the firing range protection.

746 Regional State Railway Management in Warsaw, Regulamin obstugi (1962), 7.

747 Account of 7th Sept. 2006 by Colonel Wacław Kuzak, former Head of the Field Department of the Military Institute of Armament Technology in Zielonka.

748 The technical condition of the bridges was unsatisfactory already in 1961, after some time their spans were replaced with steel ones. 
the Regional Management of State Railways in Warsaw and the design of railway traffic protection equipment (also developed by the Regional Management of State Railways in Warsaw) ${ }^{749}$

Train traffic on the military railway in Zielonka was initially based on internal instructions developed by Field Artillery Research Centre, which was adapted to the local needs. Some of its provisions, however, were contrary to the then in force - Przepisy ruchu na kolejach waskotorowych użtku publicznego $W 2,{ }^{750}$ e.g. $\$ 10$ point. 24: "In the event of sighting a train running towards another train or from a junction of the track, brake immediately and give short whistle signals until the observed train comes to a standstill, or $\$ 25$ : If a sighted train does not stop, it is imperative to reverse the train with the other train is driving towards us, giving a whistle signal, until the sighted train stops."751

The military railway transported equipment, guns and ammunition, sand for the protective dykes and building materials, as well as soldiers and civilian workers to the research stations. Ammunitions were transported from warehouses in the T-1 workshop (ammunition and artillery department). The equipment after the completion of the tests as well as the fired bullets were brought back to the institute as a return load for testing. On the premises of the institute, loads arriving (and dispatched) via the standard-gauge siding were transhipped onto the ng. rolling stock. Cannons were transported on narrowgauge flat-wagons (they were loaded on a ramp on the institute's premises), while box vans were used to transport ammunition. No protective wagons were added when trains were conveying dangerous goods (which was contrary to the regulations in force) ${ }^{752}$ In the training area, there was a top-secret armoured centre "km. 8,500" it was separated and additionally protected. Antitank ammunition was tested there. A short siding was connected to the centre, which was used to deliver marked armoured plates transported on flat wagons. These were placed in special stands and, after being placed on the research stands, they were shot at from anti-tank cannons. After the tests, the plates were transported to Zielonka in order to undergo tests. Two ramps were built near the "km. 8,500" site, which were used for unloading and loading of the cannons delivered to the centre and anti-tank launchers mounted on lorries. There was also a gantry crane on the premises of the armoured centre designed to lift the

749 Regional State Railway Management in Warsaw, Akta kolei.

750 Przepisy ruchu (1948).

751 Regional State Railway Management in Warsaw, Protokół z komisji (1960).

752 Regional State Railway Management in Warsaw, Protokół okresowego badania (1964). 
armoured plates off the wagons. The area of the armoured centre was covered with a special protective dike.

In the seventies, a body of a withdrawn four-wheeled narrow-gauge van was set up next to the track running by the armoured centre, intended as a shelter for track workers. ${ }^{753}$

From the very beginning of its existence on the military railway in Zielonka, employees were transported to work stations in adapted passenger cars. ${ }^{754} \mathrm{In}$ principle, the Łęka - Pustelnik line was intended only for transporting employees to the institute from Pustelnik. Two wooden ramps (platforms) in $\mathrm{km} 0.300$ and 3.600 were probably made to make it easier for the employees to embark and disembark the carriages already during the construction of the railway. On 29th April 1970, at the request of the Regional State Railway Management in Warsaw, the Narrow-gauge Railway Management issued a formal permission for ancillary passenger transports. ${ }^{755}$ Soldiers and employees were transported to the research stations by a train combined of a locomotive and a passenger carriage or a trolley with a GAZ-51 engine.

In order to carry higher officers and foreign delegations for demonstration shooting, a second-class Bx-2281 passenger carriage was rebuilt in the Rolling Stock Repair Plant Opole from the Jabłonowska KD into a self-propelled headquarters car/ saloon car (the engine used was from a ZIS-150 lorry), commonly called the "General Saloon." The carriage was equipped with two compartments: an elegant office lined with walnut panelling with armchairs and a conference table, and a slightly simpler compartment for 30 passengers.

During the visits of important delegations, the head of the canteen organised a buffet operated by a waiter. During the field tests of the "Malutka" anti-tank missile, General Wojciech Jaruzelski was riding it to the research station. ${ }^{756}$

This vehicle was also used to transport the invited guests during the Exhibitions of Armament Technical Progress of the Warsaw Pact. During the

753 Accounts dated 23rd Oct. 2006 of Major Jerzy Zieliński, retired head of the Internal Transport and Railway Section.

754 The military railway in Zielonka was the only non-public use line in the area of the Regional State Railway Management in Warsaw, where internal passenger transport was officially carried out.

755 Protocol of 29th April 1970.

756 Report of 7th Sept. 2006 by Colonel Wacław Kuzak, retired head of the Field Department of the Military Institute of Armament Technology in Zielonka. 
demonstrations of combat equipment, Colonel Mu’ammar al-Kaddafi also was riding it to the research station. ${ }^{757}$

The military railway was part of the organisational structure of the Section for Internal Transport and Railways under the responsibility of the Field Department, which managed the entire training ground. ${ }^{758}$ The military narrow-gauge railway and the standard-gauge railway siding No. 127 were managed by the head of the Internal Transport and Railway Section. During the existence of the narrowgauge railway, this function was performed by the following officers: from 1950s to 1974 Captain Jan Ataman, 1976-1984 Captain Jerzy Zieliński, 1984-1990 Captain Jan Mazur.

The head of the transport section supervised and controlled the operation and maintenance of the railway. He was managing the work of a traffic controller and a track foreman (an equivalent of a trackman). On the other hand, the track maintenance staff (appropriate track workers) and the track maintenance staff were subordinated to the foreman's office. ${ }^{759}$ On the Zielonka railway line, the track was maintained by one track maintenance brigade. The train traffic was managed by the manager of the transport section in accordance with $\$ 10$ point 1 of the discussed manual: Train traffic control may be ordered by the head of the traffic section and his superiors. ${ }^{760}$ In his absence, the movement of trains was managed by a directional (operational) officer of the Ordnance Research Centre, during shooting he issued a permit to run a train or a rail vehicle each time. ${ }^{761}$

In the initial period of its operation, of all the personnel employed at the military railway only a steam locomotive driver and a permanent way section supervisor (delegated from the Regional State Railways Management in Warsaw) had thorough examinations. Five railway employees were employed ${ }^{762}$ in order to operate the line soldiers of the compulsory military service (civilian railwaymen) were also assigned.

757 Accounts dated 23rd Oct. 2006 of Major Jerzy Zieliński, retired head of the Internal Transport and Railway Section.

758 Report of 7th Sept. 2006 by Colonel Wacław Kuzak, retired head of the Field Department of the Military Institute of Armament Technology in Zielonka.

759 Regional State Railway Management in Warsaw, Regulamin obstugi (1962), 8.

760 Regional State Railway Management in Warsaw, Protokół z komisji (1960).

761 Regional State Railway Management in Warsaw, Regulamin obstugi (1962),10.

762 In the mid-1960s, the number of full-time employees was increased to eight. 
On the military railway there was a lack of basic railway signalling devices, as well as indicators and distant signals which according to railway regulations should be placed along the entire line. ${ }^{763}$

After the control on 9th April 1960 the railway was allowed to operate conditionally with the reservation that the railway administration was obliged to renovate the track, to make a telephone line exclusively for train signalling communication $^{764}$ and install control, command and signalling devices. Before the introduction of these recommendations, the committee decided that: traffic on the line was to take place with speeds not exceeding $15 \mathrm{~km} / \mathrm{h}$, on curves and witches: $5 \mathrm{~km} / \mathrm{h}$. In addition, there could only be one train on the route and a train with no hand brakes could not exceed three wagons. ${ }^{765}$

The Ordnance Research Centre developed a Regulamin obstugi kolei waskotorowej (bocznica nr 182) [The Regulations for Operation of a Narrow-Gauge Railway (siding no. 182)] approved by the Regional State Railway Management in Warsaw, the Narrow-gauge Railway Management on 17th September 62, the new regulations met the requirements of the railway regulations.

Train announcements were made by means of telephone communication used for military purposes, while there was no telephone communication for announcements or dispatching. Each traction vehicle was equipped with a field telephone. The only traffic post on the line, in Zielonka (loops and branches on the complete network were not staffed) decided on the order of train departures. A train composed of six wagons was manned by the locomotive crew only (which was not in accordance with the regulations).

There could be two trains on the route during daytime and only one train at night. A deviation from the above provisions of the regulations could have been an operation, with special safety measures, of the third train during the day and the second during the night as a rescue train. ${ }^{766}$ Trains were operated as required, usually one train a day. During intensive research work, the number of trains increased accordingly, occasionally during night shooting trains were also run at night. Sometimes a large calibre bullet would hit the railway track, then a

763 During the annual railway inspections carried out by the Regional State Railway Management in Warsaw, Narrow-gauge Railways Management, attention was paid to the need to improve safety and the provision of basic signalling devices.

764 The Commission proposed to add on the existing line another circuit designed exclusively for train control communication and to provide sockets for train guard on each passing loop and junction.

765 Regional State Railway Management in Warsaw, Protokół z komisji (1960).

766 Regional State Railway Management in Warsaw, Protokół z komisji (1960). 
bomb sites of significant size (depth of several meters) were formed, which were filled-in with sand. However, it was not possible to compact the soil properly, which is why the track initially subsided in these places. ${ }^{767}$

In October 1963, the section from the Łęka passing loop to Pustelnik deadend track, about $4 \mathrm{~km}$ long, was dismantled. ${ }^{768}$

In the 1960s, the bridges on the line were rebuilt, replacing the wooden span structures with steel H-beams. However, the wooden abutments of most of the bridges were still left intact.

The deteriorating technical condition of the wooden bridges caused that on 7th July 1972 the Headquarters of the Military Transport Service issued a decision to close the bridge at $\mathrm{km}$. 6.5, the part of the railway beyond the bridge was thus withdrawn from operation. ${ }^{769}$ The Narrow-gauge Railway Management Commission has ordered that a D1 stop sign and a barrier beam permanently secured against the possibility of removing it from the track are placed on the track in front of the bridge. Due to the traffic being suspended on the complete railway line, the bridge at $\mathrm{km} 6.5$ as well as the second one that was in poor condition were quickly rebuilt within one month. On 23rd Aug. 1974 both bridges were accepted for further operation after a major rebuilt, ${ }^{770}$ check rails were fitted to the bridge in $\mathrm{km} .6 .5$ as well as on the remaining bridges.

In 1976, JW 1039 Przemyśl carried out a major reconstruction of the standardgauge military siding No. $127,{ }^{711}$ type 31 rails were replaced with S-42 rails. These were in turn used on the narrow-gauge railway to replace the worn out type H90 rails. In the following years, the narrow-gauge railway continued to replace half of the $\mathrm{H} 90$ rails used in the main tracks with type 31 and $6 \mathrm{~d}$ rails. Light rails and wooden sleepers were replaced with concrete sleepers in the first place, on the section from $\mathrm{km} 4$ to $\mathrm{km} 8$ to the river. In this difficult swampy terrain wooden sleepers rotted very quickly, and had to be frequently replaced. ${ }^{772}$

767 Accounts dated 23rd Oct. 2006 of Major Jerzy Zieliński, retired head of the Internal Transport and Railway Section.

768 Regional State Railway Management in Warsaw, Regulamin obsługi (1962), 10 amendment of 5th Oct. 1963.

769 Protocol on control of military railways of 8th Aug. 1972.

770 Official note on the acceptance of bridges after renovation.

771 The siding was also used by the Military Electronic Works (Wojskowe Zakłady Elektroniczne) on the basis of shared use.

772 Accounts dated 23rd Oct. 2006 of Major Jerzy Zieliński, retired head of the Internal Transport and Railway Section. 
In the mid-1970s, the loading equipment at the Zielonka institute had also been modernised. Around 1974 an end loading platform for rolling stock transhipment ${ }^{773}$ was built with a front wall made of bridge sleepers. A short standardgauge track from the siding to the fuel depot and a short narrow gauge track from the track leading to the transhipment ramp were both connected to the ramp. Around 1975, a wooden dock loading ramp made of sleepers was replaced by concrete retaining wall, which allowed forklift trucks to enter the wagons directly on the loading bridges. ${ }^{774}$

In the late 1970s, in order to eliminate the troublesome transhipment from the standard-gauge siding to the narrow-gauge railway, it was planned for standard gauge wagons to be transported on narrow-gauge transporter wagons at the Zielonka military railway. In order to get acquainted with this mode of transport, Major Jerzy Zieliński, head of the Internal Transport and Railway Section, was delegated to the Mława Narrow-gauge Railway. However, due to sharp curves within the institute, which would be too tight to be traversed by narrow-gauge transporter wagons, this idea had to be abandoned. ${ }^{775}$

As a non-public railway, the narrow-gauge military railway no. 182 in Zielonka was under the supervision of the Polish State Railways, Regional State Railway Management in Warsaw, Narrow-gauge Railway Management. Every two years the Narrow-gauge Railways Management commission made an inspection on the railway and controlled its operation. Periodic training of drivers was carried out by the Piaseczno narrow-gauge depot and the Tłuszcz standard-gauge depot, while periodical instructions of traffic service employees at WRS Targówek.

Around 1984, the railway workshop building was demolished. ${ }^{776}$ In the 1980s, it was decided to replace the narrow-gauge railway with road transport. The construction of an internal road in the training ground was started, which lead from the institute in Zielonka to the armoured centre "km. 8,500." It was completed up to $\mathrm{km} \mathrm{5}$, because the difficult wetland made it impossible to complete the investment. The dismantling of the railway began with the use of road transport in 1990, and in the summer of the following year the dismantling of the tracks

773 Before the end loading platform was built, the narrow-gauge rolling stock sent for repair was loaded by means of a standard-gauge railway crane leased from Polish State Railways

774 Accounts dated 23rd Oct. 2006 of Major Jerzy Zieliński, retired head of the Internal Transport and Railway Section.

775 Accounts dated 23rd Oct. 2006 of Major Jerzy Zieliński.

776 Accounts dated 23rd Oct. 2006 of Major Jerzy Zieliński. 
in the training ground and the institute was completed. After the closure of the narrow-gauge railway due to the lack of good roads within the training ground, the equipment and materials had to be transported by road to the armoured centre through Okuniew, which meant that the transport distance was extended by $67 \mathrm{~km} .{ }^{777}$

As a result of the efforts of the management and employees of the Railway Museum in Warsaw, in 1992-1993 the Head of the Military Transport Service of the Ministry of National Defence handed over to the Branch of the Railway Museum in Sochaczew the WLs150-3800 locomotive, a Bx 2281 railcar, a Bh 1122 passenger carrige, 11 freight wagons, a DSNA 175/68 motorcycle engine trolley and a battery trolley adapted for rail operation.

At present, the only remnants of the narrow-gauge railway at the Military Institute of Armament Technology in Zielonka is a single-road locomotive shed, a concrete loading ramp and a railway gate. In the training area, the embankments can still be clearly seen (partly used as forest roads) together with the remains of the telephone line, while the wooden bridges were mostly demolished (only abutments remained).

\subsubsection{Rolling stock}

Polish State Railways leased two narrow-gauge steam locomotives to the Polish Armed Forces: Ty1-1085 (Freudenstein No. 3/1899), lease started on 3rd June 1953 and Ty1-1142 (Krauss München No. 6806/1913), leased from the Warsaw Military District Nasielsk depot since 23rd September 1953.

Also in 1953, the Ministry of Transport handed over 11 freight wagons to the Field Artillery Research Centre (from the Wrocław Narrow-gauge Railway): 3 four-wheeled vans, 6 four-wheeled flat wagons and 2 bogie flat wagons. The fourwheeled vans and flat wagons were manufactured by Waggonfabrik Hofmann A.G. Breslau in 1895. Two Saxon bogie flat wagons were built at the Chemnitz factory in 1900 and 1905. All freight wagons were equipped with tramway couplings.

On 13th August 1954, the lease of the Ty1-1142 steam locomotive was terminated and it was returned to narrow-gauge depot at Biała Podlaska.

In 1957, the lease of two passenger carriages from the Polish State Railways depot Warszawa Stalowa started: on 23rd Oct. 1957 four-wheeled Bh 1125 and on 27th Dec. 1957 a bogie carriage Bx 1307 (Rolling Stock Repair Plant Opole). On 30th June 1958, the lease of this carriage was terminated and it was returned 
to the Warszawa Stalowa due to the limited turning capacity of the bogies, which prevented its operation on the narrow-gauge railway in Zielonka, due to the difficulty in negotiating tight curves.

On 1st Jan. 1972, the lease of the second carriage Bh 125 was also terminated and it was returned to the Warszawa Stalowa depot. On 3rd Dec. 1971 a fourwheeled passenger carriage Bh 1122 (Beuchelt \& Co. 1900) was handed over to Zielonka from the narrow-gauge railway in Kętrzyn.

Passenger carriages and freight wagons were sent for periodic repairs to narrow-gauge depot at Warszawa Stalowa, and then, after this depot has closed, to narrow-gauge depots in Rogów and Mława.

Before 1958, a bogie $800 \mathrm{~mm}$ passenger carriage Bx 2281 from the then closed Jabłonkowska railway, intended for work on the military railway in Zielonka, was handed over to the Polish Armed Forces by the Central Management of Narrow-gauge Railways of the Ministry of Transport. The carriage was handed over for reconstruction at the Rolling Stock Repair Plant Opole (at that point the workshop specialised in the construction and repairs of narrow-gauge carriages and railcars) where it was re-gauged for $750 \mathrm{~mm}$ (new welded construction bogies were made) and rebuilt into a saloon railcar. The railcar was fitted with a driving system powered by a petrol engine coming from a Russian ZIS-150 military lorry.

In 1960, a prototype of a narrow-gauge diesel locomotive WLs150-3800 (Chrzanów 3800/60) was purchased from the factory in Chrzanów for the Ordnance Research Centre in Zielonka.

In 1965, another narrow-gauge diesel locomotive WLs75-33 (Rolling Stock Repair Plant Poznan 33/65) was purchased from Rolling Stock Repair Plant Poznań; this purchase enabled the withdrawal of steam traction.

In the same year, the lease of the Ty1-1085 steam locomotive was terminated, it was returned to the Warszawa Stalowa depot, where it was removed from the Polish State Railways stock-list on 30th Dec. $1965^{778}$ and scrapped.

The Zielonka railway also operated an internal combustion trolley Lb 10/51, because of its looks commonly referred to as "the frog" by the railway and institute employees. There is no information about the origin or manufacturer of the vehicle. It was powered by a petrol engine from a Russian GAZ 51 military lorry.

778 Withdrawal date from the Polish State Railways lists based on the Inventory book of Polish State Railways narrow-gauge steam locomotives, the steam locomotive was cut for scrap at narrow gauge depot Warszawa Stalowa in 1966 or 1967, (report by Mr. Jan Szponder). 
It was a four-wheeled vehicle with one cab in which the engine was installed in the protruding engine compartment. The trolley had 20 seats, it had an extremely wide bodywork, which protruded $1.5 \mathrm{~m}$ on each side. When riding fast on sharp curves the trolley would often overturn (especially when passengers were sitting on a bench on one side of the vehicle only). The vehicle was scrapped in Zielonka around $1975,{ }^{779}$ due to an unsafe design and the wear of an obsolete engine.

In 1968, in the workshops of the Military Institute of Armament Technology staff sergeant Henryk Chrzanowski built, as his diploma thesis at the evening Mechanical \& Technical School in Zielonka, ${ }^{780}$ a five-person motor trolley, which was numbered DSNA $175 / 68 .{ }^{781}$ It was powered by a WFM motorcycle engine, which was soon replaced by a Jawa motorcycle engine. Initially, the trolley had standard steel wheels turned in the workshops of the Main Mechanics Department of the Military Institute of Armament Technology in Zielonka. These wheels were soon replaced by tram-design wheels equipped with rubber inserts. ${ }^{782}$

In 1977, the engine of the locomotive WLs75-33 seized, after a few years the locomotive was transferred for periodic repair in the Motor Vehicle and Equipment repair Workshop in Brzesko, where it was removed from the Polish Armed Forces inventory in 1985. After many years at the factory, the locomotive was preserved as a museum exhibit. It is currently awaiting restoration at the Cisna-Majdan station (Bieszczadzka Kolej Leśna).

In the strict T-1 area, a battery-powered Stalowa Wola trolley (built in 1955) was also used for transporting ammunition, adapted for rail operation. The trolley was handed over to the Branch of the Railway Museum in Sochaczew in 1992.

No military locomotives or wagons assigned to Zielonka were used on the standard-gauge siding No. 127. However, on 13th March 1982, a four-wheeled standard-gauge OPL wagon (built in 1933), series S, WP-38-43206 $6^{783}$ from

779 Account dated 23rd Oct. 2006 of Major Jerzy Zieliński, retired head of the Internal Transport and Railway Section.

780 Colonel Stefan Stern, the deputy commander of the Institute for Technology, has given the subject of this work.

781 Account dated 7th Sept. 2006 of Col. Wacław Kuzak, retired head of the Field Department of the Military Institute of Armament Technology in Zielonka.

782 Account dated 23rd Oct. 2006 of Major Jerzy Zieliński, retired head of the Internal Transport and Railway Section.

783 It was the last wagon of this type in the inventory of the Polish Armed Forces. In the 1950s, box vans were rebuilt into anti-aircraft defence wagons, which were used for anti-aircraft defence of military transports. Such vehicles were withdrawn in the 1970s. 
the Head of Military Transport in Kraków (Railway Equipment Storehouse in Przemyśl) was handed over to the Zielonka Military Institute of Armament Technology. The body of the wagon was to be placed near the railway track as a warehouse. As the wagon was out of gauge it was finally scrapped a few years later, and an armoured plate removed from its body was used to reinforce one of the shelters.

List of locomotives and trolleys

\begin{tabular}{|c|c|c|c|c|}
\hline $\begin{array}{l}\text { Polish Armed } \\
\text { Forces No. }\end{array}$ & $\begin{array}{l}\text { Class, type/ } \\
\text { No. }\end{array}$ & \begin{tabular}{|l|} 
Factory \\
number, maker/ \\
remarks
\end{tabular} & Received & Withdrawn \\
\hline WP-14-40451 & WLs75-33 & $\begin{array}{l}\text { Rolling Stock } \\
\text { Repair Plant } \\
\text { Poznań 33/65 }\end{array}$ & \begin{tabular}{|l}
1965 from \\
Rolling Stock \\
Repair Plant \\
Poznań \\
\end{tabular} & $+27.25 .85^{17}$ \\
\hline WP-15-40581 & WLs150-001 & $\begin{array}{l}\text { Fablok } \\
\text { Chrzanów } \\
3800 / 60^{18}\end{array}$ & $\begin{array}{l}1960 \text { from } \\
\text { Fablok for } \\
\text { the Ordnance } \\
\text { Research } \\
\text { Centre } \\
\end{array}$ & $\begin{array}{l}12.08 .92 \\
\text { Railway } \\
\text { Museum } \\
\text { Sochaczew }\end{array}$ \\
\hline \multirow[t]{2}{*}{ WP-19-40591 19} & Bx 2281 & \begin{tabular}{|l|} 
Modernisation \\
in Rolling Stock \\
Repair Plant \\
Opole 1950 \\
(converted to \\
railcar by Rolling \\
Stock Repair \\
Plant Opole in \\
1957) (engine \\
ZIS-150) \\
\end{tabular} & $\begin{array}{l}\text { before } 1958 . \\
\text { Polish State } \\
\text { Railways, } \\
\text { Jabłonowska } \\
\text { KD }(800 \mathrm{~mm})\end{array}$ & $\begin{array}{l}23 / 10 / 1989 \\
\text { Railway } \\
\text { Museum } \\
\text { Sochaczew }\end{array}$ \\
\hline & Lb $10 / 51^{21}$ & $\begin{array}{l}\text { motor trolley } \\
\text { with a GAZ-51 } \\
\text { engine }\end{array}$ & $\begin{array}{l}17.09 .62 \text { (was } \\
\text { in inventory) }\end{array}$ & $\begin{array}{l}+ \text { around } \\
1975^{22}\end{array}$ \\
\hline
\end{tabular}




\begin{tabular}{|c|c|c|c|c|}
\hline $\begin{array}{l}\text { Polish Armed } \\
\text { Forces No. }\end{array}$ & $\begin{array}{l}\text { Class, type/ } \\
\text { No. }\end{array}$ & \begin{tabular}{|l|} 
Factory \\
number, maker/ \\
remarks
\end{tabular} & Received & Withdrawn \\
\hline & & $\begin{array}{l}\text { motor trolley } \\
\text { with a WFM } \\
\text { engine }^{23}\end{array}$ & $\begin{array}{l}17.09 .62 \text { (was } \\
\text { in inventory) }\end{array}$ & $+?$ \\
\hline & $\begin{array}{l}\text { DSNA } \\
+175 / 68\end{array}$ & \begin{tabular}{|l|} 
motor trolley of \\
Military Institute \\
of Armament \\
Technology \\
in Zielonka, \\
$\begin{array}{l}1968 \text { (Java } 175 \\
\text { engine) }\end{array}$ \\
\end{tabular} & built in 1968 & $\begin{array}{l}17 / 08 / 1992 \\
\text { Railway } \\
\text { Museum } \\
\text { Sochaczew }\end{array}$ \\
\hline ? & $\begin{array}{l}\text { battery } \\
\text { trolley } \\
\text { adapted } \\
\text { for rail } \\
\text { operation }\end{array}$ & $\begin{array}{l}\text { Stalowa Wola } \\
1955 .\end{array}$ & $\begin{array}{l}\text { Military } \\
\text { Institute of } \\
\text { Armament } \\
\text { Technology } \\
\text { in Zielonka, } \\
\text { rebuilding? }\end{array}$ & $\begin{array}{l}1992 \\
\text { Railway } \\
\text { Museum } \\
\text { Sochaczew }\end{array}$ \\
\hline \multicolumn{5}{|c|}{$\begin{array}{l}{ }^{16} \text { At the request of the Headquarters of the Military Transport Service of } \\
\text { the Ministry of National Defence in Warsaw, the second locomotive of this } \\
\text { type, WLs75-30 (Rolling Stock Repair Plant Poznan 30/66), was also built } \\
\text { for } 750 \text { mm gauge - it was delivered to JW } 4149 \text { Przemyśl Bakończyce. It is } \\
\text { highly probable that this locomotive initially arrived at the Railway Equipment } \\
\text { Storehouse in Przemyśl, and then also worked at the military railway in } \\
\text { Zielonka. } \\
{ }^{17} \text { Date of removal of locomotive air reservoirs from inventory. The railway } \\
\text { inspection report of } 8 \text { September } 77 \text { states that the locomotive has a seized } \\
\text { engine to be replaced. } \\
{ }^{18} \text { A prototype locomotive of this type built in the F. Dzierżyński Locomotive } \\
\text { Factory in Chrzanów in } 1960 \text {. } \\
{ }^{19} \text { Military designation WP-WS-19 stands for a narrow-gauge diesel } \\
\text { locomotive (750 mm) } 150 \mathrm{HP} \text {, the vehicle was marked as such due to the lack } \\
\text { of military type designation for railcars. }\end{array}$} \\
\hline
\end{tabular}


${ }^{20}$ During the reconstruction, the interior of the railcar was divided into a passenger part with benches and a saloon car part. In 1987, the power unit on this railcar failed.

${ }^{21}$ Regional State Railway Management in Warsaw, Regulamin obsługi (1962),

7. Number and type of the trolley unknown to the author. According to Colonel Waclaw Kuzak, the trolley had several seats.

${ }^{22}$ Account dated 23.10.2006 of Major Jerzy Zieliński, retired head of the Internal Transport and Railway Section.

${ }^{23}$ Ibid., 7. According to Major Jerzy Zieliński's report of 23.10.2006, the trolley was equipped with a sprocket, a motorcycle engine and a wooden bench.

List of carriages

\begin{tabular}{|c|c|c|c|c|}
\hline \begin{tabular}{|l} 
Polish \\
Armed \\
Forces No. \\
\end{tabular} & $\begin{array}{l}\text { Polish State } \\
\text { Railways No., } \\
\text { Type of carriage }\end{array}$ & Received & Withdrawn & Remarks \\
\hline $\begin{array}{l}\text { WP-WC- } \\
58-43759 \text { ex } \\
\text { WP } 010 \text { ex } \\
\text { Bh } 1122^{24}\end{array}$ & $\begin{array}{l}\text { Bh } 1122 \\
\text { type: Lenz } \\
\text { Beuchelt \& Co. } \\
1900\end{array}$ & $\begin{array}{l}\text { On } 3.12 .71 \\
\text { transferred to } \\
\text { the Ministry of } \\
\text { Defence, JW } \\
2996 \text { Zielonka }\end{array}$ & $\begin{array}{l}\text { 17/08/1992 } \\
\text { MK } \\
\text { Sochaczew }\end{array}$ & $\begin{array}{l}\text { ex } \\
\text { Kętrzyńska } \\
\text { KD }\end{array}$ \\
\hline \begin{tabular}{|l} 
carriage \\
leased from \\
Polish State \\
Railways by \\
the Polish \\
Armed \\
Forces \\
\end{tabular} & $\begin{array}{l}\text { Bh } 1125 \text { (ex B } \\
1125)\end{array}$ & $\begin{array}{l}23.10 .57^{25} \\
\text { narrow-gauge } \\
\text { depot Warszawa } \\
\text { Stalowa }\end{array}$ & $\begin{array}{l}1.01 .72 \text { end of } \\
\text { lease }\end{array}$ & $\begin{array}{l}\text { ex } \\
\text { Kwidzyńska } \\
\text { KD }\end{array}$ \\
\hline $\begin{array}{l}\text { carriage } \\
\text { leased from } \\
\text { Polish State } \\
\text { Railways by } \\
\text { the Polish } \\
\text { Armed } \\
\text { Forces }\end{array}$ & $\begin{array}{l}\text { Bx } 1307 \text { Rolling } \\
\text { Stock Repair } \\
\text { Plant Opole }\end{array}$ & $\begin{array}{l}27.12 .1957 \\
\text { narrow-gauge } \\
\text { depot Warszawa } \\
\text { Stalowa }\end{array}$ & $\begin{array}{l}30.06 .58 \text { end of } \\
\operatorname{lease}^{27}\end{array}$ & ex? \\
\hline
\end{tabular}


${ }^{24}$ Military designation WP-WC-58 stands for other narrow-gauge vehicles for $1000 \mathrm{~mm}$ gauge, most likely this carriage was marked as such due to an error. On 24.12.74 the repair of the carriage was completed in the narrow-gauge depot in Rogów.

${ }^{25}$ Handed over in 1957 to the order of the Central Narrow-gauge Railways Management from Starachowice Railway to the inventory of Narrow-gauge Railways Management Warszawa (narrow-gauge depot Warszawa Stalowa) in order to lease for JW 2996 in Zielonka.

${ }^{26}$ Letter of 10.01.72 regarding the removal of the carriage from the area of the unit (in the Polish State Railways files - Regional State Railway Management in Warsaw).

${ }^{27}$ The lease was suspended due to limited curve negotiation ability.

List of freight wagons

\begin{tabular}{|l|l|l|l|l|}
\hline $\begin{array}{l}\text { Polish } \\
\text { Frmed } \\
\text { Forces No. }\end{array}$ & $\begin{array}{l}\text { Wagon type/ } \\
\text { factory and year of } \\
\text { construction }\end{array}$ & Received & Withdrawn & Remarks \\
\hline $\begin{array}{l}\text { WP-WK- } \\
45-43701\end{array}$ & $\begin{array}{l}\text { four wheel van / } \\
\text { Waggonfabrik Gebr. } \\
\text { Hofmann Breslau } \\
1895\end{array}$ & $\begin{array}{l}1953 \\
\text { Wrocławska } \\
\text { KD }\end{array}$ & $\begin{array}{l}\text { 1992 Railway } \\
\text { Museum } \\
\text { Sochaczew }\end{array}$ & \\
\hline $\begin{array}{l}\text { WP-WP- } \\
45-43702\end{array}$ & $\begin{array}{l}\text { four wheel van / } \\
\text { Waggonfabrik Gebr. } \\
\text { Hofmann Breslau } \\
1895\end{array}$ & $\begin{array}{l}1953 \\
\text { Wrocławska } \\
\text { KD }\end{array}$ & $\begin{array}{l}\text { 1992 Railway } \\
\text { Suseum } \\
\text { Sochaczew }\end{array}$ & \\
\hline $\begin{array}{l}\text { WP-WK- } \\
45-43703\end{array}$ & $\begin{array}{l}\text { four wheel van / } \\
\text { Waggonfabrik Gebr. } \\
\text { Hofmann Breslau } \\
1895\end{array}$ & $\begin{array}{l}1953 \\
\text { Wrocławska } \\
\text { KD }\end{array}$ & $\begin{array}{l}\text { Museum } \\
\text { Sochaczew }\end{array}$ & \\
\hline $\begin{array}{l}\text { WP-WP- } \\
47-43751\end{array}$ & $\begin{array}{l}\text { four wheel flat wagon } \\
\text { Waggonfabrik Gebr. } \\
\text { Hofmann Breslau } \\
1895\end{array}$ & $\begin{array}{l}1953 \\
\text { Wrocławska } \\
\text { KD }\end{array}$ & $\begin{array}{l}\text { Railway } \\
\text { Museum } \\
\text { Sochaczew }\end{array}$ & \\
\hline
\end{tabular}




\begin{tabular}{|c|c|c|c|c|}
\hline \begin{tabular}{|l} 
Polish \\
Armed \\
Forces No. \\
\end{tabular} & $\begin{array}{l}\text { Wagon type/ } \\
\text { factory and year of } \\
\text { construction }\end{array}$ & Received & Withdrawn & Remarks \\
\hline $\begin{array}{l}\text { WP-WP- } \\
47-43752\end{array}$ & $\begin{array}{l}\text { four wheel flat wagon } \\
\text { a brake/Waggonfabrik } \\
\text { Gebr. Hofmann } \\
\text { Breslau } 1895 \\
\end{array}$ & $\begin{array}{l}1953 \\
\text { Wrocławska } \\
\text { KD }\end{array}$ & \begin{tabular}{|l}
17.08 .92 \\
Railway \\
Museum \\
Sochaczew \\
\end{tabular} & \\
\hline $\begin{array}{l}\text { WP-WP- } \\
47-43753\end{array}$ & $\begin{array}{l}\text { four wheel flat wagon } \\
\text { /Waggonfabrik Gebr. } \\
\text { Hofmann Breslau } \\
1895\end{array}$ & $\begin{array}{l}1953 \\
\text { Wrocławska } \\
\text { KD }\end{array}$ & \begin{tabular}{|l}
17.08 .92 \\
Railway \\
Museum \\
Sochaczew \\
\end{tabular} & \\
\hline $\begin{array}{l}\text { WP-WP- } \\
47-43754\end{array}$ & $\begin{array}{l}\text { four wheel flat wagon } \\
\text { /Waggonfabrik Gebr. } \\
\text { Hofmann Breslau } \\
1895\end{array}$ & $\begin{array}{l}1953 \\
\text { Wrocławska } \\
\text { KD }\end{array}$ & $\begin{array}{l}17.08 .92 \\
\text { Railway } \\
\text { Museum } \\
\text { Sochaczew } \\
\end{array}$ & \\
\hline $\begin{array}{l}\text { WP-WP- } \\
47-43755\end{array}$ & \begin{tabular}{|l} 
four wheel flat \\
wagon with a brake/ \\
Waggonfabrik Gebr. \\
Hofmann Breslau \\
1895
\end{tabular} & $\begin{array}{l}1953 \\
\text { Wrocławska } \\
\text { KD }\end{array}$ & $\begin{array}{l}17.08 .92 \\
\text { Railway } \\
\text { Museum } \\
\text { Sochaczew }\end{array}$ & \\
\hline $\begin{array}{l}\text { WP-WP- } \\
47-43756\end{array}$ & $\begin{array}{l}\text { four wheel flat wagon } \\
\text { /Waggonfabrik Gebr. } \\
\text { Hofmann Breslau } \\
1895\end{array}$ & $\begin{array}{l}1953 \\
\text { Wrocławska } \\
\text { KD }\end{array}$ & $\begin{array}{l}17.08 .92 \\
\text { Railway } \\
\text { Museum } \\
\text { Sochaczew }\end{array}$ & \\
\hline $\begin{array}{l}\text { WP-WP- } \\
48-43757\end{array}$ & $\begin{array}{l}\text { bogie flat wagon / } \\
\text { K.S.St.B. Chemnitz } \\
1900 \text { 10206/? }\end{array}$ & $\begin{array}{l}1953 \\
\text { Wrocławska } \\
\text { KD }\end{array}$ & $\begin{array}{l}17.08 .92 \\
\text { Railway } \\
\text { Museum } \\
\text { Sochaczew } \\
\end{array}$ & $\begin{array}{l}\text { ex Pdx } \\
28213\end{array}$ \\
\hline $\begin{array}{l}\text { WP-WP- } \\
48-43758\end{array}$ & $\begin{array}{l}\text { flat wagon Chemnitz } \\
1905,13406 / ?\end{array}$ & $\begin{array}{l}1953 \\
\text { Wrocławska } \\
\text { KD }\end{array}$ & $\begin{array}{l}17.08 .92 \\
\text { Railway } \\
\text { Museum } \\
\text { Sochaczew }\end{array}$ & $\begin{array}{l}\text { ex Pdx } \\
28204\end{array}$ \\
\hline
\end{tabular}




\subsubsection{Narrow-gauge $600 \mathrm{~mm}$ railway on the Hel peninsula (military siding No. 582)}

In 1931, the construction of a modern war port by the peninsula promontory in the settlement of Hel began. It was led by the French-Polish Consortium for Port Construction under the direction and supervision of Polish engineers. ${ }^{784}$ The southern spur, which closed the harbour basin from the side of the fishing port, was built by eng. Jan Smidowicz. ${ }^{785}$ A standard-gauge siding branching off the tracks of the Hel railway station (Reda - Hel line) was constructed. These were basically two independent sidings leading to the coasts of both harbour basins (North and West Breakwater). One branched directly from the head of the Hel station, and the other was an extension of the main track of the Hel station. There are also tracks under the crane and under the tippers of sea mines on the newly built quay.

Parallel to the construction of the port basin in Hel, the construction of modern storage facilities on the peninsula in the form of sea mines, torpedoes and ammunition shelters was carried out. Until the completion of these investments, these materials were stored in the Modlin Fortress, where the former Russian forts housed the Central Naval Warehouse. ${ }^{786}$

In 1933, the construction of sea mines and torpedoes shelters began, these objects were located in the widest part of the peninsula, a few kilometres from the emerging war port. The storage facilities were located at a large distance from each other due to the danger of explosion transfer on a military area of considerable size. Natural dunes and a forest created favourable conditions for such objects to be masked, starting from the 1930s the action of afforestation of the peninsula was carried out in order to counteract the observation of military objects from the air. Sea mine shelters were provided in the form of reinforced concrete brick halls, with gantry cranes and narrow-gauge tracks inside. TNT depots were located at the edge of the warehouses guardhouses next to the railway gate. All buildings were reinforced concrete structures, they were masked from the top with a layer of soil. Special underground structures included four ammunition bunkers, designed mainly for the artillery ammunition for destroyers (coastal and anti-aircraft batteries had their own

784 Witkowski (1974), 82.

785 Witkowski (1974), 85.

786 Witkowski (1974), 86. 
ammunition bunkers). These shelters were recessed into the terrain to the depth of $3 \mathrm{~m}$, in addition, they were covered with soil $6 \mathrm{~m}$ thick. The narrow-gauge railway tracks passed through all the rooms of the shelter, the construction of the shelters was completed in 1937.

In 1935, the construction of a combat power plant started (construction works were carried out by the company of K. Jaskulski and K. Brygiewicz from Gdynia). It was built as a reinforced concrete hall with two internal combustion engines of $400 \mathrm{HP}$ power output each and a $100 \mathrm{HP}$ engine (for daytime operation). A diesel oil depot, together with lubricant storage were also built. A narrow-gauge railway line was also brought to the power plant, supplying fuel, lubricants and other materials. The complete object was covered with earth for masking, its construction was completed in the spring of $1939 .{ }^{787}$

After the completion of the construction of the port and storage facilities, the Hel War Port Captain's Office was created. Initially, the Port Captain was subordinate to the Commander of the section of the Hel Coast, and since 1936 to the Commander of the Fortified Region of Hel. ${ }^{788}$

On 21st Aug. 1936, by decree of the President of the Republic of Poland, the Fortified Region of Hel was established. ${ }^{789}$

For the transport of ammunition, torpedoes, war material and ship supplies from storage and support facilities scattered and located at a considerable distance from it, as well as to transport ammunition to artillery stations, a network of narrow-gauge railways was built on the area of the base.

In the first half of 1934, a tender for the construction of a narrow-gauge railway line was announced. The tender was won by K. Jaskulski and K. Brygiewicz \& Co. from Gdynia; on July 20th 1934, the head of the Navy's management ordered the company to commence works. ${ }^{790}$ Thanks to the efforts undertaken in the Ministry of Military Affairs, the first batch of surface materials - rails and switches - was obtained free of charge. ${ }^{791}$

It was planned to build $1000 \mathrm{~mm}$-gauge tracks, but a more standard $600 \mathrm{~mm}$ gauge was applied, the flat terrain of the Hel peninsula did not pose any difficulties

787 Witkowski (1974), 87.

788 Witkowski (1974), 85.

789 Witkowski (1974), 105.

790 Witkowski (1974), 96.

791 Witkowski (1974), 96. 
with earthworks, slopes and hills were minimal, and gentle curves were used on the lines. When designing the railway, a track layout typical for military railways and warehouse sidings was adopted in the form of closed loops - circumferential tracks, from which short tracks leading to individual warehouses branched off. A network of narrow-gauge tracks was built at the warehouses, entry to individual warehouses took place through a system of small single wagon turntables, produced by Walter Hoene from Gdańsk (shunting work in the warehouse area was carried out by manual repositioning of four-wheeled flat wagons). Passing loops were provided at individual objects. The entry to particularly sensitive parts of the network was possible through four track triangles - such a system provided the possibility of directly entering a given section without the need to perform complex shunting work.

At a distance of $1.9 \mathrm{~km}$ before the Hel railway station a crossing of the narrowgauge railway with the Reda - Hel railway line was built, the standard-gauge track line from Puck was led over the narrow-gauge railway track along a concrete overpass (its cross-section was $3 \mathrm{~m}$ high and $2.6 \mathrm{~m}$ wide) ${ }^{792}$ One of the lines was led to the southern tip of the Hel Peninsula, for the delivery of supplies and ammunition for the Heliodor Laskowski battery. In order to ensure independent field handling of military materials, a siding was located at the standard-gauge track at a distance of about $2.8 \mathrm{~km}$ from the station in Hel, which ended at a distance of about 300 metres behind the 32 nd artillery battery. ${ }^{793}$ In the port at the North Breakwater, another transhipment point was located at the narrowgauge siding parallel to the standard-gauge siding, while the narrow-gauge siding was also led to the West Breakwater. ${ }^{794}$

At the Hel railway station there was also a connecting station in the form of an end and side loading ramp with a narrow-gauge track layout and a standard-gauge siding. The short side loading track branched from the line leading to the cape to the H. Laskowski battery. ${ }^{795}$ Before the Hel station there was also the second intersection of the narrow-gauge railway track with

792 Labuda, (2002).

793 Labuda, (2002), 37.

794 Labuda, (2002), 37.

795 Labuda, (2002), 37-38. 
the Reda - Hel line. It was a horizontal crossing, protected only by distant signals. ${ }^{796}$

A network of narrow-gauge railways with a total length of $26 \mathrm{~km}^{797}$ and a gauge of $600 \mathrm{~mm}$ was built. ${ }^{798}$

On the most important sections the tracks were masked with anti-air observation nets. Efficient functioning of the railway was possible thanks to the telephone network connecting the guardhouses of individual warehouses and depots.

It was not possible to use steam locomotives on the narrow-gauge railway because the smoke and steam from a locomotive would betray the exact location of the train to the enemy. At the same time, sparks from steam locomotives in specific climatic conditions may have led to an unpredictable fire. ${ }^{799}$

For this reason, it was decided to use internal combustion traction. At that time Polish State Railways had a design of narrow-gauge internal combustion locomotives. At the request of the Navy Management, the vehicle documentation was handed over to the Navy ${ }^{800}$ On its basis, a tender was issued, to which companies specializing in the construction of rolling stock were invited, Wytwórnia Parowozów Zakładów Ostrowieckich (formerly: Warszawska Spółka akcyjna Budowy Parowozów) and two German companies were invited. As a result of the evaluation of the sent cost estimates, it was decided to commission the construction of two locomotives to the Polish manufacturer (the cost estimate price was PLN 80 thousand). ${ }^{801}$

The chassis and body of the locomotive were developed in the Ostrowiec Locomotive Factory. The vehicle was powered by a modern diesel engine designed by prof. Ludwik Eberman of the Lviv Polytechnic, with a power output of $50 \mathrm{HP}$ at $650 \mathrm{rpm}$, type $2 \mathrm{C} \mathrm{18/25}$. It had an air starting system by means of

796 Eisenbahndirektion Danzig plan of the Hel station from 1938, collections of the State Archive in Gdańsk, Gdynia branch, Act Ref. No. 1081, 2/730, in: Labuda, (2002).

797 Witkowski (1974), 97.

798 Witkowski reported that the military railway on Hel was of $1000 \mathrm{~mm}$ gauge, this information is incorrect, because the rolling stock was factory built for $600 \mathrm{~mm}$ track. The mistake was probably a result of incorrect interpretation of data from the technical design of the railway made by KMW, in: Witkowski (1974), 97.

799 The natural masking of the Hel Fortified Region was given great importance, even the Tp3 class steam locomotives of the Reda - Hel line, from the Puck locomotive depot, were converted to oil-burning in order to minimize the risk of fire.

800 Witkowski (1974), 97.

801 Witkowski (1974), 97. 
air cylinders mounted at the back of the locomotive. To fill them with 30 Atm compressed air, a two-stage compressor located in the gearbox was used. The locomotive was equipped with a three-speed mechanical transmission type $S$ 55 - with constantly intermeshed gears and friction multi-plate clutches. The power transmission from the gearbox to the locomotive axles was carried out by means of gear wheels and Gall chains. The vehicle was equipped with a handbrake, two sanders - one for each direction of travel, and a $12 \mathrm{~V}$ electrical system. At the request of the Navy Management two machines were built, which were delivered to Hel after acceptance tests at the beginning of 1938, several fuel stations and depots were built at Hel for diesel locomotives. ${ }^{802}$

The wagons for transporting ammunition, mines, torpedoes and all kinds of materials were built in the thirties by the Navy Port Workshops in Gdynia these were four-wheeled wagons of limited capacity. ${ }^{803}$

On June 7th 1937, the head of the Navy Headquarters ordered the entire narrow-gauge railway in $\mathrm{Hel}$ to be subordinated to the commanding officer of the Fortified Region of Hel. ${ }^{804}$

It should be emphasised that this transport system supplied the whole defence system of the Fortified Region of Hel. The direct manager of the railways was to be the Captain of the War Port of Hel, but in fact in 1938 all the narrow-gauge rolling stock belonged to the Underwater Weapons Service of the War Port of Gdynia.

During the German occupation the Port of Hel became a Kriegsmarine base. The expansion of the narrow-gauge railway was carried out by the Germans only to a limited extent. After the end of the war in Hel, sailors started to organise a new Navy base. In 1957, the Hel Port Command was established, on June 1st 1965 the Commander of the Navy subordinated the Port Command to the 9th Coastal Defence Fleet in terms of service. ${ }^{805}$

Starting from the 1960s, for safety reasons, the level crossing of the narrowgauge-railway with the Polish State Railways line, together with the adjacent sidings, was dismantled, the second line that ran under the Polish State Railways

802 Reprinting of an article - eng. J. Borowiec from »Mechanical Inspection«, "Stalowe Szlaki” No. 10/October 1990.

803 Witkowski (1974), 96 and a report by the former transport manager of the Navy Harbour Cmmand Hel, lieutenant commander Stefaniak from the Navy Logistics Administration in Gdynia.

804 Witkowski (1974), 97.

805 On the basis of materials of the Navy Harbour Command Hel. 
tracks was also dismantled together with the adjacent sidings. ${ }^{806}$ At that time a narrow-gauge line leading to the transhipment ramp at the Hel railway station was also dismantled. The 1960s saw a further decline in the importance of part of the narrow-gauge railway and its replacement by other means of transport, which resulted in the elimination of some of the disused lines. During this period, the line leading to the warehouse on the cape of the Hel Peninsula was dismantled (a siding about $5 \mathrm{~km}$ long, dismantled around 1967) as well as the siding to the pre-war liquid fuel warehouse in Jurata (dismantled in the 1950s?). ${ }^{807}$

In the 1970s, the total length of the narrow-gauge railway network was $19,049 \mathrm{~km} .{ }^{808}$ Currently, the narrow-gauge railway is used to transport torpedoes, ammunition and sea mines to the port from the warehouses and shelters (built in the 1930s) located in the area of the base. From the main narrow-gauge line, which forms a large loop, there are numerous branches leading to individual ammunition warehouses. On the main line there are four passing loops where trains can cross. Train operation is based on train radio communication by means of personal radiotelephones (where there is more than one train on the route). Rolling stock maintenance facilities provided in the port area include: a single-road locomotive depot (in 1968 the building of the former boiler house was adapted for this purpose) and a mechanical workshop, in which there is one narrow-gauge track intended for running repairs of the railway's rolling stock. The old single road narrow-gauge locomotive depot was located in another place. Within the port area, narrow-gauge tracks reach the very shore of the port basin, where an EDK80 railway crane is used to load ammunition, torpedoes, sea mines and supplies to warships. The tracks on the quay are built with concrete slabs up to the level of rail heads, switches are not equipped with switch levers and are adjusted using a rod.

After the war the railway operated low power-output two-cylinder internalcombustion locomotives. It was not possible to determine what kind of locomotives they were and what company produced them, what is known is that they worked until the 1950s, when they were replaced by WLs40 type locomotives of Polish production. According to the account of the former railway transport manager of the Port Command, two types of these locomotives were used: pre-war Polish (Zakłady Ostrowieckie?) and those imported by the Germans during the war (a frame of such a locomotive was still in the port area in the seventies). ${ }^{809}$

806 Labuda, (2002).

807 Report of the former transport manager of Navy Harbour Command Hel, lieutenant commander Stefaniak from the Gdynia Navy Logistics Administration.

808 Based on data from the Gdynia Navy Logistics Administration.

809 Report of the former transport manager of Navy Harbour Command Hel, lieutenant

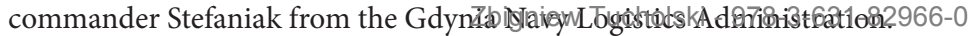


Currently the railway has four WLs40 type diesel locomotives (one being cannibalised for spare parts). In the 1970s, the Hel military railway bought two WLs50 locomotives from one of the brickyards, but due to difficulties in entering them into the army stockists, they were probably cut up for scrap or handed over to the Polish State Railways. On 6th Sept. 1977 a WLs50 locomotive (Rolling Stock Repair Plant Poznań 1709/65) was transferred from the Hel military railway to the Polish State Railways Białośliwie Narrow Gauge railway and renumbered Ld1-2. It is possible that it was one of these locomotives. ${ }^{810}$ In 1991, a WP-11-40364 WLs40 locomotive (Rolling Stock Repair Plant Poznań 291/55) was transferred to Hel from the closed narrow-gauge railway KPW Gdynia Port Oksywie, together with the following flat wagons: WPPxWP-44-43272, 43274, $4325 .{ }^{811}$

In the 1950s and 1960s, the railway used four-wheeled wagons of limited capacity, they were of different designs (with and without bodysides, with and without springs). Part of the wagon fleet operated on the Hel military railway came from the French Maginot line. ${ }^{812}$ Similarly to the Forestry Railway in Lipa $(600 \mathrm{~mm})$, these wagons were brought to Hel by the Germans during the Second World War. Some of the wagons were handed over to Hel from the narrow-gauge railway in Torun under the command of the Military Training Grounds, which was closed in the 1970s. ${ }^{813}$

Probably in the late 1950s, in order to increase the railway capacity, the old lowcapacity wagon fleet was replaced with modernised HF type bogie flat wagons and coal wagons. These wagons were rebuilt from the standard HF type flat wagons/ coal wagons produced for the German field railways (Heeresfeldbahn) during the First World War. They were the basic design of German military railways, and proved to be such a simple and robust construction that they kept being produced in the interwar period and during the Second World War in many factories. ${ }^{814}$ The wagons with fixed walls were adapted for transporting people - they had brackets

810 Polish State Railways, Narrow-gauge Locomotive Depot in Białośliwie, Księga ewidencyjna (1963).

811 Military fleet inventory of the Gdynia Navy Logistics Administration.

812 Report of the former transport manager of Navy Harbour Command Hel, lieutenant commander Stefaniak from the Gdynia Navy Logistics Administration.

813 Ibid.

814 In Poland in the interwar period wagons of this type were built on the basis of the German documentation by the Joint Stock Company "WAGON" Wagon Factory in Ostrów Wielkopolski. In the interwar period, a small batch of wagons of this type was built in Ostrów Wielkopolski for the units of Railway Sappers of the Polish Armed Forces. 
for attaching benches. Their reconstruction, which was carried out in the Lisewo narrow gauge depot (in the years 1958-1959) was reduced to the narrowing of the frames so that they would fit in the narrow gates of ammunition, torpedo and sea mine warehouses, that were to be entered by narrow-gauge wagons.

This modernisation included the construction of a practically new, almost completely welded frame and side walls. What remained as riveted were kingpins and the support for the circles supporting the wagon body on bogies. The wagon bogies were left without any structural changes - they are originally riveted, type HF (from the First World War).

Repairs of freight wagons were carried out by Koronowo, Żnin and Resko Locomotive depots on the basis of an agreement between the Ministry of National Defence and the Polish State Railways. The heavy general repairs of WLs40 locomotives of the Hel military railway were initially carried out by the Rolling Stock Repair Plant Nowy Sącz, and from the early 1980s by Zakłady Naprawcze Taboru i Sprzętu Brzesko (Motor Vehicle and Equipment repair Workshop in Brzesko). At the moment, the technical condition of the complete railway (main and additional tracks), wagon rolling stock and locomotives is much better than that of the public narrow gauge railways. Recently, a large part of the light rail infrastructure has been replaced by $\mathrm{S} 42$ heavy rail on concrete and wooden sleepers.

The locomotive WP-06-400-66 Ls150-? (Chrzanów?/62) was used to operate the standard-gauge siding branching from the Hel station. It was transferred to JW 5576 Siemirowice in 1990. In exchange for it, in 1990 the locomotive WP-01400-32 Ls40-541 (Chrzanów 5229/60) was handed over from JW 1191 Darłowo. The WP-22-404-85 ED- K80/2 (Kirow Lepzig 92/70) rail-mounted crane is also used for transhipment works on the port quay.

Technical characteristics of narrow-gauge railway No. $582^{815}$

Year of construction: $1939^{28}$

Railway length in the 1960s:

Total: 19.049

Construction: 17.194

Usable: 15.349

Maximum axle-load: $7 \mathrm{t}$

815 Based on data from the Gdynia Navy Logistics Administration. 
Maximum longitudinal incline: $2 \%$

Maximum speed: $5 \mathrm{~km} / \mathrm{h}$

28The military documentation mentions 1939 as the date of railway construction, the incorrect date most probably results from the fact that the railway was being extended until the outbreak of the Second World War.

Rolling stock list ${ }^{816}$

1. Standard-gauge rolling stock

\begin{tabular}{|l|l|l|l|l|}
\hline $\begin{array}{l}\text { Polish Armed } \\
\text { Forces No. }\end{array}$ & $\begin{array}{l}\text { Type, serial number, } \\
\text { year of construction }\end{array}$ & Received & Withdrawn & Remarks \\
\hline WP-06-400-66 & $\begin{array}{l}\text { Ls160-? } \\
\text { Chrzanów?/70 }\end{array}$ & $?$ & $\begin{array}{l}12.07 .90, \\
\text { JW 5576 } \\
\text { Siemirowice }\end{array}$ & \\
\hline WP-01-400-32 & $\begin{array}{l}\text { Ls40-541 Chrzanów } \\
5229 / 60\end{array}$ & $\begin{array}{l}\text { 30/08/1990 } \\
\text { JW 1191 } \\
\text { Darłowo }\end{array}$ & Active & 29 \\
\hline EDK-22-404-85 & $\begin{array}{l}\text { EDK80/2 Kirow } \\
\text { Leipzig 92/70 }\end{array}$ & $?$ & Active & \\
\hline WP-39-43044 & $\begin{array}{l}\text { Wood workshop } \\
\text { wagon } \\
\text { (reconstruction-1986) }\end{array}$ & $\begin{array}{l}\text { JW 2009 } \\
\text { Olsztyn }\end{array}$ & Active & \\
\hline Wechanical \\
$\begin{array}{l}\text { workshop wagon } \\
\text { (reconstruction-1977) }\end{array}$ & $\begin{array}{l}\text { JW 2009 } \\
\text { Olsztyn }\end{array}$ & Active & \\
\hline $\begin{array}{l}\text { 29 In place of the original tarpaulin curtains, metal flaps were installed in side } \\
\text { window openings. }\end{array}$
\end{tabular}

816 The rolling stock registers were compiled on the basis of data of the Gdynia Navy Logistics Administration, Headquarters of Military Transport in Gdańsk, and the Admnistration of Logistics of the Ministry of National Defence in Warsaw, the Polish State Railways lists and the factory list of diesel locomotives WLs40/50 Rolling Stock Repair Plant Poznań. 
2. Narrow-gauge locomotives

\begin{tabular}{|c|c|c|c|c|}
\hline $\begin{array}{l}\text { Polish Armed } \\
\text { Forces No. }\end{array}$ & $\begin{array}{l}\text { Type, maker, } \\
\text { factory No., year } \\
\text { of construction }\end{array}$ & Received & Withdrawn & Remarks \\
\hline WP-11-40364 & $\begin{array}{l}\text { WLs40 ZNTK } \\
\text { Poznań 291/55 }\end{array}$ & $\begin{array}{l}\text { KWP Gdynia } \\
1991 .\end{array}$ & Active & red stripe \\
\hline WP-11-40365 & $\begin{array}{l}\text { WLs40 ZNTK } \\
\text { Poznań?/55 }\end{array}$ & $?$ & Active & $\begin{array}{l}\text { yellow } \\
\text { stripe }\end{array}$ \\
\hline WP-11-40371 & $\begin{array}{l}\text { WLs40 ZNTK } \\
\text { Poznań } 436 / 36 \\
1956\end{array}$ & $\begin{array}{l}\text { JW } 2655 \\
\text { Września? }\end{array}$ & Active & $\begin{array}{l}\text { blue } \\
\text { stripe }\end{array}$ \\
\hline WP-11-40372 & $\begin{array}{l}\text { WLs40 ZNTK } \\
\text { Poznań 437/? } 1956\end{array}$ & $\begin{array}{l}\text { JW } 2655 \\
\text { Września? }\end{array}$ & Withdrawn & $\begin{array}{l}\text { for spare } \\
\text { parts }\end{array}$ \\
\hline WP-11-40373 & $\begin{array}{l}\text { WLs40 ZNTK } \\
\text { Poznań 688/57 }\end{array}$ & $\begin{array}{l}\text { Railway } \\
\text { Equipment } \\
\text { Storehouse } \\
\text { of the Polish } \\
\text { Armed Forces } \\
\text { Przemyśl? }\end{array}$ & +20.10 .93 & \\
\hline$?$ & $\begin{array}{l}\text { WLs40 ZNTK } \\
\text { Poznań 863/59 }\end{array}$ & $\begin{array}{l}\text { Railway } \\
\text { Equipment } \\
\text { Storehouse } \\
\text { of the Polish } \\
\text { Armed Forces } \\
\text { Przemyśl? }\end{array}$ & $\begin{array}{l}1974 \text { PKP } \\
\text { Warsaw } \\
\text { Military } \\
\text { District } \\
\text { Białośliwie } \\
\text { (Ld1-3) }\end{array}$ & \\
\hline$?$ & $\begin{array}{l}\text { WLs40 ZNTK } \\
\text { Poznań 1709/65 }\end{array}$ & $?$ & $\begin{array}{l}06.09 .77 \\
\text { PKP } \\
\text { Warsaw } \\
\text { Military } \\
\text { District } \\
\text { Białośliwie } \\
\text { (Ld1-2) }\end{array}$ & \\
\hline \multicolumn{5}{|c|}{$\begin{array}{l}{ }^{30} \text { Serial number unknown, false number } 308 \text { was found on the locomotive's } \\
\text { works plates (probably the plates were replaced with those of another } \\
\text { locomotive during repair). } \\
\text { Zbigniew Tucholski - 978-3-631-82966-0 }\end{array}$} \\
\hline
\end{tabular}


3. Narrow-gauge wagons

\begin{tabular}{|l|l|l|l|}
\hline Polish Armed Forces No. & $\begin{array}{l}\text { Year of } \\
\text { construction }\end{array}$ & Withdrawn & Remarks \\
\hline WP-11-40365 WLs40 & 1955 & & \\
\hline WP-11-40371 WLs40 & 1956 & & \\
\hline WP-11-40372 WLs40 & 1956 & & \\
\hline WP-11-40373 WLs40 & 1957 & & \\
\hline WP-WPPx-44-43281 & $1959 * 31$ & & \\
\hline WP-WPPx-44-43282 & $1959 *$ & & \\
\hline WP-WPPx-44-43283 & $1959 *$ & & \\
\hline WP-WPPx-44-43284 & $1959 *$ & & \\
\hline WP-WPPx-44-43285 & $1959 *$ & & \\
\hline WP-WPPx-44-43286 & $1959 *$ & & \\
\hline WP-WPPx-44-43287 & $1959 *$ & & \\
\hline WP-WPPx-44-43288 & $1959 *$ & & \\
\hline WP-WPPx-44-43289 & $1959 *$ & & \\
\hline WP-WPPx-44-43290 & $1959 *$ & & \\
\hline WP-WPPx-44-43291 & $1959 *$ & & \\
\hline WP-WPPx-44-43292 & $1959 *$ & & \\
\hline WP-WPPx-44-43293 & $1959 *$ & & \\
\hline WP-WPPx-44-43294 & $1959 *$ & & \\
\hline WP-WPPx-44-43295 & $1959 *$ & & \\
\hline WP-WPPx-44-43296 & $1959 *$ & & \\
\hline WP-WPPx-44-43297 & $1959 *$ & & \\
\hline WP-WPPx-44-43298 & $1959 *$ & & \\
\hline WP-WPPx-44-43299 & $1959 *$ & & \\
\hline WP-WPPx-44-43300 & $1959 *$ & & \\
\hline WP-WPPx-44-43901 & $1959 *$ & & \\
\hline
\end{tabular}




\begin{tabular}{|c|c|c|c|}
\hline Polish Armed Forces No. & $\begin{array}{l}\text { Year of } \\
\text { construction }\end{array}$ & Withdrawn & Remarks \\
\hline WP-WPPX-44-43902 & $1959 *$ & & \\
\hline WP-WPPX-44-43903 & $1959 *$ & & \\
\hline WP-WPPX-44-43904 & $1959^{*}$ & & \\
\hline WP-WPPX-44-43905 & $1959 *$ & & \\
\hline WP-WPPX-44-43906 & $1959 *$ & & \\
\hline WP-WPPX-44-43908 & 1918 & & \\
\hline WP-WPPx-44-43909 & $1959 *$ & & \\
\hline WP-WPPX-44-43910 & $1959 *$ & & \\
\hline WP-WPPx-44-43911 & $1958^{*}$ & & \\
\hline WP-WPPx-44-43912 & $1958^{*}$ & & \\
\hline WP-WPPx-44-43913 & $1958^{*}$ & & \\
\hline WP-WPPX-44-43914 & $1958 *$ & & \\
\hline WP-WPPx-44-43915 & $1958 *$ & & \\
\hline WP-WPPX-44-43916 & $1958^{*}$ & & \\
\hline WP-WPPx-44-43917 & $1958^{*}$ & & \\
\hline WP-WPPx-44-43918 & $1958 *$ & & \\
\hline WP-WPPx-44-43919 & $1958 *$ & & \\
\hline WP-WPPX-44-43920 & $1958 *$ & & \\
\hline WP-WPPX-44-43921 & 1959 * & & \\
\hline WP-WPPX-44-43922 & $1959 *$ & & \\
\hline WP-WPPx-44-43924 & 1927 & & \\
\hline WP-WPPX-44-43925 & 1927 & & \\
\hline WP-WPPx-44-43926 & 1927 & & \\
\hline WP-WPPx-44-43927 & 1927 & & \\
\hline WP-WPPx-44-43928 & 1927 & & \\
\hline WP-WPPx-44-43928 & 1927 & & \\
\hline
\end{tabular}




\begin{tabular}{|l|l|l|l|}
\hline WP-WPPx-44-43929 & 1927 & & \\
\hline WP-WPPx-44-43930 & $1959^{*}$ & & \\
\hline WP-WPPx-44-43932 & 1921 & & \\
\hline WP-WPPx-44-43933 & $1958^{*}$ & & \\
\hline WP-WPPx-44-43934 & 1921 & & \\
\hline WP-WPPx-44-43935 & $1959 *$ & $+7 / 79 / \mathrm{MPP}$ & \\
\hline WP-WPPx-44-43936 & 1943 & & \\
\hline WP-WPPx-44-43937 & 1943 & & \\
\hline WP-WPPx-44-43938 & $1958 *$ & & \\
\hline WP-WPPx-44-43939 & 1921 & & \\
\hline WP-WPPx-44-43940 & 1942 & & (582?) \\
\hline WP-WC-56-43941 & $1959 *$ & & snowplough \\
\hline $\begin{array}{l}31 \text { An asterisk (*) indicates the date on which the wagon was upgraded at the } \\
\text { Lisewo locomotive depot. }\end{array}$
\end{tabular}

4. Inventory of rolling stock KPW Hel status 14/026 (1980s)

\begin{tabular}{|l|l|l|}
\hline Type of rolling stock & Quantity (pcs.) & Status \\
\hline Ls40 locomotive & 1 & \\
\hline WLs40 locomotive & 4 & \\
\hline EDK-80 crane & 1 & \\
\hline Platform w/t Px & 48 & 60 \\
\hline
\end{tabular}

\subsubsection{Narrow-gauge $600 \mathrm{~mm}$ military railway Gdynia-Port Wojenny Oksywie, (military siding No. 581) JW 3643 Gdynia Port- Oksywie, siding No. 407}

The railway was built in the inter-war period by the Navy in the area of the naval base at Kępa Oksywska, for the delivery of supplies from warehouses to the 
war port. It was a short railway line - $1796.80 \mathrm{~m},{ }^{817}$ most probably the shortest narrow-gauge line of the Polish Navy.

There is no precise information about the original pre-war rolling stock, it is only known that the railway operated bogie flat wagons with sideboards ordered in the inter-war period in the Warsaw rolling stock factory Towarzystwo Akcyjne Władysław Gostyński. In the port area near the warehouses, a singleroad locomotive depot was built. During the German occupation, the line was used to transport torpedoes from the warehouse to a torpedo depot built on stilts at a short distance from the shore, the track was led to it on a trestle bridge build on stilts. ${ }^{818}$

In 1940, the Locomotive Factory in Chrzanów built a four-wheel narrowgauge internal combustion locomotive (Krenau No. 722/1940) ordered by Kriegsmarine Gotenhafen, the locomotive probably worked on a narrow-gauge railway in Oksywie during the German occupation. ${ }^{819}$

In the early 1950s, the WLs40-120 locomotive (Rolling Stock Repair Plant Poznan 120/53) was brought to Gdynia, probably from the Military Unit JW 3127 in Dęblin, while in 1955 another WLs40 machine (WLs40-291, Rolling Stock Repair Plant Poznań 291/55) was purchased from the factory. ${ }^{820}$ The line used 10 original, pre-war bogie flat wagons (with body-sides) built by the Wagon Construction Division of the Władysław Gostyński i Ska Joint Stock Company factory in Warsaw, as well as 10 four-wheeled flat wagons used for internal traffic.

The railway track was laid directly on the unreinforced quay and therefore was frequently washed and damaged by the waves and required constant laborious and costly repairs. At the end of the 1980s, it was decided to close the railway, the line was dismantled in 1989-90. The narrow-gauge rolling stock was transferred to the military railways in Świnoujście and Hel, and several wagons were cut up for scrap at Oksywie.

817 Navy Logistics Administration Gdynia, Characteristics of military.

818 Report of the former transport manager of KPW Hel, lieutenant commander Stefaniak from the Gdynia Navy Logistics Administration.

819 Szponder, Tucholski, Lista (unpublished).

820 Rolling Stock Repair Plant Poznań, Lista fabryczna WLs40/50. 
1. KPW Gdynia rolling stock list, list of rolling stock Status $14 / 025^{821}$

\begin{tabular}{|l|l|}
\hline Type of rolling stock & Quantity \\
\hline Ls160 & 1 \\
\hline Ls40 & 1 \\
\hline WLs40 & 2 \\
\hline EDK-80 crane & 1 \\
\hline Flat wagon n/a & 1 \\
\hline Flat wagon Px & 10 \\
\hline
\end{tabular}

2. List of standard-gauge rolling stock (1970s)

\begin{tabular}{|c|c|c|}
\hline $\begin{array}{l}\text { Polish Armed Forces } \\
\text { No., vehicle type, year of } \\
\text { construction }\end{array}$ & Withdrawn & Remarks \\
\hline WP-01-40023 Ls40 & $\begin{array}{l}\text { Protocol 1/78 for JW } \\
2186 \text { Hajnówka }\end{array}$ & \\
\hline \multicolumn{3}{|l|}{ WP-22-40482 EDK80/1 1965} \\
\hline Pklm WP-30-41839 1942,1920? & $\begin{array}{l}\text { + withdrawal protocol } \\
\text { JW } 5431 \text {, No } 388 / 95 \text { of } \\
30.11 .94 \text {. }\end{array}$ & $\begin{array}{l}\text { for the transport of } \\
\text { gaseous materials }\end{array}$ \\
\hline
\end{tabular}

821 The rolling stock registers were compiled on the basis of data of the Gdynia Navy Logistics Administration, Headquarters of Military Transport in Gdańsk, and the Administration of Logistics of the Ministry of National Defence in Warsaw, the Polish State Railways rolling stock list and the Rolling Stock Repair Plant Poznań, Lista fabryczna WLs40/50. 
3. List of standard-gauge rolling stock

\begin{tabular}{|l|l|l|l|l|}
\hline $\begin{array}{l}\text { Polish } \\
\text { Armed } \\
\text { Forces No. }\end{array}$ & Class & Maker, Factory No. & Received & Withdrawn \\
\hline WP-01-40020 & Ls40-247 & Chrzanów 4562/56 & $\begin{array}{l}\text { KPW } \\
\text { Gdynia }\end{array}$ & \\
\hline WP-01-40023 & Ls40-276 & Chrzanów 4591/56 & $\begin{array}{l}\text { KPW } \\
\text { Gdynia }\end{array}$ & $\begin{array}{l}\text { Hajnówka } \\
\text { Ha JW 2186 }\end{array}$ \\
\hline WP-01-40096 & Ls160-516 & Zastal 516/77 & $\begin{array}{l}21.09 .77, \\
\text { KPW } \\
\text { Gdynia }\end{array}$ & \\
\hline WP-22-40482 & EDK80/1 & Kirow Lipzig?/65 r. & & +30.11 .1994 \\
\hline WP-30-41839 & Pklm & ?/20 & & \\
\hline
\end{tabular}

4. List of narrow-gauge locomotives

\begin{tabular}{|l|l|l|l|}
\hline $\begin{array}{l}\text { Polish Armed } \\
\text { Forces No. }\end{array}$ & Factory, Factory No. & Received & Withdrawn \\
\hline WP-11-40361 & ZNTK Poznań 120/53 & JW 3127 Dęblin? & $\begin{array}{l}04.02 .91, \text { KPW } \\
\text { Swinoujście }\end{array}$ \\
\hline WP-11-40364 & $\begin{array}{l}\text { ZNTK Poznań 291/55 } \\
(307 / 53)\end{array}$ & $\begin{array}{l}1955 \text { from the } \\
\text { factory }\end{array}$ & 1991 KPW Hel \\
\hline
\end{tabular}

5. List of narrow-gauge rolling stock (1970s)

\begin{tabular}{|l|l|l|l|}
\hline $\begin{array}{l}\text { Polish Armed Forces } \\
\text { No. }\end{array}$ & $\begin{array}{l}\text { Year of } \\
\text { construction }\end{array}$ & Withdrawal & Remarks \\
\hline WP-11-40361 WLs40 & 1953 & & $\begin{array}{l}04.02 .91, \mathrm{KPW}- \\
\text { Swinoujście }\end{array}$ \\
\hline WP-11-40364 WLs40 & 1955 & & $1991, \mathrm{KPW}$ Hel \\
\hline
\end{tabular}




\begin{tabular}{|c|c|c|c|}
\hline $\begin{array}{l}\text { Polish Armed Forces } \\
\text { No. }\end{array}$ & $\begin{array}{l}\text { Year of } \\
\text { construction }^{32}\end{array}$ & Withdrawal & Remarks \\
\hline WPPx WP-44-43271 & 1942 & $+1 K / 76$ & Scrapped \\
\hline WPPx WP-44-43272 & 1942 & & 1991, KPW Hel \\
\hline WPPx WP-44-43273 & 1942 & & $\begin{array}{l}\text { 07/02/1991, } \\
\text { KPW } \\
\text { Świnoujście } \\
\end{array}$ \\
\hline WPPx WP-44-43274 & 1942 & & 1991, KPW Hel \\
\hline WPPx WP-44-43275 & 1919 & & 1991, KPW Hel \\
\hline WPPx WP-44-43276 & 1942 & & $\begin{array}{l}\text { 07/02/1991, KPW } \\
\text { Świnoujście }\end{array}$ \\
\hline WPPx WP-44-43277 & 1942 & & $\begin{array}{l}\text { 07/02/1991, } \\
\text { KPW } \\
\text { Świnoujście }\end{array}$ \\
\hline WPPx WP-44-43278 & 1942 & & $\begin{array}{l}\text { 07/02/1991, KPW } \\
\text { Świnoujście }\end{array}$ \\
\hline WPPx WP-44-43279 & 1942 & $+1 / 78$ & Scrapped \\
\hline WPPx WP-44-43280 & 1942 & $+1 / 78$ & Scrapped \\
\hline WPPx WP-43-43616 & 1942 & $62042 ?$ & $\begin{array}{l}\text { for internal } \\
\text { traffic }\end{array}$ \\
\hline WPPx WP-43-43617 & 1942 & $62142 ?$ & for internal traffic \\
\hline WPPx WP-43-43618 & 1942 & & for internal traffic \\
\hline WPPx WP-43-43619 & 1942 & & for internal traffic \\
\hline WPPx WP-43-43622 & 1942 & & for internal traffic \\
\hline WPPx WP-43-43623 & 1942 & & for internal traffic \\
\hline WPPx WP-43-43624 & 1942 & & for internal traffic \\
\hline WPPx WP-43-43625 & 1942 & & for internal traffic \\
\hline
\end{tabular}




\subsubsection{Military railway Świnoujście, military siding No. 881 (600 mm)}

Along with the development of a fortification system on the Wolin and Uznam islands, the buildings of a military port, artillery batteries, ammunition and technical depots under construction were connected by a $600 \mathrm{~mm}$ narrowgauge railway network. In 1937, a new artillery battery consisting of three barrack and an assault bunker was built near Przytór village (all were located $250 \mathrm{~m}$ apart), each of these was equipped with two firing points. To prevent the enemy from detecting the battery it was located in a wooded area $2 \mathrm{~km}$ from the coast. The decision was made to equip the battery with three $280 \mathrm{~mm}$ cannons, with the possibility of mounting $305 \mathrm{~mm}$ calibre guns. ${ }^{822}$ Auxiliary facilities were also built in the battery area: an ammunition warehouse, a power plant bunker (with two diesel-powered generators), a narrow-gauge railway locomotive depot and a command tower. The battery facilities were hermetic buildings adapted to operate in conditions of chemical contamination (they were equipped with double armoured doors and a system of gas locks). The described complex was surrounded by a barbed wire fence and the entrance to the battery led through gates protected by guardhouses. The $3 \mathrm{x}$ $283 \mathrm{~mm}$ battery was completed at the end of 1938 and was named Göben in honour of a Prussian general August Karl von Göben, commander of a corps and then an army, who fought in the Franco-Prussian war of $1870-71,{ }^{823}$ as well as, as it seems, to commemorate the extraordinary combat feats of the German cruiser Goeben during the First World War on the Mediterranean and Black Seas.

All battery objects were connected by a system of $600 \mathrm{~mm}$ narrow-gauge lines, this system was connected with the narrow-gauge lines of the neighbouring Werder (Ognica) ammunition and technical warehouse. A camouflaged concrete shelter covered with a wooden roof was provided - for the narrow-gauge vehicles between the locomotive depot building and the ammunition depot on one of the narrow-gauge sidings. A standard-gauge siding from the railway station at Przytór ended with a loading ramp with a narrow-gauge track next to it. Apart from the narrow-gauge system, each barrack and assault bunker had its own standard-gauge siding. These sections were used to transport cannons to the batteries, they were assembled with a railway crane.

822 Laskowski, Wroński, (1999), 66.

823 Laskowski, Wroński, (1999), 76. 
In July 1938, three $283 \mathrm{~mm} \mathrm{SKL/45}$ cannons (made by F. Krupp A.G.) were mounted in the battery blocks. In winter 1938/39 a test shooting was carried out. ${ }^{824}$ The outbreak of the war changed the concept of the strategic use of the batteries, in 1940 all the cannons and technical devices of the battery were dismantled and transported to Norway to Tarva island. ${ }^{825}$

After the battery was dismantled, its buildings were incorporated in the ammunition and technical warehouse complex, to be used as residential rooms and warehouses for anti-aircraft artillery. According to reports by Polish forced labourers in Świnoujście at the turn of 1944/45, the railway siding of the battery was used to store the $194 \mathrm{~mm}$ railway guns (5 cannons) that was captured in France. ${ }^{826} \mathrm{After}$ the war, the battery facilities were partly redeveloped by the army.

In the post-war period, the narrow-gauge railway of the former Göben battery together with the tracks in the ammunition and technical warehouse was under the responsibility of the War Port Headquarters in Świnoujście, it was used to transport ammunition, sea mines and supplies from warehouses to the war port area. A narrow-gauge line with a total length of $13.5 \sim 14 \mathrm{~km}$ was operated. The narrowgauge railway transhipment station was located at the siding branching from the Świnoujście Przytór railway station. The technical base of the railway was located in the area of the military unit at Ognica, together with a passing loop with a short depot track that lead to the former German two-road timber framed locomotive depot.

On this line, WLs40 type locomotives were put into operation in the 1950s, as well as original Prussian HF field railways flat wagons, ${ }^{827}$ old-design four-wheeled flat wagons and special recessed flat wagons on HF type bogies for transporting sea mines, most probably built at the beginning of the 20th century on the request of the military railways in Świnoujście. These wagons are called miners by the workers and sailors who worked on the narrow-gauge railway. In 1991, the WLs40 locomotive and five bogie flat wagons produced by W. Gostynski were handed over to Świnoujście from the closed military railway at Oksywie. Rolling stock list ${ }^{828}$

824 Laskowski, Wroński, (1999), 73.

825 Laskowski, Wroński, (1999), 76.

826 Laskowski, Wroński, (1999), 76.

827 Including Bochumer Verein factory plates.

828 The rolling stock lists are based on data of the Gdynia Navy Logistics Administration, Headquarters of Military Transport in Gdańsk, and the Administration of Logistics of the Ministry of National Defence in Warsaw, the Polish State Railways rolling stock list and the factory list of diesel locomotives WLs40/50 built by Rolling Stock Repair Plant Poznań. 
1. List of narrow-gauge locomotives

\begin{tabular}{|l|l|l|l|}
\hline $\begin{array}{l}\text { Polish Armed } \\
\text { Forces No. }\end{array}$ & Type, serial number & Received & Withdrawn \\
\hline WP-11-40361 & $\begin{array}{l}\text { WLs40 ZNTK Poznań } \\
120 / 53\end{array}$ & $\begin{array}{l}\text { 04/02/1991, KPW } \\
\text { Gdynia }\end{array}$ & +1996 \\
\hline WP-11-40363 & $\begin{array}{l}\text { WLs40 ZNTK Poznań } \\
289 / 55\end{array}$ & $\begin{array}{l}05.04 .1955 \text { new } \\
\text { from factory }\end{array}$ & Active \\
\hline WP-11-40367 & $\begin{array}{l}\text { WLs40 ZNTK Poznań } \\
402 / 56\end{array}$ & JW 24 Odra Port? & Active \\
\hline WP-11-40368 & $\begin{array}{l}\text { WLs40 ZNTK Poznań } \\
329 / 55\end{array}$ & JW 2224 Darłowo? & Active \\
\hline WP-11-40369 & $\begin{array}{l}\text { WLs40 ZNTK Poznań } \\
330 / 55\end{array}$ & $\begin{array}{l}\text { JW 2655 } \\
\text { Września? }\end{array}$ & +1996 \\
\hline
\end{tabular}

2. Standard-gauge rolling stock list

\begin{tabular}{|l|l|}
\hline Polish Armed Forces No. & Type of rolling stock \\
\hline WP-06-40??? & 409Da-? \\
\hline WP-24-40488 & EDK80/1-130 Kirow 130/64 \\
\hline
\end{tabular}

3. Wagon list

\begin{tabular}{|l|l|l|l|l|}
\hline $\begin{array}{l}\text { Polish Armed } \\
\text { Forces No. }\end{array}$ & $\begin{array}{l}\text { Year of } \\
\text { construction }\end{array}$ & Series & Type & Remarks \\
\hline WP-44-43251 & 1942 & & flat wagon & \\
\hline WP-44-43252 & 1942 & Pxh & flat wagon & \\
\hline WP-44-43253 & 1943 & Pdxh & flat wagon & \\
\hline WP-44-43254 & 1942 & Phx & flat wagon & \\
\hline WP-44-43255 & 1942 & Pdxh & flat wagon & \\
\hline
\end{tabular}




\begin{tabular}{|c|c|c|c|c|}
\hline $\begin{array}{l}\text { Polish Armed } \\
\text { Forces No. }\end{array}$ & $\begin{array}{l}\text { Year of } \\
\text { construction }\end{array}$ & Series & Type & Remarks \\
\hline WP-44-43256 & 1942 & & flat wagon & $\begin{array}{l}\text { suitable for } \\
\text { transporting } \\
\text { people }\end{array}$ \\
\hline WP-44-43257 & 1942 & & flat wagon & \\
\hline WP-44-43258 & 1942 & Pxh & flat wagon & \\
\hline WP-44-43259 & 1942 & Pxh & flat wagon & \\
\hline WP-44-43260 & 1942 & Pdxh & flat wagon & \\
\hline WP-44-43261 & 1943 & Pxh & flat wagon & \\
\hline WP-44-43262 & 1943 & Pxh? & $\begin{array}{l}\text { "miner" flat } \\
\text { wagon }\end{array}$ & \\
\hline WP-44-43263 & 1942 & Pdxh & flat wagon & \\
\hline WP-44-43264 & 1942 & Pdxh & flat wagon & \\
\hline WP-44-43265 & 1942 & Pxh & flat wagon & \\
\hline WP-44-43266 & 1942 & Pxh & flat wagon & $\begin{array}{l}\text { single } \\
\text { sideboards }\end{array}$ \\
\hline WP-44-43267 & 1942 & & flat wagon & \\
\hline WP-44-43268 & 1942 & Phd & $\begin{array}{l}\text { "miner" flat } \\
\text { wagon }\end{array}$ & \\
\hline WP-44-43269 & 1942 & Phd & $\begin{array}{l}\text { "miner" flat } \\
\text { wagon }\end{array}$ & \\
\hline WP-44-43270 & & Pdxh & $\begin{array}{l}\text { "miner" flat } \\
\text { wagon }\end{array}$ & \\
\hline WP-44-43601 & 1958 & & $\begin{array}{l}\text { four-wheeled } \\
\text { flat wagon }\end{array}$ & $\begin{array}{l}\text { inscription on } \\
\text { an axle box } \\
\text { (exelsiour) }\end{array}$ \\
\hline WP-44-43602 & & & $\begin{array}{l}\text { four-wheeled } \\
\text { flat wagon }\end{array}$ & \\
\hline WP-44-43603 & & & $\begin{array}{l}\text { four-wheeled } \\
\text { flat wagon }\end{array}$ & \\
\hline
\end{tabular}




\begin{tabular}{|c|c|c|c|c|}
\hline $\begin{array}{l}\text { Polish Armed } \\
\text { Forces No. } \\
\end{array}$ & $\begin{array}{l}\text { Year of } \\
\text { construction }\end{array}$ & Series & Type & Remarks \\
\hline WP-44-43604 & & & $\begin{array}{l}\text { four-wheeled } \\
\text { flat wagon }\end{array}$ & \\
\hline WP-44-43605 & 1958 & & $\begin{array}{l}\text { four-wheeled } \\
\text { flat wagon }\end{array}$ & sprung \\
\hline WP-44-43606 & & BDOP? & $\begin{array}{l}\text { four-wheeled } \\
\text { flat wagon }\end{array}$ & \\
\hline WP-44-43607 & & BDOP? & $\begin{array}{l}\text { four-wheeled } \\
\text { flat wagon }\end{array}$ & \\
\hline WP-44-43608 & & BDOP? & $\begin{array}{l}\text { four-wheeled } \\
\text { flat wagon }\end{array}$ & \\
\hline WP-44-43609 & & BDOP? & $\begin{array}{l}\text { four-wheeled } \\
\text { flat wagon }\end{array}$ & \\
\hline WP-44-43610 & & & $\begin{array}{l}\text { four-wheeled } \\
\text { flat wagon }\end{array}$ & \\
\hline WP-44-43611 & & & $\begin{array}{l}\text { four-wheeled } \\
\text { flat wagon }\end{array}$ & \\
\hline WP-44-43612 & & & $\begin{array}{l}\text { four-wheeled } \\
\text { flat wagon }\end{array}$ & \\
\hline WP-44-43613 & & & $\begin{array}{l}\text { four-wheeled } \\
\text { flat wagon }\end{array}$ & \\
\hline
\end{tabular}

\subsubsection{Military siding No. 181, JW 1540 Nowe Miasto and sidings for fuel re-pumping station in Piaseczno No. 101/183 (standard- and narrow-gauge)}

At the beginning of the 1950s, a military airfield was built in Nowe Miasto nad Pilica. In 1951 the airport was linked with a narrow-gauge siding of a total length of $2375 \mathrm{~m}$, which branched off from the Nowe Miasto nad Pilicą railway station (narrow-gauge line Piaseczno Miasto - Nowe Miasto nad Pilicą, $1000 \mathrm{~mm}$ gauge). ${ }^{829}$ Three passing loops, three dead-end tracks and a 15-metre-long side 
ramp were built on the siding at the loading points. The siding was intended mainly for the transport of coal and aviation fuel. From the very beginning of its existence it was operated by Polish State Railways locomotives, there was not a single army-owned locomotive that served the siding.

In 1958, in order to deliver aviation fuel to the airport, the Administration of Military Transport of the General Staff of the Polish Armed Forces purchased 16 bogie tank wagons type $3 \mathrm{Rw}$ from Zastal in Zielona Góra. Under the agreement of 11th Aug. 1959, the tank wagons were incorporated into the Polish State Railways rolling stock lists, they were given Polish State Railways designation, Rdx series designation, $\mathrm{P}$ designation (private wagon), Ministry of National Defence designation and the following Polish State Railways inventory numbers 72070, 72071, 72072, 72073, 72074, 72075, 72076, 72077, 72078, 72079, 72080, $72081,72082,72083,72084$ and 72085 . The wagons were assigned to Piaseczno station, fuel was transported on the Piaseczno Przeładunkowe - Nowe Miasto nad Pilicą section. ${ }^{830}$

Initially, fuel was transhipped from standard-gauge to narrow-gauge tank wagons at Piaseczno Przeładunkowe. Due to the fire hazard, around $1960^{831}$ the Military Fuel Station was built in Piaseczno, intended for gravity reloading of fuel from standard-gauge to narrow-gauge tank wagons. A standard-gauge siding No. 101, $0.5 \mathrm{~km}$ long, branching off from track No. 5 of the Piaseczno station, and a narrow gauge siding No. 183, $1.8 \mathrm{~km}$ long, branching off from the track system of the narrow gauge Piaseczno Przeładunkowe station was constructed to the area of the fuel re-pumping station. Both sidings ended with two dead-end tracks.

In 1970, the siding was overhauled by replacing $2456 \mathrm{~m}$ of rails. In 1974, as part of the investment plan, a fuel storage track was built in Nowe Miasto nad Pilicą.

In the 1980s, the old 3Rw tank wagons were taken out of service and replaced with new WRRdh class tank wagons. These were standard-gauge four-wheeled tank wagons together with frames placed on narrow gauge transporter wagons. At the beginning of the 1990s, the transport of fuel by rail to the airport in Nowe Miasto was discontinued. After the end of fuel transport, part of the tank wagons

830 Agreement on inclusion of Ministry of National Defence tank wagons in the Polish State Railways stock dated 11th Aug. 1959.

831 The date of construction of the siding has not been confirmed, its technical design was made on 29th Oct. 1960, by Biuro Projektów CPN "Naftoprojekt" (CPN “Naftoprojekt" Design Office). 
were transferred to the Koszalin railway. In the mid-1990s, the fuel re-pumping station, together with a narrow-gauge and standard-gauge siding was closed.

\subsubsection{Military siding in Zegrze Pomorskie and fuel re-pumping point siding in Koszalin}

In the 1950s, the construction of a military airport in Zegrze Pomorskie started. In order to transport large quantities of construction materials, it was decided to build a narrow-gauge siding from the Koszalin Wąsk. - Swielino railway line of the Pomorska $\mathrm{KD}$ system. A passenger halt was located in the village of Kurozwęcz, placed $200 \mathrm{~m}$ from the location of the later Kurozwęcz station in the direction of Świelino.

In 1951, a narrow-gauge siding, about 5,600 $\mathrm{m}$ long, was built along with the Kurozwęcz railway station, placed in a new location, with a track layout designed to accommodate several trains arriving at the siding. At that time the old passenger halt at Kurozwęcz was closed. Due to the very large quantities of materials brought to the airport under construction, a steam locomotive delegated from the Koszalińska KD depot was located at Kurozwęcz station in the 1950s.

After completion of the construction of the airport in Zegrze Pomorskie, the Kurozwęcz - Zegrze Pomorskie siding was used to deliver aviation fuel and other supplies to the airport. From the very beginning of its existence it was operated by Polish State Railways locomotives, no own locomotives were used on the siding.

In 1958, the Polish Armed Forces purchased 10 bogie tank wagons type 3 Rw type at Zastal in Zielona Góra, intended for the Zegrze Pomorskie airport. In 1959 these tank wagons, on the basis of an agreement between the PKP division in Szczecin and the Polish Armed Forces, were incorporated into the Polish State Railways rolling stock list, and their home station was Koszalin. With the beginning of air fuel transport in narrow-gauge tank-wagons on the Koszalin Wąsk. - Świelino line, fuel was transferred from standard-gauge to narrowgauge tank wagons at a point located in the area of the Koszalin Wąsk. station. It was closed in 1979, along with the modernisation of the Koszalin Wąsk. station, as the line was adapted for the transport of standard-gauge wagons on narrow gauge transporters. A new Military Fuel Station transhipment point was built together with a narrow-gauge siding approximately 500 metres long, which branched off from the track layout of the Koszalin Wąsk. station in the vicinity of the locomotive depot. In the 1980s the old $3 \mathrm{Rw}$ type tank wagons were replaced with Rgddyyhp class wagons - standard-gauge four-wheeled tank wagons with frames placed on narrow-gauge transporter wagons. Along with the suspension of transport on the Koszalin railway in 2002, the transport of fuel in tank wagons has also been stopped and the military sidings were withdrawn from operation. 


\subsubsection{Military siding JW 4420 No. 180 (Mława narrow-gauge railway)}

A military siding No. 180 (600 mm gauge), $2100 \mathrm{~m}$ long, branched off from the Przasnysz railway station (Towarowa) of the narrow-gauge Mława Wąsk. Maków Mazowiecki line and led to the Military Unit No. $3521^{832}$ in Przasnysz. The siding was probably built in 1953, it was commissioned for operation on the basis of the protocol dated 2nd Jan. 1953. The siding track was laid on gravel ballast, the route included two pipe culverts. The siding was operated by Polish State Railways freight train locomotives and did not have its own locomotive. Behind the station in Przasnysz (Towarowa) at a distance of about 140 meters behind the junction, there was a derailer protecting the entrance to the siding, the main siding track and a passing loop were built on the area of the military unit. The siding unloaded wagonloads of coal and petrol.

At the request of the Headquarters of Military Transport of the General Staff of the Polish Armed Forces in 1958 the Zaodrzańskie Zakłady Przemysłu Metalowego im. Marcelego Nowotki in Zielona Góra produced eight 2Rw type $600 \mathrm{~mm}$ tank wagons designed to transport petrol to the siding of the air force unit (JW 3521) in Przasnysz. On 9th Feb. 1959, eight narrow-gauge tank wagons arrived at Warsaw Military District Mława from the factory. ${ }^{833}$

On 2nd June 1959, the liquid fuel transhipment point at Mława Wąsk. station was officially determined in the final part of the standard-gauge dead-end track No. 25 and narrow-gauge track No. 22.834

Under the agreement of 11th Sept. 1959, the tank wagons were incorporated into the Polish State Railways rolling stock lists, they were given Polish State Railways designation, Rdx series designation, P designation (private wagon), Ministry of National Defence designation and Polish State Railways inventory numbers 70226, 70227, 70228, 70229, 70230, 70231, 70232, 70233. The wagons were assigned to Mława, fuel was transported on the Mława Wąsk. - Przasnysz line. ${ }^{835}$ The JW 3521 handed over the wagons to Warsaw Military District Mława, which was confirmed in the protocol. ${ }^{836}$

832 Unit number changed to JW 4420.

833 Protocol of 9th Feb. 1959.

834 Protocol of 2nd June 1959.

835 Agreement of 28th Sept. 1959.

836 Site acceptance certificate of 9th Sept. 1959. 
The liquid fuel handling point was located at a distance of about $60 \mathrm{~m}$ from the main standard-gauge tracks and about $200 \mathrm{~m}$ from the buildings of the narrowgauge station. During fuel re-pumping in the area protected by stop discs, the driving of shunting steam locomotives (both standard and narrow-gauge) was prohibited. One or two standard-gauge tank wagons were usually delivered to the transhipment point, which were re-pumped to 2 or 4 narrow-gauge tank wagons. The loading was carried out during daytime only, and a 50-tonne tank wagon was reloaded within 6 hours. Standard-gauge tank wagons on track No. 21 were placed at a distance of $20 \mathrm{~m}$ from the buffer stop, additionally they were secured from the side of the entrance with a D1 "stop" sign, placed at a distance of $50 \mathrm{~m}$. The narrow-gauge track No. 22 was secured in a similar way. Fuel transfer works were carried out by JW 3521, which protected them also in terms of fire prevention. The handling was carried out by means of a pumping unit, which was delivered on a narrow-gauge flat wagon from JW 3521 in Przasnysz. Loaded wagons were sent in freight trains, barrier wagons were used because of the significant fire risk (from sparks from a steam locomotive). ${ }^{837}$ As in Warsaw Military District Mława there were no wagons fitted with buffers on their buffer beams, of a weight equal to that of a tank wagon, with the consent of ZKW SG WP, two 2Rw tank wagons filled with water were used as barrier wagons. ${ }^{838}$ Tanks wagons with fuel were sealed with the Polish State Railways and JW 3521 Przasnysz seals. ${ }^{839}$ Once loaded with fuel, the tank wagons were used to store the fuel on the premises of the military unit in Przasnysz, due to the lack of stationary tanks for unloading petrol. ${ }^{840}$

Periodic repairs of the $2 \mathrm{Rw}$ type tank wagons were carried out by the 1 st class locomotive depot in Mława.

In 1964, Polish State Railways started re-gauging the Mława narrow gauge railway to $750 \mathrm{~mm}$ gauge. Together with the reconstruction of the Mława railway, the military siding in Przasnysz was also converted and modernised. On 29th Oct.1964, a committee organised by the Narrow-gauge Railways Management of the State Railway Management in Warsaw approved the military sidings No.

837 Barrier wagons - these are empty freight wagons included in a train set to separate wagons with dangerous goods from the rest of the train.

838 According to the letter of 29th July 1960. there were three tank wagons on the siding No. 180 in Przasnysz, which were intended to be used as protection for the $2 \mathrm{Rw}$ type tank wagons. However, due to their lightweight chassis construction and lighter weight, they could not be used as a barrier wagons. After technical inspections, they were to be used for transporting fuel.

839 Protocol of 2nd June 1959.

840 Letter of 22nd Dec. 1959. 
180 after the reconstruction. The siding track in the Przasnysz Towarowa station, after changing its curve radius, was connected directly into the station track No. 10 by means of a switch No. 10 .

At the end of the re-gauged track a buffer stop was built of sleepers, while the siding track at military warehouses was secured with a derailer. After a test ride with a Px48 steam locomotive, the Commission found the siding to be operational.

After re-gauging the Mława narrow gauge railway to $750 \mathrm{~mm}$ gauge, tank wagons no longer usable for transporting fuel were sold by Head of Military Transport at the Regional State Railway Management in Warsaw to the "Guzów" Sugar Factory. According to the protocol of the Management: According to the "statement of the representative of the Head of Military Transport Major Nowecki, these wagons were sold to the Guzów Sugar Factory after re-gauging the Mława Railway from a $600 \mathrm{~mm}$ gauge to $750 \mathrm{~mm}$ gauge." ${ }^{411}$ The "Guzów" sugar factory used them to transport molasses on the Guzów - Szymanów line. In 1971, after the closure of the sugar beet narrow-gauge railway, four tank wagons were purchased by Kombinat Rolno-Spożywczy "Krochmalnia" in Niechcice to transport molasses on the narrow-gauge Goszkowice - Niechcice line. After also this railway was closed at the beginning of the 1990s, all the tank wagons were cut up for scrap.

In the 1980s, the army resigned from using the siding in Przasnysz, which was dismantled a few years later.

Technical specification of type $2 \mathrm{Rw} 600 \mathrm{~mm}$ tank wagons ${ }^{842}$

\begin{tabular}{|l|l|}
\hline Manufacturer & “Zastal” Zielona Góra \\
\hline Type of construction & $2 \mathrm{Rw}$ \\
\hline Track gauge & $600 \mathrm{~mm}$ \\
\hline Load capacity & $10000 \mathrm{KG}$ \\
\hline Carrying capacity & $10500 \mathrm{KG}$ \\
\hline Deadweight & $7000 \mathrm{KG}$ \\
\hline Length with buffer & $8600 \mathrm{~mm}$ \\
\hline
\end{tabular}

841 Written annotation dated 24th October 1974.

842 Technical data on the basis of Technical Documentation of the $2 R w$ type petrol tank wagons (Central Construction Office of the Rolling Stock Industry - Poznań). 


\begin{tabular}{|l|l|}
\hline Manufacturer & “Zastal" Zielona Góra \\
\hline Chassis length & $7540 \mathrm{~mm}$ \\
\hline Wagon width & $1440 \mathrm{~mm}$ \\
\hline Max. wagon width & $1850 \mathrm{~mm}$ \\
\hline Max. wagon height & $3100 \mathrm{~mm}$ \\
\hline Capacity & 115 hectolitre \\
\hline Outer diameter of the tank & $1500 \mathrm{~mm}$ \\
\hline External length of the tank & $6900 \mathrm{~mm}$ \\
\hline Coating sheet thickness & $6 \mathrm{~mm}$ \\
\hline Bottom plate thickness & $9 \mathrm{~mm}$ \\
\hline Sheet metal material for the tank & St3s \\
\hline Test pressure & 3 atm. \\
\hline Bottom emptying of the tank wagon & $\varnothing 100$ \\
\hline Type of material transported & Petrol \\
\hline Grade material weight & 0.7 \\
\hline Bogie wheelbase & $950 \mathrm{~mm}$ \\
\hline Spacing of bogie pivots & $4700 \mathrm{~mm}$ \\
\hline Number of axles & 4 \\
\hline Wheel diameter & $600 \mathrm{~mm}$ \\
\hline Diameter / length of axle journal & $975 / 125$ \\
\hline Distance between the wheelset's \\
centre bearings & $945 \mathrm{~mm}$ \\
\hline Type of brake & R-37 \\
\hline Platform or brake box & $30 \mathrm{~km} / \mathrm{h}$ \\
\hline Year of construction & Brake platform \\
\hline Smallest curve radius & 1956 \\
\hline Max. speed & \\
\hline
\end{tabular}


List of $2 \mathrm{Rw}$ type tank wagons $(600 \mathrm{~mm})^{843}$

\begin{tabular}{|l|l|}
\hline Polish State Railways No. & Factory/year of construction \\
\hline $\operatorname{Rdx} 70226$ & “Zastal” Zielona Góra, 1958 \\
\hline $\operatorname{Rdx} 70227$ & “Zastal” Zielona Góra, 1958 \\
\hline $\operatorname{Rdx} 70228$ & “Zastal” Zielona Góra, 1958 \\
\hline $\operatorname{Rdx} 70229$ & “Zastal” Zielona Góra, 1958 \\
\hline $\operatorname{Rdx} 70230$ & “Zastal” Zielona Góra, 1958 \\
\hline $\operatorname{Rdx} 70231$ & “Zastal” Zielona Góra, 1958 \\
\hline $\operatorname{Rdx} 70232$ & “Zastal” Zielona Góra, 1958 \\
\hline $\operatorname{Rdx} 70233$ & “Zastal” Zielona Góra, 1958 \\
\hline
\end{tabular}

\subsection{Military rolling stock}

\subsubsection{Locomotives}

In the post-war period, the Polish Armed Forces used several dozen shunting locomotives for shunting work on military sidings and internal narrow-gauge railways. Due to the specific conditions of masking military objects against the observation of the enemy, already in the thirties military sidings and military railways were mostly motorised. The operation of steam locomotives in shunting operation was very uneconomical, the firing-up of a locomotive, which took several hours, and the need for constant supervision and keeping the locomotive under steam significantly increased coal consumption. In the operation of steam locomotives there was also no possibility of using one-man service, while restrictive supervision regulations and the necessity of periodic inspections and boiler repairs made it difficult to maintain steam traction.

The operation of steam locomotives in the area of ammunition, explosives and military fuel stations also posed a significant risk of fire and explosion from sparks escaping from a locomotive's ashpan and chimney. Orders realised from the Ministry of Military Affairs budget since the mid-1930s included (with a few exceptions) purchases of locomotives and diesel generators (diesel

843 Ministry of Transport, Central Management of Narrow-gauge Railways, Ksiega inwentarzowa wagonów. . $600 \mathrm{~mm}$. 
locomotives with electric transmission). Since the 1930s, the German army has also been carrying out the modernisation programme of sappers' troops and military railways. From the 1930s until 1945, large numbers of low-power narrow-gauge and standard-gauge shunting locomotives were operated in the Wehrmacht.

In the post-war period, Division IV of Military transport took over a significant number of German low-power internal combustion locomotives located on the territory of the former German military facilities. For these reasons, several dozen internal combustion locomotives were used on military sidings in the post-war period. Most of them were German four-wheeled Köf type internal combustion locomotives, their power output not exceeding $200 \mathrm{HP}$. The machines were of various designs, very many varieties, coming from numerous factories. Repairs of this rolling stock in 1940s and 1950s were concentrated in Rolling Stock Repair Plant Pruszków, where an internal combustion locomotive repair division was established. However, problems with overhauling of largely worn out and unusual locomotives as well as the lack of spare parts ${ }^{844}$ led to their withdrawal from the early 1960 s. ${ }^{845}$

At the beginning of the 1950s, the Polish rolling stock industry started producing low-power diesel locomotives. At that time, the Polish Armed Forces started purchasing modern rolling stock in order to withdraw obsolete locomotive equipment.

In 1952, the Feliks Dzierżyński Locomotive Factory in Chrzanów started the production of the first post-war diesel locomotives type Ls40 (wheel arrangement 0-2-0, power output $40 \mathrm{HP}$ ). It was an adaptation of a pre-war Deutz diesel locomotive built under licensed in the 1930s in Fablok. ${ }^{846}$ A Polish-built diesel engine

844 During periodic repairs of locomotives in Rolling Stock Repair Plant Pruszków one locomotive was often assembled from several vehicles intended for disposal.

845 The lack of technical documents in the archives dating back to the 1940s and 1950s and concerning military rolling stock made it extremely difficult today to establish the technical and evidentiary data of military rolling stock from that period. The author was only able to determine on the basis of the preserved original operating documents the data of the former German military diesel locomotive Lr 398 (with Saurer engine no. 255038), handed over on 18 July 1955 by the Polish State Railways (after repairs in Rolling Stock Repair Plant Pruszków) to the siding of JW 4824 in Stawy.

846 The start of production of Ls40 locomotives was possible thanks to the experience in the construction of diesel locomotives gained in the inter-war period and during the German occupation. Before the war production was carried out in Chrzanów in 
designed in the Central Construction Office of Combustion Engines in Łódź by a team of pre-war engineers of PZInż (State Engineering Works) was used.

In the same year the purchase of these vehicles for the purpose of operating military sidings started, in total, in the years 1952-1955 Division IV of Military transport purchased about 40 machines of this type.$^{847}$ In the years 1952-1961, a total of 581 Ls40 type locomotives were built in the factory in Chrzanów (since 1975 WP-01 series).

In the same year, the purchase of these vehicles for the purpose of operating military sidings started, in total, in the years 1952-1955 Division IV of Military Transport purchased about 40 machines of this type ${ }^{846}$. In the years 1952-1961 a total of 581 Ls40 type locomotives were built in the factory in Chrzanów (since 1975 WP-01 series).

Technical characteristics of the Ls $40^{847}$ type locomotive ${ }^{848}$

\begin{tabular}{|l|l|}
\hline $\begin{array}{l}\text { Year and author of the } \\
\text { documentation }\end{array}$ & $\begin{array}{l}\text { First Locomotive Factory in Poland } \\
\text { Chrzanów 1947. }\end{array}$ \\
\hline Factory: & $\begin{array}{l}\text { Locomotive Factory F. Dzierżyński } \\
\text { Chrzanów }\end{array}$ \\
\hline Track gauge: & $1435 \mathrm{~mm}$ \\
\hline Locomotive type: & $\begin{array}{l}\text { Light shunting work for Polish State } \\
\text { Railways and in industry. }\end{array}$ \\
\hline Weight in an idle state: & $15.8 \mathrm{t}$ \\
\hline Weight in working order: & $16.0 \mathrm{t}$ \\
\hline Gearbox weight: & $500 \mathrm{~kg}$ \\
\hline
\end{tabular}

cooperation with the German plant Humbold-Deutz Motoren AG-Köln. The design of the Ls40 locomotive was based on the pre-war German standard gauge OMZ 122 $40 \mathrm{HP}$ shunting locomotive. In the inter-war period a locomotive of this type was built in Fablok on the basis of German documentation and designated Fablok 8DL type.

847 Inventory materials of military rolling stock of the Headquarters of Military Transport of the Headquarters of the Polish Armed Forces and the Headquarters of Military Transport.

848 Prepared on the basis of: Fablok-Chrzanów, Dokumentacja... Ls 40 and the Ministry of National Defence, Head of Commission 48/67, Instrukcja budowy (1969). 


\begin{tabular}{|l|l|}
\hline $\begin{array}{l}\text { Year and author of the } \\
\text { documentation }\end{array}$ & $\begin{array}{l}\text { First Locomotive Factory in Poland } \\
\text { Chrzanów 1947. }\end{array}$ \\
\hline Axle layout: & B \\
\hline Number of powered axles: & 2 \\
\hline $\begin{array}{l}\text { Wheel diameter (for tyre } \\
\text { thickness: 70 mm) }\end{array}$ & $850 \mathrm{~mm}$ \\
\hline Maximum speed: & $11.35 \mathrm{~km} / \mathrm{h}$ \\
\hline Permanent tractive force: & $2.99 \mathrm{t}$ \\
\hline Speed with permanent tractive force: & $2.83 \mathrm{~km} / \mathrm{h}$ \\
\hline Smallest curve radius: & $80 \mathrm{~m}$ \\
\hline Number of gears: & 4 \\
\hline Brake: & Manual lever \\
\hline Buffer type: & Standard type buffer \\
\hline Type of coupling: & Screw coupling \\
\hline $\begin{array}{l}\text { Maximum tensile force of the } \\
\text { coupling: }\end{array}$ & $850 \mathrm{kN}$ \\
\hline Sander: & Zigniew Tucholski - 978-3-631-82966-0 \\
\hline Lighting: & $\begin{array}{l}\text { Manual operation in both directions } \\
\text { of travel }\end{array}$ \\
\hline Signal: & Electric 12V \\
\hline Axle load: & $\begin{array}{l}\text { Exhaust gas whistle, additional car } \\
\text { horn }\end{array}$ \\
\hline $\begin{array}{l}\text { Load per 1 m of track in working } \\
\text { order: }\end{array}$ & 8000 kg \\
\hline Engine type: & T/m: 2.67 t \\
\hline Engine factory: & $6 \mathrm{E7}$, acidic \\
\hline Battery type: & Mechanical 4-speed \\
\hline Type of gearbox: & $\begin{array}{l}\text { Wytwórnia Silników Wysokoprężnych } \\
\text { Type of gearbox control: }\end{array}$ \\
\hline
\end{tabular}




\begin{tabular}{|l|l|}
\hline Gearbox type: & L-8 22/23 \\
\hline Gearbox factory: & $\begin{array}{l}\text { Locomotive Factory F. Dzierżyński, } \\
\text { Chrzanów }\end{array}$ \\
\hline Type of clutch: & $\begin{array}{l}\text { Dry friction clutch, single-disc, } \\
\text { double-disc or triple-disc clutch }\end{array}$ \\
\hline Fuel tank capacity: & $110 \mathrm{~kg}$ \\
\hline Oil capacity: & $24 \mathrm{~kg}$ \\
\hline Water capacity: & $15 \mathrm{~kg}$ \\
\hline Sand capacity: & $68 \mathrm{~kg}$ \\
\hline $\begin{array}{l}\text { Front overhang (from front axle to } \\
\text { bumper face) }\end{array}$ & $1915 \mathrm{~mm}$ \\
\hline $\begin{array}{l}\text { Rear overhang (from rear axle to rear } \\
\text { bumper face) }\end{array}$ & $1585 \mathrm{~mm}$ \\
\hline Wheelbase: & $2500 \mathrm{~mm}$ \\
\hline Length of locomotive with buffers & $6000 \mathrm{~mm}$ \\
\hline $\begin{array}{l}\text { Height from the head of the rail to the } \\
\text { top edge of the driver's cab: }\end{array}$ & $3010 \mathrm{~mm}$ \\
\hline Height from rail head to bumper axis: & $1055 \mathrm{~mm}$ \\
\hline Maximum width: & $2420 \mathrm{~mm}$ \\
\hline
\end{tabular}

List of military Ls40 type locomotives / WP-01849

\begin{tabular}{|l|l|l|l|}
\hline $\begin{array}{l}\text { Polish Armed } \\
\text { Forces No. }\end{array}$ & $\begin{array}{l}\text { Series, factory } \\
\text { No., type, year of } \\
\text { production }\end{array}$ & Conduct of service & Remarks \\
\hline WP-01-400-01 & Ls40-? Chrzanów? & $?$ & \\
\hline
\end{tabular}

849 Prepared on the basis of military fleet inventory materials of the Headquarters of the Military Transport Service of the Polish Armed Forces Headquarters, Headquarters of Military Transport and documentation of individual military locomotives. 


\begin{tabular}{|c|c|c|c|}
\hline $\begin{array}{l}\text { Polish Armed } \\
\text { Forces No. }\end{array}$ & $\begin{array}{l}\text { Series, factory } \\
\text { No., type, year of } \\
\text { production }\end{array}$ & Conduct of service & Remarks \\
\hline WP-01-400-02 & Ls40-? Chrzanów? & $?$ & \\
\hline WP-01-400-03 & Ls40-? Chrzanów? & $?$ & \\
\hline WP-01-400-04 & $\begin{array}{l}\text { Ls40 - Chrzanów } \\
4207 / 52 \\
\end{array}$ & $\begin{array}{l}\text { 14.02.74 -> } \\
\text { JW } 1861 \text { Bezwola } \\
\end{array}$ & \begin{tabular}{|l|} 
incomplete \\
+9.12 .96 \\
\end{tabular} \\
\hline WP-01-400-05 & $\begin{array}{l}\text { Ls40-? } \\
\text { Chrzanów?/52 }\end{array}$ & JW 2199 Ostrów Maz. & \begin{tabular}{|l|} 
incomplete \\
+ \\
21.10 .1986 \\
\end{tabular} \\
\hline $\begin{array}{l}\text { WP-01-400-06 ex } \\
\text { Ls40-3100 }\end{array}$ & $\begin{array}{l}\text { Ls40 - Chrzanów } \\
3100 / 52\end{array}$ & $\begin{array}{l}\text { JW } 4824 \text { Stawy } \\
(1957) \text {->JW } \\
\text { 1523 Inowrocław, } \\
\text { Bydgoszcz/ POW }\end{array}$ & $\begin{array}{l}\text { incomplete } \\
+ \\
23.04 .1991\end{array}$ \\
\hline WP-01-400-07 & Ls40-? Chrzanów? & $?$ & \\
\hline WP-01-400-08 & Ls40-? Chrzanów? & $?$ & \\
\hline WP-01-400-09 & $\begin{array}{l}\text { Ls40-364 Chrzanów } \\
3632 / 57\end{array}$ & $\begin{array}{l}\text { UM } 2009 \text { Olsztyn } \\
02.12 .91->\text { SPW } \\
\text { Warszawa }\end{array}$ & $\begin{array}{l}\text { JW } 2009 \\
\text { incomplete } \\
+23.05 .91 \\
\end{array}$ \\
\hline WP-01-400-10 & $\begin{array}{l}\text { Ls40-? Chrzanów } \\
\text { 4061/? }\end{array}$ & JW 3303 Przewóz & $\begin{array}{l}\text { defective, } \\
\text { serial } \\
\text { number } \\
\text { matched }\end{array}$ \\
\hline $\begin{array}{l}\text { WP-01-400-11 ex } \\
\text { Ls40-4105 }\end{array}$ & $\begin{array}{l}\text { Ls40-102 Chrzanów } \\
4105 / 54\end{array}$ & $\begin{array}{l}\text { JW } 2430 \text { Szeroki Bór } \\
(31.04 .87) \text {-> } \\
\text { JW 1391 Celestynów }\end{array}$ & \\
\hline WP-01-400-12 & Ls40-? Chrzanów? & $?$ & \\
\hline WP-01-400-13 & Ls40- Chrzanów?/55 & JW 2451 Wrocław & \\
\hline WP-01-400-14 & Ls40-? Chrzanów? & $?$ & \\
\hline WP-01-400-15 & Ls40-? Chrzanów? & $\begin{array}{l}\text { 14/11/1979 -> } \\
\text { JW 1391 Celestynów }\end{array}$ & $\begin{array}{l}\text { incomplete } \\
+ \\
20.10 .1988 \\
\end{array}$ \\
\hline
\end{tabular}




\begin{tabular}{|c|c|c|c|}
\hline $\begin{array}{l}\text { Polish Armed } \\
\text { Forces No. }\end{array}$ & $\begin{array}{l}\text { Series, factory } \\
\text { No., type, year of } \\
\text { production }\end{array}$ & Conduct of service & Remarks \\
\hline WP-01-400-16 & Ls40-? Chrzanów? & $?$ & \\
\hline WP-01-400-17 & $\begin{array}{l}\text { Ls40-242 } \\
\text { Chrzanów 4557/56 }\end{array}$ & JW 3303 Przewóz & \\
\hline WP-01-400-18 & $\begin{array}{l}\text { Ls40-243 } \\
\text { Chrzanów 4558/56 }\end{array}$ & JW 1035 Przemyśl & $\begin{array}{l}\text { incomplete } \\
+ \\
18.06 .1985 \\
\end{array}$ \\
\hline WP-01-400-19 & $\begin{array}{l}\text { Ls40-244 } \\
\text { Chrzanów 4559/56 }\end{array}$ & $\begin{array}{l}\text { SPW Wrocław } 1962 \\
\text {->JW Przemyśl, } 1969 \\
\text { JW } 3748 \text { Nurzec } \\
\end{array}$ & $\begin{array}{l}\text { incomplete } \\
+ \\
24.08 .1994 \\
\end{array}$ \\
\hline WP-01-400-20 & $\begin{array}{l}\text { Ls40-247 } \\
\text { Chrzanów 4562/56 }\end{array}$ & $\begin{array}{l}\text { KPW Gdynia Gdańsk/ } \\
\text { MW }\end{array}$ & \\
\hline WP-01-400-21 & $\begin{array}{l}\text { Ls40-? } \\
\text { Chrzanów?/56 }\end{array}$ & $\begin{array}{l}\text { JW } 1590 \text { Białystok } \\
->\text { transferred free of } \\
\text { charge to the National } \\
\text { Economy }\end{array}$ & \\
\hline WP-01-400-22 & $\begin{array}{l}\text { Ls40-275 } \\
\text { Chrzanów 4590/56 }\end{array}$ & $\begin{array}{l}\text { JW } 2033 \text { Niedźwiedź } \\
16.02 .82 \text {-> JW } 2186 \\
\text { Hajnówka } 2005 \text {-> } \\
\text { Sokołów Podlaski } \\
\text { scrapyard }\end{array}$ & incomplete \\
\hline WP-01-400-23 & $\begin{array}{l}\text { Ls40-276 } \\
\text { Chrzanów 4591/56 }\end{array}$ & $\begin{array}{l}\text { KPW Gdynia } 1978 \text {-> } \\
\text { JW } 2186 \text { Hajnówka } \\
\text {-> Polish Armed } \\
\text { Forces Workshops } \\
\text { and Storehouse of } \\
\text { the Accommodation } \\
\text { and Construction } \\
\text { Service of the } \\
\text { Warsaw Garrison, ul. } \\
\text { Nieświeska 56, Warsaw }\end{array}$ & sold \\
\hline
\end{tabular}




\begin{tabular}{|c|c|c|c|}
\hline $\begin{array}{l}\text { Polish Armed } \\
\text { Forces No. }\end{array}$ & $\begin{array}{l}\text { Series, factory } \\
\text { No., type, year of } \\
\text { production }\end{array}$ & Conduct of service & Remarks \\
\hline WP-01-400-24 & $\begin{array}{l}\text { Ls40-? } \\
\text { Chrzanów?/56 } \\
\end{array}$ & $?$ & \\
\hline WP-01-400-25 & $\begin{array}{l}\text { Ls40-? } \\
\text { Chrzanów?/56 }\end{array}$ & $\begin{array}{l}\text { JW } 2549 \text { Gorzów } \\
\text { Wlkp. }\end{array}$ & \\
\hline WP-01-400-26 & $\begin{array}{l}\text { Ls40-? } \\
\text { Chrzanów?/56 }\end{array}$ & $?$ & \\
\hline WP-01-400-27 & $\begin{array}{l}\text { Ls40-297 } \\
\text { Chrzanów 4612/56 }\end{array}$ & $\begin{array}{l}\text { JW } 1367 \text { Nisko -> } \\
\text { "Nimet” Nisko }\end{array}$ & \\
\hline WP-01-400-28 & $\begin{array}{l}\text { Ls40-? } \\
\text { Chrzanów?/56 } \\
\end{array}$ & JW 1861 Bezwola & $\begin{array}{l}\text { incomplete } \\
+1980 ?\end{array}$ \\
\hline WP-01-400-29 & Ls40-? Chrzanów? & JW 1737 Debrzno & \\
\hline WP-01-400-30 & Ls40- Chrzanów?/60 & $\begin{array}{l}\text { JW } 1653 \text { 08.08.68 -> } \\
\text { JW } 2685 \text { Grudziądz, } \\
\text { Gdańsk/ POW }\end{array}$ & $\begin{array}{l}\text { incomplete } \\
+ \\
28.11 .1990 \\
\end{array}$ \\
\hline WP-01-400-31 & Ls40-? Chrzanów? & $?$ & \\
\hline WP-01-400-32 & $\begin{array}{l}\text { Ls40-541 } \\
\text { Chrzanów 5229/60 }\end{array}$ & $\begin{array}{l}1960 \text { SPW Wrocław -> } \\
\text { (1 SKK) JW } 1191 \\
\text { Darłowo 30.08.90 -> } \\
\text { KPW Hel, Gdańsk/ } \\
\text { MW }\end{array}$ & $\begin{array}{l}\text { (SPW } \\
\text { Wrocław, } \\
\text { spare } \\
\text { locomotive) }\end{array}$ \\
\hline WP-01-400-33 & Ls40-? Chrzanów? & $?$ & \\
\hline WP-01-400-34 & Ls40- Chrzanów?/59 & $\begin{array}{l}\text { 16.05.84 -> JW } 1073 \\
\text { Toruń, Gdańsk/ } \\
\text { DWOPK }\end{array}$ & $\begin{array}{l}\text { incomplete } \\
+ \\
08.02 .1991 \\
\end{array}$ \\
\hline WP-01-400-35 & $\begin{array}{l}\text { Ls40-484 } \\
\text { Chrzanów 5297/59 }\end{array}$ & $\begin{array}{l}\text { JW } 3189 \text { 1979? -> } \\
\text { JW } 2428 \text { Siemirowice } \\
\text { Gdańsk/ Navy }\end{array}$ & $\begin{array}{l}\text { incomplete } \\
+ \\
08.10 .1993 \\
\end{array}$ \\
\hline
\end{tabular}




\begin{tabular}{|l|l|l|l|}
\hline $\begin{array}{l}\text { Polish Armed } \\
\text { Forces No. }\end{array}$ & $\begin{array}{l}\text { Series, factory } \\
\text { No., type, year of } \\
\text { production }\end{array}$ & Conduct of service & Remarks \\
\hline WP-01-400-36 & $\begin{array}{l}\text { Ls40-205 } \\
\text { Chrzanów 4520/55 }\end{array}$ & $\begin{array}{l}\text { 27.12.55 JW 2558 } \\
\text { Gliwice 10.03.77 -> } \\
\text { CWWRSK Płock -> } \\
\text { JW 1367 Nisko -> } \\
\text { Wood Processing } \\
\text { Plant Nisko }\end{array}$ & transferred \\
\hline
\end{tabular}

Ls40 type locomotives not included in the above list, according to factory numbers ${ }^{850}$

\begin{tabular}{|l|l|l|}
\hline $\begin{array}{l}\text { Type and } \\
\text { number }\end{array}$ & $\begin{array}{l}\text { Series, factory No., type, } \\
\text { year of production }\end{array}$ & Conduct of service \\
\hline Ls40-13 & Chrzanów 3085/52 & Military Armament Works Grudziądz \\
\hline Ls40-101 & Chrzanów 4104/54 & $\begin{array}{l}\text { Gdynia Navy Shipyard ex the PKP } \\
\text { Lo106 }\end{array}$ \\
\hline Ls40-108 & Chrzanów 4111/5433 & $\begin{array}{l}\text { Warehouse of the Polish Armed } \\
\text { Forces No. 19 Pruszków -> PMU } \\
\text { Pruszków }\end{array}$ \\
\hline Ls40-193 & Chrzanów 4196/55 & $\begin{array}{l}\text { JW 4149 Przemyśl -> JW 2451 } \\
\text { Wrocław }\end{array}$ \\
\hline Ls40-221 & Chrzanów 4536/56 & SPW Gdańsk \\
\hline Ls40-240 & Chrzanów 4555/56 & JW 1336 Wrocław Swojczyce \\
\hline Ls40-278 & Chrzanów 4593/56 & $\begin{array}{l}\text { JW 1951 Krzystkowice (ex JW } \\
\text { Przemyśl? -> POW) }\end{array}$ \\
\hline Ls40-279 & Chrzanów 4594/56 & SPW Szczecin \\
\hline
\end{tabular}

850 Based on the register of periodic repairs of Ls40 locomotives in Rolling Stock Repair Plant Wrocław. 


\begin{tabular}{|l|l|l|}
\hline $\begin{array}{l}\text { Type and } \\
\text { number }\end{array}$ & $\begin{array}{l}\text { Series, factory No., type, } \\
\text { year of production }\end{array}$ & Conduct of service \\
\hline Ls40-309 & Chrzanów 3578/57 & SPW Poznań \\
\hline Ls40-425 & Chrzanów 5184/? & $\begin{array}{l}\text { Military Automotive Works no. } 5 \\
\text { Poznań }\end{array}$ \\
\hline Ls40-441 & Chrzanów 5200/? & $\begin{array}{l}\text { Gdynia Naval Shipyard “Obrońców } \\
\text { Westerplatte” }\end{array}$ \\
\hline Ls40-461 & Chrzanów 5064/? & SPW? \\
\hline${ }^{33}$ Attention! The locomotive did not receive a new military number. \\
\hline
\end{tabular}

At the beginning of 1960s the army also purchased individual vehicles of new rolling stock built in Fablok in Chrzanów. In 1960 a Ls60 $0^{850}$ type locomotive was purchased $^{851}$ (since 1975 series WP-02) and 2Ls75-09 (Chrzanów 5087/60) ${ }^{852}$ (since 1975 series WP-03), this machine worked in JW 4824 Stawy and then in JW 2451 Wrocław Popowice, in 4th-Divisional Equipment Storehouse.

In the years 1953-1960, for the operation of military $600 \mathrm{~mm}$ narrow-gauge railways, a dozen or so narrow-gauge diesel locomotives were purchased from Rolling Stock Repair Plant Poznań, type WLs40 ${ }^{853}$ (since 1975, series WP-11).

The next purchase of Ls150 type shunting locomotives (axle layout 0-2-0, power $150 \mathrm{HP}$ ) (from 1975 WP-05 series) from Fablok and Zastal in Zielona Góra took place in the years 1959-1969, 26 locomotives of this type were purchased then to operate military sidings.

Technical data of Ls150 type locomotive manufactured by Fablok ${ }^{854}$

\begin{tabular}{|l|l|}
\hline Year of construction & $\mathbf{1 9 5 8}$ \\
Designer & Factory Design Office Fablok-Chrzanów \\
\hline Year of prototype construction: & 1959 \\
\hline
\end{tabular}

851 Ls60 type vehicles were a development of a n Ls40 locomotive.

852 The construction of the 2Ls75 locomotive (powered by S-324Hl 75 HP engine) was a predecessor of Ls150 type vehicles.

853 The exact number of locomotives is not known due to the lack of a complete factory list of locomotives manufactured by Rolling Stock Repair Plant Poznań.

854 Based on: Fablok-Chrzanów, Dokumentacja... Ls 150 and the Ministry of National Defence, Head of commission 40/66, Instrukcja budowy i eksploatacji lokomotywy 


\begin{tabular}{|l|l|}
\hline Manufacturer & Fablok since 1965 Zastal \\
\hline Type & Ls150 \\
\hline Axle layout: & B (0-2-0) \\
\hline Purpose & Light shunting work \\
\hline Track gauge & $1435 \mathrm{~mm}$, special versions - 1524 mm \\
\hline Weight in an idle state: & $23.2 \mathrm{t}$ \\
\hline Weight in working order: & $24.0 \mathrm{t}$ \\
\hline Axle load & $12 \mathrm{t}$ \\
\hline Wheelbase: & $2500 \mathrm{~mm}$ \\
\hline Diameter of drive wheels & $950 \mathrm{~mm}$ \\
\hline Length of locomotive & $6940 \mathrm{~mm}$ \\
\hline Width & $2970 \mathrm{~mm}$ \\
\hline Height & $3210 \mathrm{~mm}$ \\
\hline Smallest curve radius & $50 \mathrm{~m}$ \\
\hline Number of gears & 4 \\
\hline Speed on individual gears & 5,$73 ; 9,42 ; 15,69 ; 25,68 \mathrm{~km} / \mathrm{h}$ \\
\hline $\begin{array}{l}\text { Maximum speed on horizontal } \\
\text { track }\end{array}$ & $25.68 \mathrm{~km} / \mathrm{h}$ \\
\hline $\begin{array}{l}\text { Highest tractive effort on a } \\
\text { straight horizontal track }\end{array}$ & 630 \\
\hline $\begin{array}{l}\text { Maximum tractive effort at } \\
\text { V=5.73 km/h }\end{array}$ & 5043 \\
\hline Air brake & Self-acting and secondary \\
\hline Driver's valve for self-acting brake & Knorr system \\
\hline Driver's valve for secondary brake & Knorr system \\
\hline
\end{tabular}

spalinowej Ls 150 (SM03) (Instructions for the construction and operation of a diesel locomotive Ls150 (SM03)), Warsaw 1967. 


\begin{tabular}{|l|l|}
\hline Hand brake & screw \\
\hline Type of coupling & Standard, screw coupling \\
\hline Coupling strength & $850 \mathrm{kN}$ (85000 kG) \\
\hline Suspension: & single leaf springs \\
\hline Sander & air, operating in both directions of travel \\
\hline Lighting: & electric \\
\hline Sound signal & air whistle or siren \\
\hline Driver's cab heating & water from the internal combustion engine \\
cooling system
\end{tabular}




\begin{tabular}{|l|l|}
\hline Gearbox \\
\hline Gearbox type and factory & 1P154, Fablok-Chrzanów \\
\hline
\end{tabular}

\begin{tabular}{|l|l|}
\hline Type of gearbox & $\begin{array}{l}\text { mechanical 4-speed, with continuously } \\
\text { intermeshed gears }\end{array}$ \\
\hline Control system & hydraulic-mechanical \\
\hline Transmissible power & $150 \mathrm{KM}$ \\
\hline Compressor & \\
\hline Type & S2P-75/100 \\
\hline Capacity with a $+/-10 \%$ tolerance & $750 \mathrm{l} / \mathrm{min}$ \\
\hline Maximum torque $-3 \%$ & $1000 \mathrm{rpm}$ \\
\hline Lowest rpm speed & $300 \mathrm{rpm}$ \\
\hline Normal compression pressure & 8 atm. \\
\hline $\begin{array}{l}\text { Highest compression pressure in } \\
\text { intermittent operation }\end{array}$ & 9 atm. \\
\hline Number of I/II degree cylinders & $2 / 1$ \\
\hline Diameter of I/II degree cylinders & $92 / 85 \mathrm{~mm}$ \\
\hline Piston stroke & $70 \mathrm{~mm}$ \\
\hline $\begin{array}{l}\text { Weight of compressor without } \\
\text { pulley }\end{array}$ & $105 \mathrm{~kg}$ \\
\hline Overall dimensions & approx. $500 \mathrm{X} 530 \mathrm{X} 760 \mathrm{~mm}$ \\
\hline $\begin{array}{l}\text { Two driver's pulpits, engine tachometer, distance thermometers for measuring } \\
\text { the temperature of water and oil in the engine, oil pressure gauge in the } \\
\text { engine, oil pressure gauge in the gearbox, oil pressure gauge in the hydraulic } \\
\text { control system, generator volt-amperometer, set of servicing tools, spare parts; }\end{array}$ \\
\hline
\end{tabular}


Inventory of military Ls150 type locomotives, WP-05 series $^{855}$

\begin{tabular}{|c|c|c|c|}
\hline $\begin{array}{l}\text { Polish Armed } \\
\text { Forces No. }\end{array}$ & $\begin{array}{l}\text { Series, factory } \\
\text { No., type, year of } \\
\text { production }\end{array}$ & Conduct of service & Remarks \\
\hline WP-05-400-51 & $\begin{array}{l}\text { Ls150-305 Chrzanów } \\
5075 / 59\end{array}$ & $\begin{array}{l}\text { JW? Wroclaw } \\
\text { (ex JW 1441 } \\
\text { Strzałkowo) } \\
\end{array}$ & $\begin{array}{l}\text { serial number } \\
\text { matched }\end{array}$ \\
\hline WP-05-400-52 & $\begin{array}{l}\text { Ls150-342 Chrzanów } \\
5613 / 59\end{array}$ & $\begin{array}{l}\text { JW? Wałcz (KDT, JW } \\
3646 \text { Mosty) }\end{array}$ & \\
\hline WP-05-400-53 & $\begin{array}{l}\text { Ls150-307 Chrzanów } \\
5078 / 59\end{array}$ & $\begin{array}{l}\text { (1962) JW } 4824 \text { Stawy } \\
\text {-> JW 1039 Przemyśl } \\
\text { 12.03.87 in JW } 4145 \\
\text { Przemyśl }\end{array}$ & $\begin{array}{l}\text { incomplete } \\
+12.01 .95, \\
\text { serial number } \\
\text { matched }\end{array}$ \\
\hline WP-05-400-54 & $\begin{array}{l}\text { Ls150-334 Chrzanów } \\
5605 / 60\end{array}$ & $\begin{array}{l}\text { 1971? -> JW } \\
3033 \text { Bydgoszcz, } \\
\text { Bydgoszcz/ DWL } \\
\end{array}$ & $\begin{array}{l}\text { JW } 3117 \\
\text { Bydgoszcz } \\
\text { Airport } \\
\end{array}$ \\
\hline WP-05-400-55 & $\begin{array}{l}\text { Ls150-334 Chrzanów } \\
5606 / 60\end{array}$ & $\begin{array}{l}\text { 1962 JW 4824 Stawy } \\
23.04 .87 \text {-> JW } 1590 \\
\text { Białystok }\end{array}$ & $\begin{array}{l}\text { serial number } \\
\text { matched }\end{array}$ \\
\hline WP-05-400-56 & $\begin{array}{l}\text { Ls150-341 Chrzanów } \\
5612 / 61\end{array}$ & $\begin{array}{l}\text { 4.11.72? JW } 2946 \\
\text { Bydgoszcz Osowa } \\
\text { Góra Bydgoszcz/OP } \\
\text { 03.04.92. ->? }\end{array}$ & $\begin{array}{l}\text { JW } 3033 \\
\text { Bydgoszcz }\end{array}$ \\
\hline WP-05-400-57 & $\begin{array}{l}\text { Ls150-343 Chrzanów } \\
5614 / 61\end{array}$ & $\begin{array}{l}1961 \text { JW } 4824 \text { Stawy } \\
\text { near Dęblin }\end{array}$ & \\
\hline WP-05-400-58 & $\begin{array}{l}\text { Ls150- } \\
\text { Chrzanów?/61 }\end{array}$ & JW 4388 Debrzno & \\
\hline
\end{tabular}

855 Prepared on the basis of military fleet inventory materials of the Headquarters of Military Transport of the Polish Armed Forces Headquarters, Headquarters of Military Transport and documentation of individual military locomotives. 


\begin{tabular}{|c|c|c|c|}
\hline $\begin{array}{l}\text { Polish Armed } \\
\text { Forces No. }\end{array}$ & $\begin{array}{l}\text { Series, factory } \\
\text { No., type, year of } \\
\text { production }\end{array}$ & Conduct of service & Remarks \\
\hline WP-05-400-59 & $\begin{array}{l}\text { Ls150-348 Chrzanów } \\
5619 / 61\end{array}$ & \begin{tabular}{|l} 
1.10.61 JW 1861 \\
Bezwola 7.01 .97 r. -> \\
KOW
\end{tabular} & $\begin{array}{l}\text { serial number } \\
\text { matched }\end{array}$ \\
\hline WP-05-400-60 & $\begin{array}{l}\text { Ls150-? } \\
\text { Chrzanów?/61 }\end{array}$ & $\begin{array}{l}23.10 .87 \text {-> JW } 1073 \\
\text { Toruń, Gdańsk/ } \\
\text { DWOPK }\end{array}$ & $\begin{array}{l}\text { incomplete }+ \\
16.02 .1993\end{array}$ \\
\hline WP-05-400-61 & $\begin{array}{l}\text { Ls150-369 Chrzanów } \\
5761 / 61\end{array}$ & $\begin{array}{l}\text { 28.06.61 JW } 2033 \\
\text { Niedźwiedź -> JW } \\
\text { 1282 Jastrzębie Śląskie }\end{array}$ & \\
\hline WP-05-400-62 & $\begin{array}{l}\text { Ls150-368 Chrzanów } \\
5760 / 61\end{array}$ & $\begin{array}{l}\text { 28.06.61 JW } 2033 \\
\text { Niedźwiedź -> } 30 \\
\text { Warehouse } 15.22 .84 \\
\text {-> JW 1590 Białystok } \\
\text { 26.08.88 -> JW } 3748 \\
\text { Nurzec }\end{array}$ & \\
\hline WP-05-400-63 & $\begin{array}{l}\text { Ls150-412 Chrzanów } \\
6101 / 62\end{array}$ & $\begin{array}{l}11.08 .79 \text {-> JW } 2430 \\
\text { Szeroki Bór }\end{array}$ & \\
\hline WP-05-400-64 & $\begin{array}{l}\text { Ls150-? Chrzanów } \\
6105 / 62\end{array}$ & $\begin{array}{l}\text { 22.01.63 JW } 1530 \\
\text { Regny 2.02.89 -> } \\
\text { Kombinat Budowlany } \\
\text { Piotrków Tryb. } \\
\end{array}$ & sold \\
\hline WP-05-400-65 & $\begin{array}{l}\text { Ls150-420 Chrzanów } \\
6109 / 62\end{array}$ & JW 3748 Nurzec & $\begin{array}{l}\text { incomplete }+ \\
30.11 .1988\end{array}$ \\
\hline WP-05-400-66 & $\begin{array}{l}\text { Ls150-? } \\
\text { Chrzanów?/62 }\end{array}$ & $\begin{array}{l}\text { KPW Hel } 12.07 .90 \text {-> } \\
\text { JW } 5576 \text { Siemirowice }\end{array}$ & \begin{tabular}{|l} 
another \\
list: Ls160 \\
Chrzanów \\
1970 \\
\end{tabular} \\
\hline WP-05-400-67 & \begin{tabular}{|l} 
Ls150-489 Chrzanów \\
$6371 / 63$
\end{tabular} & JW 1124 Osowiec & \\
\hline
\end{tabular}




\begin{tabular}{|c|c|c|c|}
\hline $\begin{array}{l}\text { Polish Armed } \\
\text { Forces No. }\end{array}$ & $\begin{array}{l}\text { Series, factory } \\
\text { No., type, year of } \\
\text { production }\end{array}$ & Conduct of service & Remarks \\
\hline WP-05-400-68 & $\begin{array}{l}\text { Ls150-490 Chrzanów } \\
6372 / 63\end{array}$ & $\begin{array}{l}\text { 1964 JW } 4149 \\
\text { Przemyśl Bakończyce } \\
\text { 18.04.67 -> JW } 1530 \\
\text { Regny, Łódź/ POW }\end{array}$ & $\begin{array}{l}\text { scrapped }+ \\
16.09 .93 \text { (cut } \\
\text { up at JW } \\
1530)\end{array}$ \\
\hline WP-05-400-69 & $\begin{array}{l}\text { Ls150-491 Chrzanów } \\
6373 / 63\end{array}$ & $\begin{array}{l}\text { 1964 JW } 2760 \text { Dęblin } \\
\text {-> JW } 1136 \text { Warszawa } \\
\text { (ul. Powązkowska) -> } \\
\text { JW } 1590 \text { Białystok } \\
\text { (JW } 3748 \text { Nurzec) is } \\
\text { in Białystok 1997. } \\
\text { (JW } 1590 \text { Białystok) }\end{array}$ & $\begin{array}{l}\text { incomplete + } \\
23 / 03 / 1988\end{array}$ \\
\hline WP-05-400-70 & $\begin{array}{l}\text { Ls150-563 Chrzanów } \\
6845 / 65\end{array}$ & $\begin{array}{l}\text { JW } 1367 \text { Nisko -> JW } \\
1382 \text { Jawidz }\end{array}$ & $\begin{array}{l}\text { serial number } \\
\text { matched }\end{array}$ \\
\hline WP-05-400-71 & $\begin{array}{l}\text { Ls150-621 Chrzanów } \\
\text { 7162/66 }\end{array}$ & $\begin{array}{l}\text { JW } 4149 \text { 1977? -> JW } \\
\text { 2009 Olsztyn 02.12.91 } \\
\text {-> SPW Warszawa }\end{array}$ & \\
\hline WP-05-400-72 & $\begin{array}{l}\text { Ls150-119 Zastal } \\
119 / 67\end{array}$ & $\begin{array}{l}\text { JW } 1031 \text { Sochaczew, } \\
\text { (Bielice airport) }\end{array}$ & $\begin{array}{l}\text { serial number } \\
\text { matched }\end{array}$ \\
\hline WP-05-400-73 & $\begin{array}{l}\text { Ls150-120 Zastal } \\
120 / 68\end{array}$ & $\begin{array}{l}\text { Zl. DWOPK 4/69 } \\
\text { JW 1656 Gardeja, } \\
\text { Gdańsk/ DWOPK }\end{array}$ & \\
\hline WP-05-400-74 & $\begin{array}{l}\text { Ls150-121 Zastal } \\
121 / 68\end{array}$ & $\begin{array}{l}1969 \text { JW } 1391 \\
\text { Celestynów (operated } \\
\text { in JW } 3425 \text { Życzyn) }\end{array}$ & $\begin{array}{l}\text { Celestynów } \\
\text { since } 22.10 .75\end{array}$ \\
\hline WP-05-400-75 & $\begin{array}{l}\text { Ls150-? } \\
\text { Chrzanów?/69 }\end{array}$ & JW 2599 Kraśnik & $\begin{array}{l}\text { (Operated } \\
\text { in JW } 1391 \\
\text { Celestynów) } \\
\end{array}$ \\
\hline WP-05-400-76 & $\begin{array}{l}\text { Ls150-167 Zastal } \\
167 / 69\end{array}$ & $\begin{array}{l}\text { Zastal } 27.06 .69 \text {-> } \\
\text { JW } 1547 \text { Gałkówek } \\
\text {-> Spirits Factory } \\
\text { "Polmos" Żyrardów }\end{array}$ & sold \\
\hline
\end{tabular}


In 1959, a diesel shunting locomotive type V-10-B (100 HP, series and number WP-04-40354) ${ }^{856}$ was imported from East Germany from the Babelsberg factory for operating in JW 2515 Kłaj.

In the years 1959-1970, 7 diesel locomotives with electric transmission of Ls300 type (power: $300 \mathrm{HP})^{857}$ were purchased from Fablok factory in Chrzanów. It was the most powerful class of military diesel locomotives ${ }^{858}$ in 1975 it was renumbered WP-07 series. In total, in the years 1957-1970, 909 locomotives of this type were built in Fablok for the Polish State Railways, the industry and the Polish Armed Forces.

Technical data of Ls300 type locomotive manufactured by Fablok ${ }^{859}$

\begin{tabular}{|l|l|}
\hline Year of construction & $\mathbf{1 9 5 6}$ \\
\hline Designed & $\begin{array}{l}\text { OBRPS Poznań/Factory Design Office } \\
\text { Fablok-Chrzanów }\end{array}$ \\
\hline Year of prototype construction: & 1957 \\
\hline Manufacturer & Fablok Chrzanów \\
\hline Type & Ls300 \\
\hline Polish State Railways class & SM30 \\
\hline Axle layout: & Bo'Bo' \\
\hline Purpose & Light shunting work \\
\hline Track gauge & 1435 mm \\
\hline Weight in an idle state: & $34.8 \mathrm{t}$ \\
\hline
\end{tabular}

856 Prepared on the basis: Ksiega ewidencyjna.

857 Prepared on the basis of military fleet inventory materials of the Headquarters of Military Transport of the Polish Armed Forces Headquarters, Headquarters of Military Transport and documentation of individual military locomotives.

858 The most powerful diesel locomotive $(600 \mathrm{HP})$ operated by the Polish Armed Forces was the Hungarian diesel locomotive SM41-1325 (Ganz Mavag No. 1325/68) purchased by the Polish Armed Forces from CPN Łódź and operated on the siding of JW 2915 Dolaszewo, it was scrapped around 2004.

859 Technical characteristics based on: Walbiner (1966) and Fablok-Chrzanów Charakterystyka... Ls300. 


\begin{tabular}{|c|c|}
\hline Year of construction & 1956 \\
\hline Weight in working order: & $36 \mathrm{t}$ \\
\hline Load on $1 \mathrm{~m}$ of track & $3.6 \mathrm{t}$ \\
\hline Spacing of bogie pivots & $4660 \mathrm{~mm}$ \\
\hline Wheel diameter & $850 \mathrm{~mm}$ \\
\hline $\begin{array}{l}\text { Total length of locomotive with } \\
\text { buffers }\end{array}$ & $10140 \mathrm{~mm}$ \\
\hline Maximum width of locomotive & $3130 \mathrm{~mm}$ \\
\hline $\begin{array}{l}\text { Maximum height from the head of } \\
\text { the rail }\end{array}$ & $4300 \mathrm{~mm}$ \\
\hline Main generator & $\begin{array}{l}\text { DC, at } 600 \mathrm{~V}, 367 \mathrm{~A}, 220 \mathrm{~kW} \text { of } \\
\text { continuous power, at } 1500 \mathrm{rpm} \text {, type } \\
\text { PABOM 186a spec }\end{array}$ \\
\hline Auxiliary generator & $\mathrm{DC}, 48 \mathrm{~V}$, power $4.5 \mathrm{~kW}$ \\
\hline Traction motors & $\begin{array}{l}\text { DC, serial, for } 600 / 113 \mathrm{~A} \text {, hourly } \\
\text { output } 60 \mathrm{~kW} \text {, at } 860 \mathrm{rpm} \text {, type } \\
\text { LT-31 or Lka-310 with magnetic field } \\
\text { attenuation hook up to } 40 \text { or } 60 \%\end{array}$ \\
\hline Battery pack & acidic, $300 \mathrm{Ah} / 48 \mathrm{~V}$ \\
\hline Gear ratio & $72 / 13 \sim 5,54$ \\
\hline Compressor & $\begin{array}{l}\text { VV/100/100 two-stage two-cylinder } \\
\text { Knorr's (capacity } 7001 / \mathrm{min} \text { ) or type } \\
\text { S2P-11534 (capacity } 1.7 \mathrm{~m} 3 / \mathrm{min} \text { ) }\end{array}$ \\
\hline Brake & $\begin{array}{l}\text { Self-acting and secondary Knorr type } \\
\text { brake, hand brake }\end{array}$ \\
\hline Driver's valve for self-acting brake & Knorr system \\
\hline Driver's valve secondary brake & Knorr system \\
\hline Hand brake & screw \\
\hline Type of coupling & Standard, screw coupling \\
\hline Coupling strength & $850 \mathrm{kN}(85000 \mathrm{kG})$ \\
\hline
\end{tabular}




\begin{tabular}{|l|l|}
\hline Year of construction & $\mathbf{1 9 5 6}$ \\
\hline Sander & $\begin{array}{l}\text { air, operating in both directions of } \\
\text { travel }\end{array}$ \\
\hline Lighting: & electric \\
\hline Sound signal & air horn \\
\hline Speedometer & non-registering \\
\hline Maximum speed & $60 \mathrm{~km} / \mathrm{h}$ \\
\hline Continuous speed & $28.7 \mathrm{~km} / \mathrm{h}$ \\
\hline $\begin{array}{l}\text { Highest momentary tractive effort } \\
\text { at wheel tyre, serial connection of } \\
\text { traction motors, speed } 5 \mathrm{~km} / \mathrm{h}\end{array}$ & $7500 \mathrm{KG}$ \\
\hline $\begin{array}{l}\text { Hourly tractive effort at wheel tyre, } \\
\text { serial connection of traction motors, } \\
\text { speed } 14 \text { km/h }\end{array}$ & $3250 \mathrm{KG}$ \\
\hline $\begin{array}{l}\text { Tractive effort at wheel tyre, speed } \\
\text { 28.7 km/h }\end{array}$ & $2050 \mathrm{KG}$ \\
\hline $\begin{array}{l}\text { Highest tractive effort on a straight } \\
\text { horizontal track }\end{array}$ & $1010 \mathrm{t}$ \\
\hline Suspension & "Wola" 3DSVRa-300 or 350 diesel \\
\hline Connection to bogie & V-engine \\
\hline Diameter and length of axle pivot & $130 \mathrm{~mm}$ X 217 mm \\
\hline Smallest radius of curve & $80 \mathrm{~m}$ \\
\hline Fuel capacity & $1000 \mathrm{~kg}$ \\
\hline Water capacity & $60 \mathrm{~kg}$ \\
\hline Oil capacity & $120 \mathrm{~kg}$ \\
\hline Stock of sand & $360 \mathrm{~kg}$ \\
\hline Engine & pivots with side slides \\
\hline Type & \\
\hline
\end{tabular}




\begin{tabular}{|c|c|}
\hline Manufacturer & $\begin{array}{l}\text { Zakłady Mechaniczne im. M. Nowotki } \\
\text { in Warsaw }\end{array}$ \\
\hline Nominal power output & 300 or $350 \mathrm{HP}$ \\
\hline RPM & $1500 \mathrm{rpm}$ \\
\hline Lowest idle run RPM & $500 \mathrm{rpm}$ \\
\hline Specific fuel consumption & $180 \mathrm{~g} / \mathrm{KMh}$ \\
\hline Specific oil consumption below & $10 \mathrm{~g} / \mathrm{KMh}$ \\
\hline Degree of compression & $14-15$ \\
\hline Number of cylinders & 12 \\
\hline Cylinder diameter & $150 \mathrm{~mm}$ \\
\hline Piston stroke & $180 \mathrm{~mm}$ \\
\hline Cubic capacity & 38.81 \\
\hline Power supply & $\begin{array}{l}\text { 12-section injection pump with } \\
\text { multiband regulator }\end{array}$ \\
\hline Lubrication & $\begin{array}{l}\text { pressurised circulating pump with } \\
\text { dry oil sump, oil pump, gear driven, } \\
\text { three-section pump with one pumping } \\
\text { section and two suction sections. }\end{array}$ \\
\hline Cooling & $\begin{array}{l}\text { water with forced circulation and one } \\
\text { centrifugal water pump }\end{array}$ \\
\hline Start-up & $\begin{array}{l}\text { electric - main generator, current from } \\
\text { batteries, starting voltage } 48 \mathrm{~V}^{35}\end{array}$ \\
\hline Weight of dry engine & $\begin{array}{l}800 \mathrm{KG} \text { (V-Roka 300, without } \\
\text { clutch and clutch disc, } 1200 \\
\text { KG - (3DVSRa-350) }\end{array}$ \\
\hline
\end{tabular}


List of military Ls300 type locomotives/ WP-07 series $^{860}$

\begin{tabular}{|l|l|l|l|}
\hline $\begin{array}{l}\text { Polish Armed } \\
\text { Forces No. }\end{array}$ & $\begin{array}{l}\text { Series, factory } \\
\text { No., type, year of } \\
\text { production }\end{array}$ & Conduct of service & Remarks \\
\hline WP-07-403-01 & $\begin{array}{l}\text { Ls300-1104 } \\
\text { Chrzanów 8210/70 }\end{array}$ & $\begin{array}{l}\text { JW 3425 Życzyn } \\
\text { (airport) WLOP }\end{array}$ & $\begin{array}{l}\text { KKW Kraków? } \\
\text { factory } \\
\text { number } \\
\text { matched }\end{array}$ \\
\hline WP-07-403-02 & $\begin{array}{l}\text { Ls300-510 } \\
\text { Chrzanów 3535/59 }\end{array}$ & $\begin{array}{l}\text { 1959? JW 2488 } \\
\text { Borzemkowo, } \\
\text { Bydgoszcz/POW } \\
\text { Maksymilianowo } \\
\text { Station }\end{array}$ & KKW Gdańsk \\
\hline $\begin{array}{l}\text { WP-07-403-03 } \\
\text { ex JW 6627 }\end{array}$ & $\begin{array}{l}\text { Ls300-662 } \\
\text { Chrzanów 6627/64 }\end{array}$ & $\begin{array}{l}\text { 8.07.64 JW 1523 } \\
\text { Inowrocław, Bydgoszcz/ } \\
\text { POW }\end{array}$ & KKW Gdańsk \\
\hline WP-07-403-04 & $\begin{array}{l}\text { Ls300-917 } \\
\text { Chrzanów 7506/67 }\end{array}$ & $\begin{array}{l}\text { 1969? (35 SKK MW) JW } \\
1903 \text { Gdynia Dębogórze } \\
\text { Gdańsk/ MW }\end{array}$ & KKW Gdańsk \\
\hline WP-07-403-05 & $\begin{array}{l}\text { Ls300-522 } \\
\text { Chrzanów 5669/60 } \\
\text { (1961) }\end{array}$ & $\begin{array}{l}\text { 1960 JW 1462 Powidz } \\
\text { (airport) Strzałkowo } \\
\text { Lódź station/WLOP }\end{array}$ & KKW Gdańsk \\
\hline Ls300E-885 & $\begin{array}{l}\text { JW 4013 Radnica ŚOW } \\
\text { Chrzanów 7374/67 }\end{array}$ & KKW Poznań \\
\hline Chrzanów 6950/65
\end{tabular}

On military sidings with a significant turnover of wagons, where it was necessary to use a high-power locomotive, and on narrow-gauge railways (due to the lack of appropriate locomotives in the early 1950s) - steam locomotives were

860 Prepared on the basis of military fleet inventory materials of the Headquarters of Military Transport of the Polish Armed Forces Headquarters, Headquarters of Military Transport and documentation of individual military locomotives. 
also operated. It should be emphasised that the production of high-power diesel locomotives was undertaken by the Polish rolling stock industry only in the sixties.

The Military Transport Unit of the 1st Army of the Polish Armed Forces used a number of captured standard-gauge steam locomotives to service the military troop trains, although the exact number is difficult to define. On the archival photo in an unpublished study by Marian Gembora Wojska Kolejowe (Railway Troops) ${ }^{861}$ one can see a German military steam locomotive BR 52 (Polish State Railways class Ty2), marked in an extremely interesting way - according to the rules of marking of Soviet military locomotives working in steam locomotive columns. On the engine driver's cab the Polish national emblem and the Russian abbreviation BO CO 1 ABn (Military Transport of the 1st Polish Armed Forces) as well as the former German class and number 52-2580 862 were painted with white paint. Most probably after the railway troops were disbanded after the end of the war, most of the locomotives were handed over to the Polish State Railways or SZD (СЖД - Soviet railways).

In the first post-war years, the Polish Armed Forces mostly operated steam locomotives taken or leased from Polish State Railways, among others, they were assigned to service armoured trains which were used in the "Wisła" operation in the Bieszczady Mountains.

Armoured trains of the Railway Security Services, part of the 1st Armoured Train Division.

The Railway Security Services trains (in Polish: Służby Ochrony Kolei) were hauled by the following steam locomotive classes: armoured train No. 1 "Szczecin" with an E class broad-gauge Russian steam locomotive (not armoured), armoured train No. 2 "Grom" with a German Tw1 class armoured locomotive, armoured train No. 3 "Huragan" with a German war design Ty2 class steam locomotive, later an Austrian Tw12 and armoured train No. 4 "Błyskawica" with an Austrian steam locomotive class $\operatorname{Tr} 12$ (unconfirmed) ${ }^{863}$ Unfortunately, there is no complete information on the steam traction then operated by the Polish Armed Forces on the territory of military sidings. Fragmented information dates back to the 1950s.

On the siding of the Military Motorisation Plant in Głowno, three standardgauge steam locomotives were used: transferred from Polish State Railways ${ }^{864}-$ TKi100-4 (Borsig No. 10777/1920) (withdrawn from the inventory of Railway

861 Gembora, Ref. No. 1138, 54.

862 Gembora, Ref. No. 1138, 54.

863 http://www.pibwl.republika.pl [accessed June 15, 2006].

864 Data based on: Railway Inspectorate of Technical Supervision in Łódź Księga ewidencyjna. 
Technical Inspection on 22 November 1972), two "Ferrum" type industrial tank locomotives $^{865}$ - TKh-5567 (Chrzanów No. 5567/1960, Sosnowiec boiler No. 18598/1960) purchased from Zdowskie Zakłady Przemysłu Bawełnianego ${ }^{866}$ and TKh-5376 (Chrzanów No. 5376/1959, Sosnowiec boiler No. 17632/1959 purchased from Zakłady Azotowe in Kędzierzyn. ${ }^{867}$

Four Prussian Tw1 class steam locomotives were also used on military sidings. Due to their low axle load, these machines were suitable for use on lightly laid military sidings. The table ${ }^{868}$ below shows data of the locomotives of this class leased by the Polish Armed Forces from Polish State Railways:

\begin{tabular}{|c|c|c|c|}
\hline Class/ No. & DOKP & Lease & Returned \\
\hline Tw1-56 & Gdańsk & $?$ & from JW? \\
\hline Tw1-73 & Gdańsk & $\begin{array}{l}\text { (JW 1523) } \\
\text { 2nd Railway Regiment } \\
\text { Inowrocław }\end{array}$ & $\begin{array}{l}3.01 .63 \text { from JW } 1523^{36} \\
\text { Inowrocław Gdańsk/POW }\end{array}$ \\
\hline Tw1-93 & Gdańsk & 15.03.50 to JW? & 05.57 \\
\hline Tw1-98 & Warsaw & $\begin{array}{l}\text { 3rd railway troops } \\
\text { battalion in Przemyśl? }{ }^{37}\end{array}$ & 04.58 - end of lease \\
\hline \multicolumn{4}{|c|}{$\begin{array}{l}\text { 36 The steam locomotive was operated on the siding of the } 2 \text { nd railway } \\
\text { regiment in Inowrocław. } \\
\text { 373rd Battalion of Railway Troops in Przemyśl, in } 15.06 .1957 \text { transformed into } \\
\text { the 2nd railway regiment. }\end{array}$} \\
\hline
\end{tabular}

In the 1950s and 1960s, two steam TKi3 class locomotives were used on the siding of JW 4824 Stawy (both machines were converted to oil-firing for fire prevention reasons). ${ }^{869}$ A TKi3 steam locomotive was also used on the siding of JW 1530 Regny in the years 1955-1958, around 1958 it was handed over to another user. ${ }^{870}$

865 Data based on: Railway Inspectorate of Technical Supervision in Łódź Księga ewidencyjna.

866 Ibid.

867 After withdrawal the locomotive was plinthed at the Łódź Widzew railway station.

868 Prepared on the basis of: Polish State Railways General Management, Central Traction Management, Księga inwentarzowa parowozów.

869 An ex-German water crane remained on the area of the warehouse in Stawy.

870 According to the information obtained from Mr. Tomasz Roszak. 
In 1953, Rolling Stock Repair Plant Nowy Sącz rebuilt two TKi3 steam locomotives (TKi3-17 and 106) to oil firing on the request of the Ministry of National Defence. After the reconstruction both steam locomotives were leased to the Ministry of National Defence. Both machines were removed from the Polish State Railways inventory in 1965. Most probably they operated on the siding of JW 4824 Stawy and JW 1530 Regny.

According to unconfirmed reports, in the same unit, $\operatorname{Tr} 202$ or Tr203 steam locomotives, earlier withdrawn from Polish State Railways, were used as stationary boilers as late as in the 1980s.

In 1950, the crew of the Fablok factory in Chrzanów renovated a four-wheeled German "Riesa" type steam locomotive for the Polish Armed Forces (Krenau No. 801/40) for a $600 \mathrm{~mm}$ gauge track. ${ }^{871}$ The locomotive worked on the military narrow-gauge railway in the training area in Mielec (JW 3682).

On the narrow-gauge railway of the Military Institute of Armament Technology in Zielonka (750 $\mathrm{mm}$ gauge), at the beginning of its operation, two narrow-gauge steam locomotives were used. These machines were leased from Polish State Railways, their data are presented in the table below: ${ }^{872}$

\begin{tabular}{|l|l|l|l|l|}
\hline $\begin{array}{l}\text { Polish } \\
\text { State } \\
\text { Railways } \\
\text { class and } \\
\text { number }\end{array}$ & $\begin{array}{l}\text { Factory No., } \\
\text { factory }\end{array}$ & Received & Withdrawn & Remarks \\
\hline Ty1-1142 & $\begin{array}{l}\text { Krauss } \\
\text { München } \\
6806 / 13\end{array}$ & $\begin{array}{l}23.09 .53 \\
\text { Warsaw Military } \\
\text { District Nasielskk }\end{array}$ & $\begin{array}{l}\text { Military District } \\
\text { Biała Podlaska }\end{array}$ & $\begin{array}{l}\text { ex Ty2-2852 } \\
(800 \mathrm{~mm}) \\
\text { ex Ty2-1124 } \\
(750 \mathrm{~mm})\end{array}$ \\
\hline
\end{tabular}

871 On the basis of correspondence from the Fablok factory in Chrzanów regarding the approval of the Krenau steam locomotive boiler No. 801 (in the author's collection).

872 Prepared on the basis of: Ministry of Transport, Central Management of Narrowgauge Railways, Ksiega inwentarzowa parowozów wąskotorowych (1948) (Polish State Railways Narrow-gauge Railways Management Central State Railway in Warsaw), files of the military siding of Military Institute of Armament Technology in Zielonka (in the author's collection). 


\begin{tabular}{|l|l|l|l|l|}
\hline $\begin{array}{l}\text { Polish } \\
\text { State } \\
\text { Railways } \\
\text { class and } \\
\text { number }\end{array}$ & $\begin{array}{l}\text { Factory No., } \\
\text { factory }\end{array}$ & Received & Withdrawn & Remarks \\
\hline $\begin{array}{l}\text { Ty1-1085 } \\
\text { (ex no. } \\
\text { 3/00?) }\end{array}$ & $\begin{array}{l}\text { Freudenstein } \\
3 / 1899\end{array}$ & $\begin{array}{l}3.06 .53 \text { lease } \\
\text { from? }\end{array}$ & $+30.12 .65^{38}$ & $\begin{array}{l}\text { + Warsaw } \\
\text { Military } \\
\text { District Stalowa } \\
1966 / 67\end{array}$ \\
\hline $\begin{array}{l}\text { 38 Withdrawal date from the Polish State Railways inventory, according to Jan } \\
\text { Szponder's account, the locomotive was cut up for scrap in the Warszawa- }\end{array}$ \\
Stalowa narrow gauge railway depot in 1966 or 1967.
\end{tabular}

\subsubsection{Wagon and special rolling stock}

For internal transport of ammunition, explosives, weapons, military equipment and fuel in the area of military depots, factories and units, the army also operated a significant number of freight wagons (about 200 four-wheeled vans, 1 bogie van), more than 100 four wheeled flat wagons and 1 four-wheeled coal wagon. ${ }^{873}$

Several four-wheeled and bogie tank wagons as well as narrow-gauge tank wagons for fuel transport were also operated on military sidings. Standard-gauge wagons were mostly of old type, withdrawn by Polish State Railways and handed over to the army. On military depot sidings with particular fire hazard, 10 fire tenders were also used, coming from the withdrawn old Polish State Railways steam locomotives. ${ }^{874}$ On military narrow-gauge railways, wagon rolling stock coal wagons and flat wagons - were used.

At the end of the 1950s, several WM $5^{875}$ type diesel trolleys together with PWM5 type trailers were purchased at Rolling Stock Repair Plant Wrocław for permanent way works on military sidings and, most probably, one Lowa motor trolley was imported from East Germany.

873 MON SSKW GKWP, Ewidencja taboru kolejowego MoND.

874 List of wagon rolling stock of Ministry of National Defence (old numbering).

875 Only two military trolleys of this type were confirmed: WM5 (Rolling Stock Repair Plant Wrocław ?/57) in JW 2186 Hajnówka from 29th Aug. 1957, incomplete 30th April 1996 and WM5-051 which was in the inventory of JW 2902 until 22nd Feb. 1971. 
The Headquarters of Military Transport also operated special rolling stock armoured wagons, armoured trolleys, sanitary wagons, disinfection and bathing wagons, laundry wagons and kitchens, mechanical and carpenter's workshops, tank wagons, flat wagons - ramps and heavy trailers for transporting standardgauge wagons on roads. There were 19 mechanical workshop wagons, ${ }^{876} 5$ carpenter's workshop wagons and 8 sanitary and pharmacy carriages made of standard 2 nd class passenger carriages. ${ }^{877}$

A dozen or so of pre-war sanitary wagons of Italian origin from the 1920s were also in operation; these were withdrawn in the 1960s.

The military rolling stock included also steam locomotives and armoured wagons that formed armoured trains and German armoured trolleys, as well as a German diesel armoured train. Most of them were wagons armoured with concrete from German improvised armoured trains.

The diesel armoured train, exhibited in the Warsaw Railway Museum and three improvised armoured wagons have been preserved until the present day: a 1915 broad-gauge van rebuilt from a wagon of Canadian origin (preserved on a siding in Małaszewicze); improvised van converted from a Hungarian Ganz wagon (exhibited at the Higher Officer School of Armoured Forces in Poznań) and an improvised van converted from a former Canadian broad-gauge wagon from 1915 (converted to the standard-gauge $1435 \mathrm{~mm}$ ), the wagon was marked in the post-war period with a Ministry of Defence series and number Kd 870020, an inscription "last maintenance WGW Żurawica 2.09.59" was also found on the wagon frame (withdrawn at JW 2189 Kazun Nowy).

In the 1940s, the 1st Division of Railway Artillery in Darłowo also used a battery of railway guns.

In 1950, two type 1A passenger carriages were adapted in the Polish State Railways Mechanical Workshops No. 2 as the Central Mobile Clinic of the Polish Armed Forces. The wagons were marked Xxo series and Ministry of National Defence numbers 806975 and $806023 .^{878}$

These wagons were used throughout the country to take small frame pictures of lungs of professional soldiers and their families.

At the beginning of the 1950s, four-wheeled vans were rebuilt into antiaircraft defence wagons. A number of wagons designed for anti-aircraft defence of military transports during the war were rebuilt. Two types of wagons were

876 All wagons were equipped with typical military field workshop sets.

877 MON SSKW GKWP, Ewidencja taboru kolejowego Ministry of National Defence.

878 On the basis of the inventory of military rolling stock of SSKW GKWP. 
made - with an open platform for setting machine guns or anti-aircraft guns. However, these wagons were withdrawn in the 1970s.

Railway cranes with a capacity of 10,50 and 80 tons were used for reloading works in military ports (Hel, Gdynia, Świnoujście). There were 8 cranes in the inventory of the Polish Armed Forces.

A dozen or so military saloon cars were used for the Minister of National Defence and senior officers of the Polish Armed Forces. Most of them were rebuilt pre-war Polish Hecht type Pullman wagons manufactured by Lilpop, Rau \& Loewenstein in Warsaw, from 1929-1930.

In the 1950s, a saloon car of German origin, Ashx 870290, was also in operation. This saloon car was intended for Marshal Marian Spychalski, part of the wagon included a purpose-built space with movable walls and a lift for transporting two cars: a passenger and an off-road (to carry out inspections of testing grounds). Four-wheeled and bogie passenger carriages provided by Polish State Railways were also operated. They were usually used for internal transport of workers and soldiers on military sidings.

\subsubsection{Management of military rolling stock}

The military rolling stock included all rail vehicles, both narrow-gauge and standard-gauge, which were in the inventory of the Polish Armed Forces. The Headquarters of Military Transport of the General Staff of the Polish Armed Forces was the central body supplying and the exclusive dispatcher of rolling stock which was used at military units, institutions, plants and enterprises. The management of military rolling stock was carried out by military institutions responsible for its maintenance and operation: Headquarters of Military Transport of the General Staff of the Polish Armed Forces, Military transport Branches of Military Districts, Navy and Land Forces and National Air Defence, Head of Military Transport (at particular Regional State Railway Management), using subordinate military transport bodies, and directly users (military units).

The Headquarters of the Military Transport Service was in charge of the rolling stock management in the army. The tasks of the Military transport were to keep records of the military rolling stock. The rolling stock management in relation to the users stationed on the territory of the relevant military district was managed by the Military transport Units of military districts with the exception of:

- users subordinate to military and service commands, with organs of Headquarters of Military Transports,

- central warehouse of military transport equipment in Przemyśl in terms of rolling stock and spare parts stored on its premises. 
Management of rolling stock in military units (users) was carried out by professional soldiers from among the technical staff - full-time or appointed by order of the commander of the military unit, who took full legal and material responsibility in this respect. On military railways that had their own locomotives, the use of Polish State Railways locomotives was prohibited without the permission of the head of military transport.

The central organ supplying military units with rolling stock was, as already stated, the Headquarters of Military Transport of the General Staff of the Polish Armed Forces. The supplying was aimed supplementing the number of rolling stock units to the required levels and to replenish the stock of the central warehouse of military transport equipment. The acceptance of rolling stock from the suppliers (after acceptance by a Polish State Railways commissioner) was carried out by a representative of the transport service and a representative of the military unit (user) taking over the rolling stock for operation. The acceptance of the rolling stock at the supplier's premises was carried out in accordance with the technical acceptance conditions and the conditions specified in the order. The transfer of rolling stock to the users took place via the central warehouse of military transport equipment or directly from the suppliers. The handover and collection of locomotives, railmounted cranes and special wagons took place in the presence of representatives of the interested Head of Military Transport. Steam locomotives, diesel locomotives and special wagons were escorted during transport. The handover of the rolling stock to the convoy commander took place on the basis of a protocol.

The authorisations to operate rail vehicles were issued by the competent chief of military transport at the user's request. The locomotive crew consisted of two persons: a driver and a driver's assistant in one shift. In military units with fulltime shunting duties, operation of locomotives up to $200 \mathrm{HP}$ could be performed by one person per shift (driver). Operation of trolleys consisted of one person per shift (driver). Only professional soldiers or civilian workers were employed as drivers to operate railway vehicles with a power output exceeding $200 \mathrm{HP}$. The activities included in the preventive maintenance were carried out by a full-time employee using the user's technical facilities. The inter-repair inspections of diesel locomotives (P3) were carried out on the principles defined by the Polish State Railways Ministry of Communication Central Traction Administration in accordance with the agreement concluded between the Minister of Communication and the Minister of National Defence.

Rolling stock repairs were divided into two groups:

- planned preventive repairs,

- emergency (accident) repairs. 
The repairs were carried out in accordance with the regulations in force on Polish State Railways. The rolling stock was sent to Rolling Stock Repair Plant workshops for repairs after a given number of kilometres has been reached. The repairs of the vehicles were supervised by the Ministry of Communication acceptance commissioners in accordance with the rules concerning the Polish State Railways rolling stock in accordance with item 3 of the Agreement concluded on 25th February 1957 between the Ministries of Communications, National Defence and Finance.

Rolling stock that was unsuitable for operation, i.e.: worn out or damaged, the repair of which was unprofitable, requiring a repair which was impossible to carry out due to the lack of spare parts, untypical or withdrawn at the order of the Head of the Headquarters of Military Transport, as well as spare parts and equipment which lost their usefulness completely or in part - were subject to transfer or scrapping against payment or free of charge in accordance with the binding order of the Minister of National Defence.

The scrapping of locomotives and special wagons was carried out only in the central warehouse of military transport equipment. Scrapping of other rolling stock units was carried out on the premises of the previous user. A team consisting of the representatives of the interested Polish Armed Forces units and the professional services of the Polish State Railways (if necessary Rolling Stock Repair Plant workshops) was set up to scrap a vehicle. The approved scrapping protocol was the basis for the given vehicle to be withdrawn from inventory. Withdrawal of the scrapped vehicle from the user's inventory took place on the basis of an approved scrapping protocol and a document confirming the execution of the instructions of the Headquarters of Military Transport of the General Staff of the Polish Armed Forces.

In connection with the need to maintain the military rolling stock on sidings in continuous operation, also in the case of sending locomotives for periodic repairs to Rolling Stock Repair Plant workshops an important problem arose of maintaining reserve locomotives, to be used as required. This was the case for diesel locomotives - referred to in the regulations as replacement locomotives. Replacement diesel locomotives constituted a reserve of the head of the Headquarters of Military Transport, intended for temporary use in military units. The replacement diesel locomotives were grouped in the central warehouse of military transport equipment or in designated military units and remained in their permanent inventory, regardless of the place of temporary use by their temporary users. A decision on the withdrawal of replacement locomotives or their inclusion in the group was made by the Head of the Headquarters of Military Transport. The reception and transfer of replacement diesel locomotives between the interested parties took place on the premises of the central warehouse of railway and handling 
equipment. The work of the replacement diesel locomotive at the user's site was carried out in accordance with the plan for the full-time operation of the locomotive. The user, after the end of the operational period of the replacement diesel locomotive, reported to the Headquarters of the Military Transport Service the readiness to hand over the locomotive to the central warehouse of Headquarters of Military Transport. A Head of Military Transport could use as replacement locomotives full-time locomotives operated by users in the subordinate area.

Another issue was the numbering scheme of military diesel locomotives, which apart from the "WP" (WP = Wojsko Polskie - Polish Armed Forces) marking and later the military number did not differ significantly from the locomotive painting scheme at Polish State Railways and industrial railways. Painting of passenger cars, except for sanitary and X-ray cars (red crosses on the side walls and car roof), except for military numbers did not differ from the Polish State Railways painting schemes for passenger vehicles. Freight wagons, e.g. narrowgauge flat wagons (KPW Hel, KPW Gdynia, KPW Świnoujście) and standardgauge wagons adapted to transport people were painted as follows: wagon chassis - black, wagon frame - green (khaki), white numbering. Frames of other freight wagons were painted in brown, just like in the case of Polish State Railways freight wagons. The arrangement of unified signs on military rolling stock was the same as on Polish State Railways rolling stock.

Until the early 1970s, military rolling stock was marked as follows: locomotives were marked with the characteristic lettering "WP", class or type designation and serial number, freight wagons and passenger carriages were marked with sixdigit Ministry of National Defence numbers beginning with 870 .

The marking and numbering scheme of military rolling stock was introduced around 1970. The aim of the unified marking of railway rolling stock was to distinguish Polish State Railways rolling stock from that owned by the Ministry of National Defence and was used on internal tracks (military railway sidings), as well as on Polish State Railways network. The new marking system was modelled to some extent on the system used by Polish State Railways. The unified marking consisted of large and small letter symbols and digital symbols (number). The symbols of capital letters on the military rolling stock were separate from the Polish State Railways symbols. The symbols of lowercase letters were the same as the lowercase letters of the alphabet applied to Polish State Railways wagons. Before the symbols of capital letters, indicating the type of rolling stock, the capital letters WP (Polish Armed Forces) were placed. The numbering of military rolling stock included all types of rolling stock (locomotives, rail-mounted cranes, coaches, special wagons, freight wagons) without distinction of track gauge. Both narrow-gauge and standard-gauge rolling stock were included in 
the same numbering range. The rolling stock registration numbers (five-digit) were assigned by the Head of the Transport Service of the Headquarters of the Polish Armed Forces, according to the logbook of registration of transport equipment. Military numbers on railway vehicles were made in white.

Principles of marking and numbering of military rolling stock ${ }^{879}$

\begin{tabular}{|c|c|c|c|c|}
\hline Type of rolling stock & $\begin{array}{l}\text { Constant } \\
\text { symbol }\end{array}$ & $\begin{array}{l}\text { Class } \\
\text { symbol }\end{array}$ & Class No. & Inventory No. \\
\hline $\begin{array}{l}\text { Standard gauge diesel } \\
\text { locomotive } 40 \text { HP Ls } 40 \\
\text { SM02 }\end{array}$ & $\begin{array}{l}\text { Polish } \\
\text { Armed } \\
\text { Forces } \\
\end{array}$ & Ls-40 & 01 & \multirow{5}{*}{$\begin{array}{l}\text { 5-digit number } \\
\text { according to } \\
\text { the logbook } \\
\text { of registration } \\
\text { of transport } \\
\text { equipment } \\
\text { assigned by } \\
\text { the Head of } \\
\text { the Transport } \\
\text { Service of the } \\
\text { Headquarters of } \\
\text { the Headquarters } \\
\text { of the Polish } \\
\text { Armed Forces }\end{array}$} \\
\hline $\begin{array}{l}\text { Standard gauge diesel } \\
\text { locomotive } 60 \text { HP Ls60 } \\
\text { SM02 }\end{array}$ & \begin{tabular}{|l|} 
Polish \\
Armed \\
Forces \\
\end{tabular} & Ls-60 & 02 & \\
\hline $\begin{array}{l}\text { Standard gauge diesel } \\
\text { locomotive } 75 \text { HP Ls75 SM }\end{array}$ & \begin{tabular}{|l|} 
Polish \\
Armed \\
Forces \\
\end{tabular} & Ls-75 & 03 & \\
\hline $\begin{array}{l}\text { Standard gauge diesel } \\
\text { locomotive } 90 \text { HP Lowa- } \\
\text { East Germany }\end{array}$ & \begin{tabular}{|l} 
Polish \\
Armed \\
Forces \\
\end{tabular} & Ls-90 & 04 & \\
\hline $\begin{array}{l}\text { Standard gauge diesel } \\
\text { locomotive } 150 \text { HP Ls-150 }\end{array}$ & $\begin{array}{l}\text { Polish } \\
\text { Armed } \\
\text { Forces } \\
\end{array}$ & Ls-150 & 05 & \\
\hline $\begin{array}{l}\text { Standard-gauge diesel } \\
\text { locomotive } \\
160 \text { HP Ls-160 }\end{array}$ & $\begin{array}{l}\text { Polish } \\
\text { Armed } \\
\text { Forces } \\
\end{array}$ & Ls- 160 & 06 & \\
\hline $\begin{array}{l}\text { Standard gauge diesel } \\
\text { locomotive } 300 \text { HP Ls-300 }\end{array}$ & $\begin{array}{l}\text { Polish } \\
\text { Armed } \\
\text { Forces } \\
\end{array}$ & Ls-300 & 07 & \\
\hline $\begin{array}{l}\text { Standard-gauge diesel } \\
\text { locomotive }\end{array}$ & $\begin{array}{l}\text { Polish } \\
\text { Armed } \\
\text { Forces }\end{array}$ & Ls & 08 & \\
\hline
\end{tabular}

879 Ministry of National Defence, Przepisy o gospodarce (1975), 126-130. 


\begin{tabular}{|c|c|c|c|c|}
\hline Type of rolling stock & $\begin{array}{l}\text { Constant } \\
\text { symbol }\end{array}$ & \begin{tabular}{|l|} 
Class \\
symbol
\end{tabular} & Class No. & Inventory No. \\
\hline $\begin{array}{l}\text { Standard-gauge diesel } \\
\text { locomotive }\end{array}$ & $\begin{array}{l}\text { Polish } \\
\text { Armed } \\
\text { Forces } \\
\end{array}$ & Ls & 09 & \\
\hline $\begin{array}{l}\text { Standard-gauge diesel } \\
\text { locomotive }\end{array}$ & $\begin{array}{l}\text { Polish } \\
\text { Armed } \\
\text { Forces }\end{array}$ & Ls & 10 & \\
\hline $\begin{array}{l}\text { Narrow-gauge } 600 \mathrm{~mm} \\
\text { diesel locomotive } 40 \mathrm{HP}\end{array}$ & $\begin{array}{l}\text { Polish } \\
\text { Armed } \\
\text { Forces } \\
\end{array}$ & WLs-40 & 11 & \\
\hline $\begin{array}{l}\text { Narrow-gauge } 600 \mathrm{~mm} \\
\text { diesel locomotive }\end{array}$ & $\begin{array}{l}\text { Polish } \\
\text { Armed } \\
\text { Forces } \\
\end{array}$ & WLs- & 12 & \\
\hline $\begin{array}{l}\text { Narrow-gauge } 600 \mathrm{~mm} \\
\text { diesel locomotive }\end{array}$ & $\begin{array}{l}\text { Polish } \\
\text { Armed } \\
\text { Forces } \\
\end{array}$ & WLs- & 13 & \multirow{6}{*}{$\begin{array}{l}\text { 5-digit number } \\
\text { according to } \\
\text { the logbook } \\
\text { of registration } \\
\text { of transport } \\
\text { equipment } \\
\text { assigned by } \\
\text { the Head of } \\
\text { the Transport } \\
\text { Service of the } \\
\text { Headquarters of } \\
\text { the Polish Armed } \\
\text { Forces }\end{array}$} \\
\hline $\begin{array}{l}\text { Narrow-gauge } 750 \mathrm{~mm} \\
\text { diesel locomotive } 75 \mathrm{HP} \\
\text { WLs-75 }\end{array}$ & $\begin{array}{l}\text { Polish } \\
\text { Armed } \\
\text { Forces } \\
\end{array}$ & WLs-75 & 14 & \\
\hline $\begin{array}{l}\text { Narrow-gauge } 750 \mathrm{~mm} \\
\text { diesel locomotive } 150 \mathrm{HP} \\
\text { Wls150 }\end{array}$ & \begin{tabular}{|l} 
Polish \\
Armed \\
Forces \\
\end{tabular} & $\begin{array}{l}\text { WLs- } \\
150\end{array}$ & 15 & \\
\hline $\begin{array}{l}\text { Narrow-gauge } 750 \mathrm{~mm} \\
\text { diesel locomotive }\end{array}$ & \begin{tabular}{|l} 
Polish \\
Armed \\
Forces \\
\end{tabular} & WLs & 16 & \\
\hline $\begin{array}{l}\text { Narrow-gauge } 1000 \mathrm{~mm} \\
\text { diesel locomotive }\end{array}$ & \begin{tabular}{|l} 
Polish \\
Armed \\
Forces \\
\end{tabular} & WLs & 17 & \\
\hline $\begin{array}{l}\text { Narrow-gauge } 1000 \mathrm{~mm} \\
\text { diesel locomotive }\end{array}$ & $\begin{array}{l}\text { Polish } \\
\text { Armed } \\
\text { Forces }\end{array}$ & WLs & 18 & \\
\hline
\end{tabular}




\begin{tabular}{|c|c|c|c|c|}
\hline Type of rolling stock & $\begin{array}{l}\text { Constant } \\
\text { symbol }\end{array}$ & $\begin{array}{l}\text { Class } \\
\text { symbol }\end{array}$ & Class No. & Inventory No. \\
\hline $\begin{array}{l}\text { Narrow-gauge } 750 \mathrm{~mm} \\
\text { diesel locomotive } 150 \mathrm{HP}\end{array}$ & \begin{tabular}{|l} 
Polish \\
Armed \\
Forces \\
\end{tabular} & WS & 19 & \\
\hline $\begin{array}{l}\text { Standard-gauge railway } \\
\text { crane } 10 \mathrm{t}\end{array}$ & \begin{tabular}{|l} 
Polish \\
Armed \\
Forces \\
\end{tabular} & DK-10 & 20 & \\
\hline $\begin{array}{l}\text { Standard-gauge railway } \\
\text { crane } 50 \mathrm{t}\end{array}$ & \begin{tabular}{|l} 
Polish \\
Armed \\
Forces \\
\end{tabular} & DK-50 & 21 & \\
\hline $\begin{array}{l}\text { Standard-gauge railway } \\
\text { crane } 80 \mathrm{t}\end{array}$ & \begin{tabular}{|l} 
Polish \\
Armed \\
Forces \\
\end{tabular} & DK-80 & 22 & \\
\hline $\begin{array}{l}\text { Standard-gauge railway } \\
\text { crane }\end{array}$ & \begin{tabular}{|l} 
Polish \\
Armed \\
Forces \\
\end{tabular} & DK- & 23 & \\
\hline $\begin{array}{l}\text { Standard-gauge railway } \\
\text { crane }\end{array}$ & \begin{tabular}{|l} 
Polish \\
Armed \\
Forces \\
\end{tabular} & DK- & 24 & \\
\hline $\begin{array}{l}\text { Standard-gauge motor } \\
\text { trolley WM-5 }\end{array}$ & \begin{tabular}{|l} 
Polish \\
Armed \\
Forces \\
\end{tabular} & WM-5 & 25 & \\
\hline $\begin{array}{l}\text { Standard-gauge diesel } \\
\text { trolley Lowa }\end{array}$ & \begin{tabular}{|l} 
Polish \\
Armed \\
Forces \\
\end{tabular} & DS-L & 26 & \\
\hline $\begin{array}{l}\text { Standard-gauge diesel } \\
\text { trolley }\end{array}$ & \begin{tabular}{|l} 
Polish \\
Armed \\
Forces \\
\end{tabular} & DS.- & 27 & \\
\hline 4 wh standard-gauge van & \begin{tabular}{|l} 
Polish \\
Armed \\
Forces \\
\end{tabular} & K & 28 & \\
\hline
\end{tabular}




\begin{tabular}{|c|c|c|c|c|}
\hline Type of rolling stock & $\begin{array}{l}\text { Constant } \\
\text { symbol }\end{array}$ & $\begin{array}{l}\text { Class } \\
\text { symbol }\end{array}$ & Class No. & Inventory No. \\
\hline Bogie standard-gauge van & $\begin{array}{l}\text { Polish } \\
\text { Armed } \\
\text { Forces } \\
\end{array}$ & KK & 29 & \\
\hline $\begin{array}{l}4 \text { wh standard-gauge flat } \\
\text { wagon }\end{array}$ & $\begin{array}{l}\text { Polish } \\
\text { Armed } \\
\text { Forces } \\
\end{array}$ & $\mathrm{P}$ & 30 & \\
\hline $\begin{array}{l}\text { Bogie standard-gauge flat } \\
\text { wagon }\end{array}$ & \begin{tabular}{|l} 
Polish \\
Armed \\
Forces \\
\end{tabular} & PP & 31 & \\
\hline $\begin{array}{l}4 \text { wh standard-gauge coal } \\
\text { wagon }\end{array}$ & \begin{tabular}{|l} 
Polish \\
Armed \\
Forces \\
\end{tabular} & W & 32 & \\
\hline $\begin{array}{l}\text { Bogie standard-gauge coal } \\
\text { wagon }\end{array}$ & \begin{tabular}{|l} 
Polish \\
Armed \\
Forces \\
\end{tabular} & WW & 33 & \\
\hline $\begin{array}{l}4 \text { wh standard-gauge tank } \\
\text { wagon }\end{array}$ & \begin{tabular}{|l} 
Polish \\
Armed \\
Forces \\
\end{tabular} & $\mathrm{R}$ & 34 & \\
\hline $\begin{array}{l}\text { Bogie standard-gauge tank } \\
\text { wagon }\end{array}$ & \begin{tabular}{|l} 
Polish \\
Armed \\
Forces \\
\end{tabular} & RR & 35 & \\
\hline $\begin{array}{l}4 \text { wh standard-gauge } \\
\text { passenger car }\end{array}$ & $\begin{array}{l}\text { Polish } \\
\text { Armed } \\
\text { Forces } \\
\end{array}$ & B & 36 & \\
\hline $\begin{array}{l}\text { Bogie standard-gauge } \\
\text { passenger car }\end{array}$ & \begin{tabular}{|l} 
Polish \\
Armed \\
Forces \\
\end{tabular} & A & 37 & \\
\hline $\begin{array}{l}\text { Special } 4 \text { wh standard- } \\
\text { gauge wagons built on } \\
\text { standard-gauge wagons }\end{array}$ & $\begin{array}{l}\text { Polish } \\
\text { Armed } \\
\text { Forces }\end{array}$ & $S$ & 38 & \\
\hline
\end{tabular}




\begin{tabular}{|c|c|c|c|c|}
\hline Type of rolling stock & $\begin{array}{l}\text { Constant } \\
\text { symbol }\end{array}$ & $\begin{array}{l}\text { Class } \\
\text { symbol }\end{array}$ & Class No. & Inventory No. \\
\hline $\begin{array}{l}\text { Special bogie standard- } \\
\text { gauge wagons built on } \\
\text { standard-gauge wagons }\end{array}$ & \begin{tabular}{|l} 
Polish \\
Armed \\
Forces \\
\end{tabular} & SS & 39 & \\
\hline $\begin{array}{l}4 \text { wh } 600 \mathrm{~mm} \text { narrow- } \\
\text { gauge vans }\end{array}$ & \begin{tabular}{|l} 
Polish \\
Armed \\
Forces \\
\end{tabular} & WK & 40 & \\
\hline $\begin{array}{l}\text { Bogie } 600 \mathrm{~mm} \text { narrow- } \\
\text { gauge vans }\end{array}$ & $\begin{array}{l}\text { Polish } \\
\text { Armed } \\
\text { Forces } \\
\end{array}$ & WKK & 41 & \\
\hline $\begin{array}{l}4 \text { wh narrow-gauge van } \\
\text { adapted to the transport of } \\
\text { people }\end{array}$ & \begin{tabular}{|l} 
Polish \\
Armed \\
Forces \\
\end{tabular} & WKKL & 42 & \\
\hline $\begin{array}{l}4 \text { wh } 600 \mathrm{~mm} \text { narrow- } \\
\text { gauge flat wagon }\end{array}$ & \begin{tabular}{|l} 
Polish \\
Armed \\
Forces \\
\end{tabular} & PA & 43 & \multirow{4}{*}{$\begin{array}{l}\text { 5-digit number } \\
\text { according to } \\
\text { the logbook } \\
\text { of registration } \\
\text { of transport } \\
\text { equipment } \\
\text { assigned by } \\
\text { the Head of } \\
\text { the Transport } \\
\text { Service of the } \\
\text { Headquarters of } \\
\text { the Headquarters } \\
\text { of the Polish } \\
\text { Armed Forces }\end{array}$} \\
\hline $\begin{array}{l}\text { Bogie } 600 \mathrm{~mm} \text { narrow- } \\
\text { gauge flat wagon }\end{array}$ & $\begin{array}{l}\text { Polish } \\
\text { Armed } \\
\text { Forces } \\
\end{array}$ & WPP & 44 & \\
\hline $\begin{array}{l}4 \text { wh } 600 \mathrm{~mm} \text { narrow- } \\
\text { gauge van }\end{array}$ & \begin{tabular}{|l} 
Polish \\
Armed \\
Forces \\
\end{tabular} & WK & 45 & \\
\hline Bogie narrow-gauge van & $\begin{array}{l}\text { Polish } \\
\text { Armed } \\
\text { Forces }\end{array}$ & WKK & 46 & \\
\hline $\begin{array}{l}4 \mathrm{wh} 750 \mathrm{~mm} \text { narrow- } \\
\text { gauge flat wagon }\end{array}$ & \begin{tabular}{|l} 
Polish \\
Armed \\
Forces \\
\end{tabular} & PA & 47 & \\
\hline $\begin{array}{l}\text { Bogie } 750 \mathrm{~mm} \text { narrow- } \\
\text { gauge flat wagon }\end{array}$ & $\begin{array}{l}\text { Polish } \\
\text { Armed } \\
\text { Forces }\end{array}$ & WPP & 48 & \\
\hline
\end{tabular}




\begin{tabular}{|c|c|c|c|c|}
\hline Type of rolling stock & $\begin{array}{l}\text { Constant } \\
\text { symbol }\end{array}$ & $\begin{array}{l}\text { Class } \\
\text { symbol }\end{array}$ & Class No. & Inventory No. \\
\hline $\begin{array}{l}4 \text { wh } 1000 \mathrm{~mm} \text { narrow- } \\
\text { gauge van }\end{array}$ & \begin{tabular}{|l} 
Polish \\
Armed \\
Forces
\end{tabular} & WK & 49 & \\
\hline $\begin{array}{l}\text { Bogie } 1000 \mathrm{~mm} \text { narrow- } \\
\text { gauge van }\end{array}$ & \begin{tabular}{|l} 
Polish \\
Armed \\
Forces
\end{tabular} & WKK & 50 & \\
\hline $\begin{array}{l}4 \text { wh } 1000 \mathrm{~mm} \text { narrow- } \\
\text { gauge flat wagon }\end{array}$ & \begin{tabular}{|l} 
Polish \\
Armed \\
Forces \\
\end{tabular} & PA & 51 & \\
\hline $\begin{array}{l}\text { Bogie } 1000 \mathrm{~mm} \text { narrow- } \\
\text { gauge flat wagon }\end{array}$ & \begin{tabular}{|l} 
Polish \\
Armed \\
Forces \\
\end{tabular} & WPP & 52 & \\
\hline $\begin{array}{l}\text { Bogie } 600 \mathrm{~mm} \text { narrow- } \\
\text { gauge tank wagon }\end{array}$ & \begin{tabular}{|l} 
Polish \\
Armed \\
Forces \\
\end{tabular} & WPP & 53 & \\
\hline $\begin{array}{l}\text { Bogie } 1000 \mathrm{~mm} \text { narrow- } \\
\text { gauge tank wagon }\end{array}$ & \begin{tabular}{|l} 
Polish \\
Armed \\
Forces \\
\end{tabular} & WRR & 54 & \\
\hline $\begin{array}{l}\text { Other standard-gauge rail } \\
\text { vehicles }\end{array}$ & \begin{tabular}{|l} 
Polish \\
Armed \\
Forces \\
\end{tabular} & C & 55 & \\
\hline $\begin{array}{l}\text { Other } 600 \mathrm{~mm} \text { narrow- } \\
\text { gauge rail vehicles }\end{array}$ & \begin{tabular}{|l} 
Polish \\
Armed \\
Forces
\end{tabular} & WC & 56 & \\
\hline $\begin{array}{l}\text { Other } 750 \mathrm{~mm} \text { narrow- } \\
\text { gauge rail vehicles }\end{array}$ & \begin{tabular}{|l} 
Polish \\
Armed \\
Forces \\
\end{tabular} & WC & 57 & \\
\hline $\begin{array}{l}\text { Other } 1000 \mathrm{~mm} \text { narrow- } \\
\text { gauge rail vehicles }\end{array}$ & \begin{tabular}{|l|} 
Polish \\
Armed \\
Forces
\end{tabular} & WC & 58 & \\
\hline
\end{tabular}


Example of marking of an Ls-40 locomotive: WP-01-37280

Example of the marking of a 4 wheeled standard-gauge van: WP-K

(corresponding lower case letters as for Polish State Railways) 28-38325

\subsubsection{Road trailers for wagon transport}

In the 1930s, the German companies Deutz, Hanomag, Faun, Carl Kaelble produced road tractors with a power output of 150-200 HP (the heaviest ballast tractors were also supplied for Deutsche Reichsbahn), equipped with pneumatic combined brake systems. The production of such vehicles was connected with the modernisation of artillery regiments and the intensive development programme of construction of tracked and half-track armoured transporters and artillery tractors.

The universal Faun 150 HP tractor could also be used as a shunting locomotive after changing wheels. ${ }^{880}$

Technical progress has soon made it possible to link road and rail transport. In 1933, the German railways introduced a new transport service, which was made possible by the rapid development of the German automotive industry. It was addressed to customers without railway sidings. It consisted of the transport of railway wagons on special road trailers transported directly to the customer by road tractors described above. This way of handling was called fahrbare Anschlusgleis (which can be translated as a mobile siding). ${ }^{881}$ The distance of the delivery of the wagons from a railway station in this system did not exceed several kilometres. ${ }^{82}$

The idea of road trailers was modelled on narrow-gauge transporters, Rollbock, used from the beginning of the century for the transport of standard gauge wagons on narrow gauge tracks.

The construction of the road trailer was developed by a higher councillor of the Reich Railway (Reichsbahnoberat) Culemeyer on the basis of the guidelines issued by the Central Office of Railway Machinery of the Reich (ReichsbahnZentralamt für Maschinenbau ${ }^{883}$ ). The first trolleys were built by the Gotha Wagon Factory (Gothaer Waggonfabrik) in $1933 .{ }^{884}$

880 Kucharski, Drogowy transport, 1.

881 Kucharski, Drogowy transport, 1.

882 Kucharski, Drogowy transport, 1.

883 Das "fahrbare Anschlusgleis" in: Verkherstechnik (1933). Also in the article Transport (1955) an information is contained that it was Culemeyer who constructed the wagon trailers

884 Kucharski, Drogowy transport, 1. 
Road trailers were used to transport four-wheel wagons, with each trailer supporting one of the wagon's axles. One trolley generally had eight wheels connected in four pairs. ${ }^{885}$ All four axles were connected by rods, which forced the wheels to turn in an appropriate way when negotiating curves. Two rail beams were placed on the trailers, on which the wagon rested when it was placed on a front loading ramp. The trailers were connected with a telescopic bar. The distribution of the weight of the wagon over 16 wheels resulted in a single wheel load of $2.5 \mathrm{t}$, which was acceptable as a rear axle load of $3.75 \mathrm{t}$ would be used for lorries. When transporting a wagon weighing 60 tons, there was a weight of 3.75 tons per wheel. The set of trailers was equipped with a pneumatic brake. The trailers were loaded using a front loading ramp. Technical tests and operation have shown that thanks to the uniform weight distribution, good springing and the use of special axles, wagons transported on roads in such a way did not damage road surfaces as much as heavy lorries. Trolleys with loaded wagons were able to travel even through corners roads with a curve radius of up to $7.5 \mathrm{~m} .^{886}$

This transport system was of great military importance, as it ensured fast reloading-free delivery of military materials from the nearest railway station to field bases and warehouses (without the need for time-consuming construction of railway sidings). In addition to transporting railway wagons, the trailers could also be used for road transport of heavy loads - e.g. armoured vehicles (evacuation of damaged equipment from the battlefield). Culemeyer's trailers were used to transport heavy tanks and other armoured vehicles by road, especially for field repair bases. Thanks to good load distribution, it was possible to transport the heaviest tanks by road.

In Poland, road trailers appeared together with the German army during the preparations for the invasion on the USSR. Eugeniusz Mackiewicz, a railwayman from Sochaczew, has already mentioned how to use the trailers in an interesting way:

A few days before the attack on Russia, the Todt workers built a strange, short railway siding in front of our building with access from the front. We were wondering what it is for. We learned about it on the day the attack started. Low-floor trailers, which we saw for the first time, drove under the siding. They approached one by one, connected to the sidings track and transported tank wagons with petrol. It was an unusual sight from a distance, when a tank wagon train was driving on the road, carrying petrol to the airport in Bielice. ${ }^{887}$

885 Verkehrstechnik (1935), there is a photo of the most likely twelve-wheeled trolleys.

886 Cholewa (1949), 149.

887 Macewicz (2000), 64. 
At that time the Germans used the transport of tank wagons with airplane fuel to serve the field airport in Bielice, about 5 kilometres from Sochaczew (later a railway siding was connected to this airport). The transport of complete wagons eliminated the troublesome reloading and transport of loads. During the preparations for the invasion on the USSR, Germany built a large number of airports, bases and field warehouses in Poland, it can be assumed that not only the airport in Bielice was served by road trailers. However, there is no information on the other military use of such trailers. ${ }^{888}$

The post-war fate of this transport system in Poland is difficult to determine in view of the scarcity of archival material. A number of trailers was taken over by the Polish Armed Forces in the post-war period, it is not known whether they were used only for transporting railway wagons or also for transporting armoured vehicles. The only information confirming their military use in the post-war period is a brief description with a technical drawing contained in Instrukcja o stosowaniu urządzeń kolejowych dla potrzeb transportów wojskowych (Instructions on the use of railway equipment for military transport), ${ }^{889}$ in Chapter 5 Other railway equipment used in military transport we can read: "[...] Trailers for transporting wagons on the road [...] are used only for the transport of standard four-wheel wagons on hard surface roads with tractors with combined brakes, to warehouses outside the railway area." 890

In Dziennik taryf i zarządzen komunikacyjnych ${ }^{891}$ issued on 15th May 1950, there is an ordinance of the Minister of Communications on the use of road trailers for transporting railway wagons on roads.

This ordinance specifies a detailed description of trailers and how to use them. According to the provisions of this ordinance, the operation of such trailers was to be provided by the Polish Motor Transport Company (Państwowa Komunikacja Samochodwoa - PKS). Road ramps were to be maintained by PKS. This transport system was probably used until the mid-1950s. ${ }^{892}$

888 Kucharski Drogowy transport, 2.

889 Polish State Railways, Instrukcja o stosowaniu (1949).

890 Polish State Railways, Instrukcja o stosowaniu (1949), 73.

891 Dziennik (1950).

892 Kucharski, Drogowy transport, 1. 


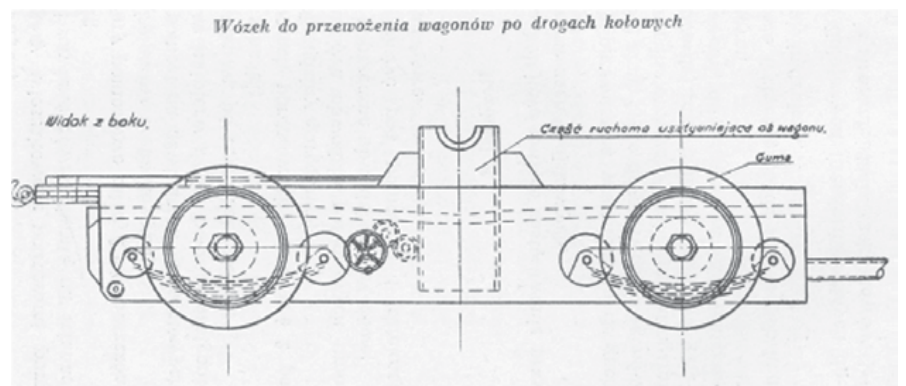

A trolley used for transporting railway wagons on roads.

Source: Polish State Railways, Instrukcja o stosowaniu (1949)

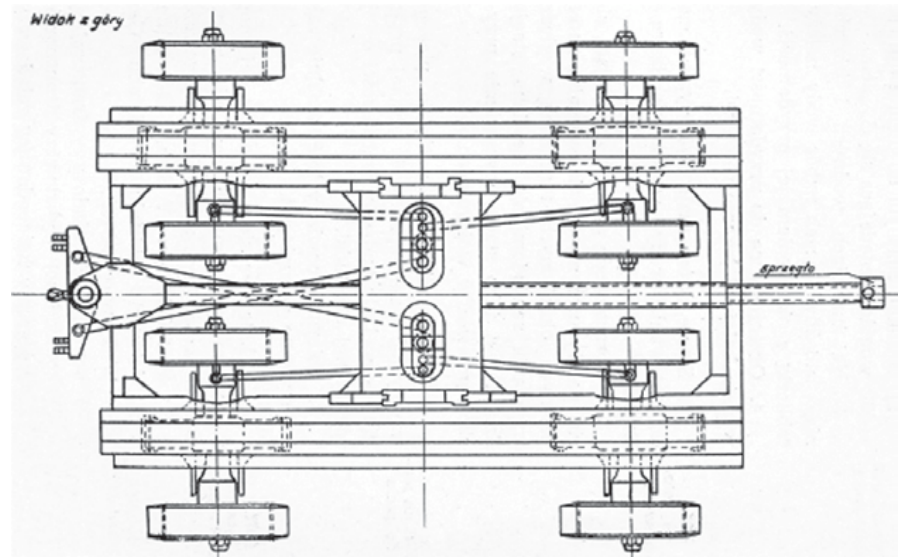

Source: Polish State Railways, Instrukcja o stosowaniu (1949)

\subsubsection{Narrow-gauge military tank wagons of the Ministry of National Defence}

For fuel delivery and supplies for military airports in Nowe Miasto nad Pilicą and Zegrze Pomorskie and for the Military Unit in Przasnysz, a decision was made to build narrow-gauge sidings from Nowe Miasto n. Pilica, Kurozwęcz and Przasnysz stations. These units were located at the Grójecko-Wilanowska, Mławska and Koszalinska narrow-gauge railway lines.

For the delivery of aviation fuel to the military airports in Nowe Miasto and Zegrze Pomorskie, the Ministry of National Defence requested an order from Zaodrzańskie Zakłady Metalowe im. Marcela Nowotki in Zielona Góra 
(formerly German manufacturer of wagons Beuchelt \& Co.) bogie $3 \mathrm{Rw}$ type tank wagons. The design of such a wagon was developed in 1956 in the Company Construction Office "Zastal" in Zielona Góra and intended for the Polish Armed Forces. These wagons were of fully welded construction. Tank wagons were equipped with a manual brake operated from the brake platform, adapted to the highest speed of $60 \mathrm{~km} / \mathrm{h}$. In total, in the years 1958-1959, 26 tank wagons were built in Zastal, intended for the airport in Nowe Miasto (16 tank wagons) and in Zegrze Pomorskie (10 tank wagons). These wagons were incorporated into the Polish State Railways rolling stock in 1959 - the wagons serving the airport in Nowe Miasto were assigned to the Piaseczno station, while the wagons serving the airport in Zegrze Pomorskie were assigned to Koszalin station.

At the end of the seventies a new type of tank wagon for the $1000 \mathrm{~mm}$ track gauge was developed for the Polish Armed Forces. This tank consisted of a narrow-gauge transporter type Tw9 Tddyhp series on which a standard-gauge four-wheeled tank wagon with cut-off axle journals was placed. The new tank wagon, which was marked with the Rgddyyhp series, had a larger tank capacity and an air brake. In 1977-1985, 35 tank wagons of this type were built for military airports in Nowe Miasto and Zegrze Pomorskie.

By the end of the 1980s, all $3 \mathrm{Rw}$ wagons had been taken out of service and replaced by new tanks on transporters. Old tank wagons were scrapped apart from a few abandoned at Piaseczno Miasto station and one, which was exhibited in the Branch of the Railway Museum in Gryfice. ${ }^{893}$

Technical data of $3 R w$ type tank wagon ${ }^{894}$

\begin{tabular}{|l|l|}
\hline Manufacturer & “Zastal” Zielona Góra \\
Type of construction & $3 \mathrm{Rw}$ \\
\hline Track gauge & $1000 \mathrm{~mm}$ \\
\hline Load capacity & $10 \mathrm{t}$ \\
\hline
\end{tabular}

893 On the narrow-gauge railways of the Warsaw Administration 3 tank wagons ( 1 at Warsaw Military District Nasielsk, 2 at Warsaw Military District Rogów) with dismantled bogies were set up as fire protection tanks for water and oil storage facilities. In the building of the locomotive depot in Koszalin, a $3 \mathrm{Rw}$ type tank wagon with no bogies was also installed.

894 Technical data on the basis: Central Construction Office of the Rolling Stock Industry - Poznań, Dokumentacja techniczna ... 3R. 


\begin{tabular}{|l|l|}
\hline Deadweight & $7443 \mathrm{kG}(7140)$ \\
\hline Length with bumpers & $8644 \mathrm{~mm}$ \\
\hline Chassis length & $7600 \mathrm{~mm}$ \\
\hline Wagon width & $1500 \mathrm{~mm}$ \\
\hline Max. wagon width & $1850 \mathrm{~mm}$ \\
\hline Max. wagon height & $3132 \mathrm{~mm}(1.60)$ \\
\hline Capacity & $115 \mathrm{hectolitre}$ \\
\hline Outer diameter of the tank & $1500 \mathrm{~mm}$ \\
\hline External length of the tank & $6900 \mathrm{~mm}$ \\
\hline Side sheet thickness & $6 \mathrm{~mm}$ \\
\hline Bottom plate thickness & $9 \mathrm{~mm}$ \\
\hline Sheet metal material for the tank bottom & St3s \\
\hline Test pressure & 3 atm. \\
\hline Bottom emptying of the tank wagon & $\varnothing 100$ \\
\hline Type of material transported & Petrol \\
\hline Weight of the material grade & 0.7 \\
\hline Bogie wheelbase & $1150 \mathrm{~mm}(1.10)$ \\
\hline Number of axles & 4 \\
\hline Wheel diameter & $600 \mathrm{~mm}(580 \mathrm{~mm})$ \\
\hline Diameter / length of axle pivot & $975 / 125$ \\
\hline $\begin{array}{l}\text { Distance between the wheelset's centres } \\
\text { bearings }\end{array}$ & $1345 \mathrm{~mm}$ \\
\hline Spacing of bogie pivots & $4700 \mathrm{~mm}$ \\
\hline Type of brake & Hand brake \\
\hline Platform or brake box & Brake platform \\
\hline Year of construction & 1956 \\
\hline Max. wagon speed & $60 \mathrm{~km} / \mathrm{h}$ \\
\hline Extreme axle spacing) & $(5.85 \mathrm{~m})$ \\
\hline
\end{tabular}


List of $3 \mathrm{Rw}$ type tank wagons $(1000 \mathrm{~mm})^{895}$ Koszalin station

\begin{tabular}{|l|l|l|l|}
\hline No. & $\begin{array}{l}\text { Old Polish State } \\
\text { Railways No. }\end{array}$ & $\begin{array}{l}\text { New Polish State } \\
\text { Railways No. }\end{array}$ & $\begin{array}{l}\text { Polish Armed } \\
\text { Forces No. }\end{array}$ \\
\hline 1. & Rdxh-72060 & $00-100744620-?$ & WP-WRRdh-54-43301 \\
\hline 2. & Rdxh-72061 & $00-100744621-?$ & WP-WRRdh-54-43302 \\
\hline 3. & Rdxh-72062 & $00-100744622-?$ & WP-WRRdh-54-43303 \\
\hline 4. & Rdxh-72063 & $00-100744623-?$ & WP-WRRdh-54-43304 \\
\hline 5. & Rdxh-72064 & $00-100744624-?$ & WP-WRRdh-54-43305 \\
\hline 6. & Rdxh-72065 & $00-100744625-?$ & WP-WRRdh-54-43306 \\
\hline 7. & Rdxh-72066 & $00-100744626-?$ & WP-WRRdh-54-43307 \\
\hline 8. & Rdxh-72067 & $00-100744627-?$ & WP-WRRdh-54-43308 \\
\hline 9. & Rdxh-72068 & $00-100744628-?$ & WP-WRRdh-54-43309 \\
\hline 10. & Rdxh-72069 & $00-100744629-?$ & WP-WRRdh-54-43310 \\
\hline
\end{tabular}

Piaseczno station

\begin{tabular}{|l|l|l|l|}
\hline No. & $\begin{array}{l}\text { Old Polish State } \\
\text { Railways No. }\end{array}$ & $\begin{array}{l}\text { New Polish State } \\
\text { Railways No. }\end{array}$ & $\begin{array}{l}\text { Polish Armed Forces } \\
\text { No. }\end{array}$ \\
\hline 1. & Rdx 72070 & $00-100744630-?$ & WP-WRRdh-54-43311 \\
\hline 2. & Rdx 72071 & $00-100744631-?$ & WP-WRRdh-54-43312 \\
\hline 3. & Rdx 72072 & $00-100744632-9$ & WP-WRRdh-54-43313 \\
\hline 4. & Rdx 72073 & $00-100744633-?$ & WP-WRRdh-54-43314 \\
\hline 5. & Rdx 72074 & $00-100744634-5$ & WP-WRRdh-54-43315 \\
\hline 6. & Rdx 72075 & $00-100744635-?$ & WP-WRRdh-54-43316 \\
\hline 7. & $\operatorname{Rdx} 72076$ & $00-100744636-?$ & WP-WRRdh-54-43317 \\
\hline
\end{tabular}

895 Ministry of Transport, Central Management of Narrow-gauge Railways, Ksiega inwentarzowa wagonów... $1000 \mathrm{~mm}$. 


\begin{tabular}{|c|l|l|l|}
\hline No. & $\begin{array}{l}\text { Old Polish State } \\
\text { Railways No. }\end{array}$ & $\begin{array}{l}\text { New Polish State } \\
\text { Railways No. }\end{array}$ & $\begin{array}{l}\text { Polish Armed Forces } \\
\text { No. }\end{array}$ \\
\hline 8. & Rdx 72077 & $00-100744637-8$ & WP-WRRdh-54-43318 \\
\hline 9. & Rdx 72078 & $00-100744638-6$ & WP-WRRdh-54-43319 \\
\hline 10. & Rdx 72079 & $00-100744639-4$ & WP-WRRdh-54-43320 \\
\hline 11. & Rdx 72080 & $00-100744640-?$ & WP-WRRdh-54-43321 \\
\hline 12. & Rdx 72081 & $00-100744641-?$ & WP-WRRdh-54-43322 \\
\hline 13. & Rdx 72082 & $00-100744642-?$ & WP-WRRdh-54-43323 \\
\hline 14. & Rdx 72083 & $00-100744643-6$ & WP-WRRdh-54-43324 \\
\hline 15. & Rdx 72084 & $00-100744644-?$ & WP-WRRdh-54-43325 \\
\hline 16. & Rdx 72085 & $00-100744645-1$ & WP-WRRdh-54-43326 \\
\hline
\end{tabular}

List of narrow-gauge tank wagons of Rgddyyhp, WP-WC-58 series built on Tddyyhp transporter wagons ( 35 vehicles) $)^{896}$

\begin{tabular}{|l|l|l|l|l|}
\hline No. & $\begin{array}{l}\text { Polish Armed } \\
\text { Forces No. }\end{array}$ & $\begin{array}{l}\text { Polish State } \\
\text { Railways No. }\end{array}$ & $\begin{array}{l}\text { Year of } \\
\text { tank wagon } \\
\text { construction: }\end{array}$ & Military Unit \\
\hline 1. & $\begin{array}{l}\text { WP-WC-58- } \\
43901\end{array}$ & $\begin{array}{l}\text { Rgddyyhp 00-20 } \\
0746001-?\end{array}$ & 1978 & $\begin{array}{l}\text { JW Zegrze Pom } \\
\text { DWLOT }\end{array}$ \\
\hline 2. & $\begin{array}{l}\text { WP-WC-58- } \\
43902\end{array}$ & $\begin{array}{l}\text { Rgddyyhp 00-20 } \\
0746002-?\end{array}$ & 1977 & $\begin{array}{l}\text { JW Zegrze Pom } \\
\text { DWLOT }\end{array}$ \\
\hline 3. & $\begin{array}{l}\text { WP-WC-58- } \\
43903\end{array}$ & $\begin{array}{l}\text { Rgddyyhp 00-20 } \\
0746003-?\end{array}$ & 1978 & $\begin{array}{l}\text { JW Zegrze Pom } \\
\text { DWLOT }\end{array}$ \\
\hline 4. & $\begin{array}{l}\text { WP-WC-58- } \\
43904\end{array}$ & $\begin{array}{l}\text { Rgddyyhp 00-20 } \\
0746004-?\end{array}$ & 1978 & $\begin{array}{l}\text { JW Zegrze Pom } \\
\text { DWLOT }\end{array}$ \\
\hline
\end{tabular}

896 Please note that the military numbers coincide with the flat wagon numbers WP-WPPx-44 KPW Hel $(600 \mathrm{~mm})$. On the basis: Headquarters of the Military Transport Service of the Headquarters of the Polish Armed Forces, Listing and Narrow-gauge Railways Management Warszawa. 


\begin{tabular}{|c|c|c|c|c|}
\hline No. & $\begin{array}{l}\text { Polish Armed } \\
\text { Forces No. }\end{array}$ & $\begin{array}{l}\text { Polish State } \\
\text { Railways No. }\end{array}$ & $\begin{array}{l}\text { Year of } \\
\text { tank wagon } \\
\text { construction: }\end{array}$ & Military Unit \\
\hline 5. & $\begin{array}{l}\text { WP-WC-58- } \\
43905\end{array}$ & $\begin{array}{l}\text { Rgddyyhp 00-20 } \\
0746 \text { 005-? }\end{array}$ & 1977 & $\begin{array}{l}\text { JW Zegrze Pom } \\
\text { DWLOT }\end{array}$ \\
\hline 6. & $\begin{array}{l}\text { WP-WC-58- } \\
43906\end{array}$ & $\begin{array}{l}\text { Rgddyyhp 00-20 } \\
0746 \text { 006-? }\end{array}$ & 1978 & $\begin{array}{l}\text { JW Zegrze Pom } \\
\text { DWLOT }\end{array}$ \\
\hline 7. & $\begin{array}{l}\text { WP-WC-58- } \\
43907\end{array}$ & \begin{tabular}{|l} 
Rgddyyhp 00-20 \\
0746 007-0
\end{tabular} & 1984 & $\begin{array}{l}\text { JW Zegrze Pom } \\
\text { DWLOT }\end{array}$ \\
\hline 8. & $\begin{array}{l}\text { WP-WC-58- } \\
43908 \\
\end{array}$ & $\begin{array}{l}\text { Rgddyyhp 00-20 } \\
\text { 0746 008-? }\end{array}$ & 1984 & \begin{tabular}{|l} 
JW Zegrze Pom \\
DWLOT
\end{tabular} \\
\hline 9. & $\begin{array}{l}\text { WP-WC-58- } \\
43909\end{array}$ & $\begin{array}{l}\text { Rgddyyhp 00-20 } \\
0746 \text { 009-6 }\end{array}$ & 1984 & $\begin{array}{l}\text { JW Zegrze Pom } \\
\text { DWLOT }\end{array}$ \\
\hline 10. & $\begin{array}{l}\text { WP-WC-58- } \\
43910\end{array}$ & $\begin{array}{l}\text { Rgddyyhp 00-20 } \\
0746 \text { 010-? }\end{array}$ & 1984 & $\begin{array}{l}\text { JW Zegrze Pom } \\
\text { DWLOT }\end{array}$ \\
\hline 11. & $\begin{array}{l}\text { WP-WC-58- } \\
43911\end{array}$ & $\begin{array}{l}\text { Rgddyyhp 00-20 } \\
\text { 0746 011-? }\end{array}$ & 1984 & $\begin{array}{l}\text { JW Zegrze Pom } \\
\text { DWLOT }\end{array}$ \\
\hline 12. & $\begin{array}{l}\text { WP-WC-58- } \\
43912 \\
\end{array}$ & $\begin{array}{l}\text { Rgddyyhp 00-20 } \\
0746 \text { 012-? }\end{array}$ & 1984 & $\begin{array}{l}\text { JW Zegrze Pom } \\
\text { DWLOT }\end{array}$ \\
\hline 13. & $\begin{array}{l}\text { WP-WC-58- } \\
43913\end{array}$ & $\begin{array}{l}\text { Rgddyyhp 00-20 } \\
0746 \text { 013-? }\end{array}$ & 1981 & $\begin{array}{l}\text { JW Nowe Miasto } \\
\text { DWLOT }\end{array}$ \\
\hline 14. & $\begin{array}{l}\text { WP-WC-58- } \\
43914\end{array}$ & $\begin{array}{l}\text { Rgddyyhp 00-20 } \\
0746 \text { 014-? }\end{array}$ & 1977 & $\begin{array}{l}\text { JW Nowe Miasto } \\
\text { DWLOT }\end{array}$ \\
\hline 15. & $\begin{array}{l}\text { WP-WC-58- } \\
43915\end{array}$ & $\begin{array}{l}\text { Rgddyyhp 00-20 } \\
0746 \text { 015-? }\end{array}$ & 1981 & $\begin{array}{l}\text { JW Nowe Miasto } \\
\text { DWLOT }\end{array}$ \\
\hline 16. & $\begin{array}{l}\text { WP-WC-58- } \\
43916 \\
\end{array}$ & $\begin{array}{l}\text { Rgddyyhp 00-20 } \\
\text { 0746 016-? }\end{array}$ & 1981 & $\begin{array}{l}\text { JW Nowe Miasto } \\
\text { DWLOT }\end{array}$ \\
\hline 17. & $\begin{array}{l}\text { WP-WC-58- } \\
43917\end{array}$ & $\begin{array}{l}\text { Rgddyyhp 00-20 } \\
\text { 0746 017-? }\end{array}$ & 1985 & $\begin{array}{l}\text { JW Zegrze Pom } \\
\text { DWLOT }\end{array}$ \\
\hline 18. & $\begin{array}{l}\text { WP-WC-58- } \\
43918\end{array}$ & $\begin{array}{l}\text { Rgddyyhp 00-20 } \\
0746 \text { 018-? }\end{array}$ & 1985 & $\begin{array}{l}\text { JW Zegrze Pom } \\
\text { DWLOT }\end{array}$ \\
\hline
\end{tabular}




\begin{tabular}{|c|c|c|c|c|}
\hline No. & $\begin{array}{l}\text { Polish Armed } \\
\text { Forces No. }\end{array}$ & $\begin{array}{l}\text { Polish State } \\
\text { Railways No. }\end{array}$ & $\begin{array}{l}\text { Year of } \\
\text { tank wagon } \\
\text { construction: }\end{array}$ & Military Unit \\
\hline 19. & $\begin{array}{l}\text { WP-WC-58- } \\
43919\end{array}$ & $\begin{array}{l}\text { Rgddyyhp 00-20 } \\
0746 \text { 019-? }\end{array}$ & 1985 & $\begin{array}{l}\text { JW Zegrze Pom } \\
\text { DWLOT }\end{array}$ \\
\hline 20. & $\begin{array}{l}\text { WP-WC-58- } \\
43920\end{array}$ & $\begin{array}{l}\text { Rgddyyhp 00-20 } \\
0746 \text { 020-? }\end{array}$ & 1985 & $\begin{array}{l}\text { JW Zegrze Pom } \\
\text { DWLOT }\end{array}$ \\
\hline 21. & $\begin{array}{l}\text { WP-WC-58- } \\
43921\end{array}$ & $\begin{array}{l}\text { Rgddyyhp 00-20 } \\
0746 \text { 021-? }\end{array}$ & 1985 & $\begin{array}{l}\text { JW Nowe Miasto } \\
\text { DWLOT }\end{array}$ \\
\hline 22. & $\begin{array}{l}\text { WP-WC-58- } \\
43922\end{array}$ & $\begin{array}{l}\text { Rgddyyhp 00-20 } \\
0746 \text { 022-9 }\end{array}$ & 1985 & $\begin{array}{l}\text { JW Nowe Miasto } \\
\text { DWLOT }\end{array}$ \\
\hline 23. & $\begin{array}{l}\text { WP-WC-58- } \\
43923\end{array}$ & $\begin{array}{l}\text { Rgddyyhp 00-20 } \\
0746 \text { 023-7 }\end{array}$ & 1985 & $\begin{array}{l}\text { JW Nowe Miasto } \\
\text { DWLOT }\end{array}$ \\
\hline 24. & $\begin{array}{l}\text { WP-WC-58- } \\
43924\end{array}$ & $\begin{array}{l}\text { Rgddyyhp 00-20 } \\
0746 \text { 024-? }\end{array}$ & 1985 & $\begin{array}{l}\text { JW Nowe Miasto } \\
\text { DWLOT }\end{array}$ \\
\hline 25. & $\begin{array}{l}\text { WP-WC-58- } \\
43925\end{array}$ & $\begin{array}{l}\text { Rgddyyhp 00-20 } \\
0746 \text { 025-? }\end{array}$ & 1985 & $\begin{array}{l}\text { JW Nowe Miasto } \\
\text { DWLOT }\end{array}$ \\
\hline 26. & $\begin{array}{l}\text { WP-WC-58- } \\
43926\end{array}$ & $\begin{array}{l}\text { Rgddyyhp 00-20 } \\
0746 \text { 026-0 }\end{array}$ & 1985 & $\begin{array}{l}\text { JW Nowe Miasto } \\
\text { DWLOT }\end{array}$ \\
\hline 27. & $\begin{array}{l}\text { WP-WC-58- } \\
43927\end{array}$ & $\begin{array}{l}\text { Rgddyyhp 00-20 } \\
0746 \text { 027-? }\end{array}$ & 1985 & $\begin{array}{l}\text { JW Nowe Miasto } \\
\text { DWLOT }\end{array}$ \\
\hline 28. & $\begin{array}{l}\text { WP-WC-58- } \\
43928\end{array}$ & $\begin{array}{l}\text { Rgddyyhp 00-20 } \\
\text { 0746 028-? }\end{array}$ & 1985 & $\begin{array}{l}\text { JW Nowe Miasto } \\
\text { DWLOT }\end{array}$ \\
\hline 29. & $\begin{array}{l}\text { WP-WC-58- } \\
43929\end{array}$ & $\begin{array}{l}\text { Rgddyyhp 00-20 } \\
0746 \text { 029-? }\end{array}$ & 1985 & $\begin{array}{l}\text { JW Nowe Miasto } \\
\text { DWLOT }\end{array}$ \\
\hline 30 & $\begin{array}{l}\text { WP-WC-58- } \\
43930\end{array}$ & $\begin{array}{l}\text { Rgddyyhp 00-20 } \\
0746 \text { 030-? }\end{array}$ & 1985 & $\begin{array}{l}\text { JW Nowe Miasto } \\
\text { DWLOT }\end{array}$ \\
\hline 31 & $\begin{array}{l}\text { WP-WC-58- } \\
43931\end{array}$ & $\begin{array}{l}\text { Rgddyyhp 00-20 } \\
\text { 0746 031-? }\end{array}$ & 1985 & $\begin{array}{l}\text { JW Nowe Miasto } \\
\text { DWLOT }\end{array}$ \\
\hline 32 & $\begin{array}{l}\text { WP-WC-58- } \\
43932\end{array}$ & $\begin{array}{l}\text { Rgddyyhp 00-20 } \\
0746 \text { 032-? }\end{array}$ & 1985 & $\begin{array}{l}\text { JW Zegrze Pom } \\
\text { DWLOT }\end{array}$ \\
\hline
\end{tabular}




\begin{tabular}{|l|l|l|l|l|}
\hline No. & $\begin{array}{l}\text { Polish Armed } \\
\text { Forces No. }\end{array}$ & $\begin{array}{l}\text { Polish State } \\
\text { Railways No. }\end{array}$ & $\begin{array}{l}\text { Year of } \\
\text { tank wagon } \\
\text { construction: }\end{array}$ & Military Unit \\
\hline 33 & $\begin{array}{l}\text { WP-WC-58- } \\
43933\end{array}$ & $\begin{array}{l}\text { Rgddyyhp 00-20 } \\
0746033-?\end{array}$ & 1985 & $\begin{array}{l}\text { JW Zegrze Pom } \\
\text { DWLOT }\end{array}$ \\
\hline 34 & $\begin{array}{l}\text { WP-WC-58- } \\
43934\end{array}$ & $\begin{array}{l}\text { Rgddyyhp 00-20 } \\
0746034-?\end{array}$ & 1985 & $\begin{array}{l}\text { JW Zegrze Pom } \\
\text { DWLOT }\end{array}$ \\
\hline 35 & $\begin{array}{l}\text { WP-WC-58- } \\
43935\end{array}$ & $\begin{array}{l}\text { Rgddyyhp 00-20 } \\
0746035-?\end{array}$ & 1985 & $\begin{array}{l}\text { JW Zegrze Pom } \\
\text { DWLOT }\end{array}$ \\
\hline
\end{tabular}


Zbigniew Tucholski - 978-3-631-82966-0 Downloaded from PubFactory at 09/30/2020 04:51:29PM by keerthiga.m@newgen.co via Peter Lang AG and keerthiga.m@newgen.co 


\section{CONCLUSION}

In the 1930s, together with the motorisation of military transport and the development of armoured weapons (the change of tactics of its use as independent units operating on the front and not as a weapon of infantry support), there was a decrease in the importance of rail transport in operational transport.

The development of aviation, in turn, led an Italian strategist General Giulio Douhet, at the end of the 1920s, to formulate a doctrine of a total air war, because the increasing range and impact power of aviation meant that this type of weapon began to threaten in no small extent the enemy's facilities, including the railway infrastructure, which was vulnerable to damage. Also the development of artillery and increasing the range and effectiveness of artillery fire (introduction of modern rangefinders and fire control systems for army equipment) deepened these tendencies. The railway infrastructure was also vulnerable to attacks from partisan and sabotage troops. As a result of the existing threats, the protection of railway lines in the deep hinterland entailed considerable forces that could not be used at the front.

In the 1930s, military theorists pointed to the shortcomings of rail transport: limited manoeuvrability, attachment to the track and high vulnerability to air strikes and artillery fire. In 1934 General Władysław Sikorski in his visionary work "The Future War" characterised these tendencies in the following way: "Air attacks are extremely dangerous for rail transport. Train routes are well known and outlined in the field, their major stations, viaducts, and bridges will in the future be sensitive to bombs and missiles even at night. The railway network has a lot of such locations. Their destruction may seriously paralyse rail traffic, causing long-lasting transport delays, and with today's growth in aviation, making it partly impossible." ${ }^{\text {9 }}$

As a consequence of the revolutionary changes in the battlefield during the Second World War, rail transport lost its priority and became a means of delivering operational transports and supplies to the rear of the operations. However, it continued to play a leading role in the delivery of reinforcements and supplies for the fighting troops. In difficult terrain conditions of the Russian off-roads of the Eastern Front, it continued to play a significant role in operational transport as well.

897 Sikorski (1984), 250. 
The adaptation of the transport system in the People's Republic of Poland to the transport tasks in the case of war, in the Western and Seaside Operational Direction, which has been carried out since the beginning of the 1950s, served precisely these purposes. The new Soviet doctrine of the operational rear together with the development of the theory of nuclear war assumed the adaptation of the transport network to function in the conditions of a new type of conflict. ${ }^{898}$

It was assumed that all means of transport would be used at the same time and that there would be a rapid shift from one mean of transport to another. However, already in the sixties and seventies, when strategic aviation became the dominant element of the modern battlefield, rocket artillery and air-landing units, rail transport in the back of operations lost its dominant importance. The attachment to the traditional use of land troops (crushing attacks of armoured and mechanised forces) in the conditions of a total conflict with the use of nuclear weapons was a sign of an anachronism of the Warsaw Pact strategists. The use of folding railway bridges assembled from SEK-500 overpass and the NZM-56 bridge elements, which were planned in the case of war, also had the main disadvantage of masking the crossing, apart from many advantages. Each folding bridge was a clear, immovable and uncovered target, and the concentration of engineering and transport equipment during its construction exposed the intentions to build a temporary crossing. ${ }^{899}$ Also, the organisation of Temporary Transhipment Areas did not ensure the confidentiality of their location in the event of the use of aerial reconnaissance and modern means of electronic intelligence.

The operational assumptions concerning the use of rail transport, which were adopted in spite of the defects and deficiencies identified, were consistently implemented until 1990. It is impossible to assess the actions taken in a completely unambiguous way. On the one hand, investments carried out in 1945-1990 on the Polish railway network related to its adaptation to wartime tasks were one of the significant factors of technological underdevelopment and limited rational management in Polish State Railways. However, the consolidation and expansion of the railway network through the construction of connections and detours of junctions and sensitive railway sections have become

898 At that time all the significant armies were working to preserve the vitality of transport and telecommunications systems in a nuclear war. It should be emphasized that the prototype of Internet was a military ICT network, the aim of which was to maintain efficiency in the conditions of a nuclear war (destruction of the central computers, automatic operation in the network of other active computers).

899 Białobrzeski (1978), 9. 
a factor increasing the efficiency of railway transport use, facilitating the organisation of railway traffic. Some of the Permanent Transhipment Areas (built with considerable effort and resources only for military purposes during the war) at the meeting points of the Russian and Polish railway networks (apart from the closed and inactive ones) are currently used to a large extent for the transhipment of goods in trade with Belarus and Russia, and they are of great economic importance. Finally, it is impossible not to notice the significant contribution made by the military rail and road units, which, since the 1950s, have invested in the construction of railway lines and engineering structures and carried out continuous replacement of the railway surface and infrastructure repairs. Also, military folding bridge structures have been widely used in peacetime for many years, as bypassing and temporary bridges. In this way, actions taken for strictly military purposes have found their application in the time of peace, mechanisms of this kind best explain in the words of the English thinker and politician Edmund Burke: [...] "Nor will short experience introduce us to this practical science, because the real effects of social enterprises are not always direct; something that at first glance seems harmful may bear excellent fruit in the future, and the initially unsuccessful results may contribute to this perfection. There are also reverse situations: very credible projects, which are promising at first glance, often have disgraceful and regrettable consequences."

The changes which resulted in a decline in the importance of classical types of military transport had a much broader dimension, due to the extremely rapid pace of technological development.

The introduction of tactical thermonuclear weapons for the US army, NATO and the Warsaw Pact, as well as the intensive development of long-range missile weapons and strategic aviation, has led to a situation in which any use of such weapons would be the cause of extermination of both sides of the conflict. It should be stressed that the total nature of a nuclear war did not provide for the possibility for both sides to retreat the fighting troops. Also, the first-line tactical units attacking at high speed would be exposed to high levels of radiation. This necessitated an increase in the rate of attack in order to exploit the combat capability of first-line units before the development of the radiation disease.

The main factor that led to a situation where weapons of this type could not achieve superiority over the opponent and success was the intensive development of military satellites, radiolocation systems, electronic intelligence and modern cryptology in the 1960s. New means of reconnaissance meant that every regrouping of troops or even opening of a rocket silos or raising the rocket to the launcher was "seen" by the enemy - this way the element of surprise was eliminated. 
Soon it turned out that the assumed operational goals could not be achieved with weapons of mass destruction. Thus one of Clausewitz's main theses that war is a continuation of the politics conducted by means of war has become obsolete in Europe at that time. Nearly one hundred years after the creation of the work Przyszła wojna [Future war], the central premise of Jan Gottlieb Bloch's doctrine of the impossibility of the outbreak of a common war due to its destructive nature is still valid. At that time Bloch argued that the extremely rapid technological development of armaments and the destructive nature of a total war would make both sides of the conflict hostage to modern military technologies, which cannot be used without risking the total annihilation of the army and the citizens of their own countries.

In other words, the assessments - premature, as it turned out at the time have now been confirmed with the introduction of thermonuclear weapons. Since then, the ownership of the thermonuclear arsenal could only be seen in terms of psychological war, and its possible use, in consequence, could lead to the extinction of life on Earth. Since then, the confrontation of opposing camps has become a field of influence all over the world, where armed conflicts for indirect confrontation and testing of new types of weapons have been fuelled. The technological change has shifted conflicts more into economic. The arms race lost by Russia and the Warsaw Pact was the cause of the economic crisis, which de facto became one of the leading reasons of the fall of communism. 


\section{BIBLIOGRAPHY}

\section{Studies}

Gembora M., Wojska kolejowe (unpublished material), Military Office of Historical Research Archive, reference number 1138.

Kucharski M., Drogowy transport wagonów normalnotorowych (unpublished material, author's archive).

Skrypt. Koleje żelazne, Course for the officers of the General Staff, Warsaw 1919.

Strózik R., Wojska kolejowe 1944-1946 (Master thesis at the Department of History at Political-Military Academy), Military Office of Historical Research Archive, ref. 1036.

Headquarters of the Military Transporrt Service, Chief Quartermaster of the Polish Armed Forces, Zarys historii Szefostwa Stużby Komunikacji Wojskowej (unpublished material).

Bureau of Transport and Military Movement - Coordination Centre for Military Movement, Rys historyczny Oddziału Komunikacji Wojskowej Warszawskiego Okregu Wojskowego (unpublished material).

Szponder J., Tucholski Z., Lista fabryczna Pierwszej Fabryki Lokomotyw w Polsce Sp. Akc. w Chrzanowie (unpublished material).

\section{Magazines and Journals}

Borowiec J. “Stalowe Szlaki," Przeglad Mechaniczny No. 10/October 1990 (Reprint of a part).

Dziennik taryf i zarzadzeń komunikacyjnych of 15 May 1950.

"Das fahrbare Anschlusgleis," Verkherstechnik, book of 20th May 1933.

Kola R., "Most pod Kwidzynem (1909-1928)," Świat Kolei No. 8, 2001.

Kuczera A., "Tunel łupkowski - 10 lat ponownej eksploatacji," Świat Kolei, No. 5, 2007.

Kwiatkowski M., "Wojskowy rejon przeładunkowy w Skandawie," Eksplorator No. 8.

Labuda K., "Wojskowa kolej wąskotorowa na Helu," Świat Kolei No. 9, 2002.

Mioduszewski K., "Powstanie i organizacja służby komunikacji wojskowej w armii polskiej po I wojnie światowej," Przegląd Kwatermistrzowski No. 1/134, 1974. 
Szynkiewicz A., "Elektryczna Śląska Kolej Górska," Koleje Dawniej i Dziś No. 1, 2004.

“Transport w Pojemnikach," Motoryzacja, No. 11, 1955.

Zamkowska S., "Wojskowy transport kolejowy 1944-1945 Problemy i koncepcje wykorzystania transportu kolejowego dla potrzeb wojskowych i gospodarczych kraju," Wojskowy Przeglad Historyczny No. 1, 1982.

\section{Military regulations and instructions}

[Czaplin K.A.], Sprawocznyi sbornik k prawilam podgatowki żeleznych darog $k$ masowym perewozkam wojsk, Moscow 1895.

Ministry of Transport, D 29, Wykaz linii kolejowych i ich klasyfikacja na poszczególne kategorie, Warsaw 1985.

Ministry of Transport, Instrukcja o organizacji i wykonywaniu wojskowych przewozów kolejowych, Warsaw 1958.

Ministry of Transport, Pk-31, Instrukcja o przygotowaniu, wyposażaniu, zestawianiu i pracy wojskowych pociagów sanitarnych, Warsaw 1970.

Ministry of Transport, Podręcznik odbudowy zniszczeń na kolejach, Warsaw 1939.

Ministry of Transport, Przepisy o przewozach wojskowych dla ZSRR, Warsaw 1945.

Ministry of Transport, Przepisy o wojskowych przewozach na kolejach PRL dla wojsk radzieckich czasowo stacjonujacych w Polsce, Warsaw 1954.

Ministry of Transport, Przepisy tymczasowe o przepuszczaniu pociagów ZSRR przez koleje polskie, Warsaw 1946.

Ministry of Transport, Warunki techniczne projektowania oraz budowy lub odbudowy doraźnej lub tymczasowej nawierzchni kolejowych, Warsaw 1965.

Ministry of Military Affairs, Department V of Technical Forces, Manual of Railway Minesweepers, Budowa wojennych mostów kolejowych składanych syst. "R.W." $i$ " $K$ ", Warsaw 1926.

Ministry of Military Affairs, Instrukcja o wojskowych transportach kolejowych, Warsaw 1932.

Ministry of Military Affairs, Instrukcja saperska do użytku wszystkich rodzajów broni, Warsaw 1930.

Ministry of National Defence, Charakterystyka zasadniczych przeszkód wodnych i przepraw stalych na środkowoeuropejskim TDW, Warsaw 1982.

Ministry of National Defence, Instrukcja saperska materiały wybuchowe i niszczenia, Warsaw 1947. 
Ministry of National Defence, Przepisy o eksploatacji wojskowych bocznic kolejowych, Warsaw 1960.

Ministry of National Defence, Przepisy o gospodarce kolejami wojskowymi i wojskowym taborem kolejowym, Warsaw 1975.

Ministry of National Defence, Headquarters of Transport, 33/64, Komunikacja wojskowa, Warsaw 1965.

Ministry of National Defence, Headquarters of Transport, 40/66, Instrukcja budowy i eksploatacji lokomotywy spalinowej Ls150 (SM03), Warsaw 1967.

Ministry of National Defence, Headquarters of Transport, 48/67, Instrukcja budowy i eksploatacji lokomotywy spalinowej Ls40 (SM02), Warsaw 1969.

Ministry of National Defence, General Staff, 118/53, Zbiór przykładów bojowych z działań zaczepnych oddziałów i pododdziałów 1 Armii Wojska Polskiego połączonych z pokonywaniem przeszkód wodnych wodnych, Warsaw 1953.

Ministry of National Defence, Ministry of Transport, 181/56, Rozgromienie wojsk niemiecko-faszystowskich w Polsce, Operacja Wiślańsko-Odrzańska (styczeń 1945 r.), Warsaw 1956.

Ministry of National Defence, General Staff, Doświadczenia i wnioski z ćwiczenia "BAŁTYK-ODRA", Warsaw November 1962.

Ministry of National Defence, Tymczasowa instrukcja o wojskowych transportach kolejowych, Warsaw 1947.

Ministry of Railways, Przepisy eksploatacji technicznej kolei, Warsaw 1956.

Okólnik Ministerstwa Komunikacji nr CZD7/57 of 7 February 1957.

Polish State Railways, D 1, Przepisy budowy i utrzymania nawierzchni na kolejach o torze normalnym, Warsaw 1957.

Polish State Railways, D 29, Wykaz linii, łącznic i torów łączących, Warsaw 1995.

Polish State Railways, Instrukcja o stosowaniu urządzeń kolejowych dla potrzeb transportów wojskowych, Warsaw 1949.

Polish State Railways, Polsko-Radziecka Bezpośrednia Komunikacja Kolejowa, Przepisy o przepuszczaniu pociagów ZSRR przez Polskie Koleje Państwowe, approved on 1 June 1950.

Polish State Railways, Przepisy o postępowaniu na PKP w czasie pokoju przy przewozach wojskowych ładunków amunicji, materiałów wybuchowych, środków zapalających i materiałów trujących (jadowitych), Warsaw 1950.

Polish State Railways, R 57, Przepisy o przewozie przesyłek nadzwyczajnych, Warsaw 1980.

Polish State Railways, Dodatek 5 do stużbowego rozkładu jazdy zawierajacy tablice odległości do obliczania osio-kilometrów, ważny od dnia 27 maja 1990 r., Lublin 1990. 
Polish State Railways, Wykaz zmian i uzupetnień do Przepisów o przepuszczaniu pociągów ZSRR przez PKP, Warsaw 1951.

Przepisy ruchu na kolejach wąskotorowych użytku publicznego W 2, Warsaw 1948.

General Staff, VII Unit (scientific), Instrukcja minerska, Warsaw 1919.

Minister of Communication Regulation No. 21, 17 January 1963, on the principles for maintenance and operation of non-public railways used by the Ministry of National Defence and Ministry of Internal Affairs.

\section{Secondary sources}

Adamczak A., Balewski A., Stochmal J., Stacja Toruń Główny, 1861-1995, rys historyczny, Toruń 1996.

Antipenko N., Na głównym kierunku, Warszawa 1970.

Białobrzeski T., Mosty składane, Warszawa 1978.

Bloch J., Przyszła wojna, Warszawa 1900, vol. I-II.

Cholewa Z., Urzadzenia przeładunkowe, Warszawa 1949.

Bochenek R., Fortyfikacja rosyjska na ziemiach polskich, stan badań i problemy ochrony, Warszawa-Kraków 1996.

Dzieje Katowickiego Okregu Kolejowego, Katowice 1997.

Gawroński W., Kolejnictwo rosyjskie w okresie wojny światowej 1914-1918, Warszawa 1930.

Gołowin N., Rossija w perwoi mirawoi woinie, Moscow 2006, 363-364.

Izdebski H., Kulesza M., Administracja publiczna, zagadnienia ogólne, Warszawa 2000.

Krogulski M., Okupacja w imię sojuszu, Warszawa 2000.

Kroma R., Sosiński J., Poznański węzeł kolejowy wczoraj i dziś, Poznań 2003.

Kuczborski S., 25 lat elektryfikacji PKP, Warszawa 1963.

Kuhlmann A., Eisenbahnen über die Oder-Neiße-Grenze, Pürgen 2004.

Laskowski P., Wroński A., Świnoujskie fortyfikacje, Świnoujście 1999.

Lijewski T., Koziarski S., Rozwój sieci kolejowej w Polsce, Warszawa 1995.

Lijewski T., Lenk J., Piotrowska H., Rozwój komunikacji kolejowej i autobusowej w Polsce w okresie 1946-1965, Warszawa 1967.

Łaniec S., Partyzanci żelaznych dróg roku 1863, Warszawa 1974.

Łaszkiewicz H., Gospodarka parowozowa na kolejach, Warszawa 1959.

Macewicz E., "M3". Wspomnienia młodego kolejarza łacznika w Szarych

Szeregach i AK 1939-1945, Warszawa 2000.

Mała encyklopedia wojskowa, vol 2, Warszawa 1970. 
Nowak E., Komunikacje i wojna, Warszawa 1994.

Odbudowa mostów kolejowych. Stalowe konstrukcje składane, Part I, Warszawa 1966; Part II, Warszawa 1968.

Odrodzenie polskiego kolejnictwa, Warszawa 1947.

Orzechowska H., Orzechowski F., Architektura obronna województwa Warszawskiego, twierdza Warszawa i twierdza Modlin, Warszawa 1989.

Osóbka-Morawski E., Dziennik polityczny 1943-1948, Gdańsk 1981.

Owsińska A., Powstanie palatynacko-badeńskie 1849 roku oraz udział w nim Polaków, Wrocław-Warszawa-Kraków 1965.

Paszke A., Jerczyński M., Koziarski S., 150 lat Drogi Żelaznej WarszawskoWiedeńskiej, Warszawa 1995.

Pisarski M., Koleje Polskie, Warszawa 1974.

Pociagi pancerne 1918-1943 organizacja - struktura - działania wojenne, Białystok 1999.

Sikorski W., Przyszła wojna, Warszawa 1984.

Sterner W., Mosty Warszawy, Warszawa 1960.

[Tchaplin K.A.], Spravochnyi sbornik k pravilam podgatovki zheleznyih darog $k$ masovym perevozkam woyisk, Moscow 1895.

Tjagowoje chazjaistwo, Moscow 1935.

Walbiner Z., Lokomotywa spalinowa serii SM30, Warszawa 1966.

Wielopolski A., Zarys dziejów transportu, Szczecin 1969.

Witkowski R., Hel na straży wybrzeża 1920-1939, Warszawa 1974.

Wojasiewicz W., Mosty dróg żelaznych Królestwa Polskiego, Warszawa 1982.

Wrześniowski T., Odbudowa mostów, vol. 1, Warszawa 1955.

Wyszczelski L., Historia polskiej myśli wojskowej, Warszawa 2001.

Zamkowska S., Odbudowa i funkcjonowanie kolei polskich 1944-1949, Warszawa 1984.

Żeleznodorożniki w welikoi oteczestwennoj wojnie, Moscow 1987.

Żotnierze żelaznych szlaków. Wspomnienia polskich kolejarzy 1939-1945, Warszawa 1988.

\section{Archival materials}

Agreement on the inclusion of Ministry of National Defence tank wagons into the Polish State Railways rolling stock of 11th Aug. 1959, (author's archive). 
Admnistration of Logistics, Ministry of National Defence, Ewidencja taboru wojskowego, (author's archive).

Central Management of Narrow-gauge Railways, Ksiega inwentarzowa parowozów wąskotorowych PKP, Warsaw 1948 '(author's archive)'

Central Construction Office of Rolling Stock Industry - Poznań, Dokumentacja techniczna cysterny w/t typu $2 R w$ do przewozu benzyny, (author's archive).

Central Construction Office of Rolling Stock Industry - Poznań, Dokumentacja techniczna cysterny w/t typu $3 R w$ do przewozu benzyny, (author's archive).

Command of the Military Transports Service, Warsaw Military District, Analiza prognozowanych zniszczeń bronia konwencjonalna sieci komunikacyjnej na obszarze WOW, Warsaw 1978, (photocopy in author's archive).

Dokumentacja motowozu Deutz nr 398, (author's archive).

Dokumentacja odbiorcza kotła parowozu Krenau 801/40, (author's archive).

Dokumentacje (ksiażki spalinowego pojazdu trakcyjnego) poszczególnych lokomotyw wojskowych, (odpisy przebiegów służby lokomotyw w zbiorach autora).

Fablok-Chrzanów, Correspondence of Fablok Chrzanów on approval of Krenau steam locomotive boiler No. 801, (author's archive).

Fablok-Chrzanów, Dokumentacja techniczno-ruchowa lokomotywy spalinowej typu Ls150, (author's archive).

Fablok-Chrzanów, Dokumentacja techniczno-ruchowa lokomotywy typu Ls40, (author's archive).

Fablok-Chrzanów, Dokumentacja techniczno-ruchowa lokomotywy typu Ls300, (author's archive).

Headquarters of the Headquarters of Military Transport, Chief Quartermaster of the Polish Armed Forces, Materiaty ewidencyjne taboru wojskowego, (author's archive).

Head of the Headquarters of Military Transport, Ewidencja taboru wojskowego, (author's archive).

Headquarters of Military Transport at Regional State Railway Management in Warsaw, Ogólna charakterystyka techniczno-eksploatacyjna linii, obiektów i urządzeń sieci kolejowej CDOKP Warszawa zabezpieczajacych masowe przewozy wojskowe, Warsaw 1984. Library of the Military Command of Transport, Warsaw, ref. No. 434, (author's archive).

Headquarters of Military Transport at Regional State Railway Management in Warsaw, Plan schematyczny wojskowej bocznicy kolejowej $n r$, as of 31st Dec. 1959, (author's archives). 
Headquarters of Military Transport at Regional State Railway Management in Warsaw, Plan schematyczny wojskowej bocznicy kolejowej nr 182, (undated, probably from the mid-1950s), (author's archives).

Karta ewidencyjna wojskowej bocznicy kolejowej Nr 181 - WWL, (author's archive).

Mapa stużbowa sieci kolejowej PKP - 1945, (author's archive).

Mapa stużbowa DOKP Gdańsk, (author’s archive).

Mapa służbowa DOKP Kraków, (author's archive).

Mapa stużbowa DOKP Lublin, (author's archive).

Ministry of Transport, Central Board of Narrow-gauge Railways, Ksiega inwentarzowa wąskotorowych wagonów osobowych PKP, Warsaw 1958, (author's archive).

Ministry of Transport, Central Board of Narrow-gauge Railway, Ksiegga inwentarzowa wagonów towarowych PKP na tor o prześwicie $600 \mathrm{~mm}$, (author's archives).

Ministry of Transport, Central Board of Narrow-gauge Railway, Księga inwentarzowa wagonów towarowych PKP na tor o prześwicie $1000 \mathrm{~mm}$, (author's archives).

Headquarters of Military Transport, Gdynia, Ewidencja taboru wojskowego, (author's archive).

Headquarters of Military Transport Central Management of Narrow-gauge Railways, Materialy ewidencyjne taboru wojskowego (author's archive).

Naval Port Command Hel, Archive materials (author's archive).

Navy Logistics Administration Gdynia, Archive materials, (author's archive).

Navy Logistics Administration, Gdynia, Charakterystyka kolei wojskowej $n r$ 581, (author's archive).

Navy Logistics Administration, Gdynia, Charakterystyki kolei wojskowych, (author's archive).

Navy Logistics Administration, Gdynia, Ewidencja taboru wojskowego Zarzadu Logistyki Marynarki Wojennej w Gdyni (author's archive).

Plan schematyczny SRP Terespol (no date stamp, probably from 1970s), (author's archives).

Protokót ZKD Warszawa w sprawie eksploatacji cystern wojskowych na Mławskiej Kolei Dojazdowej, (author's archives).

Polish State Railways General Management, Central Traction Administration, Ksiegga inwentarzowa parowozów PKP, (photocopy from Eng. Tadeusz Suchorolski's archive). 
Polish State Railways, Narrow-gauge Locomotive Depot in Białośliwie, Księga ewidencyjna środków trwałych, 1963, (author's archive).

Road Administration Regional State Railway Management in Gdańsk, Archive materials, (author's archive).

Regional State Railway Management in Szczecin, Ewidencja mostów na terenie Zarzadu Drogowego DOKP Szczecin, (Sławomir Fedorowicz archive).

Regional State Railway Management in Warsaw, Ewidencja bocznic na terenie DOKP Warszawa, (author's archive).

Regional State Railway Management in Warsaw, Narrow-gauge Railways Management, Protokót $z$ komisji odbytej $w$ dniach od 7 do 9 kwietnia 1960 w sprawie badania stanu technicznego kolei wąskotorowej (bocznicy) Nr 182 należacej do C.B.P.Art.w Zielonce, (author's archive).

Regional State Railway Management in Warsaw, Narrow-gauge Railways Management, Akta bocznicy wojskowej WITU Zielonka, (author's archive).

Regional State Railway Management in Warsaw, Wojskowo-techniczny opis łacznic kolejowych DOKP Warszawa, Warsaw 1972, (author's archive).

Regional State Railway Management in Warsaw, Protokót okresowego badania kolei użytku niepublicznego administrowanej przez C.B.U. w Zielonce, 11th August 1964.

Regional State Railway Management in Warsaw, Narrow-gauge Railways Management, Akta kolei użytku niepublicznego, (author's archive).

Regional State Railway Management in Warsaw, Narrow-gauge Railways Management, Akta bocznicy wojskowej Nr 180 w Przasnyszu, (author's archive).

Regional State Railway Management in Warsaw, Narrow-gauge Railways Management, Regulamin obstugi kolei waskotorowej C.B.U. (bocznica Nr 182), 17th Sept. 1962, (author's archive).

Regional State Railway Management in Wrocław, Ewidencja mostów na terenie Zarzadu Drogowego DOKP Wrocław, (Sławomir Fedorowicz archive).

Regional State Railway Management in Wrocław, Ewidencja napraw okresowych lokomotyw Ls40 w Zakładach Naprawczych Taboru Kolejowego Wrocław, (author's archive).

Railway Technical Inspection Inspectorate, Łodź, Księga ewidencyjna kotłów parowozów przemysłowych, (author's archive).

Railway Technical Inspection Inspectorate, Warsaw, Rejestr zbiorników hamulcowych lokomotyw, (author's archive).

Transport Department, Warsaw Military District, Księga ewidencyjna taboru wojskowego, (author's archive). 
Transport Department, Silesian Military District, Dokumenty ewidencyjne oraz charakterystyki kolei wojskowych, (author's archive).

Andrychów Diesel Engine Factory, Instrukcja obstugi silnika S-64L oraz S-324HL, (author's archive).

Wykaz taboru wagonowego MON (stara numeracja), (elaborated on the basis of records and correspondence of the Polish State Railways and Polish Armed Forces).

Rail Rolling Stock Repair Workshops Opole, Księga inwentarzowa środków trwatych, (author's archive).

Rail Rolling Stock Repair Workshops Poznań, Dokumentacja technicznoruchowa lokomotywy spalinowej WLs40/50, (author's archive).

Rail Rolling Stock Repair Workshops Poznań, Lista fabryczna lokomotyw WLs40/50, (author's archive).

Rail Rolling Stock Repair Workshops Poznań, Lista fabryczna lokomotyw WLs75, (author's archive).

\section{Accounts}

Account of the adviser to the Ministry of Transport, late Jerzy Wasilewski. Account of former manager of transport of Naval Port Command Hel, Lieutenant Commander Stefaniak of Navy Logistics Administration, Gdynia. Account of Mr Jan Szponder, a son to a locomotive driver employed at Warsaw Military District Warszawa - Stalowa.

Account of 12nd May 2003 of retired locomotive driver and mechanical controller Warsaw Military District Ełk, Mr Leszek Zumbrzycki.

Account of 5th Oct. 2005 of a retired traffic controller of the Regional State Railway Management in Warsaw, Mr Aleksander Matecki from Mława. Account of 3rd Sept. 2006 of former deputy director of Regional State Railway Management in Lublin MA Eng. Jerzy Brych.

Account of 4th Sept. 2006 of Colonel Jerzy Jarzyna.

Account of 6th May 2006 of Eng. Wojciech Dembiński.

Account of 15th June 2006 of Colonel Józef Szwajk, former commander of the 2nd railway battalion at Inowrocław.

Account of 7th Sept. 2006 of Colonel Wacław Kuzak, retired head of the Field

Division at the Military Institute of Armament Technology in Zielonka.

Account of 28th Aug. 2006 of Col. Jacek Wyszyński.

Account of 20th Oct. 2006 of Colonel Jerzy Maj, retired head of the Military

Services Directorate at Regional State Railway Management in Warsaw. 
Account of 23rd Oct. 2006 of Major Jerzy Zieliński, retired head of the Section for Internal Transport and Railways of the Military Institute of Armament Technology.

Account of 11th Sept. 2006 of Prof. Ph.D. Eng. Henryk Bałuch, who in the 1950's designed and supervised the construction of the Medyka transhipment station and the M (Medyka) Region.

Account of 12th May 2006 of a retired locomotive driver MD Warszawa-Praga, Mr Bogdan Pokropiński.

Account of 7th Dec. 2006 of Col. Aleksander Jakimczuk, who was involved in preparations to "WISŁA 75" coalition exercises.

Account of 10th Dec. 2006 of Lt. Col Kazimierz Balog.

\section{Web sources}

http://www.pibwl.republika.pl Pociągi pancerne SOK [accessed June 15, 2006]. http://www.starejuchy.pl/kolej/wrpbran/wrpbraniewo.htm Wojskowy Rejon Przeładunkowy Braniewo czyli PRL Ostbahn. 


\section{INDEX}

A

Agreement Regarding Polish-

Soviet Direct Railway

Communication 279

air bombing of railway tracks 204

Air Force Command 287, 290, 304

American Civil War 13

Andreev, A. 32

anti-aircraft defence $72-74,79$, 251-253

- air raid alert signalling system 252

- armaments 251-252

- diagram of 253

- permanent state of 251

- purpose of 251

- small-calibre anti-aircraft artillery batteries 252 anti-aircraft wagon 264

Antipenko, N. 34, 36, 38, 39, 87

anti-tank defence 253-254

- armaments 253

- instructions 253-254

- preparations for 253-254

arched stone and concrete

bridges 203

Artemenko, N. 34

Ataman, Jan 321

Austrian railway policy 18

Austro-Hungarian border 15

B

BARIERA 70 military exercise 234-235

BARIERA 79 military exercise 112-113, 236-243

Bloch, Jan 17, 412

Board IV of Headquarters of Military Transport 58
Bordziłowski, Jerzy 233

Borisov, N. 29, 33, 38, 39

Borowiecki, Jan 73

Branch IV of Headquarters of Military Transport 56-57, 65,69

bridge destruction 187,188 , 198-203

- arched stone and concrete bridges 203

- brief description of 198-199

- damming in military terminology 200

- delayed-action mining 203-204

- delayed explosion time 204

- explosives 200-201

- fixed mine devices 202-203

- reinforced concrete bridges 201

- special-purpose mining appliances 203

- steel bridges 202

- stone (arched) bridges 201

- timber cribs 200

- wooden bridges 200-202

Bridge Reconstruction Train 114, 139, 153, 175-176, 177

broad-gauge sidings 37,115 , 119-120, 122-123, 128, 135, 125-126, 135

broad-gauge stations 126

broad-gauge steam

locomotive 46, 128

broad-gauge tracks 118-119,

121-125, 127, 129-130

broad-gauge Ty 23

locomotives 123, 136

Brych, Jerzy 12, 102

Brygiewicz, K. 334 
C

carriages 19, 51, 159-161, 163-165,

176, 184, 258-259, 267, 279-280, 282, 284-285, 295, 320, 325-326, 330-331, 387-388, 391

Cegielski, H. 51

Centre for Ballistic Research 79

Chrzanowski, Henryk 327

circuit track system 291

Civil Defence facilities 61

coal wagons $31,154,250-251,258$, 259, 263, 267, 339, 386

Coastal Operational

Directions 10, 23, 84

Command of the Polish Air Defence

Forces 290

commercial ramps 269, 273

compound locks 212

Czerwiakow, Herman 58

D

damming in military

terminology 200

delayed-action mining 203-204

delayed explosion time 204

Department of Military transport,

Military District Command

I Warsaw 64-66

Department of Military Transport of the Russian General Staff 14

Devil's Loop 27

diesel locomotives of WLs 40/50

type 308-312

double locks 212

dual-gauge track layout 123-124

dual-gauge track system 117, 135

Dzerzhinsky, Felix 20

E

Eberman, Ludwik 336

Eisenbahnen über die Oder-Neiße-

Grenze (Kuhlmann) 12 electrified railways lines 51-53

electromechanical (sliding) VES

type signalling devices 22

engineering-miner trains 185, 189

evacuation transfers 245

F

Field Artillery Research Centre in Zielonka 314-325

- 5th Railway Troops Batallion 315

- 7th Railway Troops Batallion 315

- Internal Transport and Railway Section 321

- main and peripheral lines 316-317

- maintenance facilities 315-316

- non-public railway 324

- Ordnance Research Centre 321, 322

- permanent loading ramps and platforms 317-318

- temporary wooden bridges 317

- train announcements 322

- training area 316, 319

- train traffic 319

field railway equipment storage depot 174-175

5 th railway troops battalion $69-74$, 78-80, 318

1st Belarussian Front 28-30, 32-35, 37-39, 43, 47

1st Guardian Railway Brigade 29, 34

First World War 17-18, 19, 209, 210, 216, 217, 218, 339, 340,350

fixed mine devices 202-203

fixed ramps 72, 273

fixed wagon furnishings 256, 259

folding railway bridges 217-232, 410

- carriageway of bridge sleepers 225-226 
- economic and military importance of railways 217

- Exposition Universelle 217

- K-type bridges 220-221

- L-30 span diagram 223, 225

- L-36 span diagram 224, 225, 226

- military point of view 217

- military-purpose 226-227

- NZM-56, 231

- Polish Armed Forces troops 222

- pushers 231

- railway troops 221

- riverbank spans 232

- Roth-Waagner bridges 218

- Roth-Waagner spans 218-219

- S49 rails 228-229

- SEK-500 overpass 227-228, 230

- SRK-30/40 folding crane 230

- standard-gauge railway bridges 218-219

- in Warsaw Pact 227

4th Ukrainian Front territory 27

Franco-Prussian War of 1870 $187113,184,350$

freight wagons 51, 178, 230, 256, 258-259, 295, 331-333, 325-326, $340,386,391$

French-Polish Consortium 333

French-Polish Railway Society 19

frontal railway lines 18

Frontline Board for Military

Transports 44

frontline-bound railway lines 115,150

frontline offensive campaign military transport $142-158$

- anticipated nuclear attack 145

- front railway lines 145-146

- labour-intensive nature of reconstruction works 151

- mechanisation of tactical compounds 158
- operational continuity 142,144

- operational transport diagram 150

- organisational structure 174-179

- Permanent Transhipment Areas 150-152

- planning of 152,158

- radio communication 144

- rolling stock decommissioning points 147-149

- Soviet Army and Polish Armed Forces troops 149

- strategic bridge component reserve list 153-154

- structure of transport network 143

- Substitute Transhipment Areas 151

- technical solution diagram for railway junction 146

- Temporary Transhipment Areas 150-152

- wagon side wall removal facilities list $155-156$

- Warsaw Military District of the Bureau of Military Transport 150

- zones of frontline railway network 157

frontline railways operability 174

fuel re-pumping point sidings $356-357$

G

Gaponiuk, Anatol 56

Gembora, Marian 11, 383

German railway troops 41

Godek, Włodzimierz 78

Grubecki, Jan 26, 49

H

hazardous goods transport 247, 249,250

Head of Frontline Transport 62, 63

Zbigniew Tucholski - 978-3-631-82966-0 
Headquarters of Military Transport (1944-1962)

- Board IV of 58

- Branch IV of 56-57, 65, 69

- Chief Quartermaster of the Polish Armed Forces 11, 56, 63

- of General Staff 58

- of General Staff of Polish Armed Forces 10, 63, 69, 75, 76, 355, 357, 388-390

- line units of railway and inland 59

- for liquidation 291

- Military District Command I Warsaw 64-66

- military offices 254

- military railway sidings in Warsaw 296-300

- military-technical description of rail links 90-93

- Ministry of National Defence 246, 255,325

- order and commission 291

- peacetime activities of 63-64

- planning of training and dispatching of railway troops 58

- raiway unit reconstructions 66-81

- Regional State Railway Management 55, 59, 60, 65, 74, 119,359

- siding and siding-related facilities 289

- special rolling stock 386-387

- during wartime 61

Heads of Traffic and Trade

Departments 271

heavy-duty railway flat wagons 276

Herbst, Stanisław 11

Hrubieszów narrow-gauge railway 314

hydrographic properties 107

\section{I}

improvised frontal double ramp 274 improvised frontal single ramp 275 improvised parallel ramp 269, 273, 275,279

improvised ramps 269, 273

improvised side oblique ramps 273 improvised side perpendicular ramp 276, 277

Independent Squadron of AntiAircraft Defence of Military Transports $72,73,74,78,79$ Instructions Concerning the Organisation and Delivery of Military Railway Transports 248, 258 internal railway systems 291 Iznyarov, A. 37

\section{J} Jaśman, Aleksander 65 Jarzyna, J. 103-107, 113, 239, 240 Jaskulski, K. 334

K

Kaganovich, L. 32

key locks 124, 211-212

Komunikacje i wojna (Nowak) 12

Korczyc, Władysław 58, 67

Kostap transfer rules 249, 255

Kotow, A. 30

Kovalev, I. 32

Krawiec, Edmund 71

K-type bridges $220-221$

Kuhlmann, A. 12

Kuźmienko, Grzegorz 56

L

L-30 span diagram 223, 225

L-36 span diagram 224, 225, 226

labour-intensive nature of reconstruction works 151 
Leciak, Zygmunt 76

Lesnikov, A. 39

Lewiński, Piotr 233

loading areas, stations, and sites, military transports $268-279$

- commercial ramps 273

- definition of 270

- fixed ramps 273

- heavy-duty railway flat wagons 276

- improvised frontal double ramp 274

- improvised frontal single ramp 275

- improvised parallel ramp 275

- improvised side perpendicular ramp 276, 277

- loading yards 272

- military ramps 269

- mobile ramps 274

- Ppwwp ramp flat wagon 278

- primary loading areas 270

- process of selecting and organising 270

- provisional makeshift ramps 273

- special bogie flat wagons 276

- steel ramps and resources 278-279

- supplementary loading areas 270

- z-type portable ramps 276

locomotives

- in military rolling stock $361-386$ Ls40 type 363-369

Ls150 type 371-377

Ls300 type $378-382$

- narrow-gauge 342-343, 348, 352

- in post-war period $361-362$

- servicing point $122-123$

- steam 186-187, 195, 196

- and trolleys 328-330

- Tw1-98, 74
Ls40 type locomotives

- military 367-369

- technical characteristics 363-366

Ls150 type locomotive

- military 374-377

- technical data of 371-374

Ls300 type locomotive

- military 382

- technical data of 378-381

Lublin Regional State Railway Management 12, 31

M

Macewicz, Eugeniusz 42

Mackiewicz, Eugeniusz 400

Manual of Railway Damage

Reconstruction 187, 199, 204, 207, 209, 210, 213

Mazur, Jan 321

Mława narrow-gauge railway 324, 357-361

mechanical railway signalling devices 116

Mechanised Permanent-Way Train 176, 177

Mierosławski, Ludwik 183

Mikoyan, A. 32

Military Academy of Rear and Transport Services 68

Military Agitation Points 59

Military Command of Railway Section 61

Military Commands of Frontline and Army Distribution Stations 61

Military Commands of Railway Sections 61

Military Commands of Supply Stations 61

Military Commands of Waterway Sections and Ports 59

Military Commission of the Political Bureau of the Central Committee 
of the Polish United Workers

Party 67

Military District Command

I Warsaw 64-66

Military District Commands 55, $58,59,64$

Military Food Points 59

Military Frontline Transport Board 61

Military Institute of Armament

Technology 325, 327, 328, 385

military journals 11

Military Office of Historical

Research Archive 11

military rail transfers 245,248

military rail transports

- block trains usage 247

- classification of 245

- definition of 245

- deliveries of 248

- deployment locations 251

- extraordinary precautions 250

- general transport rules 248-249

- hazardous goods transport 247, 249-250

- intermediate stations 251

- Kostap transfer rules 249

- military troop trains 247-248, 267

- non-scheduled trains 248

- scheduled trains 248

- typical and specific properties 246

Military Railway Section

Commands 59

military railway sidings

- assumptions 293

- categorisation 290

- definition of sidings 288

- direct management 288

- general supervision 288

- grouping by construction period 287

- Head of Military Transport in Warsaw 296-300
- internal railway systems 291

- locally operated switches 295

- No.143 Military Unit 3748292

- No.145 Military Unit 2186 Hajnówka 294

- No.289 Hrubieszów 314

- railways operated by military units 289-290

- registration of 289

- sample standard 292

- Silesian Military District 300-302

- users of military railways 288

Military Railways

Management 176-177, 179, 183

Military Railway Transports

- instructions regarding 269

- temporary instructions regarding 269

military ramps 61, 269, 271, 273

military rolling stock

- locomotives 361-386

Ls40 type 363-369

Ls150 type 371-377

Ls300 type 378-382

- management 388-398

central organ supplying military units 389

marking and numbering scheme of 391, 392-398

Military transport Units of military districts 388

registration numbers 391-392

Rolling Stock Repair

Plant 389-390

scrapping of locomotives and special wagons 390

- narrow-gauge military tank wagons 402-408

- road trailers for wagon transport 398-401

- special rolling stock $386-388$

- wagons 386-388 
Military Service of Accommodation and Construction 289

Military Stage Points 59

Military Station Commands 59

Military Training Grounds 339

Military Transfer Command 289

military transfers 245

Military Transhipment

Base 117, 118

Military Transhipment Base Mamonovo II of the USSR, 121

Military Transport Board 272

Military Transport Board of the General Staff of the Polish Armed Forces 289, 291

Military Transport Commands 289

- evidence lists of tracks and junctions 138

- main tasks of 60

- repair and maintenance of all tracks, equipment and facilities 136

- responsibilities of 60 military transports

- anti-aircraft defence 251-253 air raid alert signalling system 252 armaments 251-252 diagram of 253 permanent state of 251 purpose of 251 small-calibre anti-aircraft artillery batteries 252

- anti-tank defence 253-254 armaments 253 instructions 253-254

preparations for 253-254

- authorities 289

- as communication system 9

- definitions of 9

- Division IV of 362, 363

- field bodies 61
- field (frontline) services 62

- loading areas, stations, and sites 268-279 commercial ramps 273 definition of 270 fixed ramps 273 heavy-duty railway flat wagons 276 improvised frontal double ramp 274 improvised frontal single ramp 275 improvised parallel ramp 275 improvised side perpendicular ramp 276, 277

loading yards 272 military ramps 269 mobile ramps 274 Ppwwp ramp flat wagon 278 primary and supplementary loading areas 270 process of selecting and organising 270 provisional makeshift ramps 273 special bogie flat wagons 276 steel ramps and resources 278-279 z-type portable ramps 276

- ordinances and documentation 254

- rolling stock usage 255-268 anti-aircraft wagon 264 covered vans and coal wagons 259 field kitchens transported in van 266

fixed wagon furnishings 256 furnished box van 257,258 furnishing of $\mathrm{Kl}$ vans 265 $\mathrm{Kl}$ vans with lying and sitting places 261-263

loading diagram and use of loading devices 268 
mobile furnishings 256 people-carrying wagons 261

Polish State Railways 258-259 special-purpose standard mobile wagon components 255 special-purpose storage depots 259 troops-carrying goods vans 256

- rules for trains 267

- safeguarding confidentiality of 254-255

- Soviet Army troops in

Poland 283-286 financial settlements 286 military troop trains 285 scheduled passenger train 284

- Soviet Army troops in Polish State Railways 279-283 border crossing stations 281 military train traffic 280 re-forming of train sets 280 routes in transit $281-282$ train crews 280 transit trains 280

USSR block trains 281

USSR Ministry of Transport 282, 283

Military Transport Unit of the 1st Army of the Polish Armed Forces 383

military troop trains $72,118,122$, $125,137,144,171,176,234$, 247, 248, 250-251, 267, 270, 283, 284, 285

Milutin, Dimitri 14

Miners' Manual 184, 198 mining bridges 203-204

Minister of National Defence 57, 58, $66,67,73,77,388-390$

Ministry of Communication Central Traction Administration 389
Ministry of Defence Central Archives 11

Ministry of Military Affairs 185, 199, 213, 335, 362

Ministry of National Defence 60, 63-64, 68, 71, 136, 340, 384-385

- 3rd railway troops battalion 73-77

- 5th railway troops battalion $70-73$

- 7th railway troops battalion 77-81

- definition of military railways $287-288$

- Komunikacja Wojskowa handbook 85

- military railways 290

- narrow-gauge military tank wagons 402-408

- Sappers' Manual - Explosives and Destruction 189

Ministry of Railways and Inland Navigation 62, 63

Ministry of Transport

- guidelines 254

- Manual of Railway Damage Reconstruction 187, 199, 203, 207, 209, 213

- at service units of 254

- Technical Specifications for the Design and Construction or Reconstruction of Temporary Railway Infrastructure 207 Miridonov, V. 37 Mińsk Mazowiecki - Pilawa line 29 mobile furnishings 256 mobile ramps 274 mobilisation-related transfers 245 Mochnacki, Stanisław 64 Muzyczek, Adam 64 


\section{$\mathbf{N}$}

narrow-gauge diesel locomotive

WLs150-3800, 326

narrow-gauge locomotives 338, $342-343,348,352$

narrow-gauge military railways

- description of 302-303

- diesel locomotives of WLs 40/50 type 308-312

- Field Artillery Research Centre in Zielonka 314-325

5th Railway Troops Batallion 315 7th Railway Troops Batallion 315 Internal Transport and Railway

Section 321

main and peripheral lines $316-317$ maintenance facilities $315-316$

non-public railway 324

Ordnance Research

Centre 321, 322

permanent loading ramps and

platforms $317-318$

temporary wooden bridges 317

train announcements 322

training area 316,319

train traffic 319

- fuel re-pumping point siding 356-357

- JW 1540 Nowe Miasto (No.

181) 356-357

- Piaseczno No. 101/183 356-357

- post-war period 302-308, 314, 351, 361-362, 387, 400

- rolling stock 325-333

carriages $330-331$

freight wagons $331-333$

locomotives and trolleys $328-330$

- S64L type engine

characteristics 313

- S-324 HL type engine

characteristics 313-314

$-600 \mathrm{~mm}$ railway
Gdynia-Port Wojenny Oksywie

(No. 581) 346-350

on Hel peninsula 333-346

JW 3643 Gdynia Port-Oksywie

(No. 407) 346-350

JW 4420 No. 180 357-361

Świnoujście (No. 881) 350-354

- standard-gauge siding No.

127 314-325

- in Zegrze Pomorskie 356-357

narrow-gauge military tank wagons 402-408

Narrow-gauge Railway Management Commission 323

narrow-gauge rolling stock 337 , 347, 349-350

narrow-gauge wagons 340, 343-345

Natalevich, A. 37

National Air Defence 388

National Defence Committee 246

Navy and Land Forces 388

Navy railway artillery battalion 67,70

non-scheduled trains 248

North Military Group of the Soviet Army 283, 285

Nowak, Eugeniusz 12

NZM-56 bridge 98-101, 112, 113, 231, 232

O

Object-83, 112

Odbudowa mostów kolejowych, Stalowe konstrukcje składane, (Reconstruction of Railway bridges - Folding Structures), Part I, Warsaw 1966, Part II, Warsaw 196811

Officers' Military Engineering Academy 68, 73, 78, 100

Ogarkov, V. 37

Ogoyev, I. 27 
operational transfers 18,245 operational transport diagram 150 operational transports

- carriage of 247

- confidentiality 255

- peacetime 246

- wartime plans 246

Operation Berlin 38-39

Operation 'Coal', 30-31

Operation Otto 21-22

Ordnance Research Centre 321, $322,326,328$

organisational structure, military transport on frontline 174-179

- Bridge Reconstruction Train 177

- field railway equipment storage depot 175

- frontline railways operability 174

- Mechanised Permanent-Way Train 177

- military command 176

- railway frontline dispatching station 175

- Railway Traffic and Communication Appliance Reconstruction Train 177-178

- railway troop brigades 175

- steam locomotive columns 178

- Steam Locomotives Repair Train 178

- Track Reconstruction Train 177

- Wagon Repair Train 178

- Water Facility Reconstruction Train 178

Osokin, Sergiusz 56

Ołtarzewski, Stefan 64

$\mathbf{P}$

peacetime operational transports 246 permanent railway bridges
- on Lausitzer Neiße - Odra DŸwina line 108-110

- on River Vistula 95-97

Permanent Transhipment Areas 116-119, 122

- in Bartoszyce 121

- Braniewo 121

- in Dorohusk 133

- at Medyka 134-136

- in Narewka 125, 127

- Regional State Railway Management 122, 132-133

- Skandawa 118-119

- Terespol 127, 128, 130, 131-132

- Werchrata 134

- at Zubki Białostockie 123-124

Piszczyk, Antoni 78

Poland, Soviet Army troops 283-286

- financial settlements 286

- military troop trains 285

- scheduled passenger train 284

Polish Committee of National Liberation 26, 30, 49, 50

Polish-German state border 98

Polish Military Transhipment Areas 284

Polish railway network $10,23,26$, 83, 410-411

Polish-Soviet Railway Agreement 279

Polish State Railways

- 12th railway regiment 101

- 1950s slogan of 23

- auxiliary work purposes 137

- BARIERA 79 112-113

- bridge destruction 198-203 arched stone and concrete bridges 203 brief description of $198-199$ damming in military terminology 200 delayed-action mining 203-204 
delayed explosion time 204 explosives 200-201

fixed mine devices 202-203 reinforced concrete bridges 201 special-purpose mining appliances 203 steel bridges 202 stone (arched) bridges 201 timber cribs 200 wooden bridges 200-202

- broad-gauge marshalling yard 128

- broad-gauge siding 122-123, 125-126

- broad-gauge stations 126

- broad-gauge tracks 124-125

- broad-gauge Ty23 locomotives 136

- destruction-caused interruptions 86

- dual-gauge track layout 123-124

- East-to-West strategic transit network 88-89

- electrified railways lines 51-53

- evacuation of wounded 159-183 hospital trains 159, 161, 163 military ambulance purpose carriage 161-162 military shuttle trains 165 passenger carriage 160 Permanent Military Hospital Trains 163-164

Rolling Stock Repair Plant 159-160

Temporary Military Hospital Trains 163-166 wartime destruction to staff carriages 163

- folding railway bridges 217-232 carriageway of bridge sleepers 225-226 economic and military importance of railways 217
Exposition Universelle 217

K-type bridges 220-221

L-30 span diagram 223, 225

L-36 span diagram 224, 225, 226

military point of view 217

military-purpose 226-227

NZM-56, 231

Polish Armed Forces troops 222

pushers 231

railway troops 221

riverbank spans 232

Roth-Waagner bridges 218

Roth-Waagner spans 218-219

S49 rails 228-229

SEK-500 overpass 227-228, 230

SRK-30/40 folding crane 230

standard-gauge railway bridges 218-219 in Warsaw Pact 227

- frontline-bound railway lines 115

- frontline offensive campaign military transport $142-158$ anticipated nuclear attack 145 front railway lines 145-146 labour-intensive nature of reconstruction works 151 mechanisation of tactical compounds 158 operational continuity 142,144 operational transport diagram 150

organisational structure 174-179 Permanent Transhipment

Areas 150-152 planning of 152,158 radio communication 144 rolling stock decommissioning points 147-149 Soviet Army and Polish Armed Forces troops 149 strategic bridge component reserve list 153-154 
structure of transport network 143

Substitute Transhipment Areas 151 technical solution diagram for railway junction 146 Temporary Transhipment Areas 150-152

wagon side wall removal facilities list 155-156

Warsaw Military District of the Bureau of Military Transport 150 zones of frontline railway network 157

- hydrographic properties 107

- infrastructure 115

- inventory numbers 355

- Komunikacja Wojskowa handbook 85

- Kostrzyn - Küstrin Kietz section 111

- locomotive servicing point $122-123$

- mechanical railway signalling devices 116

- Mechanical Services Division 259-260

- military loading locations 271-272

- mining bridges 203-204

- Ministry of Communication Central Traction Administration 389

- mobilisation plans 139

- mobility and continuity of transport 86

- modernisation works 119-121

- narrow-gauge lines 43

- network 9, 10, 136, 139, 279

- nuclear war conditions 87

- NZM-56 bridge 98-101, 112, 113
- Object-83, 112

- organisational structure, military transport on frontline 174-179 Bridge Reconstruction Train 177 field railway equipment storage depot 175

frontline railways operability 174

Mechanised Permanent-Way

Train 177

military command 176

railway frontline dispatching station 175

Railway Traffic and

Communication Appliance Reconstruction Train 177-178 railway troop brigades 175 steam locomotive columns 178 Steam Locomotives Repair Train 178 Track Reconstruction Train 177 Wagon Repair Train 178 Water Facility Reconstruction Train 178

- permanent railway bridges on Lausitzer Neiße Odra -

DŸwina line 108-110 on River Vistula 95-97

- Permanent Transhipment Areas 116-119, 122 in Bartoszyce 121 Braniewo 121 in Dorohusk 133 at Medyka 134-136 in Narewka 125, 127 Regional State Railway Management 122, 132-133 Skandawa $118-119$ Terespol 127, 128, 130, 131-132 Werchrata 134 at Zubki Białostockie 123-124

- prevalent theory 86

- railway bridge crossings $232-243$ 
2nd railway regiment $232-233$

BARIERA 70 military exercise 234-235

BARIERA 79 military exercise 236-243

high-water temporary bridge on River Nogat in Malbork 235-236

NZM-56 bridge construction 232 railway bridge construction in Małkinia 235

- railway lines, stations, facilities and rolling stock destruction 183-204 arrival switches 186 brick water tower 194 cutting rails with explosives 191 damage type 187 description of 184 destroying of railway station devices and rolling stock 191 engineering-miner trains 185 fundamental destruction types $187-188$ masked railway track damage 188 mass destruction $187-188$

Palatine Uprising of

1849 183-184

partial destruction 187

rail traffic 188

railway tracks 185

reinforced concrete water tower 195 sequence of destruction 188-189 signalling and block devices, central devices 197-198 special-purpose engineeringminer trains 189 steam locomotives 186-187, 195, 196 switch crossbars, destroying 192 telegraph and telephone lines 185,197 tenders 196 turntables and water cranes, destroying 193 valves and pipes 194 wagons 186, 197 water towers 186,193 work diagram for platoon 190

- railway signalling devices reconstruction $210-213$ catch points 212 complete destruction 213 compound locks 212 double locks 212 key control panels 212-213 key locks 211-212 maximum permitted speed 210-211 railway traffic efficiency $210-211$ simple-version key boxes 212-213 traffic control post 211

- Regional State Railway Management Permanent Transhipment Areas 121 railway bridges 114 wartime plans 114

- REM-500 overpass bridge 100, 103, 104, 106-108, 110-113

- Rembertów - Zielonka rail link 94

- reserve mobilisation units 23

- reserve railway section 99

- River Odra 97-98, 111-113

- River Vistula 95-101, 105, 106

- Soviet Army troops in 279-283 border crossing stations 281 military train traffic 280 re-forming of train sets 280 routes in transit $281-282$ train crews 280 
transit trains 280

USSR block trains 281

USSR Ministry of

Transport 282, 283

- standard-gauge railway lines 117

- standard-gauge siding 123, 128,130

- standard-gauge tracks 122,124 , 125,127

- Substitute Transhipment Areas 117, 122

- technical protection, frontline railway network 179-183 catenary support poles 182 large bridge reconstruction 181 mechanisation battalion 180 nuclear explosion 182 railway troops brigade $179-180$ special-purpose disinfectant solution 183 stage II railway junctions 180 stage I railway junctions 180 stationing (dislocation) sites 180 thermonuclear war 183 transport and technical battalions 180 wartime technical protection 182

- temporary bridge reconstruction 213-217 openings 214 partial damage 214-215 railway troops 216 steel bridges 217 temporary railway bridge span types 216

- temporary reconstruction (construction) of railway lines 204-217

- air bombing of railway tracks 204

- buildings indispensable to railway traffic reconstruction 210

- destroyed frogs 206
- interim reconstruction (construction) 207-209

- planned reconstruction of railway surface 207

- protective dead-end track 207

- during rail-cutting attempts 205

- railway tracks by joint or rail blasting 204-205

- repair recommendations 206

- roundhouses 206

- spare switch parts 206

- warfare damage 205

- temporary road-rail crossing 101

- Temporary Transhipment Areas 115, 132-133, 166-174 access roads and marinas 170-171 isolated railway sections 166 length of rail section 171-172 longitudinal type 171 military transports and supplies 167 mixed-type 171 mobilisation plans $173-174$ on primary frontal direction 167,172 regulation of military traffic 169-170 section-based shuttle traffic 168 Soviet Army 166 technological process 168 transfer of goods 168 transverse 171 wartime destruction 167

- thermonuclear warfare conditions 88

- track layouts 117

- traffic posts 119-121, 128-130

- transfer facilities $119-121$

- transhipment facility $126-127$

- VISTULA 73 exercise 103-107

- VISTULA 85 exercise 101, 102 
- Warsaw Pact military doctrine 86

- wartime construction, folding railway bridge 111

- wartime efficiency 110-111

- wartime plans 127

- wartime storage of surface materials 138

- wartime transport continuity 95

- Zazulak system interlocking boards 138

Polish State Railways Central Bureau for Foreign Clearance 282, 286 portable ramps 269, 273, 276, 285 Półturzycki, Bronisław 70

Ppwwp ramp flat wagon 278 prevalent theory 86 provisional makeshift ramps 273 provisional military ramps 269 Prussian military powers 16 Prussian Tw1 class steam locomotives 384

Przeglad Kwatermistrzowski (military journal) 11

Przyszła wojna [The Future War] (Bloch) 17, 412 pushers 231

R

Rabanowski, Jan 49 railway bridge crossings $232-243$

- 2nd railway regiment 232-233

- BARIERA 70 military exercise 234-235

- BARIERA 79 military exercise 236-243

- high-water temporary bridge on River Nogat in Malbork 235-236

- NZM-56 bridge construction 232

- railway bridge construction in Małkinia 235

railway lines, stations, facilities and rolling stock destruction 183-204
- arrival switches 186

- brick water tower 194

- cutting rails with explosives 191

- damage type 187

- description of 184

- destroying of railway station devices and rolling stock 191

- engineering-miner trains 185

- fundamental destruction types $187-188$

- masked railway track damage 188

- mass destruction 187-188

- Palatine Uprising of 1849 183-184

- partial destruction 187

- rail traffic 188

- railway tracks 185

- reinforced concrete water tower 195

- sequence of destruction 188-189

- signalling and block devices, central devices 197-198

- special-purpose engineeringminer trains 189

- steam locomotives 186-187, 195, 196

- switch crossbars, destroying 192

- telegraph and telephone lines 185,197

- tenders 196

- turntables and water cranes, destroying 193

- valves and pipes 194

- wagons 186, 197

- water towers 186, 193

- work diagram for platoon 190

railway numbering 289

Railway Rolling Stock Repair facilities 60-61

Railway Security Services trains 383 
railway signalling devices reconstruction $210-213$

- catch points 212

- complete destruction 213

- compound locks 212

- double locks 212

- key control panels 212-213

- key locks 211-212

- maximum permitted speed $210-211$

- railway traffic efficiency 210-211

- simple-version key boxes 212-213

- traffic control post 211

Railway Traffic and Communication Appliance Reconstruction Train 176, 177-178

railway troop brigades 175 Railway Works Company No.9, 134, 135

railway unit reconstructions $66-81$

- 3rd railway troops battalion 73-77

- 5th railway troops battalion $70-73$

- 7th railway troops battalion $77-81$

- Ministry of National Defence resources 68

- non-commissioned officers 68,69

- railway troops battalions 69

- reconstruction programme of railway troops 69

Red Army forces transport 10

Red Army military transport 25-54

- broad-gauge line 31, 40

- broad-gauge steam locomotive 46

- Devil's Loop 27

- disbanding of railway columns 48

- 1st Belarussian Front 28-29, 30, 32, 35, 39

- 1st Guardian Railway Brigade 34

- 4th Ukrainian Front territory 27
- Mińsk Mazowiecki - Pilawa line 29

- operational units 26

- Operation Berlin 38-39

- operation Coal 30-31

- reconstruction of lines 40

- Rembertów - Wesoła 30

- River Odra 35, 37

- River Vistula 26-27, 30, 32-35, 38

- River Warta 36

- 2nd Belarussian Front 35, 39

- simplified servicing procedures 47

- standard-gauge line 31

- steam locomotive columns 45-46

- Warsaw Brigade 34, 35, 38

- Wisła - Odra operation 43

- Zagórz - Medzilaborce line 28

Regional State Railway Management

- assembly and furnishing locations 260

- broad-gauge network of 51

- electrified railway lines of 53

- Headquarters of Military Transport 55, 59, 60, 65, 74, 119,359

- infrastructure departments of 55

- military offices of 89-90

- military-technical description of rail links 90-93

- 1952-1953 railway lines and junctions 65

- Permanent Transhipment Areas 121

- railway bridges 114

- railway network 31, 60

- rolling stock decommissioning points 147-149

- strategic bridge component reserve list 153-154

- Technical Regulations for Railway Operation 318-319 
- Tw1-98 locomotive 74

- wagon side wall removal facilities list 155-156

- Warsaw 90-93, 138-140, 147-149, 173-174

- wartime plans of 114

Regulations Concerning the Management of Military Railways and Military Railway Rolling Stock 287

reinforced concrete bridges 201

REM-500 overpass bridge 100, 103, 104, 106-108, 110-113

Rembertów - Wesoła line 30

Resolution of the Council of Ministers 77, 81

resource evacuation-related transfers 245

Rgddyyhp narrow-gauge tank wagons 406-408

River Bug 25, 28, 93, 114, 127, 232, 235

River Narew 25, 114, 222

River Odra 12, 35, 37, 83, 97-98, 111-113, 149, 222, 234, 236-237

River San 76, 80, 135

River Vistula 14, 16, 25, 26-27, 30, $32-35,38,41,43,76,83,95-101$, $105,106,114,151-152,173-174$, 222, 233

River Warta 36, 80, 114

road ramps 401

Rogala, Czesław 70

Rogatko, V. 34

Rokossowski, Konstanty 57, 67, 115

rolling stock 325-333

- inventory 346

- military transports 255-268

anti-aircraft wagon 264

covered vans and coal wagons 259

field kitchens transported in van 266 fixed wagon furnishings 256

furnished box van 257, 258

furnishing of $\mathrm{Kl}$ vans 265

$\mathrm{Kl}$ vans with lying and sitting places 261-263

loading diagram and use of loading devices 268 mobile furnishings 256 people-carrying wagons 261 Polish State Railways 258-259 special-purpose standard mobile wagon components 255 special-purpose storage depots 259

troops-carrying goods vans 256

- narrow-gauge 349-350

- narrow-gauge military

railways $325-333$

carriages $330-331$

freight wagons $331-333$

locomotives and trolleys $328-330$

- standard-gauge 341-342, 347, 348, 352

Romaniuk, Konstanty 65

Roth-Waagner bridges 218

Roth-Waagner spans 218-219

Rumyantsev, P. 49

Russian military doctrine 14,16

Russian military transports 284

Russian Ministry of War 13

Russian rail transport

- decapitalisation of 20

- pre-Revolution decline 19

- Trans-Siberian railway 15

Russian railway troops 42,44

- token system 44

Russo-Japanese War 15

Russo-Turkish War of 1877-1878 14

Rybałtowski, Alfons 65

\section{$S$}

S49 rails 225, 228-229 
S64L type engine characteristics 313 S-324 HL type engine characteristics 313-314

Sappers' Manual - Explosives and Destruction 189

Sappers' Manual for Use by all Types of Armed Forces 185, 199, 213 scheduled trains 248

Seaside Operational Direction 410 2nd Belarussian Front 35, 38, 39

Second World War 23, 25, 84, 86, $93,142,166,203,217,221,222$, $339,341,409$

SEK-500 overpass 101,103 , 227-228, 230, 231, 233, 410

7 th railway troops battalion 69 , $72,77-81$

Sikorski, Władysław 409

Silesian Military District 78, 81, 189, 300-302

simple-version key boxes $212-213$

Siwicki, Florian 102

$600 \mathrm{~mm}$ narrow-gauge military railways

- Gdynia-Port Wojenny Oksywie (No. 581) 346-350

- on Hel peninsula 333-346

- JW 3643 Gdynia Port-Oksywie (No. 407) 346-350

- JW 4420 No. 180 357-361

- Świnoujście (No. 881) 350-354

Skurtys, Stanisław 72

Smaczyński, Anatol 67

small-calibre anti-aircraft artillery batteries 252

Śmidowicz, Jan 333

Sokolov, W. 37

Soviet Army troops

- in Poland 283-286 financial settlements 286 military troop trains 285 scheduled passenger train 284
- Polish State Railways 279-283 border crossing stations 281 military train traffic 280 re-forming of train sets 280 routes in transit 281-282 train crews 280 transit trains 280 USSR block trains 281 USSR Ministry of Transport 282, 283

Soviet art of military operations 84 special bogie flat wagons 276 special-purpose disinfectant solution 183 special-purpose engineering-miner trains 189 special rolling stock - Headquarters of Military Transport 386-387

- wagons and 386-388 Spychalski, Marian 233, 388 SRK-30/40 folding crane 230 Stalin, J. 32 standard-gauge railway bridges 218-219 standard-gauge railway lines 117 standard-gauge rolling stock 26,33 , $36,115,156,341-342,347,348$, 352,391 standard-gauge siding 119-120, 123-125, 127-130, 287, 319, 324, $327,333,335,351,355-356$ standard-gauge siding No.

$127 \quad 314-325$ standard-gauge tracks $117,122,124$, $125,127,128,129,130,133,358$ State Defence Committee 32 State Railway Managements 55, 60, $62,84,113,260,285,288$ steam locomotives $36,45-47,51$, $53,67,87,88,118,123,124,130$, $136,137,178,183,186-187,195$, 
196, 206, 220, 250, 279-282, 325, 336, 358, 362, 382-387, 389

Steam Locomotives Repair Train 178 steel bridges 202, 209, 216-217 steel ramps and resources 278-279 stone (arched) bridges 201

Strózik, Ryszard 11

Substitute Transhipment Areas 95, $117,122,151$

Supreme Board of Military

Transports 26, 32, 44, 49, 83, 84,281

Supreme Board of Military

Transports of the Red Army at the General Staff of the Polish Armed Forces 284-286

Suprowicz, Mikołaj 56

Suprynowicz, Mikołaj 56

Świrski, Konstanty 66, 70, 73

T

Tarasiewicz, Aleksander 71 technical protection, frontline railway network $179-183$

- catenary support poles 182

- large bridge reconstruction 181

- mechanisation battalion 180

- nuclear explosion 182

- railway troops brigade 179-180

- special-purpose disinfectant solution 183

- stage II railway junctions 180

- stage I railway junctions 180

- stationing (dislocation) sites 180

- thermonuclear war 183

- transport and technical battalions 180

- wartime technical protection 182

Technical Regulations for Railway

Operation 318-319

Technical Specifications for the Design and Construction or
Reconstruction of Temporary Railway Infrastructure 207

Telegin, K. 34, 39 telegraph and telephone lines 179 , 184-186, 197

temporary bridge reconstruction 213-217

- openings 214

- partial damage 214-215

- railway troops 216

- steel bridges 217

- temporary railway bridge span types 216

temporary reconstruction (construction) of railway lines 204-217

- air bombing of railway tracks 204

- buildings indispensable to railway traffic reconstruction 210

- destroyed frogs 206

- interim reconstruction (construction) 207-209

- planned reconstruction of railway surface 207

- protective dead-end track 207

- during rail-cutting attempts 205

- railway tracks by joint or rail blasting 204-205

- repair recommendations 206

- roundhouses 206

- spare switch parts 206

- warfare damage 205

Temporary Regulations on the Use of the Polish Railways by USSR Trains 279

temporary road-rail crossing 101, 234

Temporary Transhipment Areas 115, 132-133, 166-174

- access roads and marinas $170-171$

- isolated railway sections 166 
- length of rail section 171-172

- longitudinal type 171

- military transports and supplies 167

- mixed-type 171

- mobilisation plans 173-174

- on primary frontal direction 167,172

- regulation of military traffic 169-170

- section-based shuttle traffic 168

- Soviet Army 166

- technological process 168

- transfer of goods 168

- transverse 171

- wartime destruction 167

Terlecki, Michał 56, 66

Territorial Defence resources 246

thermonuclear war $85,88,183$

thermonuclear warfare conditions 88

3rd railway troops battalion $69-71$, 73-77, 81, 384

30th Training Company of Railway Military Reserve Officers 74, 78

3Rw type tank wagon

- Koszalin station 404

- Piaseczno station 405

- technical data of 403-404

timber cribs 200, 214

Tisson, W. 34

Track Reconstruction Train 114, 177

traffic posts 119-121, 128-130, 213

Training Curriculum for Reserve

Officers of the Railway Military

Forces 71,78

transfer of supplies 245

transport and technical

battalions 180

Transport Board of the General Staff of the Polish Armed

Forces 289, 291
Trans-Siberian railway 15

Transversal Railway 18

trudfront (labour battalion) campaign 41

tsarist defensive military doctrine 88

Ty1-1085 (Freudenstein No.3/1899) steam locomotive 325

Ty1-1142 (Krauss München No.6806/1913) steam locomotive 325 type $2 \mathrm{Rw} 600 \mathrm{~mm}$ tank wagons 360-361

U

USSR block trains 280, 281

USSR Ministry of Transport 282, 283

V

valves and pipes 194 von Göben, August Karl 350 von Moltke, Helmut 13, 17

W

wagon(s) 353-354

- anti-aircraft 264

- coal 259

- freight 331-333, 340

- heavy-duty railway flat 276

- narrow-gauge 343-345

- narrow-gauge military tank 402-408

- people-carrying 261

- special bogie flat 276

- special rolling stock and 386-388

- 3Rw type tank Koszalin station 404 Piaseczno station 405 technical data of 403-404

Wagon Repair Train 178 
War Council of 1st Belarussian

Front 32, 33, 34, 37

War Directorate for Railway

Reconstruction 27, 29, 33, 37, 39

Warsaw Brigade 34, 35, 38

Warsaw Military District of the

Bureau of Military Transport 150

Warsaw Pact 70

- BARIERA 79 112-113

- Exhibitions of Armament Technical Progress 320

- folding railway bridges 227

- international military exercises of 115

- military doctrine 86

- operational plans of 23

- Polish railway network 23

- tactical thermonuclear weapons 411

Warsaw Regional State Railway Management 90-93, 173-174

- list of rail links 90

- Ministry of Transport militarised units of 139-140

- rolling stock decommissioning points 147-149

- storage facilities of surface and material supplies of 138-139

- Technical Regulations for Railway Operation 318-319

wartime anti-tank defence 253-254

wartime military transfers 246

Water Facility Reconstruction Train 178

Water Transport Command of the Regional Directorate of Waterways 59

Wehrmacht railway troops 41
Western Operational Direction 10, $23,88,107,115,117,149,410$

white intelligence 21

wilderness strategy 14

Wisła - Odra operation 43

WLs40-120 locomotive 346

WLs40 type diesel locomotives 339,340

WLs50 type diesel locomotives 339

Wojska kolejowe (Gembora) 11, 383

Wojska kolejowe 1944-1946, [The Railway Military 1944-1946]

(Strózik) 11

wooden bridges $74,79,198$, 200-202, 216-217, 317, 323, 325

Y

Yatsino, T. 35,36

$\mathbf{Z}$

Zagórz - Medzilaborce line 28

Zamczyński, Anatol 57

Zamkowska S. 27

Zarys historii Szefostwa Stużby Komunikacji Wojskowej (unpublished) 11

Zazulak system interlocking boards 138

Żheleznodorozhniki v velikoy otchestvennoy voyne 11

Zheltikov, V. 38

Zhukovskyi, A. 37

Zieliński, Jerzy 321, 324

Zieminski, Wiktor 233

zones of frontline railway network 157

Z-type portable ramps 276

Zydel, Wacław 64 
Zbigniew Tucholski - 978-3-631-82966-0 Downloaded from PubFactory at 09/30/2020 04:51:29PM by keerthiga.m@newgen.co via Peter Lang AG and keerthiga.m@newgen.co 


\section{Geschichte - Erinnerung - Politik Studies in History, Memory and Politics}

Edited by Anna Wolff-Powęska \& Piotr Forecki

Bd./Vol. 1 Machteld Venken: Stradding the Iron Curtain? Immigrants, Immigrant Organisations, War Memories. 2011.

Bd./Vol. 2 Anna Wolff-Powęska / Piotr Forecki: Der Holocaust in der polnischen Erinnerungskultur. 2012.

Bd./Vol. 3 Marta Grzechnik: Regional Histories and Historical Regions. The Concept of the Baltic Sea Region in Polish and Swedish Historiographies. 2012.

Bd./Vol. 4 Lutz Niethammer: Memory and History. Essays in Contemporary History. 2012.

Bd./Vol. 5 Piotr Forecki: Reconstructing Memory. The Holocaust in Polish Public Debates. 2013.

Bd./Vol. 6 Marek Słoń (ed.): Historical Atlas of Poland in the 2nd Half of the 16th Century. Voivodeships of Cracow, Sandomierz, Lublin, Sieradz, Łęczyca, Rawa, Płock and Mazovia. Volume 1-4. Translated by Agata Staszewska, Editorial Assistance Martha Brożyna. 2014.

Bd./Vol. 7 Maciej Janowski: Birth of the Intelligentsia 1750-1831. A History of the Polish Intelligentsia - Part 1. Edited by Jerzy Jedlicki. Translated by Tristan Korecki. 2014.

Bd./Vol. 8 Jerzy Jedlicki: The Vicious Circle 1832-1864. A History of the Polish Intelligentsia - Part 2. Edited by Jerzy Jedlicki. Translated by Tristan Korecki. 2014.

Bd./Vol. 9 Magdalena Micińska: At the Crossroads 1865-1918. A History of the Polish Intelligentsia - Part 3. Edited by Jerzy Jedlicki. Translated by Tristan Korecki. 2014.

Bd./Vol. 10 Anna Wolff-Powęska: Memory as Burden and Liberation. Germans and their Nazi Past (1945-2010). Translated by Marta Skowrońska. 2015.

Bd./Vol. 11 Thomasz Szarota: On the Threshold of the Holocaust. Anti-Jewish Riots and Pogroms in Occupied Europe. Warsaw - Paris - The Hague - Amsterdam Antwerp - Kaunas. Translated by Tristan Korecki. 2015.

Bd./Vol. 12 Anna Wolff-Powęska / Piotr Forecki (eds.): World War II and Two Occupations. Dilemmas of Polish Memory. Translated by Marta Skowrońska and Blanka Zahorjanova. 2016.

Bd./Vol. 13 Elżbieta Katarzyna Dzikowska / Agata Handley / Piotr Zawilski (eds.): The Great War. Insights and Perspectives. 2016.

Bd./Vol. 14 Jerzy Jedlicki: A Degenerate World. Translated by Tristan Korecki. Edited by Elena Rozbicka. 2016.

Bd./Vol. 15 Miroslaw Matyja: Zwischen Krieg und Hoffnung. Internierung der 2. polnischen Infanterieschützen-Division in der Schweiz 1940-45. 2016.

Bd./Vol. 16 Adam Leszczyński: Leap into Modernity - Political Economy of Growth on the Periphery, 1943-1980. 2017.

Bd./Vol. 17 Antoine Marès / Wojciech Prażuch / Inga Kawka (eds.) : Les exilés polonais en France et la réorganisation pacifique de l'Europe (1940-1989). 2017. 
Bd./Vol. 18 Dominika Gortych / Guido Hinterkeuser / Łukasz Skoczylas: Erinnerungsimplantate - Der (Wieder-)Aufbau der Schlösser in Posen und Berlin im interdisziplinären Vergleich. Unter Mitwirkung von Karsten Holste. 2017.

Bd./Vol. 19 Elżbieta Katarzyna Dzikowska / Agata G. Handley / Piotr Zawilski (eds.): Beyond the Trenches - The Social and Cultural Impact of the Great War. 2017. Second Edition 2019.

Bd./Vol. 20 Marcin Zaremba: Communism - Legitimacy - Nationalism. Nationalist Legitimization of the Communist Regime in Poland. 2019.

Bd./Vol. 21 Klaus Bachmann: Genocidal Empires. German Colonialism in Africa and the Third Reich. Edited by Barbara Kurowska. 2018.

Bd./Vol. 22 Krzysztof Trybuś / Michael Düring / Maciej Junkiert (Hrsg.): Polen und Deutsche in Europa. Polacy i Niemcy w Europie. Beiträge zur internationalen Konferenz, 16. und 17. November 2015, Poznań. Tom podsumowujący międzynarodową konferencję, 16 i 17 listopada 2015, Poznań. 2018.

Bd./Vol. 23 Monika Jaglarz / Katarzyna Jaśtal (Hrsg.): Bestände der ehemaligen Preußischen Staatsbibliothek zu Berlin in der Jagiellonen-Bibliothek. Forschungsstand und -perspektiven. 2018.

Bd./Vol. 24 Zuzanna Bogumił / Małgorzata Głowacka-Grajper: Milieux de mémoire in Late Modernity. Local Community, Religion and Historical Politics. 2019.

Bd./Vol. 25 Bruno Kamiński: Fear Management. Foreign Threats in the Post-War Polish Propaganda. The Influence and the Reception of the Communist Media (1944-1956). 2019.

Bd./Vol. 26 Anna Wylegała: Displaced Memories. Remembering and Forgetting in PostWar Poland and Ukraine. 2019.

Bd./Vol. 27 Iwona Zamkowska: Religious Liberty in the Educational System of the United States. From the 1980s to the Present. 2019.

Bd./Vol. 28 Sylwia Bykowska: The Rehabilitation and Ethnic Vetting of the Polish Population in the Voivodship of Gdańsk after World War II. 2019.

Bd./Vol. 29 Aleksander Łupienko: Order in the Streets. The Political History of Warsaw's Public Space in the First Half of the 19th Century. 2019.

Bd./Vol. 30 Josef Vladár / Egon Wiedermann (eds.): The World behind the World. Intercultural Processes in the Prehistory of European Civilization. 2020.

Bd./Vol. 31 Krzysztof Brzechczyn: Historical Distinctiveness of Central Europe.A Study from Philosophy of History. 2020.

Bd./Vol. 32 Jacek Surzyn: Return to the Promised Land. The Birth and Philosophical Foundations of Zi-onism. 2020.

Bd./Vol. 33 Ryszard Kaczmarek: Poles in Kaiser's Army. On the Front of the First World War. 2020.

Bd./Vol. 34 Tomasz Wiślicz: Earning Heavenly Salvation. Peasant Religion in Lesser Poland. Mid-Sixteenth to Eighteenth Centuries. 2020.

Bd./Vol. 35 Zbigniew Tucholski: Polish State Railways as a Mode of Transport for Troops of the Warsaw Pact. Technology in Service of a Doctrine. Translated by Marek Ciesielski. 2020. 
Bd./Vol. 36 Paweł Kras: The System of the Inquisition in Medieval Europe. Translated from Polish by Magdalena Panz-Sochacka. 2020.

www.peterlang.com 
Zbigniew Tucholski - 978-3-631-82966-0 Downloaded from PubFactory at 09/30/2020 04:51:29PM by keerthiga.m@newgen.co via Peter Lang AG and keerthiga.m@newgen.co 